Prepared for the U.S. Department of Energy

under Contract DE-AC05-76RL01830

\title{
Ion Exchange Kinetics Testing with SRF Resin
}

\author{
RL Russell PP Schonewill \\ DE Rinehart RA Peterson \\ GN Brown
}

April 2012

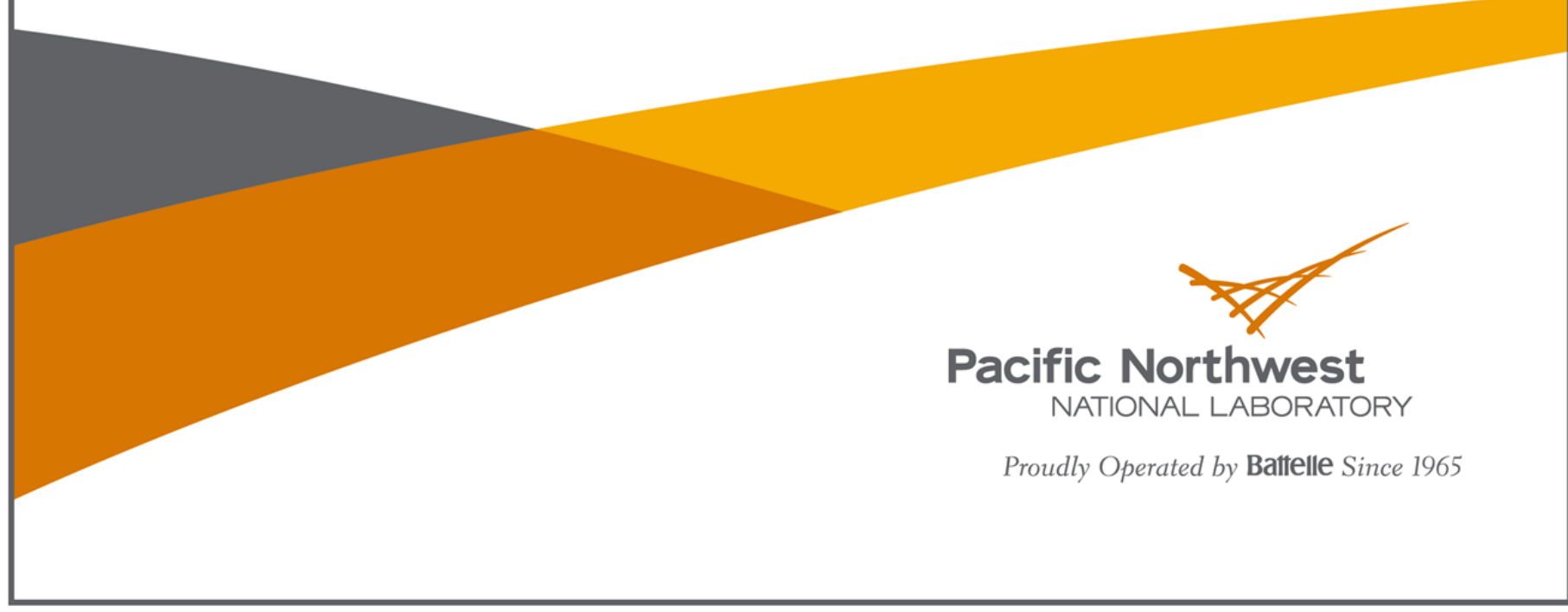




\title{
DISCLAIMER
}

This report was prepared as an account of work sponsored by an agency of the United States Government. Neither the United States Government nor any agency thereof, nor Battelle Memorial Institute, nor any of their employees, makes any warranty, express or implied, or assumes any legal liability or responsibility for the accuracy, completeness, or usefulness of any information, apparatus, product, or process disclosed, or represents that its use would not infringe privately owned rights. Reference herein to any specific commercial product, process, or service by trade name, trademark, manufacturer, or otherwise does not necessarily constitute or imply its endorsement, recommendation, or favoring by the United States Government or any agency thereof, or Battelle Memorial Institute. The views and opinions of authors expressed herein do not necessarily state or reflect those of the United States Government or any agency thereof.

\author{
PACIFIC NORTHWEST NATIONAL LABORATORY \\ operated by \\ BATTELLE \\ for the \\ UNITED STATES DEPARTMENT OF ENERGY \\ under Contract DE-AC05-76RL01830
}

Printed in the United States of America
Available to DOE and DOE contractors from the Office of Scientific and Technical Information, P.O. Box 62, Oak Ridge, TN 37831-0062; ph: (865) 576-8401 fax: $(865) \mathbf{5 7 6 - 5 7 2 8}$
email: reports@adonis.osti.gov

Available to the public from the National Technical Information Service 5301 Shawnee Rd., Alexandria, VA 22312 ph: (800) 553-NTIS (6847) email: orders@ntis.gov $<$ http://www.ntis.gov/about/form.aspx > Online ordering: http://www.ntis.gov 
PNNL-21109

WTP-RPT-214

\title{
Ion Exchange Kinetics Testing with SRF Resin
}

\author{
RL Russell PP Schonewill \\ DE Rinehart RA Peterson \\ GN Brown
}

April 2012

Test Specification: 24590 PTF-TSP-RT-09-002, Rev. 0

Test Plan: TP-WTPSP-002, Rev. 2.0

Test Exceptions: 24590-PTF-TEF-RT-10-00001, Rev. 0, 24590-PTF-TEF-RT-10-00002, Rev. 1, and 24590-PTF-TEF-RT-11-00001, Rev. 0

R\&T Focus Area: Pretreatment

Test Scoping Statement: None

Prepared for the U.S. Department of Energy

Under Contract DE-AC05-76RL01830

Pacific Northwest National Laboratory

Richland, Washington 99352 



\section{Completeness of Testing}

This report describes the results of work and testing specified by Test Specification, 24590-PTF-TSP-RT-09-002, Rev 0 and Test Plan TP-WTPSP-002, Rev. 2.0. The work followed the quality assurance requirements outlined in the test specification and test plan. The descriptions provided in this report are an accurate account of both the conduct of the work and the data collected. Test plan results are reported. Also reported are any unusual or anomalous occurrences that are different from expected results. The test results and this report have been reviewed and verified.

Approved:

$\theta \sum$ Kenate

Dean E. Kurath, Manager

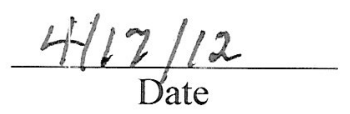





\section{Testing Summary}

Ion exchange using the Spherical Resorcinol-Formaldehyde (SRF) resin has been selected by the U.S. Department of Energy's Office of River Protection (DOE-ORP) for use in the Pretreatment Facility (PTF) of the Hanford Tank Waste Treatment and Immobilization Plant (WTP) and for potential application in an at-tank deployment. Numerous studies have shown the SRF resin to be effective for removing ${ }^{137} \mathrm{Cs}$ from a wide variety of actual and simulated tank waste supernatants (Adamson et al. 2006; Blanchard et al. 2008; Burgeson et al. 2004; Duignan and Nash 2009; Fiskum et al. 2006a; Fiskum et al. 2006b; Fiskum et al. 2006c; Fiskum et al. 2007; Hassan and Adu-Wusu 2003; King et al. 2004; Nash et al. 2006). Most of the prior work at the Pacific Northwest National Laboratory (PNNL) focused primarily on the loading behavior for 4 to $6 \underline{\mathrm{M}}$ Na solutions at $25^{\circ} \mathrm{C}$ to $45^{\circ} \mathrm{C}$ and the eluting behavior of the loaded SRF resin with virgin $0.5 \underline{\mathrm{M} \mathrm{HNO}_{3}}$. Recent proposed changes to the WTP ion exchange process baseline indicate that loading may include a broader range of sodium molarities (2 to $8 \underline{\mathrm{M}}$ ) and higher temperatures $\left(50^{\circ} \mathrm{C}\right)$ to alleviate post-filtration precipitation issues. In addition, elution will likely utilize variable-strength recycled nitric acid containing trace amounts of ${ }^{137} \mathrm{Cs}$ as reported by Brown et al. (2011).

This report discusses the ion exchange loading kinetics testing activities in accordance with the test $\operatorname{plan}^{\text {(a) }}$ prepared and approved in response to the Test Specification 24590-PTF-TSP-RT-09-002, Rev. 0 (Lehrman 2010). This testing focuses on broadening the data range of SRF resin testing under the conditions expected with the new equipment and process changes. These changes include a broader range of sodium molarities ( 2 to $8 \underline{\mathrm{M}}$ ) and higher temperatures that may be required to alleviate post-filtration precipitation issues.

\section{Objectives}

The test objectives were to:

- Determine the impact of $2 \underline{\mathrm{M}}$ to $8 \underline{\mathrm{M}}$ sodium, $\mathrm{Na} / \mathrm{Cs}$ ratio, and total hydroxide on Cs ion exchange kinetics and loading of the SRF resin.

- Determine the impact of multiple moderate temperature loading cycles on Cs ion exchange kinetics and loading of the SRF resin.

- Determine the impact of temperature on Cs ion exchange loading of the SRF resin during extended (>30-day) exposure to flowing waste simulants.

- Determine if the presence of organic compounds in the waste stream has an effect on the loading kinetics and overall Cs loading of the SRF resin.

- Determine the impact of free hydroxide in the waste simulant on the Cs loading kinetics and loading performance of the SRF resin.

- Determine the impact that long-term exposure to $0.5 \underline{\mathrm{M}} \mathrm{HNO}_{3}$ at higher temperature $\left(>45^{\circ} \mathrm{C}\right)$ has on the subsequent Cs loading of the SRF resin.

(a) RL Russell. 2010. Cesium Ion Exchange Simulant Testing in Support of M6. TP-WTPSP-002, Rev. 2.0, Pacific Northwest National Laboratory, Richland, Washington. 
Table S.1 provides the objectives that applied to the ion exchange loading kinetics testing task. Other objectives identified in Test Plan TP-WTPSP-002 ${ }^{\text {(a) }}$ did not apply to this activity but instead apply to the small-column elution testing task that was discussed in WTP-RPT-210 (Brown et al. 2011).

Table S.1. Summary of Test Objectives and Results

\begin{tabular}{|c|c|c|}
\hline Test Objective & $\begin{array}{l}\text { Objective } \\
\text { Met? }\end{array}$ & Discussion \\
\hline $\begin{array}{l}\text { Determine the impact of } 2 \mathrm{M} \\
\text { to } 8 \mathrm{M} \text { sodium, Na/Cs ratio, } \\
\text { and total hydroxide on Cs ion } \\
\text { exchange kinetics and loading } \\
\text { of the SRF resin. }\end{array}$ & Yes & $\begin{array}{l}\text { Kinetic tests were performed with simulants with varying Na } \\
\text { concentrations, OH concentrations, and Na/Cs ratios using SRF } \\
\text { resin in a column. It was found that the kinetics and Cs loading } \\
\text { were not affected by these variables. However, it was found } \\
\text { that feed flow velocity did affect the kinetics and Cs loading } \\
\text { with them being directly related. These results are discussed in } \\
\text { Section 4.1. }\end{array}$ \\
\hline $\begin{array}{l}\text { - Determine the impact of } \\
\text { multiple moderate } \\
\text { temperature loading cycles on } \\
\text { Cs ion exchange kinetics and } \\
\text { loading of the SRF resin. }\end{array}$ & Yes & $\begin{array}{l}\text { The columns were loaded with a } 5 \underline{\mathrm{M}} \text { Na feed initially and then } \\
\text { cycled through several loading and elution tests. After a total } \\
\text { of four cycles, the column was loaded with the same } 5 \underline{\mathrm{M}} \mathrm{Na} \\
\text { feed as used initially. The level of Cs loading on the resin was } \\
\text { then compared. Moderate temperature cycling did not affect } \\
\text { the loading kinetics. However, the overall Cs loading was } \\
\text { impacted at } 60^{\circ} \mathrm{C} \text { and above. These results are discussed in } \\
\text { Section } 4.1 .\end{array}$ \\
\hline $\begin{array}{l}\text { - Determine the impact of } \\
\text { temperature on Cs ion } \\
\text { exchange loading of the SRF } \\
\text { resin during extended } \\
\text { (>30-day) exposure to } \\
\text { flowing waste simulants. }\end{array}$ & Yes & $\begin{array}{l}\text { Columns were held at varying temperatures from } 45^{\circ} \mathrm{C} \text { to } 75^{\circ} \mathrm{C} \\
\text { for } 30 \text { days with feed being passed through them. Samples } \\
\text { were taken periodically to assess the loading of the resin. It } \\
\text { was found that the loading capacity of the resin was } \\
\text { significantly reduced above } 45^{\circ} \mathrm{C} \text { and did not appear to load } \\
\text { above } 60^{\circ} \mathrm{C} \text {. The resin disintegrated at } 75^{\circ} \mathrm{C} \text { and partially } \\
\text { disintegrated at } 65^{\circ} \mathrm{C} \text { causing the column to plug in both tests. } \\
\text { These results are discussed in Section } 4.2 \text {. }\end{array}$ \\
\hline $\begin{array}{l}\text { Determine if the presence of } \\
\text { organic compounds in the } \\
\text { waste stream has an effect on } \\
\text { the loading kinetics and } \\
\text { overall Cs loading of the SRF } \\
\text { resin. }\end{array}$ & Yes & $\begin{array}{l}\text { When compared to a reference column, which was tested under } \\
\text { the same conditions and feed without the organics, the presence } \\
\text { of organics did not affect the loading capacity or kinetics of the } \\
\text { loading at } 45^{\circ} \mathrm{C} \text {. This indicates that organics should not be a } \\
\text { factor during ion exchange operation for the WTP. These } \\
\text { results are discussed in Section 4.4. }\end{array}$ \\
\hline $\begin{array}{l}\text { Determine the impact of free } \\
\text { hydroxide in the waste } \\
\text { simulant on the Cs loading } \\
\text { kinetics and loading } \\
\text { performance of the SRF resin. }\end{array}$ & Yes & $\begin{array}{l}\text { Kinetic tests were performed with simulants with varying } \mathrm{OH} \\
\text { concentrations using SRF resin in a column. It was found that } \\
\text { the kinetics and Cs loading were not affected by OH } \\
\text { concentration. These results are discussed in Section 4.1. }\end{array}$ \\
\hline
\end{tabular}

(a) RL Russell, GN Brown, and RA Peterson. 2010. Cesium Ion Exchange Simulant Testing in Support of M-6. TP-WTPSP-002, Rev 1.0, Pacific Northwest National Laboratory, Richland, Washington. 
- Determine the impact that long-term exposure to $0.5 \underline{\mathrm{M}}$ $\mathrm{HNO}_{3}$ at higher temperature $\left(>45^{\circ} \mathrm{C}\right)$ has on the subsequent Cs loading of the SRF resin.
Small samples were contacted with $0.5 \underline{\mathrm{M}} \mathrm{HNO}_{3}$ for 70 days at $25^{\circ} \mathrm{C}, 45^{\circ} \mathrm{C}$, and $55^{\circ} \mathrm{C}$. One sample was contacted with de-ionized water for 70 days at $25^{\circ} \mathrm{C}$ as a reference. It was found that the loading capacity of the resin afterwards was significantly lowered at $45^{\circ} \mathrm{C}$ while the resin held at $55^{\circ} \mathrm{C}$ dissolved and could not be loaded. The resin held at $25^{\circ} \mathrm{C}$ showed no effect in the subsequent loading. These results are discussed in Section 4.3.

\section{Test Exceptions}

The test exceptions that were applicable to Test Plan TP-WTPSP-002 are presented in Table S.2.

Table S.2. Test Exceptions

\begin{tabular}{|c|c|}
\hline Test Exception Number & Description of Test Exception \\
\hline 24590-PTF-TEF-RT-10-00001, Rev 0 & $\begin{array}{l}\text { This test exception was received from Bechtel National, Inc. (BNI) on } \\
\text { September } 13,2010 \text {. The primary temperature selected for testing was } \\
45^{\circ} \mathrm{C} \text {. However, the operating temperatures have been changed in the } \\
\text { design of the ultra-filtration process (UFP) and Cs ion exchange process. } \\
\text { Temperatures were added and changed to include } 50^{\circ} \mathrm{C} \text { to determine } \\
\text { cesium removal performance impacts based on these design updates. }\end{array}$ \\
\hline 24590-PTF-TEF-RT-10-00002, Rev 1 & $\begin{array}{l}\text { This test exception was received from BNI on September } 25,2010 \text {. The } \\
\text { kinetics testing described in the test plan }{ }^{(\mathrm{a})} \text { had an elution flow rate of } \\
1.4 \text { bed volumes (BV)/hour. It was determined that the lowest accurate } \\
\text { flow rate that the pumps can support was } 2.8 \mathrm{BV} / \text { hour. It was determined } \\
\text { that using } 2.8 \mathrm{BV} / \text { hour would not impact the test objective, so it was } \\
\text { changed. }\end{array}$ \\
\hline & $\begin{array}{l}\text { It was also determined that the } \mathrm{Cl} \text { concentration for stock solutions } 8 \mathrm{C} 20 \text {, } \\
8 \mathrm{D} 40 \text {, and } 8 \mathrm{E} 40 \text { were above the solubility limits. For these stock } \\
\text { solutions, the } \mathrm{Cl} \text { was eliminated and the } \mathrm{NO}_{3} \text { concentration was increased } \\
\text { to maintain the Na concentration. }\end{array}$ \\
\hline 24590-PTF-TEF-RT-11-00001, Rev 0 & $\begin{array}{l}\text { This test exception was received from BNI on March } 11,2011 \text {. Results } \\
\text { for the testing of Cs kinetic load tests indicated that further investigation } \\
\text { was required. Further work was added to identify the potential } \\
\text { precipitates and particles observed during the } 65^{\circ} \mathrm{C} \text { and } 75^{\circ} \mathrm{C} \\
\text { long-duration runs. The highest temperature to complete the } 30 \text {-day } \\
\text { duration test without issues was } 50^{\circ} \mathrm{C} \text {. Therefore, tests at } 55^{\circ} \mathrm{C} \text { and } 60^{\circ} \mathrm{C} \\
\text { were added also. }\end{array}$ \\
\hline
\end{tabular}

(a) RL Russell. 2011. Cesium Ion Exchange Simulant Testing in Support of M6. TP-RPP-WTPSP-002, Rev. 2.0, Pacific Northwest National Laboratory, Richland, Washington.

\section{Results and Performance Against Success Criteria}

The Research and Technology (R\&T) success criteria for achieving the test objective is discussed in Table S.3. Only the success criteria for the ion exchange loading kinetics testing task are displayed in the 
table. The success criteria for the portion of the small-column elution testing of Test Plan TP-WTPSP-002 are not shown in this table and were discussed in WTP-RPT-210 (Brown et al. 2011).

Table S.3. Success Criteria Ion Exchange Loading Kinetics

\begin{tabular}{|c|c|}
\hline & List Success Criteria \\
\hline 1) & $\begin{array}{l}\text { Develop empirical information that } \\
\text { allows determination of the effect of } \\
\text { initial } \mathrm{Na} \text { ion concentration, } \\
\text { equilibrium } \mathrm{Na} / \mathrm{Cs} \text { ratio, and total } \mathrm{OH} \\
\text { on the apparent Cs diffusivity in the ion } \\
\text { exchange media. }\end{array}$ \\
\hline
\end{tabular}

2) Develop empirical information that allows determination of the effect of multiple moderate temperature loading cycles on the Cs kinetics and loading of the SRF resin.

3) Develop empirical information that allows determination of the impact of temperature on Cs loading of the SRF resin during extended (>30-day) exposure to flowing waste simulants.

4) Measure the Cs removal performance (resin Cs load capacity and Cs removal kinetics) after a high organic content feed is used on the resin.

5) Develop empirical information that allows determination of the effect of free $\mathrm{OH}$ on the $\mathrm{Cs}$ kinetics and loading of the SRF resin.

6) Provide Cs load performance data collected after the resin has been stored at variable temperatures including $\left(>45^{\circ} \mathrm{C}\right)$ in $0.5 \underline{\mathrm{M}} \mathrm{HNO}_{3}$.

\section{Explain How the Tests Did or Did Not} Meet the Success Criteria

This success criterion was met. The columns were loaded with various compositions of simulants for 10 hours. The level of Cs in the solution was periodically measured and then compared. It was found that none of these variables played a role in the kinetics of the Cs loading under these conditions. However, it was found that feed flow velocity did affect the kinetics and Cs loading with them being directly related.

This success criterion was met. The columns were loaded with a $5 \underline{\mathrm{M}}$ Na feed initially and then cycled through several loading and elution tests. After a total of four cycles the column was loaded with the same $5 \underline{\mathrm{M}}$ Na feed as used initially. The level of Cs loading on the resin was then compared to determine the effect of these variables. The kinetics of loading was not affected after moderate temperature cycling; however, in the $60^{\circ} \mathrm{C}$ and above tests the overall loading was impacted.

This success criterion was not met. Most of the extended run tests that were intended to run for 720 hours were aborted after $\sim 336$ hours due to resin degradation and column plugging. Columns were held at varying temperatures from $45^{\circ} \mathrm{C}$ to $75^{\circ} \mathrm{C}$ for 14 to 30 days with feed being passed through them. Samples were taken periodically to assess the loading of the resin. It was found that the loading capacity of the resin was significantly reduced above $45^{\circ} \mathrm{C}$ and did not appear to load above $60^{\circ} \mathrm{C}$. The resin also disintegrated at $75^{\circ} \mathrm{C}$ until left with minimal residue and partially disintegrated at $65^{\circ} \mathrm{C}$ causing the column to plug in both tests.

This success criterion was met. The column was loaded with a high organic feed for 10 hours and then eluted for 10 hours. There was no difference in the loading or eluting capacity of the resin when processing high organic feed.

This success criterion was met. Kinetics tests were performed with simulants with varying $\mathrm{OH}$ concentrations using SRF resin in a column. It was found that the kinetics and Cs loading were not affected by $\mathrm{OH}$ concentration.

This success criterion was met. Several samples of resin were placed in $0.5 \underline{\mathrm{M} \mathrm{HNO}} \mathrm{HN}_{3}$ and held at $25^{\circ} \mathrm{C}, 45^{\circ} \mathrm{C}$, or $55^{\circ} \mathrm{C}$ for 70 days. One set of samples was held at $25^{\circ} \mathrm{C}$ in de-ionized water (DIW) for 70 days as a control batch. Then each sample was removed and loaded with Cs in a batch contact at $25^{\circ} \mathrm{C}$ for 24 hours with periodic samples taken to assess the level of Cs loading. The results showed that the acid did not seem to affect the loading of the resin at $25^{\circ} \mathrm{C}$. However, at $45^{\circ} \mathrm{C}$ the kinetics of the resin loading were significantly reduced with a lower overall loading and at $55^{\circ} \mathrm{C}$ the resin had completely disintegrated and was unable to be loaded for a comparison. 


\section{Quality Requirements}

The PNNL Quality Assurance (QA) Program is based on the requirements defined in the U.S. Department of Energy Order 414.1D, Quality Assurance, and 10 CFR 830, Energy/Nuclear Safety Management, and Subpart A-Quality Assurance Requirements (a.k.a. the Quality Rule). PNNL has chosen to implement the following consensus standards in a graded approach:

- ASME NQA-1-2000, Quality Assurance Requirements for Nuclear Facility Applications, Part 1, Requirements for Quality Assurance Programs for Nuclear Facilities.

- ASME NQA-1-2000, Part II, Subpart 2.7, Quality Assurance Requirements for Computer Software for Nuclear Facility Applications.

- ASME NQA-1-2000, Part IV, Subpart 4.2, Graded Approach Application of Quality Assurance Requirements for Research and Development.

The procedures necessary to implement the requirements are documented through PNNL's “How Do I...?” $\left(\mathrm{HDI}^{(\mathrm{a})}\right)$.

The Waste Treatment Plant Support Project (WTPSP) implements an NQA-1-2000 Quality Assurance Program, graded on the approach presented in NQA-1-2000, Part IV, Subpart 4.2. The WTPSP Quality Assurance Manual (QA-WTPSP-0002) describes the technology life cycle stages under the WTPSP Quality Assurance Plan (QA-WTPSP-0001). The technology life cycle includes the progression of technology development, commercialization, and retirement in process phases of basic and applied research and development $(R \& D)$, engineering and production and operation until process completion. The life cycle is characterized by flexible and informal quality assurance activities in basic research, which becomes more structured and formalized through the applied R\&D stages.

The work described in this report has been completed under the QA technology level of Applied Research. WTPSP addresses internal verification and validation activities by conducting an Independent Technical Review of the final data report in accordance with WTPSP's procedure QA-WTPSP-601, Document Preparation and Change. This review verifies that the reported results are traceable, that inferences and conclusions are soundly based, and that the reported work satisfies the test plan objectives.

Section 5.0 is for information only. The work described in this section uses a commercially available software program (VERSE-LC) in order to model the kinetic experiments. However, the software was not added to the approved software list under the QA program and thus, despite the technical validity of the work presented in this section, must be considered for information only.

\section{R\&T Test Conditions}

This report summarizes the ion exchange removal of Cs from a simple waste simulant using Microbeads SRF resin, Lot 5E-370/641. The resin was sub-sampled from existing stock that had been stored under $\mathrm{N}_{2}$ at PNNL for more than 4 years in the $\mathrm{H}^{+}$-form. The resin was bulk pretreated with

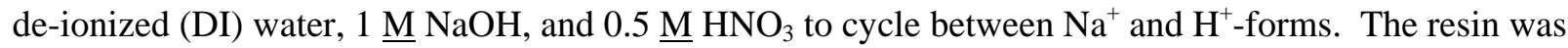

(a) System for managing the delivery of PNNL policies, requirements, and procedures. 
then further pretreated in the column with another acid/base cycle prior to simulant loading. Dry resin density was determined by drying duplicate samples under vacuum at $50^{\circ} \mathrm{C}$ to constant mass.

Several columns of SRF resin were loaded with various simple simulants containing various amounts of $\mathrm{Cs}$, Na, and Al, partially eluted with $3 \mathrm{BV} 0.5 \underline{\mathrm{M}} \mathrm{HNO}_{3}$ and then eluted with $25+\mathrm{BV}$ of $0.25 \underline{\mathrm{M}} \mathrm{HNO}_{3}$ solution.

All test conditions delineated by the test plan and test exceptions were met. A summary of test conditions is provided in Table S.4.

Table S.4. R\&T Test-Condition Summary

\section{List R\&T Test Conditions}

1) Ion Exchange Loading Kinetics Tests

Small-column ion exchange loading tests were performed near prototypic flow conditions with feed recycle until equilibrium loading was achieved in order to evaluate cesium uptake kinetics. The scoping tests included a fractional factorial experimental design and the various simulant feed compositions. They:

- $\quad$ Examined the impact of linear load velocity $(4,6$, $8 \mathrm{~cm} / \mathrm{min}$ )

- $\quad$ Examined the impact of initial Na concentration (2, 5, $8 \underline{\mathrm{M}})$

- Examined the impact of initial $\mathrm{Na} / \mathrm{Cs}$ ratio $(1.4 \mathrm{E}+05$, $2.1 \mathrm{E}+05,2.8 \mathrm{E}+05 \mathrm{~mol} / \mathrm{mol})$

- Examined the impact of initial $\mathrm{Na} / \mathrm{OH}$ ratio (2.0, 3.0, $4.0 \mathrm{~mol} / \mathrm{mol}$ )

- Examined the impact of high free $\mathrm{OH}$ on resin degradation during extended solution flow using elevated temperature $\left(45^{\circ}, 50^{\circ}, 55^{\circ}, 60^{\circ}, 65^{\circ}, 75^{\circ} \mathrm{C}\right)$ to derive a degradation rate equation.

If filtration was performed prior to ion exchange, the filtration temperature was to be $40^{\circ} \mathrm{C}$. If precipitation was observed in simulant samples before or after ion exchange, the Process Technology lead was to be notified and the observations and sample storage conditions were to be recorded in the final test report. Samples where precipitation was observed were to be saved until disposition of the sample was agreed upon with the Process Technology lead.

The crystalline precipitate observed in the feed solution that was heated to $75^{\circ} \mathrm{C}$ was evaluated with a polarized light microscope (PLM) to identify the crystal. Photographs of the bottle containing the precipitate and photographs of the magnified precipitate were taken.
A series of column loading and elution cycles were completed as detailed in Table 3.3. The composition of the simulants used is shown in Table 3.1. The general column processing steps (e.g., pretreatment, loading, feed displacement, rinsing, elution, rinsing, regeneration) are described in Table 3.2.

The ion exchange columns were loaded with simulant feed solution at temperatures between $25 \pm 2^{\circ} \mathrm{C}$ and $75 \pm 2^{\circ} \mathrm{C}$. The solution was processed at various flow velocities, initial $\mathrm{Na}$ concentrations, initial $\mathrm{Na} / \mathrm{Cs}$ ratios, free $\mathrm{OH}$ concentrations, and initial $\mathrm{Na} / \mathrm{OH}$ ratios as shown in Table 3.3 for the $10 \mathrm{~h}$ of loading. Following loading, the feed solution was

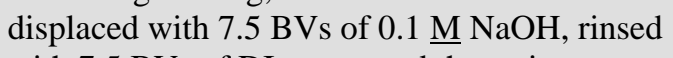
with 7.5 BVs of DI water, and the resin was neutralized with $3 \mathrm{BVs}$ of $0.5 \underline{\mathrm{M} \mathrm{HNO}} 3$ at $3 \mathrm{BV} / \mathrm{h}$ as is outlined in Table 3.2 .

Filtration was not performed before the ion exchange. Precipitation was observed in the initial $8 \underline{\mathrm{M}}$ Na simulant solutions after testing and during the long-term testing. The Process Technology lead was notified and observations were made. Samples were also saved.

The crystalline precipitate was evaluated with PLM to identify the crystals and photographs were taken as shown in Section 4.2. 
The filtered and dried solids from the water solutions used to rinse the wet beads and white residue from the glass column wall in columns C and B were evaluated with a PLM and with a scanning electron microscope (SEM).

The sludge/particulates observed in the tubing during the $75^{\circ} \mathrm{C}$ and $65^{\circ} \mathrm{C}$ runs were evaluated with a PLM and with a SEM.
The filtered, dried solids from the water solutions used to rinse the wet beads and white residue from the glass column wall in columns $\mathrm{C}$ and B were evaluated with PLM and SEM as shown in Section 4.2.

All of the other particulates that were observed were also evaluated with PLM and/or SEM as shown in Section 4.2.
List R\&T Test Conditions

The resin from the kinetics tests were compared using SEM to the fresh resin to see if there were any notable changes in the resin with variations in process conditions and compositions.

Solutions and spent resin materials from the kinetics tests were reserved until concurrence for disposal was received from the WTP Process Technology lead.

Upon completion of these scoping tests, a surface response factorial design was developed based on the fractional factorial design. This surface response design evaluated the two parameters determined to have the most significant effect on resin kinetics. This design was provided to BNI personnel for review and approval. Approval was to be provided by the BNI point of contact, prior to additional surface response factorial testing.

The results from these tests were used to assess the impact of process conditions on the diffusivity and film mass transfer coefficient. Tests performed at varying axial velocity provided a measure of the impact of the film mass transfer coefficient. Tests performed at varying $\mathrm{Na}$ concentrations and $\mathrm{Cs} / \mathrm{Na}$ ratios provided a measure of the impact of the diffusivity on ion exchange performance. These results were analyzed to evaluate the film mass transfer coefficient and the diffusivity.

Preliminary results of testing were transmitted to WTP for modeling of test column performance by WTP personnel using ion exchange column modeling software.
Were Test Conditions Followed?

Pictures of the used resin and the fresh resin were taken using the SEM to compare. We have not disposed of the solutions and spent resin materials from the kinetics tests.

These test conditions were replaced with a test exception and therefore were not performed.

The results were analyzed using the VERSE-LC model system. The final simulation results (the parameters that gave the best fit as measured) are shown in Section 5.4.

All of the preliminary results were transmitted to WTP.
2) Ion Exchange Interaction with Organics Tests

In order to evaluate the effect that organic compounds have on Cs ion exchange of the SRF resin, a single kinetics test was completed and compared to Test-1-A-1. The organics scoping test consisted of a single solution containing $5 \underline{\mathrm{M} \mathrm{Na}}$, $1.67 \underline{\mathrm{M}} \mathrm{OH}, 2.08 \mathrm{E}+05$ initial Na/Cs ratio and a wide variety of organic compounds. The solution containing the inorganic and organic compounds was loaded at $45^{\circ} \mathrm{C}$ for $10 \mathrm{~h}$ at $6 \mathrm{~cm} / \mathrm{min}$. The
The impact of organics test was performed using the simulant ID 5B17 listed in Table 3.1 with the organics listed in Tables 3.5 and 3.6 added. The simulant solution was prepared in the same manner with the organics added at the end to make $250 \mathrm{~mL}$. 
experimental conditions were identical (except the organic compounds) to Test-1-A-1.

- Examined the impact of organic compounds in the loading solution. The organics added are the same organics that were previously tested (Nash 2004) in Savannah River National Laboratory (SRNL) resin testing (Table 8 of SCT-M0SRLE60-00-110-00027, Rev. B) along with antifoam and its degradation products. The antifoam was added at a concentration of $2000 \mathrm{ppm}$, along with $1000 \mathrm{ppm}$ of each of the degradation products. The simulant spiked with organics was filtered with a 0.1 micron filter prior to contacting the resin.

- After the organics were filtered, total inorganic carbon/total organic carbon (TIC/TOC) analysis was used to estimate the quantity of organic carbon that passed through the 0.1 micron filter and contacted the resin.

If filtration was performed prior to ion exchange, the filtration temperature was to be $40^{\circ} \mathrm{C}$. If precipitation was observed in simulant samples before or after ion exchange, the Process Technology lead was to be notified and the observations and sample storage conditions were to be recorded in the final test report. Samples where precipitation was observed were to be saved until disposition of the sample was agreed upon with the Process Technology lead.
The impact of organics test was performed using the simulant ID 5B17 listed in Table 3.1 with the organics listed in Tables 3.5 and 3.6 added. The antifoam agent was added at a concentration of $2000 \mathrm{ppm}$ and the antifoam degradation products were added at $1000 \mathrm{ppm}$. After adding the organics, the solution had a significant amount of gelatinous material present. Therefore, it was filtered through a KimWipe $^{\mathrm{TM}}$ paper to remove this before filtering through a $0.1 \mu \mathrm{m}$ filter to remove any undissolved solids still present.

A TIC/TOC analysis of the feed was performed both before filtering and after filtering had occurred. The organics did not appear to have any impact in the loading. However, the antifoam created a slightly gelatinous solid in the solution.

No precipitation was observed after simulant preparation and filtration.

\section{3) Elution Temperature Effect on Resin}

Three small $(<10 \mathrm{~mL})$ batches of fresh SRF resin were each contacted with $0.5 \mathrm{M} \mathrm{HNO}_{3}$ for 70 days. One of the three batches was stored at $\sim 25^{\circ} \mathrm{C}$, one batch was stored at $\sim 45^{\circ} \mathrm{C}$, one batch was stored at $\sim 55^{\circ} \mathrm{C}$, and a fourth batch (fresh resin that was not exposed to $\mathrm{HNO}_{3}$ ) was stored at $\sim 25^{\circ} \mathrm{C}$ as a control sample. After 70 days, each of the four batches of SRF resin were converted to the Na form, and then contacted with the same Cs loading solution from Test-1-A-1. The identical conditions facilitated a direct comparison.
Fresh SRF resin was contacted with $0.5 \underline{\mathrm{M}}$ $\mathrm{HNO}_{3}$ while continually mixing on a shaker for 70 days at three different

temperatures- $25^{\circ} \mathrm{C}, 45^{\circ} \mathrm{C}, 55^{\circ} \mathrm{C}$. A fourth set of samples of fresh resin was contacted with DI water at $\sim 25^{\circ} \mathrm{C}$ as a control sample while continually mixing on a shaker for 70 days. A ratio of 1:100 was used for all resin and solution mixtures $(0.1 \mathrm{~g}$ resin in $10 \mathrm{~mL}$ solution). After 70 days, the resin was removed from the acid (or DI water), rinsed three times for 30 minutes each time with $10 \mathrm{~mL}$ of DI water and then contacted twice with $10 \mathrm{~mL}$ of $0.5 \mathrm{M} \mathrm{NaOH}$, once for an hour and then once for 24 hours, to convert the resin to the $\mathrm{Na}$ form. After the 24-hour $\mathrm{NaOH}$ contact, the resin was removed and contacted with $25 \mathrm{~mL}$ of the cesium loading solution (5 $\underline{\mathrm{M}} \mathrm{Na}, 1.67 \underline{\mathrm{M}} \mathrm{OH}$, and 2.4E-05 $\underline{\mathrm{M}} \mathrm{Cs}$ ). The 


\begin{tabular}{|c|c|}
\hline List R\&T Test Conditions & Were Test Conditions Followed? \\
\hline & $\begin{array}{l}\text { experimental matrix is shown in Table } 3.4 \text {. } \\
\text { Analytical samples were collected at } 0,1,4 \text {, } \\
10 \text {, and } 24 \text { hours to define the Cs uptake curve } \\
\text { by filtering } ~ 10 \mathrm{~mL} \text { of the supernate from the } \\
\text { sample bottle using a } 0.45 \mu \mathrm{m} \text { disposable } \\
\text { syringe filter and placing it in the specified } \\
\text { sample vial. Each test was performed in } \\
\text { duplicate with a blank sample taken at } 0 \text { and } \\
24 \text { hours. Simulant samples were submitted to } \\
\text { SwRI for analysis. Analysis methods included } \\
\text { ICP-MS for Cs, ICP-OES for Na, and Al, IC } \\
\text { for anions and OH analysis. }\end{array}$ \\
\hline $\begin{array}{l}\text { If filtration is performed prior to ion exchange, the } \\
\text { filtration temperature is to be } 40^{\circ} \mathrm{C} \text {. If precipitation is } \\
\text { observed in simulant samples before or after ion exchange, } \\
\text { the Process Technology lead is to be notified and the } \\
\text { observations and sample storage conditions are to be } \\
\text { recorded in the final test report. Samples where } \\
\text { precipitation is observed are to be saved until disposition } \\
\text { of the sample is agreed upon with the Process Technology } \\
\text { lead. }\end{array}$ & $\begin{array}{l}\text { No filtration was performed prior to ion } \\
\text { exchange. No precipitation was observed. } \\
\text { However, the resin totally disintegrated at } \\
55^{\circ} \mathrm{C} \text {. }\end{array}$ \\
\hline $\begin{array}{l}\text { Data from this testing will be analyzed to determine the } \\
\text { impact of elevated elution temperature on resin } \\
\text { degradation and performance. }\end{array}$ & $\begin{array}{l}\text { The resin was loaded and the Cs loading curve } \\
\text { was analyzed using the ICP-MS data. It was } \\
\text { determined that elevated elution temperature } \\
\text { did have a significant impact on the resin } \\
\text { degradation and performance. The resin } \\
\text { degraded so badly at } 55^{\circ} \mathrm{C} \text { that a loading curve } \\
\text { was unable to be obtained. }\end{array}$ \\
\hline
\end{tabular}

\section{Simulant Use}

The small-column kinetics loading testing task was performed using several non-radioactive aqueous solutions for loading of the SRF resin. These simple simulant compositions were provided by BNI as documented in Test Specification RF Resin Cesium Removal with Expanded Load and Elution Conditions. $^{\text {(a) }}$ The $\mathrm{Na}, \mathrm{Cs}, \mathrm{Al}$, and $\mathrm{OH}$ concentrations were within the ranges expected for aqueous waste feeds to the PTF. The nominal Na concentration was selected to be $5 \underline{\mathrm{M}}$, and the nominal Cs concentration was selected to be $2.4 \mathrm{E}-05 \underline{\mathrm{M}}$. No K was included in the simulant. The nominal free $\mathrm{OH}$ concentration was selected to be $1.55 \underline{\mathrm{M}}$, and the $\mathrm{Al}$ concentration was selected to be $0.115 \underline{\mathrm{M}}$, approximately $90 \%$ of the solubility limit. The simulant was not selected to represent any particular Hanford tank waste type.

(a) S Lehrman and M Thorson. 2010. RF Resin Cesium Removal with Expanded Load and Elution Conditions. 24590-PTF-TSP-RT-09-002, Rev 0, Bechtel National, Inc., Richland, Washington. 


\section{Discrepancies and Follow-on Tests}

Most of the extended run tests that were intended to run for 720 hours were aborted after $\sim 336$ hours due to resin degradation and column plugging.

It was found that the loading capacity of the resin was significantly reduced above $45^{\circ} \mathrm{C}$ and did not appear to load above $60^{\circ} \mathrm{C}$. The resin also disintegrated at $75^{\circ} \mathrm{C}$ until left with minimal residue and partially disintegrated at $65^{\circ} \mathrm{C}$ causing the column to plug in both tests. Therefore, it is recommended that the temperature effect on the resin loading and degradation be examined more carefully and bracketed closer so that the upper resin use temperature may be known.

It is also recommended that a simulant containing $\mathrm{K}$ be tested so that the effect of $\mathrm{K}$ on the Cs loading of the resin can be determined.

There were some limitations to using the VERSE-LC model that could be mitigated with additional time. First, the interface of the software was not conducive to a more automated minimization routine. This could be automated to find a minimum using any standard optimization routine, but would have to involve a second software platform. Second, the accuracy of the results could also be improved with better input data, in particular a good estimate of the maximum solute capacity for cesium and accurate measurement of the physical properties of the solution (viscosity and diffusion coefficients in particular). Third, a more complex model could be built that incorporates some of the ignored species such as $\mathrm{Rb}^{+}$, $\mathrm{K}^{+}$, and $\mathrm{Na}^{+}$that compete with $\mathrm{Cs}^{+}$for adsorption sites on the resin. 


\section{Acknowledgments}

The authors would like to thank the Southwest Research Institute (Daniel Ramirez and other staff, San Antonio, Texas) for analytical support. The authors also would like to thank Jennifer Meehan, David Sherwood and Fred Damerow of the Hanford Tank Waste Treatment and Immobilization Plant project for their technical insights and much helpful discussion and support. The authors are grateful for the assistance of Pacific Northwest National Laboratory staff members Dave Payson for editorial and

document design support, Amanda Casella for technical review, and Brian Riley for performing SEM and PLM analysis. 



\section{Acronyms and Abbreviations}

\begin{tabular}{|c|c|}
\hline ASTM & American Society for Testing and Materials \\
\hline BNI & Bechtel National, Inc. \\
\hline BV & bed volumes \\
\hline CSTR & Continuously Stirred Reactor \\
\hline DIW & de-ionized water \\
\hline DOE & U.S. Department of Energy \\
\hline EDS & energy dispersive scattering \\
\hline FFPM & perfluorinated elastomer \\
\hline GGRF & ground gel resorcinol-formaldehyde \\
\hline HDI & How Do I \\
\hline HLW & high-level waste \\
\hline IC & ion chromatography \\
\hline ICP & inductively coupled plasma \\
\hline MS & mass spectroscopy \\
\hline NA & not applicable \\
\hline OES & optical emission spectroscopy \\
\hline ORP & Office of River Protection \\
\hline PLM & polarized light microscopy \\
\hline PNNL & Pacific Northwest National Laboratory \\
\hline PTF & Pretreatment Facility \\
\hline PTFE & polytetrafluoroethylene \\
\hline PVDF & polyvinylidene fluoride \\
\hline QA & quality assurance \\
\hline $\mathrm{R} \& \mathrm{D}$ & research and development \\
\hline $\mathrm{RF}$ & resorcinol-formaldehyde \\
\hline RMSE & root mean square error \\
\hline $\mathrm{RPP}$ & River Protection Project \\
\hline $\mathrm{R} \& \mathrm{~T}$ & research and technology \\
\hline RV & resin volume \\
\hline SEM & scanning electron microscopy \\
\hline SRF & spherical resorcinol formaldehyde \\
\hline SRNL & Savannah River National Laboratory \\
\hline SwRI & Southwest Research Institute \\
\hline TIC & total inorganic carbon \\
\hline TOC & total organic carbon \\
\hline TRU & transuranic \\
\hline
\end{tabular}


UFP

VERSE-LC

WSRC

WTP

WTPSP ultra-filtration process

VErsatile Reaction-SEparation model for Liquid Chromatography applications

Westinghouse Savannah River Company

Hanford Tank Waste Treatment and Immobilization Plant

Waste Treatment Plant Support Project 


\section{Contents}

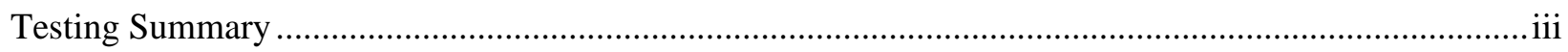

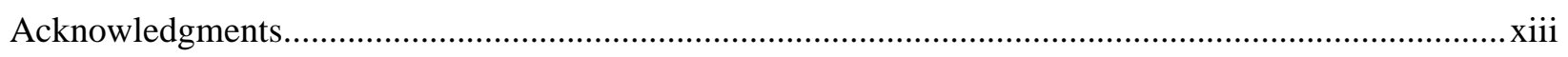

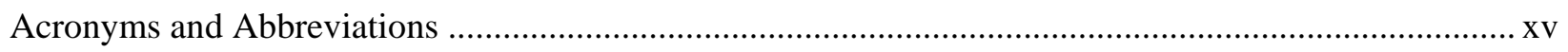

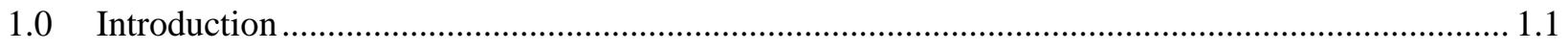

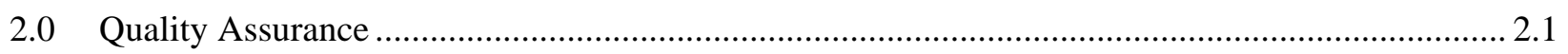

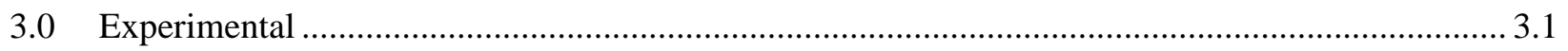

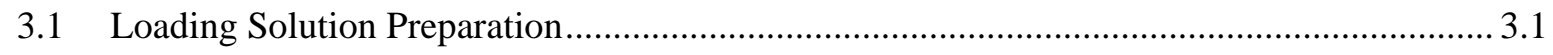

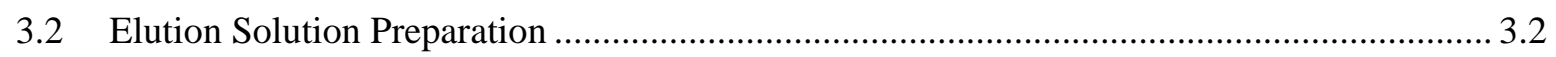

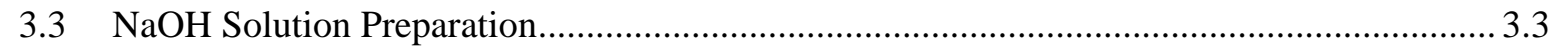

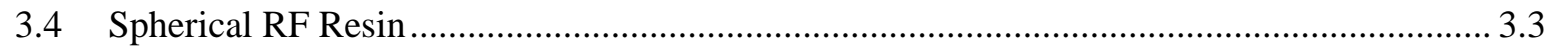

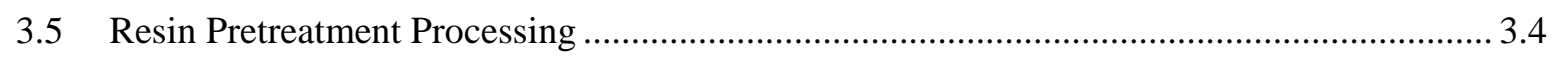

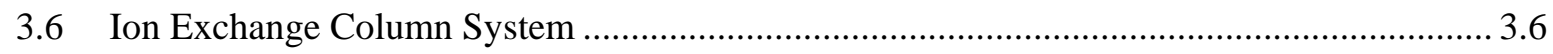

3.7 Column Testing Experimental Procedure …................................................................... 3.7

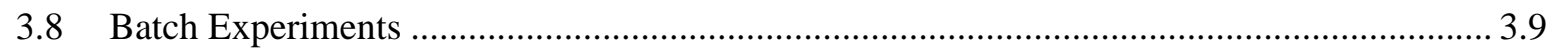

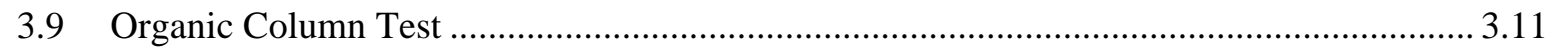

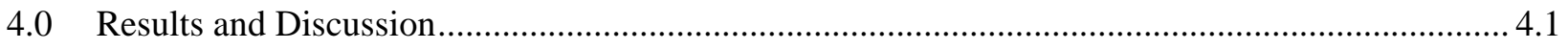

4.1 Impacts of Variables on Loading Kinetics .................................................................. 4.1

4.2 Impacts of Elevated Temperature on Resin Loading ....................................................... 4.7

4.3 Effect of Aging Resin in an Acid Environment ..................................................................28

4.4 Effect on the Resin of Volatile Organics in the Feed ....................................................... 4.30

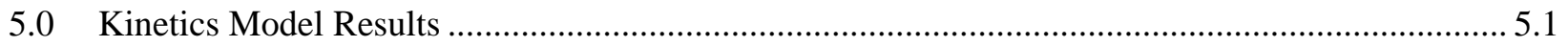

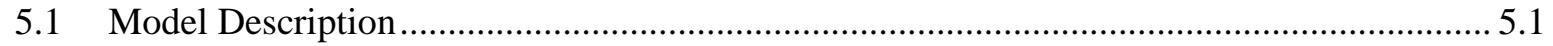

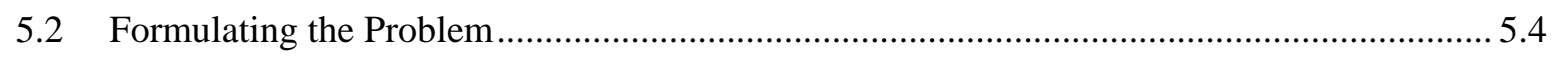

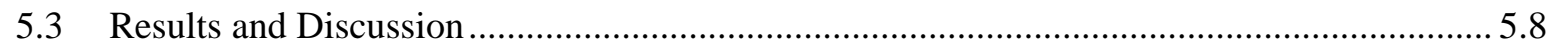

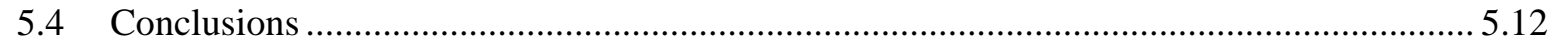

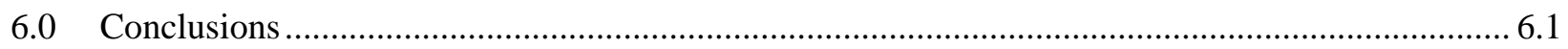

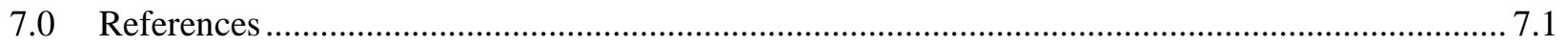

Appendix A : Column Sampling Information.................................................................................... A.1

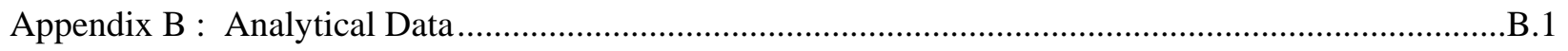




\section{Figures}

3.1. Representative SRF Resin Sample for Column Testing Showing Darkened Resin Beads .............. 3.3

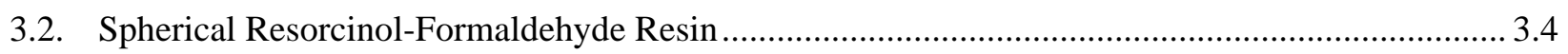

3.3. SRF Resin Dispensed for Column Experiments. ........................................................................ 3.5

3.4. Differential Column Ion Exchange Kinetics Schematic ............................................................. 3.7

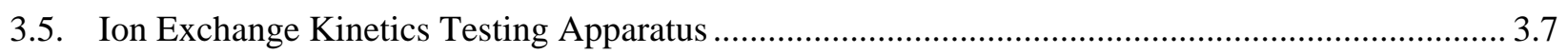

3.6. Volumetric Flask After Mixing Organic Feed Solution.......................................................... 3.12

4.1. Velocity Impact on Kinetics of Column Loading ...................................................................... 4.2

4.2. Initial Na Impact on Kinetics of Column Loading..................................................................... 4.3

4.3. $\mathrm{Na} / \mathrm{Cs}$ Ratio Impact on Kinetics of Column Loading .................................................................... 4.3

4.4. $\mathrm{Na} / \mathrm{OH}$ Ratio Impact on Kinetics of Column Loading .................................................................. 4.4

4.5. Initial Na Impact on Column Loading Capacity ......................................................................... 4.4

4.6. First and Fifth Resin Loading Cycles Compared at $55^{\circ} \mathrm{C}$.......................................................... 4.5

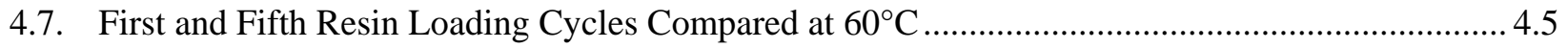

4.8. First and Fifth Resin Loading Cycles Compared at $50^{\circ} \mathrm{C}$ with Long Loading Cycle at $65^{\circ} \mathrm{C}$......... 4.6

4.9. First and Fifth Resin Loading Cycles Compared at $50^{\circ} \mathrm{C}$ with Long Loading Cycle at $75^{\circ} \mathrm{C}$......... 4.6

4.10. Resin Degradation During Extended Flow Testing .................................................................. 4.7

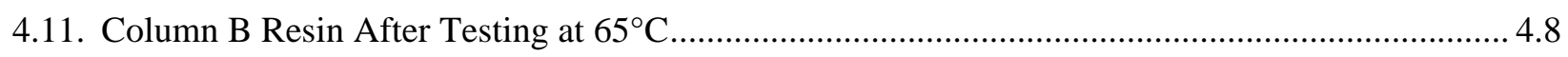

4.12. White Crystalline Material on Top of the O-Ring and Wedged Between the Bed Support

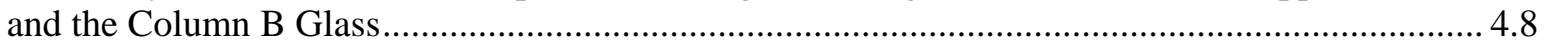

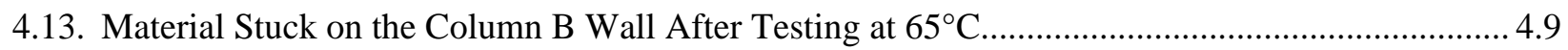

4.14. Material Washed from the Plugged Resin Bed in Test $B\left(65^{\circ} \mathrm{C}\right)$ from Optical

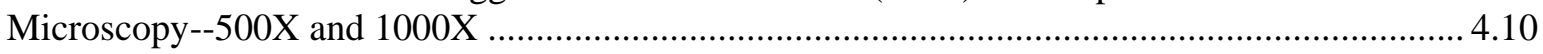

4.15. Material Washed from the Plugged Resin Bed in Test B $\left(65^{\circ} \mathrm{C}\right)$ from PLM.............................. 4.11

4.16. Material Washed from the Plugged Resin Bed in Test B $\left(65^{\circ} \mathrm{C}\right)$ from SEM-EDS $(150 \mu \mathrm{m}$

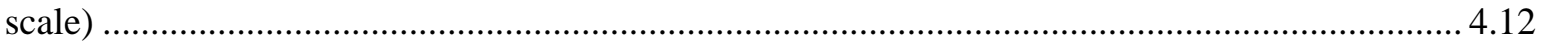

4.17. Material Washed from the Plugged Resin Bed in Test B $\left(65^{\circ} \mathrm{C}\right)$ from SEM-EDS $(50 \mu \mathrm{m}$

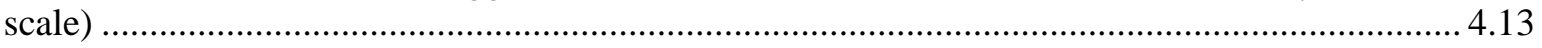

4.18. Material Washed from the Plugged Resin Bed in Test B $\left(65^{\circ} \mathrm{C}\right)$ from SEM-EDS $(20 \mu \mathrm{m}$

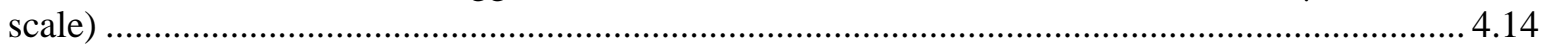

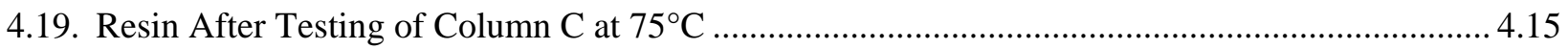

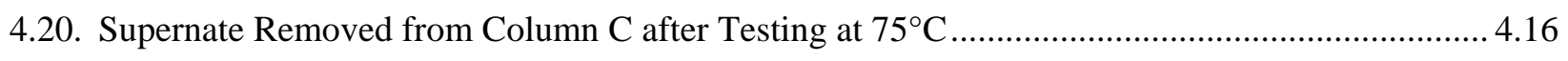

4.21. Material Between Column C Wall and Bed Support ................................................................. 4.16

4.22. Material Washed from the Plugged Resin Bed in Test $\mathrm{C}\left(75^{\circ} \mathrm{C}\right)$ from Optical

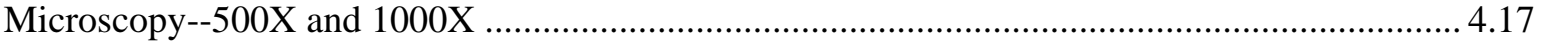

4.23. Material Washed from the Plugged Resin Bed in Test $\mathrm{C}\left(75^{\circ} \mathrm{C}\right)$ from PLM.............................. 4.18

4.24. Material Washed from the Plugged Resin Bed in Test C $\left(75^{\circ} \mathrm{C}\right)$ from SEM-EDS $(10 \mu \mathrm{m})$.......... 4.19

4.25. Material Washed from the Plugged Resin Bed in Test C $\left(75^{\circ} \mathrm{C}\right)$ from SEM-EDS $(20 \mu \mathrm{m}) \ldots \ldots \ldots . . .4 .20$ 
4.26. Sample Scraped and Washed from Lower Column Support after Test C $\left(75^{\circ} \mathrm{C}\right)$ from Optical Microscopy-70X

4.27. Sample Scraped and Washed from Lower Column Support after Test C $\left(75^{\circ} \mathrm{C}\right)$ from PLM ....... 4.21

4.28. Sample Scraped and Washed from Lower Column Support after Test C $\left(75^{\circ} \mathrm{C}\right)$ from Trans PLM

4.29. Sample Scraped and Washed from Lower Column Support after Test C $\left(75^{\circ} \mathrm{C}\right)$ from SEM-EDS (small spot at $250 \mu \mathrm{m}$ )

4.30. Sample Scraped and Washed from Lower Column Support after Test C $\left(75^{\circ} \mathrm{C}\right)$ from SEM-EDS (upper place at $10 \mu \mathrm{m}$ )

4.31. Sample Scraped and Washed from Lower Column Support after Test C $\left(75^{\circ} \mathrm{C}\right)$ from SEM-EDS (lower place at $10 \mu \mathrm{m}$ )

4.32. Debris Stuck to Column $\mathrm{C}$ after Testing at $75^{\circ} \mathrm{C}$

4.33. Sample Washed from the Lower Column Wall of Glass after Test $\mathrm{C}\left(75^{\circ} \mathrm{C}\right)$ from Optical Microscopy--70X

4.34. Resin Loading After 70 Days of Acid Aging...

4.35. Resin Sample After Aging at $25^{\circ} \mathrm{C}$ for 70 Days Compared with $55^{\circ} \mathrm{C}$ Sample ............

4.36. SEM of $25^{\circ} \mathrm{C}$ Acid Aged Resin and $45^{\circ} \mathrm{C}$ Acid Aged Resin .....

4.37. Results of the Organic Loading Test. 4.30

5.1. General Schematic of the VERSE-LC Equation System .......................................................... 5.2

5.2. Schematic of the Model Column and Relevant Physical Dimensions .......................................... 5.2

5.3. Comparison of VERSE-LC System with Experimental System Used........................................... 5.5

5.4. Fit of the VERSE-LC Simulation to the Column A1 Experimental Data ....................................... 5.8

5.5. Fit of the VERSE-LC Simulation to the Column E4 Experimental Data ....................................... 5.9

5.6. Comparison of Experimental Data with Simulation Results When Only the Flow Rate is Changed in the Column C3 Simulation...

\section{Tables}

3.1. Planned Stock Simulant Solutions for Cesium Ion Exchange Loading ....................................... 3.2

3.2. Ion Exchange Pretreatment and Process Steps....................................................................... 3.5

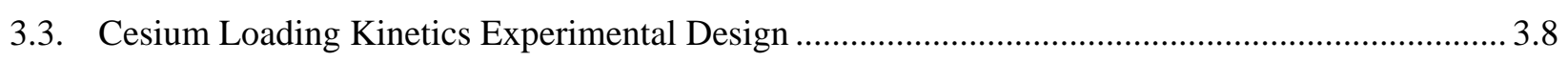

3.4. Batch Contact Elution Temperature Experimental Design ......................................................... 3.10

3.5. Antifoam Degradation Products Added to Organic Feed Solution ............................................... 3.11

3.6. Organic Products Added to Organic Feed Solution ................................................................. 3.12

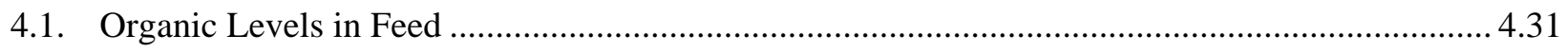

5.1. Effect of Sodium Concentration on Adsorption and Desorption Rate Constants ......................... 5.10

5.2. Effect of Temperature on Adsorption and Desorption Rate Constants........................................ 5.10

5.3. Effect of Flow Rate on Adsorption and Desorption Rate Constants.......................................... 5.11

5.4. Effect of $\mathrm{OH}^{-}$Concentration on Adsorption and Desorption Rate Constants .............................. 5.12

5.5. Effect of Column Processing Time/Cycling on Adsorption and Desorption Rate Constants ........ 5.12

5.6. Final Simulation Results for All Experiments Modeled Using VERSE-LC................................ 5.13 



\subsection{Introduction}

The U.S. Department of Energy (DOE) Hanford Site contains more than 53 million gallons of legacy waste generated as a byproduct of plutonium production and reprocessing operations. The wastes are a complex mixture composed mostly of $\mathrm{NaNO}_{3}, \mathrm{NaNO}_{2}, \mathrm{NaOH}, \mathrm{NaAlO}_{2}, \mathrm{Na}_{3} \mathrm{PO}_{4}$, and $\mathrm{Na}_{2} \mathrm{SO}_{4}$, with a number of minor and trace metals, organics, and radionuclides stored in underground waste tanks. The DOE Office of River Protection (ORP) has contracted Bechtel National Incorporated (BNI) to build a pretreatment facility, the River Protection Project-Waste Treatment Plant (RPP-WTP), that will separate long-lived transuranics (TRU) and highly radioactive components (specifically ${ }^{137} \mathrm{Cs}$ and, in selected cases, ${ }^{90} \mathrm{Sr}$ ) from the bulk (non-radioactive) constituents and immobilize the wastes by vitrification. The plant is designed to produce two waste streams: a high-volume low-activity waste (LAW) and a low-volume high-activity waste (HLW).

Ion exchange using the spherical resorcinol-formaldehyde (SRF) resin has been selected by WTP project and approved by DOE ORP for use in the Pretreatment Facility (PTF) of the RPP-WTP. The SRF resin is an engineered spherical form of the older ground gel resorcinol-formaldehyde (GGRF) resin, also termed resorcinol-formaldehyde (RF), which was developed and evaluated at the Westinghouse Savannah River Company (WSRC) in the 1980s (Ebra and Wallace 1983; Bibler et al. 1989). Numerous studies at Hanford and other DOE sites have shown the GGRF and SRF resins to be effective for removing ${ }^{137} \mathrm{Cs}$ from a wide variety of simulated and actual tank waste supernatants and for achieving less than the proposed spent waste classification criteria of $<100 \mathrm{nCi}$ TRU and $<60 \mu \mathrm{Ci}{ }^{137} \mathrm{Cs}$ per gram of spent resin (Adamson et al. 2006; Blanchard et al. 2008; Burgeson et al. 2004; Duignan and Nash 2009; Fiskum et al. 2006a; Fiskum et al. 2006b; Fiskum et al. 2006c; Fiskum et al. 2007; Hassan and Adu-Wusu 2003; King et al. 2004; Kurath et al. 1994; Nash et al. 2006).

Prior work has focused primarily on loading behavior for $5 \underline{\mathrm{M}}$ Na solutions at $25^{\circ} \mathrm{C}$. Recent proposed changes to the process baseline indicate that both a broader range of sodium molarities ( 2 to $8 \underline{\mathrm{M}}$ ) and higher temperatures may be required to alleviate post-filtration precipitation issues. Also, to date, no work has been done to establish the impact of organic compounds on the ion exchange system. The objective of this report is to summarize the results of the resin loading behavior under these various conditions.

Section 1.0 provides a brief historical background for HLW, Cs ion exchange, and the test design. Section 2.0 details the basis of the PNNL QA Program as applied to the RPP-WTP quality requirements. Section 3.0 describes the test design, solution and resin preparations, equipment, process steps, and chemical and radiochemical analyses. Section 4.0 provides a summary of the experimental data and includes a discussion of the results of the Cs ion exchange kinetics testing. Section 5.0 describes the modeling of the Cs ion exchange results, Section 6.0 provides a list of conclusions obtained from this experimental work, Section 7.0 provides a list of pertinent references, Appendix A lists experimental conditions, and Appendix B displays the analytical data. 



\subsection{Quality Assurance}

The PNNL Quality Assurance (QA) Program is based on the requirements defined in the U.S. Department of Energy Order 414.1D, Quality Assurance, and 10 CFR 830, Energy/Nuclear Safety Management, and Subpart A-Quality Assurance Requirements (a.k.a. the Quality Rule). PNNL has chosen to implement the following consensus standards in a graded approach:

- ASME NQA-1-2000, Quality Assurance Requirements for Nuclear Facility Applications, Part 1, Requirements for Quality Assurance Programs for Nuclear Facilities.

- ASME NQA-1-2000, Part II, Subpart 2.7, Quality Assurance Requirements for Computer Software for Nuclear Facility Applications.

- ASME NQA-1-2000, Part IV, Subpart 4.2, Graded Approach Application of Quality Assurance Requirements for Research and Development.

The procedures necessary to implement the requirements are documented through PNNL's “How Do I...?” (HDI $\left.{ }^{(a)}\right)$.

The Waste Treatment Plant Support Project (WTPSP) implements an NQA-1-2000 Quality Assurance Program, graded on the approach presented in NQA-1-2000, Part IV, Subpart 4.2. The WTPSP Quality Assurance Manual (QA-WTPSP-0002) describes the technology life cycle stages under the WTPSP Quality Assurance Plan (QA-WTPSP-0001). The technology life cycle includes the progression of technology development, commercialization, and retirement in process phases of basic and applied research and development $(\mathrm{R} \& \mathrm{D})$, engineering and production and operation until process completion. The life cycle is characterized by flexible and informal quality assurance activities in basic research, which becomes more structured and formalized through the applied R\&D stages.

The work described in this report has been completed under the QA technology level of Applied Research. WTPSP addresses internal verification and validation activities by conducting an Independent Technical Review of the final data report in accordance with WTPSP's procedure QA-WTPSP-601, Document Preparation and Change. This review verifies that the reported results are traceable, that inferences and conclusions are soundly based, and that the reported work satisfies the test plan objectives.

Section 5.0 is for information only. The work described in this section uses a commercially available software program (VERSE-LC) in order to model the kinetic experiments. However, the software was not added to the approved software list under the QA program and thus, despite the technical validity of the work presented in this section, must be considered for information only.

(a) System for managing the delivery of PNNL policies, requirements, and procedures. 



\subsection{Experimental}

This section summarizes the SRF resin, resin preparation, simple simulant preparation, ion exchange system, and solution processing. Detailed laboratory test instructions were provided by internal documentation. . (a,b,d,e) Data and observations were recorded on photocopied datasheets and the printed test instruction. Experimental conditions and analytical data are provided in Appendix A and Appendix B, respectively.

\subsection{Loading Solution Preparation}

The small-column loading kinetics testing task was performed using several non-radioactive aqueous solutions for loading the SRF resin. These loading simulant compositions (Table 3.1) were provided by BNI as documented in Test Specification, RF Resin Cesium Removal with Expanded Load and Elution Conditions (Lehrman 2010). The Na, Cs, Al, and $\mathrm{OH}$ concentrations were within the ranges expected for aqueous waste feeds to the PTF. The nominal Na concentration was selected to be between $2 \underline{\mathrm{M}}$ and $8 \underline{\mathrm{M}}$, and the nominal Cs concentration was selected to be between $1.4 \mathrm{E}-05 \underline{\mathrm{M}}$ and 5.8E-05 $\underline{\mathrm{M}}$. No K was included in the simulant. The nominal free $\mathrm{OH}$ concentration was selected to be between $0.47 \underline{\mathrm{M}}$ and $4 \underline{\mathrm{M}}$, and the $\mathrm{Al}$ concentration was selected to be between $0.0325 \underline{\mathrm{M}}$ and $0.334 \underline{\mathrm{M}}$, approximately $90 \%$ of the solubility limit. The $\mathrm{NaCl}$ was only used to obtain the correct level of $\mathrm{Na}$ in the feed without adding more nitrate. The $\mathrm{Cl}$ level exceeded the contract amount. An evaluation of the impact of the higher concentration on kinetics was not conducted. These simple, loading simulants were not selected to represent any particular Hanford tank waste type.

Approximately 1 liter of each simple, loading simulant solution was prepared. All chemicals were added to the bottle based on weight $( \pm 0.1 \mathrm{~g})$ and were within $0.1 \%$ of the target. The density of the loading simulants ranged from $1.086 \mathrm{~g} / \mathrm{mL}$ to $1.371 \mathrm{~g} / \mathrm{mL}$ using a $10-\mathrm{mL}$ pycnometer. A new 1-liter batch of simulant was prepared as needed.

(a) RL Russell. 2010. Simulant Preparation for Ion Exchange Kinetics Testing. TI-WTPSP-024, Rev. 0, Pacific Northwest National Laboratory, Richland, Washington.

(b) RL Russell. 2010. Small Column SRF Ion Exchange Kinetics Testing. TI-WTPSP-026, Rev 0, Pacific Northwest National Laboratory, Richland, Washington.

(c) RL Russell. 2011. Small Column SRF Ion Exchange Kinetics Testing Set 2. TI-WTPSP-029, Rev 0, Pacific Northwest National Laboratory, Richland, Washington.

(d) RL Russell. 2011. Batch Contact Elution Temperature Effect on Resin Tests. TI-WTPSP-030, Rev. 0, Pacific Northwest National Laboratory, Richland, Washington.

(e) RL Russell. 2011. Small Column SRF Ion Exchange Organic Impact Testing. TI-WTPSP-042, Rev 0, Pacific Northwest National Laboratory, Richland, Washington. 
Table 3.1. Planned Stock Simulant Solutions for Cesium Ion Exchange Loading

\begin{tabular}{|c|c|c|c|c|c|c|c|}
\hline & Stock ID No. ${ }^{(a)}$ & 2A05 & 2A10 & $5 B 17$ & $8 \mathrm{C} 20$ & 8D40 & 8E40 \\
\hline \multicolumn{8}{|c|}{ Species $(g / L)$} \\
\hline & $\mathrm{NaOH}(\mathrm{s})$ & 23.8969 & 48.0705 & 80.4969 & 96.5788 & 200.0953 & 200.0953 \\
\hline & $\mathrm{Al}\left(\mathrm{NO}_{3}\right)_{3} \cdot 9 \mathrm{H}_{2} \mathrm{O}(\mathrm{s})$ & 12.1878 & 25.2406 & 43.2541 & 51.8502 & 125.3902 & 125.3902 \\
\hline & $\mathrm{NaNO}_{3}(\mathrm{~s})$ & 48.3798 & 39.5075 & 112.2604 & 474.7472 & 254.7639 & 254.7620 \\
\hline & $\mathrm{NaCl}(\mathrm{s})$ & 48.7014 & 19.4809 & 97.4026 & 0.0000 & 0.0000 & 0.0000 \\
\hline & $\mathrm{CsNO}_{3}(\mathrm{~s})$ & 0.0027 & 0.0027 & 0.0047 & 0.0057 & 0.0074 & 0.0113 \\
\hline \multicolumn{8}{|c|}{ Species $(\underline{\mathrm{M}})$} \\
\hline & $\mathrm{NaOH}(\mathrm{s})$ & 0.5975 & 1.2018 & 2.0126 & 2.4146 & 5.0027 & 5.0027 \\
\hline & $\mathrm{Al}\left(\mathrm{NO}_{3}\right)_{3} \cdot 9 \mathrm{H}_{2} \mathrm{O}(\mathrm{s})$ & 0.0325 & 0.0673 & 0.1153 & 0.1382 & 0.3342 & 0.3342 \\
\hline & $\mathrm{NaNO}_{3}(\mathrm{~s})$ & 0.5692 & 0.4648 & 1.3207 & 5.5854 & 2.9973 & 2.9973 \\
\hline & $\mathrm{NaCl}(\mathrm{s})$ & 0.8333 & 0.3333 & 1.6667 & 0.0000 & 0.0000 & 0.0000 \\
\hline & $\mathrm{CsNO}_{3}(\mathrm{~s})$ & $1.4 \mathrm{E}-05$ & $1.4 \mathrm{E}-05$ & $2.4 \mathrm{E}-05$ & 2.9E-05 & $3.8 \mathrm{E}-05$ & $5.8 \mathrm{E}-05$ \\
\hline \multicolumn{8}{|c|}{ Composition (M) } \\
\hline & $\mathrm{Na}^{(\mathrm{b})}$ & 2.0000 & 2.0000 & 5.0000 & 8.0000 & 8.0000 & 8.0000 \\
\hline & $\mathrm{Al}^{(\mathrm{c})}$ & 0.0325 & 0.0673 & 0.1153 & 0.1382 & 0.3342 & 0.3342 \\
\hline & Cs & $1.4 \mathrm{E}-05$ & $1.4 \mathrm{E}-05$ & 2.4E-05 & 2.9E-05 & 3.8E-05 & 5.8E-05 \\
\hline & OH-Total $^{(\mathrm{d})}$ & 0.5975 & 1.2018 & 2.0126 & 2.4146 & 5.0027 & 5.0027 \\
\hline & OH-Free ${ }^{(\mathrm{d})}$ & 0.4675 & 0.9327 & 1.5514 & 1.8618 & 3.6658 & 3.6658 \\
\hline & $\mathrm{NO}_{3}$ & 0.6667 & 0.6667 & 1.6667 & 6.0001 & 4.0001 & 4.0001 \\
\hline & $\mathrm{Cl}^{(\mathrm{e})}$ & 0.8333 & 0.3333 & 1.6667 & 0.0000 & 0.0000 & 0.0000 \\
\hline \multicolumn{8}{|c|}{ Ratios (mol/mol) } \\
\hline & Initial Na/Cs & $1.43 E+05$ & $1.43 \mathrm{E}+05$ & $2.08 E+05$ & $2.76 \mathrm{E}+05$ & $2.11 \mathrm{E}+05$ & $1.38 \mathrm{E}+05$ \\
\hline & $\mathrm{Na} / \mathrm{Al}$ & 61.5603 & 29.7253 & 43.3651 & 57.8811 & 23.9344 & 23.9344 \\
\hline & $\mathrm{Na} / \mathrm{NO}_{3}$ & 3.0000 & 3.0000 & 3.0000 & 1.3333 & 2.0000 & 2.0000 \\
\hline & $\mathrm{Na} / \mathrm{OH}_{\text {Total }}$ & 3.3475 & 1.6641 & 2.4844 & 3.3131 & 1.5991 & 1.5991 \\
\hline & $\mathrm{Na} / \mathrm{OH}_{\text {Free }}$ & 4.2780 & 2.1443 & 3.2230 & 4.2970 & 2.1824 & 2.1824 \\
\hline & Density $(\mathrm{g} / \mathrm{mL})$ & 1.086 & 1.087 & 1.211 & 1.371 & 1.344 & 1.348 \\
\hline $\begin{array}{l}\text { (b) } \\
\text { (c) } \\
\text { (d) } \\
\text { (e) }\end{array}$ & $\begin{array}{l}1^{\text {st }} \text { Position: Initia } \\
2^{\text {nd }} \text { Position: Initi } \\
3^{\text {rd }} \text { Position: NaO } \\
\text { Sodium varied as } \mathrm{p} \\
\text { Aluminum varied a } \\
\text { Hydroxide varied p } \\
\text { Chloride varied de }\end{array}$ & $\begin{array}{l}\text { Na } \underline{M}(2=2 . \\
\text { Cs } \underline{M}(\mathbf{A}=1 . \\
\underline{M} \text { Before } \mathrm{C} \\
\text { r experiment } \\
90 \% \text { solubil } \\
\text { r experimen } \\
\text { ending on } \mathrm{N} \text {. }\end{array}$ & $\begin{array}{l}\mathbf{5}=5.00, \mathbf{8} \\
\mathrm{E}-05, \mathbf{B}=2.4 \\
\text { bbsite }(\mathbf{0 5}=0 \\
\text { design }[\mathrm{Na}] \\
\text { y as calculat } \\
\text { design }[\mathrm{OH} \\
\mathrm{O}_{3} \text { added to }\end{array}$ & $\begin{array}{l}.00 \mathrm{M} \mathrm{Na}) \\
-05, \mathbf{C}=2.9 \mathrm{~F} \\
0, \mathbf{1 0}=1.00 \\
=2,5,0 \\
\text { otal from hydr } \\
\text { Free }=0.50, \\
\text { reep sodium }\end{array}$ & $\begin{array}{l}05, \mathbf{D}=3.8 \mathrm{E}- \\
7=1.67,20= \\
\mathrm{M} \text {. } \\
\text { xide per Li et } \\
00,1.67,2.0 \\
\text { t prescribed }\end{array}$ & $\begin{array}{l}5, \mathbf{E}=5.8 \mathrm{E}-0 \\
2.00, \mathbf{4 0}=4.00 \\
\text { al. (2005). } \\
\text { 4.00 } \underline{\mathrm{M}} \text {. } \\
\text { level. }\end{array}$ & \\
\hline
\end{tabular}

\subsection{Elution Solution Preparation}

Elution $\left(0.25 \underline{\mathrm{M}} \mathrm{HNO}_{3}\right)$ and acid conversion solutions $\left(0.50 \underline{\mathrm{M}} \mathrm{HNO}_{3}\right)$ were prepared by volumetric dilution of reagent-grade concentrated $\mathrm{HNO}_{3}$ with de-ionized (DI) water in a volumetric flask. 


\subsection{NaOH Solution Preparation}

$\mathrm{NaOH}$ solutions for SRF resin pretreatment $(1.0 \underline{\mathrm{M}})$, regeneration $(0.50 \underline{\mathrm{M}})$, and feed displacement $(0.10 \underline{\mathrm{M}})$ were prepared by weighing $( \pm 0.1 \mathrm{~g}) 50 \% \mathrm{NaOH}$ solution into volumetric flasks and diluting to volume using DI water.

\subsection{Spherical RF Resin}

The SRF resin used in these tests was from existing stock (Microbeads, Skedsmokorset, Norway, Lot Number 5E-370/641) that had been stored at PNNL for more than 4 years. The resin had been stored in the $\mathrm{H}^{+}$-form in water under $\mathrm{N}_{2}$ in sealed 2-L plastic bottles. A small $(\sim 3 \mathrm{~mm})$ layer of the resin was dark brown, indicating possible oxidative degradation, in contrast to the orange color of the remaining bulk. Upon opening the container, the top layer of resin was removed by vacuum sluicing and disposed of without use. The remaining resin was thoroughly mixed, and a representative sample was removed for use in the experiment using a coring technique consistent with the American Society for Testing and Materials (ASTM) Method 2687, Standard Practice for Sampling Particulate Ion-Exchange Materials (ASTM 2001). Even after vacuum sluicing of the top, darker brown layer and mixing the remaining material, a small fraction $(<1 \%)$ of the sampled resin still exhibited the darker brown color as shown in Figure 3.1. The small fraction was deemed inconsequential and no further separation was attempted. Figure 3.2 displays an example visible light microscopy image of the SRF resin.

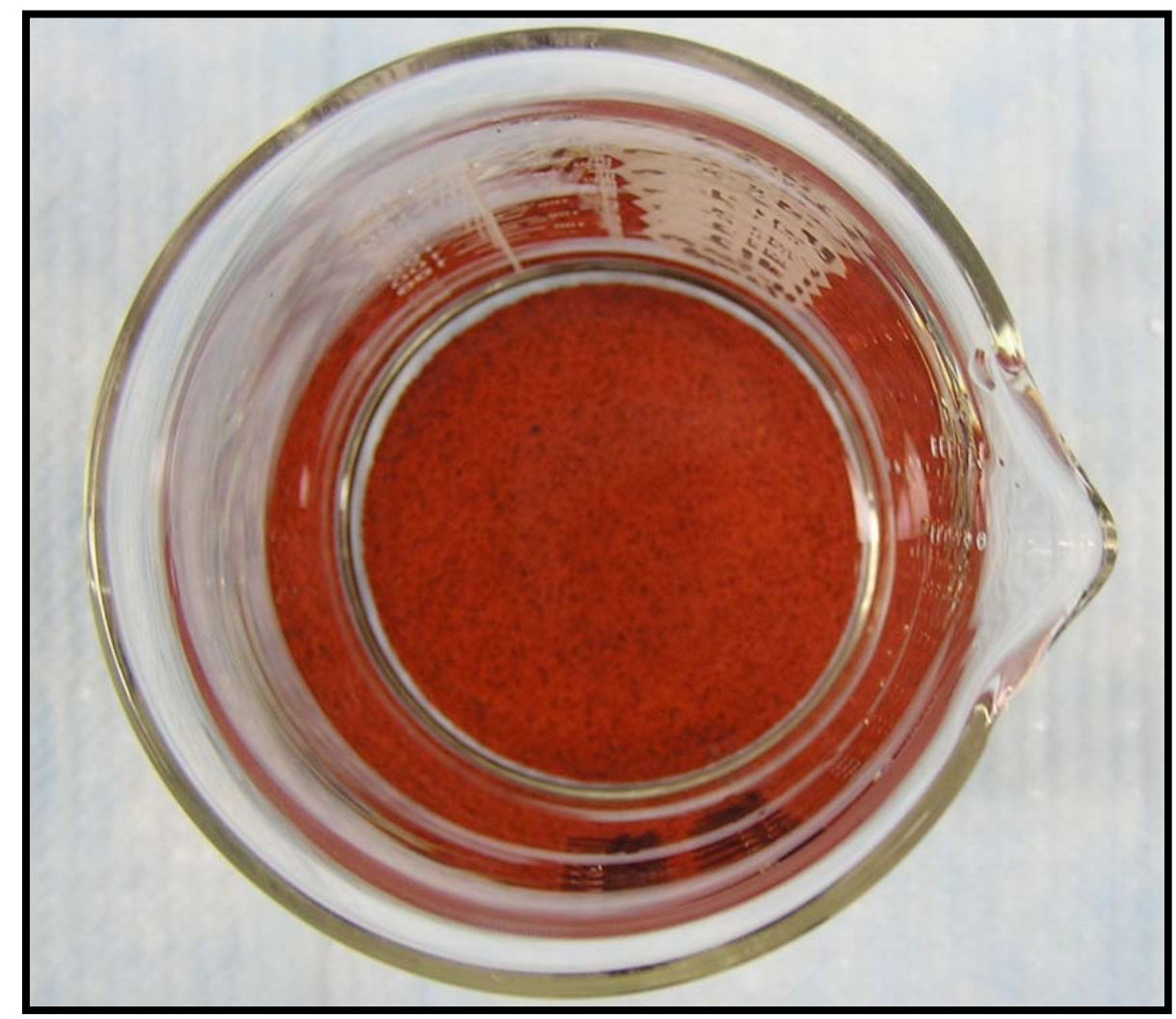

Figure 3.1. Representative SRF Resin Sample for Column Testing Showing Darkened Resin Beads 


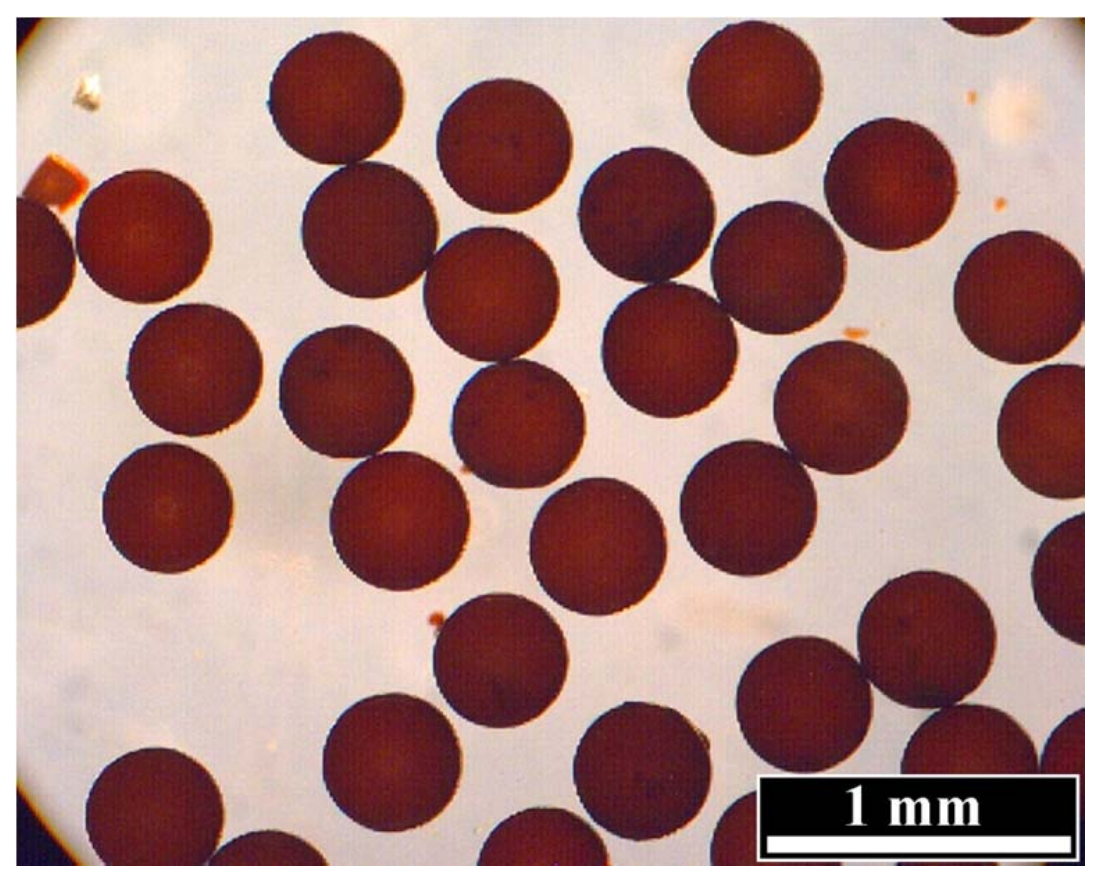

Figure 3.2. Spherical Resorcinol-Formaldehyde Resin

\subsection{Resin Pretreatment Processing}

Approximately $10.7 \mathrm{~mL}$ of the resin $\left(\mathrm{H}^{+}\right.$-form) was dispensed into five 25 - $\mathrm{mL}$ graduated cylinders and allowed to settle for more than 30 minutes to a constant volume during tapping/vibration. The resin sub-samples were then transferred into 100 -mL glass beakers. One was used for the kinetics loading column experiments. The remaining four sub-samples, two in the $\mathrm{H}^{+}$-form and two that had been converted to the $\mathrm{Na}^{+}$-form, were dried to a constant mass at $50^{\circ} \mathrm{C}$ in a vacuum oven. Constant mass was defined as $<0.1 \%$ mass variation over two consecutive measurements taken at an interval of at least $7 \mathrm{~h}$. The average density was calculated to be $0.456 \mathrm{~g} / \mathrm{mL}$ (mass of dried $\mathrm{H}^{+}$-form resin per $\mathrm{mL}$ of settled $\mathrm{H}^{+}$-form resin under water in a 25 -mL graduated cylinder) and is consistent with values reported previously (Fiskum et al. 2006b; Fiskum et al. 2006c).

Figure 3.3 displays a comparison of the $\mathrm{H}^{+}$- and $\mathrm{Na}^{+}$-forms of the SRF resin. The left-most cylinder contains the orange-colored, $\mathrm{H}^{+}$-form of the resin $(\sim 10.7 \mathrm{~mL})$, while the three right-most cylinders contain the final, dark black/brown-colored, pretreated $\mathrm{Na}^{+}$-form of the resin $(\sim 15.7 \mathrm{~mL})$. The volume of the initial $\mathrm{H}^{+}$-form resin aliquot expanded slightly more than the targeted 15 -mL volume that was based on previous reports (Fiskum et al. 2006a; Fiskum et al. 2006b).

The overall resin bulk pretreatment and column pretreatment steps are shown in Table 3.2 and are consistent with previous testing $^{(\mathrm{a})}$ (Arm and Blanchard 2004; Fiskum et al. 2006b; Fiskum et al. 2006c). The bulk pretreatment processes utilized a full resin expansion/contraction cycle in an open beaker format, which allows for full expansion of the resin without being constrained inside the ion exchange column (Fiskum et al. 2007).

(a) CA Nash and CE Duffey. August 17, 2004. Hanford RPP-WTP Alternate Resin Program-Protocol P1-RF: Spherical Resin Sampling from Containers, Resin Pretreatment, F-Factor, and Resin Loading to Column, WTP 097893, Savannah River National Laboratory. 


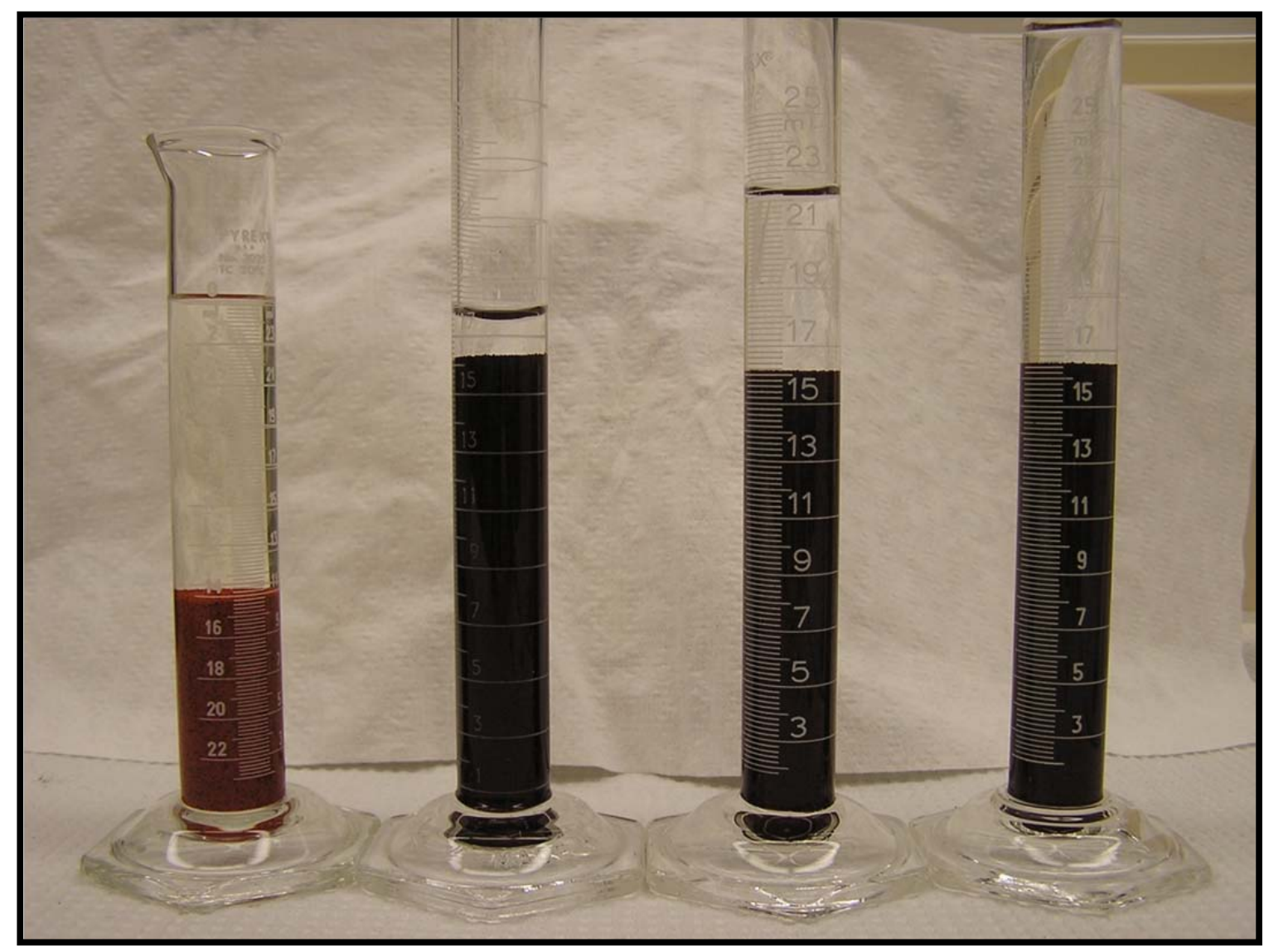

Figure 3.3. SRF Resin Dispensed for Column Experiments. Left column in $\mathrm{H}^{+}$-form and others in $\mathrm{Na}^{+}$-form.

Following bulk pretreatment, the $\mathrm{Na}^{+}$-form resin was slurry-transferred into the ion exchange column, rinsed with DI water, and converted into the $\mathrm{H}^{+}$-form with up-flow $0.5 \underline{\mathrm{M}} \mathrm{HNO}_{3}$. The resin was then re-converted back into the $\mathrm{Na}^{+}$-form with up-flow $0.5 \underline{\mathrm{M}} \mathrm{NaOH}$.

Table 3.2. Ion Exchange Pretreatment and Process Steps

\begin{tabular}{|c|c|c|c|c|c|}
\hline Process/Pretreatment Step & Solution & Volume & Time & Mixing & Flowrate \\
\hline \multicolumn{6}{|c|}{ Bulk Pretreatment } \\
\hline Water Rinse & DI Water & $5 R V^{(a)}$ & $30 \mathrm{~min}$ & Swirl $^{(b)}$ & $\mathrm{NA}^{(\mathrm{c})}$ \\
\hline Resin Expansion & $1 \underline{\mathrm{M} \mathrm{NaOH}}$ & $5 \mathrm{RV}$ & $1 \mathrm{~h}$ & Swirl & NA \\
\hline Resin Expansion & $1 \underline{\mathrm{M} \mathrm{NaOH}}$ & $5 \mathrm{RV}$ & $>12 \mathrm{~h}$ & Soak & NA \\
\hline Water Rinse $-1^{\text {st }}$ & DI Water & $3 R V$ & $30 \mathrm{~min}$ & Swirl & NA \\
\hline Water Rinse $-2^{\text {nd }}$ & DI Water & $3 R V$ & $30 \mathrm{~min}$ & Swirl & NA \\
\hline Water Rinse $-3^{\text {rd }}$ & DI Water & $3 R V$ & $30 \mathrm{~min}$ & Swirl & NA \\
\hline Resin Conversion & $0.5 \underline{\mathrm{M}} \mathrm{HNO}_{3}$ & $10 \mathrm{RV}$ & $2 \mathrm{~h}$ & Swirl & NA \\
\hline Water Rinse $-4^{\text {th }}$ & DI Water & $3 \mathrm{RV}$ & $1 \mathrm{~min}$ & Swirl & NA \\
\hline Resin Expansion & $1 \underline{\mathrm{M} \mathrm{NaOH}}$ & $10 \mathrm{RV}$ & $1 \mathrm{~h}$ & Swirl & NA \\
\hline Water Rinse $-5^{\text {th }}$ & DI Water & $10 \mathrm{RV}$ & $1 \mathrm{~min}$ & Swirl & NA \\
\hline
\end{tabular}


Table 3.2. Ion Exchange Pretreatment and Process Steps (contd)

\begin{tabular}{|c|c|c|c|c|c|c|}
\hline & Process/Pretreatment Step & Solution & Volume & Time & Mixing & Flowrate \\
\hline \multicolumn{7}{|c|}{ Column Pretreatment } \\
\hline & Water Rinse & DI Water & $7.5 \mathrm{BV}^{(\mathrm{d})}$ & $2.5 \mathrm{~h}$ & Flow & $3 \mathrm{BV} / \mathrm{h}$ \\
\hline & Acid Rinse & $0.5 \underline{\mathrm{M}} \mathrm{HNO}_{3}$ & $8 \mathrm{BV}$ & $2.7 \mathrm{~h}$ & Flow & $3 \mathrm{BV} / \mathrm{h}$ \\
\hline & Water Rinse & DI Water & $3 \mathrm{BV}$ & $1 \mathrm{~h}$ & Flow & $3 \mathrm{BV} / \mathrm{h}$ \\
\hline & Feed Prep & $0.5 \underline{\mathrm{M}} \mathrm{NaOH}$ & $6 \mathrm{BV}$ & $2 \mathrm{~h}$ & Flow & $3 \mathrm{BV} / \mathrm{h}$ \\
\hline \multicolumn{7}{|c|}{ Column Loading/Elute } \\
\hline & Simulant & Simulant & variable & $10 \mathrm{~h}$ & Flow & variable \\
\hline & Feed Displaced & $0.1 \underline{\mathrm{M}} \mathrm{NaOH}$ & $7.5 \mathrm{BV}$ & $2.5 \mathrm{~h}$ & Flow & $3 \mathrm{BV} / \mathrm{h}$ \\
\hline & Water Rinse & DI Water & $7.5 \mathrm{BV}$ & $2.5 \mathrm{~h}$ & Flow & $3 \mathrm{BV} / \mathrm{h}$ \\
\hline & Neutralization & $0.5 \underline{\mathrm{M}} \mathrm{HNO}_{3}$ & $3 \mathrm{BV}$ & $1 \mathrm{~h}$ & Flow & $3 \mathrm{BV} / \mathrm{h}$ \\
\hline & Acid Elution & Variable & $28 \mathrm{BV}$ & $10 \mathrm{~h}$ & Flow & $2.8 \mathrm{BV} / \mathrm{h}$ \\
\hline & Water Rinse & DI Water & $3 \mathrm{BV}$ & $1 \mathrm{~h}$ & Flow & $3 \mathrm{BV} / \mathrm{h}$ \\
\hline & Regeneration & $0.5 \underline{\mathrm{M} \mathrm{NaOH}}$ & $6 \mathrm{BV}$ & $2 \mathrm{~h}$ & Flow & $3 \mathrm{BV} / \mathrm{h}$ \\
\hline \multicolumn{7}{|c|}{$\begin{array}{l}\text { Resin volume (RV). } \\
\text { Gently swirling by hand every } 10 \text { min. } \\
\text { Not applicable (NA). } \\
\text { Bed volume (BV). }\end{array}$} \\
\hline
\end{tabular}

\subsection{Ion Exchange Column System}

The kinetics experimental setup was based on a differential column concept described in detail previously (Duffey et al. 2003). This concept uses a thin resin bed exposed to a feed solution with nearly uniform uptake throughout the bed. In essence, this setup is designed to determine resin adsorption properties of a differential cross-sectional area of an ion exchange column. Implementation requires a controlled flow of liquid through the resin bed, a controlled temperature throughout the system, and continuous homogenization of the liquid phase. A schematic of the kinetics experimental setup is shown in Figure 3.4 with an actual picture of the system shown in Figure 3.5.

Resin test samples were placed into the jacketed column. The resin was held in place between 200 mesh stainless steel screens. The simulant was fed through the column in an up-flow manner to minimize the amount of air initially in the system. The entire system remained closed with the exception of a small vent/sampling port. The target resin bed path length and diameter were $10.1 \mathrm{~mm}$ and $15.0 \mathrm{~mm}$ respectively, giving a target resin volume of $1.8 \mathrm{~mL}$, which is similar to those reported by Duffey et al. (2003).

The simulant feed was held within a capped $125-\mathrm{mL}$ polyethylene bottle and was continually stirred with a 1-inch PTFE stir bar. Approximately 2-mL samples were taken from the bottle at $0,6,12,18,24$, $36,48,60,80,120,180,240$, and 600 minutes using a 10-mL plastic syringe with a 4-inch \#18 stainless steel needle. The feed bottle was wrapped in a heat jacket that was temperature controlled using a thermocouple and temperature controller. These experiments were conducted with a Stepdos reduced pulsation diaphragm-metering pump (KNF Neuberger, Trenton, NJ) with a PVDF (polyvinylidene fluoride) head, FFPM (perfluorinated elastomer) valves and gaskets, and PTFE (polytetrafluoroethylene)-coated diaphragm. The jacketed column temperature was controlled using a Haake DC-5 (Thermo Electron, Newington, NH) recirculating chiller/heater. 


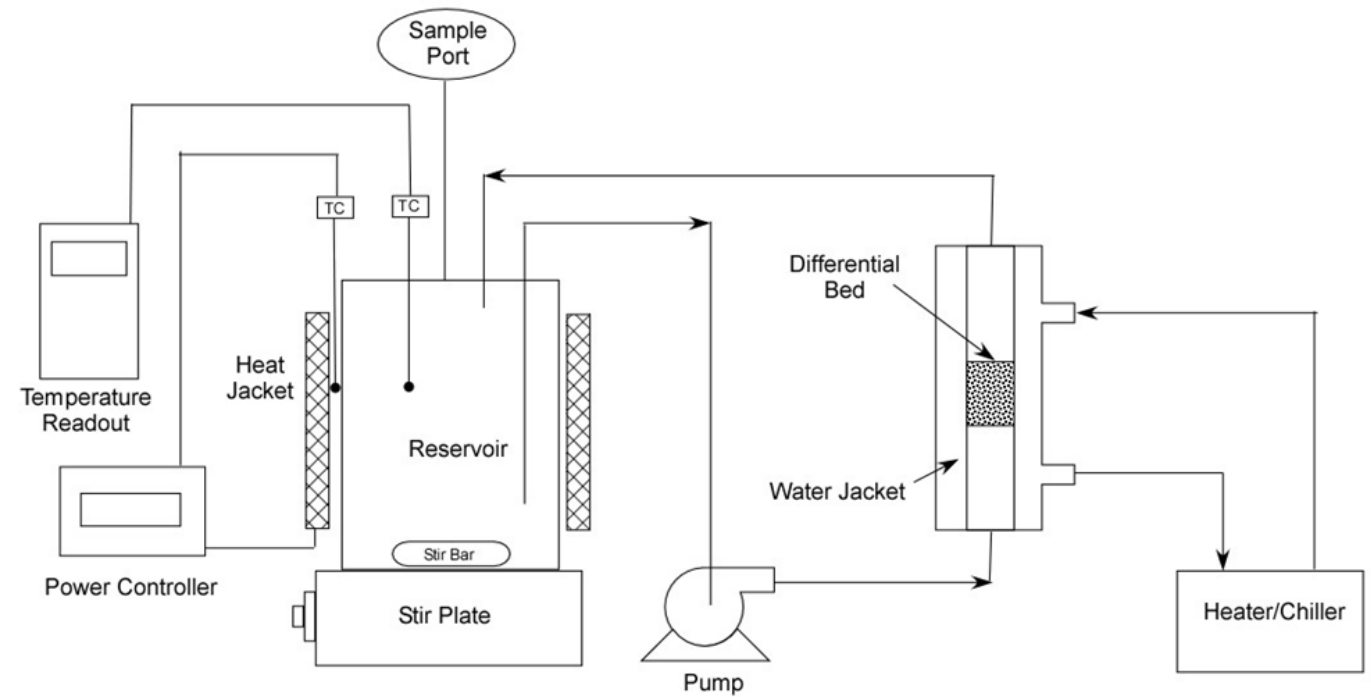

Figure 3.4. Differential Column Ion Exchange Kinetics Schematic

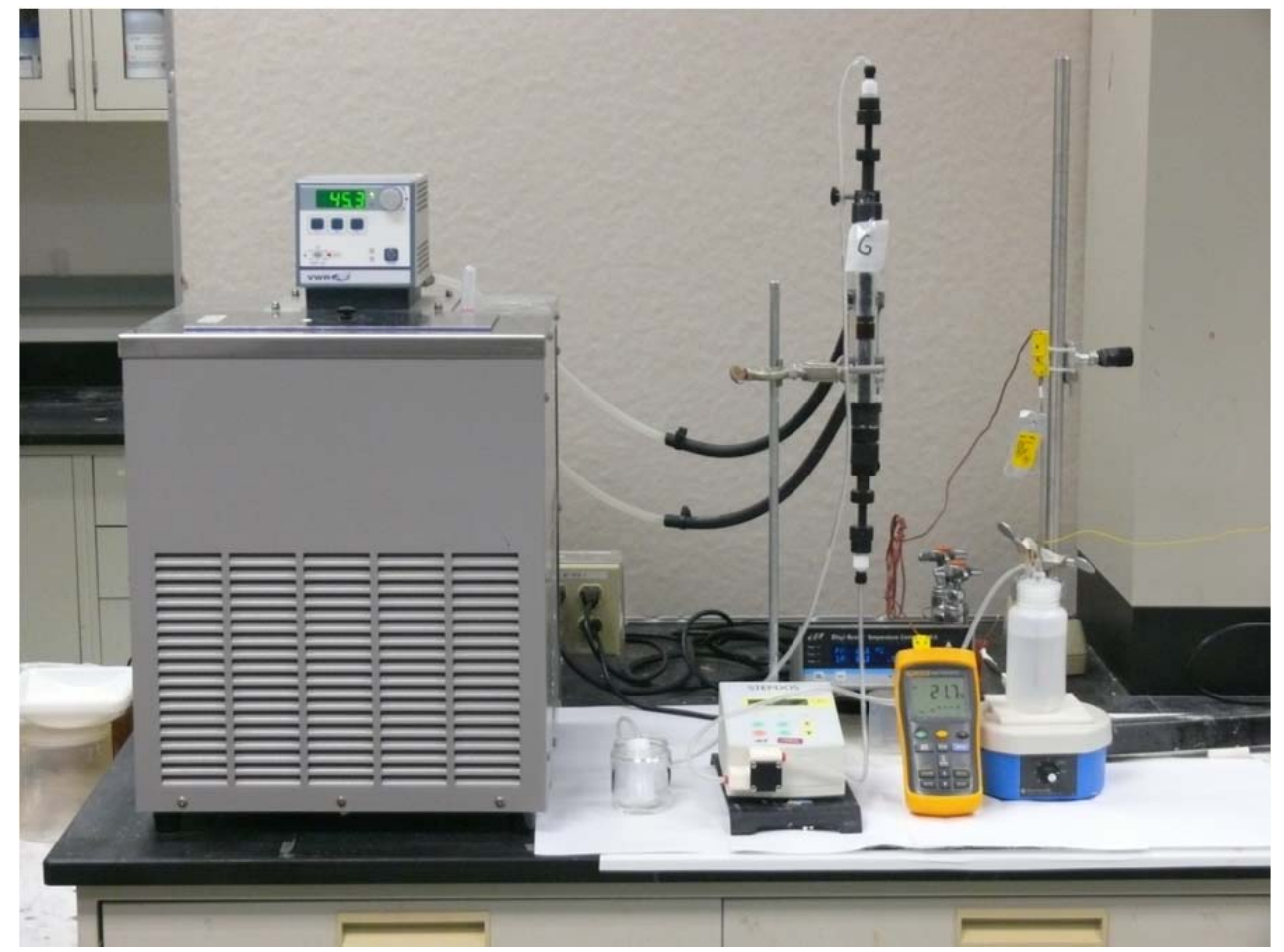

Figure 3.5. Ion Exchange Kinetics Testing Apparatus

\subsection{Column Testing Experimental Procedure}

A series of column loading and elution cycles was completed as detailed in Table 3.3. The composition of the simulants used is shown in Table 3.1. The general column processing steps (e.g., pretreatment, loading, feed displacement, rinsing, elution, rinsing, and regeneration) are described in Table 3.3. 
Table 3.3. Cesium Loading Kinetics Experimental Design

\begin{tabular}{|c|c|c|c|c|c|c|c|c|c|c|c|c|}
\hline \multirow[b]{2}{*}{ Run ID ${ }^{(a)}$} & \multicolumn{7}{|c|}{ Ion Exchange Kinetic Loading Conditions } & \multicolumn{5}{|c|}{ Column Elution Conditions } \\
\hline & $\underset{(\mathrm{b}, \mathrm{c})}{\mathrm{h}}$ & $\begin{array}{c}\mathrm{T} \\
{ }^{\circ} \mathrm{C}\end{array}$ & $\begin{array}{l}\mathrm{Cs}^{(\mathrm{d})} \\
\mathrm{C} / \mathrm{C}_{0}\end{array}$ & $\begin{array}{c}\text { Flow } \\
\text { Velocity } \\
\mathrm{cm} / \mathrm{min}\end{array}$ & $\begin{array}{l}\mathrm{Na} \\
\underline{\mathrm{M}}\end{array}$ & $\begin{array}{c}\mathrm{OH} \\
\underline{\mathrm{M}}\end{array}$ & $\begin{array}{l}\text { Initial } \\
\text { Cs, } \underline{M}\end{array}$ & $\begin{array}{c}\mathrm{T} \\
{ }^{\circ} \mathrm{C}\end{array}$ & $\begin{array}{c}\text { BV } \\
\text { (e) }\end{array}$ & $\frac{\mathrm{BV}}{\mathrm{h}^{(\mathrm{f})}}$ & $\begin{array}{c}\mathrm{HNO}_{3} \\
\underline{\mathrm{M}}^{(\mathrm{e})}\end{array}$ & $\begin{array}{l}\mathrm{Cs} \\
\mathrm{M}\end{array}$ \\
\hline Test-1-A-1 & 10 & 45 & 0.52 & 6 & 5.0 & 1.67 & $2.4 \mathrm{E}-05$ & 25 & 25 & 2.8 & 0.25 & 0 \\
\hline Test-1-A-2 & 10 & 45 & 0.52 & 6 & 8.0 & 2.0 & 2.9E-05 & 25 & 25 & 2.8 & 0.25 & 0 \\
\hline Test-1-A-3 & 10 & 45 & 0.52 & 4 & 8.0 & 2.0 & 2.9E-05 & 25 & 25 & 2.8 & 0.25 & 0 \\
\hline Test-1-A-4 & 10 & 45 & 0.52 & 6 & 8.0 & 4.0 & 5.8E-05 & 25 & NA & NA & NA & 0 \\
\hline Test-1-A-4B & 720 & 45 & 0.52 & $<0.1^{(\mathrm{g})}$ & 8.0 & 4.0 & $5.8 \mathrm{E}-05$ & 25 & 25 & 2.8 & 0.25 & 0 \\
\hline Test-1-A-5 & 10 & 45 & 0.52 & 6 & 5.0 & 1.67 & 2.4E-05 & 25 & 25 & 2.8 & 0.25 & 0 \\
\hline Test-1-B-1 & 10 & 50 & 0.52 & 6 & 5.0 & 1.67 & $2.4 \mathrm{E}-05$ & 25 & 25 & 2.8 & 0.25 & 0 \\
\hline Test-1-B-2 & 10 & 50 & 0.52 & 8 & 2.0 & 0.50 & $1.4 \mathrm{E}-05$ & 25 & 25 & 2.8 & 0.25 & 0 \\
\hline Test-1-B-3 & 10 & 50 & 0.52 & 4 & 2.0 & 0.50 & $1.4 \mathrm{E}-05$ & 25 & 25 & 2.8 & 0.25 & 0 \\
\hline Test-1-B-4 & 10 & 50 & 0.52 & 4 & 8.0 & 4.0 & 2.9E-05 & 25 & NA & NA & NA & 0 \\
\hline Test-1-B-4B & 720 & 65 & 0.52 & $<0.1^{(\mathrm{g})}$ & 8.0 & 4.0 & 2.9E-05 & 25 & 25 & 2.8 & 0.25 & 0 \\
\hline Test-1-B-5 & 10 & 50 & 0.52 & 6 & 5.0 & 1.67 & 2.4E-05 & 25 & 25 & 2.8 & 0.25 & 0 \\
\hline Test-1-C-1 & 10 & 50 & 0.52 & 6 & 5.0 & 1.67 & $2.4 \mathrm{E}-05$ & 25 & 25 & 2.8 & 0.25 & 0 \\
\hline Test-1-C-2 & 10 & 50 & 0.52 & 8 & 2.0 & 1.0 & $1.4 \mathrm{E}-05$ & 25 & 25 & 2.8 & 0.25 & 0 \\
\hline Test-1-C-3 & 10 & 50 & 0.52 & 4 & 2.0 & 1.0 & $1.4 \mathrm{E}-05$ & 25 & 25 & 2.8 & 0.25 & 0 \\
\hline Test-1-C-4 & 10 & 50 & 0.52 & 8 & 8.0 & 4.0 & 3.8E-05 & 25 & NA & NA & NA & 0 \\
\hline Test-1-C-4B & 720 & 75 & 0.52 & $<0.1^{(\mathrm{g})}$ & 8.0 & 4.0 & $3.8 \mathrm{E}-05$ & 25 & 25 & 2.8 & 0.25 & 0 \\
\hline Test-1-C-5 & 10 & 50 & 0.52 & 6 & 5.0 & 1.67 & 2.4E-05 & 25 & 25 & 2.8 & 0.25 & 0 \\
\hline Test-1-D-1 & 10 & 25 & 0.52 & 6 & 5.0 & 1.67 & $2.4 \mathrm{E}-05$ & 25 & 25 & 2.8 & 0.25 & 0 \\
\hline Test-1-E-1 & 10 & 50 & 0.52 & 6 & 5.0 & 1.67 & 2.4E-05 & 25 & 25 & 2.8 & 0.25 & 0 \\
\hline Test-1-E-2 & 10 & 50 & 0.52 & 6 & 8.0 & 2.0 & 2.9E-05 & 25 & 25 & 2.8 & 0.25 & 0 \\
\hline Test-1-E-3 & 10 & 50 & 0.52 & 4 & 8.0 & 2.0 & 2.9E-05 & 25 & 25 & 2.8 & 0.25 & 0 \\
\hline Test-1-E-4 & 10 & 50 & 0.52 & 6 & 8.0 & 4.0 & 5.8E-05 & 25 & NA & NA & NA & 0 \\
\hline Test-1-E-4B & 720 & 50 & 0.52 & $<0.1^{(\mathrm{g})}$ & 8.0 & 4.0 & 5.8E-05 & 25 & 25 & 2.8 & 0.25 & 0 \\
\hline Test-1-E-5 & 10 & 50 & 0.52 & 6 & 5.0 & 1.67 & $2.4 \mathrm{E}-05$ & 25 & 25 & 2.8 & 0.25 & 0 \\
\hline Test-1-F-1 & 10 & 55 & 0.52 & 6 & 5.0 & 1.67 & 2.4E-05 & 25 & 25 & 2.8 & 0.25 & 0 \\
\hline Test-1-F-2 & 10 & 55 & 0.52 & 6 & 8.0 & 2.0 & 2.9E-05 & 25 & 25 & 2.8 & 0.25 & 0 \\
\hline Test-1-F-3 & 10 & 55 & 0.52 & 4 & 8.0 & 2.0 & 2.9E-05 & 25 & 25 & 2.8 & 0.25 & 0 \\
\hline Test-1-F-4 & 10 & 55 & 0.52 & 6 & 8.0 & 4.0 & 5.8E-05 & 25 & NA & NA & NA & 0 \\
\hline Test-1-F-4B & 720 & 55 & 0.52 & $<0.1^{(\mathrm{g})}$ & 8.0 & 4.0 & $5.8 \mathrm{E}-05$ & 25 & 25 & 2.8 & 0.25 & 0 \\
\hline Test-1-F-5 & 10 & 55 & 0.52 & 6 & 5.0 & 1.67 & $2.4 \mathrm{E}-05$ & 25 & 25 & 2.8 & 0.25 & 0 \\
\hline Test-1-G-1 & 10 & 60 & 0.52 & 6 & 5.0 & 1.67 & 2.4E-05 & 25 & 25 & 2.8 & 0.25 & 0 \\
\hline Test-1-G-2 & 10 & 60 & 0.52 & 6 & 8.0 & 2.0 & 2.9E-05 & 25 & 25 & 2.8 & 0.25 & 0 \\
\hline Test-1-G-3 & 10 & 60 & 0.52 & 4 & 8.0 & 2.0 & 2.9E-05 & 25 & 25 & 2.8 & 0.25 & 0 \\
\hline Test-1-G-4 & 10 & 60 & 0.52 & 6 & 8.0 & 4.0 & $5.8 \mathrm{E}-05$ & 25 & NA & NA & NA & 0 \\
\hline Test-1-G-4B & 720 & 60 & 0.52 & $<0.1^{(\mathrm{g})}$ & 8.0 & 4.0 & 5.8E-05 & 25 & 25 & 2.8 & 0.25 & 0 \\
\hline Test-1-G-5 & 10 & 60 & 0.52 & 6 & 5.0 & 1.67 & $2.4 \mathrm{E}-05$ & 25 & 25 & 2.8 & 0.25 & 0 \\
\hline
\end{tabular}

(a) Each test series (e.g., A, B, C, D, E, F and G) represented an independent ion exchange column that was loaded and eluted one or more times using the conditions listed. The exact BV of the ion exchange resin depended on the final construction of the apparatus but was 1 to $2 \mathrm{~mL}$.

(b) Resin loading was expected to require approximately $10 \mathrm{~h}$ to achieve kinetic equilibrium. Samples were collected periodically to define the cesium uptake curve (e.g., 0, 6, 12, 18, 24, 36, 48, 60, 80, 120, 180, 240, 600 min).

(c) The 10-h kinetics tests were completed at temperatures specified for each run. Six extended-duration (720 h) solution flow tests were completed at $45^{\circ}, 50^{\circ}, 55^{\circ}, 60^{\circ}, 65^{\circ}$ and $75^{\circ} \mathrm{C}$. Most of the extended run tests were aborted after $\sim 336$ hours due to resin degradation and column plugging.

(d) The total simulant solution volume was varied to target an expected loading of $0.52 \mathrm{C} \mathrm{C}_{0}$ where $\mathrm{C}_{\mathrm{o}}$ is the initial concentration.

(e) $\mathrm{BV}=$ Bed Volume. Elution with $0.25 \underline{\mathrm{M}} \mathrm{HNO}_{3}$ commenced after feed displacement (7.5 BV 0.1 $\left.\underline{\mathrm{M}} \mathrm{NaOH}\right)$ and water rinse (7.5 BV DI Water) solutions were passed through the column. A single elution composite sample was collected and analyzed.

(f) The flow rate for elution was expected to be approximately $2.8 \mathrm{BV} / \mathrm{h}$. The flow rate was approximately $5 \mathrm{~mL} / \mathrm{h}$ and the equivalent $\mathrm{BV} / \mathrm{h}$ varied slightly with the exact BV for each column.

(g) The actual flow velocity was limited by the pump configuration and was determined at the time of experimentation but was estimated to be approximately $0.08 \mathrm{~cm} / \mathrm{min}$. 
The ion exchange columns were loaded with simulant feed solution at temperatures of $25,45,50,55$, 60,65 , and $75 \pm 2{ }^{\circ} \mathrm{C}$. The solution was processed at various linear flow velocities $(4,6$, and $8 \mathrm{~cm} / \mathrm{min})$ as

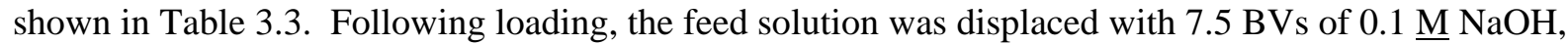
rinsed with $7.5 \mathrm{BVs}$ of DI water, and the resin was neutralized with $3 \mathrm{BVs}$ of $0.5 \underline{\mathrm{M} \mathrm{HNO}} 3$ at $3 \mathrm{BV} / \mathrm{h}$ as is outlined in Table 3.3.

The ion exchange columns were eluted with approximately $28 \mathrm{BVs}$ of $\mathrm{HNO}_{3}$ processed at $25^{\circ} \mathrm{C}$ and at 2.8 BV/h. As is shown in Table 3.3, the elution solution for each cycle was $0.25 \underline{\mathrm{M}} \mathrm{HNO}_{3}$. Following elution, the columns were rinsed with $3 \mathrm{BVs}$ of DI water and regenerated with $6 \mathrm{BVs} 0.5 \underline{\mathrm{M}} \mathrm{NaOH}$ at $3 \mathrm{BV} / \mathrm{h}$ before beginning the next loading cycle. Weights of each sample and the temperature of the simulant were recorded for each sampling.

Simulant samples were submitted to Southwest Research Institute (SwRI) for analysis. Analysis methods included inductively coupled plasma-mass spectroscopy (ICP-MS) for Cs, inductively coupled plasma-optical emission spectroscopy (ICP-OES) for $\mathrm{Na}$ and $\mathrm{Al}$, ion chromatography (IC) for anions and titration for $\mathrm{OH}$ analysis. Quality assurance and control procedures using blanks, duplicates, and spikes along with standard results for each analysis set are maintained in records and are not reported here.

\subsection{Batch Experiments}

Fresh SRF resin was contacted with $0.5 \underline{\mathrm{M}} \mathrm{HNO}_{3}$ while continually mixing on a shaker for 70 days at three different temperatures $\left(\sim 25^{\circ} \mathrm{C}, 45^{\circ} \mathrm{C}\right.$, and $\left.55^{\circ} \mathrm{C}\right)$. A fourth set of samples of fresh resin were contacted with DI water at $\sim 25^{\circ} \mathrm{C}$ as control samples while continually mixing on a shaker for 70 days. A ratio of 1:100 was used for all resin and solution mixtures ( $0.1 \mathrm{~g}$ resin in $10 \mathrm{~mL}$ solution). After 70 days, the resin was removed from the acid (or DI water), rinsed three times for 30 minutes each time with $10 \mathrm{~mL}$ of DI water and then contacted twice with $10 \mathrm{~mL}$ of $0.5 \mathrm{M} \mathrm{NaOH}$, once for an hour and then once for 24 hours, to convert the resin to the $\mathrm{Na}^{+}$-form. After the 24-hour $\mathrm{NaOH}$ contact, all of the resin was removed and contacted with $25 \mathrm{~mL}$ of the Cs loading solution (5 $\underline{\mathrm{M}} \mathrm{Na}, 1.67 \underline{\mathrm{M}} \mathrm{OH}, 0.12 \underline{\mathrm{M}} \mathrm{Al}, 1.67 \underline{\mathrm{M}}$ $\mathrm{Cl}, 1.67 \underline{\mathrm{M} \mathrm{NO}} \mathrm{N}_{3}$ and 2.4E-05 $\underline{\mathrm{M}} \mathrm{Cs}$ ). The experimental matrix is shown in Table 3.4. Analytical samples were collected at $0,1,4,10$, and 24 hours from individual batches of resin and loading solution to define the Cs uptake curve. Samples were filtered $\sim 10 \mathrm{~mL}$ of supernate from the sample bottle using a $0.45 \mu \mathrm{m}$ disposable syringe filter and placing it in the specified sample vial. Each test was performed in duplicate with a blank sample taken at 0 and 24 hours for the $25^{\circ} \mathrm{C}$ and $45^{\circ} \mathrm{C}$ tests. Simulant samples were submitted to SwRI for analysis. Analysis methods included ICP-MS for Cs, ICP-OES for Na and Al, IC for anions and titration for $\mathrm{OH}$ analysis. Quality assurance and control procedures using blanks, duplicates, and spikes along with standard results for each analysis set are maintained in records and are not reported here. 
Table 3.4. Batch Contact Elution Temperature Experimental Design

\begin{tabular}{|c|c|c|c|c|c|c|}
\hline Run ID & $\mathrm{h}$ & $\begin{array}{c}\mathrm{T} \\
{ }^{\circ} \mathrm{C} \\
\end{array}$ & $\begin{array}{l}\mathrm{HNO}_{3} \\
\text { Aged? }\end{array}$ & $\begin{array}{l}\mathrm{Na} \\
\underline{\mathrm{M}} \\
\end{array}$ & $\begin{array}{c}\mathrm{OH} \\
\underline{\mathrm{M}} \\
\end{array}$ & $\begin{array}{l}\text { Initial } \\
\text { Cs, } \underline{M}\end{array}$ \\
\hline Test-25-A-0 & 0 & 25 & $\bar{Y}$ & 5.0 & 1.67 & $2.4 \mathrm{E}-05$ \\
\hline Test-25-A-1 & 1 & 25 & $\mathrm{Y}$ & 5.0 & 1.67 & 2.4E-05 \\
\hline Test-25-A-4 & 4 & 25 & $\mathrm{Y}$ & 5.0 & 1.67 & 2.4E-05 \\
\hline Test-25-A-10 & 10 & 25 & $\mathrm{Y}$ & 5.0 & 1.67 & 2.4E-05 \\
\hline Test-25-A-24 & 24 & 25 & $\mathrm{Y}$ & 5.0 & 1.67 & 2.4E-05 \\
\hline Test-25-B-0 & 0 & 25 & $\mathrm{Y}$ & 5.0 & 1.67 & 2.4E-05 \\
\hline Test-25-B-1 & 1 & 25 & $\mathrm{Y}$ & 5.0 & 1.67 & 2.4E-05 \\
\hline Test-25-B-4 & 4 & 25 & $\mathrm{Y}$ & 5.0 & 1.67 & 2.4E-05 \\
\hline Test-25-B-10 & 10 & 25 & $\mathrm{Y}$ & 5.0 & 1.67 & $2.4 \mathrm{E}-05$ \\
\hline Test-25-B-24 & 24 & 25 & $\mathrm{Y}$ & 5.0 & 1.67 & 2.4E-05 \\
\hline Test-25-C-0 & 0 & 25 & $\mathrm{~N}$ & 5.0 & 1.67 & 2.4E-05 \\
\hline Test-25-C-1 & 1 & 25 & $\mathrm{~N}$ & 5.0 & 1.67 & 2.4E-05 \\
\hline Test-25-C-4 & 4 & 25 & $\mathrm{~N}$ & 5.0 & 1.67 & 2.4E-05 \\
\hline Test-25-C-10 & 10 & 25 & $\mathrm{~N}$ & 5.0 & 1.67 & 2.4E-05 \\
\hline Test-25-C-24 & 24 & 25 & $\mathrm{~N}$ & 5.0 & 1.67 & 2.4E-05 \\
\hline Test-25-D-0 & 0 & 25 & $\mathrm{~N}$ & 5.0 & 1.67 & $2.4 \mathrm{E}-05$ \\
\hline Test-25-D-1 & 1 & 25 & $\mathrm{~N}$ & 5.0 & 1.67 & 2.4E-05 \\
\hline Test-25-D-4 & 4 & 25 & $\mathrm{~N}$ & 5.0 & 1.67 & 2.4E-05 \\
\hline Test-25-D-10 & 10 & 25 & $\mathrm{~N}$ & 5.0 & 1.67 & $2.4 \mathrm{E}-05$ \\
\hline Test-25-D-24 & 24 & 25 & $\mathrm{~N}$ & 5.0 & 1.67 & 2.4E-05 \\
\hline Test-45-A-0 & 0 & 45 & $\mathrm{Y}$ & 5.0 & 1.67 & 2.4E-05 \\
\hline Test-45-A-1 & 1 & 45 & $\mathrm{Y}$ & 5.0 & 1.67 & 2.4E-05 \\
\hline Test-45-A-4 & 4 & 45 & $\mathrm{Y}$ & 5.0 & 1.67 & 2.4E-05 \\
\hline Test-45-A-10 & 10 & 45 & $\mathrm{Y}$ & 5.0 & 1.67 & 2.4E-05 \\
\hline Test-45-A-24 & 24 & 45 & $\mathrm{Y}$ & 5.0 & 1.67 & 2.4E-05 \\
\hline Test-45-B-0 & 0 & 45 & $\mathrm{Y}$ & 5.0 & 1.67 & 2.4E-05 \\
\hline Test-45-B-1 & 1 & 45 & $\mathrm{Y}$ & 5.0 & 1.67 & 2.4E-05 \\
\hline Test-45-B-4 & 4 & 45 & $\mathrm{Y}$ & 5.0 & 1.67 & 2.4E-05 \\
\hline Test-45-B-10 & 10 & 45 & $\mathrm{Y}$ & 5.0 & 1.67 & 2.4E-05 \\
\hline Test-45-B-24 & 24 & 45 & $\mathrm{Y}$ & 5.0 & 1.67 & 2.4E-05 \\
\hline Test-45-BB-0 & 0 & 45 & $\mathrm{~N}$ & 5.0 & 1.67 & 2.4E-05 \\
\hline Test-45-BB-24 & 24 & 45 & $\mathrm{~N}$ & 5.0 & 1.67 & 2.4E-05 \\
\hline Test-55-A-0 & 0 & 55 & $\mathrm{Y}$ & 5.0 & 1.67 & $2.4 \mathrm{E}-05$ \\
\hline Test-55-A-1 & 1 & 55 & $\mathrm{Y}$ & 5.0 & 1.67 & 2.4E-05 \\
\hline Test-55-A-4 & 4 & 55 & $\mathrm{Y}$ & 5.0 & 1.67 & 2.4E-05 \\
\hline Test-55-A-10 & 10 & 55 & $\mathrm{Y}$ & 5.0 & 1.67 & 2.4E-05 \\
\hline Test-55-A-24 & 24 & 55 & $\mathrm{Y}$ & 5.0 & 1.67 & 2.4E-05 \\
\hline Test-55-B-0 & 0 & 55 & $\mathrm{Y}$ & 5.0 & 1.67 & 2.4E-05 \\
\hline Test-55-B-1 & 1 & 55 & Y & 5.0 & 1.67 & 2.4E-05 \\
\hline Test-55-B-4 & 4 & 55 & $\mathrm{Y}$ & 5.0 & 1.67 & 2.4E-05 \\
\hline Test-55-B-10 & 10 & 55 & $\mathrm{Y}$ & 5.0 & 1.67 & 2.4E-05 \\
\hline Test-55-B-24 & 24 & 55 & $\mathrm{Y}$ & 5.0 & 1.67 & 2.4E-05 \\
\hline
\end{tabular}




\subsection{Organic Column Test}

The impact of organics test was performed using the simulant ID 5B17 listed in Table 3.1 with the organics listed in Table 3.5 and Table 3.6 added. The organics were added at a ratio of 0.54 mol TOC per mol Na, which compares closely to the BNI contract specification of $0.5 \mathrm{~mol}$ TOC per mol of Na. The simulant solution was prepared in the same manner as described in Section 3.1 with the organics added at the end to make $250 \mathrm{~mL}$. The antifoam agent (Dow Corning Q2-3183A antifoam) was added at a concentration of $2000 \mathrm{ppm}$ and the antifoam degradation products were added at $1000 \mathrm{ppm}$. After adding the antifoam and antifoam degradation products, the solution had a significant amount of gelatinous material present. Therefore, it was filtered through a KimWipe ${ }^{\mathrm{TM}}$ paper to remove this before filtering through a $0.1 \mu \mathrm{m}$ filter. A total inorganic carbon and total organic carbon (TIC/TOC) analysis of the feed was performed both before filtering and after filtering had occurred. Some of this gelatinous material adhered to the flask as shown in Figure 3.6.

Table 3.5. Antifoam Degradation Products Added to Organic Feed Solution

\begin{tabular}{lcccc}
\hline \multicolumn{1}{c}{ Chemical } & Formula & CAS\# & Sp.G & Molecular Weight \\
\hline $\begin{array}{l}\text { Dimethyl-oxo-silane } \\
\text { (or dimethylsilanediol, DMSD) }\end{array}$ & $\left(\mathrm{C}_{2} \mathrm{H}_{6} \mathrm{OSi}\right)_{n}(\mathrm{n}=1)$ & $9087-49-4$ & & 74.154 \\
Hexamethylcyclotrisiloxane $\left(\mathrm{D}_{3}\right)$ & $\mathrm{C}_{6} \mathrm{H}_{18} \mathrm{O}_{3} \mathrm{Si}_{3}$ or $\left(\mathrm{C}_{2} \mathrm{H}_{6} \mathrm{OSi}\right)_{3}$ & $541-05-9$ & 1.02 & 222.46 \\
Octamethylcyclotetrasiloxane $\left(\mathrm{D}_{4}\right)$ & $\mathrm{C}_{8} \mathrm{H}_{24} \mathrm{O}_{4} \mathrm{Si}_{4}$ or $\left(\mathrm{C}_{2} \mathrm{H}_{6} \mathrm{OSi}\right)_{4}$ & $556-67-2$ & 0.95 & 296.62 \\
$\begin{array}{l}\text { Decamethylcyclopentasiloxane } \\
\text { (or Cyclomethicone, } \mathrm{D}_{5} \text { ) }\end{array}$ & $\mathrm{C}_{10} \mathrm{H}_{30} \mathrm{O}_{5} \mathrm{Si}_{5}$ or $\left(\mathrm{C}_{2} \mathrm{H}_{6} \mathrm{OSi}\right)_{5}$ & $541-02-6$ & 0.96 & 370.78 \\
$\begin{array}{l}\text { Dodecamethylcyclohexansiloxane } \\
\text { (or Cyclohexasiloxane, } \mathrm{D}_{6} \text { ) }\end{array}$ & $\mathrm{C}_{12} \mathrm{H}_{36} \mathrm{O}_{6} \mathrm{Si}_{6}$ or $\left(\mathrm{C}_{2} \mathrm{H}_{6} \mathrm{OSi}\right)_{6}$ & $540-97-6$ & 0.96 & 444.93 \\
\hline
\end{tabular}


Table 3.6. Organic Products Added to Organic Feed Solution

\begin{tabular}{cccc}
\hline Chemical & $\mathrm{Formula}_{2}$ & $\mathrm{CAS \#}$ & Spike Level (mg/L) \\
\hline Benzene & $\mathrm{C}_{6} \mathrm{H}_{6}$ & $71-43-2$ & 18.7 \\
\hline Chloroform & $\mathrm{CHCl}_{3}$ & $67-66-3$ & 18.7 \\
1,2-Dichloroethane & $\mathrm{C}_{2} \mathrm{H}_{4} \mathrm{Cl}_{2}$ & $107-06-2$ & 18.7 \\
1,1-Dichloroethylene & $\mathrm{C}_{2} \mathrm{H}_{2} \mathrm{Cl}_{2}$ & $75-35-4$ & 18.7 \\
\hline Hexachlorobutadiene & $\mathrm{C}_{4} \mathrm{Cl}_{6}$ & $87-68-3$ & 18.7 \\
Hexachloroethane & $\mathrm{C}_{2} \mathrm{Cl}_{6}$ & $67-72-1$ & 84.8 \\
Methylethylketone & $\mathrm{C}_{4} \mathrm{H}_{8} \mathrm{O}$ & $78-93-3$ & 18.7 \\
Nitrobenzene & $\mathrm{C}_{6} \mathrm{H}_{5} \mathrm{NO}_{2}$ & $98-95-3$ & 84.8 \\
Pyridine & $\mathrm{C}_{5} \mathrm{H}_{5} \mathrm{~N}$ & $110-86-1$ & 84.8 \\
Tetrachloroethylene & $\mathrm{C}_{2} \mathrm{Cl}_{4}$ & $127-18-4$ & 18.7 \\
Trichloroethylene & $\mathrm{C}_{2} \mathrm{HCl}_{3}$ & $79-01-6$ & 18.7 \\
Acetone & $\mathrm{CH}_{3} \mathrm{COCH}_{3}$ & $67-64-1$ & 101.8 \\
n-Butyl alcohol & $\mathrm{C}_{4} \mathrm{H}_{10} \mathrm{O}$ & $71-36-3$ & 18.7 \\
Carbon disulfide & $\mathrm{CS}_{2}$ & $75-15-0$ & 18.7 \\
O-Dichlorobenzene & $\mathrm{C}_{6} \mathrm{H}_{4} \mathrm{Cl}_{2}$ & $95-50-1$ & 18.7 \\
Ethyl acetate & $\mathrm{CH}_{3} \mathrm{COOC}_{2} \mathrm{H}_{5}$ & $141-78-6$ & 84.8 \\
Ethyl benzene & $\mathrm{C}_{8} \mathrm{H}_{10}$ & $100-41-4$ & 18.7 \\
Isobutyl alcohol & $\left(\mathrm{CH}_{3}\right)_{2} \mathrm{CHCH}_{2} \mathrm{OH}$ & $78-83-1$ & 84.8 \\
Methanol & $\mathrm{CH}_{4} \mathrm{O}$ & $67-56-1$ & 18.7 \\
\hline Methylene chloride & $\mathrm{CH}_{2} \mathrm{Cl}_{2}$ & $75-09-2$ & 18.7 \\
Methyl isobutyl ketone & $\mathrm{C}_{6} \mathrm{H}_{12} \mathrm{O}$ & $108-10-1$ & 18.7 \\
Toluene & $\mathrm{C}_{6} \mathrm{H}_{5} \mathrm{CH}_{3}$ & $108-88-3$ & 18.7 \\
1,1,1-Trichloroethane & $\mathrm{C}_{2} \mathrm{H}_{3} \mathrm{Cl}_{3}$ & $71-55-6$ & 18.7 \\
1,1,2-Trichloroethane & $\mathrm{C}_{2} \mathrm{H}_{3} \mathrm{Cl}_{3}$ & $79-00-5$ & 18.7 \\
Trichloromonofluoromethane & $\mathrm{CCl}_{3} \mathrm{~F}$ & $75-69-4$ & 18.7 \\
Xylene-mixed isomers & $\mathrm{C}_{8} \mathrm{H}_{10}$ & $1330-20-7$ & 18.7 \\
\hline
\end{tabular}

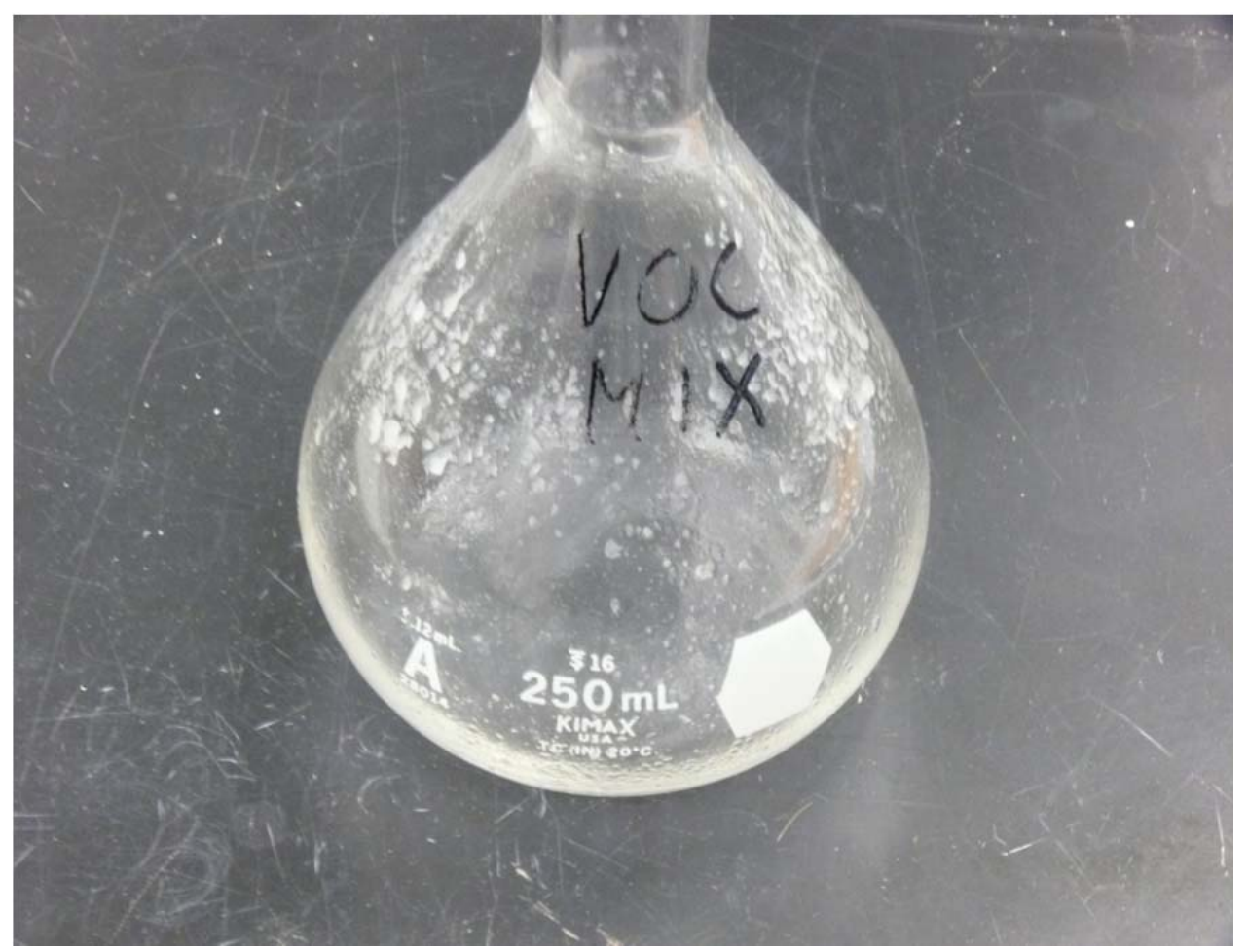

Figure 3.6. Volumetric Flask After Mixing Organic Feed Solution 
The ion exchange column was loaded with simulant feed solution at a temperature of $45 \pm 2^{\circ} \mathrm{C}$. The solution was processed at a linear flow velocity of $6 \mathrm{~cm} / \mathrm{min}$ for the $10 \mathrm{~h}$ of loading. These conditions were identical to Test 1-A-1 in Table 3.3. Following loading, the feed solution was displaced with

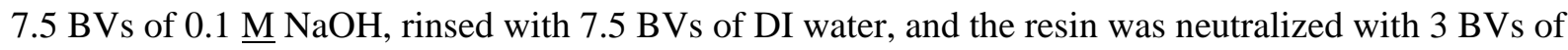

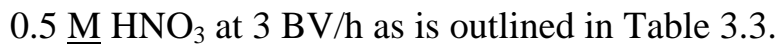

The ion exchange column was then eluted with approximately $28 \mathrm{BVs}$ of $0.25 \underline{\mathrm{M}} \mathrm{HNO}_{3}$ processed at $25^{\circ} \mathrm{C}$ and at $2.8 \mathrm{BV} / \mathrm{h}$. Following elution, the column was rinsed with $3 \mathrm{BVs}$ of DI water. Weights of each sample and the temperature of the simulant were recorded at each sampling.

Simulant samples were submitted to SwRI for analysis. Analysis methods included ICP-MS for Cs, ICP-OES for $\mathrm{Na}$ and $\mathrm{Al}$, IC for anions, titration for $\mathrm{OH}$ analysis, total inorganic carbon (TIC), and total organic carbon (TOC). Quality assurance and control procedures using blanks, duplicates, and spikes along with standard results for each analysis set are maintained in records and are not reported here. 



\subsection{Results and Discussion}

This research examined the impact of linear load velocity $(4,6,8 \mathrm{~cm} / \mathrm{min})$, initial Na concentration (2, 5, $8 \underline{\mathrm{M}}$ ), initial Na/Cs ratio (1.4E+05, 2.1E+05, 2.8E+05 mol/mol), initial Na/OH ratio (2.0, 3.0, $4.0 \mathrm{~mol} / \mathrm{mol})$, and high free $\mathrm{OH}$ concentration $(4 \underline{\mathrm{M}})$ on resin loading kinetics and resin degradation during extended solution flow using elevated temperatures $\left(45^{\circ}, 50^{\circ}, 55^{\circ}, 60^{\circ}, 65^{\circ}, 75^{\circ} \mathrm{C}\right)$. The results of this research are discussed in this section. In addition, the effect of aging the resin in an acid environment and the effect on the resin of volatile organics in the feed were also tested and are discussed here as well.

\subsection{Impacts of Variables on Loading Kinetics}

A series of column loading and elution cycles were completed using a fractional factorial experimental design as detailed in Table 3.3. This allowed each variable to be studied as well as the variable interactions. The axial velocity, sodium concentration, hydroxide concentration, cesium-to-sodium ratio, and cesium concentration were the primary variables studied. Tests were then compared using ones that had similar variables except for the one being analyzed.

The results from these tests were used to assess the impact of process conditions on the diffusivity and film mass transfer coefficient. Tests performed at varying axial velocity provided a measure of the impact of the film mass transfer coefficient. Tests performed at varying sodium concentrations and cesium-to-sodium ratios provided a measure of the impact of the diffusivity on ion exchange performance.

It was found that linear load velocity had a significant impact on the loading kinetics of the column as shown in Figure 4.1. The higher the loading velocity, the faster the column loaded. This is shown by comparing Test E2 to E3 and Test C2 to C3. The other pairs with the same variables tested showed the same trends. This indicates that the loading rate of the WTP ion exchange columns may be controlled by the rate the feed is passed through the column. However, the highest linear load velocity tested corresponds to the design feed rate of $30 \mathrm{gpm}$ and it hasn't been tested to show that this correlation is true at higher linear load rates or if there is a limiting maximum. 


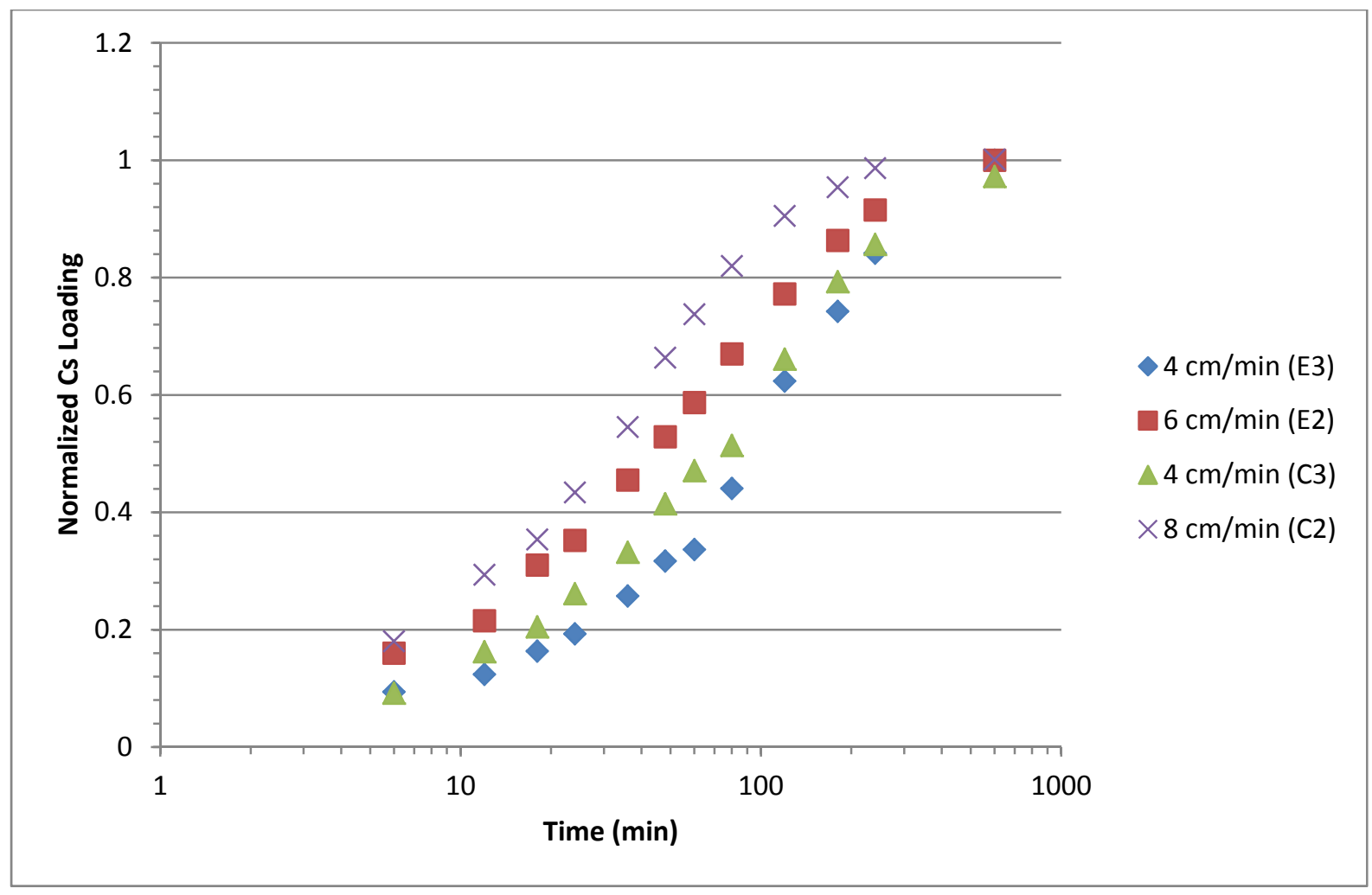

Figure 4.1. Velocity Impact on Kinetics of Column Loading

The levels of initial Na concentration tested made little difference in the loading kinetics of the column as shown in Figure 4.2. The loading curves for both $5 \underline{\mathrm{M}} \mathrm{Na}$ and $8 \underline{\mathrm{M}} \mathrm{Na}$ lie almost on top of each other. The loading curve for $2 \underline{\mathrm{M}}$ Na may have a slight effect on the loading kinetics but was insignificant compared to the effect of the linear velocity and was not worth pursuing. The only tests performed using $2 \underline{\mathrm{M}}$ Na had several different variables which would affect the data and it wouldn't be a clean comparison.

Also, neither the initial $\mathrm{Na} / \mathrm{Cs}$ ratio nor the $\mathrm{Na} / \mathrm{OH}$ ratio affected the loading kinetics as shown in Figure 4.3 and Figure 4.4. Regardless of the initial ratio, the column loaded at essentially the same rate as demonstrated by nearly overlapping Cs uptake curves. This indicates that the WTP should not have a problem processing high $\mathrm{Na}$ content (up to $8 \underline{\mathrm{M}} \mathrm{Na}$ ) feeds through the ion exchange column. However, there will be a difference in that at higher Na levels, the overall Cs uptake will be lower as shown in Figure 4.5. These tests showed between a $10 \%$ and $15 \%$ decrease in Cs uptake when the Na was increased from $5 \underline{\mathrm{M}}$ to $8 \underline{\mathrm{M}} \mathrm{Na}$. 


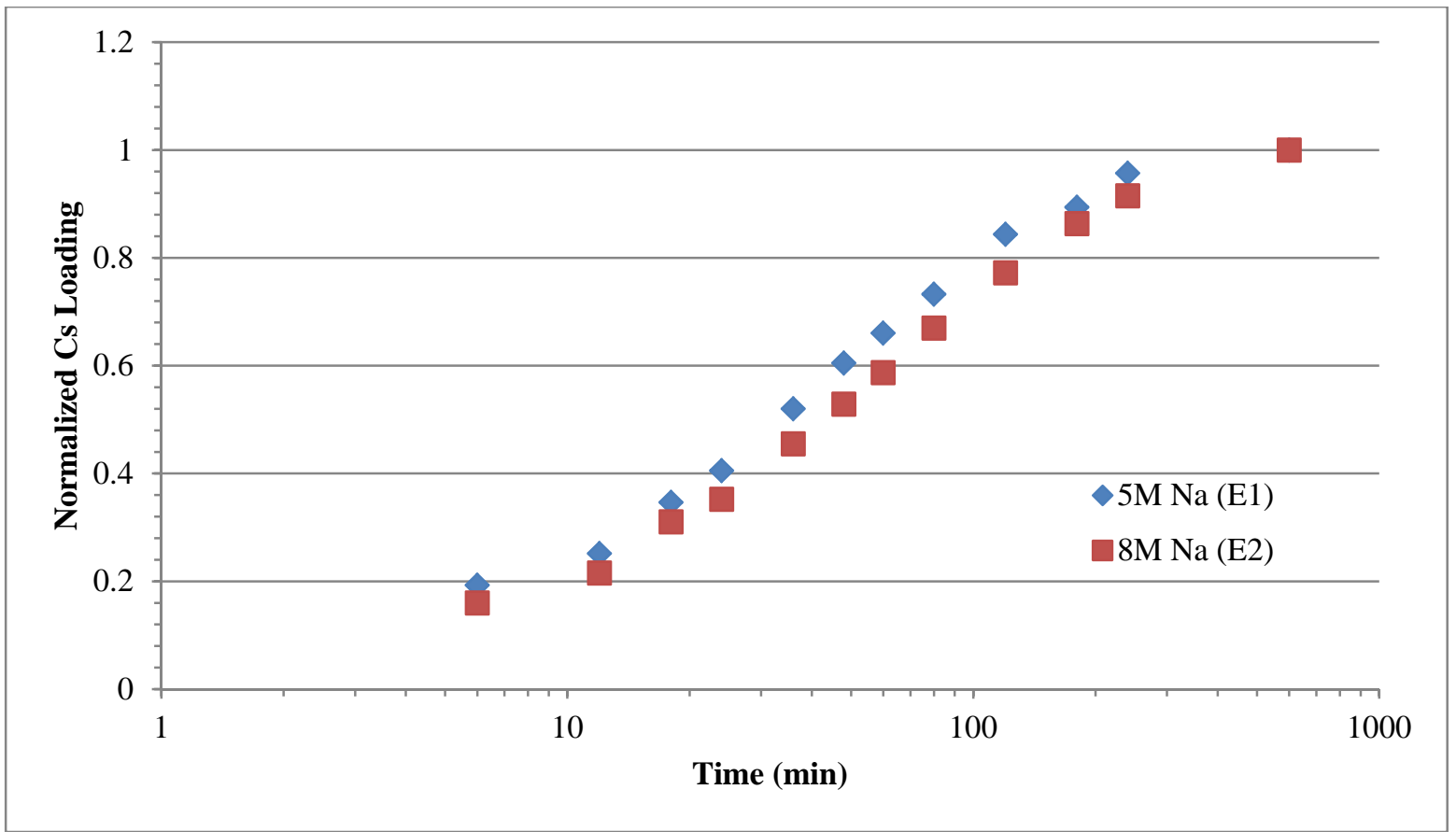

Figure 4.2. Initial Na Impact on Kinetics of Column Loading

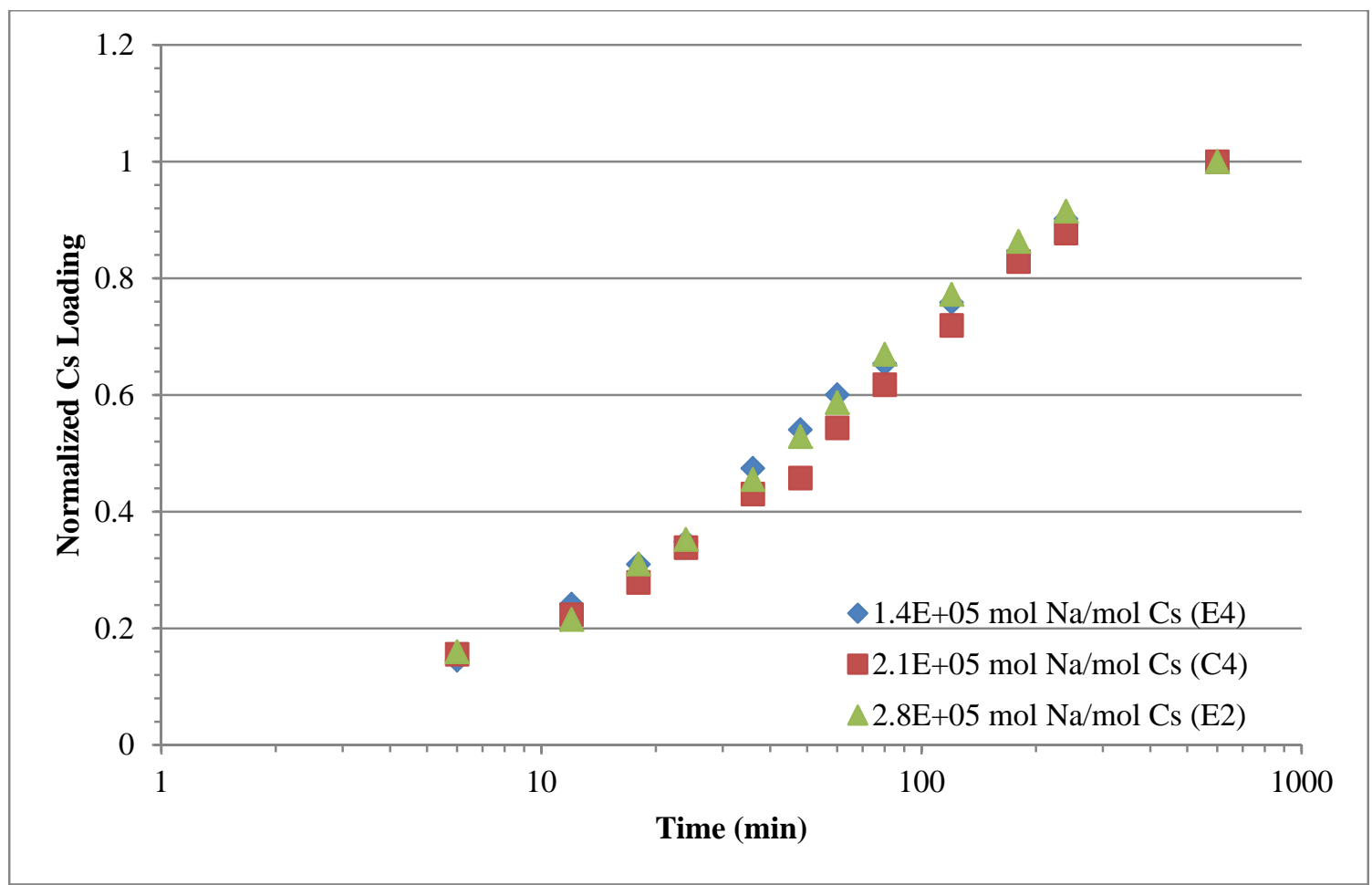

Figure 4.3. Na/Cs Ratio Impact on Kinetics of Column Loading 


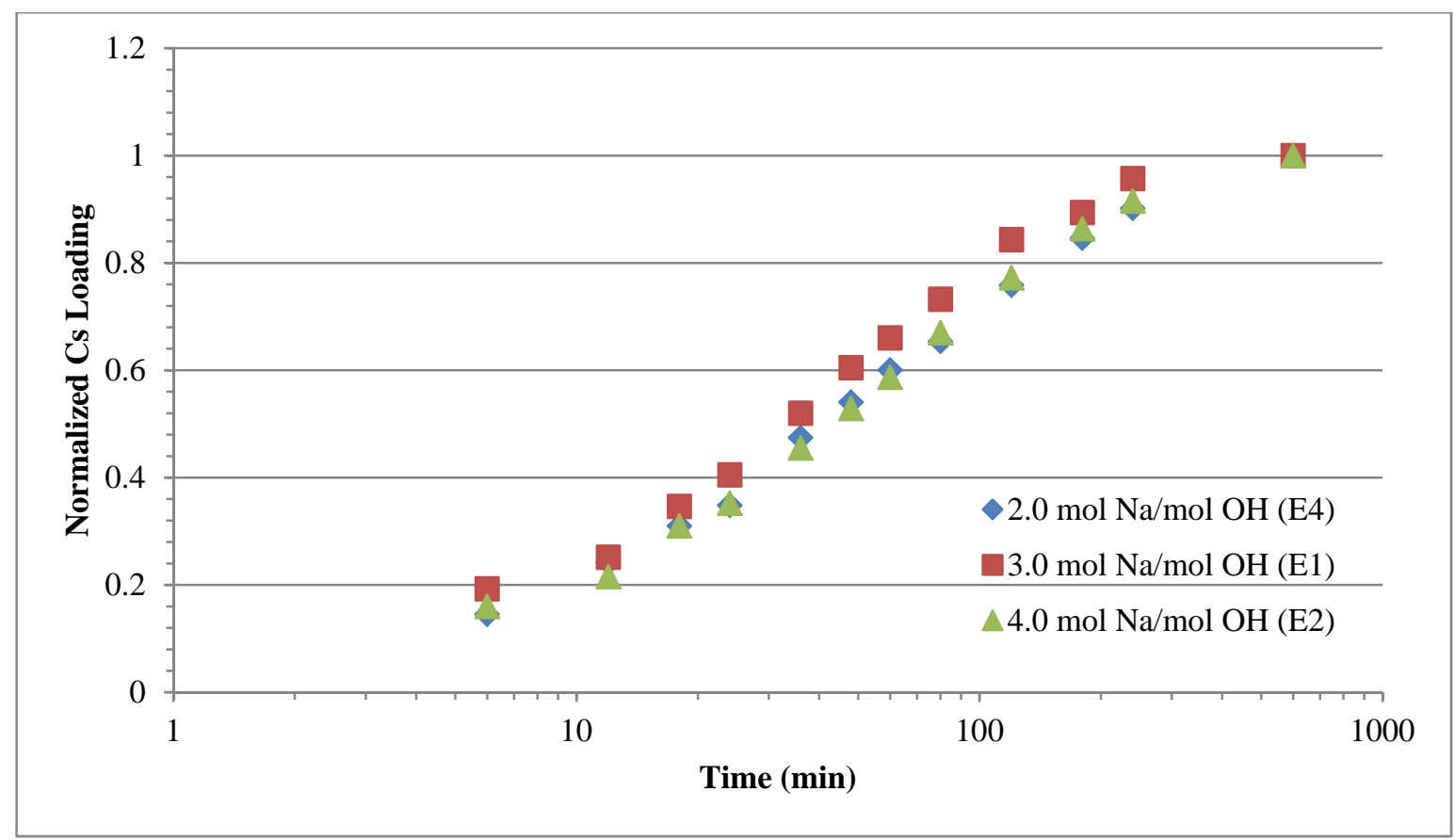

Figure 4.4. Na/OH Ratio Impact on Kinetics of Column Loading

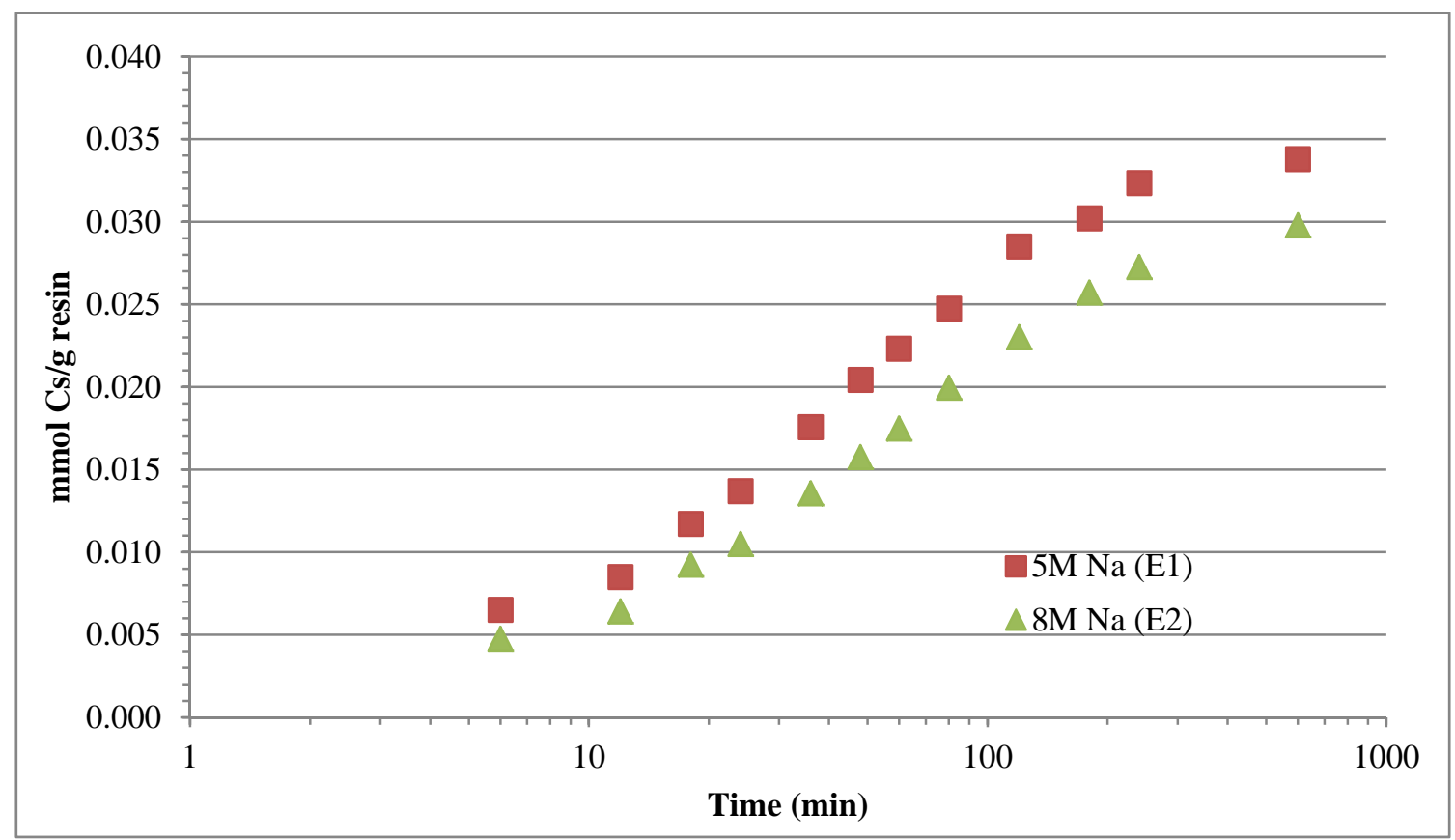

Figure 4.5. Initial Na Impact on Column Loading Capacity

After cycling the resin through four 10-hour loading and elution cycles and a 336-hour loading cycle, the resin was loaded again for 10 hours with the same conditions as the initial cycle. This is the last test of each series in Table $3.3(-5)$, and was used to determine the resin loss of Cs loading kinetics and/or Cs loading capacity. It was found that with the cycles kept at $55^{\circ} \mathrm{C}$ or lower there did not appear to be any significant resin loss of Cs loading kinetics or Cs loading capacity with the kinetics and loading capacity essentially the same as shown in Figure 4.6. However, the overall loading capacity of the resin 
was lower than at lower temperatures. For the tests performed continually at $60^{\circ} \mathrm{C}$ and higher in the 336-hour loading cycle, there was a significant decrease in the resin Cs loading capacity although the initial Cs loading kinetics remained essentially the same, as shown in Figure 4.7 through Figure 4.9. Therefore, in order to avoid a resin loading capacity decrease, the resin loading temperature should be kept $55^{\circ} \mathrm{C}$ or lower.

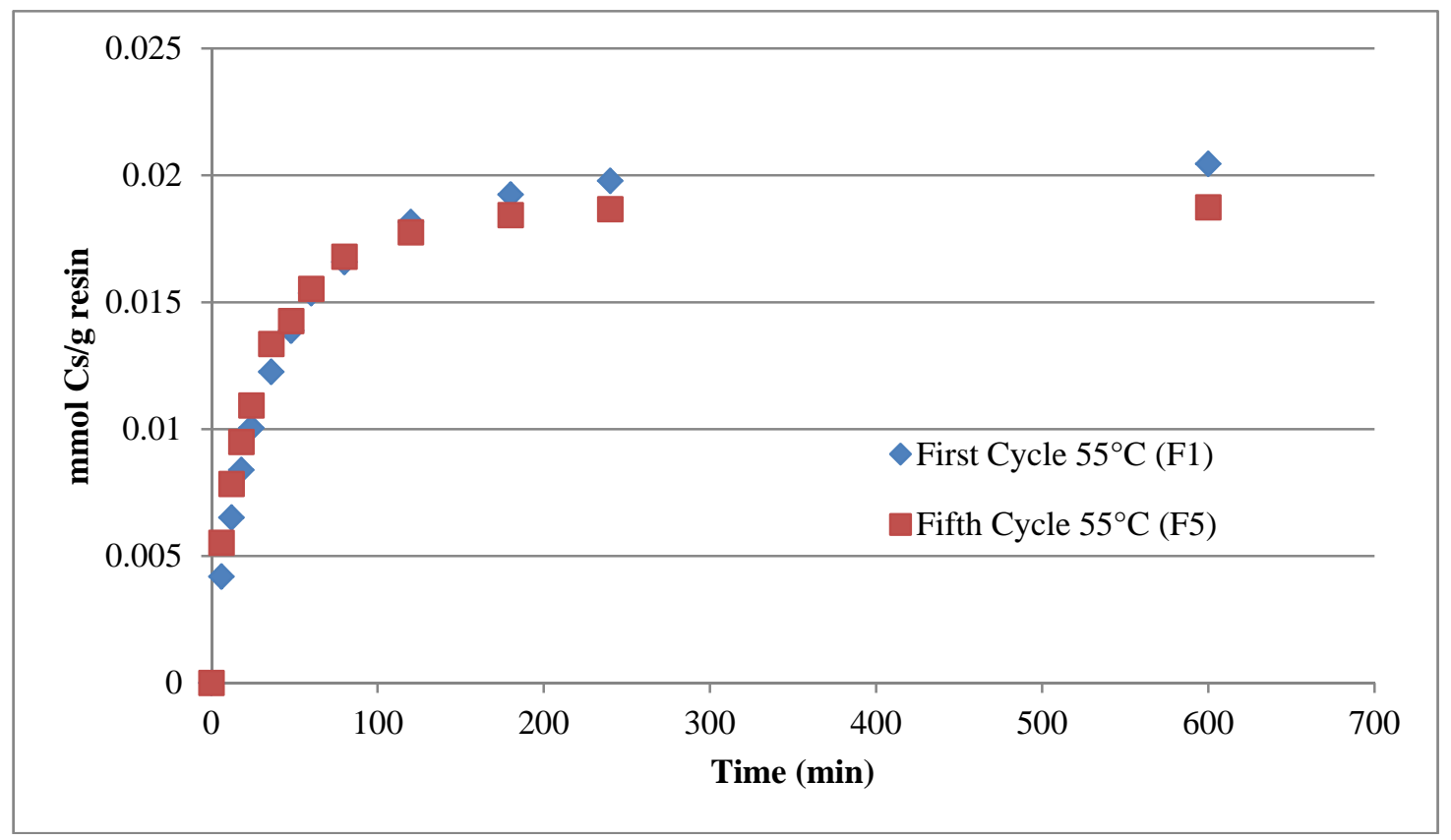

Figure 4.6. First and Fifth Resin Loading Cycles Compared at $55^{\circ} \mathrm{C}$

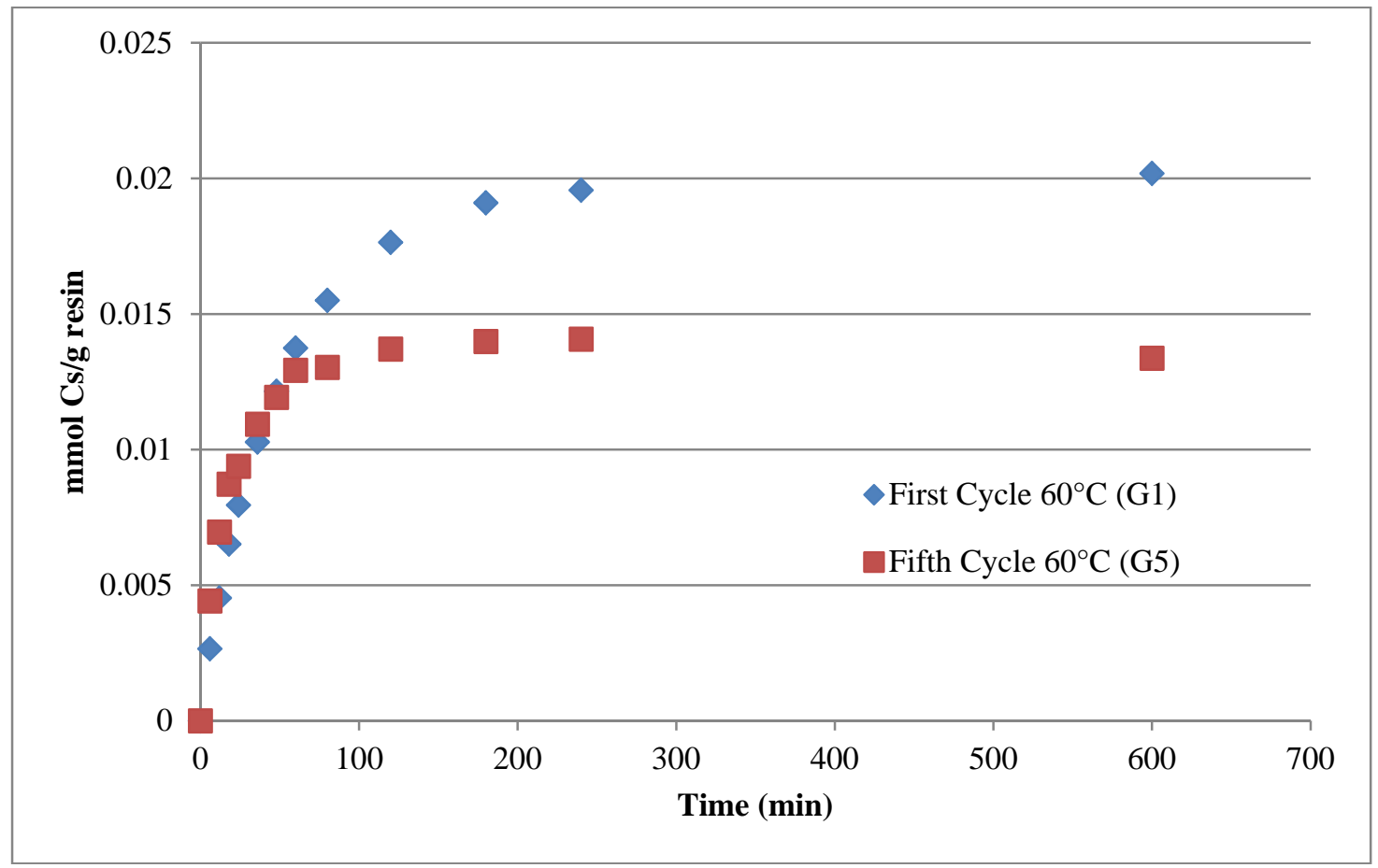

Figure 4.7. First and Fifth Resin Loading Cycles Compared at $60^{\circ} \mathrm{C}$ 


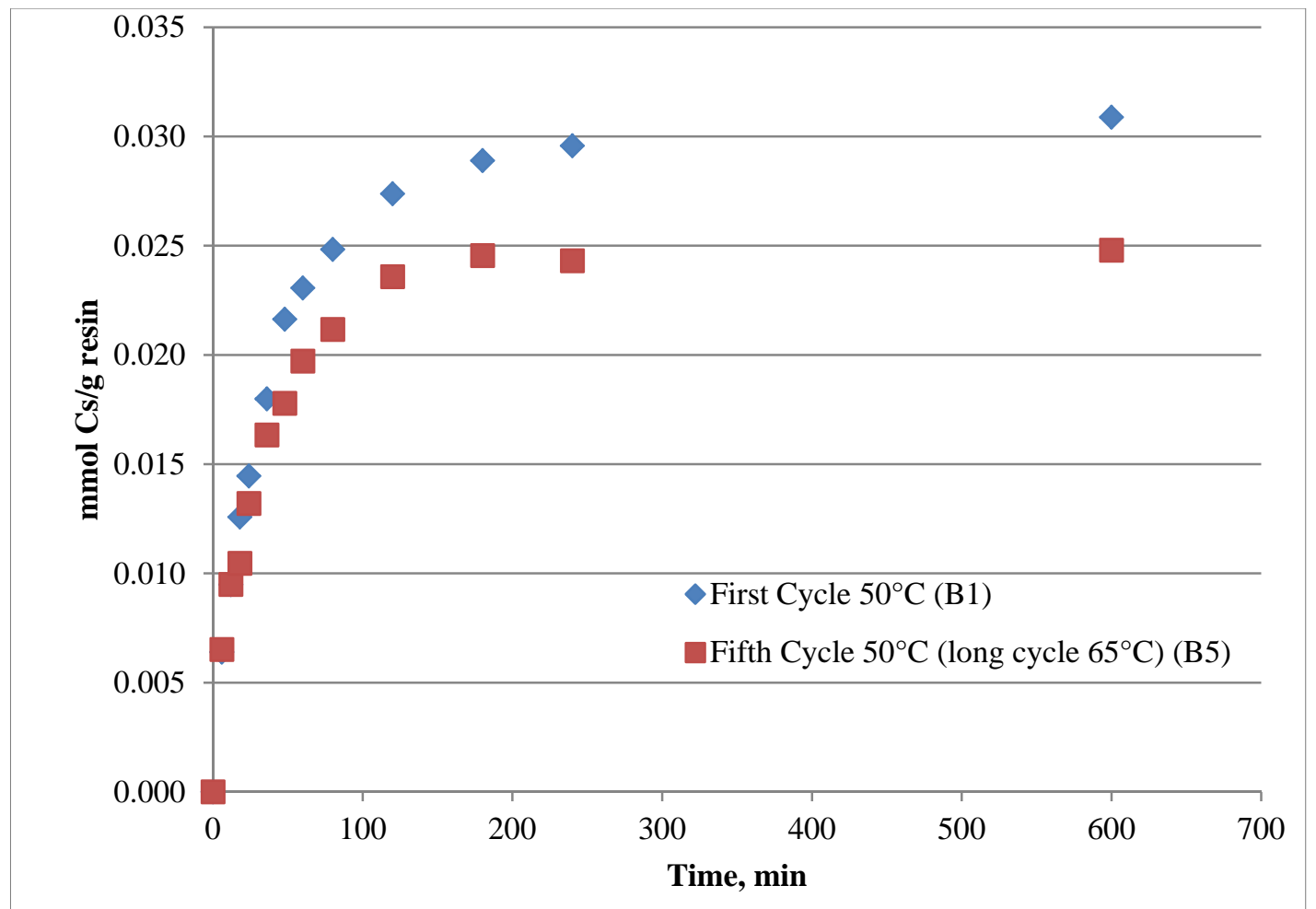

Figure 4.8. First and Fifth Resin Loading Cycles Compared at $50^{\circ} \mathrm{C}$ with Long Loading Cycle at $65^{\circ} \mathrm{C}$

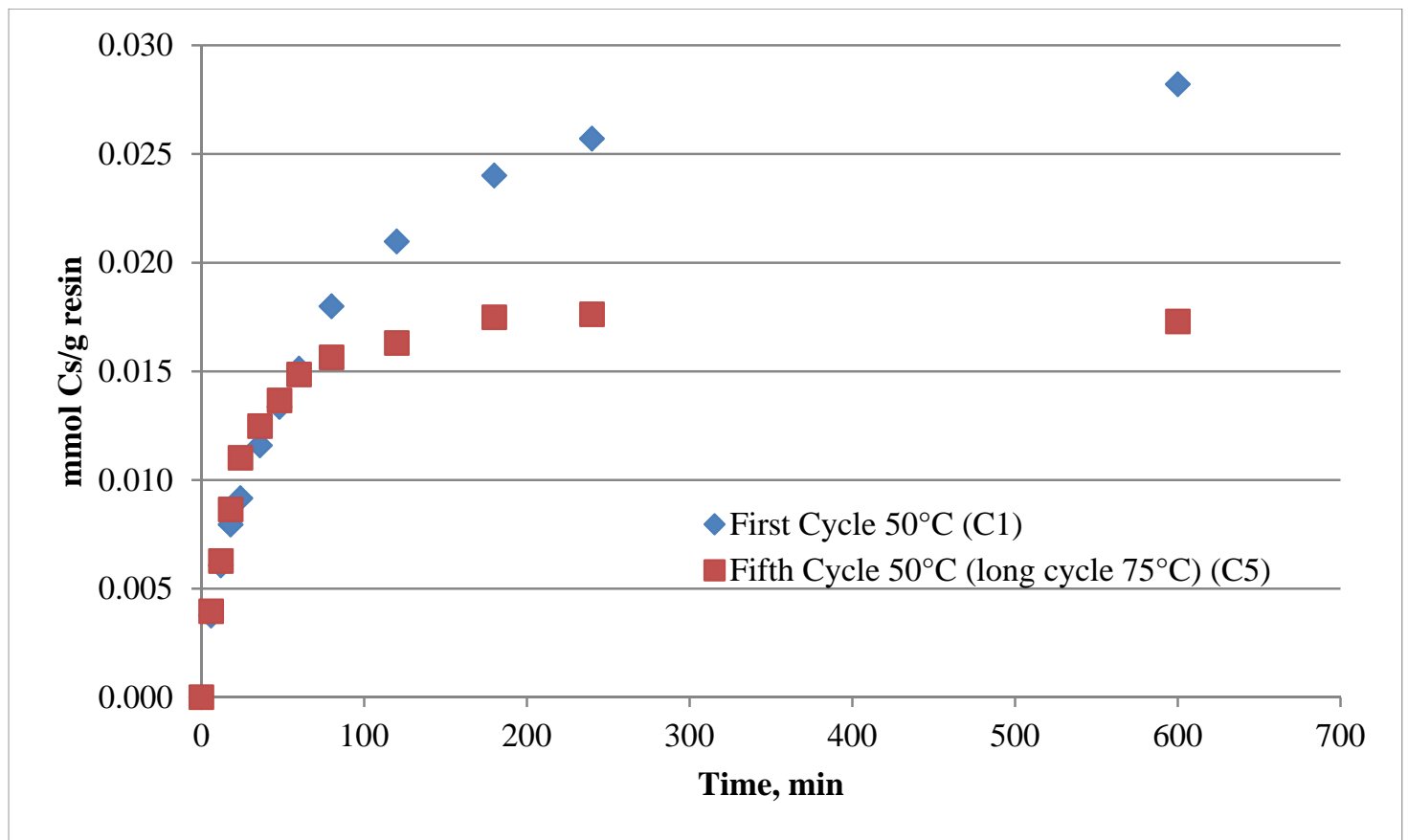

Figure 4.9. First and Fifth Resin Loading Cycles Compared at $50^{\circ} \mathrm{C}$ with Long Loading Cycle at $75^{\circ} \mathrm{C}$ 


\subsection{Impacts of Elevated Temperature on Resin Loading}

Resin was loaded at a very low flow rate $(\sim 5 \mathrm{~mL} / \mathrm{h})$ for $\sim 336$ hours at a variety of elevated temperatures. These tests were designated as $-4 \mathrm{~B}$ in all of the series of tests. Samples were taken periodically throughout the test to determine the cesium uptake curve. These tests were all performed using $8 \underline{\mathrm{M}} \mathrm{Na}$ and $4 \underline{\mathrm{M}} \mathrm{OH}$ simulants.

Testing for these extended times at elevated temperatures showed that the resin degrades above $45^{\circ} \mathrm{C}$, and above $60^{\circ} \mathrm{C}$ it did not load at all (see Figure 4.10). It was observed that the resin disintegrated at $75^{\circ} \mathrm{C}$ and partially disintegrated at $65^{\circ} \mathrm{C}$, which caused the column to plug during both tests after about 14 days.

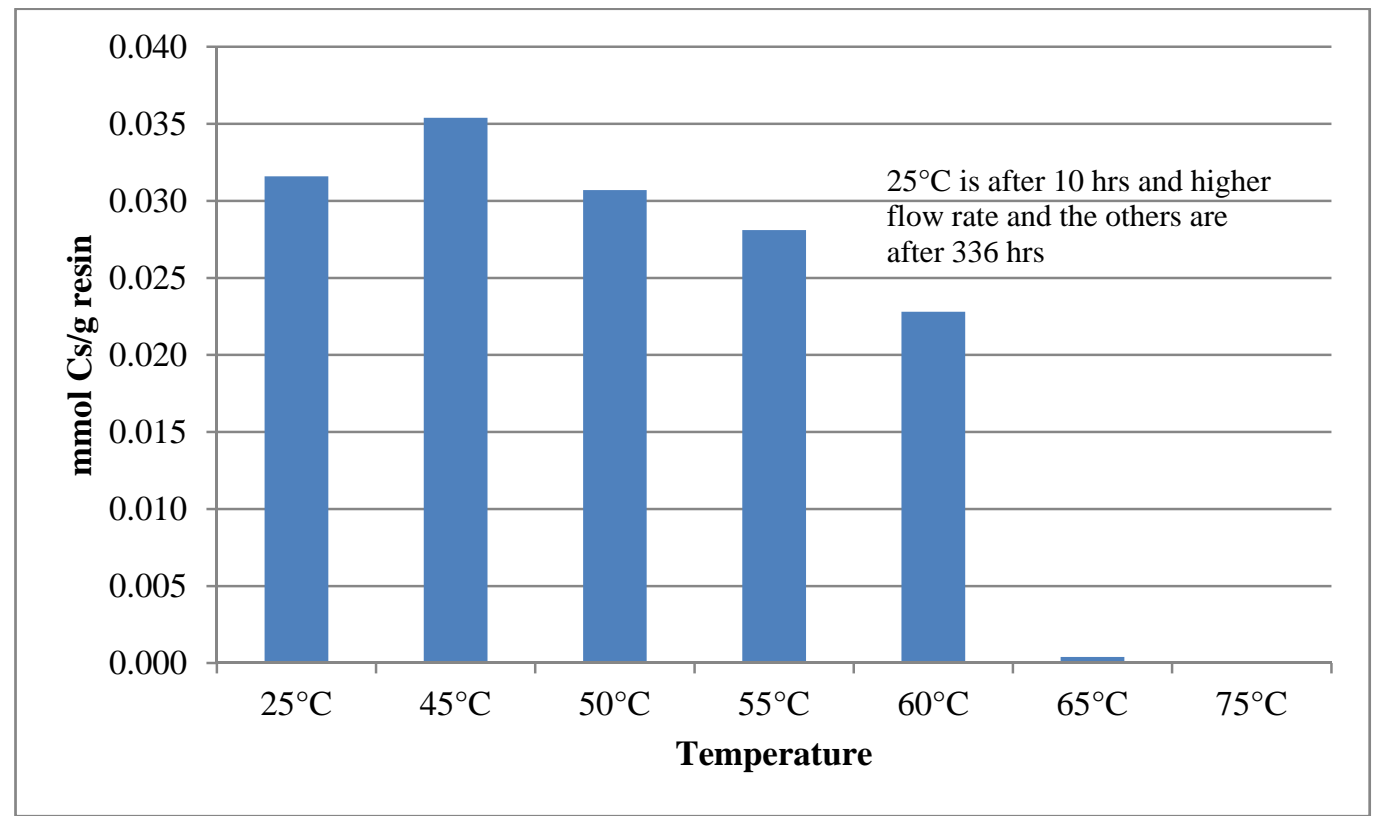

Figure 4.10. Resin Degradation During Extended Flow Testing

After the elevated temperature extended flow testing, the $65^{\circ} \mathrm{C}$ and $75^{\circ} \mathrm{C}$ columns were dismantled and observed for resin degradation and precipitates. The resin in the $75^{\circ} \mathrm{C}$ column (C4B) appeared to be significantly more degraded than the resin in the $65^{\circ} \mathrm{C}$ column (B4B). The B4B resin was free-flowing and loose as shown in Figure 4.11. The column was initially loaded with $1.8 \mathrm{~mL}$ of resin and about $1.55 \mathrm{~mL}$ remained after testing. The bottom column support o-ring was stuck to the column glass. A small amount of resin and a white crystalline looking material was on top of the o-ring and wedged between the bed support and the column glass as shown in Figure 4.12. The lower bed support was removed and the debris stuck to it was washed into a glass $20 \mathrm{~mL}$ vial with DI water. The material stuck on the column wall, as shown in Figure 4.13, was washed into the same vial. This debris was analyzed through optical microscopy, polarized light microscopy (PLM), and scanning electron microscopy-energy dispersive scattering (SEM-EDS) and is shown in Figure 4.14 through Figure 4.18. Palladium was added to the sample to assist in the EDS analysis. The white crystalline material appeared to be sodium aluminate that had crystallized from the simulant being fed through the column based on the EDS analysis. 


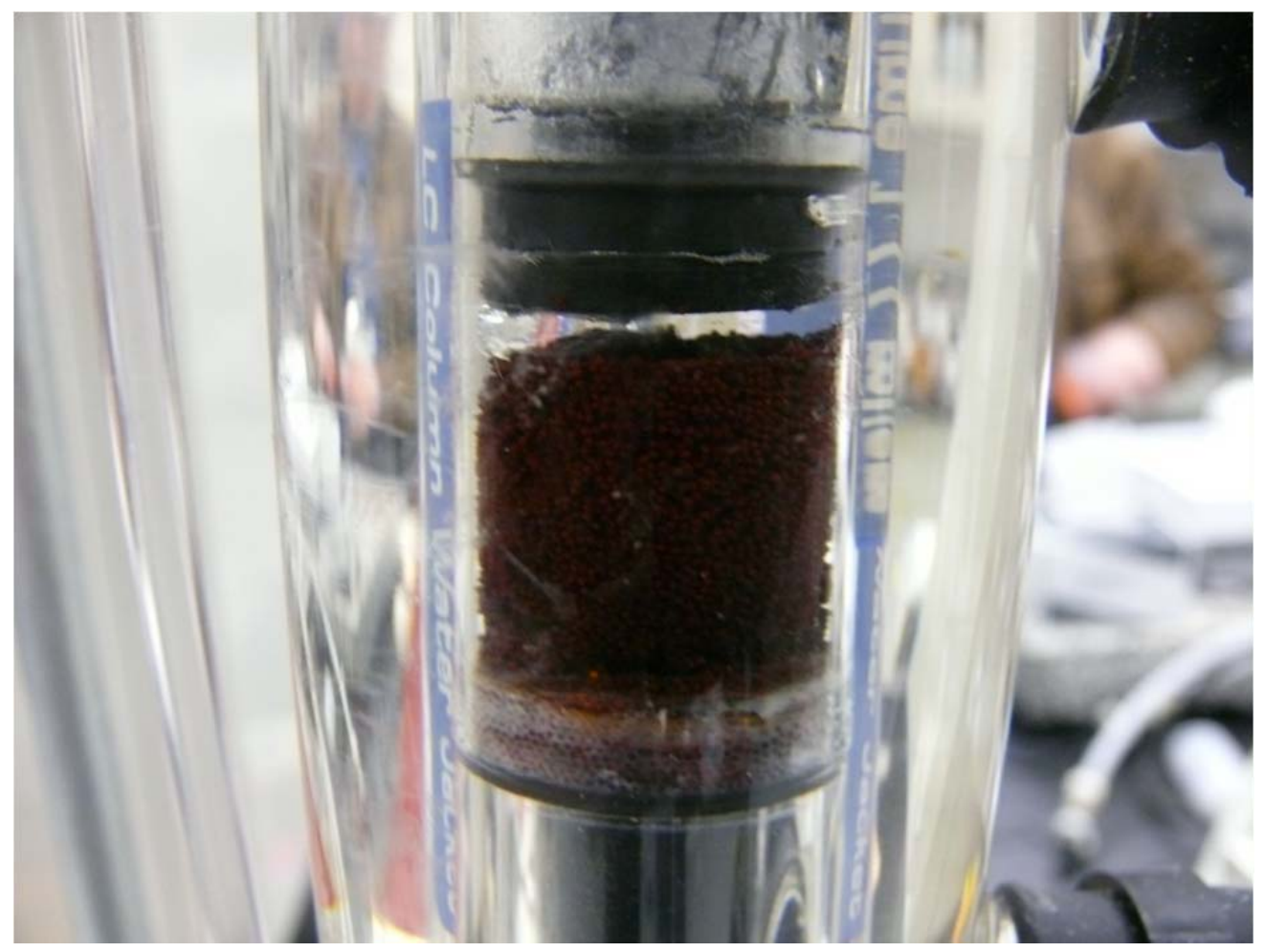

Figure 4.11. Column B Resin After Testing at $65^{\circ} \mathrm{C}$

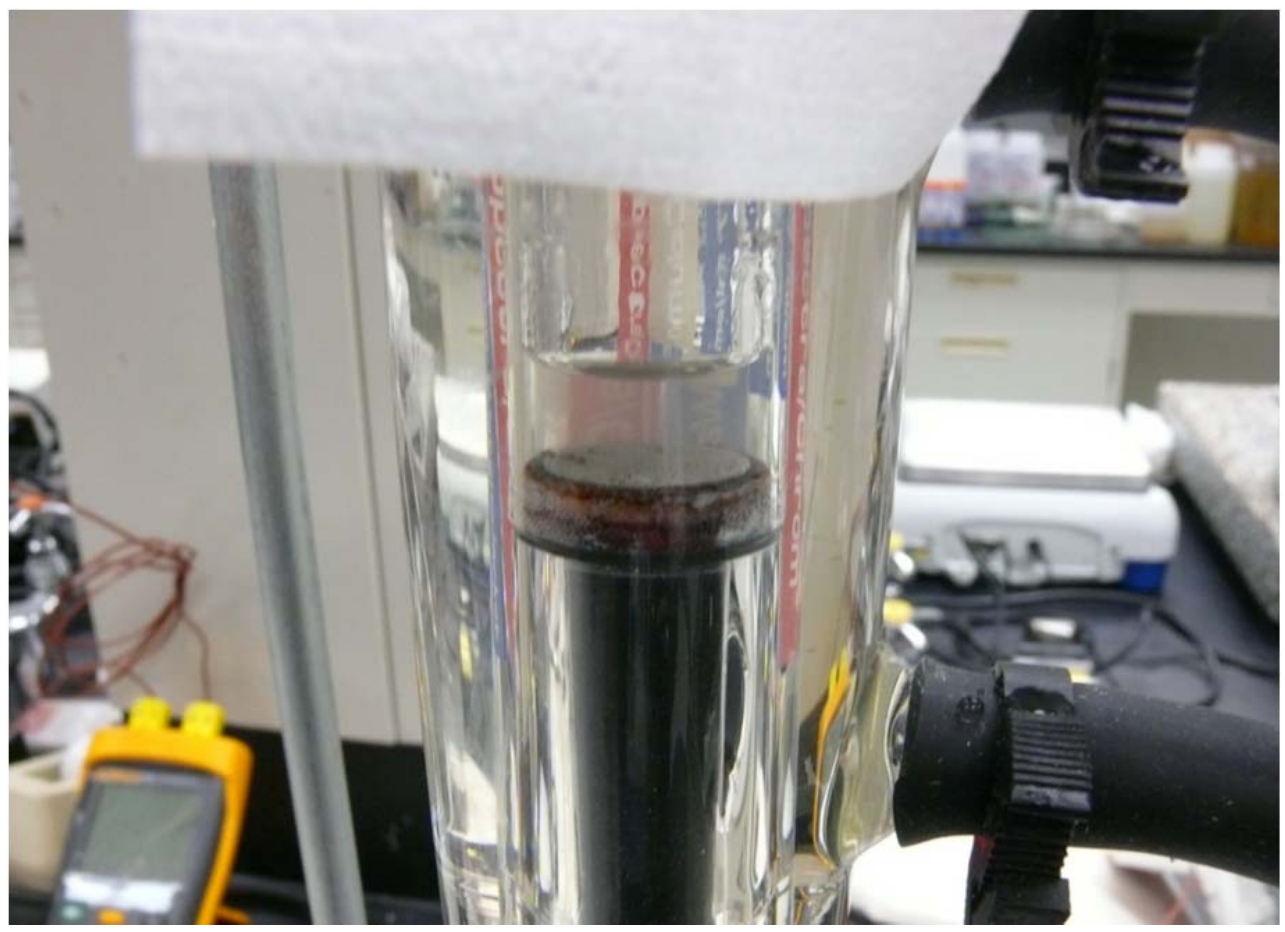

Figure 4.12. White Crystalline Material on Top of the O-Ring and Wedged Between the Bed Support and the Column B Glass 


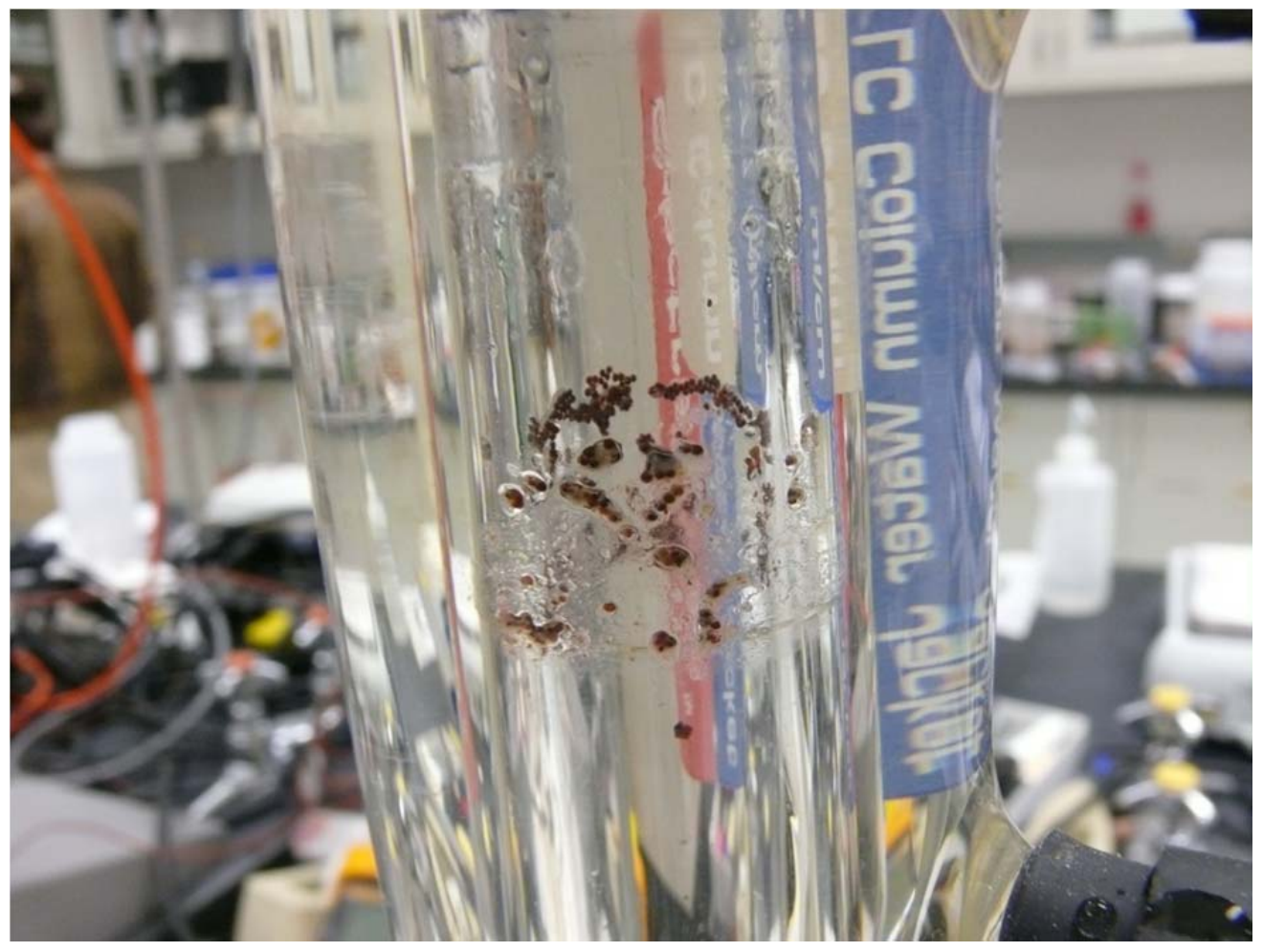

Figure 4.13. Material Stuck on the Column B Wall After Testing at $65^{\circ} \mathrm{C}$ 


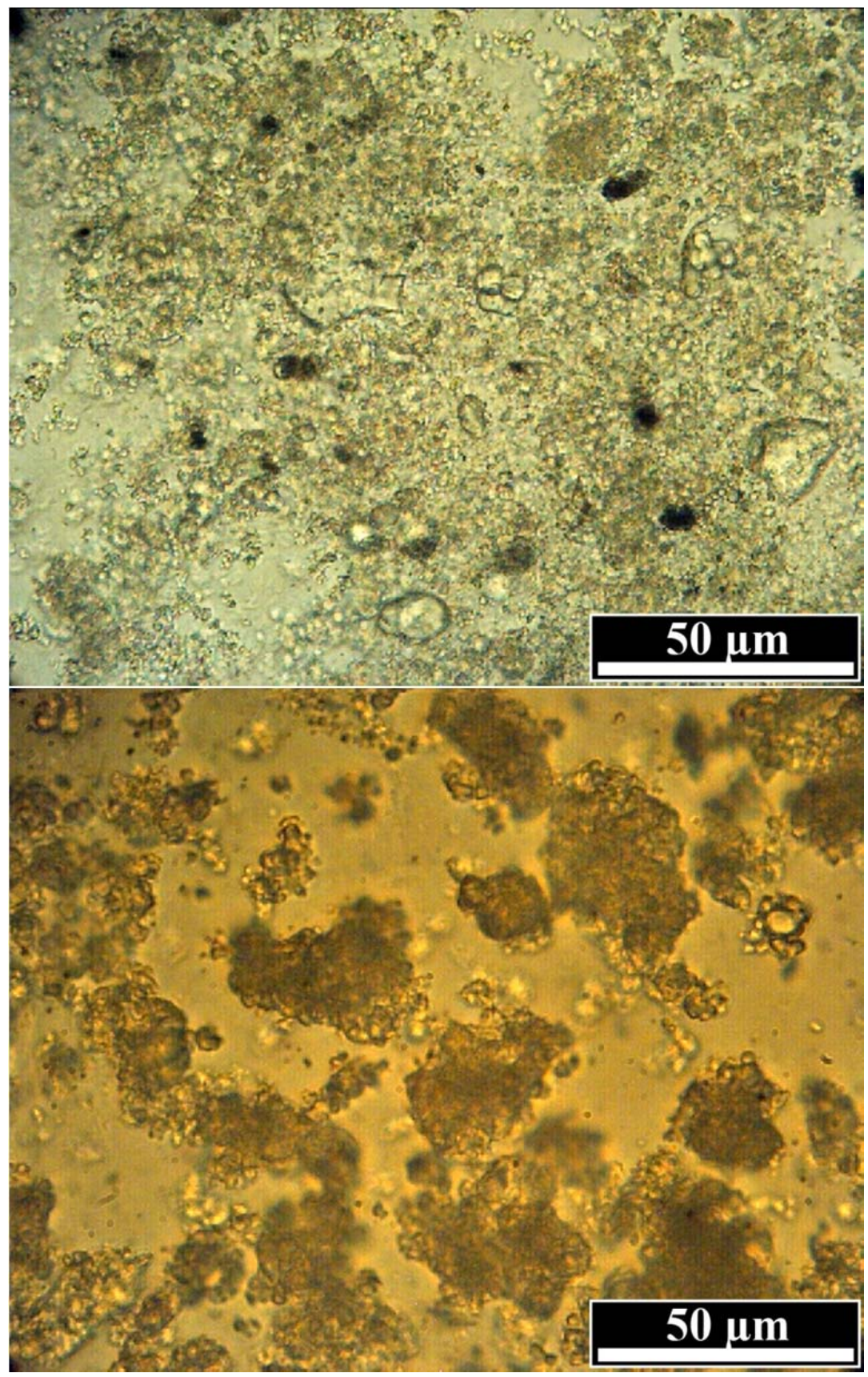

Figure 4.14. Material Washed from the Plugged Resin Bed in Test $\mathrm{B}\left(65^{\circ} \mathrm{C}\right)$ from Optical Microscopy--500X (top) and 1000X (bottom) 


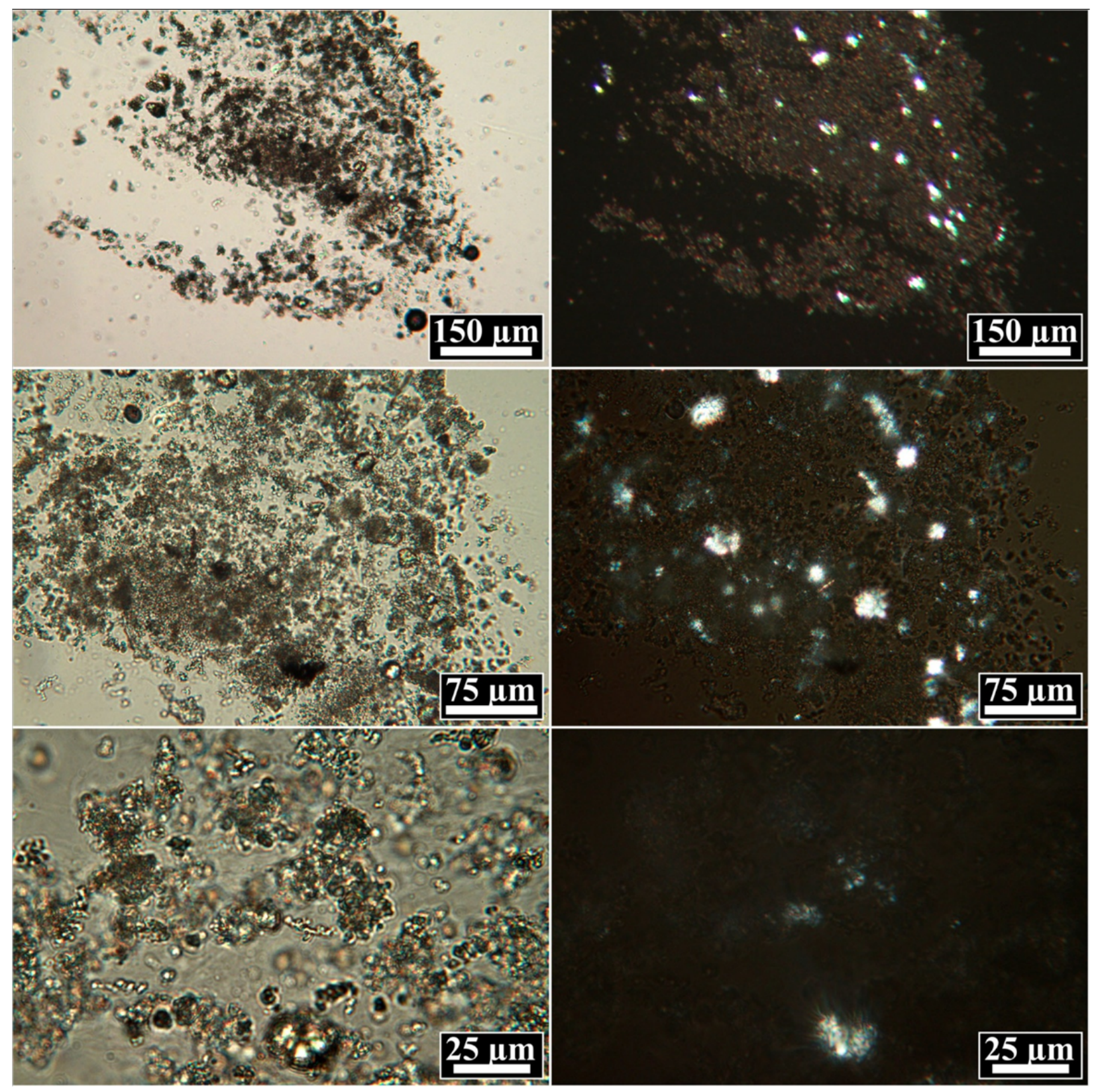

Figure 4.15. Material Washed from the Plugged Resin Bed in Test $\mathrm{B}\left(65^{\circ} \mathrm{C}\right)$ from PLM 

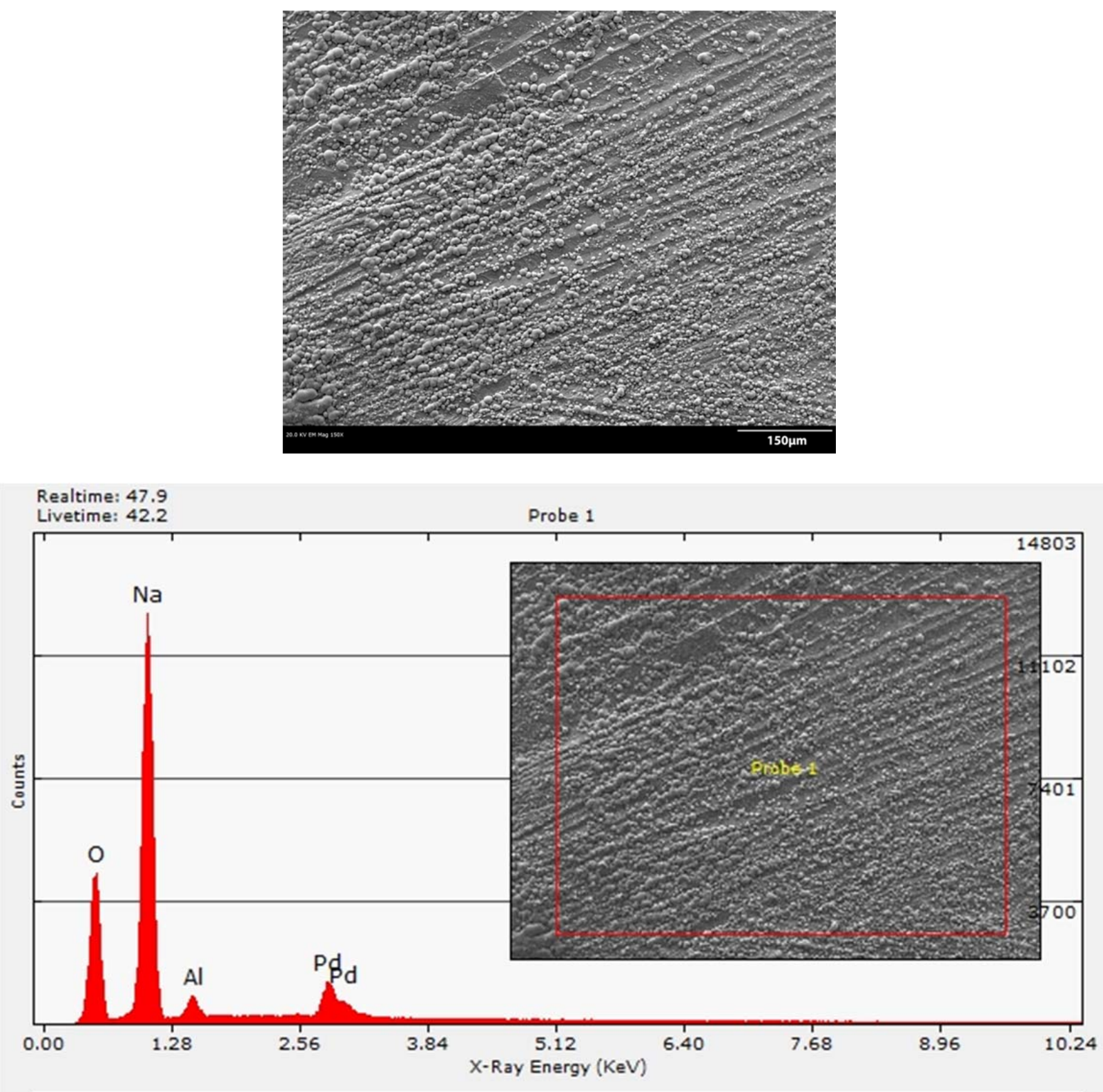

Quantitative Results for Probe 1

Analysis: Bulk Method: Standardless

Acquired 27-Sep-2011,20.0 KeV @10 eV/channel

$\begin{array}{rrrr}\text { Element } & \text { Weight \% } & \text { Std. Dev. } & \text { Atomic \% } \\ 0 & 30.31 & 1.04 & 40.36 \\ \mathrm{Na} & 59.61 & 1.36 & 55.23 \\ \mathrm{Al} & 4.05 & 0.98 & 3.20 \\ \mathrm{Pd} & 6.03 & 1.07 & 1.21 \\ \text { Total } & 100.00 & & \end{array}$

Figure 4.16. Material Washed from the Plugged Resin Bed in Test B $\left(65^{\circ} \mathrm{C}\right)$ from SEM-EDS $(150 \mu \mathrm{m}$ scale) 

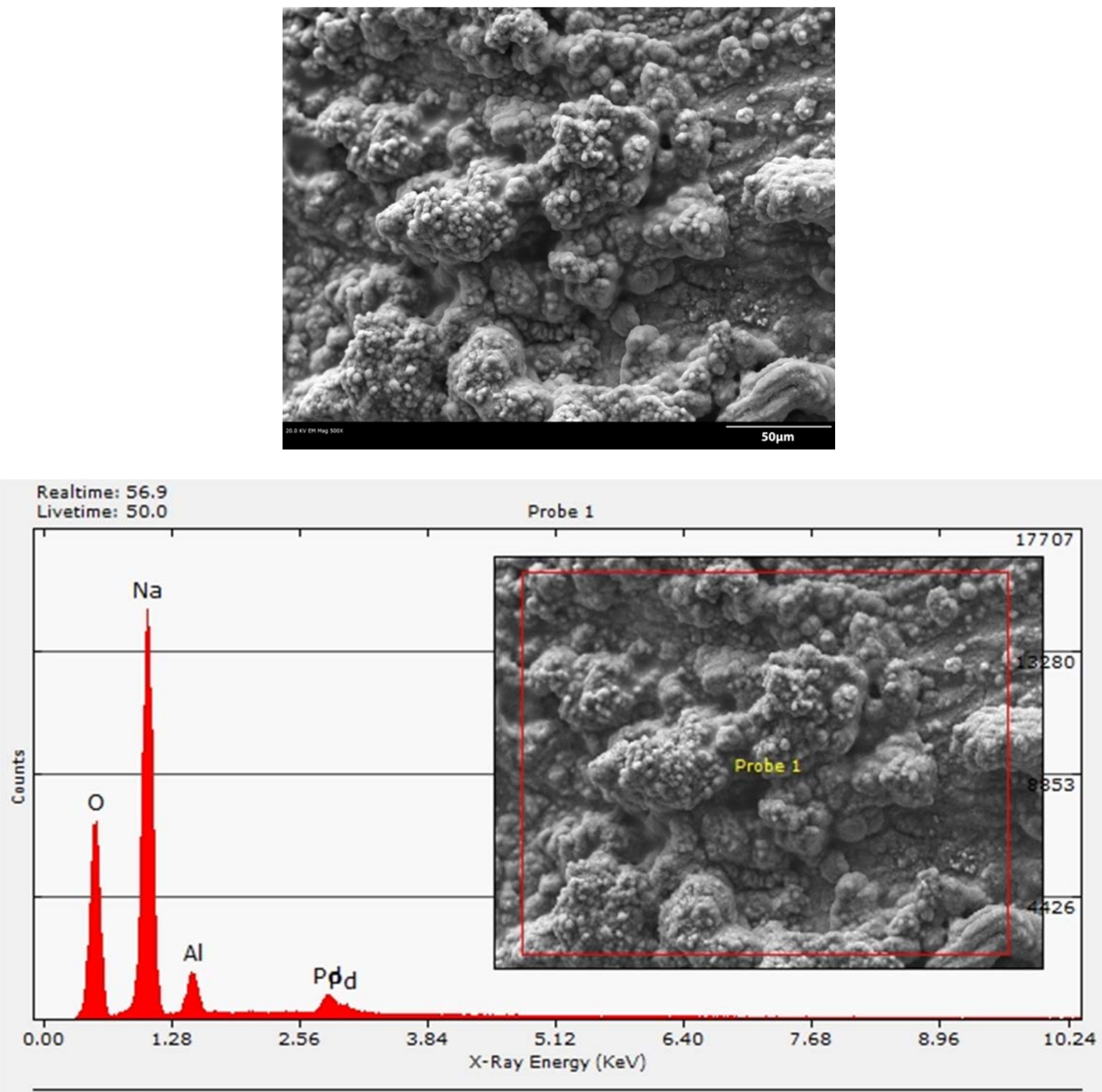

Quantitative Results for Probe 1

Analysis: Bulk Method: Standardless

Acquired 27-Sep-2011,20.0 KeV @10 eV/channel

$\begin{array}{rrrr}\text { Element } & \text { Weight \% } & \text { Std. Dev. } & \text { Atomic \% } \\ 0 & 36.03 & 1.00 & 46.06 \\ \mathrm{Na} & 54.11 & 1.22 & 48.13 \\ \mathrm{Al} & 6.91 & 1.04 & 5.24 \\ \mathrm{Pd} & 2.95 & 0.80 & 0.57 \\ \text { Total } & 100.00 & & \end{array}$

Figure 4.17. Material Washed from the Plugged Resin Bed in Test B $\left(65^{\circ} \mathrm{C}\right)$ from SEM-EDS $(50 \mu \mathrm{m}$ scale) 

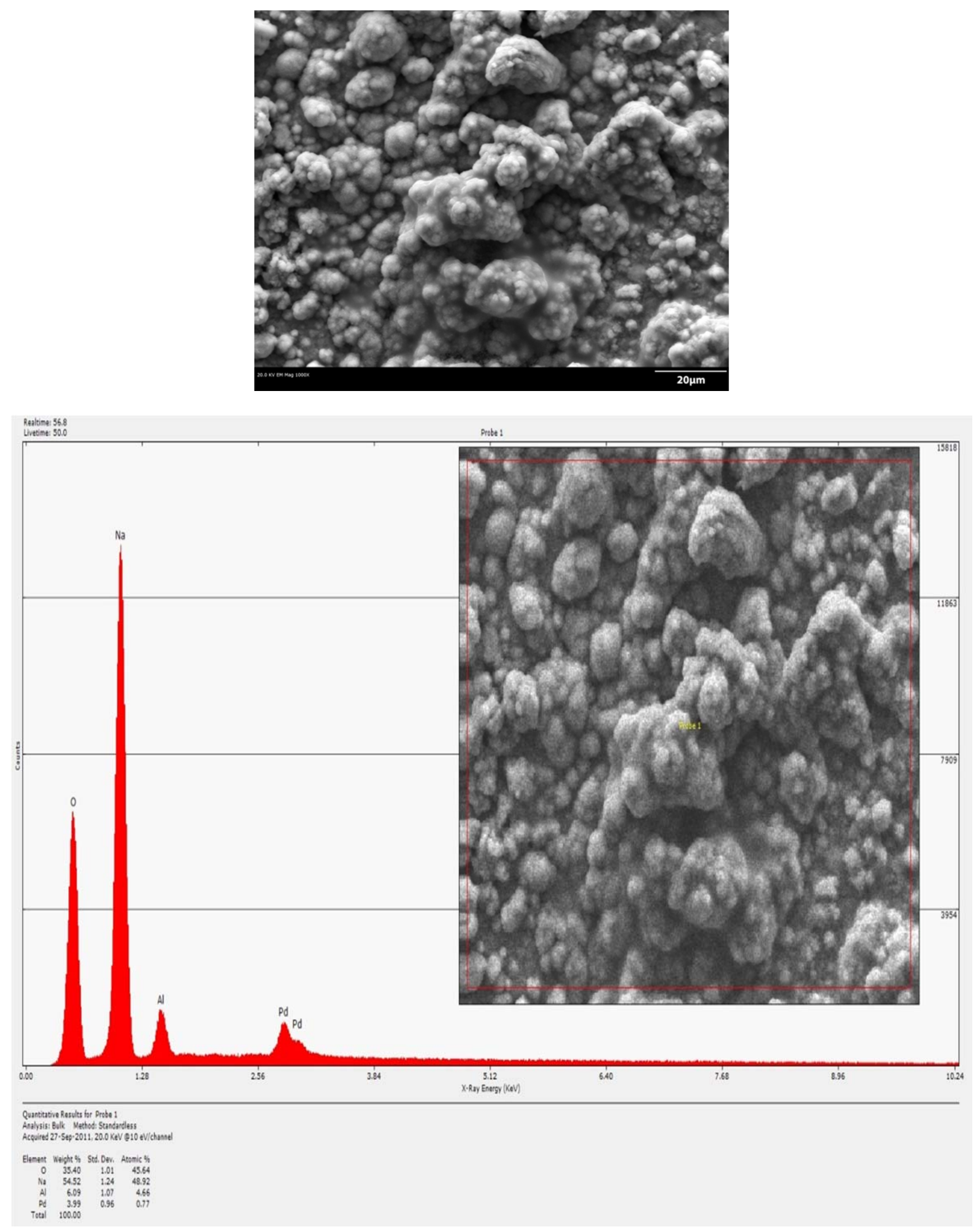

Figure 4.18. Material Washed from the Plugged Resin Bed in Test $\mathrm{B}\left(65^{\circ} \mathrm{C}\right)$ from SEM-EDS $(20 \mu \mathrm{m}$ scale) 
In the C4B resin, Figure 4.19 shows how degraded the resin appeared before column removal and Figure 4.20 shows the color of the supernate removed from the column. Only the top $80 \%$ was loose and free-flowing with the bottom portion hard-set and stuck to the glass. A Teflon coated metal spatula was used to break this material loose. Once the o-ring was broken loose from the column, the lower bed support was removed. The buildup of material between the bed support and the wall of the column, shown in Figure 4.21, made removing the support very difficult. The column was initially loaded with $1.8 \mathrm{~mL}$ of resin with about $1.5 \mathrm{~mL}$ remaining after testing. After removal of the lower support, the resin and other debris on the lower support bed were washed into the graduated cylinder with the resin. The total volume of resin and black residue was $1.8 \mathrm{~mL}$. This resin and debris were analyzed with optical microscopy, PLM, and SEM-EDS and are shown in Figure 4.22 through Figure 4.25. Again, the white crystalline material appeared to be sodium aluminate that had crystallized from the simulant being fed through the column based on the EDS analysis.

After washing the lower bed support, there was still significant debris stuck to the outside and top edge of the support. A metal spatula was used to scrape this material from the support. The resulting debris was washed into another glass vial and analyzed using the same methods. The material was very dark, almost black, in color. These results are shown in Figure 4.26 through Figure 4.32. The presence of $\mathrm{Si}$ and $\mathrm{Ca}$ in the solids analyzed by EDS suggests that the glass column was degraded by the high concentration, high temperature caustic solution over an extended period of time.

The material that was left on the inside of the column (shown in Figure 4.33) was washed into a third vial and analyzed similarly, with the results shown in Figure 4.34. This appears to be a combination of resin and sodium aluminate again; however, EDS was not performed on this sample to confirm this.

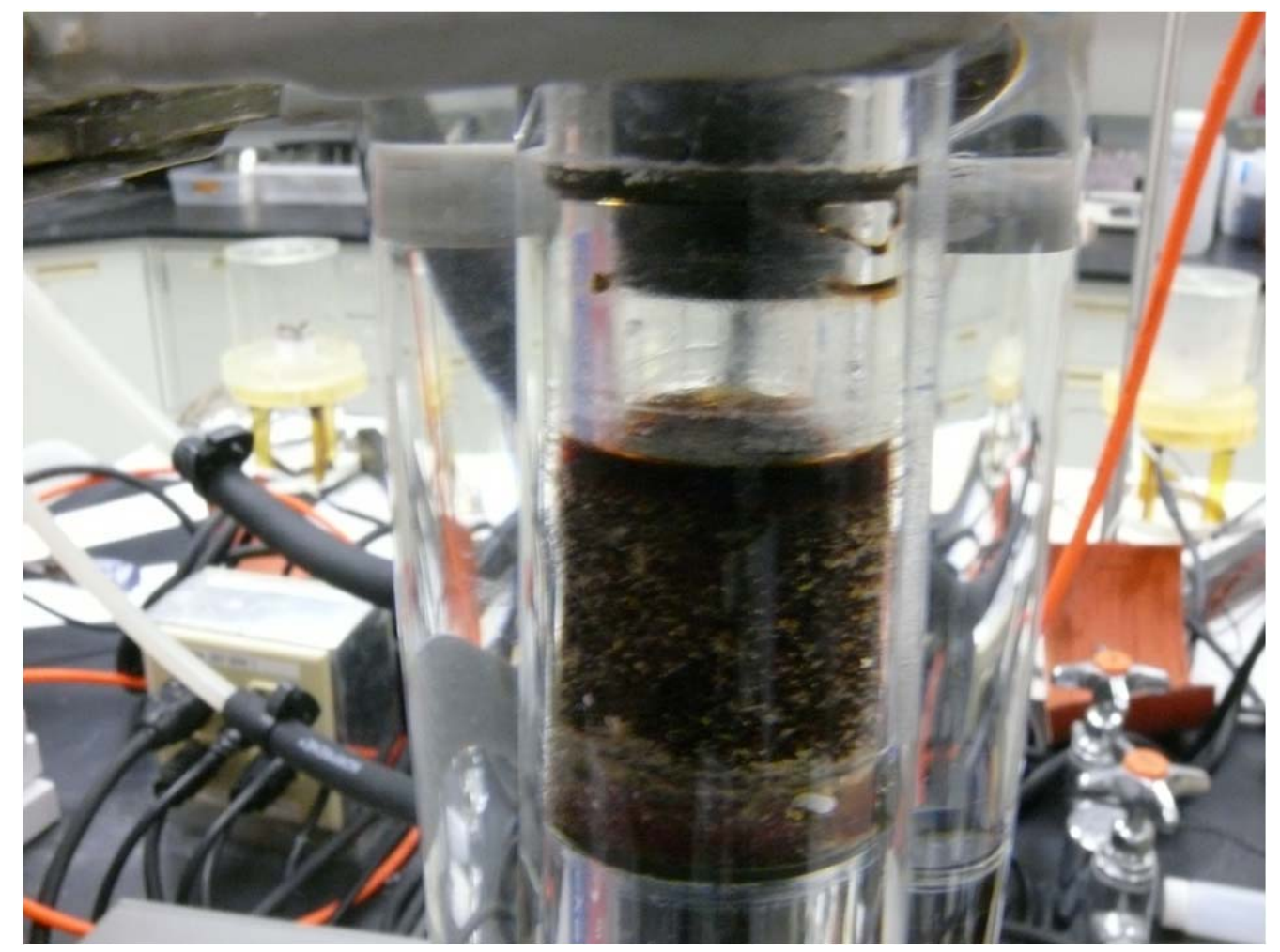

Figure 4.19. Resin After Testing of Column $\mathrm{C}$ at $75^{\circ} \mathrm{C}$ 


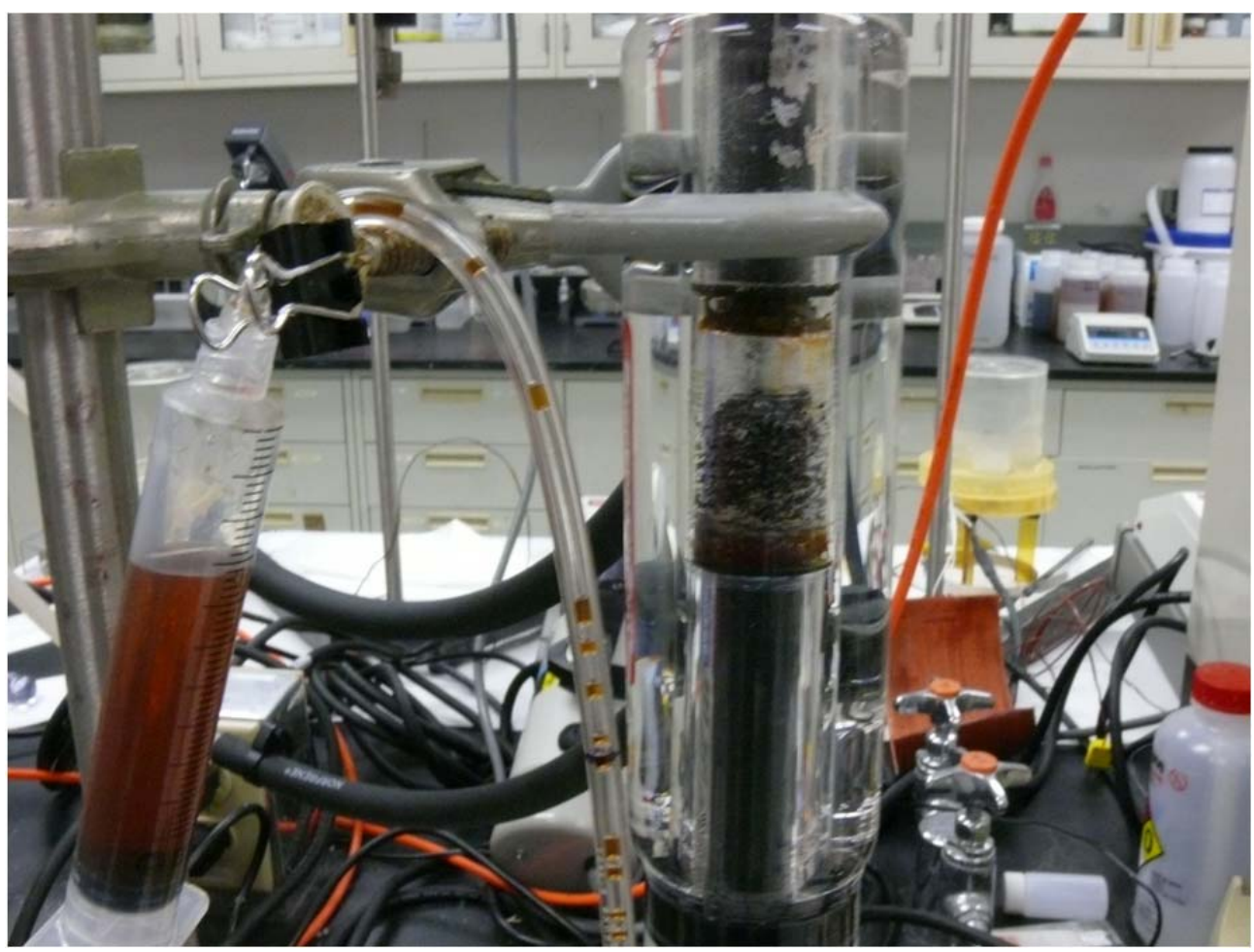

Figure 4.20. Supernate Removed from Column $\mathrm{C}$ after Testing at $75^{\circ} \mathrm{C}$

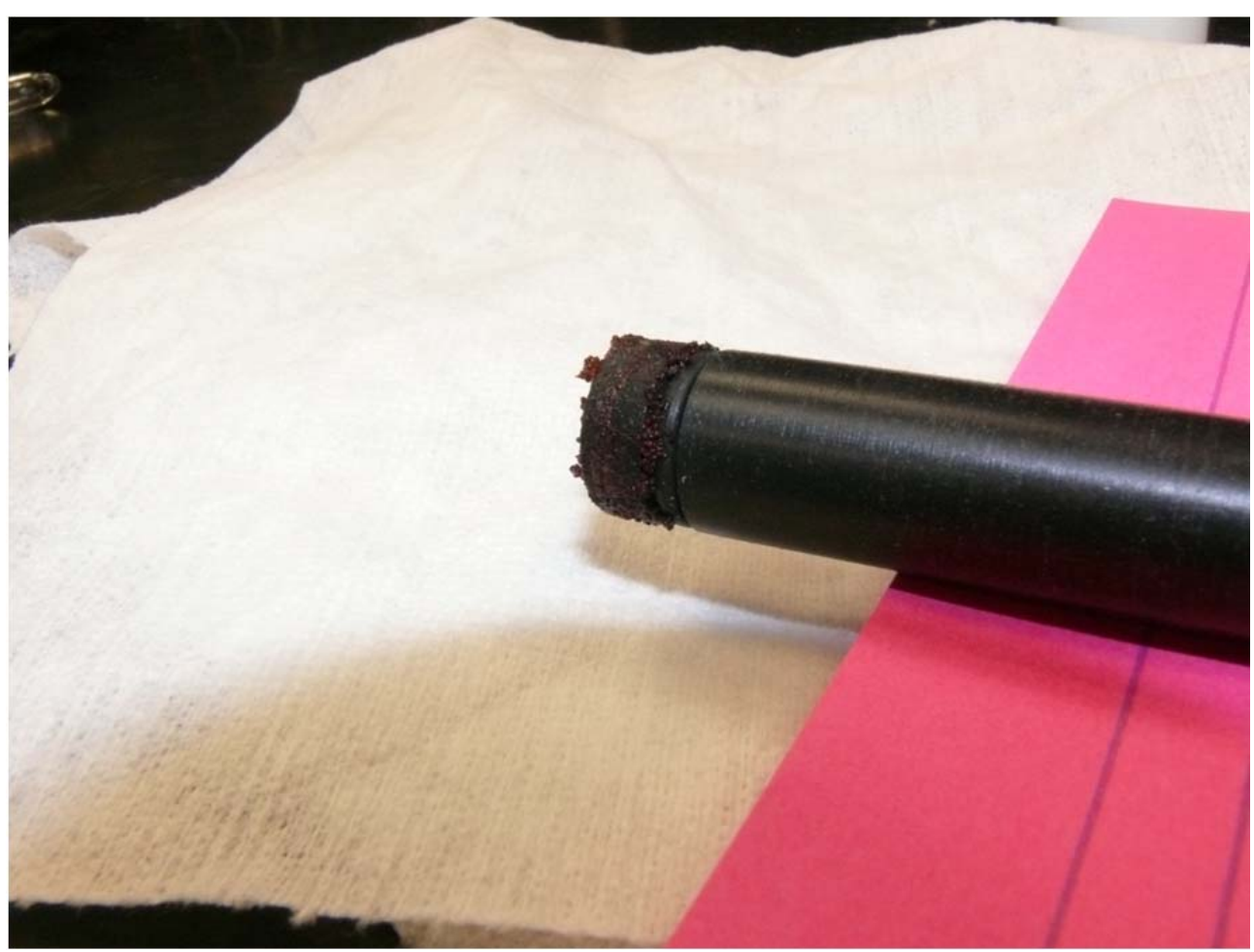

Figure 4.21. Material Between Column C Wall and Bed Support 


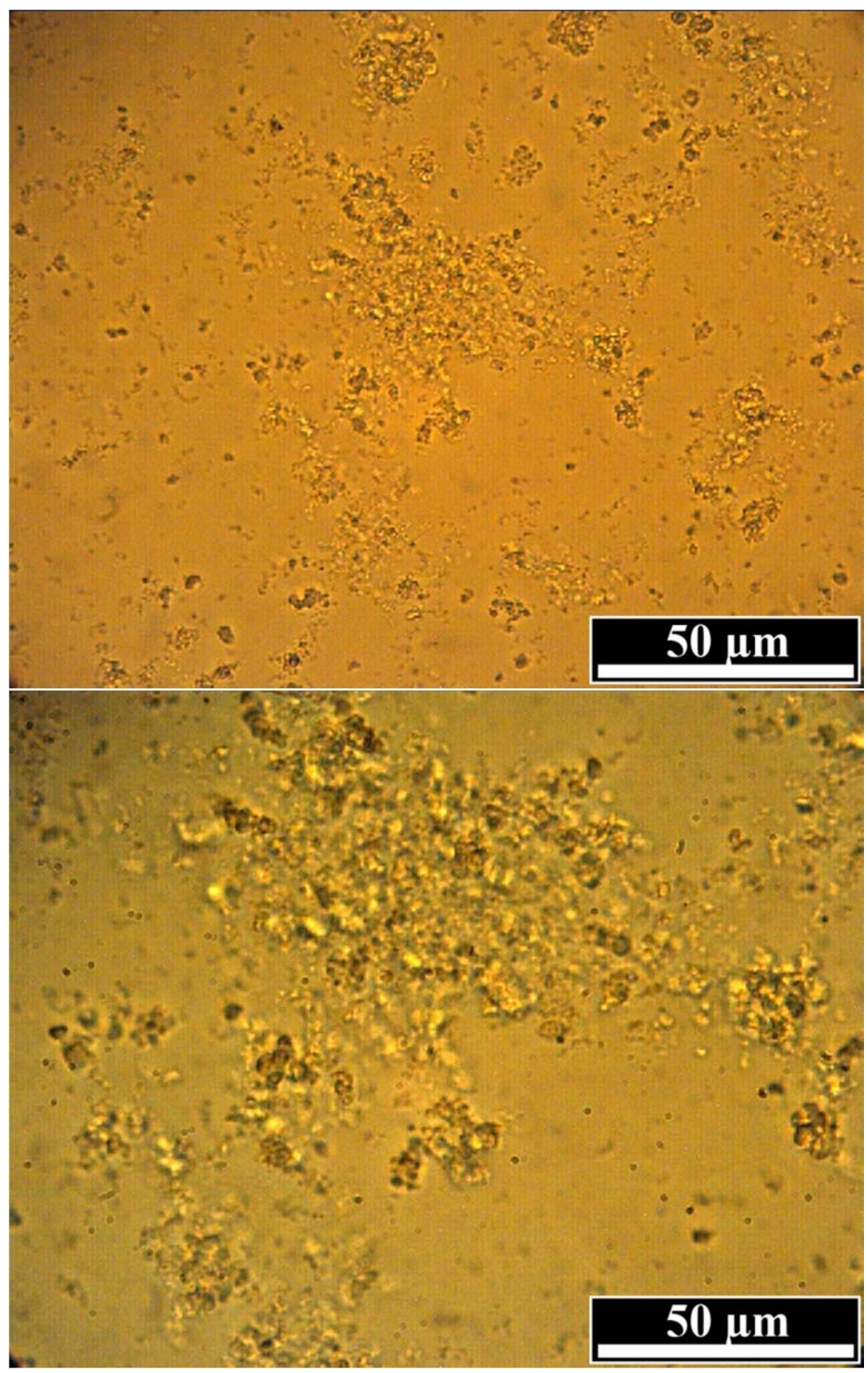

Figure 4.22. Material Washed from the Plugged Resin Bed in Test $\mathrm{C}\left(75^{\circ} \mathrm{C}\right)$ from Optical Microscopy--500X (top) and 1000X (bottom) 


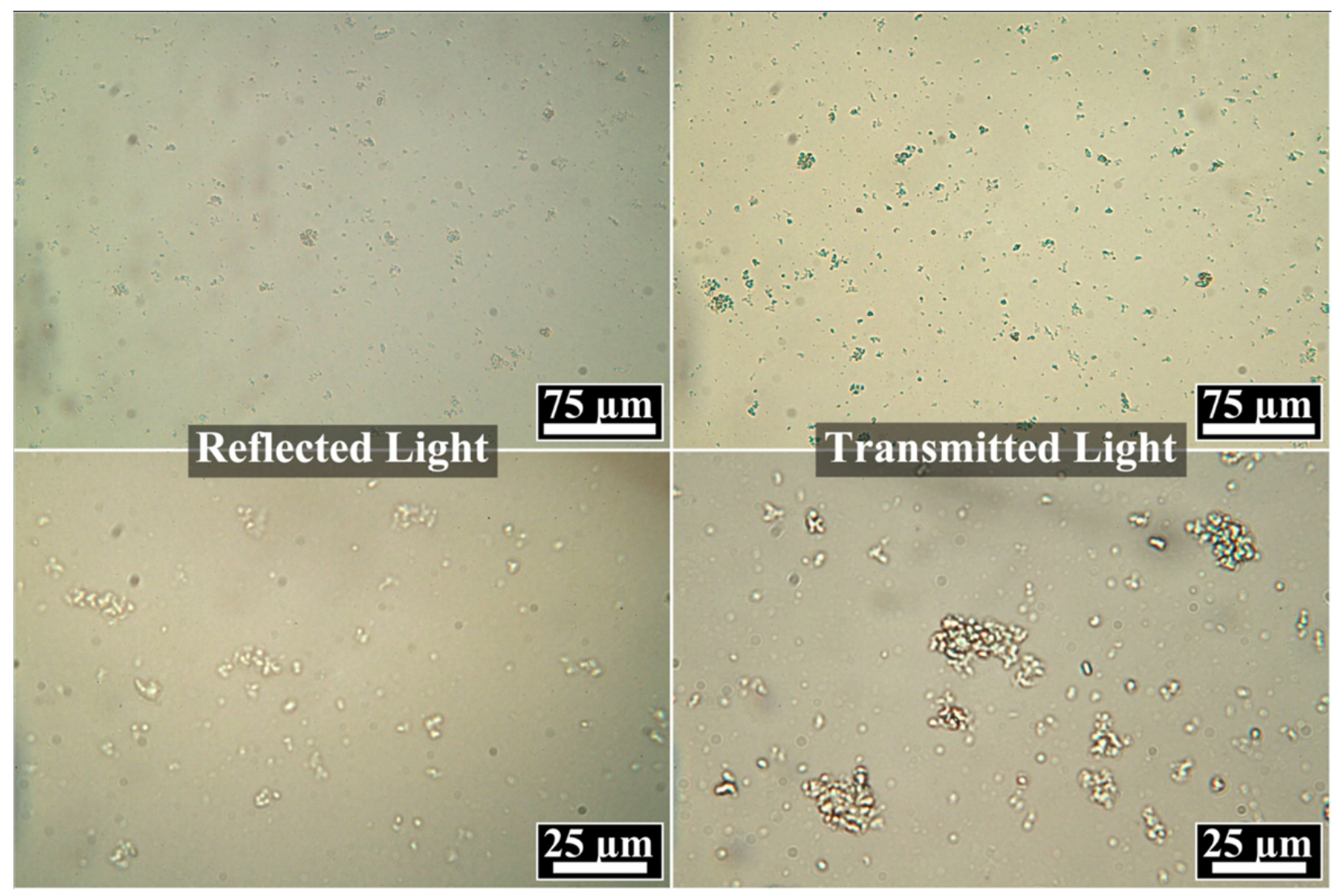

Figure 4.23. Material Washed from the Plugged Resin Bed in Test $\mathrm{C}\left(75^{\circ} \mathrm{C}\right)$ from PLM 

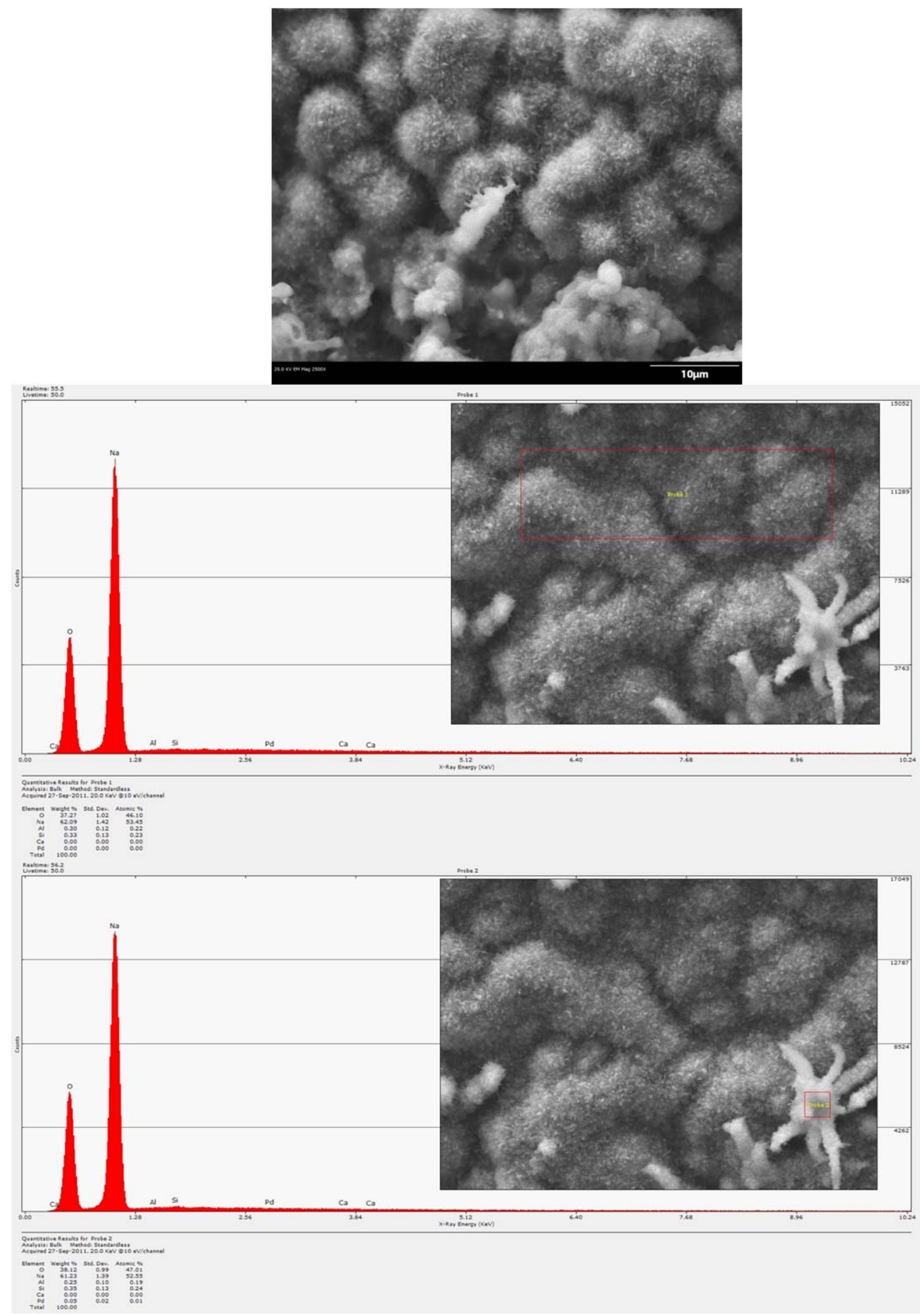

Figure 4.24. Material Washed from the Plugged Resin Bed in Test $\mathrm{C}\left(75^{\circ} \mathrm{C}\right)$ from SEM-EDS $(10 \mu \mathrm{m})$ 


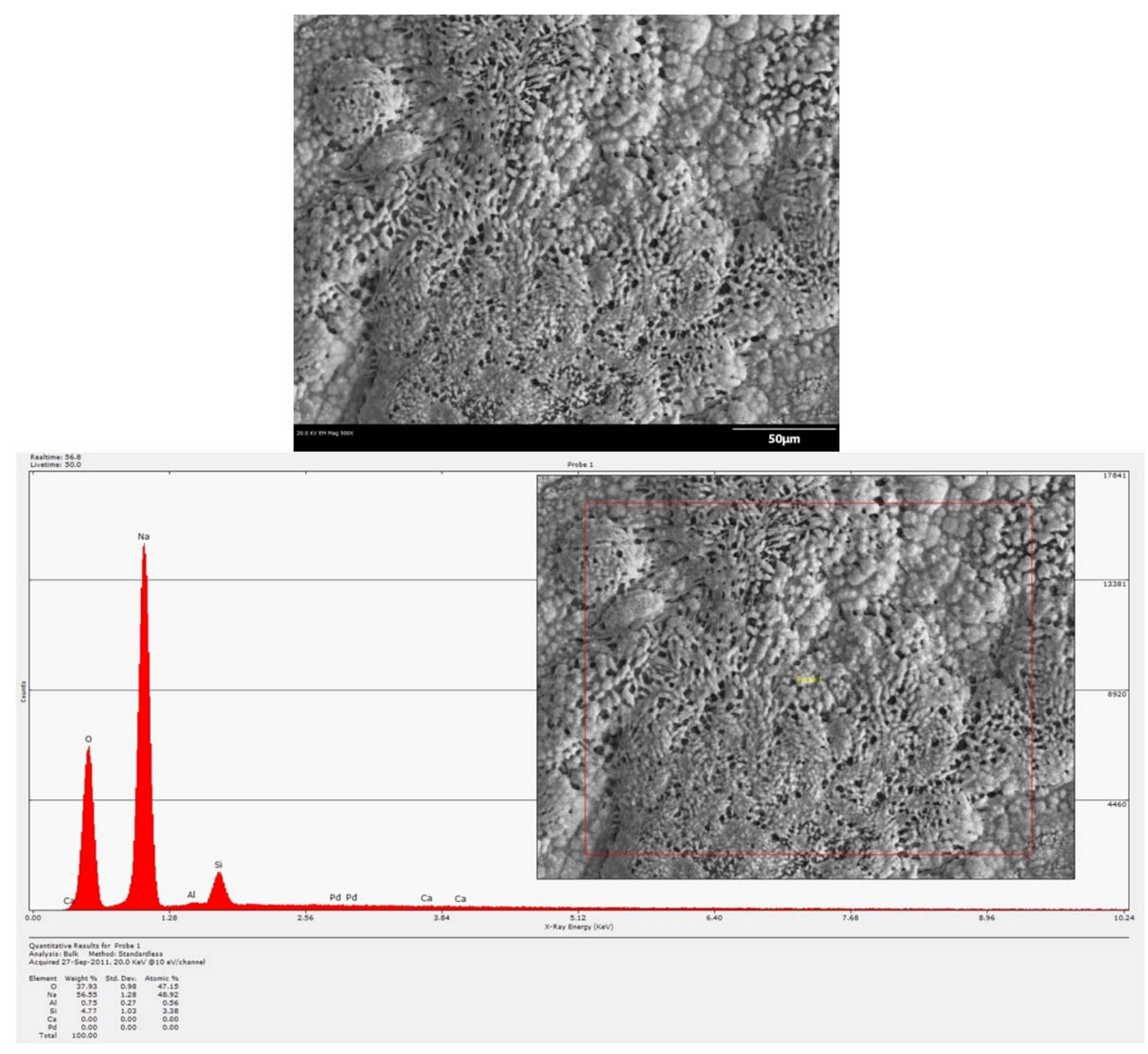

Figure 4.25. Material Washed from the Plugged Resin Bed in Test C $\left(75^{\circ} \mathrm{C}\right)$ from SEM-EDS $(20 \mu \mathrm{m})$ 


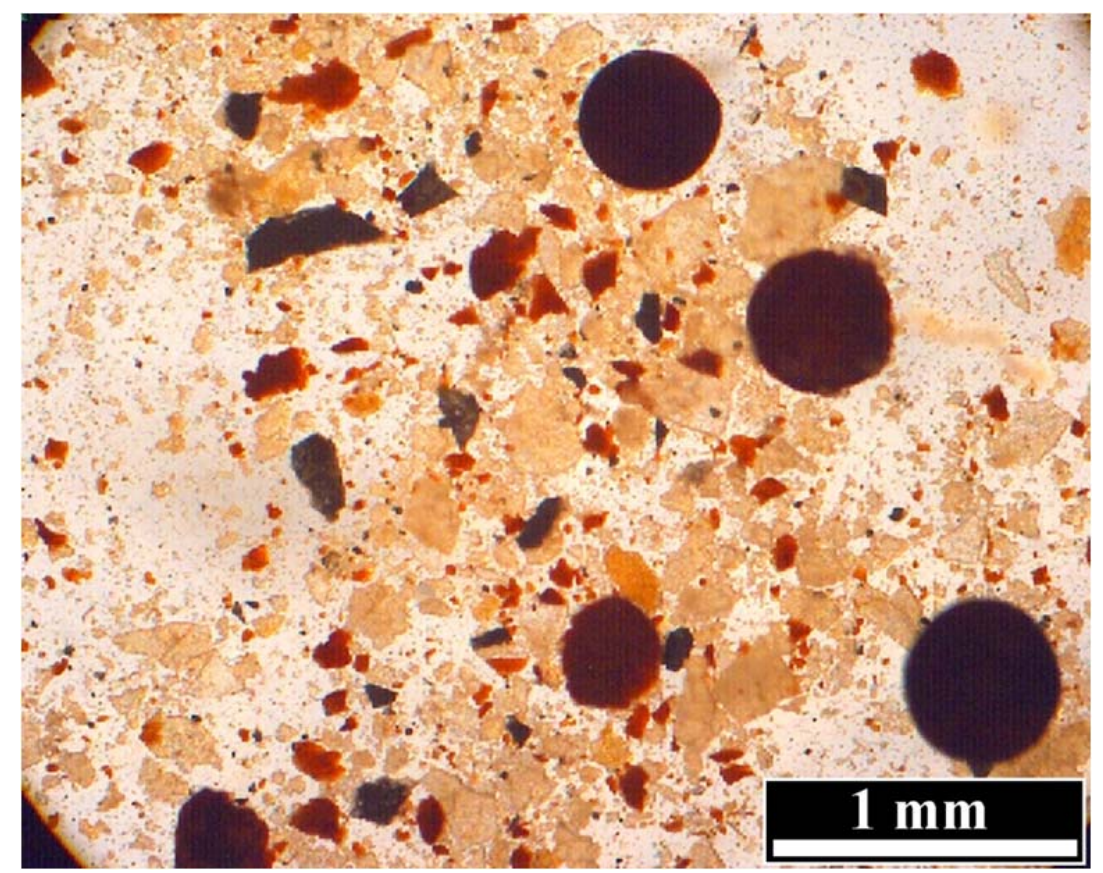

Figure 4.26. Sample Scraped and Washed from Lower Column Support after Test $\mathrm{C}\left(75^{\circ} \mathrm{C}\right)$ from Optical Microscopy-70X

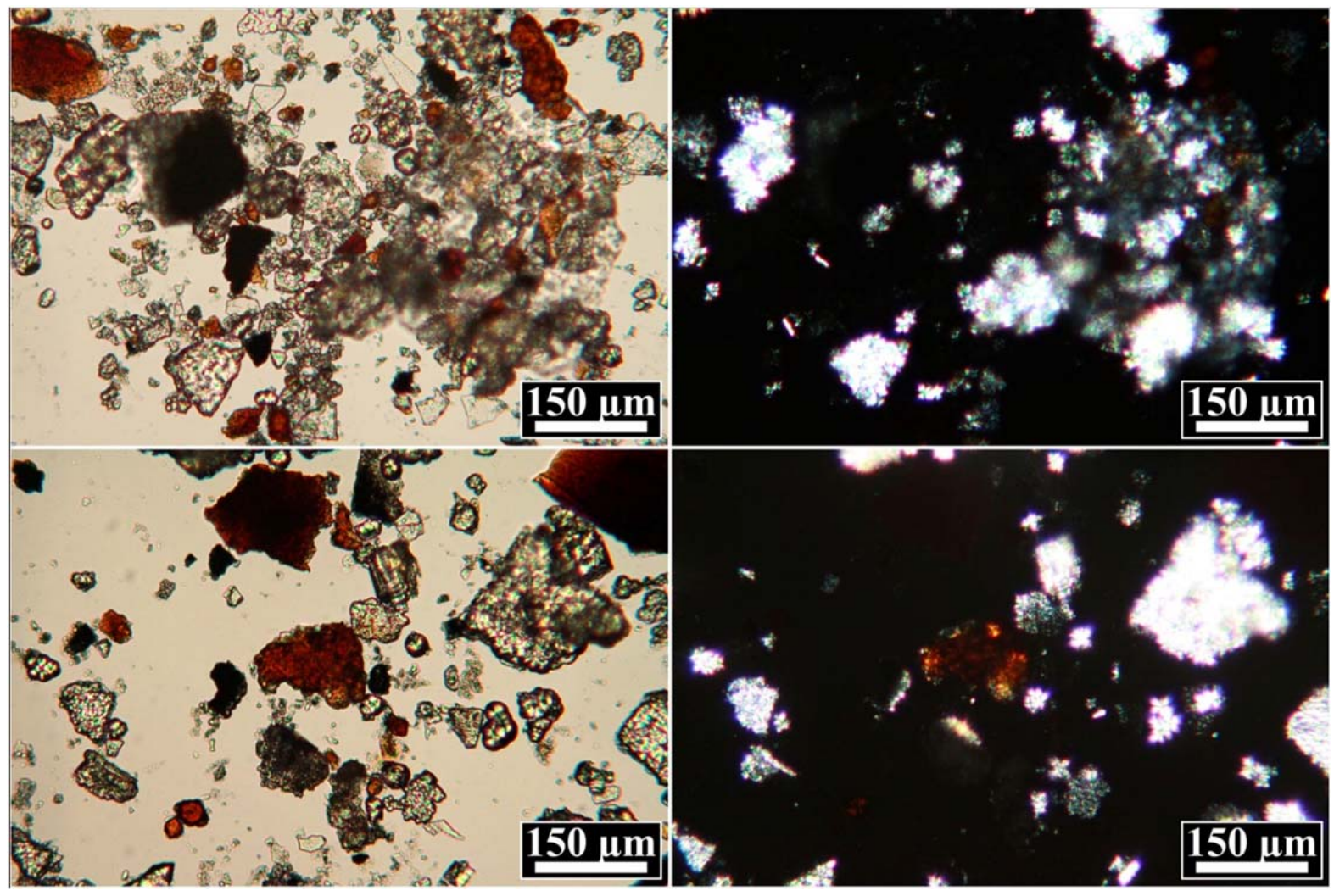

Figure 4.27. Sample Scraped and Washed from Lower Column Support after Test C $\left(75^{\circ} \mathrm{C}\right)$ from PLM 


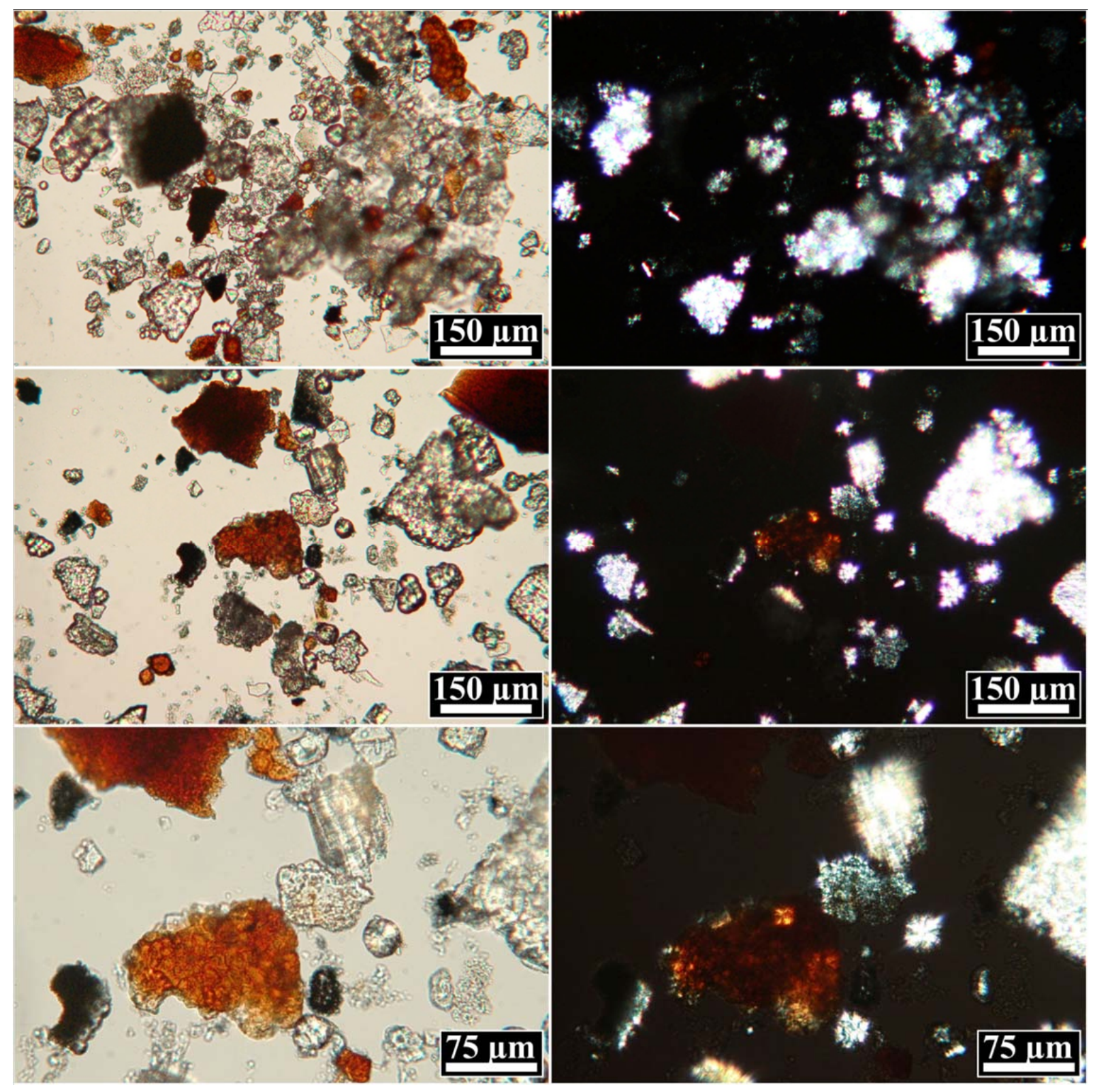

Figure 4.28. Sample Scraped and Washed from Lower Column Support after Test C $\left(75^{\circ} \mathrm{C}\right)$ from Trans PLM 

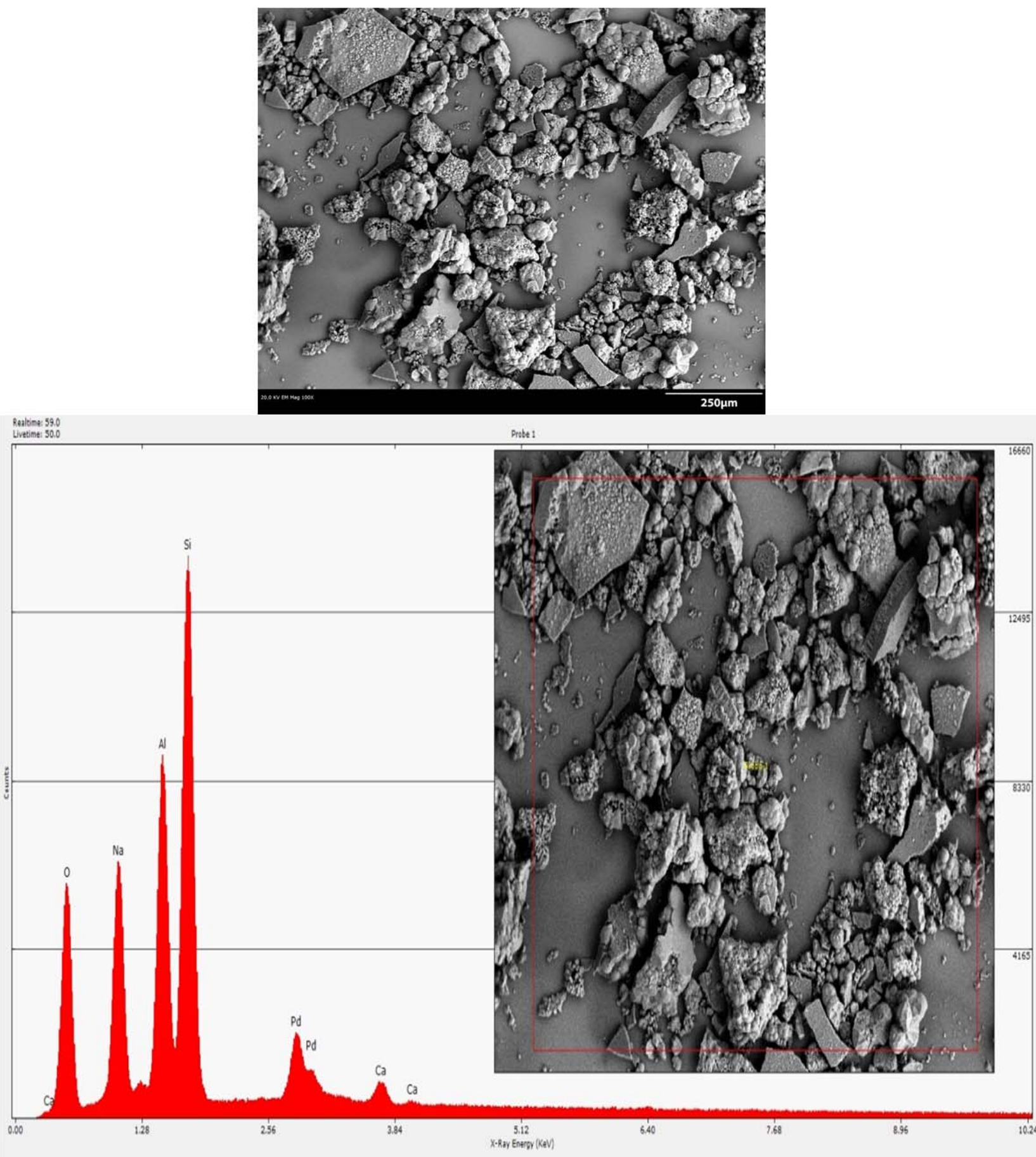

$$
\begin{aligned}
& \text { Quncutive Results for Probe: }
\end{aligned}
$$

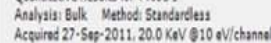

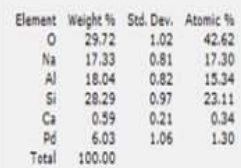

Figure 4.29. Sample Scraped and Washed from Lower Column Support after Test $\mathrm{C}\left(75^{\circ} \mathrm{C}\right)$ from SEM-EDS (large area at $250 \mu \mathrm{m}$ ) 

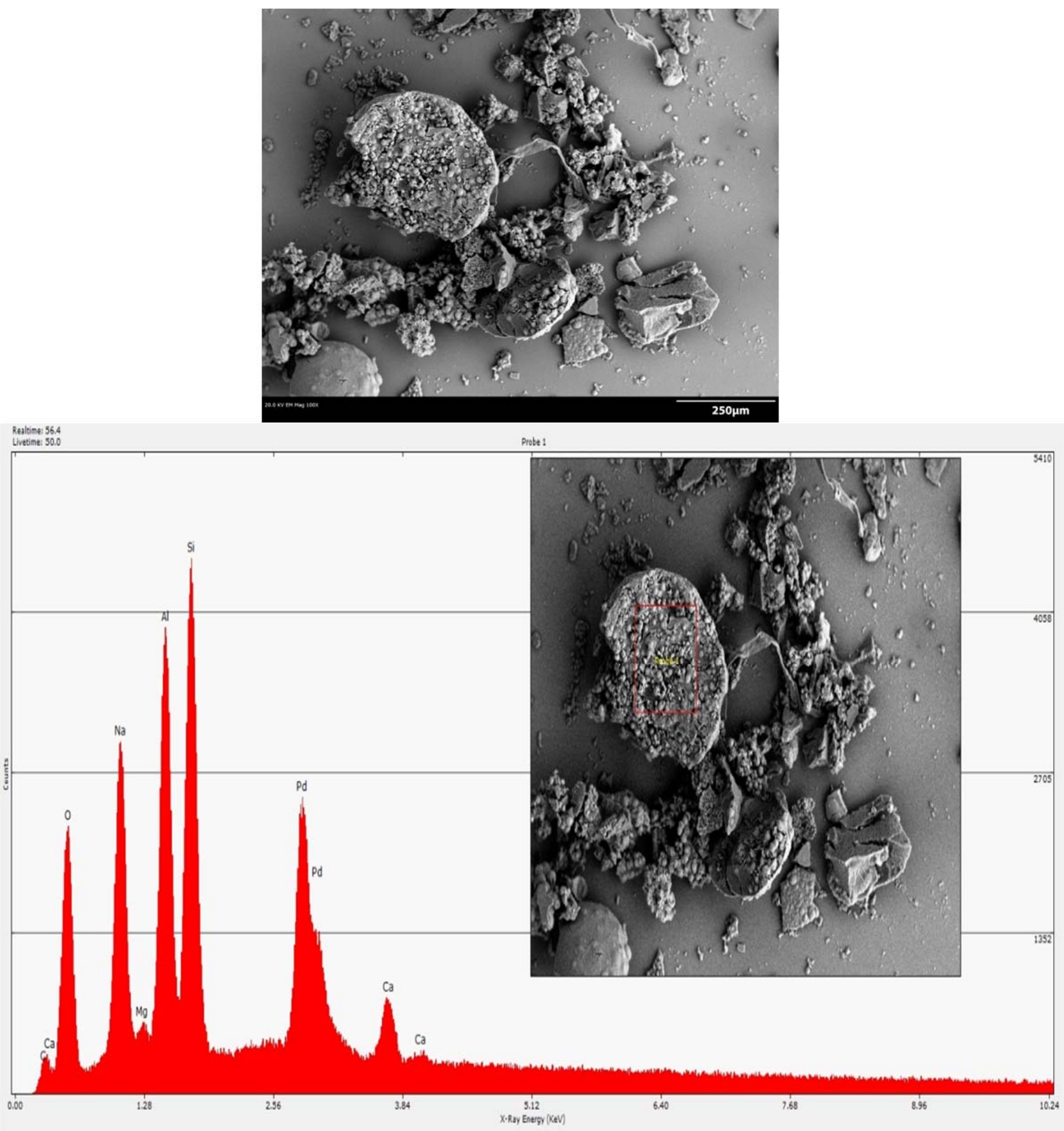

Quntcutive Resulta for Prebe :

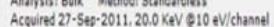

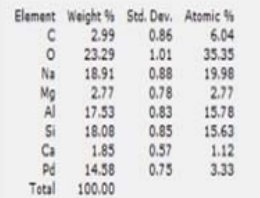

Figure 4.29. Sample Scraped and Washed from Lower Column Support after Test $C\left(75^{\circ} \mathrm{C}\right)$ from SEM-EDS (small spot at $250 \mu \mathrm{m}$ ) 

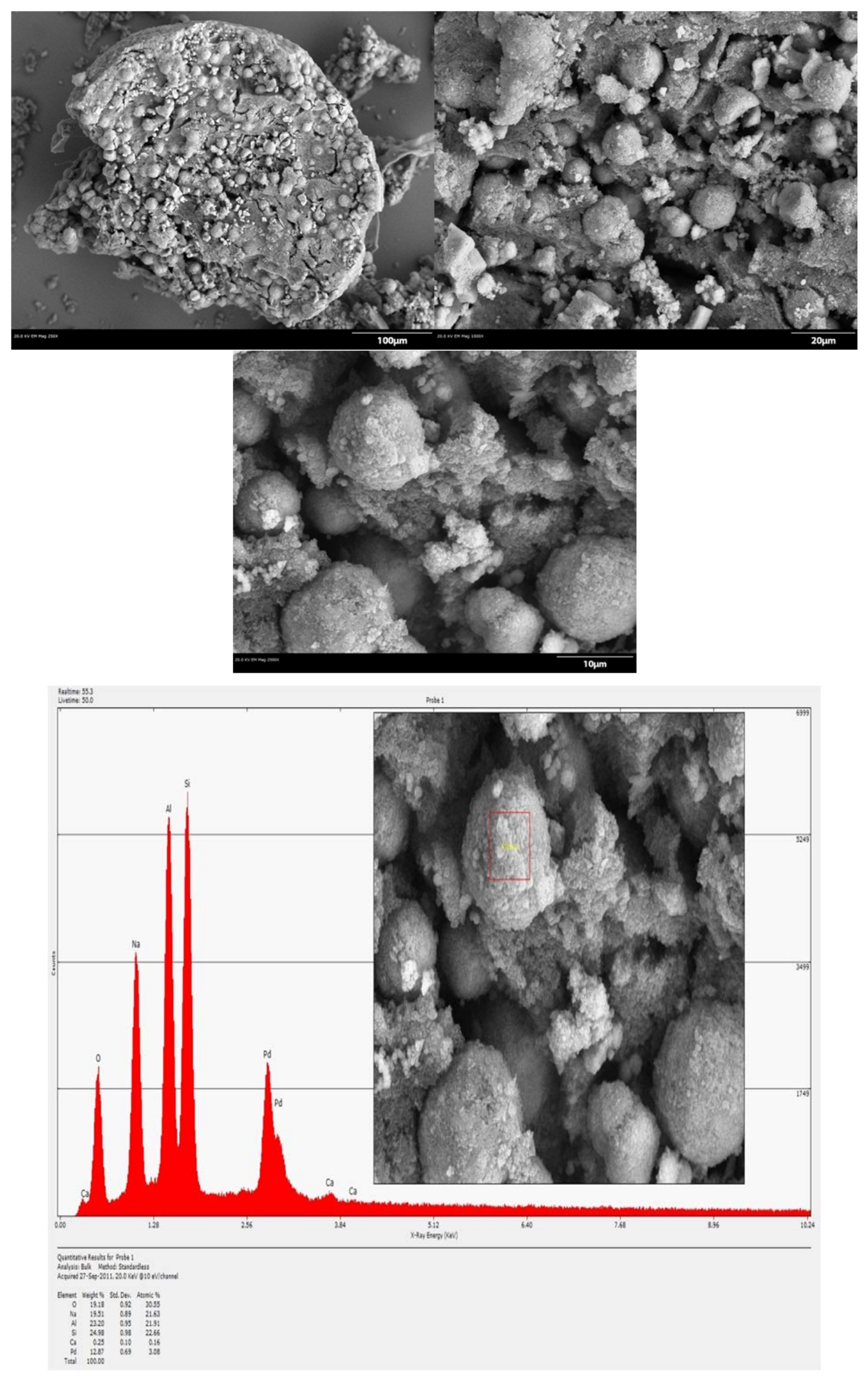

Figure 4.30. Sample Scraped and Washed from Lower Column Support after Test $\mathrm{C}\left(75^{\circ} \mathrm{C}\right)$ from SEM-EDS (upper place at $10 \mu \mathrm{m}$ ) 


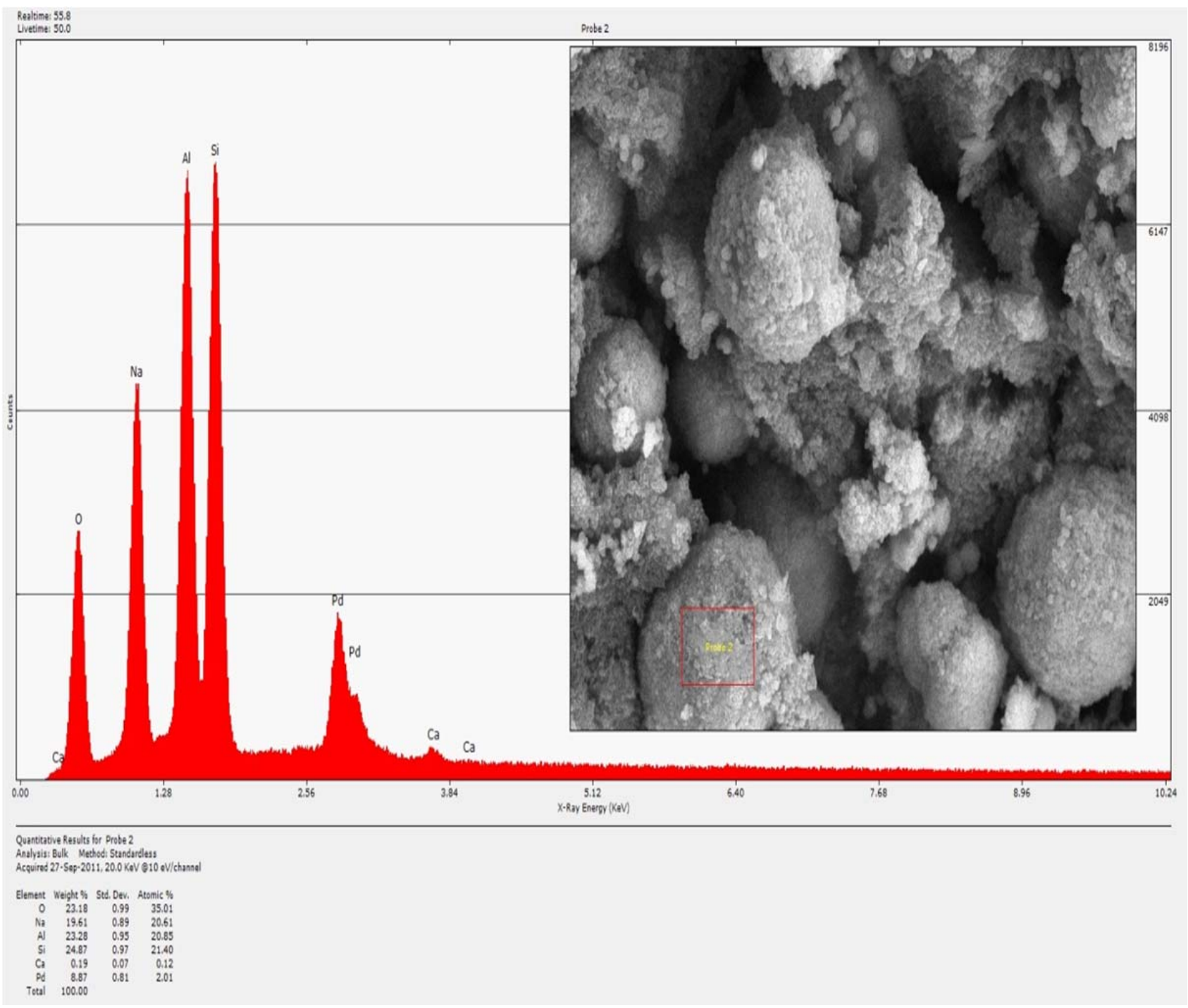

Figure 4.31. Sample Scraped and Washed from Lower Column Support after Test $\mathrm{C}\left(75^{\circ} \mathrm{C}\right)$ from SEM-EDS (lower place at $10 \mu \mathrm{m}$ ) 


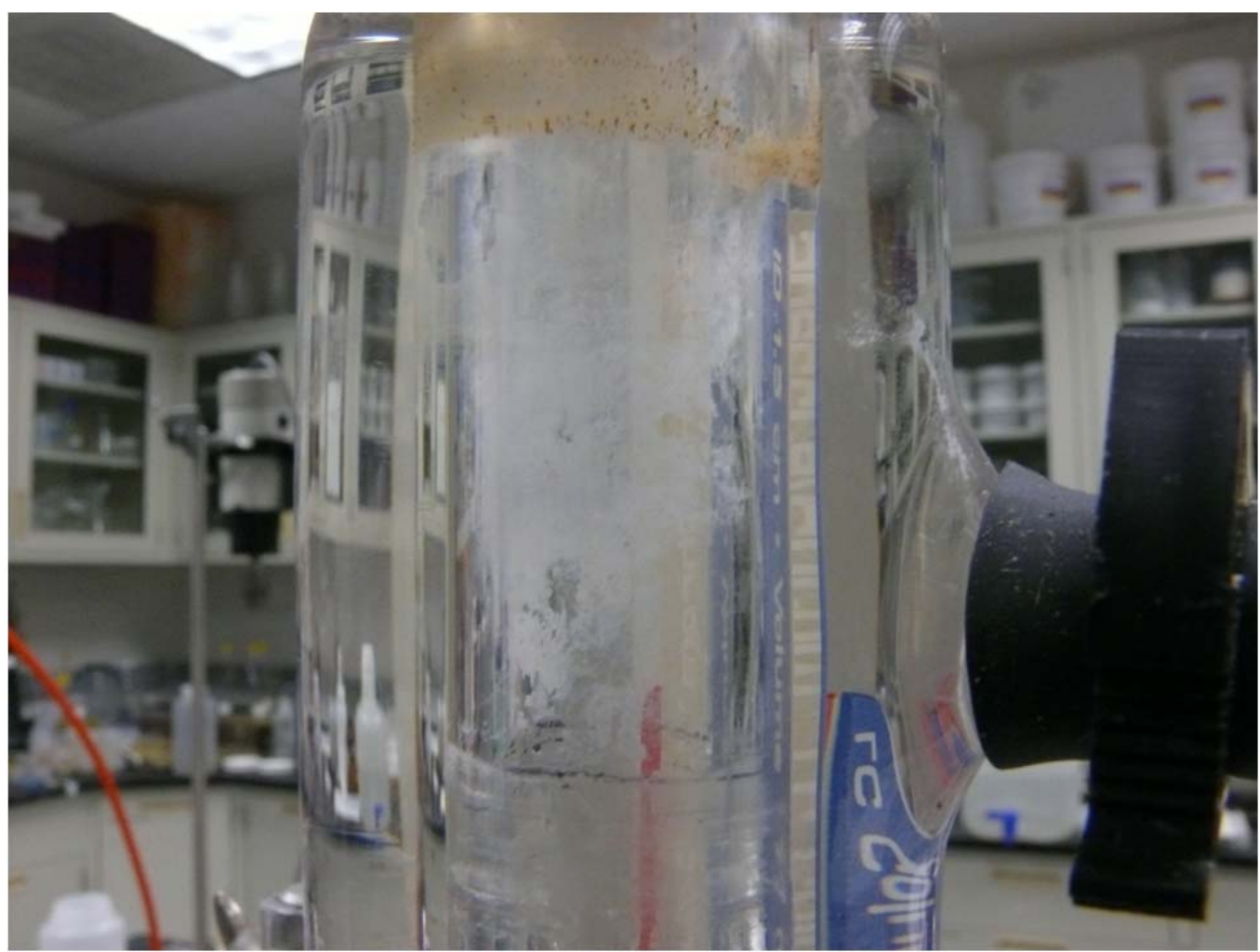

Figure 4.32. Debris Stuck to Column C after Testing at $75^{\circ} \mathrm{C}$

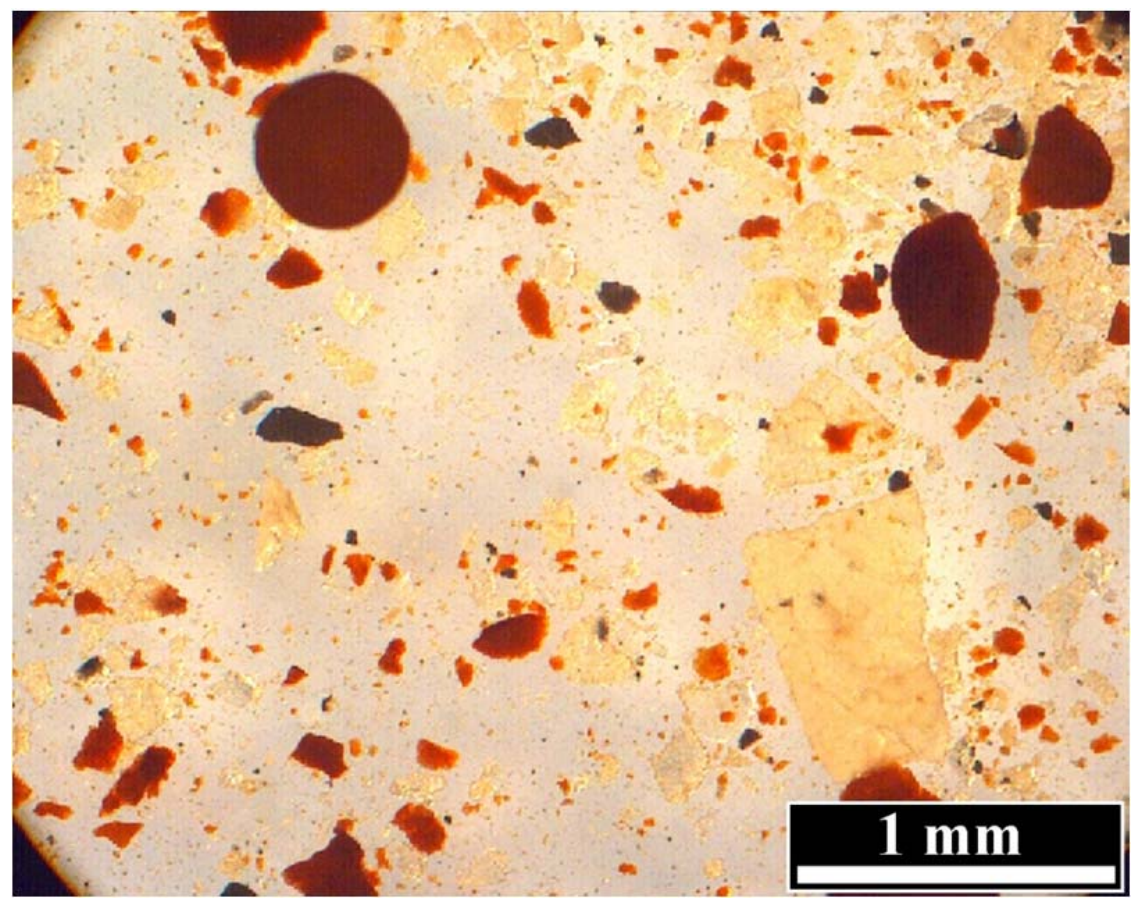

Figure 4.33. Sample Washed from the Lower Column Wall of Glass after Test $\mathrm{C}\left(75^{\circ} \mathrm{C}\right)$ from Optical Microscopy--70X 


\subsection{Effect of Aging Resin in an Acid Environment}

Figure 4.34 portrays the results of the batch contact loading tests after the resin had been aged in $0.5 \underline{\mathrm{M} \mathrm{HNO}_{3} \text { for }} 70$ days at various temperatures $\left(25^{\circ} \mathrm{C}, 45^{\circ} \mathrm{C}\right.$, and $\left.55^{\circ} \mathrm{C}\right)$. The non-aged samples were held in water for the 70 days instead of acid. Samples were taken after $0,1,4,10$, and 24 hours. The results show that the acid did not seem to affect the loading of the resin at $25^{\circ} \mathrm{C}$. However, at $45^{\circ} \mathrm{C}$, the kinetics of the resin loading were significantly reduced with a lower overall loading capacity (Figure 4.36). At $55^{\circ} \mathrm{C}$ the resin had completely disintegrated, as shown in Figure 4.35, and could not be loaded for comparison.

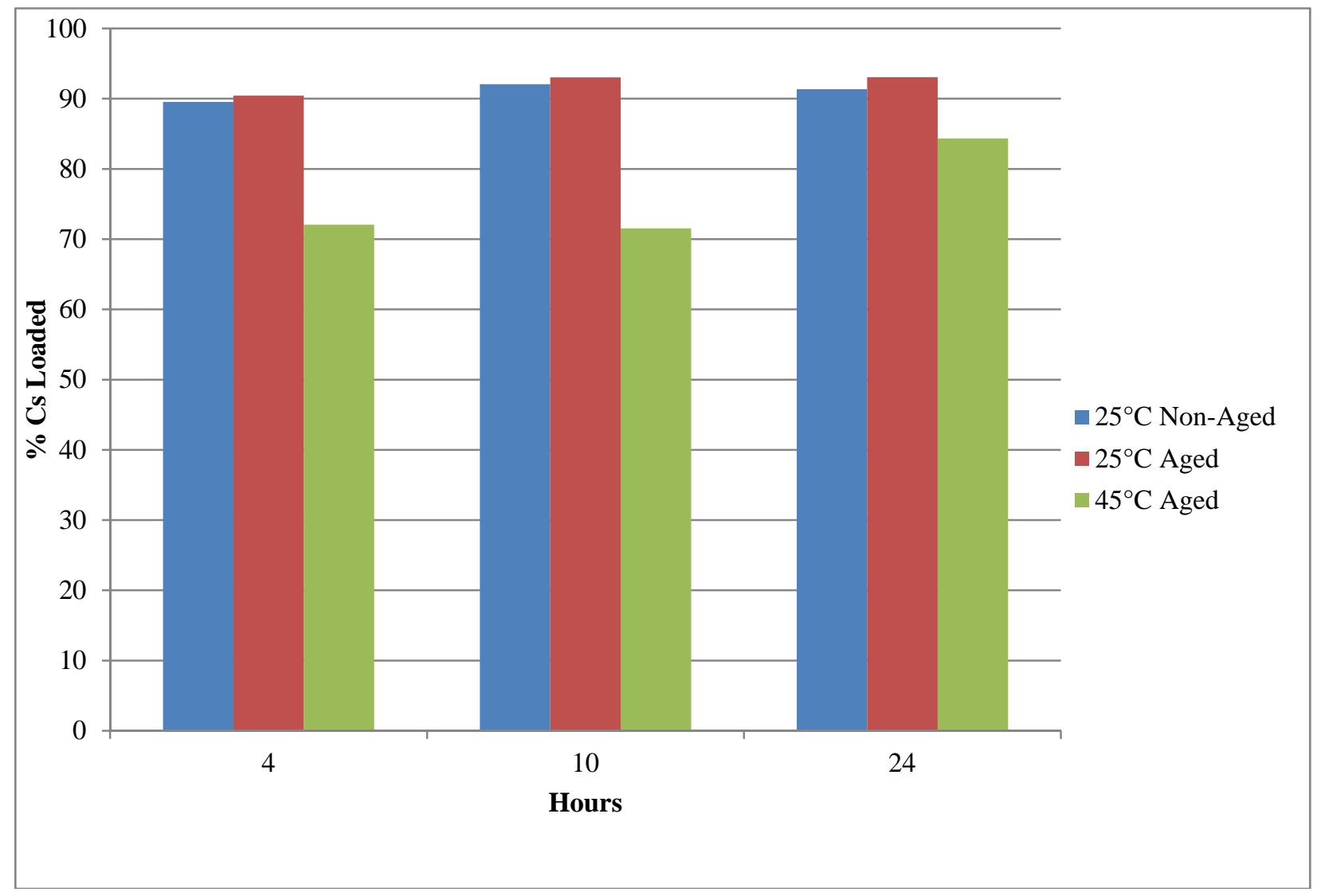

Figure 4.34. Resin Loading After 70 Days of Acid Aging 


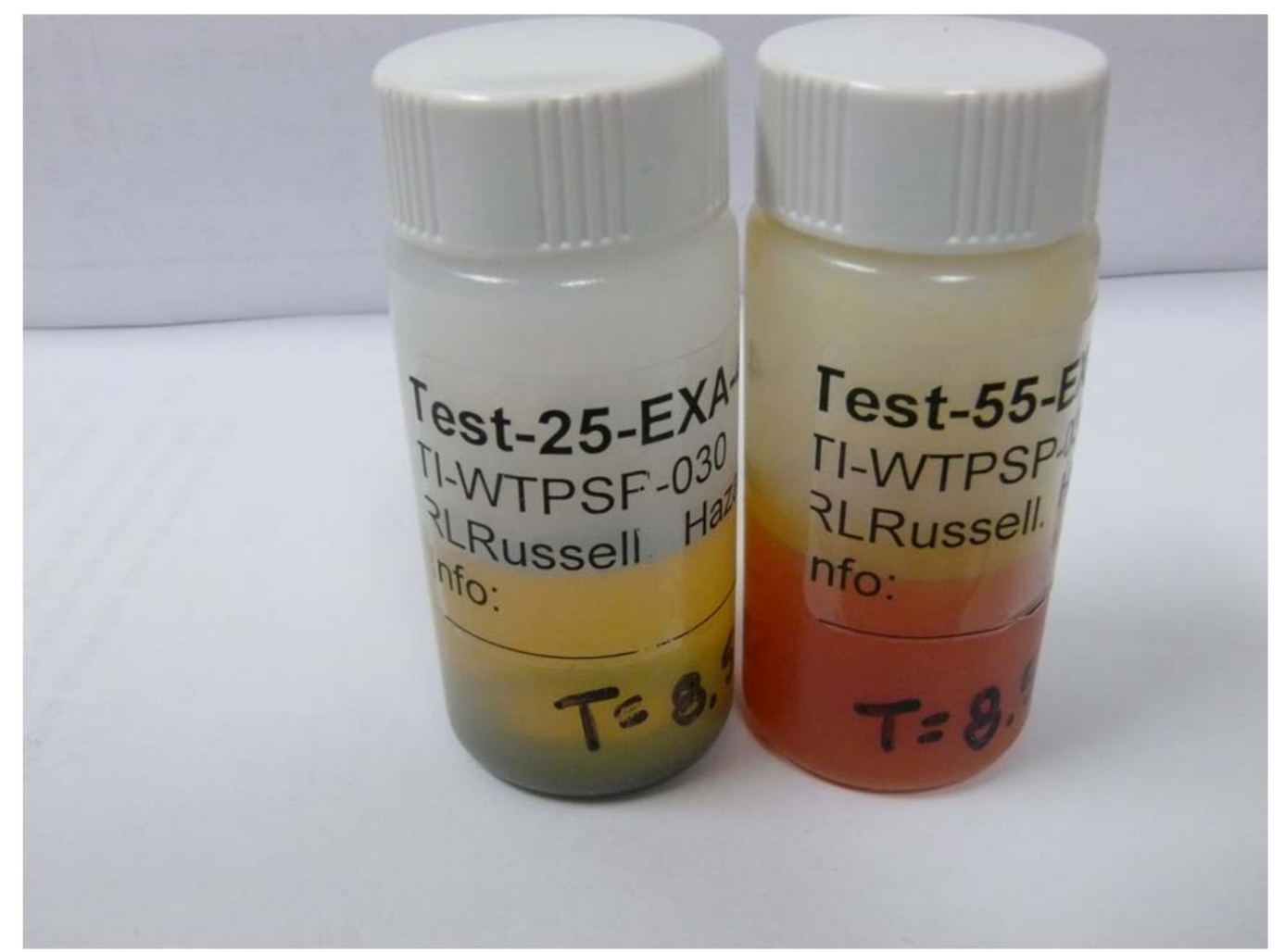

Figure 4.35. Resin Sample After Aging at $25^{\circ} \mathrm{C}$ for 70 Days Compared with $55^{\circ} \mathrm{C}$ Sample

SEM photos were taken of the aged resin at $25^{\circ} \mathrm{C}$ and $45^{\circ} \mathrm{C}$ and are shown in Figure 4.36. Not much difference was noticed in size of the resin spheres. However, the $45^{\circ} \mathrm{C}$ aged sample was darker in color indicating more oxidation, perhaps. Oxidation of the resin during the aging process could lead to reduced loading capacity.

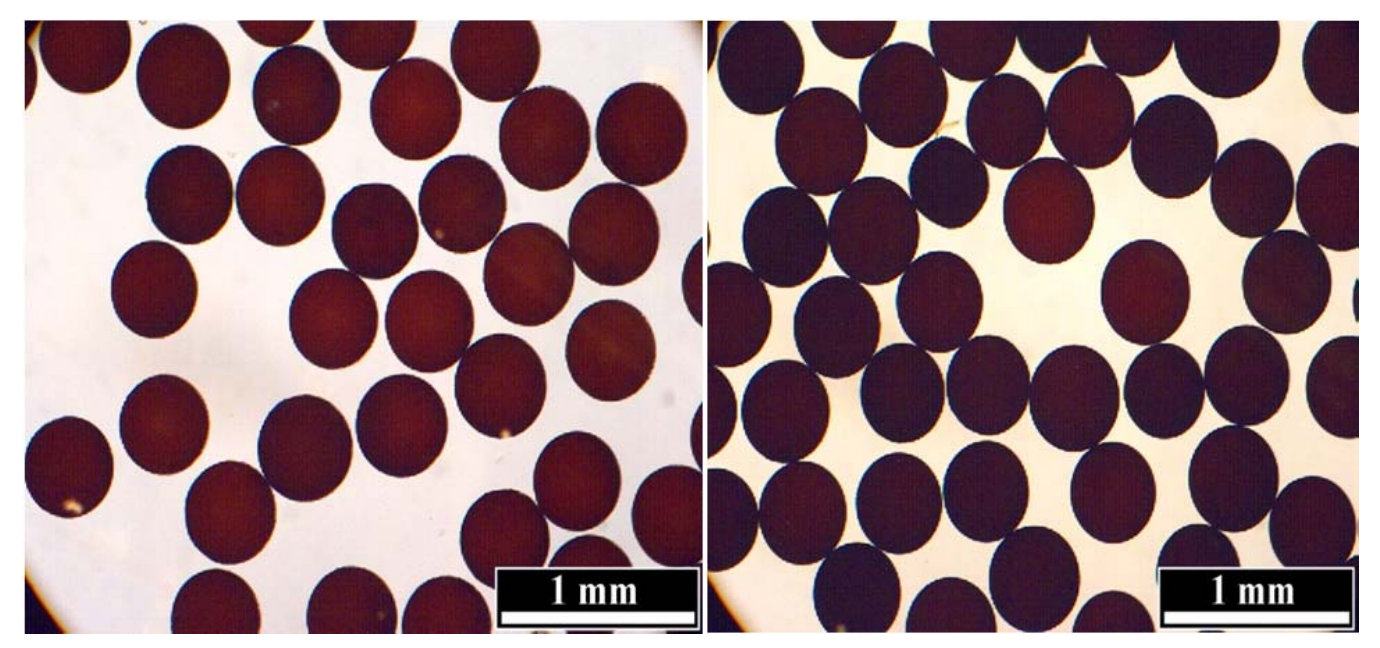

Figure 4.36. $\mathrm{SEM}$ of $25^{\circ} \mathrm{C}$ Acid Aged Resin (left) and $45^{\circ} \mathrm{C}$ Acid Aged Resin (right) 


\subsection{Effect on the Resin of Volatile Organics in the Feed}

Figure 4.37 shows the results of the column ion exchange test performed with organics added to the feed. It is compared to Column A1 which was performed under the same conditions $\left(45^{\circ} \mathrm{C}\right.$ for 10 hours

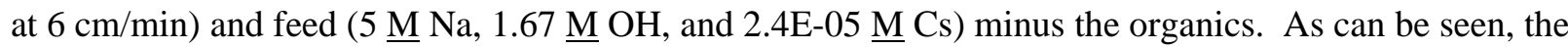
presence of organics did not affect the loading capacity or kinetics of the loading at $45^{\circ} \mathrm{C}$. This indicates that organics should not be a factor during ion exchange operation for the WTP at $45^{\circ} \mathrm{C}$. However, increasing the temperature will decrease the overall resin loading capacity for the WTP.

About $8 \%$ of the added organics were removed by filtering through the KimWipe ${ }^{\mathrm{TM}}$ and a $0.1 \mu \mathrm{m}$ filter after the feed was prepared. About $15 \%$ of the remaining organics were volatilized during heating from $25^{\circ} \mathrm{C}$ to $45^{\circ} \mathrm{C}$. After heating and during column loading, no more organics were lost and the concentration remained essentially the same at about $44,000 \mathrm{mg} / \mathrm{L}$ TOC or about $5 \mathrm{wt} \%$. The expected value in the WTP is $<\sim 4 \mathrm{wt} \%{ }^{(a)}$ indicating that the simulant was slightly higher in TOC than the expected feed. Table 4.1shows the measured values. The TIC values are most likely carbonates from the dissolved $\mathrm{CO}_{2}$ present in the feed.

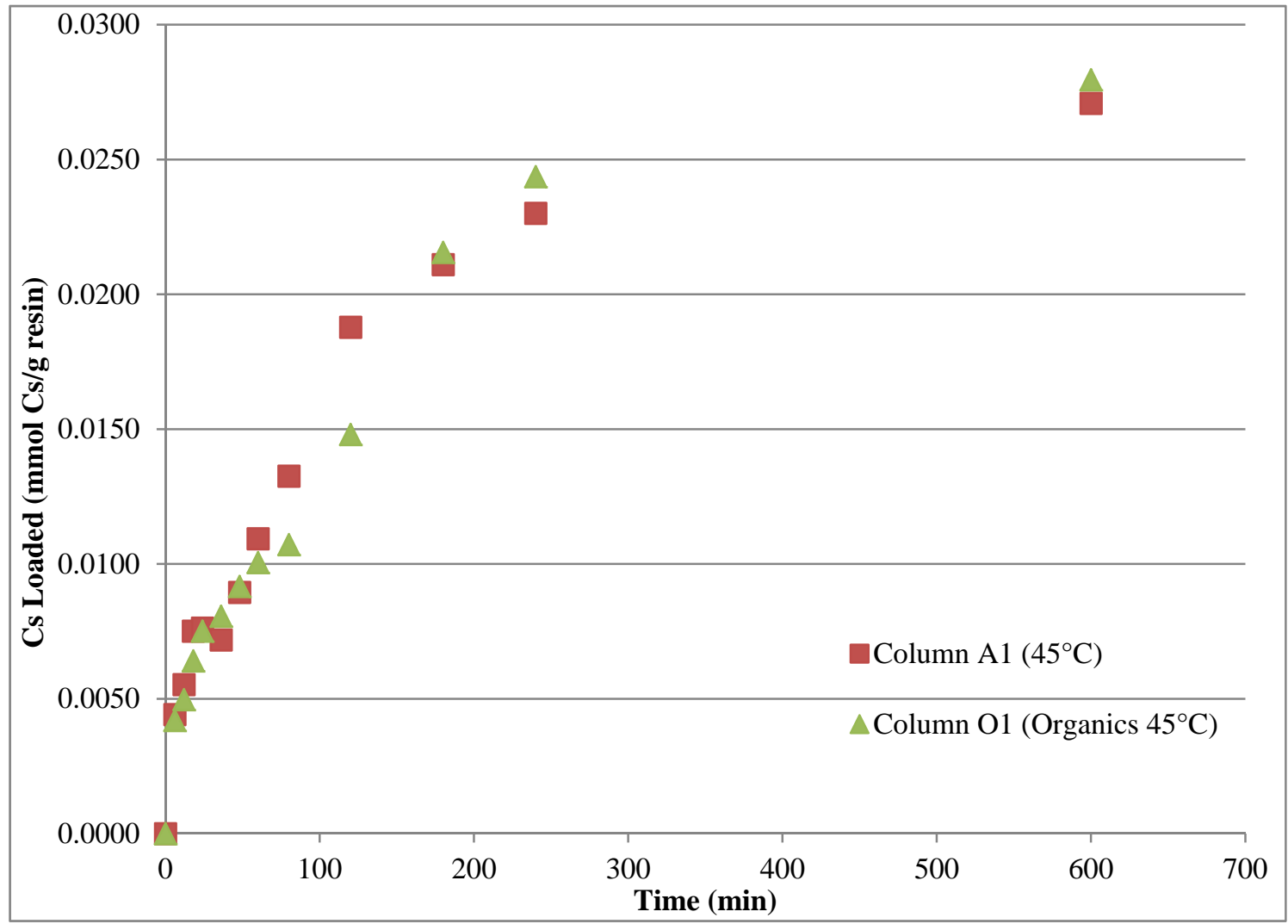

Figure 4.37. Results of the Organic Loading Test

(a) Received in e-mail from David Sherwood on March 14, 2012. 
Table 4.1. Organic Levels in Feed

\begin{tabular}{lcc}
\hline \multicolumn{1}{c}{ Sample ID } & TOC (mg/L) & TIC (mg/L) \\
Feed Before Filtering & 55,700 & 25.8 \\
Feed After Filtering & 51,350 & 63.4 \\
Feed After Heating & 43,800 & 69.0 \\
Feed at End of Loading & 44,900 & 70.0 \\
\hline
\end{tabular}





\subsection{Kinetics Model Results}

Note: This section is for information only. The work described in this section uses a commercially available software program (VERSE-LC) in order to model the kinetic experiments. However, the software was not added to the approved software list under the QA program and thus, despite the technical validity of the work presented in this section, must be considered for information only.

The parametric tests conducted in the ion exchange columns described in Sections 3.7 and 4.1 demonstrated the effect of various conditions on column performance. In an attempt to understand how the parameter changes affected the kinetic behavior, the ion exchange experiments were modeled using the VErsatile Reaction-SEparation model for Liquid Chromatography applications (VERSE-LC). VERSE-LC is available for license from Purdue University, where it was originally developed (Berninger et al. 1991).

In the following sections, the application of VERSE-LC to the ion exchange experiments is presented. First, the model is briefly described. Second, the formulation of the problem of interest is elucidated, including the estimation of some of the input parameters that are required to perform physically realistic simulations. Third, the results of the modeling are presented. Finally, the results are summarized and possible improvements to the model are discussed.

\subsection{Model Description}

The VERSE-LC general equations are based on the general schematic given in Figure 5.1, where all of the general processes that may occur in a multiphase reaction-separation system are represented. The model has the capacity to include all the processes pictured in Figure 5.1, but in the ion exchange experiments the processes enclosed in the red dashed areas should be most important (i.e., film diffusion, intraparticle diffusion, and adsorption/desorption). The model was restricted to consider only these mechanisms when performing simulations. An exception is that cesium is in competition for adsorption on the resin with sodium and potassium, but these other species were not included for this kinetic study. The system is assumed to be a packed-bed column of length $L$ and radius $R$ with a mobile phase moving with the interstitial velocity $u_{o}$. The column is represented by a simple schematic in Figure 5.2. A series of dimensionless variables can be defined for space and time:

$$
x=\frac{z}{L} ; \quad \xi=\frac{r}{R} ; \quad \tau=\frac{L}{u_{o}} ; \quad \theta=\frac{t}{\tau},
$$

where $\tau=L / u_{o}$ is the residence time, so defined to scale time. A series of dimensionless concentrations for the bulk (mobile), particle (pore), and solid phase concentrations are defined, respectively, as

$$
c_{b_{i}}=\frac{C_{b_{i}}}{C_{e_{i}}} ; \quad c_{p_{i}}=\frac{C_{p_{i}}}{C_{e_{i}}} ; \quad \overline{\mathrm{C}}_{p_{i}}=\frac{\bar{C}_{p_{i}}}{\bar{C}_{T_{i}}},
$$

where $C_{e i}$ is the maximum possible inlet concentration for species $i$ and $\bar{C}_{T_{i}}$ is the maximum solute capacity for species $i$. The subscripts $b$ and $p$ refer to concentrations in the bulk (mobile) phase and 
particle (pore) phase. The overline indicates a solid phase concentration, whereas no overline implies liquid phase.

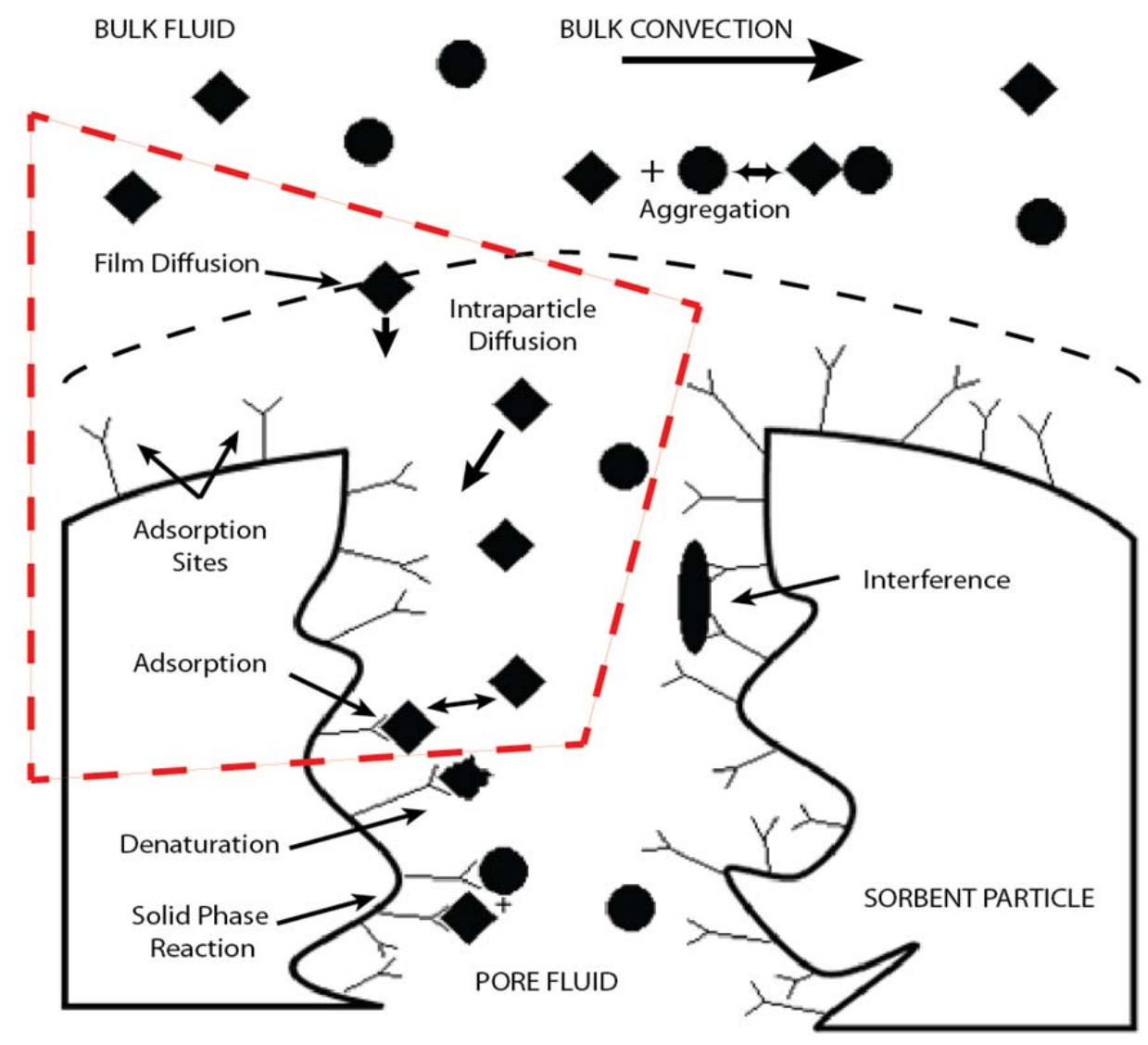

Figure 5.1. General Schematic of the VERSE-LC Equation System. The physical processes enclosed by the red dashed areas are dominant in the ion exchange system and will be the only processes considered.

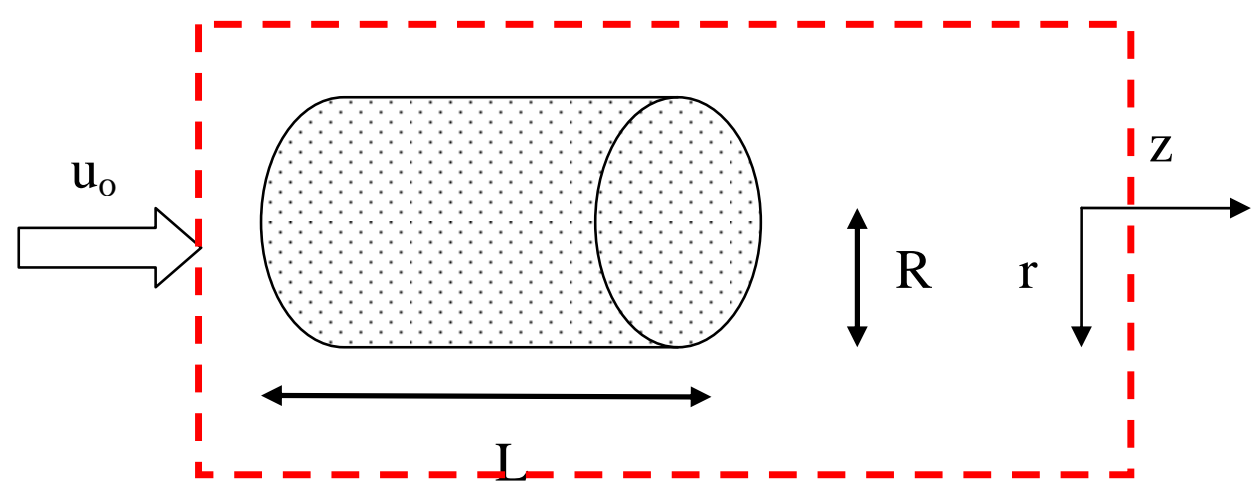

Figure 5.2. Schematic of the Model Column and Relevant Physical Dimensions 
With these dimensionless variables, the general equations for each phase are written as follows:

$\underline{\text { Mobile phase }}$

$$
\frac{\partial c_{b_{i}}}{\partial \theta}=\frac{1}{P e_{b_{i}}} \frac{\partial^{2} c_{b_{i}}}{\partial x^{2}}-\frac{\partial c_{b_{i}}}{\partial x}+Y_{b_{i}}-N_{f_{i}}\left(c_{b_{i}}-\left.c_{p_{i}}\right|_{\xi=1}\right)
$$

where $P e_{b}$ is the Peclet number in the bulk phase, $Y_{b}$ is the generation of species by reaction in the bulk phase, and $N_{f}$ is dimensionless film mass transfer number based on the feed. These are defined more specifically below. Equation (5.1.) is subject to the boundary conditions

$$
\begin{gathered}
x=0 ; \quad \frac{\partial c_{b_{i}}}{\partial x}=P e_{b_{i}}\left(c_{b_{i}}-c_{f_{i}}(\theta)\right), \\
x=1 ; \quad \frac{\partial c_{b_{i}}}{\partial x}=0 \\
\theta=0 ; \quad c_{b_{i}}=c_{b_{i}}(0, x)
\end{gathered}
$$

Pore phase

$$
K e_{i}\left[\varepsilon_{p} \frac{\partial c_{p_{i}}}{\partial \theta}-\varepsilon_{p} Y_{p_{i}}\right]+\left(1-\varepsilon_{p}\right)\left(\frac{\bar{C}_{T_{i}}}{C_{e_{i}}}\right) Y_{l_{i}}=N_{p_{i}} \frac{1}{\xi^{2}} \frac{\partial}{\partial \xi}\left[\xi^{2} \frac{\partial c_{p_{i}}}{\partial \xi}\right]
$$

where $K e$ is a size exclusion factor and $\varepsilon_{\mathrm{p}}$ is the intraparticle void fraction. Equation (5.5) is subject to the boundary conditions

$$
\begin{gathered}
\xi=0 ; \quad \frac{\partial c_{p_{i}}}{\partial \xi}=0, \\
\xi=1 ; \quad \frac{\partial c_{p_{i}}}{\partial \xi}=B i_{i}\left(c_{b_{i}}-c_{p_{i}}\right), \\
\theta=0 ; \quad c_{p_{i}}=c_{p_{i}}(0, \xi) .
\end{gathered}
$$

Recall as previously discussed that the subscript $i$ refers to species $i$, and these equations can be written for multiple-component systems. For simplicity, the $i$ will be dropped in subsequent equations since this is a single-component system (only the kinetics of cesium will be considered). The subscripts $b, p$, and $f$ refer to the bulk (mobile) phase, particle (pore) phase, and feed stream, respectively. The variable $Y$ represents generation by reaction, which needs to be specified but in general can occur in the 
bulk phase, particle phase, or by an adsorption/desorption process (subscript $l$ ). The dimensionless numbers $P e_{b}, B i, N_{f}$, and $N_{p}$ are defined as follows:

$$
P e_{b}=\frac{u_{o} L}{E_{b}} ; \quad B i=\frac{k_{f} R}{E_{p}} ; \quad N_{f}=3\left(\frac{L}{R}\right) \frac{\left(1-\varepsilon_{b}\right) k_{f}}{\varepsilon_{b} u_{o}} ; \quad N_{p}=\frac{L}{R}\left(\frac{E_{p}}{u_{o} R}\right),
$$

where $E_{b}$ is the axial dispersion coefficient, $E_{p}$ is the effective intraparticle diffusivity, $\varepsilon_{b}$ is the interparticle void fraction, and $k_{f}$ is the film mass transfer coefficient.

Given the requisite information, Equations (5.1) through (5.8) can be solved by numerical methods. There are five basic assumptions required for the solution to be representative of the physical system it is modeling:

1. The column packing is homogeneous (spherical particles, same particle and pore size);

2. The column is packed homogenously, resulting in a uniform flow distribution;

3. The system is isothermal;

4. Concentration gradients are in the radial direction $r$ and in the angular directions inside a particle;

5. Mass transfer coefficients are constant and do not depend on other mechanisms.

Using these assumptions, the equations are discretized and solved using the method of orthogonal collocation on finite elements. This is a robust method, even for stiff problems since the discretization is flexible enough to handle shallow or steep concentration fronts. The method and solution methods are described in more detail in Yu and Wang (1989) and Berninger et al. (1991).

\subsection{Formulating the Problem}

The ion exchange experiments were performed slightly differently than the VERSE-LC model system is setup, so some adjustments were needed to match the simulation with the physical situation. The base VERSE-LC model system, shown in Figure 5.3, is compared to the experimental system. The major differences are that recycle is not assumed in the VERSE-LC model and there are continuous stirred tank reactors (CSTRs) on the inlet and outlet sides of the column. VERSE-LC does have a recycle mode option but there are two complications when using this mode, namely

1. The initial concentration applies to the entire column. This cannot be altered in the software. ${ }^{(a)}$ If the actual cesium feed concentration were to be input at $t=0$, there is no reaction/adsorption because mathematically the system is already at equilibrium.

2. The CSTRs are assumed to be at the same equilibrium concentration as the column. Thus, they cannot be specified to reflect the physical reality of a feed vessel inputting a stream that has a much higher cesium concentration than the column itself.

These complications are artifacts of the original scope of VERSE-LC simulations, which were primarily for liquid chromatography experiments.

(a) Current version of VERSE-LC is 2011-07-12-183156. 


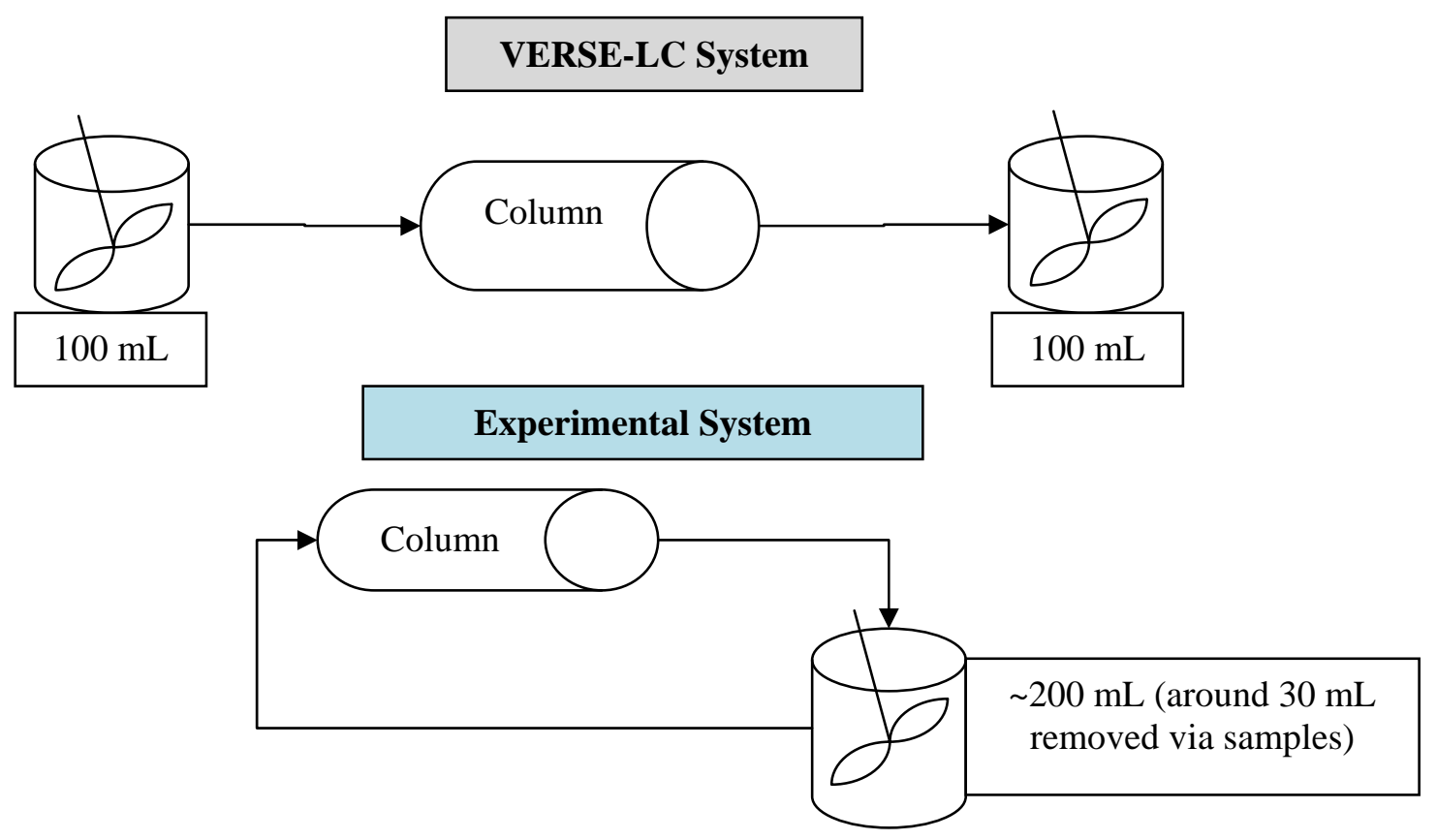

Figure 5.3. Comparison of VERSE-LC System with Experimental System Used

To circumvent these complications, the simulation was started without recycle in order to "flood" the column and CSTRs with a high flow rate $(1000 \mathrm{~mL} / \mathrm{min})$. The objective of the "flooding" was to reach the target initial concentration of Cs rapidly without appreciably reducing the capacity of the column. This was accomplished in one minute or less. The flow rate and concentration were then step-changed to the desired initial values and the recycle was initiated a microsecond after the step-change. The limitation of this approach is that there is a small amount of Cs adsorbed during the high flow rate period, which will affect the kinetic parameter estimation. It is not clear from the software where the recycle stream returns in the model system; it is assumed to be a total recycle as in the experimental system.

Because this is a system where the feed concentration is changing in response to adsorption in the column, the simulations cannot use an isotherm to accurately model the experiments. Isotherms have been studied in detail for Cs ion exchange using this resin, including modeling using VERSE-LC, in particular at Savannah River National Laboratory (Hamm et al. 2002; King et al. 2004; Hardy et al. 2004; Smith 2007; and Smith et al. 2009). In this case, the ion exchange is inherently a non-equilibrium separation process. The most common kinetic (i.e., non-equilibrium) model is a Langmuir model of the form

$$
Y_{l}=\frac{\tau}{\bar{C}_{T}}\left[\ell_{+} C_{p} \bar{C}_{T}\left(1-\sum_{k=1}^{N} \frac{\bar{C}_{p . k}}{\bar{C}_{T, k}}\right)-\ell_{-} \bar{C}_{p}\right],
$$

where $\ell_{+}$and $\ell_{-}$are the adsorption and desorption reaction rate constants, respectively. Recall that the overbar refers to the solid phase concentrations and that the subscript $i$ was removed because this is a single component system (Cs kinetics only). The summation term is shown for generality, but in the single component case of this study, $N=1$ and no summation is required. 
The accuracy of the non-equilibrium Langmuir kinetic equation will depend heavily on an accurate estimate of $C_{T}$, which is the maximum solute capacity of the resin for Cs. The capacity is assumed to be a property of the resin alone and not affected by temperature, composition, or other feed conditions. There are a few sources from which $C_{T}$ can be evaluated. One method is to use available information from King et al. (2004). The capacity of the SRF resin is quoted as $0.5 \mathrm{mmol} \mathrm{Cs} / \mathrm{g}$ dry resin. Thus, to convert into units of $\mathrm{mol} / \mathrm{L}$ :

$$
\bar{C}_{T} \square\left(\frac{0.5 \mathrm{mmol}}{\text { g dry resin }}\right)\left(\frac{0.40 \text { g dry resin }}{\mathrm{mL}}\right)=0.2 \mathrm{~mol} \mathrm{~L}^{-1}
$$

where the dry bed density is based on estimates of bed volume for the ion exchange columns used in this work. There is also an extensive set of Langmuir isotherm data already available [see, for example, Smith (2007)]. The single component Langmuir isotherm is typically written as

$$
\bar{C}_{p}=\frac{a C_{p}}{1+b C_{p}}
$$

where $a$ and $b$ are isotherm constants. In the case of fast adsorption/desorption, the non-equilibrium and isotherm Langmuir models are related via the expressions

$$
b=\frac{\ell_{+}}{\ell_{-}}
$$

and

$$
a=\frac{\ell_{+}}{\ell_{-}} \bar{C}_{T}
$$

Thus, upon a simple rearrangement

$$
\bar{C}_{T}=\frac{a}{b}
$$

and the available isotherm data give an average $a / b$ of 0.17 . The same isotherm data also indicate that $\ell_{+}$ $\sim 10^{3} \ell$. The $C_{T}$ value of 0.17 was used as a reasonable starting point for the simulations.

The estimation of physical parameters was also challenging, in particular the viscosity of the solution and the diffusion coefficient of Cs. The viscosity is a function of the temperature and composition, both of which were varied during these experiments. The diffusion coefficient depends on the presence of counter ions, temperature, and the solution viscosity. Both of these parameters were estimated by constructing them from mass (viscosity) or molar (diffusion coefficient) averages of simpler data sets. 
The viscosity was calculated using the equation

$$
\mu_{a g g}=\left(\frac{\mu_{T, \mathrm{NaNO}_{3}}}{\mu_{25, \mathrm{NaNO}_{3}}}\right) \sum_{j=1}^{3} x_{j} \mu_{\mathrm{Na}-j}
$$

where $\mu_{\text {agg }}$ is the aggregate viscosity of the mixture, $\mu_{T, \mathrm{NaNO} 3}$ and $\mu_{25, \mathrm{NaNO} 3}$ are experimentally determined viscosities for an aqueous $\mathrm{NaNO}_{3}$ system (Abdulagatov and Azizov 2005), $x_{j}$ is the mass fraction of compound $j$, and $\mu_{\mathrm{Na}-j}$ is the viscosity of an aqueous solution of $\mathrm{Na}^{+}-\mathrm{j}$ at the experimental weight fraction and $25^{\circ} \mathrm{C}$. In this case, $j$ represents the three anions $\mathrm{NO}_{3}{ }^{-}, \mathrm{OH}^{-}$, and $\mathrm{Cl}^{-}$. The effect of aluminum is ignored. The viscosity of each sodium compound was correlated with weight fraction using data from Perry's Chemical Engineering Handbook ( $7^{\text {th }}$ edition) using cubic polynomials. The temperature dependence of the $\mathrm{NaNO}_{3}$ compound is assumed to be representative of the composite temperature dependence.

The calculation of the diffusion coefficient depends on binary interactions between ions. At infinite dilution,

$$
D_{ \pm}^{\infty}=\left(\frac{R T}{F^{2}}\right)\left[\frac{\frac{1}{z_{+}}+\frac{1}{z_{-}}}{\frac{1}{\lambda_{+}^{o}}+\frac{1}{\lambda_{-}^{o}}}\right],
$$

where $R$ is the ideal gas constant, $T$ is the absolute temperature, $F$ is Faraday's constant, $z_{+}$and $z_{\text {- }}$ are the valences of the binary ion pair, and ${\lambda_{+}}^{\circ}$ and $\lambda_{-}{ }^{o}$ are the limiting conductivity for the ion pair. The limiting conductivity is calculated via

$$
\ln \left[\lambda^{o}(T) \eta(T)\right]=A+\frac{B}{T}
$$

where $\eta(T)$ is the viscosity of pure water and $A$ and $B$ are constants (available from sources such as the CRC Handbook of Chemistry and Physics). Assuming that the Stokes-Einstein relationship is valid for these scenarios, then the diffusion coefficient will be reduced by a ratio of viscosities, giving the final relationship for the overall Cs diffusion coefficient:

$$
\left\langle D_{C s}\right\rangle=\frac{\eta(T)}{\mu_{\text {agg }}} \sum_{i} X_{i} D_{C s-i}^{\infty}
$$

The viscosity is already described by Equation (5.14). The summation includes all the relevant binary pairs in the solution fed to the ion exchange column, with $X_{i}$ being the mole fraction of the Cs-i pair and $D_{C s-i}{ }^{\infty}$ the binary diffusion coefficient as calculated by Equation (5.15). The pore diffusivity can be estimated as either

$$
D_{p}=\frac{\left\langle D_{C s}\right\rangle}{\psi} \quad \text { or } \quad D_{p}=\frac{\varepsilon_{p}}{\left(2-\varepsilon_{p}\right)^{2}}\left\langle D_{C s}\right\rangle \text {. }
$$


The first approach that was taken in these simulations was with the tortuosity $\psi=3$. Note that the values of $D_{p}$ are very similar if the second approach is used with the known value of $\varepsilon_{p}$.

Other physical parameters not mentioned specifically in this section were either measured during the experimentation or values were used based on previous work with the same resin (e.g., King et al. 2004; Hardy et al. 2004; Smith 2007).

\subsection{Results and Discussion}

The results discussed in this section were obtained in the following manner. Simulations in VERSE-LC were run using guesses for $\ell_{+}$and $\ell_{-}$with $C_{T}=0.17$. The resulting concentration time series were compared to experimental results of the ion exchange work at discrete points in time. Iterations were conducted on this process in an effort to minimize the square of the residuals. Due to limitations of the VERSE-LC software interface, this was a manually iterative process. Thus, though some effort was expended to minimize the error between the simulation and the data, the result is not a true minimum. Optimization of the method was not performed in the interest of computation time.

An example model fit is shown in Figure 5.4. The fit is in good agreement with the data and satisfies

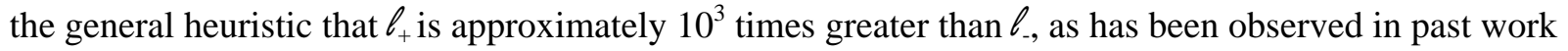
(Smith 2007). A second example is shown in Figure 5.5. Again, the fit is in good agreement with the data and $\ell_{+}$is approximately $10^{3}$ times greater than $\ell_{-}$. This fit is shown to demonstrate that the simulation can approximate the experimental data when the adsorption and desorption rates are faster than the ones in Figure 5.4. These two figures are representative of the results obtained from the manual optimization method used to compare the simulations with the data.

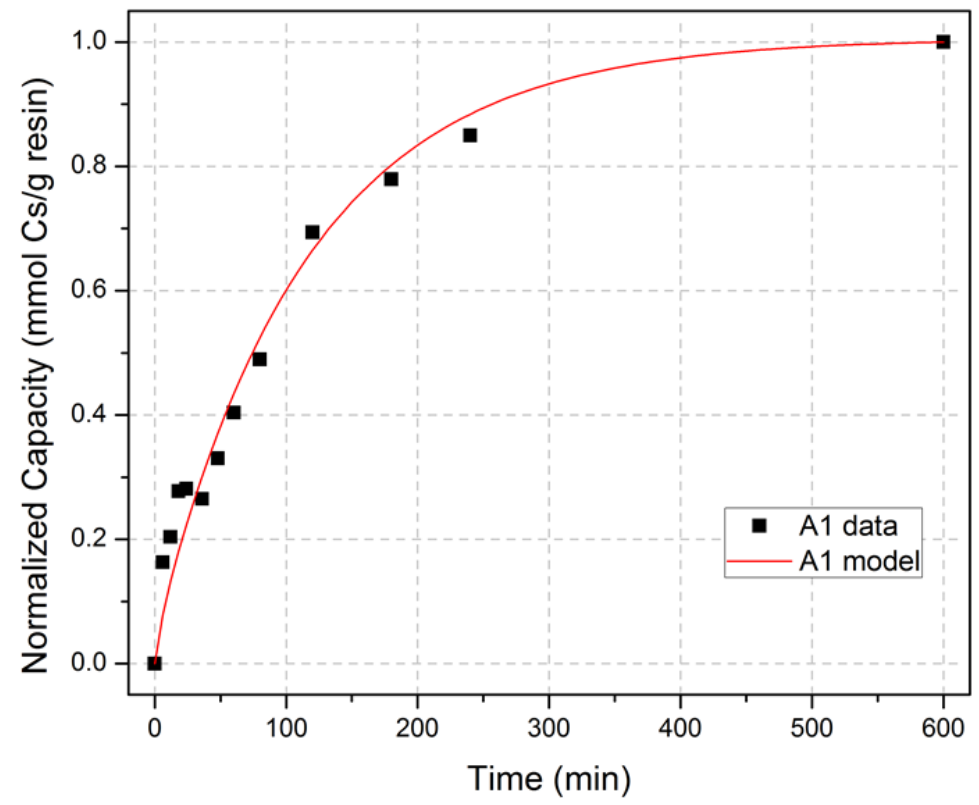

Figure 5.4. Fit of the VERSE-LC Simulation to the Column A1 Experimental Data. The final model had the following values: $\ell_{+}=25 \mathrm{~L} \mathrm{~mol}^{-1} \mathrm{~s}^{-1}, \ell_{-}=2.0 \times 10^{-3} \mathrm{~s}^{-1}$, with a root mean squared error of 0.042 . 


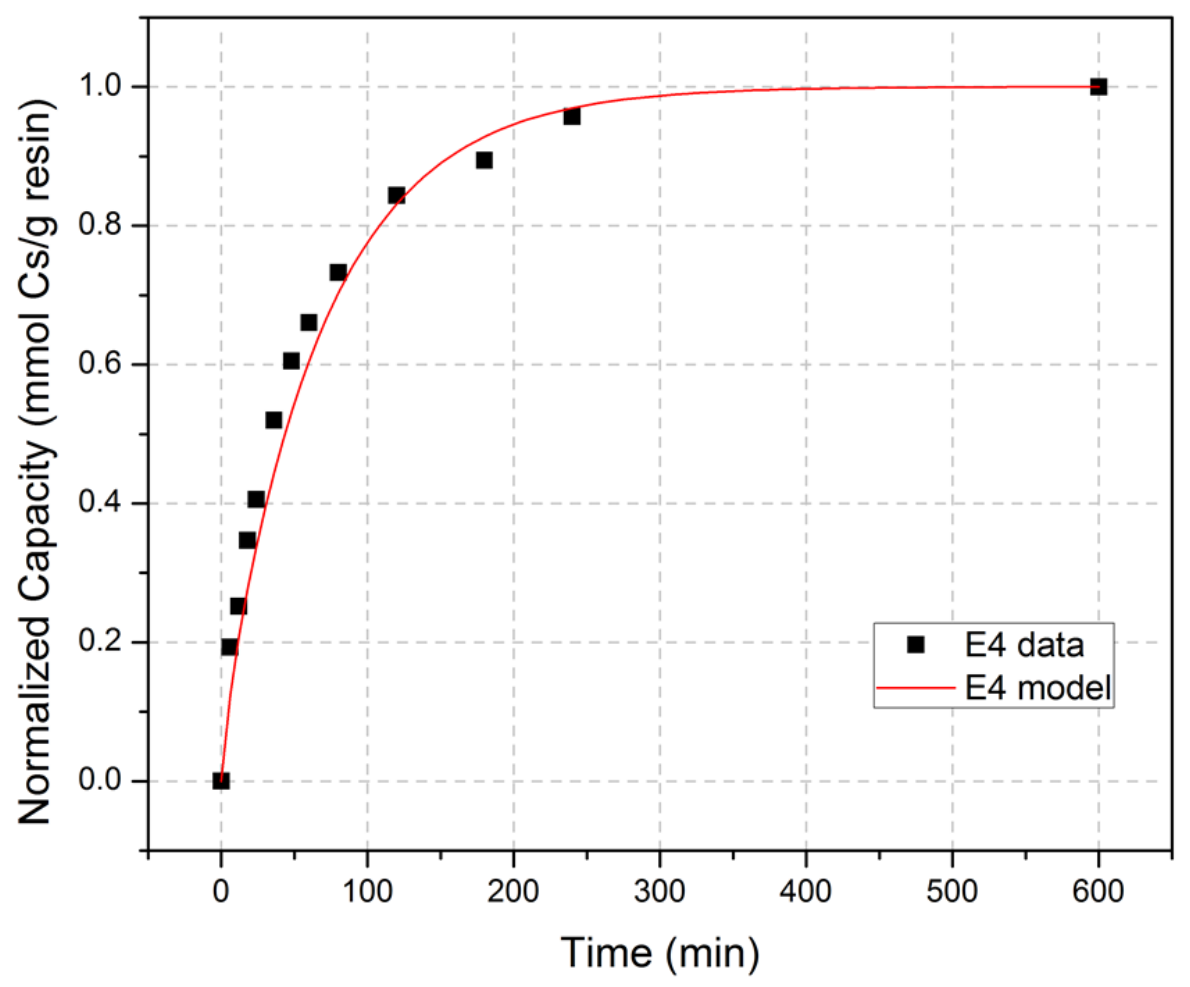

Figure 5.5. Fit of the VERSE-LC Simulation to the Column E4 Experimental Data. The final model had the following values: $\ell_{+}=60 \mathrm{~L} \mathrm{~mol}^{-1} \mathrm{~s}^{-1}, \ell_{-}=7.5 \times 10^{-3} \mathrm{~s}^{-1}$, with a root mean squared error of 0.025 .

The approach for the remainder of this section is to look at cross-sections of the experimental data in an attempt to determine if there are any discernible trends in adsorption and desorption behavior with changes in a given parameter. Note that some of the parameter changes are taken into account directly in the model; for instance, changes in mobile phase flow rate are handled via correlations for the axial dispersion and film diffusion coefficients.

First, simulation results for different sodium concentrations in the feed solution are given in Table 5.1. In each case, the ratio of the adsorption and desorption rate constants are calculated from experiments conducted as part of the same data set. The sodium molarities are given in parentheses. The adsorption rate constant does not appear to change if sodium is present at 5 or $8 \underline{\mathrm{M}}$, but the $8 \underline{\mathrm{M}}$ sodium has a lower adsorption rate than $2 \underline{\mathrm{M}}$ sodium. This is consistent with the expectation that sodium competes with Cs for adsorption sites in the resin pores. The desorption rate constant is larger when the sodium molarity is higher, suggesting a similar competition effect. The VERSE-LC simulations indicate that running the ion exchange columns at low sodium concentration is optimal for the best kinetic performance. However, above a certain Na concentration (above $2 \underline{\mathrm{M}}$ but $5 \underline{\mathrm{M}}$ or less), the adsorption kinetics are not changed much. Since adsorption dominates the desorption process, above this point there will be little difference in column performance (as observed experimentally). Furthermore, the model does not account for the interaction of sodium with the column. Inclusion of sodium in a future model would help clarify the role sodium plays in adsorption/desorption kinetics of cesium.

Next, the effect of temperature is considered. Table 5.2 presents the results of experiments at 25, 45 , and $50^{\circ} \mathrm{C}$. The results at $50^{\circ} \mathrm{C}$ give an idea of the variability between simulation results based on three 
experiments conducted at the same conditions. Considering that each experiment is also subject to some random error, the spread in the simulation results is quite reasonable. The temperature data did not indicate a strong trend of adsorption or desorption rate with temperature. In fact, if the discontinuity in the Column A1 data is discarded and only the initial data are modeled, the values that are given in brackets were found to be the best fit to the data. The dimensionless number $\left(\mathrm{C}_{\mathrm{f}} \ell_{+} / \ell_{-}---\right.$a dimensionless adsorption number) in the fourth column is essentially invariant to temperature; thus, no discernible trend with temperature was observed.

Table 5.1. Effect of Sodium Concentration on Adsorption and Desorption Rate Constants

\begin{tabular}{cccc}
\hline Ratio of Experiments $\left(\mathrm{Na}^{+} \mathrm{M}\right)$ & $\ell_{+}$Ratio & $\ell_{\text {. Ratio }}$ & Velocity (cm/min) \\
A2 (8) / A1 (5) & 1.00 & 2.50 & 6 \\
B4 (8) / B3 (2) & 0.35 & 1.67 & 4 \\
C4 (8) / C2 (2) & 0.29 & 1.67 & 8 \\
E2 (8) / E1 (5) & 1.00 & 2.25 & 6 \\
E4 (8) / E1 (5) & 0.80 & 1.88 & 6 \\
\hline
\end{tabular}

Table 5.2. Effect of Temperature on Adsorption and Desorption Rate Constants

\begin{tabular}{|c|c|c|c|c|}
\hline Experiment $\left(\mathrm{T}\right.$ in $\left.{ }^{\circ} \mathrm{C}\right)$ & $\ell_{+}\left(\mathrm{L} \mathrm{mol}^{-1} \mathrm{~s}^{-1}\right)$ & $\ell_{-}\left(\mathrm{s}^{-1}\right)$ & $\left(\mathrm{C}_{\mathrm{f}} \ell_{+}\right) / \ell_{-}$ & Notes \\
\hline D1 (25) & 80 & $3.75 \times 10^{-3}$ & 0.58 & \multirow{6}{*}{$\begin{array}{l}\text { All experiments at: } \\
\text { velocity of } 6 \mathrm{~cm} / \mathrm{min}, \\
\mathrm{Na}^{+}=5 \underline{\mathrm{M}}, \\
\mathrm{OH}^{-}=1.67 \underline{\mathrm{M}}, \\
\text { initial } \mathrm{Cs}=2.4 \times 10^{5} \\
\underline{\mathrm{M}}\end{array}$} \\
\hline A1 (45) & $25[55]$ & $2.00 \times 10^{-3}\left[2.00 \times 10^{-3}\right]$ & $0.33[0.66]$ & \\
\hline B1 (50) & 110 & $4.50 \times 10^{-3}$ & 0.71 & \\
\hline C1 (50) & 50 & $3.00 \times 10^{-3}$ & 0.46 & \\
\hline E1 (50) & 75 & $4.00 \times 10^{-3}$ & 0.61 & \\
\hline Average (50) & 78 & $3.83 \times 10^{-3}$ & 0.59 & \\
\hline
\end{tabular}

The results of the VERSE-LC simulations for subsets where the flow rate was varied between experiments are presented in Table 5.3. The adsorption rate constant goes up with increases in flow rate. Likewise, the desorption rate constant also increases, particularly at higher Na concentrations. This is surprising because it suggests that the Cs adsorption kinetics depend on the flow rate of the mobile phase. The flow rate is expected to affect mass transport mechanisms, such as is already captured in the film diffusion coefficient and axial dispersion coefficient. However, this effect alone is not sufficient to capture the difference in the data that was observed in the ion exchange columns experimentally. This is demonstrated graphically in Figure 5.6. The data from Column C2 experiment and the simulation fit to it are shown. Then the constants from the Column C2 fit were used to model the Column C3 experiment (which was conducted at half the flow rate of Column C2), changing only the flow rate to the Column C3 value. The change in the simulation result is very small compared to the change in the data. This result does not match what is expected based on current understanding of the ion exchange system and should be investigated further. 
Table 5.3. Effect of Flow Rate on Adsorption and Desorption Rate Constants

\begin{tabular}{cccc}
\hline $\begin{array}{c}\text { Ratio of Experiments } \\
\text { (velocity in cm/min) }\end{array}$ & $\ell_{+}$Ratio & $\ell_{\text {. Ratio }}$ & $\mathrm{Na}^{+}(\underline{\mathrm{M}})$ \\
A2 (6) / A3 (4) & 0.76 & 1.32 & 8 \\
B2 (8) / B3 (4) & 1.50 & 1.00 & 2 \\
C2 (8) / C3 (4) & 3.43 & 1.50 & 2 \\
E2 (6) / E3 (4) & 3.00 & 2.25 & 8 \\
\hline
\end{tabular}

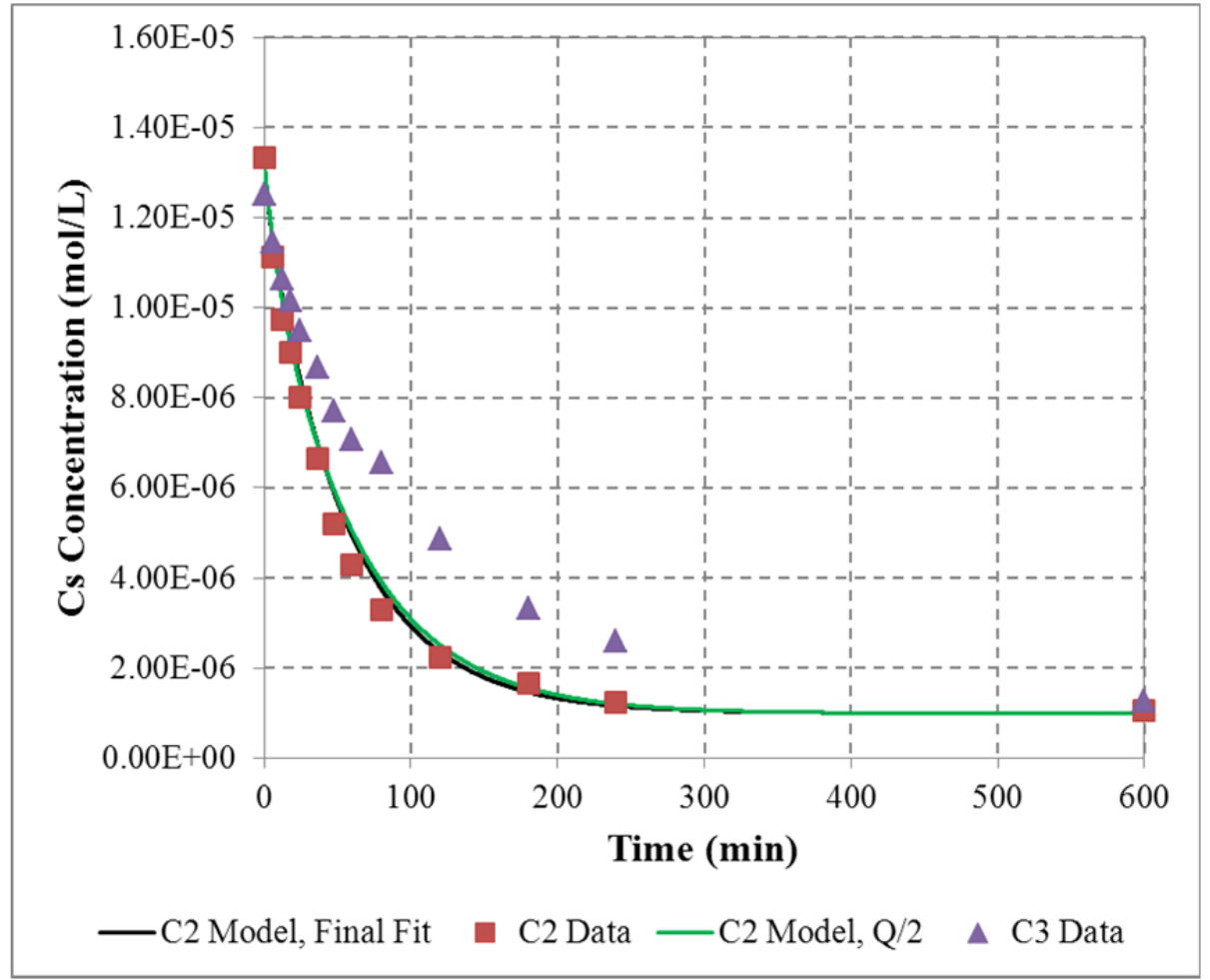

Figure 5.6. Comparison of Experimental Data with Simulation Results When Only the Flow Rate is Changed in the Column C3 Simulation

It is possible that some mechanism that is outside of the processes captured by the VERSE-LC model is having some effect in the physical experiments. If VERSE-LC does not contain the proper physics, then the difference will show up in the adsorption and desorption rate constant since it is not being captured correctly by the simulation. A couple potential causes can be proposed. One is that the column is not packed uniformly and is subject to experiencing channeling in the packed bed. This will be magnified at lower flow rates where the fluid will choose the path of least resistance and thus not be exposed to all the active sites in the resin. As the flow rate increases, it becomes sufficient to access parts of the porous substructure that was previously not accessible and the effective adsorption and desorption rates increase. Another possibility is that there is an intraparticle convection that enhances the diffusivity of Cs at higher flow rates, thereby bringing more Cs in proximity to adsorption sites. This would also 
appear to be a higher adsorption rate constant. The first cause would be more likely given the dimensions of the test column and the flow rates used.

The effect of $\mathrm{OH}^{-}$concentration on rate constants is shown in Table 5.4. The effect is difficult to separate from other variables, since $\mathrm{OH}^{-}$dependence was not a variable that was intentionally examined during the testing. $\mathrm{Na}^{+}$concentration also necessarily increases with $\mathrm{OH}^{-}$concentration so this complicates the analysis. However, if the adsorption and desorption rate constants are adjusted on the

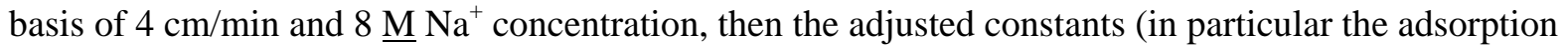
rate constant) show almost no change with $\mathrm{OH}^{-}$concentration above $1 \underline{\mathrm{M}}$.

Table 5.4. Effect of $\mathrm{OH}^{-}$Concentration on Adsorption and Desorption Rate Constants

\begin{tabular}{|c|c|c|c|c|c|c|}
\hline $\begin{array}{c}\text { Experiment }\left(\mathrm{OH}^{-}\right. \\
\mathrm{M})\end{array}$ & $\ell_{+}\left(\mathrm{L} \mathrm{mol}^{-1} \mathrm{~s}^{-1}\right)$ & $\ell_{-}\left(\mathrm{s}^{-1}\right)$ & $\mathrm{Na}^{+}(\mathrm{M})$ & $\begin{array}{l}\text { Velocity } \\
\text { (cm/min) }\end{array}$ & Adjusted $\ell_{+}$ & Adjusted $\ell$. \\
\hline B2 (0.5) & 150 & $4.50 \times 10^{-3}$ & 2 & 8 & 100 & $4.50 \times 10^{-3}$ \\
\hline C2 (1.0) & 120 & $3.00 \times 10^{-3}$ & 2 & 8 & 35 & $2.00 \times 10^{-3}$ \\
\hline A1 (1.67) & 25 & $2.00 \times 10^{-3}$ & 5 & 6 & 33 & $1.52 \times 10^{-3}$ \\
\hline A2 (2.0) & 25 & $5.00 \times 10^{-3}$ & 8 & 6 & 33 & $3.80 \times 10^{-3}$ \\
\hline B4 (4.0) & 35 & $7.50 \times 10^{-3}$ & 8 & 4 & 35 & $7.50 \times 10^{-3}$ \\
\hline
\end{tabular}

Each experimental set included a repeat experiment after some experiments were conducted in between. The simulation results from the repeat sets are shown in Table 5.5. On average, the adsorption rate does not appear to be affected by the amount of elapsed processing time a column experiences. However, the desorption rate was larger for every repeat experiment, suggesting that elapsed processing time improves the desorption kinetics. This is consistent with what is known about SRF resin, since it degrades over time and is affected by processing cycles. Note that due to increased desorption kinetics, a column will reach steady-state faster the more times in has been used, albeit at a lower Cs capacity.

Table 5.5. Effect of Column Processing Time/Cycling on Adsorption and Desorption Rate Constants

\begin{tabular}{cccc}
\hline Ratio of Experiments & $\ell_{+}$Ratio & $\ell_{-}$Ratio & Notes \\
\hline A5 / A1 & 1.60 & 2.50 & All experiments at: \\
B5 / B1 & 0.50 & 2.44 & velocity of $6 \mathrm{~cm} / \mathrm{min}^{+} \mathrm{Na}^{+}$ \\
C5 / C1 & 1.00 & 6.67 & $=5 \underline{\mathrm{M}}$, \\
E5 / E1 & 1.00 & 1.63 & $\mathrm{OH}^{-}=1.67 \underline{\mathrm{M}}$, \\
Average & $\mathbf{1 . 0 3}$ & $\mathbf{3 . 3 1}$ & initial Cs $=2.4 \times 10^{5} \underline{\mathrm{M}}$ \\
\hline
\end{tabular}

\subsection{Conclusions}

The VERSE-LC simulation tool provided insight regarding the kinetic behavior of the ion exchange experiments described in this report. The final simulation results [the parameters that gave the best fit as measured by minimizing the RMSE (root mean square error)] are shown in Table 5.6. In general, the following conclusions can be drawn: 
- Increased sodium content (above $2 \underline{\mathrm{M}}$ ) may slow down the adsorption/desorption as sodium competes with cesium for resin actives sites. However, simulations indicated that 5 and $8 \underline{\mathrm{M}}$ sodium have very similar adsorption/desorption rates.

- Temperature did not strongly impact adsorption/desorption rate constants.

- Contrary to expectation, the flow rate had a strong effect on the adsorption/desorption rate constants that is outside usual mass transfer mechanisms. This was speculated to arise from channeling in the column, convectively-enhanced pore diffusion of cesium, or some other unknown mechanism that is not currently a part of the model.

- The hydroxide concentration has little or no effect on adsorption and desorption above a concentration of $1 \underline{\mathrm{M}}$.

- As a column is used over time, it will reach steady-state faster during each subsequent processing cycle. The steady-state will have a lower cesium capacity.

Table 5.6. Final Simulation Results for All Experiments Modeled Using VERSE-LC

\begin{tabular}{|c|c|c|c|c|c|}
\hline Experiment & $\ell_{+}\left(\mathrm{L} \mathrm{mol}^{-1} \mathrm{~s}^{-1}\right)$ & $\ell_{-}\left(\mathrm{s}^{-1}\right)$ & $\begin{array}{l}\text { Sum of square of } \\
\text { residuals }\left(\Sigma \Delta^{2}\right)\end{array}$ & $\begin{array}{c}\text { Number of } \\
\text { data points }(\mathrm{N})\end{array}$ & $\begin{array}{l}\text { Root mean squared } \\
\text { error (RMSE) }\end{array}$ \\
\hline D1 & 80 & $3.75 \times 10^{-3}$ & $2.15 \times 10^{-2}$ & 13 & $4.06 \times 10^{-2}$ \\
\hline A1 & 25 & $2.00 \times 10^{-3}$ & $2.28 \times 10^{-2}$ & 13 & $4.19 \times 10^{-2}$ \\
\hline A2 & 25 & $5.00 \times 10^{-3}$ & $8.39 \times 10^{-3}$ & 13 & $2.54 \times 10^{-2}$ \\
\hline A3 & 33 & $3.80 \times 10^{-3}$ & $1.85 \times 10^{-2}$ & 13 & $3.77 \times 10^{-2}$ \\
\hline A4 & 25 & $7.00 \times 10^{-3}$ & $2.93 \times 10^{-2}$ & 13 & $4.75 \times 10^{-2}$ \\
\hline A4B & 0.15 & $8.00 \times 10^{-5}$ & $4.53 \times 10^{-1}$ & 12 & $1.94 \times 10^{-1}$ \\
\hline A5 & 40 & $5.00 \times 10^{-3}$ & $6.23 \times 10^{-2}$ & 15 & $6.44 \times 10^{-2}$ \\
\hline E1 & 75 & $4.00 \times 10^{-3}$ & $2.16 \times 10^{-2}$ & 13 & $4.07 \times 10^{-2}$ \\
\hline E2 & 75 & $9.00 \times 10^{-3}$ & $6.67 \times 10^{-3}$ & 13 & $2.27 \times 10^{-2}$ \\
\hline E3 & 25 & $4.00 \times 10^{-3}$ & $6.08 \times 10^{-3}$ & 13 & $2.16 \times 10^{-2}$ \\
\hline E4 & 60 & $7.50 \times 10^{-3}$ & $8.33 \times 10^{-3}$ & 13 & $2.53 \times 10^{-2}$ \\
\hline E4B & 1 & $5.00 \times 10^{-3}$ & $5.22 \times 10^{-2}$ & 12 & $6.59 \times 10^{-2}$ \\
\hline E5 & 75 & $6.50 \times 10^{-3}$ & $3.06 \times 10^{-2}$ & 15 & $4.52 \times 10^{-2}$ \\
\hline B1 & 110 & $4.50 \times 10^{-3}$ & $3.38 \times 10^{-2}$ & 15 & $4.75 \times 10^{-2}$ \\
\hline B2 & 150 & $4.50 \times 10^{-3}$ & $6.25 \times 10^{-2}$ & 15 & $6.45 \times 10^{-2}$ \\
\hline B3 & 100 & $4.50 \times 10^{-3}$ & $7.73 \times 10^{-3}$ & 15 & $2.27 \times 10^{-2}$ \\
\hline B4 & 35 & $7.50 \times 10^{-3}$ & $2.16 \times 10^{-3}$ & 13 & $1.29 \times 10^{-2}$ \\
\hline B4B & 0.25 & $5.00 \times 10^{-4}$ & $1.10 \times 10^{-1}$ & 10 & $1.05 \times 10^{-1}$ \\
\hline B5 & 55 & $1.10 \times 10^{-2}$ & $1.10 \times 10^{-2}$ & 13 & $2.91 \times 10^{-2}$ \\
\hline C1 & 50 & $3.00 \times 10^{-3}$ & $6.36 \times 10^{-3}$ & 15 & $2.06 \times 10^{-2}$ \\
\hline C2 & 120 & $3.00 \times 10^{-3}$ & $1.38 \times 10^{-2}$ & 15 & $3.03 \times 10^{-2}$ \\
\hline C3 & 35 & $2.00 \times 10^{-3}$ & $1.05 \times 10^{-2}$ & 15 & $2.64 \times 10^{-2}$ \\
\hline $\mathrm{C} 4$ & 35 & $5.00 \times 10^{-3}$ & $1.46 \times 10^{-2}$ & 13 & $3.35 \times 10^{-2}$ \\
\hline $\mathrm{C} 4 \mathrm{~B}$ & -- & -- & -- & 9 & -- \\
\hline C5 & 50 & $2.00 \times 10^{-2}$ & $3.23 \times 10^{-3}$ & 13 & $1.58 \times 10^{-2}$ \\
\hline
\end{tabular}


There were some limitations to using the VERSE-LC model that could be mitigated with additional time. First, the interface of the software was not conducive to a more automated minimization routine. This could be automated to find a minimum using any standard optimization routine, but would have to involve a second software platform. Second, the accuracy of the results could also be improved with better input data, in particular a good estimate of the maximum solute capacity for cesium and accurate measurement of the physical properties of the solution (viscosity and diffusion coefficients in particular). Third, a more complex model could be built that incorporates some of the ignored species such as $\mathrm{Rb}^{+}$, $\mathrm{K}^{+}$, and $\mathrm{Na}^{+}$that compete with $\mathrm{Cs}^{+}$for adsorption sites on the resin. 


\subsection{Conclusions}

Kinetics tests were performed with simulants with varying Na concentrations, OH concentrations, $\mathrm{Na} / \mathrm{Cs}$ ratios, $\mathrm{Na} / \mathrm{OH}$ ratios, and linear velocities using $\mathrm{SRF}$ resin in an ion exchange column. It was found that Cs loading kinetics were not significantly impacted by the sodium concentration, $\mathrm{OH}$ concentration, $\mathrm{Na} / \mathrm{Cs}$ ratio, or $\mathrm{Na} / \mathrm{OH}$ ratio over the range tested. However, the Cs loading kinetics were significantly impacted by the linear load velocity. These results indicated that at the test temperature, the adsorption of cesium is strongly dependent on mass transfer through the film and not significantly impacted by interparticle diffusion. The Cs uptake kinetics were similar between the $5 \underline{\mathrm{M}} \mathrm{Na}$ and $8 \underline{\mathrm{M}} \mathrm{Na}$ simulants indicating that WTP should not have an issue with the Cs loading kinetics in higher Na concentration streams up to $8 \underline{\mathrm{M}} \mathrm{Na}$ being processed through the ion exchange columns. However, there will be a difference in that at higher Na levels, the overall Cs uptake will be lower. Also, the amount of free $\mathrm{OH}$ present did not appear to have any effect on the Cs loading in the columns under the conditions tested.

The Cs ion exchange columns were loaded with a $5 \underline{\mathrm{M}}$ Na simulant initially. The columns were then cycled through several loading and elution tests. After a total of four cycles the columns were loaded with the same $5 \underline{\mathrm{M}} \mathrm{Na}$ feed as used initially. The level of Cs loading on the resin was then compared. It was found that with the cycles kept at $55^{\circ} \mathrm{C}$ or lower there didn't appear to be any resin degradation with the kinetics and loading capacity essentially the same. However, for the tests performed continually at $60^{\circ} \mathrm{C}$ and higher in the 336-hour loading cycle, the resin definitely degraded in loading capacity although the initial loading kinetics remained essentially the same. Therefore, in order to avoid resin loading kinetics degradation, the loading temperature should probably be kept at $55^{\circ} \mathrm{C}$ or lower giving WTP restricted operating range of temperatures or the need to replace resin much more frequently.

The Cs ion exchange columns were held at varying temperatures from $45^{\circ} \mathrm{C}$ to $75^{\circ} \mathrm{C}$ for 14 to 30 days with feed being passed through them at very slow rates. Samples were taken periodically to assess the loading of the resin. Testing at elevated temperatures showed that the resin does degrade and loading capacity is reduced at and above $45^{\circ} \mathrm{C}$. Above $60^{\circ} \mathrm{C}$ the resin appears to not load at all. It was observed that the resin disintegrated at $75^{\circ} \mathrm{C}$ and it partially disintegrated at $65^{\circ} \mathrm{C}$, which caused the column to plug on both tests causing them to be aborted after 14 days. These results indicate that WTP will lose resin loading capacity if the ion exchange process is performed above $25^{\circ} \mathrm{C}$ and the resin will disintegrate above $65^{\circ} \mathrm{C}$. Therefore, WTP will have restricted operating range of temperatures to perform its ion exchange process with this resin. PNNL and WTP are currently evaluating the limits of the resin in further detail to determine the operating range of temperatures for the resin.

Small SRF resin samples were contacted with $0.5 \underline{\mathrm{M}} \mathrm{HNO}_{3}$ for 70 days at $25^{\circ} \mathrm{C}, 45^{\circ} \mathrm{C}$, and $55^{\circ} \mathrm{C}$. One SRF resin sample was contacted with de-ionized water for 70 days at $25^{\circ} \mathrm{C}$ as the baseline. It was found that the loading of the resin afterwards was significantly affected at $45^{\circ} \mathrm{C}$ while the resin held at $55^{\circ} \mathrm{C}$ dissolved and could not be loaded. The resin held at $25^{\circ} \mathrm{C}$ showed no effect on the subsequent loading. Again, WTP will have a restricted operating range of temperatures when dealing with the elution of the resin with nitric acid in order to maintain resin loading capacity and avoid the disintegration of the resin.

A kinetics test was performed with the same simulant as was used in Column A1 under the same conditions with the only difference being the presence of several volatile organics. When compared to 
Column A1, the presence of organics did not appear to have an effect on the Cs loading capacity or kinetics at $45^{\circ} \mathrm{C}$. The Cs loading kinetics were essentially the same as well as the loading capacity. This indicates that organics should not be a factor during ion exchange operation for the WTP.

In an attempt to understand how the parameter changes affected the kinetic behavior, the ion exchange experiments were modeled using VERSE-LC to provide insight on the kinetics of the ion exchange experiments described in this report. In general, the following conclusions can be drawn:

- Increased sodium content slows down the adsorption/desorption as sodium competes with cesium for resin active sites. However, simulations indicated that 5 and $8 \underline{\mathrm{M}}$ sodium have very similar adsorption/desorption rates indicating that they are too high to observe a difference.

- Temperature did not strongly impact adsorption/desorption rate constants.

- Contrary to expectation, the flow rate had a strong effect on the adsorption/desorption rate constants that is outside usual mass transfer mechanisms. This was speculated to arise from channeling in the column, convectively-enhanced pore diffusion of cesium, or some other unknown mechanism that is not currently a part of the model.

- The hydroxide concentration has little or no effect on adsorption and desorption above a concentration of $1 \underline{\mathrm{M}}$.

- As a column is used over time, it will reach steady-state faster during each subsequent processing cycle. The steady-state will have a lower cesium capacity.

- There were some limitations to using the VERSE-LC model that could be mitigated with additional time. First, the model returned some kinetic results that were not expected (in particular, results relating to the effect of flow rate). This requires further exploration to match the column physics better. Second, the interface of the software was not conducive to a more automated minimization routine. Third, the accuracy of the results could also be improved with better input data, in particular a good estimate of the maximum solute capacity for cesium and accurate measurement of the physical properties of the solution (viscosity and diffusion coefficients in particular). Finally, a more complex model could be built that incorporates some of the ignored species such as $\mathrm{Rb}^{+}, \mathrm{K}^{+}$, and $\mathrm{Na}^{+}$that compete with $\mathrm{Cs}^{+}$for adsorption sites on the resin.

The overall conclusions from this testing were:

- The Cs uptake kinetics were similar between the $5 \underline{\mathrm{M}} \mathrm{Na}$ and $8 \underline{\mathrm{M}} \mathrm{Na}$ simulants indicating that WTP should not have an issue with the Cs loading kinetics in higher Na concentration streams up to $8 \underline{\mathrm{M}}$ Na being processed through the ion exchange columns.

- In order to avoid resin loading kinetics degradation, the loading temperature should probably be kept at $55^{\circ} \mathrm{C}$ or lower giving WTP restricted operating range of temperatures or the need to replace resin much more frequently.

- These results indicate that WTP will lose resin loading capacity if the ion exchange process is performed above $25^{\circ} \mathrm{C}$ and the resin will disintegrate above $65^{\circ} \mathrm{C}$. Therefore, WTP will have restricted operating range of temperatures to perform its ion exchange process with this resin. PNNL and WTP are currently evaluating the limits of the resin in further detail to determine the operating range of temperatures for the resin. 
- The presence of organics did not appear to have an effect on the Cs loading capacity or kinetics at $45^{\circ} \mathrm{C}$. The Cs loading kinetics were essentially the same as well as the loading capacity. This indicates that organics should not be a factor during ion exchange operation for the WTP. 



\subsection{References}

Abdulagatov IM and ND Azizov. "Densities, Apparent Molar Volumes and Viscosities of Concentrated Aqueous $\mathrm{NaNO}_{3}$ Solutions at Temperatures from 298 to $607 \mathrm{~K}$ and at Pressures up to $30 \mathrm{MPa}$." Journal of Solution Chemistry 34(6):645-685 (2005).

Adamson DJ, MD Fowley, JL Steimke, TJ Steeper, MR Williams, CE Duffey, and F Fondeur. 2006. Testing of Resorcinol Formaldehyde Ion Exchange Resin. WSRC-TR-2005-00570, SRNL-RPP-2006-00013, Savannah River National Laboratory, Aiken, South Carolina.

Arm ST and DL Blanchard JR. 2004. Pre-Conditioning and Regeneration Requirements of Ground Gel Resorcinol Formaldehyde Ion Exchange Resin. PNWD-3390, WTP-RPT-104, Battelle-Pacific Northwest Division, Richland, Washington.

Berninger JA, RD Whitley, X Zhang, and N-H L Wang. The VERSE Model: Simulation of Reaction and Non-Equilibrium Dynamics in Multicomponent Fixed-Bed Adsorption Processes. Computers \& Chemical Engineering 15(11):749-768 (1991).

Bibler JP, RM Wallace, and LA Bray. 1989. Testing a New Cesium-Specific Ion Exchange Resin for Decontamination of Alkaline High-Activity Waste. WSRC-RP-89-682, Westinghouse Savannah River Company, Savannah River Laboratory, Aiken, South Carolina.

Blanchard Jr DL, SK Fiskum, JM Peterson, AF Farawila, and DE Kurath. 2008. Small Column Ion Exchange Testing for the Near Tank Cesium Removal Project. PNWD-3985, Battelle-Pacific Northwest Division, Richland, Washington.

Brown GN, RL Russell, and RA Peterson. 2011. Small-Column Cesium Ion Exchange Elution Testing Spherical Resorcinol-Formaldehyde. PNNL-20603, WTP-RPT-210, Pacific Northwest National Laboratory, Richland, Washington.

Burgeson IE, DL Blanchard Jr, BJ Cook, and JR Deschane. 2004. Elution Testing of Resorcinol Formaldehyde Resins with AN-105 Simulant. PNWD-3388, WTP-RPT-105, Battelle-Pacific Northwest Division, Richland, Washington.

Duignan MR and CA Nash. 2009. Removal of Cesium from Savannah River Site Waste with Spherical Resorcinol Formaldehyde Ion Exchange Resin: Experimental Tests. SRNL-STI-2009-00367, Rev. 0, Savannah River National Laboratory, Aiken, South Carolina.

Ebra MA and RM Wallace. December 27, 1983. "Phenolic cation exchange resin material for recovery of cesium and strontium.” US Patent 4,423,159.

Fiskum SK, ST Arm, WC Buchmiller, T Trang-Le, JE Martinez, J Matyas, MJ Steele, KK Thomas, and DL Blanchard, Jr. 2006a. Comparison Testing of Multiple Spherical Resorcinol-Formaldehyde Resins the River Protection Project-Waste Treatment Plant. PNWD-3785, WTP-RPT-143, Battelle-Pacific Northwest Division, Richland, Washington. 
Fiskum SK, ST Arm, MS Fountain, MJ Steele, and DL Blanchard, Jr. 2006b. Spherical Resorcinol Formaldehyde Resin Testing for Cs-137 Removal from Simulated and Actual Hanford Waste Tank 241-AP-101 Diluted Feed (Envelope A) Using Small Column Ion Exchange. PNWD-3697, WTP-RPT-134, Battelle-Pacific Northwest Division, Richland, Washington.

Fiskum SK, BS Augspurger, KP Brooks, WC Buchmiller, RL Russell, MJ Schweiger, LA Snow, MJ Steele, KK Thomas, DE Wallace, NH Wong, JD Yeager, and DL Blanchard, Jr. 2004. Comparison Testing of Multiple Resorcinol-Formaldehyde Resins for the River Protection Project - Waste Treatment Plant. PNWD-3387, WTP-RPT-103, Battelle-Pacific Northwest Division, Richland, Washington.

Fiskum SK, MJ Steele, and DL Blanchard, Jr. 2006c. Small Column Ion Exchange Testing of Spherical Resorcinol Formaldehyde Resin for Cs-137 Removal from Pre-treated Hanford Tank 241-AN-102 Waste (Envelope C). PNWD-3751, WTP-RPT-135, Battelle-Pacific Northwest Division, Richland, Washington.

Fiskum SK, ST Arm, MK Edwards, MJ Steele, and KK Thomas. 2007. Storage and Aging Effects on Spherical Resorcinol Formaldehyde Resin Ion Exchange Performance. PNNL-16832, WTP-RPT-148, Pacific Northwest National Laboratory, Richland, Washington.

Hamm LL, T Hang, DJ McCabe, and WD King. Preliminary Ion Exchange Modeling for Removal of Cesium from Hanford Waste Using Hydrous Crystalline Silicotitanate Material. 2002.

WSRC-TR-2001-00400 Westinghouse Savannah River Company, Savannah River Laboratory, Aiken, South Carolina.

Hardy B, LL Hamm, and SE Aleman. 2004. Ion Exchange Modeling for Removal of Cesium using Resorcinol-Formaldehyde Resin. WSRC-TR-2004-00100, Westinghouse Savannah River Company, Savannah River Laboratory, Aiken, South Carolina.

Hassan NM and K Adu-Wusu. 2003. Cesium Removal from Hanford Tank 241-AW-101 Supernate using Resorcinol-Formaldehyde Resin. WSRC-TR-2003-00433, SRT-RPP-2003-00224, Savannah River National Laboratory, Aiken, South Carolina.

King WD, CE Duffey, and SH Malene. 2004. Determination of Cesium (Cs+) Adsorption Kinetics and Equilibrium Isotherms from Hanford Waste Simulants using Resorcinol-Formaldehyde Resins. WSRC-TR-2003-00574, SRT-RPP-2003-00252, Rev. 0, Savannah River National Laboratory, Aiken, South Carolina.

Kurath DE, LA Bray, KP Brooks, GN Brown, SA Bryan, CD Carlson, KJ Carson, JR DesChane, RJ Elovich, and AY Kim. 1994. Experimental Data and Analysis to Support the Design of an Ion-Exchange Process for the Treatment of Hanford Tank Waste Supernatant Liquids. PNL-10187, Pacific Northwest Laboratory, Richland, Washington.

Lehrman S. 2010. RF Resin Cesium Removal with Expanded Load and Elution Conditions. WTP Project Doc. No. 24590-PTF-TSP-RT-09-002, Rev. 0, Bechtel National Inc., Richland, Washington.

Li H, J Addai-Mensah, JC Thomas, and AR Gerson. 2005. “The Influence of Al(III) Supersaturation and $\mathrm{NaOH}$ Concentration on the Rate of Crystallization of $\mathrm{Al}(\mathrm{OH})_{3}$ Precursor Particles from Sodium Aluminate Solutions.” J. Colloid Inter. Sci. 286(2):511-519. 
Nash CA, MR Duignan, and CE Duffey. 2006. Batch, Kinetics, and Column Data from Spherical Resorcinol-Formaldehyde Resin. WSRC-STI-2006-00071, SRNL-RPP-2006-00024, Savannah River National Laboratory, Aiken, South Carolina.

Smith FG. Modeling of Ion-Exchange for Cesium Removal from Dissolved Saltcake in SRS Tanks 1-3, 37 and 41. Savannah River National Laboratory, WSRC-STI-2007-00315 (2007).

Smith FG, LL Hamm, SE Aleman, and ME Johnson. Modeling Ion-Exchange for Cesium Removal from Alkaline Radioactive Waste Solutions. Separation Science and Technology 44:2983-3012 (2009).

Taylor PA and HL Johnson. 2009. "Alternate Methods for Eluting Cesium From Spherical Resorcinol-Formaldehyde Resin-9160.” In Proceedings of the Waste Management 2009 Conference. Phoenix, Arizona.

Yu, Q and N-HL Wang. Computer Simulations of the Dynamics of Multicomponent Ion Exchange in Fixed Beds - Rate Equation Model. Computers \& Chemical Engineering 13(8):915-926 (1989).

\section{BNI Project Documents}

24590-WTP-PL-07-0003, Rev 0. Issue Response Plan to Mature WTP Radioactive Cesium Removal To Technical Readiness Level 6.

SCT-M0SRLE60-00-110-00027, Rev. 0B. Batch Contact and Column Testing of Spherical Resorcinol Formaldehyde. 



\section{Appendix A: Column Sampling Information}



Table A.1. Datasheet for Column A1 Pretreatment, Loading, and Rinsing Information

\begin{tabular}{|c|c|c|c|c|c|c|c|c|c|c|c|c|c|c|}
\hline \multirow{2}{*}{$\begin{array}{l}\text { Sample } \\
\text { ID No. }\end{array}$} & \multirow{2}{*}{$\begin{array}{c}\text { Bottle } \\
\text { Size } \\
(\mathrm{mL})\end{array}$} & \multirow{2}{*}{$\begin{array}{c}\text { Temp } \\
\text { Set } \\
\left({ }^{\circ} \mathrm{C}\right)\end{array}$} & \multirow{2}{*}{$\begin{array}{c}\text { Pump } \\
\text { Setting } \\
\text { (mL/min) }\end{array}$} & \multirow{2}{*}{$\begin{array}{l}\text { Sampling } \\
\text { Start Time }\end{array}$} & \multirow{2}{*}{$\begin{array}{l}\text { Sampling } \\
\text { Stop Time }\end{array}$} & \multirow{2}{*}{$\begin{array}{c}\text { Resin } \\
\text { Height } \\
\text { (cm) }\end{array}$} & \multirow{2}{*}{$\begin{array}{l}\text { Resin } \\
\text { Color }\end{array}$} & \multirow{2}{*}{$\begin{array}{l}\text { Temp } \\
\left({ }^{\circ} \mathrm{C}\right)\end{array}$} & \multicolumn{3}{|c|}{$\begin{array}{c}\text { Effluent Bottle Weight, } \\
\text { g }\end{array}$} & \multicolumn{3}{|c|}{ Sample Vial Weight, g } \\
\hline & & & & & & & & & Tare & Gross & Net & Tare & Gross & Net \\
\hline A1-PT-DIW1 & 20 & 45 & 0.09 & 10/25/10 21:05 & 10/25/10 23:35 & 1.10 & $\begin{array}{c}\text { dark } \\
\text { red }\end{array}$ & NA & 8.34 & 23.02 & 14.68 & NA & NA & NA \\
\hline A1-PT-ACID & 20 & 45 & 0.09 & 10/26/10 8:00 & $10 / 26 / 10$ 10:40 & 0.85 & orange & 45.4 & 8.37 & 23.18 & 14.81 & NA & NA & NA \\
\hline A1-PT-DIW2 & 20 & 45 & 0.09 & 10/26/10 11:16 & $10 / 26 / 1012: 16$ & 0.85 & orange & 41.0 & 8.36 & 13.76 & 5.40 & NA & NA & NA \\
\hline A1-PT-NaOH & 20 & 45 & 0.09 & $10 / 26 / 1012: 24$ & $10 / 26 / 1014: 24$ & 1.10 & $\begin{array}{c}\text { dark } \\
\text { red }\end{array}$ & 46.7 & 8.28 & 19.10 & 10.82 & NA & NA & NA \\
\hline A1-LD-0 & 20 & 45 & 0.09 & 10/27/10 6:57 & 10/27/10 6:57 & NA & $\begin{array}{c}\text { dark } \\
\text { red }\end{array}$ & 44.5 & NA & NA & NA & 8.53 & 11.33 & 2.80 \\
\hline \multicolumn{4}{|c|}{ Loading (LD) Phase Start Date/Time: } & 10/27/10 7:03 & & & & & & & & & & \\
\hline A1-LD-006 & 20 & 45 & 10.62 & 10/27/10 7:09 & 10/27/10 7:09 & NA & $\begin{array}{c}\text { dark } \\
\text { red }\end{array}$ & 41.6 & NA & NA & NA & 8.43 & 11.48 & 3.05 \\
\hline A1-LD-012 & 20 & 45 & 10.62 & 10/27/10 7:15 & 10/27/10 7:15 & NA & $\begin{array}{c}\text { dark } \\
\text { red }\end{array}$ & 41.1 & NA & NA & NA & 8.64 & 11.38 & 2.74 \\
\hline A1-LD-018 & 20 & 45 & 10.62 & 10/27/10 7:21 & 10/27/10 7:21 & NA & $\begin{array}{c}\text { dark } \\
\text { red }\end{array}$ & 41.5 & NA & NA & NA & 8.48 & 11.31 & 2.83 \\
\hline A1-LD-024 & 20 & 45 & 10.62 & 10/27/10 7:27 & 10/27/10 7:27 & NA & $\begin{array}{c}\text { dark } \\
\text { red }\end{array}$ & 42.2 & NA & NA & NA & 8.48 & 11.42 & 2.94 \\
\hline A1-LD-036 & 20 & 45 & 10.62 & 10/27/10 7:39 & 10/27/10 7:39 & NA & $\begin{array}{c}\text { dark } \\
\text { red }\end{array}$ & 43.4 & NA & NA & NA & 8.35 & 10.96 & 2.61 \\
\hline A1-LD-048 & 20 & 45 & 10.62 & 10/27/10 7:51 & 10/27/10 7:51 & NA & $\begin{array}{c}\text { dark } \\
\text { red }\end{array}$ & 44.0 & NA & NA & NA & 8.53 & 11.31 & 2.78 \\
\hline A1-LD-060 & 20 & 45 & 10.62 & 10/27/10 8:03 & 10/27/10 8:03 & NA & $\begin{array}{c}\text { dark } \\
\text { red }\end{array}$ & 44.4 & NA & NA & NA & 8.60 & 11.43 & 2.83 \\
\hline A1-LD-080 & 20 & 45 & 10.62 & 10/27/10 8:23 & 10/27/10 8:23 & NA & $\begin{array}{c}\text { dark } \\
\text { red }\end{array}$ & 44.8 & NA & NA & NA & 8.55 & 11.13 & 2.58 \\
\hline A1-LD-120 & 20 & 45 & 10.62 & 10/27/10 9:03 & 10/27/10 9:03 & NA & $\begin{array}{c}\text { dark } \\
\text { red }\end{array}$ & 45.6 & NA & NA & NA & 8.47 & 11.26 & 2.79 \\
\hline A1-LD-180 & 20 & 45 & 10.62 & 10/27/10 10:03 & 10/27/10 10:03 & NA & $\begin{array}{c}\text { dark } \\
\text { red }\end{array}$ & 46.3 & NA & NA & NA & 8.63 & 11.48 & 2.85 \\
\hline A1-LD-240 & 20 & 45 & 10.62 & 10/27/10 11:03 & 10/27/10 11:03 & NA & $\begin{array}{c}\text { dark } \\
\text { red }\end{array}$ & 45.2 & NA & NA & NA & 8.51 & 11.24 & 2.73 \\
\hline
\end{tabular}


Table A.1. Datasheet for Column A1 Pretreatment, Loading, and Rinsing Information

\begin{tabular}{|c|c|c|c|c|c|c|c|c|c|c|c|c|c|c|}
\hline \multirow{2}{*}{$\begin{array}{l}\text { Sample } \\
\text { ID No. }\end{array}$} & \multirow{2}{*}{$\begin{array}{l}\text { Bottle } \\
\text { Size } \\
(\mathrm{mL})\end{array}$} & \multirow{2}{*}{$\begin{array}{l}\text { Temp } \\
\text { Set } \\
\left({ }^{\circ} \mathrm{C}\right)\end{array}$} & \multirow{2}{*}{$\begin{array}{c}\text { Pump } \\
\text { Setting } \\
\text { (mL/min) }\end{array}$} & \multirow{2}{*}{$\begin{array}{l}\text { Sampling } \\
\text { Start Time }\end{array}$} & \multirow{2}{*}{$\begin{array}{l}\text { Sampling } \\
\text { Stop Time }\end{array}$} & \multirow{2}{*}{$\begin{array}{c}\text { Resin } \\
\text { Height } \\
\text { (cm) }\end{array}$} & \multirow{2}{*}{$\begin{array}{l}\text { Resin } \\
\text { Color }\end{array}$} & \multirow{2}{*}{$\begin{array}{l}\text { Temp } \\
\left({ }^{\circ} \mathrm{C}\right)\end{array}$} & \multicolumn{3}{|c|}{$\begin{array}{c}\text { Effluent Bottle Weight, } \\
\text { g }\end{array}$} & \multicolumn{3}{|c|}{ Sample Vial Weight, g } \\
\hline & & & & & & & & & Tare & Gross & Net & Tare & Gross & Net \\
\hline A1-LD-600 & 20 & 45 & 10.62 & 10/27/10 17:03 & 10/27/10 17:03 & 1.15 & $\begin{array}{l}\text { dark } \\
\text { red }\end{array}$ & 44.3 & NA & NA & NA & 8.47 & 11.39 & 2.92 \\
\hline A1-FD-CP & 20 & 45 & 0.09 & $10 / 27 / 1017: 15$ & 10/27/10 19:45 & 1.10 & $\begin{array}{l}\text { dark } \\
\text { red }\end{array}$ & 45.1 & 8.45 & 22.89 & 14.44 & NA & NA & NA \\
\hline A1-FDI-CP & 20 & 45 & 0.09 & 10/27/10 21:10 & $10 / 27 / 1022: 40$ & 1.15 & $\begin{array}{l}\text { very } \\
\text { dark } \\
\text { red }\end{array}$ & 24.4 & 8.51 & 21.69 & 13.18 & NA & NA & NA \\
\hline A1-AN-CP & 20 & 45 & 0.09 & 10/27/10 23:00 & 10/28/10 00:00 & 1.15 & $\begin{array}{l}\text { very } \\
\text { dark } \\
\text { red }\end{array}$ & 23.8 & 8.57 & 13.75 & 5.18 & NA & NA & NA \\
\hline
\end{tabular}

Table A.2. Datasheet for Column A1 Elution, Rinsing, and Regeneration Information

\begin{tabular}{|c|c|c|c|c|c|c|c|c|c|c|c|c|c|c|}
\hline Sample & Bottle & Temp & Pump & Sampling & Sampling & Resin & Resin & Temp & Efflu & at Bottle & Jeight, & Sam & Vial W & ht, g \\
\hline ID No. & $\begin{array}{l}\text { Size } \\
(\mathrm{mL})\end{array}$ & $\begin{array}{l}\text { Set } \\
\left({ }^{\circ} \mathrm{C}\right)\end{array}$ & $\begin{array}{c}\text { Setting } \\
(\mathrm{mL} / \mathrm{min})\end{array}$ & Start Time & Stop Time & $\begin{array}{c}\text { Height } \\
(\mathrm{cm})\end{array}$ & Color & $\left({ }^{\circ} \mathrm{C}\right)$ & Tare & Gross & Net & Tare & Gross & Net \\
\hline \multicolumn{4}{|c|}{ Elution (EL) Phase Start Date/Time: } & 10/28/10 6:55 & & & & & & & & & & \\
\hline A1-EL-CP & 60 & 25 & 0.08 & 10/28/10 6:55 & $10 / 28 / 1015: 55$ & 0.9 & orange & 25.3 & 14.92 & 57.53 & 42.61 & 8.47 & 15.54 & 7.07 \\
\hline A1-EDI-CP & 20 & 25 & 0.09 & 10/28/10 16:10 & 10/28/10 17:10 & 0.9 & orange & 24.5 & 8.39 & 13.65 & 5.26 & NA & NA & NA \\
\hline A1-RG-CP & 20 & 25 & 0.09 & $10 / 28 / 1017: 22$ & $10 / 28 / 1019: 23$ & 1.2 & $\begin{array}{c}\text { dark } \\
\text { red }\end{array}$ & 25.0 & 8.64 & 18.99 & 10.35 & NA & NA & NA \\
\hline
\end{tabular}

Table A.3. Datasheet for Column A2 Loading and Rinsing Information

\begin{tabular}{|c|c|c|c|c|c|c|c|c|c|c|c|c|c|c|}
\hline \multirow{2}{*}{$\begin{array}{l}\text { Sample } \\
\text { ID No. }\end{array}$} & \multirow{2}{*}{$\begin{array}{c}\text { Bottle } \\
\text { Size } \\
(\mathrm{mL}) \\
\end{array}$} & \multirow{2}{*}{$\begin{array}{c}\text { Temp } \\
\text { Set } \\
\left({ }^{\circ} \mathrm{C}\right) \\
\end{array}$} & \multirow{2}{*}{$\begin{array}{c}\text { Pump } \\
\text { Setting } \\
\text { (mL/min) }\end{array}$} & \multirow{2}{*}{$\begin{array}{l}\text { Sampling } \\
\text { Start Time }\end{array}$} & \multirow{2}{*}{$\begin{array}{l}\text { Sampling } \\
\text { Stop Time }\end{array}$} & \multirow{2}{*}{$\begin{array}{c}\text { Resin } \\
\text { Height } \\
\text { (cm) }\end{array}$} & \multirow{2}{*}{$\begin{array}{l}\text { Resin } \\
\text { Color }\end{array}$} & \multirow{2}{*}{$\begin{array}{l}\text { Temp } \\
\left({ }^{\circ} \mathrm{C}\right)\end{array}$} & \multicolumn{3}{|c|}{ Effluent Bottle Weight,g } & \multicolumn{3}{|c|}{ Sample Vial Weight, g } \\
\hline & & & & & & & & & Tare & Gross & Net & Tare & Gross & Net \\
\hline A2-LD-0 & 20 & 45 & NA & $11 / 1 / 106: 57$ & $11 / 1 / 10$ 6:57 & 1.2 & $\begin{array}{c}\text { dark } \\
\text { red }\end{array}$ & 47.6 & NA & NA & NA & 8.55 & NA & 3.37 \\
\hline
\end{tabular}


Table A.3. Datasheet for Column A2 Loading and Rinsing Information

\begin{tabular}{|c|c|c|c|c|c|c|c|c|c|c|c|c|c|c|}
\hline \multirow{2}{*}{$\begin{array}{l}\text { Sample } \\
\text { ID No. }\end{array}$} & \multirow{2}{*}{$\begin{array}{l}\text { Bottle } \\
\text { Size } \\
(\mathrm{mL})\end{array}$} & \multirow{2}{*}{$\begin{array}{l}\text { Temp } \\
\text { Set } \\
\left({ }^{\circ} \mathrm{C}\right) \\
\end{array}$} & \multirow{2}{*}{$\begin{array}{c}\text { Pump } \\
\text { Setting } \\
\text { (mL/min) }\end{array}$} & \multirow{2}{*}{$\begin{array}{l}\text { Sampling } \\
\text { Start Time }\end{array}$} & \multirow{2}{*}{$\begin{array}{l}\text { Sampling } \\
\text { Stop Time }\end{array}$} & \multirow{2}{*}{$\begin{array}{l}\text { Resin } \\
\text { Height } \\
(\mathrm{cm}) \\
\end{array}$} & \multirow{2}{*}{$\begin{array}{l}\text { Resin } \\
\text { Color }\end{array}$} & \multirow{2}{*}{$\begin{array}{l}\text { Temp } \\
\left({ }^{\circ} \mathrm{C}\right)\end{array}$} & \multicolumn{3}{|c|}{ Effluent Bottle Weight, g } & \multicolumn{3}{|c|}{ Sample Vial Weight, g } \\
\hline & & & & & & & & & Tare & Gross & Net & Tare & Gross & Net \\
\hline \multicolumn{4}{|c|}{ Loading (LD) Phase Start Date/Time: } & $11 / 1 / 107: 03$ & & & & & & & & & & \\
\hline A2-LD-006 & 20 & 45 & 10.62 & 11/1/10 7:09 & 11/1/10 7:09 & NA & $\begin{array}{c}\text { dark } \\
\text { red }\end{array}$ & 44.5 & NA & NA & NA & 8.55 & NA & 3.21 \\
\hline A2-LD-012 & 20 & 45 & 10.62 & 11/1/10 7:15 & 11/1/10 7:15 & NA & $\begin{array}{l}\text { dark } \\
\text { red }\end{array}$ & 43.2 & NA & NA & NA & 8.52 & NA & 3.18 \\
\hline A2-LD-018 & 20 & 45 & 10.62 & 11/1/10 7:21 & $11 / 1 / 107: 21$ & NA & $\begin{array}{l}\text { dark } \\
\text { red }\end{array}$ & 42.6 & NA & NA & NA & 8.40 & NA & 2.89 \\
\hline A2-LD-024 & 20 & 45 & 10.62 & 11/1/10 7:27 & 11/1/10 7:27 & NA & $\begin{array}{c}\text { dark } \\
\text { red }\end{array}$ & 42.8 & NA & NA & NA & 8.62 & NA & 2.41 \\
\hline A2-LD-036 & 20 & 45 & 10.62 & 11/1/10 7:39 & 11/1/10 7:39 & NA & $\begin{array}{l}\text { dark } \\
\text { red }\end{array}$ & 43.6 & NA & NA & NA & 8.42 & NA & 3.24 \\
\hline A2-LD-048 & 20 & 45 & 10.62 & 11/1/10 7:51 & 11/1/10 7:51 & NA & $\begin{array}{l}\text { dark } \\
\text { red }\end{array}$ & 44.3 & NA & NA & NA & 8.46 & NA & 3.21 \\
\hline A2-LD-060 & 20 & 45 & 10.62 & 11/1/10 8:03 & 11/1/10 8:03 & NA & $\begin{array}{l}\text { dark } \\
\text { red }\end{array}$ & 44.5 & NA & NA & NA & 8.56 & NA & 3.26 \\
\hline A2-LD-080 & 20 & 45 & 10.62 & 11/1/10 8:23 & 11/1/10 8:23 & NA & $\begin{array}{c}\text { dark } \\
\text { red }\end{array}$ & 44.7 & NA & NA & NA & 8.53 & NA & 2.53 \\
\hline A2-LD-120 & 20 & 45 & 10.62 & 11/1/10 9:03 & 11/1/10 9:03 & NA & $\begin{array}{l}\text { dark } \\
\text { red }\end{array}$ & 44.5 & NA & NA & NA & 8.53 & NA & 3.27 \\
\hline A2-LD-180 & 20 & 45 & 10.62 & 11/1/10 10:03 & 11/1/10 10:03 & NA & $\begin{array}{c}\text { dark } \\
\text { red }\end{array}$ & 44.8 & NA & NA & NA & 8.50 & NA & 3.16 \\
\hline A2-LD-240 & 20 & 45 & 10.62 & $11 / 1 / 1011: 03$ & 11/1/10 11:03 & NA & $\begin{array}{l}\text { almost } \\
\text { black }\end{array}$ & 45.1 & NA & NA & NA & 8.63 & NA & 3.41 \\
\hline A2-LD-600 & 20 & 45 & 10.62 & 11/1/10 17:03 & 11/1/10 17:03 & 1.2 & $\begin{array}{l}\text { almost } \\
\text { black }\end{array}$ & 44.2 & NA & NA & NA & 8.48 & NA & 2.99 \\
\hline A2-FD-CP & 20 & 45 & 0.09 & $11 / 1 / 1017: 13$ & $11 / 1 / 1019: 43$ & 1.1 & $\begin{array}{l}\text { almost } \\
\text { black }\end{array}$ & 44.2 & 8.46 & 24.37 & 15.91 & NA & NA & NA \\
\hline A2-FDI-CP & 20 & 25 & 0.09 & $11 / 1 / 1020: 17$ & 11/1/10 22:47 & 1.0 & $\begin{array}{c}\text { very } \\
\text { dark } \\
\text { red }\end{array}$ & 25.2 & 8.47 & 21.71 & 13.24 & NA & NA & NA \\
\hline A2-AN-CP & 20 & 25 & 0.09 & 11/1/10 23:00 & $11 / 2 / 1000: 00$ & 0.9 & $\begin{array}{c}\text { very } \\
\text { dark } \\
\text { red }\end{array}$ & 24.9 & 8.51 & 13.77 & 5.26 & NA & NA & NA \\
\hline
\end{tabular}


Table A.4. Datasheet for Column A2 Elution, Rinsing, and Regeneration Information

\begin{tabular}{|c|c|c|c|c|c|c|c|c|c|c|c|c|c|c|}
\hline \multirow{2}{*}{$\begin{array}{l}\text { Sample } \\
\text { ID No. }\end{array}$} & \multirow{2}{*}{$\begin{array}{c}\text { Bottle } \\
\text { Size } \\
(\mathrm{mL}) \\
\end{array}$} & \multirow{2}{*}{$\begin{array}{c}\text { Temp } \\
\text { Set } \\
\left({ }^{\circ} \mathrm{C}\right)\end{array}$} & \multirow{2}{*}{$\begin{array}{c}\text { Pump } \\
\text { Setting } \\
\text { (mL/min) }\end{array}$} & \multirow{2}{*}{$\begin{array}{l}\text { Sampling } \\
\text { Start Time }\end{array}$} & \multirow{2}{*}{$\begin{array}{l}\text { Sampling } \\
\text { Stop Time }\end{array}$} & \multirow{2}{*}{$\begin{array}{c}\text { Resin } \\
\text { Height } \\
(\mathrm{cm}) \\
\end{array}$} & \multirow{2}{*}{$\begin{array}{l}\text { Resin } \\
\text { Color }\end{array}$} & \multirow{2}{*}{$\begin{array}{l}\text { Temp } \\
\left({ }^{\circ} \mathrm{C}\right)\end{array}$} & \multicolumn{3}{|c|}{ Effluent Bottle Weight, g } & \multicolumn{3}{|c|}{ Sample Vial Weight, g } \\
\hline & & & & & & & & & Tare & Gross & Net & Tare & Gross & Net \\
\hline \multicolumn{4}{|c|}{ Elution (EL) Phase Start Date/Time: } & $11 / 2 / 107: 00$ & & & & & & & & & & \\
\hline A2-EL-CP & 60 & 25 & 0.08 & $11 / 2 / 107: 00$ & $11 / 2 / 1017: 00$ & 0.9 & orange & 25.4 & 14.96 & 62.36 & 47.40 & 8.56 & 17.35 & 8.79 \\
\hline A2-EDI-CP & 20 & 25 & 0.09 & $11 / 2 / 1017: 30$ & $11 / 2 / 1018: 30$ & 0.9 & orange & 24.6 & 8.52 & 13.76 & 5.24 & NA & NA & NA \\
\hline A2-RG-CP & 20 & 25 & 0.09 & 11/2/10 18:40 & $11 / 2 / 1020: 40$ & 1.1 & $\begin{array}{c}\text { dark } \\
\text { red }\end{array}$ & 25.4 & 8.55 & 18.98 & 10.43 & NA & NA & NA \\
\hline
\end{tabular}

Table A.5. Datasheet for Column A3 Loading and Rinsing Information

\begin{tabular}{|c|c|c|c|c|c|c|c|c|c|c|c|c|c|c|}
\hline \multirow{2}{*}{$\begin{array}{l}\text { Sample } \\
\text { ID No. }\end{array}$} & \multirow{2}{*}{$\begin{array}{c}\text { Bottle } \\
\text { Size } \\
(\mathrm{mL}) \\
\end{array}$} & \multirow{2}{*}{$\begin{array}{c}\text { Temp } \\
\text { Set } \\
\left({ }^{\circ} \mathrm{C}\right) \\
\end{array}$} & \multirow{2}{*}{$\begin{array}{c}\text { Pump } \\
\text { Setting } \\
\text { (mL/min) }\end{array}$} & \multirow{2}{*}{$\begin{array}{l}\text { Sampling } \\
\text { Start Time }\end{array}$} & \multirow{2}{*}{$\begin{array}{l}\text { Sampling } \\
\text { Stop Time }\end{array}$} & \multirow{2}{*}{$\begin{array}{c}\text { Resin } \\
\text { Height } \\
(\mathrm{cm}) \\
\end{array}$} & \multirow{2}{*}{$\begin{array}{l}\text { Resin } \\
\text { Color }\end{array}$} & \multirow{2}{*}{$\begin{array}{l}\text { Temp } \\
\left({ }^{\circ} \mathrm{C}\right)\end{array}$} & \multicolumn{3}{|c|}{ Effluent Bottle Weight, g } & \multicolumn{3}{|c|}{ Sample Vial Weight, g } \\
\hline & & & & & & & & & Tare & Gross & Net & Tare & Gross & Net \\
\hline A3-LD-0 & 20 & 45 & NA & $11 / 3 / 106: 50$ & 11/3/10 6:50 & 1.1 & $\begin{array}{c}\text { dark } \\
\text { red }\end{array}$ & 46.8 & NA & NA & NA & 8.46 & NA & 3.33 \\
\hline \multicolumn{4}{|c|}{ Loading (LD) Phase Start Date/Time: } & 11/3/10 6:58 & & & & & & & & & & \\
\hline A3-LD-006 & 20 & 45 & 7.08 & 11/3/10 7:04 & $11 / 3 / 107: 04$ & NA & $\begin{array}{c}\text { dark } \\
\text { red }\end{array}$ & 45.5 & NA & NA & NA & 8.48 & NA & 3.13 \\
\hline A3-LD-012 & 20 & 45 & 7.08 & 11/3/10 7:10 & 11/3/10 7:10 & NA & $\begin{array}{c}\text { dark } \\
\text { red }\end{array}$ & 44.6 & NA & NA & NA & 8.54 & NA & 3.18 \\
\hline A3-LD-018 & 20 & 45 & 7.08 & 11/3/10 7:16 & 11/3/10 7:16 & NA & $\begin{array}{c}\text { dark } \\
\text { red }\end{array}$ & 44.7 & NA & NA & NA & 8.49 & NA & 2.48 \\
\hline A3-LD-024 & 20 & 45 & 7.08 & $11 / 3 / 107: 22$ & $11 / 3 / 107: 22$ & NA & $\begin{array}{c}\text { dark } \\
\text { red }\end{array}$ & 44.9 & NA & NA & NA & 8.48 & NA & 2.43 \\
\hline A3-LD-036 & 20 & 45 & 7.08 & $11 / 3 / 107: 34$ & $11 / 3 / 107: 34$ & NA & $\begin{array}{c}\text { dark } \\
\text { red }\end{array}$ & 45.2 & NA & NA & NA & 8.45 & NA & 3.42 \\
\hline A3-LD-048 & 20 & 45 & 7.08 & 11/3/10 7:46 & 11/3/10 7:46 & NA & $\begin{array}{c}\text { dark } \\
\text { red }\end{array}$ & 45.2 & NA & NA & NA & 8.59 & NA & 2.97 \\
\hline A3-LD-060 & 20 & 45 & 7.08 & 11/3/10 7:58 & 11/3/10 7:58 & NA & $\begin{array}{c}\text { dark } \\
\text { red }\end{array}$ & 45.0 & NA & NA & NA & 8.54 & NA & 3.29 \\
\hline A3-LD-080 & 20 & 45 & 7.08 & 11/3/10 8:18 & 11/3/10 8:18 & NA & $\begin{array}{c}\text { dark } \\
\text { red }\end{array}$ & 44.9 & NA & NA & NA & 8.43 & NA & 3.26 \\
\hline
\end{tabular}


Table A.5. Datasheet for Column A3 Loading and Rinsing Information

\begin{tabular}{|c|c|c|c|c|c|c|c|c|c|c|c|c|c|c|}
\hline \multirow{2}{*}{$\begin{array}{l}\text { Sample } \\
\text { ID No. }\end{array}$} & \multirow{2}{*}{$\begin{array}{c}\text { Bottle } \\
\text { Size } \\
(\mathrm{mL}) \\
\end{array}$} & \multirow{2}{*}{$\begin{array}{c}\text { Temp } \\
\text { Set } \\
\left({ }^{\circ} \mathrm{C}\right)\end{array}$} & \multirow{2}{*}{$\begin{array}{c}\text { Pump } \\
\text { Setting } \\
\text { (mL/min) }\end{array}$} & \multirow{2}{*}{$\begin{array}{l}\text { Sampling } \\
\text { Start Time }\end{array}$} & \multirow{2}{*}{$\begin{array}{l}\text { Sampling } \\
\text { Stop Time }\end{array}$} & \multirow{2}{*}{$\begin{array}{c}\text { Resin } \\
\text { Height } \\
(\mathrm{cm}) \\
\end{array}$} & \multirow{2}{*}{$\begin{array}{l}\text { Resin } \\
\text { Color }\end{array}$} & \multirow{2}{*}{$\begin{array}{l}\text { Temp } \\
\left({ }^{\circ} \mathrm{C}\right)\end{array}$} & \multicolumn{3}{|c|}{ Effluent Bottle Weight, g } & \multicolumn{3}{|c|}{ Sample Vialal Weight,g g } \\
\hline & & & & & & & & & Tare & Gross & Net & Tare & Gross & Net \\
\hline A3-LD-120 & 20 & 45 & 7.08 & $11 / 3 / 108: 58$ & 11/3/10 8:58 & NA & $\begin{array}{l}\text { dark } \\
\text { red }\end{array}$ & 44.9 & NA & NA & NA & 8.56 & NA & 3.19 \\
\hline A3-LD-180 & 20 & 45 & 7.08 & 11/3/10 9:58 & 11/3/10 9:58 & NA & $\begin{array}{l}\text { almost } \\
\text { black }\end{array}$ & 44.9 & NA & NA & NA & 8.51 & NA & 3.28 \\
\hline A3-LD-240 & 20 & 45 & 7.08 & $11 / 3 / 1010: 58$ & $11 / 3 / 1010: 58$ & NA & $\begin{array}{l}\text { almost } \\
\text { black }\end{array}$ & 45.1 & NA & NA & NA & 8.51 & NA & 3.31 \\
\hline A3-LD-600 & 20 & 45 & 7.08 & 11/3/10 16:58 & 11/3/10 16:58 & 1.3 & $\begin{array}{l}\text { almost } \\
\text { black }\end{array}$ & 45.1 & NA & NA & NA & 8.47 & NA & 3.20 \\
\hline A3-FD-CP & 20 & 45 & 0.09 & $11 / 3 / 1017: 05$ & 11/3/10 19:35 & 1.3 & $\begin{array}{l}\text { almost } \\
\text { black }\end{array}$ & 45.3 & 8.48 & 24.24 & 15.76 & NA & NA & NA \\
\hline A3-FDI-CP & 20 & 25 & 0.09 & $11 / 3 / 1019: 45$ & $11 / 3 / 1022: 15$ & 1.3 & $\begin{array}{l}\text { almost } \\
\text { black }\end{array}$ & 26.9 & 8.38 & 21.41 & 13.03 & NA & NA & NA \\
\hline A3-AN-CP & 20 & 25 & 0.09 & $11 / 3 / 1022: 22$ & 11/3/10 23:22 & 1.3 & $\begin{array}{l}\text { almost } \\
\text { black }\end{array}$ & 23.8 & 8.53 & 13.78 & 5.25 & NA & NA & NA \\
\hline
\end{tabular}

Table A.6. Datasheet for Column A3 Elution, Rinsing, and Regeneration Information

\begin{tabular}{|c|c|c|c|c|c|c|c|c|c|c|c|c|c|c|}
\hline \multirow{2}{*}{$\begin{array}{l}\text { Sample } \\
\text { ID No. }\end{array}$} & \multirow{2}{*}{$\begin{array}{l}\text { Bottle } \\
\text { Size } \\
(\mathrm{mL}) \\
\end{array}$} & \multirow{2}{*}{$\begin{array}{c}\text { Temp } \\
\text { Set } \\
\left({ }^{\circ} \mathrm{C}\right) \\
\end{array}$} & \multirow{2}{*}{$\begin{array}{c}\text { Pump } \\
\text { Setting } \\
(\mathrm{mL} / \mathrm{min})\end{array}$} & \multirow{2}{*}{$\begin{array}{l}\text { Sampling } \\
\text { Start Time }\end{array}$} & \multirow{2}{*}{$\begin{array}{l}\text { Sampling } \\
\text { Stop Time }\end{array}$} & \multirow{2}{*}{$\begin{array}{l}\text { Resin } \\
\text { Height } \\
(\mathrm{cm})\end{array}$} & \multirow{2}{*}{$\begin{array}{l}\text { Resin } \\
\text { Color }\end{array}$} & \multirow{2}{*}{$\begin{array}{l}\text { Temp } \\
\left({ }^{\circ} \mathrm{C}\right)\end{array}$} & \multicolumn{3}{|c|}{ Effluent Bottle Weight, g } & \multicolumn{3}{|c|}{ 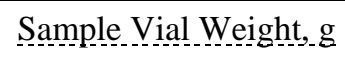 } \\
\hline & & & & & & & & & Tare & Gross & Net & Tare & Gross & Net \\
\hline \multicolumn{4}{|c|}{ Elution (EL) Phase Start Date/Time: } & $11 / 4 / 106: 53$ & & & & & & & & & 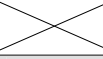 & \\
\hline A3-EL-CP & 60 & 25 & 0.08 & $11 / 4 / 106: 53$ & $11 / 4 / 1016: 53$ & 1.0 & orange & 24.8 & 14.91 & 61.81 & 46.90 & 8.43 & 15.00 & 6.57 \\
\hline A3-EDI-CP & 20 & 25 & 0.09 & $11 / 4 / 1017: 02$ & 11/4/10 18:02 & 0.9 & orange & 23.6 & 8.52 & 13.82 & 5.30 & NA & NA & NA \\
\hline A3-RG-CP & 20 & 25 & 0.09 & 11/4/10 18:03 & $11 / 4 / 1020: 23$ & 1.2 & $\begin{array}{l}\text { dark } \\
\text { red }\end{array}$ & 23.4 & 8.55 & 20.40 & 11.85 & NA & NA & NA \\
\hline
\end{tabular}


Table A.7. Datasheet for Column A4 Loading and Rinsing Information

\begin{tabular}{|c|c|c|c|c|c|c|c|c|c|c|c|c|c|c|}
\hline \multirow{2}{*}{$\begin{array}{l}\text { Sample } \\
\text { ID No. }\end{array}$} & \multirow{2}{*}{$\begin{array}{c}\text { Bottle } \\
\text { Size } \\
(\mathrm{mL}) \\
\end{array}$} & \multirow{2}{*}{$\begin{array}{c}\text { Temp } \\
\text { Set } \\
\left({ }^{\circ} \mathrm{C}\right) \\
\end{array}$} & \multirow{2}{*}{$\begin{array}{c}\text { Pump } \\
\text { Setting } \\
(\mathrm{mL} / \mathrm{min}) \\
\end{array}$} & \multirow{2}{*}{$\begin{array}{l}\text { Sampling } \\
\text { Start Time }\end{array}$} & \multirow{2}{*}{$\begin{array}{l}\text { Sampling } \\
\text { Stop Time }\end{array}$} & \multirow{2}{*}{$\begin{array}{l}\text { Resin } \\
\text { Height } \\
\text { (cm) }\end{array}$} & \multirow{2}{*}{$\begin{array}{l}\text { Resin } \\
\text { Color }\end{array}$} & \multirow{2}{*}{$\begin{array}{l}\text { Temp } \\
\left({ }^{\circ} \mathrm{C}\right)\end{array}$} & \multicolumn{3}{|c|}{ Effluent Bottle Weight, g } & \multicolumn{3}{|c|}{ Sample Vial Weight, g } \\
\hline & & & & & & & & & Tare & Gross & Net & Tare & Gross & Net \\
\hline A4-LD-0 & 20 & 45 & NA & $11 / 5 / 106: 50$ & $11 / 5 / 106: 50$ & 1.2 & $\begin{array}{c}\text { dark } \\
\text { red }\end{array}$ & 46.0 & NA & NA & NA & 8.50 & NA & 3.18 \\
\hline \multicolumn{4}{|c|}{ Loading (LD) Phase Start Date/Time: } & 11/5/10 6:52 & & & & & & & & & & \\
\hline A4-LD-006 & 20 & 45 & 10.62 & $11 / 5 / 106: 58$ & $11 / 5 / 106: 58$ & NA & $\begin{array}{c}\text { dark } \\
\text { red }\end{array}$ & 44.6 & NA & NA & NA & 8.58 & NA & 2.72 \\
\hline A4-LD-012 & 20 & 45 & 10.62 & 11/5/10 7:04 & 11/5/10 7:04 & NA & $\begin{array}{c}\text { dark } \\
\text { red }\end{array}$ & 44.1 & NA & NA & NA & 8.54 & NA & 3.29 \\
\hline A4-LD-018 & 20 & 45 & 10.62 & $11 / 5 / 107: 10$ & $11 / 5 / 107: 10$ & NA & $\begin{array}{l}\text { dark } \\
\text { red }\end{array}$ & 44.2 & NA & NA & NA & 8.56 & NA & 3.17 \\
\hline A4-LD-024 & 20 & 45 & 10.62 & $11 / 5 / 107: 16$ & 11/5/10 7:16 & NA & $\begin{array}{c}\text { dark } \\
\text { red }\end{array}$ & 44.4 & NA & NA & NA & 8.46 & NA & 3.16 \\
\hline A4-LD-036 & 20 & 45 & 10.62 & $11 / 5 / 107: 28$ & $11 / 5 / 107: 28$ & NA & $\begin{array}{c}\text { dark } \\
\text { red }\end{array}$ & 44.8 & NA & NA & NA & 8.54 & NA & 3.33 \\
\hline A4-LD-048 & 20 & 45 & 10.62 & 11/5/10 7:40 & $11 / 5 / 107: 40$ & NA & $\begin{array}{c}\text { dark } \\
\text { red }\end{array}$ & 45.3 & NA & NA & NA & 8.51 & NA & 3.03 \\
\hline A4-LD-060 & 20 & 45 & 10.62 & 11/5/10 7:52 & 11/5/10 7:52 & NA & $\begin{array}{c}\text { dark } \\
\text { red }\end{array}$ & 47.1 & NA & NA & NA & 8.50 & NA & 3.08 \\
\hline A4-LD-080 & 20 & 45 & 10.62 & 11/5/10 8:12 & 11/5/10 8:12 & NA & $\begin{array}{c}\text { dark } \\
\text { red }\end{array}$ & 47.6 & NA & NA & NA & 8.45 & NA & 3.30 \\
\hline A4-LD-120 & 20 & 45 & 10.62 & 11/5/10 8:52 & 11/5/10 8:52 & NA & $\begin{array}{c}\text { dark } \\
\text { red }\end{array}$ & 47.0 & NA & NA & NA & 8.40 & NA & 3.19 \\
\hline A4-LD-180 & 20 & 45 & 10.62 & 11/5/10 9:52 & 11/5/10 9:52 & NA & $\begin{array}{l}\text { dark } \\
\text { red }\end{array}$ & 46.1 & NA & NA & NA & 8.51 & NA & 2.81 \\
\hline A4-LD-240 & 20 & 45 & 10.62 & $11 / 5 / 1010: 52$ & $11 / 5 / 1010: 52$ & NA & $\begin{array}{c}\text { dark } \\
\text { red }\end{array}$ & 45.3 & NA & NA & NA & 8.44 & NA & 3.29 \\
\hline A4-LD-600 & 20 & 45 & 10.62 & $11 / 5 / 1016: 52$ & 11/5/10 16:52 & 1.3 & $\begin{array}{c}\text { dark } \\
\text { red }\end{array}$ & 46.3 & NA & NA & NA & 8.61 & NA & 3.22 \\
\hline A4-FD-CP & 20 & 45 & 0.09 & 11/5/10 17:00 & 11/5/10 19:30 & 1.3 & $\begin{array}{c}\text { dark } \\
\text { red }\end{array}$ & 46.2 & 8.61 & 17.09 & 8.48 & NA & NA & NA \\
\hline
\end{tabular}


Table A.8. Datasheet for Column A4B Loading and Rinsing Information

\begin{tabular}{|c|c|c|c|c|c|c|c|c|c|c|c|c|c|c|}
\hline \multirow{2}{*}{$\begin{array}{l}\text { Sample } \\
\text { ID No. }\end{array}$} & \multirow{2}{*}{$\begin{array}{c}\text { Bottle } \\
\text { Size } \\
(\mathrm{mL})\end{array}$} & \multirow{2}{*}{$\begin{array}{c}\text { Temp } \\
\text { Set } \\
\left({ }^{\circ} \mathrm{C}\right) \\
\end{array}$} & \multirow{2}{*}{$\begin{array}{c}\text { Pump } \\
\text { Setting } \\
(\mathrm{mL} / \mathrm{min}) \\
\end{array}$} & \multirow{2}{*}{$\begin{array}{l}\text { Sampling } \\
\text { Start Time }\end{array}$} & \multirow{2}{*}{$\begin{array}{l}\text { Sampling } \\
\text { Stop Time }\end{array}$} & \multirow{2}{*}{$\begin{array}{l}\text { Resin } \\
\text { Height } \\
(\mathrm{cm}) \\
\end{array}$} & \multirow{2}{*}{$\begin{array}{l}\text { Resin } \\
\text { Color }\end{array}$} & \multirow{2}{*}{$\begin{array}{l}\text { Temp } \\
\left({ }^{\circ} \mathrm{C}\right)\end{array}$} & \multicolumn{3}{|c|}{ Effluent Bottle Weight, g } & \multicolumn{3}{|c|}{ Sample Vial Weight, g } \\
\hline & & & & & & & & & Tare & Gross & Net & Tare & Gross & Net \\
\hline A4B-LD-0 & 20 & 45 & NA & 11/8/10 8:26 & 11/8/10 8:26 & 1.3 & $\begin{array}{c}\text { dark } \\
\text { red }\end{array}$ & 45.1 & NA & NA & NA & 8.51 & NA & 3.31 \\
\hline \multicolumn{4}{|c|}{ Loading (LD) Phase Start Date/Time: } & 11/8/10 8:33 & & & & & & & & & & \\
\hline A4B-LD-004 & 20 & 45 & 0.08 & $11 / 8 / 1012: 33$ & $11 / 8 / 1012: 33$ & NA & $\begin{array}{c}\text { dark } \\
\text { red }\end{array}$ & 45.5 & NA & NA & NA & 8.41 & NA & 3.24 \\
\hline A4B-LD-008 & 20 & 45 & 0.08 & 11/8/10 16:33 & 11/8/10 16:33 & NA & $\begin{array}{l}\text { dark } \\
\text { red }\end{array}$ & 45.0 & NA & NA & NA & 8.55 & NA & 3.29 \\
\hline A4B-LD-012 & 20 & 45 & 0.08 & $11 / 8 / 1020: 33$ & $11 / 8 / 1020: 33$ & NA & $\begin{array}{l}\text { dark } \\
\text { red }\end{array}$ & 44.9 & NA & NA & NA & 8.54 & NA & 3.02 \\
\hline A4B-LD-024 & 20 & 45 & 0.08 & 11/9/10 8:33 & 11/9/10 8:33 & NA & $\begin{array}{l}\text { dark } \\
\text { red }\end{array}$ & 44.2 & NA & NA & NA & 8.54 & NA & 3.66 \\
\hline A4B-LD-072 & 20 & 45 & 0.08 & 11/11/10 8:33 & 11/11/10 8:33 & NA & $\begin{array}{l}\text { almost } \\
\text { black }\end{array}$ & 44.8 & NA & NA & NA & 8.47 & NA & 3.35 \\
\hline A4B-LD-120 & 20 & 45 & 0.08 & 11/13/10 8:33 & 11/13/10 8:33 & NA & $\begin{array}{l}\text { almost } \\
\text { black }\end{array}$ & 45.0 & NA & NA & NA & 8.48 & NA & 3.25 \\
\hline A4B-LD-168 & 20 & 45 & 0.08 & 11/15/10 8:33 & 11/15/10 8:33 & NA & $\begin{array}{l}\text { almost } \\
\text { black }\end{array}$ & 45.1 & NA & NA & NA & 8.59 & NA & 3.29 \\
\hline A4B-LD-336 & 20 & 45 & 0.08 & 11/22/10 8:33 & 11/22/10 8:33 & NA & $\begin{array}{l}\text { almost } \\
\text { black }\end{array}$ & 45.0 & NA & NA & NA & 8.54 & NA & 3.15 \\
\hline A4B-LD-504 & 20 & 45 & 0.08 & 11/29/10 8:33 & 11/29/10 8:33 & NA & $\begin{array}{l}\text { almost } \\
\text { black }\end{array}$ & 45.1 & NA & NA & NA & 8.52 & NA & 3.20 \\
\hline A4B-LD-672 & 20 & 45 & 0.08 & 12/6/10 8:33 & 12/6/10 8:33 & NA & $\begin{array}{l}\text { almost } \\
\text { black }\end{array}$ & 45.0 & NA & NA & NA & 8.56 & NA & 3.27 \\
\hline A4B-LD-720 & 20 & 45 & 0.08 & 12/8/10 8:33 & 12/8/10 8:33 & 1.4 & $\begin{array}{l}\text { almost } \\
\text { black }\end{array}$ & 45.0 & NA & NA & NA & 8.50 & NA & 3.14 \\
\hline A4B-FD-CP & 20 & 45 & 0.09 & 12/8/10 11:47 & $12 / 8 / 1014: 17$ & 1.4 & $\begin{array}{l}\text { almost } \\
\text { black }\end{array}$ & 45.1 & 8.49 & 21.05 & 12.56 & NA & NA & NA \\
\hline A4B-FDI-CP & 20 & 25 & 0.09 & $12 / 8 / 1014: 25$ & $12 / 8 / 1016: 55$ & 1.4 & $\begin{array}{l}\text { almost } \\
\text { black }\end{array}$ & 25.0 & 8.53 & 18.87 & 10.34 & NA & NA & NA \\
\hline A4B-AN-CP & 20 & 25 & 0.09 & 12/8/10 17:06 & 12/8/10 18:06 & 1.4 & $\begin{array}{l}\text { almost } \\
\text { black }\end{array}$ & 24.1 & 8.40 & 12.51 & 4.11 & NA & NA & NA \\
\hline
\end{tabular}


Table A.9. Datasheet for Column A4B Elution, Rinsing, and Regeneration Information

\begin{tabular}{|c|c|c|c|c|c|c|c|c|c|c|c|c|c|c|}
\hline \multirow{2}{*}{$\begin{array}{l}\text { Sample } \\
\text { ID No. }\end{array}$} & \multirow{2}{*}{$\begin{array}{l}\text { Bottle } \\
\text { Size } \\
(\mathrm{mL}) \\
\end{array}$} & \multirow{2}{*}{$\begin{array}{l}\text { Temp } \\
\text { Set } \\
\left({ }^{\circ} \mathrm{C}\right) \\
\end{array}$} & \multirow{2}{*}{$\begin{array}{l}\text { Pump } \\
\text { Setting } \\
\text { (mL/min) }\end{array}$} & \multirow{2}{*}{$\begin{array}{l}\text { Sampling } \\
\text { Start Time }\end{array}$} & \multirow{2}{*}{$\begin{array}{l}\text { Sampling } \\
\text { Stop Time }\end{array}$} & \multirow{2}{*}{$\begin{array}{l}\text { Resin } \\
\text { Height } \\
(\mathrm{cm}) \\
\end{array}$} & \multirow{2}{*}{$\begin{array}{l}\text { Resin } \\
\text { Color }\end{array}$} & \multirow{2}{*}{$\begin{array}{l}\text { Temp } \\
\left({ }^{\circ} \mathrm{C}\right)\end{array}$} & \multicolumn{3}{|c|}{ Effluent Bottle Weight, g } & \multicolumn{3}{|c|}{ Sample Vial Weight, g } \\
\hline & & & & & & & & & Tare & Gross & Net & Tare & Gross & Net \\
\hline \multicolumn{4}{|c|}{ Elution (EL) Phase Start Date/Time: } & $12 / 9 / 106: 50$ & & & & & & & & & & \\
\hline A4B-EL-CP & 60 & 25 & 0.08 & 12/9/10 6:50 & 12/9/10 16:51 & 1.2 & orange & 24.8 & 14.94 & 52.46 & 37.52 & 8.51 & 18.59 & 10.08 \\
\hline A4B-EDI-CP & 20 & 25 & 0.08 & 12/9/10 17:08 & 12/9/10 18:08 & 1.1 & orange & 24.0 & 8.47 & 12.15 & 3.68 & NA & NA & NA \\
\hline A4B-RG-CP & 20 & 25 & 0.09 & $12 / 9 / 1018: 20$ & 12/9/10 21:20 & 1.3 & $\begin{array}{c}\text { dark } \\
\text { red }\end{array}$ & 24.3 & 8.60 & 20.88 & 12.28 & NA & NA & NA \\
\hline
\end{tabular}

Table A.10. Datasheet for Column A5 Loading and Rinsing Information

\begin{tabular}{|c|c|c|c|c|c|c|c|c|c|c|c|c|c|c|}
\hline Sample & Bottle & Temp & Pump & Sampling & Sampling & Resin & Resin & Temp & \multicolumn{3}{|c|}{ Effluent Bottle Weight, g } & \multicolumn{3}{|c|}{ Sample Vial Weight, g } \\
\hline ID No. & $\begin{array}{l}\text { Size } \\
(\mathrm{mL})\end{array}$ & $\begin{array}{l}\text { Set } \\
\left({ }^{\circ} \mathrm{C}\right)\end{array}$ & $\begin{array}{c}\text { Setting } \\
\text { (mL/min) }\end{array}$ & Start Time & Stop Time & $\begin{array}{l}\text { Height } \\
(\mathrm{cm})\end{array}$ & Color & $\left({ }^{\circ} \mathrm{C}\right)$ & Tare & Gross & Net & Tare & Gross & Net \\
\hline A5-LD-0 & 20 & 45 & NA & $1 / 4 / 116: 56$ & $1 / 4 / 116: 56$ & 1.8 & $\begin{array}{c}\text { dark } \\
\text { brown }\end{array}$ & 42.9 & NA & NA & NA & 8.59 & 11.46 & 2.87 \\
\hline \multicolumn{4}{|c|}{ Loading (LD) Phase Start Date/Time: } & $1 / 4 / 117: 03$ & & & & & & & & & & \\
\hline A5-LD-006 & 20 & 45 & 10.62 & 1/4/11 7:09 & $1 / 4 / 117: 09$ & NA & $\begin{array}{c}\text { dark } \\
\text { brown }\end{array}$ & 41.4 & NA & NA & NA & 8.49 & 11.35 & 2.86 \\
\hline A5-LD-012 & 20 & 45 & 10.62 & 1/4/11 7:15 & 1/4/11 7:15 & NA & $\begin{array}{c}\text { dark } \\
\text { brown }\end{array}$ & 40.8 & NA & NA & NA & 8.40 & 11.13 & 2.73 \\
\hline A5-LD-018 & 20 & 45 & 10.62 & 1/4/11 7:21 & 1/4/11 7:21 & NA & $\begin{array}{l}\text { dark } \\
\text { brown }\end{array}$ & 40.7 & NA & NA & NA & 8.43 & 11.26 & 2.83 \\
\hline A5-LD-024 & 20 & 45 & 10.62 & 1/4/11 7:27 & $1 / 4 / 117: 27$ & NA & $\begin{array}{c}\text { dark } \\
\text { brown }\end{array}$ & 41.1 & NA & NA & NA & 8.39 & 11.41 & 3.02 \\
\hline A5-LD-036 & 20 & 45 & 10.62 & $1 / 4 / 117: 39$ & $1 / 4 / 117: 39$ & NA & $\begin{array}{c}\text { dark } \\
\text { brown }\end{array}$ & 41.5 & NA & NA & NA & 8.48 & 11.43 & 2.95 \\
\hline A5-LD-048 & 20 & 45 & 10.62 & $1 / 4 / 117: 51$ & $1 / 4 / 117: 51$ & NA & $\begin{array}{c}\text { dark } \\
\text { brown }\end{array}$ & 42.6 & NA & NA & NA & 8.50 & 11.42 & 2.92 \\
\hline A5-LD-060 & 20 & 45 & 10.62 & $1 / 4 / 118: 03$ & $1 / 4 / 118: 03$ & NA & $\begin{array}{c}\text { dark } \\
\text { brown }\end{array}$ & 43.2 & NA & NA & NA & 8.69 & 11.52 & 2.83 \\
\hline A5-LD-080 & 20 & 45 & 10.62 & 1/4/11 8:23 & 1/4/11 8:23 & NA & $\begin{array}{c}\text { dark } \\
\text { brown }\end{array}$ & 43.8 & NA & NA & NA & 8.48 & 11.12 & 2.64 \\
\hline
\end{tabular}


Table A.10. Datasheet for Column A5 Loading and Rinsing Information

\begin{tabular}{|c|c|c|c|c|c|c|c|c|c|c|c|c|c|c|}
\hline \multirow{2}{*}{$\begin{array}{l}\text { Sample } \\
\text { ID No. }\end{array}$} & \multirow{2}{*}{$\begin{array}{l}\text { Bottle } \\
\text { Size } \\
(\mathrm{mL})\end{array}$} & \multirow{2}{*}{$\begin{array}{c}\text { Temp } \\
\text { Set } \\
\left({ }^{\circ} \mathrm{C}\right)\end{array}$} & \multirow{2}{*}{$\begin{array}{c}\text { Pump } \\
\text { Setting } \\
\text { (mL/min) }\end{array}$} & \multirow{2}{*}{$\begin{array}{l}\text { Sampling } \\
\text { Start Time }\end{array}$} & \multirow{2}{*}{$\begin{array}{l}\text { Sampling } \\
\text { Stop Time }\end{array}$} & \multirow{2}{*}{$\begin{array}{l}\text { Resin } \\
\text { Height } \\
(\mathrm{cm})\end{array}$} & \multirow{2}{*}{$\begin{array}{l}\text { Resin } \\
\text { Color }\end{array}$} & \multirow{2}{*}{$\begin{array}{l}\text { Temp } \\
\left({ }^{\circ} \mathrm{C}\right)\end{array}$} & \multicolumn{3}{|c|}{ Effluent Bottle Weight, g } & \multicolumn{3}{|c|}{ Sample Vial Weight, g } \\
\hline & & & & & & & & & Tare & Gross & Net & Tare & Gross & Net \\
\hline A5-LD-120 & 20 & 45 & 10.62 & 1/4/11 9:03 & 1/4/11 9:03 & NA & $\begin{array}{l}\text { lighter } \\
\text { brown }\end{array}$ & 43.9 & NA & NA & NA & 8.51 & 11.28 & 2.77 \\
\hline A5-LD-180 & 20 & 45 & 10.62 & 1/4/11 10:03 & 1/4/11 10:03 & NA & $\begin{array}{l}\text { lighter } \\
\text { brown }\end{array}$ & 44.0 & NA & NA & NA & 8.50 & 11.38 & 2.88 \\
\hline A5-LD-240 & 20 & 45 & 10.62 & 1/4/11 11:03 & 1/4/11 11:03 & NA & $\begin{array}{l}\text { almost } \\
\text { black }\end{array}$ & 44.0 & NA & NA & NA & 8.47 & 11.39 & 2.92 \\
\hline A5-LD-600 & 20 & 45 & 10.62 & 1/4/11 17:03 & 1/4/11 17:03 & NA & $\begin{array}{l}\text { almost } \\
\text { black }\end{array}$ & 44.1 & NA & NA & NA & 8.44 & 11.42 & 2.98 \\
\hline A5-LD-900 & 20 & 45 & 10.62 & 1/4/11 22:03 & 1/4/11 22:03 & NA & $\begin{array}{l}\text { almost } \\
\text { black }\end{array}$ & 45.8 & NA & NA & NA & 8.53 & 11.84 & 3.31 \\
\hline A5-LD-1200 & 20 & 45 & 10.62 & 1/5/11 3:03 & 1/5/11 3:03 & NA & $\begin{array}{l}\text { almost } \\
\text { black }\end{array}$ & 45.6 & NA & NA & NA & 8.37 & 11.53 & 3.16 \\
\hline A5-FD-CP & 20 & 45 & 0.09 & 1/5/11 3:20 & 1/5/11 5:50 & 1.7 & $\begin{array}{l}\text { almost } \\
\text { black }\end{array}$ & 44.4 & 8.54 & 22.92 & 14.38 & NA & NA & NA \\
\hline A5-FDI-CP & 20 & 25 & 0.09 & 1/5/11 6:10 & 1/5/11 8:40 & 1.7 & $\begin{array}{l}\text { almost } \\
\text { black }\end{array}$ & 24.8 & 8.41 & 21.38 & 12.97 & NA & NA & NA \\
\hline A5-AN-CP & 20 & 25 & 0.09 & 1/5/11 8:45 & 1/5/11 9:51 & 1.7 & $\begin{array}{c}\text { dark } \\
\text { brown }\end{array}$ & 24.5 & 8.49 & 14.30 & 5.81 & NA & NA & NA \\
\hline
\end{tabular}

Table A.11. Datasheet for Column A5 Elution, Rinsing, and Regeneration Information

\begin{tabular}{|c|c|c|c|c|c|c|c|c|c|c|c|c|c|c|}
\hline Sample & Bottle & Temp & Pump & Sampling & Sampling & Resin & Resin & Temp & Efflu & gt Bottle & eight, & Samp & Vial W & hht, g \\
\hline ID No. & $\begin{array}{l}\text { Size } \\
(\mathrm{mL})\end{array}$ & $\begin{array}{l}\text { Set } \\
\left({ }^{\circ} \mathrm{C}\right)\end{array}$ & $\begin{array}{l}\text { Setting } \\
\text { (mL/min) }\end{array}$ & Start Time & Stop Time & $\begin{array}{l}\text { Height } \\
\text { (cm) }\end{array}$ & Color & $\left({ }^{\circ} \mathrm{C}\right)$ & Tare & Gross & Net & Tare & Gross & Net \\
\hline \multicolumn{4}{|c|}{ Elution (EL) Phase Start Date/Time: } & 1/5/11 22:04 & & & & & & & & & & \\
\hline A5-EL-CP & 60 & 25 & 0.08 & 1/5/11 22:04 & 1/6/11 9:04 & 1.4 & $\begin{array}{l}\text { reddish } \\
\text { orange }\end{array}$ & 24.6 & 14.94 & 65.60 & 50.66 & 8.44 & 21.13 & 12.69 \\
\hline A5-EDI-CP & 20 & 25 & 0.09 & 1/6/11 9:10 & 1/6/11 10:13 & 1.3 & $\begin{array}{l}\text { reddish } \\
\text { orange }\end{array}$ & 24.1 & 8.25 & 13.56 & 5.31 & NA & NA & NA \\
\hline
\end{tabular}


Table A.12. Datasheet for Column B1 Pretreatment, Loading, and Rinsing Information

\begin{tabular}{|c|c|c|c|c|c|c|c|c|c|c|c|c|c|c|}
\hline \multirow{2}{*}{$\begin{array}{l}\text { Sample } \\
\text { ID No. }\end{array}$} & \multirow{2}{*}{$\begin{array}{l}\text { Bottle } \\
\text { Size } \\
(\mathrm{mL})\end{array}$} & \multirow{2}{*}{$\begin{array}{c}\text { Temp } \\
\text { Set } \\
\left({ }^{\circ} \mathrm{C}\right)\end{array}$} & \multirow{2}{*}{$\begin{array}{c}\text { Pump } \\
\text { Setting } \\
\text { (mL/min) }\end{array}$} & \multirow{2}{*}{$\begin{array}{l}\text { Sampling } \\
\text { Start Time }\end{array}$} & \multirow{2}{*}{$\begin{array}{l}\text { Sampling } \\
\text { Stop Time }\end{array}$} & \multirow{2}{*}{$\begin{array}{l}\text { Resin } \\
\text { Height } \\
(\mathrm{cm})\end{array}$} & \multirow{2}{*}{$\begin{array}{l}\text { Resin } \\
\text { Color }\end{array}$} & \multirow{2}{*}{$\begin{array}{l}\text { Temp } \\
\left({ }^{\circ} \mathrm{C}\right)\end{array}$} & \multicolumn{3}{|c|}{$\begin{array}{c}\text { Effluent Bottle Weight, } \\
\text { g }\end{array}$} & \multicolumn{3}{|c|}{ Sample Vial Weight, g } \\
\hline & & & & & & & & & Tare & Gross & Net & Tare & Gross & Net \\
\hline B1-PT-DIW1 & 20 & 25 & 0.09 & 1/10/11 7:05 & 1/10/11 9:39 & 1.2 & $\begin{array}{l}\text { reddish } \\
\text { orange }\end{array}$ & 23.9 & 8.45 & 21.20 & 12.75 & NA & NA & NA \\
\hline B1-PT-ACID & 20 & 25 & 0.09 & 1/10/11 10:20 & 1/10/11 13:20 & 0.9 & orange & 24.0 & 8.55 & 23.72 & 15.17 & NA & NA & NA \\
\hline B1-PT-DIW2 & 20 & 25 & 0.09 & 1/10/11 13:25 & 1/10/11 14:34 & 0.9 & orange & 23.9 & 8.52 & 14.22 & 5.70 & NA & NA & NA \\
\hline B1-PT-NaOH & 20 & 25 & 0.09 & 1/10/11 14:41 & 1/10/11 16:41 & 1.1 & $\begin{array}{c}\text { dark } \\
\text { red }\end{array}$ & 24.1 & 8.52 & 18.80 & 10.28 & NA & NA & NA \\
\hline B1-LD-0 & 20 & 50 & NA & $1 / 11 / 116: 57$ & $1 / 11 / 116: 57$ & 1.1 & $\begin{array}{c}\text { dark } \\
\text { red }\end{array}$ & 48.6 & NA & NA & NA & 8.49 & 11.39 & 2.90 \\
\hline \multicolumn{4}{|c|}{ Loading (LD) Phase Start Date/Time: } & 1/11/11 7:02 & & & & & & & & & & \\
\hline B1-LD-006 & 20 & 50 & 10.62 & 1/11/11 7:09 & 1/11/11 7:09 & NA & $\begin{array}{c}\text { dark } \\
\text { red }\end{array}$ & 45.5 & NA & NA & NA & 8.45 & 11.20 & 2.75 \\
\hline B1-LD-012 & 20 & 50 & 10.62 & 1/11/11 7:14 & 1/11/11 7:14 & NA & $\begin{array}{c}\text { dark } \\
\text { red }\end{array}$ & 45.4 & NA & NA & NA & 8.50 & 11.39 & 2.89 \\
\hline B1-LD-018 & 20 & 50 & 10.62 & 1/11/11 7:20 & $1 / 11 / 117: 20$ & NA & $\begin{array}{c}\text { dark } \\
\text { red }\end{array}$ & 45.8 & NA & NA & NA & 8.37 & 11.35 & 2.98 \\
\hline B1-LD-024 & 20 & 50 & 10.62 & 1/11/11 7:26 & 1/11/11 7:26 & NA & $\begin{array}{c}\text { dark } \\
\text { red }\end{array}$ & 46.3 & NA & NA & NA & 8.46 & 11.45 & 2.99 \\
\hline B1-LD-036 & 20 & 50 & 10.62 & 1/11/11 7:38 & 1/11/11 7:38 & NA & $\begin{array}{c}\text { dark } \\
\text { red }\end{array}$ & 47.6 & NA & NA & NA & 8.57 & 11.37 & 2.80 \\
\hline B1-LD-048 & 20 & 50 & 10.62 & 1/11/11 7:50 & 1/11/11 7:50 & NA & $\begin{array}{l}\text { dark } \\
\text { red }\end{array}$ & 49.0 & NA & NA & NA & 8.47 & 11.48 & 3.01 \\
\hline B1-LD-060 & 20 & 50 & 10.62 & 1/11/11 8:02 & 1/11/11 8:02 & NA & $\begin{array}{l}\text { almost } \\
\text { black }\end{array}$ & 49.6 & NA & NA & NA & 8.51 & 11.58 & 3.07 \\
\hline B1-LD-080 & 20 & 50 & 10.62 & 1/11/11 8:22 & 1/11/11 8:22 & NA & $\begin{array}{l}\text { almost } \\
\text { black }\end{array}$ & 49.9 & NA & NA & NA & 8.52 & 11.48 & 2.96 \\
\hline B1-LD-120 & 20 & 50 & 10.62 & 1/11/11 9:02 & 1/11/11 9:02 & NA & $\begin{array}{l}\text { almost } \\
\text { black }\end{array}$ & 49.6 & NA & NA & NA & 8.56 & 11.52 & 2.96 \\
\hline B1-LD-180 & 20 & 50 & 10.62 & 1/11/11 10:02 & 1/11/11 10:02 & NA & $\begin{array}{l}\text { almost } \\
\text { black }\end{array}$ & 49.5 & NA & NA & NA & 8.54 & 11.48 & 2.94 \\
\hline B1-LD-240 & 20 & 50 & 10.62 & 1/11/11 11:06 & 1/11/11 11:06 & NA & $\begin{array}{l}\text { almost } \\
\text { black }\end{array}$ & 49.3 & NA & NA & NA & 8.51 & 11.46 & 2.95 \\
\hline
\end{tabular}


Table A.12. Datasheet for Column B1 Pretreatment, Loading, and Rinsing Information

\begin{tabular}{|c|c|c|c|c|c|c|c|c|c|c|c|c|c|c|}
\hline \multirow{2}{*}{$\begin{array}{l}\text { Sample } \\
\text { ID No. }\end{array}$} & \multirow{2}{*}{$\begin{array}{l}\text { Bottle } \\
\text { Size } \\
(\mathrm{mL})\end{array}$} & \multirow{2}{*}{$\begin{array}{l}\text { Temp } \\
\text { Set } \\
\left({ }^{\circ} \mathrm{C}\right) \\
\end{array}$} & \multirow{2}{*}{$\begin{array}{c}\text { Pump } \\
\text { Setting } \\
\text { (mL/min) }\end{array}$} & \multirow{2}{*}{$\begin{array}{l}\text { Sampling } \\
\text { Start Time }\end{array}$} & \multirow{2}{*}{$\begin{array}{l}\text { Sampling } \\
\text { Stop Time }\end{array}$} & \multirow{2}{*}{$\begin{array}{l}\text { Resin } \\
\text { Height } \\
(\mathrm{cm})\end{array}$} & \multirow{2}{*}{$\begin{array}{l}\text { Resin } \\
\text { Color }\end{array}$} & \multirow{2}{*}{$\begin{array}{l}\text { Temp } \\
\left({ }^{\circ} \mathrm{C}\right)\end{array}$} & \multicolumn{3}{|c|}{$\begin{array}{c}\text { Effluent Bottle Weight, } \\
\text { g }\end{array}$} & \multicolumn{3}{|c|}{ Sample Vial Weight, g } \\
\hline & & & & & & & & & Tare & Gross & Net & Tare & Gross & Net \\
\hline B1-LD-600 & 20 & 50 & 10.62 & 1/11/11 17:02 & 1/11/11 17:02 & NA & $\begin{array}{l}\text { almost } \\
\text { black }\end{array}$ & 49.6 & NA & NA & NA & 8.46 & 11.40 & 2.94 \\
\hline B1-LD-900 & 20 & 50 & 10.62 & 1/11/11 22:02 & 1/11/11 22:02 & 1.1 & $\begin{array}{l}\text { dark } \\
\text { red }\end{array}$ & 49.4 & NA & NA & NA & 8.49 & 11.25 & 2.76 \\
\hline B1-LD-1200 & 20 & 50 & 10.62 & 1/12/11 3:02 & 1/12/11 3:02 & 1.1 & $\begin{array}{l}\text { dark } \\
\text { red }\end{array}$ & 51.7 & NA & NA & NA & 8.49 & 11.16 & 2.67 \\
\hline B1-FD-CP & 20 & 50 & 0.09 & 1/12/11 3:29 & 1/12/11 5:59 & 1.1 & $\begin{array}{l}\text { almost } \\
\text { black }\end{array}$ & 49.4 & 8.55 & 22.96 & 14.41 & NA & NA & NA \\
\hline B1-FDI-CP & 20 & 25 & 0.09 & 1/12/11 6:02 & 1/12/11 8:32 & 1.1 & $\begin{array}{l}\text { almost } \\
\text { black }\end{array}$ & 24.2 & 8.54 & 21.39 & 12.85 & NA & NA & NA \\
\hline B1-AN-CP & 20 & 25 & 0.09 & 1/12/11 9:10 & 1/12/11 10:10 & 1.1 & $\begin{array}{l}\text { dark } \\
\text { brown }\end{array}$ & 23.9 & 8.57 & 13.73 & 8.57 & NA & NA & NA \\
\hline
\end{tabular}

Table A.13. Datasheet for Column B1 Elution, Rinsing, and Regeneration Information

\begin{tabular}{|c|c|c|c|c|c|c|c|c|c|c|c|c|c|c|}
\hline \multirow{2}{*}{$\begin{array}{l}\text { Sample } \\
\text { ID No. }\end{array}$} & \multirow{2}{*}{$\begin{array}{c}\text { Bottle } \\
\text { Size } \\
(\mathrm{mL}) \\
\end{array}$} & \multirow{2}{*}{$\begin{array}{l}\text { Temp } \\
\text { Set } \\
\left({ }^{\circ} \mathrm{C}\right) \\
\end{array}$} & \multirow{2}{*}{$\begin{array}{c}\text { Pump } \\
\text { Setting } \\
\text { (mL/min) }\end{array}$} & \multirow{2}{*}{$\begin{array}{l}\text { Sampling } \\
\text { Start Time }\end{array}$} & \multirow{2}{*}{$\begin{array}{l}\text { Sampling } \\
\text { Stop Time }\end{array}$} & \multirow{2}{*}{$\begin{array}{l}\text { Resin } \\
\text { Height } \\
(\mathrm{cm})\end{array}$} & \multirow{2}{*}{$\begin{array}{l}\text { Resin } \\
\text { Color }\end{array}$} & \multirow{2}{*}{$\begin{array}{l}\text { Temp } \\
\left({ }^{\circ} \mathrm{C}\right)\end{array}$} & \multicolumn{3}{|c|}{ Effluent Bottle Weight, g } & \multicolumn{3}{|c|}{ Sample_Vial Weight,g } \\
\hline & & & & & & & & & Tare & Gross & Net & Tare & Gross & Net \\
\hline \multicolumn{4}{|c|}{ Elution (EL) Phase Start Date/Time: } & 1/12/11 10:16 & & $\mathrm{r}$ & & & & & & & 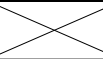 & $=$ \\
\hline B1-EL-CP & 60 & 25 & 0.08 & 1/12/11 10:16 & 1/12/11 20:16 & NA & orange & 24.5 & 14.91 & 60.33 & 45.42 & 8.60 & 19.30 & 10.70 \\
\hline B1-EDI-CP & 20 & 25 & 0.09 & 1/13/11 1:15 & 1/13/11 3:45 & NA & orange & 24.5 & 8.48 & 20.66 & 12.18 & NA & NA & NA \\
\hline B1-RG-CP & 20 & 25 & 0.09 & 1/13/11 4:34 & 1/13/11 6:59 & 1.1 & $\begin{array}{c}\text { dark } \\
\text { brown }\end{array}$ & 24.3 & 8.56 & 20.80 & 12.24 & NA & NA & NA \\
\hline
\end{tabular}


Table A.14. Datasheet for Column B2 Loading and Rinsing Information

\begin{tabular}{|c|c|c|c|c|c|c|c|c|c|c|c|c|c|c|}
\hline \multirow{2}{*}{$\begin{array}{l}\text { Sample } \\
\text { ID No. }\end{array}$} & \multirow{2}{*}{$\begin{array}{c}\text { Bottle } \\
\text { Size } \\
(\mathrm{mL}) \\
\end{array}$} & \multirow{2}{*}{$\begin{array}{c}\text { Temp } \\
\text { Set } \\
\left({ }^{\circ} \mathrm{C}\right) \\
\end{array}$} & \multirow{2}{*}{$\begin{array}{c}\text { Pump } \\
\text { Setting } \\
\text { (mL/min) }\end{array}$} & \multirow{2}{*}{$\begin{array}{l}\text { Sampling } \\
\text { Start Time }\end{array}$} & \multirow{2}{*}{$\begin{array}{l}\text { Sampling } \\
\text { Stop Time }\end{array}$} & \multirow{2}{*}{$\begin{array}{c}\text { Resin } \\
\text { Height } \\
(\mathrm{cm})\end{array}$} & \multirow{2}{*}{$\begin{array}{l}\text { Resin } \\
\text { Color }\end{array}$} & \multirow{2}{*}{$\begin{array}{l}\text { Temp } \\
\left({ }^{\circ} \mathrm{C}\right)\end{array}$} & \multicolumn{3}{|c|}{ Effluent Bottle Weight,g } & \multicolumn{3}{|c|}{ Sample Vial Weight, g } \\
\hline & & & & & & & & & Tare & Gross & Net & Tare & Gross & Net \\
\hline B2-LD-0 & 20 & 50 & NA & 1/16/11 21:00 & 1/16/11 21:00 & 1.1 & $\begin{array}{c}\text { dark } \\
\text { red }\end{array}$ & 49.6 & NA & NA & NA & 8.52 & 11.20 & 2.68 \\
\hline \multicolumn{4}{|c|}{ Loading (LD) Phase Start Date/Time: } & $1 / 16 / 1121: 00$ & & & & & & & & & & \\
\hline B2-LD-006 & 20 & 50 & 14.16 & 1/16/11 21:06 & 1/16/11 21:06 & NA & $\begin{array}{c}\text { dark } \\
\text { red }\end{array}$ & 48.8 & NA & NA & NA & 8.42 & 10.80 & 2.38 \\
\hline B2-LD-012 & 20 & 50 & 14.16 & 1/16/11 21:12 & 1/16/11 21:12 & NA & $\begin{array}{c}\text { dark } \\
\text { red }\end{array}$ & 47.5 & NA & NA & NA & 8.47 & 11.35 & 2.88 \\
\hline B2-LD-018 & 20 & 50 & 14.16 & 1/16/11 21:18 & 1/16/11 21:18 & NA & $\begin{array}{c}\text { dark } \\
\text { red }\end{array}$ & 46.8 & NA & NA & NA & 8.54 & 11.06 & 2.52 \\
\hline B2-LD-024 & 20 & 50 & 14.16 & 1/16/11 21:24 & $1 / 16 / 1121: 24$ & NA & $\begin{array}{c}\text { dark } \\
\text { red }\end{array}$ & 46.7 & NA & NA & NA & 8.33 & 11.06 & 2.73 \\
\hline B2-LD-036 & 20 & 50 & 14.16 & 1/16/11 21:36 & 1/16/11 21:36 & NA & $\begin{array}{c}\text { dark } \\
\text { red }\end{array}$ & 46.9 & NA & NA & NA & 8.51 & 11.01 & 2.50 \\
\hline B2-LD-048 & 20 & 50 & 14.16 & 1/16/11 21:48 & 1/16/11 21:48 & NA & $\begin{array}{c}\text { dark } \\
\text { red }\end{array}$ & 47.0 & NA & NA & NA & 8.43 & 11.24 & 2.81 \\
\hline B2-LD-060 & 20 & 50 & 14.16 & 1/16/11 22:00 & 1/16/11 22:00 & NA & $\begin{array}{l}\text { almost } \\
\text { black }\end{array}$ & 47.2 & NA & NA & NA & 8.47 & 10.88 & 2.41 \\
\hline B2-LD-080 & 20 & 50 & 14.16 & 1/16/11 22:20 & $1 / 16 / 1122: 20$ & NA & $\begin{array}{l}\text { almost } \\
\text { black }\end{array}$ & 47.3 & NA & NA & NA & 8.43 & 10.92 & 2.49 \\
\hline B2-LD-120 & 20 & 50 & 14.16 & 1/16/11 23:00 & 1/16/11 23:00 & NA & $\begin{array}{l}\text { almost } \\
\text { black }\end{array}$ & 47.6 & NA & NA & NA & 8.39 & 11.05 & 2.66 \\
\hline B2-LD-180 & 20 & 50 & 14.16 & 1/17/11 00:00 & 1/17/11 00:00 & NA & $\begin{array}{l}\text { almost } \\
\text { black }\end{array}$ & 47.8 & NA & NA & NA & 8.52 & 11.10 & 2.58 \\
\hline B2-LD-240 & 20 & 50 & 14.16 & 1/17/11 1:00 & 1/17/11 1:00 & NA & $\begin{array}{l}\text { almost } \\
\text { black }\end{array}$ & 47.9 & NA & NA & NA & 8.55 & 11.30 & 2.75 \\
\hline B2-LD-600 & 20 & 50 & 14.16 & 1/17/11 7:03 & 1/17/11 7:03 & NA & $\begin{array}{l}\text { almost } \\
\text { black }\end{array}$ & 48.5 & NA & NA & NA & 8.37 & 11.12 & 2.75 \\
\hline B2-LD-900 & 20 & 50 & 14.16 & 1/17/11 12:03 & 1/17/11 12:03 & NA & $\begin{array}{l}\text { almost } \\
\text { black }\end{array}$ & 48.9 & NA & NA & NA & 8.45 & 11.38 & 2.93 \\
\hline B2-LD-1200 & 20 & 50 & 14.16 & 1/17/11 17:00 & 1/17/11 17:00 & 1.3 & $\begin{array}{l}\text { almost } \\
\text { black }\end{array}$ & 48.2 & NA & NA & NA & 8.54 & 11.29 & 2.75 \\
\hline
\end{tabular}


Table A.14. Datasheet for Column B2 Loading and Rinsing Information

\begin{tabular}{|c|c|c|c|c|c|c|c|c|c|c|c|c|c|c|}
\hline \multirow{2}{*}{$\begin{array}{l}\text { Sample } \\
\text { ID No. }\end{array}$} & \multirow{2}{*}{$\begin{array}{c}\text { Bottle } \\
\text { Size } \\
(\mathrm{mL})\end{array}$} & \multirow{2}{*}{$\begin{array}{c}\text { Temp } \\
\text { Set } \\
\left({ }^{\circ} \mathrm{C}\right)\end{array}$} & \multirow{2}{*}{$\begin{array}{c}\text { Pump } \\
\text { Setting } \\
\text { (mL/min) }\end{array}$} & \multirow{2}{*}{$\begin{array}{l}\text { Sampling } \\
\text { Start Time }\end{array}$} & \multirow{2}{*}{$\begin{array}{l}\text { Sampling } \\
\text { Stop Time }\end{array}$} & \multirow{2}{*}{$\begin{array}{c}\text { Resin } \\
\text { Height } \\
\text { (cm) }\end{array}$} & \multirow{2}{*}{$\begin{array}{l}\text { Resin } \\
\text { Color }\end{array}$} & \multirow{2}{*}{$\begin{array}{l}\text { Temp } \\
\left({ }^{\circ} \mathrm{C}\right)\end{array}$} & \multicolumn{3}{|c|}{ Effluent Bottle Weight,g g } & \multicolumn{3}{|c|}{ Sample Vial Weight,g } \\
\hline & & & & & & & & & Tare & Gross & Net & Tare & Gross & Net \\
\hline B2-FD-CP & 20 & 50 & 0.09 & 1/17/11 17:14 & 1/17/11 19:44 & 1.3 & $\begin{array}{c}\text { almost } \\
\text { black }\end{array}$ & 51.1 & 8.42 & 21.66 & 13.24 & NA & NA & NA \\
\hline B2-FDI-CP & 20 & 25 & 0.09 & 1/17/11 19:55 & 1/17/11 22:25 & 1.3 & $\begin{array}{c}\text { almost } \\
\text { black }\end{array}$ & 24.7 & 8.46 & 20.59 & 12.13 & NA & NA & NA \\
\hline B2-AN-CP & 20 & 25 & 0.09 & 1/17/11 22:45 & 1/17/11 23:45 & 1.3 & $\begin{array}{c}\text { almost } \\
\text { black }\end{array}$ & 24.3 & 8.48 & 13.45 & 4.97 & NA & NA & NA \\
\hline
\end{tabular}

Table A.15. Datasheet for Column B2 Elution, Rinsing, and Regeneration Information

\begin{tabular}{|c|c|c|c|c|c|c|c|c|c|c|c|c|c|c|}
\hline Sample & Bottle & Temp & Pump & Sampling & Sampling & Resin & Resin & Temp & Efflue & Bottle & ight, g & Sam & Vial & sht, g \\
\hline ID No. & $\begin{array}{l}\text { Size } \\
(\mathrm{mL})\end{array}$ & $\begin{array}{l}\text { Set } \\
\left({ }^{\circ} \mathrm{C}\right)\end{array}$ & $\begin{array}{c}\text { Setting } \\
(\mathrm{mL} / \mathrm{min})\end{array}$ & Start Time & Stop Time & $\begin{array}{l}\text { Height } \\
(\mathrm{cm})\end{array}$ & Color & $\left({ }^{\circ} \mathrm{C}\right)$ & Tare & Gross & Net & Tare & Gross & Net \\
\hline Elution & EL) Pha & e Start & ate/Time: & 1/17/11 23:58 & & & & & & & & & & \\
\hline B2-EL-CP & 60 & 25 & 0.09 & $1 / 7 / 1023: 58$ & 1/18/11 8:58 & 0.95 & $\begin{array}{c}\text { dark } \\
\text { red }\end{array}$ & 24.6 & 14.89 & 58.68 & 43.79 & 8.46 & 18.68 & 10.22 \\
\hline B2-EDI-CP & 20 & 25 & 0.09 & 1/18/11 9:06 & 1/18/11 10:06 & 0.95 & $\begin{array}{c}\text { dark } \\
\text { red }\end{array}$ & 24.1 & 8.53 & 13.39 & 4.86 & NA & NA & NA \\
\hline B2-RG-CP & 20 & 25 & 0.09 & 1/18/11 10:12 & 1/18/11 12:42 & 1.2 & $\begin{array}{l}\text { almost } \\
\text { black }\end{array}$ & 24.4 & 8.49 & 20.69 & 12.20 & NA & NA & NA \\
\hline
\end{tabular}

Table A.16. Datasheet for Column B3 Loading and Rinsing Information

\begin{tabular}{|c|c|c|c|c|c|c|c|c|c|c|c|c|c|c|}
\hline Sample & Bottle & Temp & Pump & Sampling & Sampling & Resin & Resin & Temp & \multicolumn{3}{|c|}{ Effluent Bottle Weight,g } & \multicolumn{3}{|c|}{ Sample Vial Weight, g } \\
\hline ID No. & $\begin{array}{l}\text { Size } \\
(\mathrm{mL})\end{array}$ & $\begin{array}{l}\text { Set } \\
\left({ }^{\circ} \mathrm{C}\right)\end{array}$ & $\begin{array}{c}\text { Setting } \\
\text { (mL/min) }\end{array}$ & Start Time & Stop Time & $\begin{array}{c}\text { Height } \\
\text { (cm) }\end{array}$ & Color & $\left({ }^{\circ} \mathrm{C}\right)$ & Tare & Gross & Net & Tare & Gross & Net \\
\hline B3-LD-0 & 20 & 50 & NA & 1/18/11 21:13 & 1/18/11 21:13 & 1.3 & $\begin{array}{c}\text { dark } \\
\text { red }\end{array}$ & 51.3 & NA & NA & NA & 8.56 & 11.33 & 2.77 \\
\hline \multicolumn{4}{|c|}{ Loading (LD) Phase Start Date/Time: } & 1/18/11 21:13 & & & & & & & & & & \\
\hline B3-LD-006 & 20 & 50 & 7.08 & 1/18/11 21:19 & 1/18/11 21:19 & NA & $\begin{array}{c}\text { dark } \\
\text { red }\end{array}$ & 48.9 & NA & NA & NA & 8.45 & 11.10 & 2.65 \\
\hline
\end{tabular}


Table A.16. Datasheet for Column B3 Loading and Rinsing Information

\begin{tabular}{|c|c|c|c|c|c|c|c|c|c|c|c|c|c|c|}
\hline \multirow{2}{*}{$\begin{array}{l}\text { Sample } \\
\text { ID No. }\end{array}$} & \multirow{2}{*}{$\begin{array}{l}\text { Bottle } \\
\text { Size } \\
(\mathrm{mL})\end{array}$} & \multirow{2}{*}{$\begin{array}{l}\text { Temp } \\
\text { Set } \\
\left({ }^{\circ} \mathrm{C}\right) \\
\end{array}$} & \multirow{2}{*}{$\begin{array}{c}\text { Pump } \\
\text { Setting } \\
\text { (mL/min) }\end{array}$} & \multirow{2}{*}{$\begin{array}{l}\text { Sampling } \\
\text { Start Time }\end{array}$} & \multirow{2}{*}{$\begin{array}{l}\text { Sampling } \\
\text { Stop Time }\end{array}$} & \multirow{2}{*}{$\begin{array}{l}\text { Resin } \\
\text { Height } \\
(\mathrm{cm}) \\
\end{array}$} & \multirow{2}{*}{$\begin{array}{l}\text { Resin } \\
\text { Color }\end{array}$} & \multirow{2}{*}{$\begin{array}{l}\text { Temp } \\
\left({ }^{\circ} \mathrm{C}\right)\end{array}$} & \multicolumn{3}{|c|}{ Effluent Bottle Weight,g } & \multicolumn{3}{|c|}{ Sample Vial Weight,g } \\
\hline & & & & & & & & & Tare & Gross & Net & Tare & Gross & Net \\
\hline B3-LD-012 & 20 & 50 & 7.08 & 1/18/11 21:25 & 1/18/11 21:25 & NA & $\begin{array}{l}\text { dark } \\
\text { red }\end{array}$ & 47.3 & NA & NA & NA & 8.55 & 11.20 & 2.65 \\
\hline B3-LD-018 & 20 & 50 & 7.08 & 1/18/11 21:31 & 1/18/11 21:31 & NA & $\begin{array}{l}\text { dark } \\
\text { red }\end{array}$ & 46.7 & NA & NA & NA & 8.55 & 11.10 & 2.55 \\
\hline B3-LD-024 & 20 & 50 & 7.08 & 1/18/11 21:37 & 1/18/11 21:37 & NA & $\begin{array}{l}\text { dark } \\
\text { red }\end{array}$ & 46.2 & NA & NA & NA & 8.48 & 11.29 & 2.81 \\
\hline B3-LD-036 & 20 & 50 & 7.08 & 1/18/11 21:49 & 1/18/11 21:49 & NA & $\begin{array}{l}\text { dark } \\
\text { red }\end{array}$ & 46.0 & NA & NA & NA & 8.48 & 11.16 & 2.68 \\
\hline B3-LD-048 & 20 & 50 & 7.08 & 1/18/11 22:01 & 1/18/11 22:01 & NA & $\begin{array}{l}\text { dark } \\
\text { red }\end{array}$ & 46.0 & NA & NA & NA & 8.38 & 10.95 & 2.57 \\
\hline B3-LD-060 & 20 & 50 & 7.08 & 1/18/11 22:13 & 1/18/11 22:13 & NA & $\begin{array}{l}\text { almost } \\
\text { black }\end{array}$ & 46.1 & NA & NA & NA & 8.50 & 11.06 & 2.56 \\
\hline B3-LD-080 & 20 & 50 & 7.08 & 1/18/11 22:33 & 1/18/11 22:33 & NA & $\begin{array}{l}\text { almost } \\
\text { black }\end{array}$ & 46.2 & NA & NA & NA & 8.53 & 11.07 & 2.54 \\
\hline B3-LD-120 & 20 & 50 & 7.08 & 1/18/11 23:13 & 1/18/11 23:13 & NA & $\begin{array}{l}\text { almost } \\
\text { black }\end{array}$ & 46.2 & NA & NA & NA & 8.49 & 11.16 & 2.67 \\
\hline B3-LD-180 & 20 & 50 & 7.08 & 1/19/11 00:13 & 1/19/11 00:13 & NA & $\begin{array}{c}\text { almost } \\
\text { black }\end{array}$ & 46.5 & NA & NA & NA & 8.48 & 11.10 & 2.62 \\
\hline B3-LD-240 & 20 & 50 & 7.08 & 1/19/11 1:13 & 1/19/11 1:13 & NA & $\begin{array}{l}\text { almost } \\
\text { black }\end{array}$ & 46.6 & NA & NA & NA & 8.36 & 10.95 & 2.59 \\
\hline B3-LD-600 & 20 & 50 & 7.08 & 1/19/11 7:13 & 1/19/11 7:13 & NA & $\begin{array}{l}\text { almost } \\
\text { black }\end{array}$ & 50.7 & NA & NA & NA & 8.55 & 11.27 & 2.72 \\
\hline B3-LD-900 & 20 & 50 & 7.08 & 1/19/11 12:13 & 1/19/11 12:13 & NA & $\begin{array}{l}\text { almost } \\
\text { black }\end{array}$ & 50.7 & NA & NA & NA & 8.55 & 11.29 & 2.74 \\
\hline B3-LD-1200 & 20 & 50 & 7.08 & 1/19/11 17:13 & 1/19/11 17:13 & 1.3 & $\begin{array}{l}\text { almost } \\
\text { black }\end{array}$ & 50.3 & NA & NA & NA & 8.54 & 11.37 & 2.83 \\
\hline B3-FD-CP & 20 & 50 & 0.09 & 1/19/11 17:26 & 1/19/11 19:56 & 1.2 & $\begin{array}{l}\text { almost } \\
\text { black }\end{array}$ & 50.9 & 8.45 & 21.86 & 13.41 & NA & NA & NA \\
\hline B3-FDI-CP & 20 & 25 & 0.09 & 1/19/11 20:10 & 1/19/11 22:40 & 1.2 & $\begin{array}{l}\text { almost } \\
\text { black }\end{array}$ & 24.0 & 8.54 & 21.19 & 12.65 & NA & NA & NA \\
\hline B3-AN-CP & 20 & 25 & 0.09 & 1/19/11 22:47 & 1/19/11 23:47 & 1.1 & $\begin{array}{l}\text { almost } \\
\text { black }\end{array}$ & 24.2 & 8.54 & 13.66 & 5.12 & NA & NA & NA \\
\hline
\end{tabular}


Table A.17. Datasheet for Column B3 Elution, Rinsing, and Regeneration Information

\begin{tabular}{|c|c|c|c|c|c|c|c|c|c|c|c|c|c|c|}
\hline \multirow{2}{*}{$\begin{array}{l}\text { Sample } \\
\text { ID No. }\end{array}$} & \multirow{2}{*}{$\begin{array}{c}\text { Bottle } \\
\text { Size } \\
(\mathrm{mL})\end{array}$} & \multirow{2}{*}{$\begin{array}{c}\text { Temp } \\
\text { Set } \\
\left({ }^{\circ} \mathrm{C}\right) \\
\end{array}$} & \multirow{2}{*}{$\begin{array}{c}\text { Pump } \\
\text { Setting } \\
\text { (mL/min) }\end{array}$} & \multirow{2}{*}{$\begin{array}{l}\text { Sampling } \\
\text { Start Time }\end{array}$} & \multirow{2}{*}{$\begin{array}{l}\text { Sampling } \\
\text { Stop Time }\end{array}$} & \multirow{2}{*}{$\begin{array}{l}\text { Resin } \\
\text { Height } \\
(\mathrm{cm}) \\
\end{array}$} & \multirow{2}{*}{$\begin{array}{l}\text { Resin } \\
\text { Color }\end{array}$} & \multirow{2}{*}{$\begin{array}{l}\text { Temp } \\
\left({ }^{\circ} \mathrm{C}\right)\end{array}$} & \multicolumn{3}{|c|}{ Effluent Bottle Weight, g } & \multicolumn{3}{|c|}{ Sample Vial Weight, g } \\
\hline & & & & & & & & & Tare & Gross & Net & Tare & Gross & Net \\
\hline \multicolumn{4}{|c|}{ Elution (EL) Phase Start Date/Time: } & 1/19/11 23:54 & & & & & & & & & & \\
\hline B3-EL-CP & 60 & 25 & 0.08 & 1/19/11 23:54 & 1/20/11 9:54 & 0.9 & $\begin{array}{c}\text { dark } \\
\text { red }\end{array}$ & 24.5 & 14.91 & 59.19 & 44.28 & 8.50 & 20.04 & 11.54 \\
\hline B3-EDI-CP & 20 & 25 & 0.09 & 1/20/11 10:00 & 1/20/11 11:00 & 0.95 & red & 24.2 & 8.49 & 13.47 & 4.98 & NA & NA & NA \\
\hline B3-RG-CP & 20 & 25 & 0.09 & 1/20/11 11:05 & 1/20/11 14:05 & 1.2 & $\begin{array}{c}\text { dark } \\
\text { red }\end{array}$ & 24.5 & 8.53 & 23.27 & 14.74 & NA & NA & NA \\
\hline
\end{tabular}

Table A.18. Datasheet for Column B4 Loading and Rinsing Information

\begin{tabular}{|c|c|c|c|c|c|c|c|c|c|c|c|c|c|c|}
\hline Sample & Bottle & Temp & Pump & Sampling & Sampling & Resin & Resin & Temp & \multicolumn{3}{|c|}{ Effluent Bottle Weight, g } & \multicolumn{3}{|c|}{ Sample Vial Weight, g } \\
\hline ID No. & $\begin{array}{l}\text { Size } \\
(\mathrm{mL})\end{array}$ & $\begin{array}{l}\text { Set } \\
\left({ }^{\circ} \mathrm{C}\right)\end{array}$ & $\begin{array}{c}\text { Setting } \\
\text { (mL/min) }\end{array}$ & Start Time & Stop Time & $\begin{array}{c}\text { Height } \\
\text { (cm) }\end{array}$ & Color & $\left({ }^{\circ} \mathrm{C}\right)$ & Tare & Gross & Net & Tare & Gross & Net \\
\hline B4-LD-0 & 20 & 50 & NA & 1/25/11 7:02 & $1 / 25 / 117: 02$ & 1.2 & $\begin{array}{c}\text { dark } \\
\text { red }\end{array}$ & 50.3 & NA & NA & NA & 8.57 & NA & 3.40 \\
\hline \multicolumn{4}{|c|}{ Loading (LD) Phase Start Date/Time: } & 1/25/11 7:04 & & & & & & & & & & \\
\hline B4-LD-006 & 20 & 50 & 7.08 & 1/25/11 7:10 & $1 / 25 / 117: 10$ & NA & $\begin{array}{l}\text { dark } \\
\text { red }\end{array}$ & 48.3 & NA & NA & NA & 8.51 & NA & 3.10 \\
\hline B4-LD-012 & 20 & 50 & 7.08 & 1/25/11 7:16 & 1/25/11 7:16 & NA & $\begin{array}{c}\text { dark } \\
\text { red }\end{array}$ & 47.8 & NA & NA & NA & 8.53 & NA & 3.29 \\
\hline B4-LD-018 & 20 & 50 & 7.08 & 1/25/11 7:22 & $1 / 25 / 117: 22$ & NA & $\begin{array}{l}\text { dark } \\
\text { red }\end{array}$ & 48.0 & NA & NA & NA & 8.44 & NA & 2.91 \\
\hline B4-LD-024 & 20 & 50 & 7.08 & 1/25/11 7:28 & $1 / 25 / 117: 28$ & NA & $\begin{array}{l}\text { dark } \\
\text { red }\end{array}$ & 48.5 & NA & NA & NA & 8.51 & NA & 3.24 \\
\hline B4-LD-036 & 20 & 50 & 7.08 & $1 / 25 / 117: 40$ & $1 / 25 / 117: 40$ & NA & $\begin{array}{c}\text { dark } \\
\text { red }\end{array}$ & 49.4 & NA & NA & NA & 8.55 & NA & 3.33 \\
\hline B4-LD-048 & 20 & 50 & 7.08 & 1/25/11 7:52 & 1/25/11 7:52 & NA & $\begin{array}{l}\text { dark } \\
\text { red }\end{array}$ & 50.0 & NA & NA & NA & 8.58 & NA & 2.90 \\
\hline B4-LD-060 & 20 & 50 & 7.08 & 1/25/11 8:04 & 1/25/11 8:04 & NA & $\begin{array}{l}\text { almost } \\
\text { black }\end{array}$ & 50.2 & NA & NA & NA & 8.48 & NA & 3.37 \\
\hline B4-LD-080 & 20 & 50 & 7.08 & 1/25/11 8:24 & 1/25/11 8:24 & NA & $\begin{array}{l}\text { almost } \\
\text { black }\end{array}$ & 50.0 & NA & NA & NA & 8.53 & NA & 2.36 \\
\hline
\end{tabular}


Table A.18. Datasheet for Column B4 Loading and Rinsing Information

\begin{tabular}{|c|c|c|c|c|c|c|c|c|c|c|c|c|c|c|}
\hline \multirow{2}{*}{$\begin{array}{l}\text { Sample } \\
\text { ID No. }\end{array}$} & \multirow{2}{*}{$\begin{array}{c}\text { Bottle } \\
\text { Size } \\
(\mathrm{mL})\end{array}$} & \multirow{2}{*}{$\begin{array}{c}\text { Temp } \\
\text { Set } \\
\left({ }^{\circ} \mathrm{C}\right)\end{array}$} & \multirow{2}{*}{$\begin{array}{c}\text { Pump } \\
\text { Setting } \\
\text { (mL/min) }\end{array}$} & \multirow{2}{*}{$\begin{array}{l}\text { Sampling } \\
\text { Start Time }\end{array}$} & \multirow{2}{*}{$\begin{array}{l}\text { Sampling } \\
\text { Stop Time }\end{array}$} & \multirow{2}{*}{$\begin{array}{c}\text { Resin } \\
\text { Height } \\
\text { (cm) }\end{array}$} & \multirow{2}{*}{$\begin{array}{l}\text { Resin } \\
\text { Color }\end{array}$} & \multirow{2}{*}{$\begin{array}{l}\text { Temp } \\
\left({ }^{\circ} \mathrm{C}\right)\end{array}$} & \multicolumn{3}{|c|}{ Effluent Bottle Weight, g } & \multicolumn{3}{|c|}{ Sample Vial Weight,g g } \\
\hline & & & & & & & & & Tare & Gross & Net & Tare & Gross & Net \\
\hline B4-LD-120 & 20 & 50 & 7.08 & 1/25/11 9:04 & 1/25/11 9:04 & NA & $\begin{array}{c}\text { almost } \\
\text { black }\end{array}$ & 49.8 & NA & NA & NA & 8.53 & NA & 2.63 \\
\hline B4-LD-180 & 20 & 50 & 7.08 & 1/25/11 10:10 & 1/25/11 10:10 & NA & $\begin{array}{c}\text { almost } \\
\text { black }\end{array}$ & 49.8 & NA & NA & NA & 8.52 & NA & 3.28 \\
\hline B4-LD-240 & 20 & 50 & 7.08 & 1/25/11 11:04 & 1/25/11 11:04 & NA & $\begin{array}{l}\text { almost } \\
\text { black }\end{array}$ & 49.7 & NA & NA & NA & 8.47 & NA & 3.29 \\
\hline B4-LD-600 & 20 & 50 & 7.08 & 1/25/11 17:04 & 1/25/11 17:04 & NA & $\begin{array}{c}\text { almost } \\
\text { black }\end{array}$ & 49.8 & NA & NA & NA & 8.39 & NA & 3.11 \\
\hline B4-FD-CP & 20 & 50 & 0.09 & 1/25/11 17:15 & 1/25/11 19:45 & 1.3 & $\begin{array}{c}\text { almost } \\
\text { black }\end{array}$ & 49.8 & 8.38 & 23.58 & 15.20 & NA & NA & NA \\
\hline
\end{tabular}

Table A.19. Datasheet for Column B4B Loading and Rinsing Information

\begin{tabular}{|c|c|c|c|c|c|c|c|c|c|c|c|c|c|c|}
\hline Sample & Bottle & Temp & Pump & Sampling & Sampling & Resin & Resin & Temp & \multicolumn{3}{|c|}{ Effluent Bottle Weight, g } & \multicolumn{3}{|c|}{ Sample Vial Weight, g } \\
\hline ID No. & $\begin{array}{l}\text { Size } \\
(\mathrm{mL})\end{array}$ & $\begin{array}{l}\text { Set } \\
\left({ }^{\circ} \mathrm{C}\right)\end{array}$ & $\begin{array}{c}\text { Setting } \\
\text { (mL/min) }\end{array}$ & Start Time & Stop Time & $\begin{array}{c}\text { Height } \\
\text { (cm) }\end{array}$ & Color & $\left({ }^{\circ} \mathrm{C}\right)$ & Tare & Gross & Net & Tare & Gross & Net \\
\hline B4B-LD-0 & 20 & 65 & NA & $1 / 26 / 118: 27$ & 1/26/11 8:27 & 1.3 & $\begin{array}{c}\text { almost } \\
\text { black }\end{array}$ & 63.3 & NA & NA & NA & 8.37 & NA & 2.97 \\
\hline \multicolumn{4}{|c|}{ Loading (LD) Phase Start Date/Time: } & 1/26/11 8:33 & & & & & & & & & & \\
\hline B4B-LD-004 & 20 & 65 & 0.08 & $1 / 26 / 1112: 33$ & $1 / 26 / 1112: 33$ & NA & $\begin{array}{l}\text { almost } \\
\text { black }\end{array}$ & 64.9 & NA & NA & NA & 8.52 & NA & 3.12 \\
\hline B4B-LD-008 & 20 & 65 & 0.08 & 1/26/11 16:33 & 1/26/11 16:33 & NA & $\begin{array}{l}\text { almost } \\
\text { black }\end{array}$ & 65.1 & NA & NA & NA & 8.46 & NA & 2.99 \\
\hline B4B-LD-012 & 20 & 65 & 0.08 & 1/26/11 20:33 & 1/26/11 20:33 & NA & $\begin{array}{l}\text { almost } \\
\text { black }\end{array}$ & 65.2 & NA & NA & NA & 8.55 & NA & 3.30 \\
\hline B4B-LD-024 & 20 & 65 & 0.08 & 1/27/11 8:33 & 1/27/11 8:33 & NA & $\begin{array}{l}\text { almost } \\
\text { black }\end{array}$ & 65.1 & NA & NA & NA & 8.48 & NA & 3.36 \\
\hline B4B-LD-072 & 20 & 65 & 0.08 & 1/29/11 8:33 & 1/29/11 8:33 & NA & $\begin{array}{l}\text { almost } \\
\text { black }\end{array}$ & 65.2 & NA & NA & NA & 8.49 & NA & 3.53 \\
\hline B4B-LD-120 & 20 & 65 & 0.08 & 1/31/11 8:37 & 1/31/11 8:37 & NA & $\begin{array}{c}\text { almost } \\
\text { black }\end{array}$ & 65.5 & NA & NA & NA & 8.43 & NA & 3.15 \\
\hline
\end{tabular}


Table A.19. Datasheet for Column B4B Loading and Rinsing Information

\begin{tabular}{|c|c|c|c|c|c|c|c|c|c|c|c|c|c|c|}
\hline \multirow{2}{*}{$\begin{array}{l}\text { Sample } \\
\text { ID No. }\end{array}$} & \multirow{2}{*}{$\begin{array}{c}\text { Bottle } \\
\text { Size } \\
(\mathrm{mL}) \\
\end{array}$} & \multirow{2}{*}{$\begin{array}{c}\text { Temp } \\
\text { Set } \\
\left({ }^{\circ} \mathrm{C}\right) \\
\end{array}$} & \multirow{2}{*}{$\begin{array}{c}\text { Pump } \\
\text { Setting } \\
\text { (mL/min) }\end{array}$} & \multirow{2}{*}{$\begin{array}{l}\text { Sampling } \\
\text { Start Time }\end{array}$} & \multirow{2}{*}{$\begin{array}{l}\text { Sampling } \\
\text { Stop Time }\end{array}$} & \multirow{2}{*}{$\begin{array}{c}\text { Resin } \\
\text { Height } \\
(\mathrm{cm}) \\
\end{array}$} & \multirow{2}{*}{$\begin{array}{l}\text { Resin } \\
\text { Color }\end{array}$} & \multirow{2}{*}{$\begin{array}{l}\text { Temp } \\
\left({ }^{\circ} \mathrm{C}\right)\end{array}$} & \multicolumn{3}{|c|}{ Effluent Bottle Weight,g } & \multicolumn{3}{|c|}{ Sample Vial Weight, g } \\
\hline & & & & & & & & & Tare & Gross & Net & Tare & Gross & Net \\
\hline B4B-LD-168 & 20 & 65 & 0.08 & 2/2/11 8:33 & 2/2/11 8:33 & NA & $\begin{array}{c}\text { almost } \\
\text { black }\end{array}$ & 65.3 & NA & NA & NA & 8.48 & NA & 3.43 \\
\hline B4B-LD-336 & 20 & 65 & 0.08 & 2/9/11 8:33 & 2/9/11 8:33 & NA & $\begin{array}{c}\text { almost } \\
\text { black }\end{array}$ & 65.5 & NA & NA & NA & 8.55 & NA & 3.43 \\
\hline B4B-LD-504 & 20 & 65 & 0.08 & 2/16/11 8:31 & 2/16/11 8:31 & NA & $\begin{array}{c}\text { almost } \\
\text { black }\end{array}$ & 66.0 & NA & NA & NA & 8.47 & NA & 3.57 \\
\hline B4B-FD-CP & 20 & 65 & 0.09 & 2/21/11 13:20 & 2/21/11 15:50 & 1.3 & $\begin{array}{l}\text { almost } \\
\text { black }\end{array}$ & 65.2 & 8.48 & 23.90 & 15.42 & NA & NA & NA \\
\hline B4B-FDI-CP & 20 & 25 & 0.09 & $2 / 22 / 1114: 20$ & 2/22/11 16:50 & 1.3 & $\begin{array}{c}\text { almost } \\
\text { black }\end{array}$ & 25.8 & 8.60 & 23.40 & 14.80 & NA & NA & NA \\
\hline B4B-AN-CP & 20 & 25 & 0.09 & 2/22/11 16:55 & 2/22/11 17:55 & 1.3 & $\begin{array}{l}\text { almost } \\
\text { black }\end{array}$ & 25.8 & 8.57 & 14.68 & 6.11 & NA & NA & NA \\
\hline
\end{tabular}

$\stackrel{p}{v}$

Table A.20. Datasheet for Column B4B Elution, Rinsing, and Regeneration Information

\begin{tabular}{|c|c|c|c|c|c|c|c|c|c|c|c|c|c|c|}
\hline \multirow{2}{*}{$\begin{array}{l}\text { Sample } \\
\text { ID No. }\end{array}$} & \multirow{2}{*}{$\begin{array}{l}\text { Bottle } \\
\text { Size } \\
(\mathrm{mL})\end{array}$} & \multirow{2}{*}{$\begin{array}{l}\text { Temp } \\
\text { Set } \\
\left({ }^{\circ} \mathrm{C}\right)\end{array}$} & \multirow{2}{*}{$\begin{array}{l}\text { Pump } \\
\text { Setting } \\
\text { (mL/min) }\end{array}$} & \multirow{2}{*}{$\begin{array}{l}\text { Sampling } \\
\text { Start Time }\end{array}$} & \multirow{2}{*}{$\begin{array}{l}\text { Sampling } \\
\text { Stop Time }\end{array}$} & \multirow{2}{*}{$\begin{array}{l}\text { Resin } \\
\text { Height } \\
(\mathrm{cm})\end{array}$} & \multirow{2}{*}{$\begin{array}{l}\text { Resin } \\
\text { Color }\end{array}$} & \multirow{2}{*}{$\begin{array}{l}\text { Temp } \\
\left({ }^{\circ} \mathrm{C}\right)\end{array}$} & \multicolumn{3}{|c|}{ Effluent Bottle Weight, } & \multicolumn{3}{|c|}{ Sample Vial Weight, g } \\
\hline & & & & & & & & & Tare & Gross & Net & Tare & Gross & Net \\
\hline \multicolumn{4}{|c|}{ Elution (EL) Phase Start Date/Time: } & 2/23/11 6:43 & & & & & & & & & & \\
\hline B4B-EL-CP & 60 & 25 & 0.09 & 2/23/11 6:43 & 2/23/11 16:43 & 1.0 & $\begin{array}{l}\text { blackish } \\
\text { red }\end{array}$ & 23.6 & 14.65 & 67.80 & 53.15 & 8.54 & 15.71 & 7.17 \\
\hline B4B-EDI-CP & 20 & 25 & 0.09 & 2/23/11 16:55 & 2/23/11 17:55 & 1.0 & $\begin{array}{l}\text { blackish } \\
\text { red }\end{array}$ & 23.7 & 8.36 & 14.14 & 5.78 & NA & NA & NA \\
\hline B4B-RG-CP & 20 & 25 & 0.09 & 2/23/11 18:12 & 2/23/11 21:12 & 1.3 & black & 23.4 & 8.38 & 24.20 & 15.82 & NA & NA & NA \\
\hline
\end{tabular}


Table A.21. Datasheet for Column B5 Loading and Rinsing Information

\begin{tabular}{|c|c|c|c|c|c|c|c|c|c|c|c|c|c|c|}
\hline \multirow{2}{*}{$\begin{array}{l}\text { Sample } \\
\text { ID No. }\end{array}$} & \multirow{2}{*}{$\begin{array}{c}\text { Bottle } \\
\text { Size } \\
(\mathrm{mL}) \\
\end{array}$} & \multirow{2}{*}{$\begin{array}{l}\text { Temp } \\
\text { Set } \\
\left({ }^{\circ} \mathrm{C}\right) \\
\end{array}$} & \multirow{2}{*}{$\begin{array}{c}\text { Pump } \\
\text { Setting } \\
\text { (mL/min) }\end{array}$} & \multirow{2}{*}{$\begin{array}{l}\text { Sampling } \\
\text { Start Time }\end{array}$} & \multirow{2}{*}{$\begin{array}{l}\text { Sampling } \\
\text { Stop Time }\end{array}$} & \multirow{2}{*}{$\begin{array}{l}\text { Resin } \\
\text { Height } \\
(\mathrm{cm}) \\
\end{array}$} & \multirow{2}{*}{$\begin{array}{l}\text { Resin } \\
\text { Color }\end{array}$} & \multirow{2}{*}{$\begin{array}{l}\text { Temp } \\
\left({ }^{\circ} \mathrm{C}\right)\end{array}$} & \multicolumn{3}{|c|}{ Effluent Bottle Weight,g } & \multicolumn{3}{|c|}{ Sample Vial Weight, g } \\
\hline & & & & & & & & & Tare & Gross & Net & Tare & Gross & Net \\
\hline B5-LD-0 & 20 & 50 & NA & 2/28/11 6:54 & 2/28/11 6:54 & 1.65 & black & 58.7 & NA & NA & NA & 8.42 & 11.54 & 3.12 \\
\hline \multicolumn{4}{|c|}{ Loading (LD) Phase Start Date/Time: } & 2/28/11 6:58 & 8 & 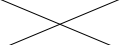 & 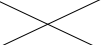 & $x$ & 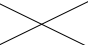 & 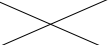 & $\infty$ & 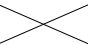 & $><$ & 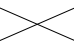 \\
\hline B5-LD-006 & 20 & 50 & 10.62 & 2/28/11 7:04 & 2/28/11 7:04 & NA & black & 54.5 & NA & NA & NA & 8.50 & 11.39 & 2.89 \\
\hline B5-LD-012 & 20 & 50 & 10.62 & 2/28/11 7:10 & 2/28/11 7:10 & NA & black & 51.9 & NA & NA & NA & 8.50 & 11.65 & 3.15 \\
\hline B5-LD-018 & 20 & 50 & 10.62 & 2/28/11 7:16 & 2/28/11 7:16 & NA & black & 50.3 & NA & NA & NA & 8.49 & 11.45 & 2.96 \\
\hline B5-LD-024 & 20 & 50 & 10.62 & 2/28/11 7:22 & 2/28/11 7:22 & NA & black & 49.2 & NA & NA & NA & 8.49 & 11.81 & 3.32 \\
\hline B5-LD-036 & 20 & 50 & 10.62 & 2/28/11 7:34 & 2/28/11 7:34 & NA & black & 48.0 & NA & NA & NA & 8.49 & 11.71 & 3.22 \\
\hline B5-LD-048 & 20 & 50 & 10.62 & 2/28/11 7:46 & 2/28/11 7:46 & NA & black & 48.2 & NA & NA & NA & 8.43 & 11.54 & 3.11 \\
\hline B5-LD-060 & 20 & 50 & 10.62 & 2/28/11 7:58 & 2/28/11 7:58 & NA & black & 48.3 & NA & NA & NA & 8.40 & 11.50 & 3.10 \\
\hline B5-LD-080 & 20 & 50 & 10.62 & 2/28/11 8:18 & 2/28/11 8:18 & NA & black & 49.5 & NA & NA & NA & 8.53 & 11.79 & 3.26 \\
\hline B5-LD-120 & 20 & 50 & 10.62 & 2/28/11 8:58 & 2/28/11 8:58 & NA & black & 50.3 & NA & NA & NA & 8.47 & 11.29 & 2.82 \\
\hline B5-LD-180 & 20 & 50 & 10.62 & 2/28/11 9:58 & 2/28/11 9:58 & NA & black & 50.3 & NA & NA & NA & 8.47 & 11.70 & 3.23 \\
\hline B5-LD-240 & 20 & 50 & 10.62 & 2/28/11 10:58 & 2/28/11 10:58 & NA & black & 50.3 & NA & NA & NA & 8.53 & 11.87 & 3.34 \\
\hline B5-LD-600 & 20 & 50 & 10.62 & 2/28/11 16:58 & 2/28/11 16:58 & NA & black & 50.4 & NA & NA & NA & 8.55 & 12.70 & 4.15 \\
\hline B5-FD-CP & 20 & 50 & 0.09 & 2/28/11 17:07 & 2/28/11 19:37 & NA & black & 61.4 & 8.45 & 23.24 & 14.79 & NA & NA & NA \\
\hline B5-FDI-CP & 20 & 25 & 0.09 & 2/28/11 20:15 & 2/28/11 22:45 & NA & black & 23.9 & 8.45 & 21.53 & 13.08 & NA & NA & NA \\
\hline B5-AN-CP & 20 & 25 & 0.09 & 2/28/11 22:51 & 2/28/11 23:51 & NA & black & 23.4 & 8.66 & 13.94 & 5.28 & NA & NA & NA \\
\hline
\end{tabular}


Table A.22. Datasheet for Column B5 Elution, Rinsing, and Regeneration Information

\begin{tabular}{|c|c|c|c|c|c|c|c|c|c|c|c|c|c|c|}
\hline \multirow{2}{*}{$\begin{array}{l}\text { Sample } \\
\text { ID No. }\end{array}$} & \multirow{2}{*}{$\begin{array}{l}\text { Bottle } \\
\text { Size } \\
(\mathrm{mL})\end{array}$} & \multirow{2}{*}{$\begin{array}{l}\text { Temp } \\
\text { Set } \\
\left({ }^{\circ} \mathrm{C}\right)\end{array}$} & \multirow{2}{*}{$\begin{array}{c}\text { Pump } \\
\text { Setting } \\
\text { (mL/min) }\end{array}$} & \multirow{2}{*}{$\begin{array}{l}\text { Sampling } \\
\text { Start Time }\end{array}$} & \multirow{2}{*}{$\begin{array}{l}\text { Sampling } \\
\text { Stop Time }\end{array}$} & \multirow{2}{*}{$\begin{array}{l}\text { Resin } \\
\text { Height } \\
\text { (cm) }\end{array}$} & \multirow{2}{*}{$\begin{array}{l}\text { Resin } \\
\text { Color }\end{array}$} & \multirow{2}{*}{$\begin{array}{l}\text { Temp } \\
\left({ }^{\circ} \mathrm{C}\right)\end{array}$} & \multicolumn{3}{|c|}{$\begin{array}{c}\text { Effluent Bottle Weight, } \\
\text { g }\end{array}$} & \multicolumn{3}{|c|}{ Sample Vial Weight, g } \\
\hline & & & & & & & & & Tare & Gross & Net & Tare & Gross & Net \\
\hline \multicolumn{4}{|c|}{ Elution (EL) Phase Start Date/Time: } & 3/1/11 6:53 & & & & & & & & & & \\
\hline B5-EL-CP & 60 & 25 & 0.08 & 3/1/11 6:53 & 3/1/11 16:53 & 1.55 & $\begin{array}{l}\text { dark } \\
\text { red }\end{array}$ & 23.9 & 14.94 & 61.82 & 46.88 & 8.46 & 18.86 & 10.40 \\
\hline B5-EDI-CP & 20 & 25 & 0.09 & 3/1/11 17:15 & 3/1/11 18:15 & 1.55 & $\begin{array}{l}\text { dark } \\
\text { red }\end{array}$ & 24.0 & 8.57 & 13.87 & 5.30 & NA & NA & NA \\
\hline
\end{tabular}

Table A.23. Datasheet for Column C1 Pretreatment, Loading, and Rinsing Information

\begin{tabular}{|c|c|c|c|c|c|c|c|c|c|c|c|c|c|c|}
\hline \multirow{2}{*}{$\begin{array}{l}\text { Sample } \\
\text { ID No. }\end{array}$} & \multirow{2}{*}{$\begin{array}{l}\text { Bottle } \\
\text { Size } \\
(\mathrm{mL})\end{array}$} & \multirow{2}{*}{$\begin{array}{l}\text { Temp } \\
\text { Set } \\
\left({ }^{\circ} \mathrm{C}\right)\end{array}$} & \multirow{2}{*}{$\begin{array}{c}\text { Pump } \\
\text { Setting } \\
\text { (mL/min) }\end{array}$} & \multirow{2}{*}{$\begin{array}{l}\text { Sampling } \\
\text { Start Time }\end{array}$} & \multirow{2}{*}{$\begin{array}{l}\text { Sampling } \\
\text { Stop Time }\end{array}$} & \multirow{2}{*}{$\begin{array}{l}\text { Resin } \\
\text { Height } \\
(\mathrm{cm})\end{array}$} & \multirow{2}{*}{$\begin{array}{l}\text { Resin } \\
\text { Color }\end{array}$} & \multirow{2}{*}{$\begin{array}{l}\text { Temp } \\
\left({ }^{\circ} \mathrm{C}\right)\end{array}$} & \multicolumn{3}{|c|}{ Effluent Bottle Weight, } & \multicolumn{3}{|c|}{ Sample Vial Weight, g } \\
\hline & & & & & & & & & Tare & Gross & Net & Tare & Gross & Net \\
\hline C1-PT-DIW1 & 20 & 25 & 0.09 & 1/10/11 7:05 & 1/10/11 9:39 & 0.9 & $\begin{array}{l}\text { reddish } \\
\text { orange }\end{array}$ & 25.2 & 8.43 & 16.82 & 8.39 & NA & NA & NA \\
\hline C1-PT-ACID & 20 & 25 & 0.09 & 1/10/11 10:20 & $1 / 10 / 11$ 13:20 & 0.8 & orange & 25.9 & 8.61 & 23.14 & 14.53 & NA & NA & NA \\
\hline C1-PT-DIW2 & 20 & 25 & 0.09 & 1/10/11 13:25 & 1/10/11 14:34 & 0.8 & orange & 25.4 & 8.52 & 14.19 & 5.67 & NA & NA & NA \\
\hline C1-PT-NaOH & 20 & 25 & 0.09 & 1/10/11 14:41 & 1/10/11 16:41 & 1.0 & $\begin{array}{l}\text { dark } \\
\text { red }\end{array}$ & 25.7 & 8.44 & 18.18 & 9.74 & NA & NA & NA \\
\hline C1-LD-0 & 20 & 50 & NA & 1/11/11 6:55 & 1/11/11 6:55 & 1.1 & $\begin{array}{c}\text { dark } \\
\text { red }\end{array}$ & 48.9 & NA & NA & NA & 8.35 & 11.37 & 3.02 \\
\hline \multicolumn{4}{|c|}{ Loading (LD) Phase Start Date/Time: } & $1 / 11 / 116: 59$ & & & & & & & & & & \\
\hline C1-LD-006 & 20 & 50 & 10.62 & 1/11/11 7:05 & 1/11/11 7:05 & NA & $\begin{array}{c}\text { dark } \\
\text { red }\end{array}$ & 45.9 & NA & NA & NA & 8.47 & 11.46 & 2.99 \\
\hline C1-LD-012 & 20 & 50 & 10.62 & 1/11/11 7:11 & 1/11/11 7:11 & NA & $\begin{array}{c}\text { dark } \\
\text { red }\end{array}$ & 45.0 & NA & NA & NA & 8.56 & 11.40 & 2.84 \\
\hline C1-LD-018 & 20 & 50 & 10.62 & 1/11/11 7:17 & 1/11/11 7:17 & NA & $\begin{array}{c}\text { dark } \\
\text { red }\end{array}$ & 45.2 & NA & NA & NA & 8.55 & 11.66 & 3.11 \\
\hline C1-LD-024 & 20 & 50 & 10.62 & 1/11/11 7:23 & 1/11/11 7:23 & NA & $\begin{array}{l}\text { dark } \\
\text { red }\end{array}$ & 45.8 & NA & NA & NA & 8.52 & 11.60 & 3.08 \\
\hline C1-LD-036 & 20 & 50 & 10.62 & 1/11/11 7:35 & 1/11/11 7:35 & NA & $\begin{array}{l}\text { dark } \\
\text { red }\end{array}$ & 46.9 & NA & NA & NA & 8.47 & 11.36 & 2.89 \\
\hline
\end{tabular}


Table A.23. Datasheet for Column C1 Pretreatment, Loading, and Rinsing Information

\begin{tabular}{|c|c|c|c|c|c|c|c|c|c|c|c|c|c|c|}
\hline \multirow{2}{*}{$\begin{array}{l}\text { Sample } \\
\text { ID No. }\end{array}$} & \multirow{2}{*}{$\begin{array}{l}\text { Bottle } \\
\text { Size } \\
(\mathrm{mL})\end{array}$} & \multirow{2}{*}{$\begin{array}{l}\text { Temp } \\
\text { Set } \\
\left({ }^{\circ} \mathrm{C}\right)\end{array}$} & \multirow{2}{*}{$\begin{array}{c}\text { Pump } \\
\text { Setting } \\
\text { (mL/min) }\end{array}$} & \multirow{2}{*}{$\begin{array}{l}\text { Sampling } \\
\text { Start Time }\end{array}$} & \multirow{2}{*}{$\begin{array}{l}\text { Sampling } \\
\text { Stop Time }\end{array}$} & \multirow{2}{*}{$\begin{array}{l}\text { Resin } \\
\text { Height } \\
(\mathrm{cm})\end{array}$} & \multirow{2}{*}{$\begin{array}{l}\text { Resin } \\
\text { Color }\end{array}$} & \multirow{2}{*}{$\begin{array}{l}\text { Temp } \\
\left({ }^{\circ} \mathrm{C}\right)\end{array}$} & \multicolumn{3}{|c|}{$\begin{array}{c}\text { Effluent Bottle Weight, } \\
\text { g }\end{array}$} & \multicolumn{3}{|c|}{ Sample Vial Weight, g } \\
\hline & & & & & & & & & Tare & Gross & Net & Tare & Gross & Net \\
\hline C1-LD-048 & 20 & 50 & 10.62 & 1/11/11 7:47 & 1/11/11 7:47 & NA & $\begin{array}{l}\text { dark } \\
\text { red }\end{array}$ & 48.3 & NA & NA & NA & 8.52 & 11.57 & 3.05 \\
\hline C1-LD-060 & 20 & 50 & 10.62 & 1/11/11 7:59 & 1/11/11 7:59 & NA & $\begin{array}{l}\text { almost } \\
\text { black }\end{array}$ & 49.0 & NA & NA & NA & 8.38 & 11.29 & 2.91 \\
\hline C1-LD-080 & 20 & 50 & 10.62 & 1/11/11 8:19 & 1/11/11 8:19 & NA & $\begin{array}{l}\text { almost } \\
\text { black }\end{array}$ & 49.6 & NA & NA & NA & 8.52 & 11.26 & 2.74 \\
\hline C1-LD-120 & 20 & 50 & 10.62 & 1/11/11 8:59 & 1/11/11 8:59 & NA & $\begin{array}{l}\text { almost } \\
\text { black }\end{array}$ & 49.6 & NA & NA & NA & 8.40 & 11.27 & 2.87 \\
\hline C1-LD-180 & 20 & 50 & 10.62 & 1/11/11 9:59 & 1/11/11 9:59 & NA & $\begin{array}{l}\text { almost } \\
\text { black }\end{array}$ & 49.6 & NA & NA & NA & 8.57 & 10.86 & 2.29 \\
\hline C1-LD-240 & 20 & 50 & 10.62 & 1/11/11 11:06 & 1/11/11 11:06 & NA & $\begin{array}{l}\text { almost } \\
\text { black }\end{array}$ & 49.6 & NA & NA & NA & 8.39 & 11.41 & 3.02 \\
\hline C1-LD-600 & 20 & 50 & 10.62 & 1/11/11 16:59 & 1/11/11 16:59 & NA & $\begin{array}{l}\text { almost } \\
\text { black }\end{array}$ & 49.6 & NA & NA & NA & 8.52 & 11.36 & 2.84 \\
\hline C1-LD-900 & 20 & 50 & 10.62 & 1/11/11 21:59 & 1/11/11 21:59 & 1.15 & $\begin{array}{l}\text { dark } \\
\text { red }\end{array}$ & 48.8 & NA & NA & NA & 8.48 & 10.88 & 2.40 \\
\hline C1-LD-1200 & 20 & 50 & 10.62 & 1/12/11 2:59 & 1/12/11 2:59 & 1.15 & $\begin{array}{l}\text { dark } \\
\text { red }\end{array}$ & 51.4 & NA & NA & NA & 8.48 & 11.41 & 2.93 \\
\hline C1-FD-CP & 20 & 50 & 0.09 & 1/12/11 3:24 & 1/12/11 5:54 & 1.2 & $\begin{array}{l}\text { almost } \\
\text { black }\end{array}$ & 49.6 & 8.50 & 18.93 & 10.43 & NA & NA & NA \\
\hline C1-FDI-CP & 20 & 25 & 0.09 & 1/12/11 5:59 & 1/12/11 9:07 & 1.2 & $\begin{array}{l}\text { almost } \\
\text { black }\end{array}$ & 26.6 & 8.53 & 15.51 & 6.98 & NA & NA & NA \\
\hline C1-AN-CP & 20 & 25 & 0.09 & 1/12/11 9:10 & 1/12/11 10:10 & 1.2 & $\begin{array}{c}\text { dark } \\
\text { brown }\end{array}$ & 25.0 & 8.57 & 10.96 & 2.39 & NA & NA & NA \\
\hline
\end{tabular}


Table A.24. Datasheet for Column C1 Elution, Rinsing, and Regeneration Information

\begin{tabular}{|c|c|c|c|c|c|c|c|c|c|c|c|c|c|c|}
\hline \multirow{2}{*}{$\begin{array}{l}\text { Sample } \\
\text { ID No. }\end{array}$} & \multirow{2}{*}{$\begin{array}{l}\text { Bottle } \\
\text { Size } \\
(\mathrm{mL})\end{array}$} & \multirow{2}{*}{$\begin{array}{c}\text { Temp } \\
\text { Set } \\
\left({ }^{\circ} \mathrm{C}\right)\end{array}$} & \multirow{2}{*}{$\begin{array}{c}\text { Pump } \\
\text { Setting } \\
(\mathrm{mL} / \mathrm{min})\end{array}$} & \multirow{2}{*}{$\begin{array}{l}\text { Sampling } \\
\text { Start Time }\end{array}$} & \multirow{2}{*}{$\begin{array}{l}\text { Sampling } \\
\text { Stop Time }\end{array}$} & \multirow{2}{*}{$\begin{array}{c}\text { Resin } \\
\text { Height } \\
\text { (cm) }\end{array}$} & \multirow{2}{*}{$\begin{array}{l}\text { Resin } \\
\text { Color }\end{array}$} & \multirow{2}{*}{$\begin{array}{l}\text { Temp } \\
\left({ }^{\circ} \mathrm{C}\right)\end{array}$} & \multicolumn{3}{|c|}{ Effluent Bottle Weight, g } & \multicolumn{3}{|c|}{ Sample Vial Weight,g } \\
\hline & & & & & & & & & Tare & Gross & Net & Tare & Gross & Net \\
\hline \multicolumn{4}{|c|}{ Elution (EL) Phase Start Date/Time: } & 1/12/11 10:16 & & & & & & & & & & \\
\hline C1-EL-CP & 60 & 25 & 0.08 & 1/12/11 10:16 & 1/13/11 00:16 & NA & orange & 24.5 & 24.98 & 88.82 & 63.84 & 8.52 & 21.56 & 13.04 \\
\hline C1-EDI-CP & 20 & 25 & 0.09 & 1/13/11 1:15 & 1/13/11 3:45 & NA & orange & 24.5 & 8.47 & 20.31 & 11.84 & NA & NA & NA \\
\hline C1-RG-CP & 20 & 25 & 0.09 & 1/13/11 4:34 & 1/13/11 6:59 & 1.1 & $\begin{array}{c}\text { dark } \\
\text { brown }\end{array}$ & 26.4 & 8.52 & 18.85 & 10.33 & NA & NA & NA \\
\hline
\end{tabular}

Table A.25. Datasheet for Column C2 Loading and Rinsing Information

\begin{tabular}{|c|c|c|c|c|c|c|c|c|c|c|c|c|c|c|}
\hline \multirow{2}{*}{$\begin{array}{l}\text { Sample } \\
\text { ID No. }\end{array}$} & \multirow{2}{*}{$\begin{array}{l}\text { Bottle } \\
\text { Size } \\
(\mathrm{mL}) \\
\end{array}$} & \multirow{2}{*}{$\begin{array}{l}\text { Temp } \\
\text { Set } \\
\left({ }^{\circ} \mathrm{C}\right) \\
\end{array}$} & \multirow{2}{*}{$\begin{array}{c}\text { Pump } \\
\text { Setting } \\
\text { (mL/min) } \\
\end{array}$} & \multirow{2}{*}{$\begin{array}{l}\text { Sampling } \\
\text { Start Time }\end{array}$} & \multirow{2}{*}{$\begin{array}{l}\text { Sampling } \\
\text { Stop Time }\end{array}$} & \multirow{2}{*}{$\begin{array}{l}\text { Resin } \\
\text { Height } \\
(\mathrm{cm}) \\
\end{array}$} & \multirow{2}{*}{$\begin{array}{l}\text { Resin } \\
\text { Color }\end{array}$} & \multirow{2}{*}{$\begin{array}{l}\text { Temp } \\
\left({ }^{\circ} \mathrm{C}\right)\end{array}$} & \multicolumn{3}{|c|}{ Effluent Bottle Weight, g } & \multicolumn{3}{|c|}{ Sample Vial Weight, g } \\
\hline & & & & & & & & & Tare & Gross & Net & Tare & Gross & Net \\
\hline C2-LD-0 & 20 & 50 & NA & 1/16/11 21:03 & 1/16/11 21:03 & 1.1 & $\begin{array}{l}\text { dark } \\
\text { red }\end{array}$ & 51.3 & NA & NA & NA & 8.51 & 10.96 & 2.45 \\
\hline \multicolumn{4}{|c|}{ Loading (LD) Phase Start Date/Time: } & 1/16/11 21:03 & & & & & & & & & & \\
\hline C2-LD-006 & 20 & 50 & 14.16 & 1/16/11 21:09 & 1/16/11 21:09 & NA & $\begin{array}{c}\text { dark } \\
\text { red }\end{array}$ & 49.9 & NA & NA & NA & 8.51 & 11.16 & 2.65 \\
\hline C2-LD-012 & 20 & 50 & 14.16 & 1/16/11 21:15 & 1/16/11 21:15 & NA & $\begin{array}{c}\text { dark } \\
\text { red }\end{array}$ & 48.3 & NA & NA & NA & 8.56 & 11.16 & 2.60 \\
\hline C2-LD-018 & 20 & 50 & 14.16 & $1 / 16 / 1121: 21$ & $1 / 16 / 1121: 21$ & NA & $\begin{array}{c}\text { dark } \\
\text { red }\end{array}$ & 47.8 & NA & NA & NA & 8.50 & 11.18 & 2.68 \\
\hline C2-LD-024 & 20 & 50 & 14.16 & $1 / 16 / 1121: 27$ & $1 / 16 / 1121: 27$ & NA & $\begin{array}{c}\text { dark } \\
\text { red }\end{array}$ & 48.0 & NA & NA & NA & 8.49 & 11.36 & 2.87 \\
\hline C2-LD-036 & 20 & 50 & 14.16 & 1/16/11 21:39 & 1/16/11 21:36 & NA & $\begin{array}{c}\text { dark } \\
\text { red }\end{array}$ & 48.5 & NA & NA & NA & 8.42 & 11.01 & 2.59 \\
\hline C2-LD-048 & 20 & 50 & 14.16 & 1/16/11 21:51 & 1/16/11 21:51 & NA & $\begin{array}{c}\text { dark } \\
\text { red }\end{array}$ & 48.7 & NA & NA & NA & 8.47 & 11.08 & 2.61 \\
\hline C2-LD-060 & 20 & 50 & 14.16 & 1/16/11 22:03 & 1/16/11 22:00 & NA & $\begin{array}{l}\text { almost } \\
\text { black }\end{array}$ & 48.9 & NA & NA & NA & 8.48 & 11.17 & 2.69 \\
\hline C2-LD-080 & 20 & 50 & 14.16 & 1/16/11 22:23 & 1/16/11 22:20 & NA & $\begin{array}{l}\text { almost } \\
\text { black }\end{array}$ & 48.8 & NA & NA & NA & 8.56 & 11.05 & 2.49 \\
\hline
\end{tabular}


Table A.25. Datasheet for Column C2 Loading and Rinsing Information

\begin{tabular}{|c|c|c|c|c|c|c|c|c|c|c|c|c|c|c|}
\hline \multirow{2}{*}{$\begin{array}{l}\text { Sample } \\
\text { ID No. }\end{array}$} & \multirow{2}{*}{$\begin{array}{l}\text { Bottle } \\
\text { Size } \\
(\mathrm{mL}) \\
\end{array}$} & \multirow{2}{*}{$\begin{array}{c}\text { Temp } \\
\text { Set } \\
\left({ }^{\circ} \mathrm{C}\right) \\
\end{array}$} & \multirow{2}{*}{$\begin{array}{c}\text { Pump } \\
\text { Setting } \\
\text { (mL/min) }\end{array}$} & \multirow{2}{*}{$\begin{array}{l}\text { Sampling } \\
\text { Start Time }\end{array}$} & \multirow{2}{*}{$\begin{array}{l}\text { Sampling } \\
\text { Stop Time }\end{array}$} & \multirow{2}{*}{$\begin{array}{l}\text { Resin } \\
\text { Height } \\
(\mathrm{cm})\end{array}$} & \multirow{2}{*}{$\begin{array}{l}\text { Resin } \\
\text { Color }\end{array}$} & \multirow{2}{*}{$\begin{array}{l}\text { Temp } \\
\left({ }^{\circ} \mathrm{C}\right)\end{array}$} & \multicolumn{3}{|c|}{ Effluent Bottle Weight, g } & \multicolumn{3}{|c|}{ Sample Vial Weight, g } \\
\hline & & & & & & & & & Tare & Gross & Net & Tare & Gross & Net \\
\hline C2-LD-120 & 20 & 50 & 14.16 & 1/16/11 23:03 & 1/16/11 23:03 & NA & $\begin{array}{c}\text { almost } \\
\text { black }\end{array}$ & 49.3 & NA & NA & NA & 8.40 & 11.07 & 2.67 \\
\hline C2-LD-180 & 20 & 50 & 14.16 & 1/17/11 00:03 & 1/17/11 00:03 & NA & $\begin{array}{l}\text { almost } \\
\text { black }\end{array}$ & 49.4 & NA & NA & NA & 8.33 & 10.97 & 2.64 \\
\hline C2-LD-240 & 20 & 50 & 14.16 & 1/17/11 1:03 & 1/17/11 1:00 & NA & $\begin{array}{l}\text { almost } \\
\text { black }\end{array}$ & 49.7 & NA & NA & NA & 8.51 & 11.33 & 2.82 \\
\hline C2-LD-600 & 20 & 50 & 14.16 & 1/17/11 7:00 & 1/17/11 7:00 & NA & $\begin{array}{l}\text { almost } \\
\text { black }\end{array}$ & 49.6 & NA & NA & NA & 8.45 & 11.46 & 3.01 \\
\hline C2-LD-900 & 20 & 50 & 14.16 & 1/17/11 12:01 & 1/17/11 12:01 & NA & $\begin{array}{l}\text { almost } \\
\text { black }\end{array}$ & 49.7 & NA & NA & NA & 8.52 & 11.23 & 2.71 \\
\hline C2-LD-1200 & 20 & 50 & 14.16 & 1/17/11 17:03 & 1/17/11 17:03 & 1.3 & $\begin{array}{l}\text { almost } \\
\text { black }\end{array}$ & 47.0 & NA & NA & NA & 8.46 & 11.30 & 2.84 \\
\hline C2-FD-CP & 20 & 50 & 0.09 & 1/17/11 17:14 & 1/17/11 19:44 & 1.3 & $\begin{array}{c}\text { almost } \\
\text { black }\end{array}$ & 50.4 & 8.42 & 21.00 & 12.58 & NA & NA & NA \\
\hline C2-FDI-CP & 20 & 25 & 0.09 & 1/17/11 19:55 & 1/17/11 22:25 & 1.3 & $\begin{array}{l}\text { almost } \\
\text { black }\end{array}$ & 24.4 & 8.42 & 21.46 & 13.04 & NA & NA & NA \\
\hline C2-AN-CP & 20 & 25 & 0.09 & 1/17/11 22:45 & 1/17/11 23:45 & 1.3 & $\begin{array}{c}\text { almost } \\
\text { black }\end{array}$ & 24.6 & 8.46 & 13.48 & 5.02 & NA & NA & NA \\
\hline
\end{tabular}

Table A.26. Datasheet for Column C2 Elution, Rinsing, and Regeneration Information

\begin{tabular}{|c|c|c|c|c|c|c|c|c|c|c|c|c|c|c|}
\hline \multirow{2}{*}{$\begin{array}{l}\text { Sample } \\
\text { ID No. }\end{array}$} & \multirow{2}{*}{$\begin{array}{c}\text { Bottle } \\
\text { Size } \\
(\mathrm{mL}) \\
\end{array}$} & \multirow{2}{*}{$\begin{array}{c}\text { Temp } \\
\text { Set } \\
\left({ }^{\circ} \mathrm{C}\right) \\
\end{array}$} & \multirow{2}{*}{$\begin{array}{c}\text { Pump } \\
\text { Setting } \\
\text { (mL/min) } \\
\end{array}$} & \multirow{2}{*}{$\begin{array}{l}\text { Sampling } \\
\text { Start Time }\end{array}$} & \multirow{2}{*}{$\begin{array}{l}\text { Sampling } \\
\text { Stop Time }\end{array}$} & \multirow{2}{*}{$\begin{array}{c}\text { Resin } \\
\text { Height } \\
(\mathrm{cm}) \\
\end{array}$} & \multirow{2}{*}{$\begin{array}{l}\text { Resin } \\
\text { Color }\end{array}$} & \multirow{2}{*}{$\begin{array}{l}\text { Temp } \\
\left({ }^{\circ} \mathrm{C}\right)\end{array}$} & \multicolumn{3}{|c|}{ Effluent Bottle Weight, g } & \multicolumn{3}{|c|}{ Sample Vial Weight, g } \\
\hline & & & & & & & & & Tare & Gross & Net & Tare & Gross & Net \\
\hline \multicolumn{4}{|c|}{ Elution (EL) Phase Start Date/Time: } & 1/17/11 23:58 & & & & & & & & & & \\
\hline C2-EL-CP & 60 & 25 & 0.09 & 1/7/10 23:58 & 1/18/11 8:58 & 0.9 & $\begin{array}{c}\text { dark } \\
\text { red }\end{array}$ & 26.9 & 14.90 & 59.45 & 44.55 & 8.34 & 17.10 & 8.76 \\
\hline C2-EDI-CP & 20 & 25 & 0.09 & 1/18/11 9:06 & 1/18/11 10:06 & 0.9 & $\begin{array}{c}\text { dark } \\
\text { red }\end{array}$ & 25.9 & 8.53 & 13.32 & 4.79 & NA & NA & NA \\
\hline C2-RG-CP & 20 & 25 & 0.09 & 1/18/11 10:12 & 1/18/11 12:42 & 1.2 & $\begin{array}{c}\text { almost } \\
\text { black }\end{array}$ & 26.5 & 8.56 & 20.94 & 12.38 & NA & NA & NA \\
\hline
\end{tabular}


Table A.27. Datasheet for Column C3 Loading and Rinsing Information

\begin{tabular}{|c|c|c|c|c|c|c|c|c|c|c|c|c|c|c|}
\hline \multirow{2}{*}{$\begin{array}{l}\text { Sample } \\
\text { ID No. }\end{array}$} & \multirow{2}{*}{$\begin{array}{c}\text { Bottle } \\
\text { Size } \\
(\mathrm{mL}) \\
\end{array}$} & \multirow{2}{*}{$\begin{array}{c}\text { Temp } \\
\text { Set } \\
\left({ }^{\circ} \mathrm{C}\right) \\
\end{array}$} & \multirow{2}{*}{$\begin{array}{c}\text { Pump } \\
\text { Setting } \\
\text { (mL/min) } \\
\end{array}$} & \multirow{2}{*}{$\begin{array}{l}\text { Sampling } \\
\text { Start Time }\end{array}$} & \multirow{2}{*}{$\begin{array}{l}\text { Sampling } \\
\text { Stop Time }\end{array}$} & \multirow{2}{*}{$\begin{array}{c}\text { Resin } \\
\text { Height } \\
(\mathrm{cm})\end{array}$} & \multirow{2}{*}{$\begin{array}{l}\text { Resin } \\
\text { Color }\end{array}$} & \multirow{2}{*}{$\begin{array}{l}\text { Temp } \\
\left({ }^{\circ} \mathrm{C}\right)\end{array}$} & \multicolumn{3}{|c|}{ Effluent Bottle Weight,g } & \multicolumn{3}{|c|}{ Sample Vial Weight, g } \\
\hline & & & & & & & & & Tare & Gross & Net & Tare & Gross & Net \\
\hline C3-LD-0 & 20 & 50 & NA & 1/18/11 21:10 & $1 / 18 / 1121: 10$ & 1.3 & $\begin{array}{c}\text { dark } \\
\text { red }\end{array}$ & 50.9 & NA & NA & NA & 8.58 & 11.43 & 2.85 \\
\hline \multicolumn{4}{|c|}{ Loading (LD) Phase Start Date/Time: } & $1 / 18 / 1121: 10$ & & & & & & & & & & \\
\hline C3-LD-006 & 20 & 50 & 7.08 & 1/18/11 21:16 & 1/18/11 21:19 & NA & $\begin{array}{c}\text { dark } \\
\text { red }\end{array}$ & 50.4 & NA & NA & NA & 8.47 & 11.17 & 2.70 \\
\hline C3-LD-012 & 20 & 50 & 7.08 & 1/18/11 21:22 & 1/18/11 21:25 & NA & $\begin{array}{c}\text { dark } \\
\text { red }\end{array}$ & 48.8 & NA & NA & NA & 8.43 & 11.04 & 2.61 \\
\hline C3-LD-018 & 20 & 50 & 7.08 & $1 / 18 / 1121: 28$ & $1 / 18 / 1121: 28$ & NA & $\begin{array}{c}\text { dark } \\
\text { red }\end{array}$ & 47.9 & NA & NA & NA & 8.48 & 11.11 & 2.63 \\
\hline C3-LD-024 & 20 & 50 & 7.08 & 1/18/11 21:34 & 1/18/11 21:37 & NA & $\begin{array}{l}\text { dark } \\
\text { red }\end{array}$ & 47.4 & NA & NA & NA & 8.58 & 11.34 & 2.76 \\
\hline C3-LD-036 & 20 & 50 & 7.08 & 1/18/11 21:46 & 1/18/11 21:46 & NA & $\begin{array}{c}\text { dark } \\
\text { red }\end{array}$ & 47.4 & NA & NA & NA & 8.45 & 11.29 & 2.84 \\
\hline C3-LD-048 & 20 & 50 & 7.08 & 1/18/11 21:58 & 1/18/11 21:58 & NA & $\begin{array}{c}\text { dark } \\
\text { red }\end{array}$ & 47.7 & NA & NA & NA & 8.46 & 11.30 & 2.84 \\
\hline C3-LD-060 & 20 & 50 & 7.08 & 1/18/11 22:10 & 1/18/11 22:10 & NA & $\begin{array}{l}\text { almost } \\
\text { black }\end{array}$ & 48.2 & NA & NA & NA & 8.49 & 10.96 & 2.47 \\
\hline C3-LD-080 & 20 & 50 & 7.08 & 1/18/11 22:30 & 1/18/11 22:30 & NA & $\begin{array}{l}\text { almost } \\
\text { black }\end{array}$ & 48.6 & NA & NA & NA & 8.46 & 11.05 & 2.59 \\
\hline C3-LD-120 & 20 & 50 & 7.08 & 1/18/11 23:10 & $1 / 18 / 1123: 10$ & NA & $\begin{array}{l}\text { almost } \\
\text { black }\end{array}$ & 48.7 & NA & NA & NA & 8.42 & 11.03 & 2.61 \\
\hline C3-LD-180 & 20 & 50 & 7.08 & 1/19/11 00:10 & 1/19/11 00:10 & NA & $\begin{array}{l}\text { almost } \\
\text { black }\end{array}$ & 49.2 & NA & NA & NA & 8.51 & 11.10 & 2.59 \\
\hline C3-LD-240 & 20 & 50 & 7.08 & 1/19/11 1:10 & 1/19/11 1:10 & NA & $\begin{array}{l}\text { almost } \\
\text { black }\end{array}$ & 49.8 & NA & NA & NA & 8.57 & 11.26 & 2.69 \\
\hline C3-LD-600 & 20 & 50 & 7.08 & 1/19/11 7:10 & 1/19/11 7:10 & NA & $\begin{array}{l}\text { almost } \\
\text { black }\end{array}$ & 47.7 & NA & NA & NA & 8.48 & 11.18 & 2.70 \\
\hline C3-LD-900 & 20 & 50 & 7.08 & 1/19/11 12:10 & 1/19/11 12:10 & NA & $\begin{array}{l}\text { almost } \\
\text { black }\end{array}$ & 48.2 & NA & NA & NA & 8.49 & 11.15 & 2.66 \\
\hline C3-LD-1200 & 20 & 50 & 7.08 & 1/19/11 17:10 & 1/19/11 17:10 & 1.3 & $\begin{array}{l}\text { almost } \\
\text { black }\end{array}$ & 49.2 & NA & NA & NA & 8.52 & 11.42 & 2.90 \\
\hline
\end{tabular}


Table A.27. Datasheet for Column C3 Loading and Rinsing Information

\begin{tabular}{|c|c|c|c|c|c|c|c|c|c|c|c|c|c|c|}
\hline \multirow{2}{*}{$\begin{array}{l}\text { Sample } \\
\text { ID No. }\end{array}$} & \multirow{2}{*}{$\begin{array}{c}\text { Bottle } \\
\text { Size } \\
(\mathrm{mL})\end{array}$} & \multirow{2}{*}{$\begin{array}{l}\text { Temp } \\
\text { Set } \\
\left({ }^{\circ} \mathrm{C}\right)\end{array}$} & \multirow{2}{*}{$\begin{array}{c}\text { Pump } \\
\text { Setting } \\
\text { (mL/min) }\end{array}$} & \multirow{2}{*}{$\begin{array}{l}\text { Sampling } \\
\text { Start Time }\end{array}$} & \multirow{2}{*}{$\begin{array}{l}\text { Sampling } \\
\text { Stop Time }\end{array}$} & \multirow{2}{*}{$\begin{array}{l}\text { Resin } \\
\text { Height } \\
(\mathrm{cm})\end{array}$} & \multirow{2}{*}{$\begin{array}{l}\text { Resin } \\
\text { Color }\end{array}$} & \multirow{2}{*}{$\begin{array}{l}\text { Temp } \\
\left({ }^{\circ} \mathrm{C}\right)\end{array}$} & \multicolumn{3}{|c|}{ Effluent Bottle Weight,g } & \multicolumn{3}{|c|}{ Sample Vial Weight,g } \\
\hline & & & & & & & & & Tare & Gross & Net & Tare & Gross & Net \\
\hline C3-FD-CP & 20 & 50 & 0.09 & 1/19/11 17:26 & 1/19/11 19:56 & 1.2 & $\begin{array}{l}\text { almost } \\
\text { black }\end{array}$ & 49.7 & 8.38 & 21.02 & 12.64 & NA & NA & NA \\
\hline C3-FDI-CP & 20 & 25 & 0.09 & 1/19/11 20:10 & 1/19/11 22:40 & 1.2 & $\begin{array}{l}\text { almost } \\
\text { black }\end{array}$ & 23.8 & 8.45 & 20.98 & 12.53 & NA & NA & NA \\
\hline C3-AN-CP & 20 & 25 & 0.09 & 1/19/11 22:47 & 1/19/11 23:47 & 1.1 & $\begin{array}{l}\text { almost } \\
\text { black }\end{array}$ & 25.2 & 8.57 & 13.61 & 5.04 & NA & NA & NA \\
\hline
\end{tabular}

Table A.28. Datasheet for Column C3 Elution, Rinsing, and Regeneration Information

\begin{tabular}{|c|c|c|c|c|c|c|c|c|c|c|c|c|c|c|}
\hline Sample & Bottle & Temp & Pump & Sampling & Sampling & Resin & Resin & Temp & Efflue & Bottle I & ight, g & Samp & Vial W & ht, g \\
\hline ID No. & $\begin{array}{l}\text { Size } \\
(\mathrm{mL})\end{array}$ & $\begin{array}{l}\text { Set } \\
\left({ }^{\circ} \mathrm{C}\right)\end{array}$ & $\begin{array}{c}\text { Setting } \\
(\mathrm{mL} / \mathrm{min})\end{array}$ & Start Time & Stop Time & $\begin{array}{l}\text { Height } \\
\text { (cm) }\end{array}$ & Color & $\left({ }^{\circ} \mathrm{C}\right)$ & Tare & Gross & Net & Tare & Gross & Net \\
\hline \multicolumn{4}{|c|}{ Elution (EL) Phase Start Date/Time: } & $1 / 19 / 1123: 54$ & & & & & & & & & & \\
\hline C3-EL-CP & 60 & 25 & 0.08 & 1/19/11 23:54 & 1/20/11 9:54 & 0.9 & $\begin{array}{c}\text { dark } \\
\text { red }\end{array}$ & 27.0 & 14.92 & 59.53 & 44.61 & 8.48 & 21.10 & 12.62 \\
\hline C3-EDI-CP & 20 & 25 & 0.09 & 1/20/11 10:00 & $1 / 20 / 1111: 00$ & 0.95 & red & 26.0 & 8.47 & 13.41 & 4.94 & NA & NA & NA \\
\hline C3-RG-CP & 20 & 25 & 0.09 & 1/20/11 11:05 & 1/20/11 14:05 & 1.25 & $\begin{array}{c}\text { dark } \\
\text { red }\end{array}$ & 26.7 & 8.49 & 23.27 & 14.78 & NA & NA & NA \\
\hline
\end{tabular}

Table A.29. Datasheet for Column C4 Loading and Rinsing Information

\begin{tabular}{|c|c|c|c|c|c|c|c|c|c|c|c|c|c|c|}
\hline Sample & Bottle & Temp & Pump & Sampling & Sampling & Resin & Resin & Temp & \multicolumn{3}{|c|}{ Effluent Bottle Weight, g } & \multicolumn{3}{|c|}{ Sample Vial Weight,g } \\
\hline ID No. & $\begin{array}{l}\text { Size } \\
(\mathrm{mL})\end{array}$ & $\begin{array}{l}\text { Set } \\
\left({ }^{\circ} \mathrm{C}\right)\end{array}$ & $\begin{array}{c}\text { Setting } \\
(\mathrm{mL} / \mathrm{min})\end{array}$ & Start Time & Stop Time & $\begin{array}{c}\text { Height } \\
(\mathrm{cm})\end{array}$ & Color & $\left({ }^{\circ} \mathrm{C}\right)$ & Tare & Gross & Net & Tare & Gross & Net \\
\hline C4-LD-0 & 20 & 50 & NA & 1/25/11 6:55 & 1/25/11 6:55 & 1.3 & $\begin{array}{c}\text { dark } \\
\text { red }\end{array}$ & 54.3 & NA & NA & NA & 8.55 & NA & 3.60 \\
\hline \multicolumn{4}{|c|}{ Loading (LD) Phase Start Date/Time: } & $1 / 25 / 117: 01$ & & & & & & & & & & \\
\hline C4-LD-006 & 20 & 50 & 7.08 & 1/25/11 7:07 & 1/25/11 7:07 & NA & $\begin{array}{l}\text { dark } \\
\text { red }\end{array}$ & 50.8 & NA & NA & NA & 8.50 & NA & 3.40 \\
\hline
\end{tabular}


Table A.29. Datasheet for Column C4 Loading and Rinsing Information

\begin{tabular}{|c|c|c|c|c|c|c|c|c|c|c|c|c|c|c|}
\hline \multirow{2}{*}{$\begin{array}{l}\text { Sample } \\
\text { ID No. }\end{array}$} & \multirow{2}{*}{$\begin{array}{c}\text { Bottle } \\
\text { Size } \\
(\mathrm{mL}) \\
\end{array}$} & \multirow{2}{*}{$\begin{array}{c}\text { Temp } \\
\text { Set } \\
\left({ }^{\circ} \mathrm{C}\right)\end{array}$} & \multirow{2}{*}{$\begin{array}{c}\text { Pump } \\
\text { Setting } \\
\text { (mL/min) }\end{array}$} & \multirow{2}{*}{$\begin{array}{l}\text { Sampling } \\
\text { Start Time }\end{array}$} & \multirow{2}{*}{$\begin{array}{l}\text { Sampling } \\
\text { Stop Time }\end{array}$} & \multirow{2}{*}{$\begin{array}{l}\text { Resin } \\
\text { Height } \\
(\mathrm{cm})\end{array}$} & \multirow{2}{*}{$\begin{array}{l}\text { Resin } \\
\text { Color }\end{array}$} & \multirow{2}{*}{$\begin{array}{l}\text { Temp } \\
\left({ }^{\circ} \mathrm{C}\right)\end{array}$} & \multicolumn{3}{|c|}{ Effluent Bottle Weight, g } & \multicolumn{3}{|c|}{ Sampole Vial Weil Weight, g } \\
\hline & & & & & & & & & Tare & Gross & Net & Tare & Gross & Net \\
\hline C4-LD-012 & 20 & 50 & 7.08 & 1/25/11 7:13 & 1/25/11 7:13 & NA & $\begin{array}{l}\text { dark } \\
\text { red }\end{array}$ & 48.9 & NA & NA & NA & 8.55 & NA & 3.37 \\
\hline C4-LD-018 & 20 & 50 & 7.08 & 1/25/11 7:19 & 1/25/11 7:19 & NA & $\begin{array}{l}\text { dark } \\
\text { red }\end{array}$ & 48.3 & NA & NA & NA & 8.48 & NA & 3.28 \\
\hline C4-LD-024 & 20 & 50 & 7.08 & 1/25/11 7:25 & $1 / 25 / 117: 25$ & NA & $\begin{array}{l}\text { dark } \\
\text { red }\end{array}$ & 48.2 & NA & NA & NA & 8.46 & NA & 3.36 \\
\hline C4-LD-036 & 20 & 50 & 7.08 & $1 / 25 / 117: 37$ & $1 / 25 / 117: 37$ & NA & $\begin{array}{l}\text { dark } \\
\text { red }\end{array}$ & 48.5 & NA & NA & NA & 8.37 & NA & 3.28 \\
\hline C4-LD-048 & 20 & 50 & 7.08 & 1/25/11 7:49 & $1 / 25 / 117: 49$ & NA & $\begin{array}{l}\text { dark } \\
\text { red }\end{array}$ & 49.1 & NA & NA & NA & 8.41 & NA & 3.12 \\
\hline C4-LD-060 & 20 & 50 & 7.08 & 1/25/11 8:01 & 1/25/11 8:01 & NA & $\begin{array}{l}\text { almost } \\
\text { black }\end{array}$ & 49.6 & NA & NA & NA & 8.46 & NA & 2.97 \\
\hline C4-LD-080 & 20 & 50 & 7.08 & 1/25/11 8:21 & 1/25/11 8:21 & NA & $\begin{array}{l}\text { almost } \\
\text { black }\end{array}$ & 49.9 & NA & NA & NA & 8.58 & NA & 3.44 \\
\hline C4-LD-120 & 20 & 50 & 7.08 & 1/25/11 9:01 & 1/25/11 9:01 & NA & $\begin{array}{l}\text { almost } \\
\text { black }\end{array}$ & 50.2 & NA & NA & NA & 8.48 & NA & 3.21 \\
\hline C4-LD-180 & 20 & 50 & 7.08 & 1/25/11 10:10 & 1/25/11 10:10 & NA & $\begin{array}{l}\text { almost } \\
\text { black }\end{array}$ & 50.1 & NA & NA & NA & 8.46 & NA & 3.35 \\
\hline C4-LD-240 & 20 & 50 & 7.08 & 1/25/11 11:01 & 1/25/11 11:01 & NA & $\begin{array}{l}\text { almost } \\
\text { black }\end{array}$ & 50.0 & NA & NA & NA & 8.48 & NA & 3.16 \\
\hline C4-LD-600 & 20 & 50 & 7.08 & 1/25/11 17:01 & 1/25/11 17:01 & NA & $\begin{array}{l}\text { almost } \\
\text { black }\end{array}$ & 50.2 & NA & NA & NA & 8.44 & NA & 3.21 \\
\hline C4-FD-CP & 20 & 50 & 0.09 & 1/25/11 17:15 & 1/25/11 19:45 & 1.3 & $\begin{array}{l}\text { almost } \\
\text { black }\end{array}$ & 51.7 & 8.39 & 22.54 & 14.15 & NA & NA & NA \\
\hline
\end{tabular}


Table A.30. Datasheet for Column C4B Loading and Rinsing Information

\begin{tabular}{|c|c|c|c|c|c|c|c|c|c|c|c|c|c|c|}
\hline \multirow{2}{*}{$\begin{array}{l}\text { Sample } \\
\text { ID No. }\end{array}$} & \multirow{2}{*}{$\begin{array}{l}\text { Bottle } \\
\text { Size } \\
(\mathrm{mL}) \\
\end{array}$} & \multirow{2}{*}{$\begin{array}{l}\text { Temp } \\
\text { Set } \\
\left({ }^{\circ} \mathrm{C}\right) \\
\end{array}$} & \multirow{2}{*}{$\begin{array}{c}\text { Pump } \\
\text { Setting } \\
\text { (mL/min) }\end{array}$} & \multirow{2}{*}{$\begin{array}{l}\text { Sampling } \\
\text { Start Time }\end{array}$} & \multirow{2}{*}{$\begin{array}{l}\text { Sampling } \\
\text { Stop Time }\end{array}$} & \multirow{2}{*}{$\begin{array}{l}\text { Resin } \\
\text { Height } \\
(\mathrm{cm}) \\
\end{array}$} & \multirow{2}{*}{$\begin{array}{l}\text { Resin } \\
\text { Color }\end{array}$} & \multirow{2}{*}{$\begin{array}{l}\text { Temp } \\
\left({ }^{\circ} \mathrm{C}\right)\end{array}$} & \multicolumn{3}{|c|}{ Effluent Bottle Weight, g } & \multicolumn{3}{|c|}{ Sampole Vial Weil Weight, g } \\
\hline & & & & & & & & & Tare & Gross & Net & Tare & Gross & Net \\
\hline C4B-LD-0 & 20 & 75 & NA & 1/26/11 8:25 & 1/26/11 8:25 & 1.3 & $\begin{array}{l}\text { almost } \\
\text { black }\end{array}$ & 71.0 & NA & NA & NA & 8.52 & NA & 2.65 \\
\hline \multicolumn{4}{|c|}{ Loading (LD) Phase Start Date/Time: } & 1/26/11 8:30 & & & & & & & & & $<$ & $>$ \\
\hline C4B-LD-004 & 20 & 75 & 0.08 & 1/26/11 12:30 & 1/26/11 12:30 & NA & $\begin{array}{l}\text { almost } \\
\text { black }\end{array}$ & 75.5 & NA & NA & NA & 8.54 & NA & 2.99 \\
\hline C4B-LD-008 & 20 & 75 & 0.08 & 1/26/11 16:30 & 1/26/11 16:30 & NA & $\begin{array}{l}\text { almost } \\
\text { black }\end{array}$ & 75.4 & NA & NA & NA & 8.51 & NA & 3.41 \\
\hline C4B-LD-012 & 20 & 75 & 0.08 & 1/26/11 20:30 & 1/26/11 20:30 & NA & $\begin{array}{l}\text { almost } \\
\text { black }\end{array}$ & 75.3 & NA & NA & NA & 8.57 & NA & 3.38 \\
\hline C4B-LD-024 & 20 & 75 & 0.08 & 1/27/11 8:30 & 1/27/11 8:30 & NA & $\begin{array}{l}\text { almost } \\
\text { black }\end{array}$ & 75.5 & NA & NA & NA & 8.46 & NA & 3.18 \\
\hline C4B-LD-072 & 20 & 75 & 0.08 & 1/29/11 8:30 & 1/29/11 8:30 & NA & $\begin{array}{l}\text { almost } \\
\text { black }\end{array}$ & 75.5 & NA & NA & NA & 8.51 & NA & 3.41 \\
\hline C4B-LD-120 & 20 & 75 & 0.08 & 2/1/11 13:15 & 2/1/11 13:15 & NA & $\begin{array}{l}\text { almost } \\
\text { black }\end{array}$ & 75.3 & NA & NA & NA & 8.56 & NA & 3.04 \\
\hline C4B-LD-168 & 20 & 75 & 0.08 & 2/3/11 13:15 & 2/3/11 13:15 & NA & $\begin{array}{l}\text { almost } \\
\text { black }\end{array}$ & 75.2 & NA & NA & NA & 8.49 & NA & 3.30 \\
\hline C4B-LD-336 & 20 & 75 & 0.08 & 2/10/11 13:17 & 2/10/11 13:17 & NA & black & 74.6 & NA & NA & NA & 8.44 & NA & 3.08 \\
\hline C4B-FD-CP & 20 & 75 & 0.09 & 2/21/11 13:20 & 2/21/11 15:50 & 1.3 & $\begin{array}{l}\text { almost } \\
\text { black }\end{array}$ & 74.8 & 8.47 & 22.16 & 13.69 & NA & NA & NA \\
\hline C4B-FDI-CP & 20 & 25 & 0.09 & 2/22/11 14:20 & 2/22/11 16:50 & 1.3 & $\begin{array}{l}\text { almost } \\
\text { black }\end{array}$ & 23.8 & 8.44 & 22.07 & 13.63 & NA & NA & NA \\
\hline CB4-AN-CP & 20 & 25 & 0.09 & 2/22/11 16:55 & 2/22/11 17:55 & 1.3 & $\begin{array}{l}\text { almost } \\
\text { black }\end{array}$ & 23.4 & 8.46 & 14.17 & 5.71 & NA & NA & NA \\
\hline
\end{tabular}


Table A.31. Datasheet for Column C4B Elution, Rinsing, and Regeneration Information

\begin{tabular}{|c|c|c|c|c|c|c|c|c|c|c|c|c|c|c|}
\hline \multirow{2}{*}{$\begin{array}{l}\text { Sample } \\
\text { ID No. }\end{array}$} & \multirow{2}{*}{$\begin{array}{l}\text { Bottle } \\
\text { Size } \\
(\mathrm{mL})\end{array}$} & \multirow{2}{*}{$\begin{array}{c}\text { Temp } \\
\text { Set } \\
\left({ }^{\circ} \mathrm{C}\right) \\
\end{array}$} & \multirow{2}{*}{$\begin{array}{c}\text { Pump } \\
\text { Setting } \\
\text { (mL/min) }\end{array}$} & \multirow{2}{*}{$\begin{array}{l}\text { Sampling } \\
\text { Start Time }\end{array}$} & \multirow{2}{*}{$\begin{array}{l}\text { Sampling } \\
\text { Stop Time }\end{array}$} & \multirow{2}{*}{$\begin{array}{c}\text { Resin } \\
\text { Height } \\
(\mathrm{cm}) \\
\end{array}$} & \multirow{2}{*}{$\begin{array}{l}\text { Resin } \\
\text { Color }\end{array}$} & \multirow{2}{*}{$\begin{array}{l}\text { Temp } \\
\left({ }^{\circ} \mathrm{C}\right)\end{array}$} & \multicolumn{3}{|c|}{ Effluent Bottle Weight, g } & \multicolumn{3}{|c|}{ Sample Vial Weight, g } \\
\hline & & & & & & & & & Tare & Gross & Net & Tare & Gross & Net \\
\hline \multicolumn{4}{|c|}{ Elution (EL) Phase Start Date/Time: } & 2/23/11 6:43 & & & & & & & & & & \\
\hline C4B-EL-CP & 60 & 25 & 0.09 & 2/23/11 6:43 & 2/23/11 16:43 & 1.0 & $\begin{array}{c}\text { blackish } \\
\text { red }\end{array}$ & 23.1 & 14.58 & 63.85 & 49.27 & 8.46 & 15.87 & 7.41 \\
\hline C4B-EDI-CP & 20 & 25 & 0.09 & 2/23/11 16:55 & 2/23/11 17:55 & 1.0 & $\begin{array}{c}\text { blackish } \\
\text { red }\end{array}$ & 23.4 & 8.35 & 13.70 & 5.35 & NA & NA & NA \\
\hline C4B-RG-CP & 20 & 25 & 0.09 & 2/23/11 18:12 & 2/23/11 21:12 & 1.3 & black & 23.3 & 8.38 & 23.22 & 14.84 & NA & NA & NA \\
\hline
\end{tabular}

Table A.32. Datasheet for Column C5 Loading and Rinsing Information

\begin{tabular}{|c|c|c|c|c|c|c|c|c|c|c|c|c|c|c|}
\hline Sample & Bottle & Temp & Pump & Sampling & Sampling & Resin & Resin & Temp & \multicolumn{3}{|c|}{ Effluent Bottle Weight, g } & \multicolumn{3}{|c|}{ Sample Vial Weight, g } \\
\hline ID No. & $\begin{array}{l}\text { Size } \\
(\mathrm{mL})\end{array}$ & $\begin{array}{l}\text { Set } \\
\left({ }^{\circ} \mathrm{C}\right)\end{array}$ & $\begin{array}{c}\text { Setting } \\
\text { (mL/min) }\end{array}$ & Start Time & Stop Time & $\begin{array}{l}\text { Height } \\
\text { (cm) }\end{array}$ & Color & $\left({ }^{\circ} \mathrm{C}\right)$ & Tare & Gross & Net & Tare & Gross & Net \\
\hline C5-LD-0 & 20 & 50 & NA & 2/28/11 6:51 & 2/28/11 6:51 & 1.6 & black & 60.5 & NA & NA & NA & 8.49 & 11.33 & 2.84 \\
\hline \multicolumn{4}{|c|}{ Loading (LD) Phase Start Date/Time: } & 2/28/11 6:55 & & & & & & & & & & \\
\hline C5-LD-006 & 20 & 50 & 10.62 & 2/28/11 7:01 & 2/28/11 7:04 & NA & black & 55.4 & NA & NA & NA & 8.55 & 12.05 & 3.50 \\
\hline C5-LD-012 & 20 & 50 & 10.62 & 2/28/11 7:07 & 2/28/11 7:07 & NA & black & 52.4 & NA & NA & NA & 8.43 & 11.55 & 3.12 \\
\hline C5-LD-018 & 20 & 50 & 10.62 & 2/28/11 7:13 & 2/28/11 7:13 & NA & black & 49.8 & NA & NA & NA & 8.52 & 11.95 & 3.43 \\
\hline C5-LD-024 & 20 & 50 & 10.62 & 2/28/11 7:19 & 2/28/11 7:19 & NA & black & 48.3 & NA & NA & NA & 8.48 & 11.59 & 3.11 \\
\hline C5-LD-036 & 20 & 50 & 10.62 & 2/28/11 7:31 & 2/28/11 7:31 & NA & black & 46.9 & NA & NA & NA & 8.48 & 11.97 & 3.49 \\
\hline C5-LD-048 & 20 & 50 & 10.62 & 2/28/11 7:43 & 2/28/11 7:43 & NA & black & 47.1 & NA & NA & NA & 8.44 & 11.69 & 3.25 \\
\hline C5-LD-060 & 20 & 50 & 10.62 & 2/28/11 7:55 & 2/28/11 7:55 & NA & black & 47.5 & NA & NA & NA & 8.45 & 11.65 & 3.20 \\
\hline C5-LD-080 & 20 & 50 & 10.62 & 2/28/11 8:15 & 2/28/11 8:15 & NA & black & 49.2 & NA & NA & NA & 8.46 & 11.61 & 3.15 \\
\hline C5-LD-120 & 20 & 50 & 10.62 & 2/28/11 8:55 & 2/28/11 8:55 & NA & black & 50.3 & NA & NA & NA & 8.40 & 11.56 & 3.16 \\
\hline C5-LD-180 & 20 & 50 & 10.62 & 2/28/11 9:55 & 2/28/11 9:55 & NA & black & 50.2 & NA & NA & NA & 8.54 & 11.87 & 3.33 \\
\hline C5-LD-240 & 20 & 50 & 10.62 & 2/28/11 10:55 & 2/28/11 10:58 & NA & black & 50.2 & NA & NA & NA & 8.42 & 11.51 & 3.09 \\
\hline C5-LD-600 & 20 & 50 & 10.62 & 2/28/11 16:55 & 2/28/11 16:55 & NA & black & 50.3 & NA & NA & NA & 8.47 & 12.58 & 4.11 \\
\hline C5-FD-CP & 20 & 50 & 0.09 & 2/28/11 17:07 & 2/28/11 19:37 & NA & black & 60.4 & 8.41 & 21.18 & 12.77 & NA & NA & NA \\
\hline
\end{tabular}


Table A.32. Datasheet for Column C5 Loading and Rinsing Information

\begin{tabular}{|c|c|c|c|c|c|c|c|c|c|c|c|c|c|c|}
\hline \multirow{2}{*}{$\begin{array}{l}\text { Sample } \\
\text { ID No. }\end{array}$} & \multirow{2}{*}{$\begin{array}{l}\text { Bottle } \\
\text { Size } \\
(\mathrm{mL})\end{array}$} & \multirow{2}{*}{$\begin{array}{l}\text { Temp } \\
\text { Set } \\
\left({ }^{\circ} \mathrm{C}\right) \\
\end{array}$} & \multirow{2}{*}{$\begin{array}{c}\text { Pump } \\
\text { Setting } \\
\text { (mL/min) }\end{array}$} & \multirow{2}{*}{$\begin{array}{l}\text { Sampling } \\
\text { Start Time }\end{array}$} & \multirow{2}{*}{$\begin{array}{l}\text { Sampling } \\
\text { Stop Time }\end{array}$} & \multirow{2}{*}{$\begin{array}{l}\text { Resin } \\
\text { Height } \\
(\mathrm{cm}) \\
\end{array}$} & \multirow{2}{*}{$\begin{array}{l}\text { Resin } \\
\text { Color }\end{array}$} & \multirow{2}{*}{$\begin{array}{l}\text { Temp } \\
\left({ }^{\circ} \mathrm{C}\right)\end{array}$} & \multicolumn{3}{|c|}{ Effluent Bottle Weight,g } & \multicolumn{3}{|c|}{ Sample Vial Weight, g } \\
\hline & & & & & & & & & Tare & Gross & Net & Tare & Gross & Net \\
\hline C5-FDI-CP & 20 & 25 & 0.09 & $2 / 28 / 1120: 15$ & $2 / 28 / 1122: 45$ & NA & black & 25.8 & 8.50 & 20.34 & 11.84 & NA & NA & NA \\
\hline C5-AN-CP & 20 & 25 & 0.09 & 2/28/11 22:51 & 2/28/11 23:51 & NA & black & 24.5 & 8.55 & 13.20 & 4.65 & NA & NA & NA \\
\hline
\end{tabular}

Table A.33. Datasheet for Column C5 Elution, Rinsing, and Regeneration Information

\begin{tabular}{|c|c|c|c|c|c|c|c|c|c|c|c|c|c|c|}
\hline Sample & Bottle & Temp & Pump & Sampling & Sampling & Resin & Resin & Temp & \multicolumn{3}{|c|}{ Effluent Bottle Weight,g } & \multicolumn{3}{|c|}{ Sample Vial Weight, g } \\
\hline ID No. & $\begin{array}{l}\text { Size } \\
(\mathrm{mL})\end{array}$ & $\begin{array}{l}\text { Set } \\
\left({ }^{\circ} \mathrm{C}\right)\end{array}$ & $\begin{array}{c}\text { Setting } \\
(\mathrm{mL} / \mathrm{min})\end{array}$ & Start Time & Stop Time & $\begin{array}{l}\text { Height } \\
(\mathrm{cm})\end{array}$ & Color & $\left({ }^{\circ} \mathrm{C}\right)$ & Tare & Gross & Net & Tare & Gross & Net \\
\hline \multicolumn{4}{|c|}{ Elution (EL) Phase Start Date/Time: } & 3/1/11 6:53 & & & & & & & & & & \\
\hline C5-EL-CP & 60 & 25 & 0.08 & 3/1/11 6:53 & 3/1/11 16:53 & 1.0 & $\begin{array}{l}\text { dark } \\
\text { red }\end{array}$ & 25.3 & 14.93 & 56.61 & 41.68 & 8.36 & 20.63 & 12.27 \\
\hline C5-EDI-CP & 20 & 25 & 0.09 & 3/1/11 17:15 & 3/1/11 18:15 & 1.0 & $\begin{array}{c}\text { dark } \\
\text { red }\end{array}$ & 25.6 & 8.47 & 13.13 & 4.66 & NA & NA & NA \\
\hline
\end{tabular}

Table A.34. Datasheet for Column D1 Pretreatment, Loading, and Rinsing Information

\begin{tabular}{|c|c|c|c|c|c|c|c|c|c|c|c|c|c|c|}
\hline \multirow{2}{*}{$\begin{array}{l}\text { Sample } \\
\text { ID No. }\end{array}$} & \multirow{2}{*}{$\begin{array}{l}\text { Bottle } \\
\text { Size } \\
(\mathrm{mL})\end{array}$} & \multirow{2}{*}{$\begin{array}{c}\text { Temp } \\
\text { Set } \\
\left({ }^{\circ} \mathrm{C}\right) \\
\end{array}$} & \multirow{2}{*}{$\begin{array}{c}\text { Pump } \\
\text { Setting } \\
\text { (mL/min) }\end{array}$} & \multirow{2}{*}{$\begin{array}{l}\text { Sampling } \\
\text { Start Time }\end{array}$} & \multirow{2}{*}{$\begin{array}{l}\text { Sampling } \\
\text { Stop Time }\end{array}$} & \multirow{2}{*}{$\begin{array}{l}\text { Resin } \\
\text { Height } \\
(\mathrm{cm})\end{array}$} & \multirow{2}{*}{$\begin{array}{l}\text { Resin } \\
\text { Color }\end{array}$} & \multirow{2}{*}{$\begin{array}{l}\text { Temp } \\
\left({ }^{\circ} \mathrm{C}\right)\end{array}$} & \multicolumn{3}{|c|}{$\begin{array}{l}\text { Effluent Bottle } \\
\text { Weight,g }\end{array}$} & \multicolumn{3}{|c|}{ Sample Vial Weight, g } \\
\hline & & & & & & & & & Tare & Gross & Net & Tare & Gross & Net \\
\hline D1-PT-DIW1 & 20 & 25 & 0.09 & $10 / 14 / 108: 45$ & 10/14/10 11:15 & 1.1 & $\begin{array}{c}\text { dark } \\
\text { red }\end{array}$ & 24.5 & 8.60 & 21.18 & 12.58 & NA & NA & NA \\
\hline D1-PT-ACID & 20 & 25 & 0.09 & 10/14/10 11:24 & $10 / 14 / 10$ 14:07 & 0.95 & orange & 24.7 & 8.53 & 23.06 & 14.53 & NA & NA & NA \\
\hline D1-PT-DIW2 & 20 & 25 & 0.09 & $10 / 14 / 1014: 33$ & $10 / 14 / 1015: 33$ & 0.9 & orange & 22.2 & 8.55 & 13.72 & 5.17 & NA & NA & NA \\
\hline D1-PT-NaOH & 20 & 25 & 0.09 & 10/14/10 15:38 & 10/14/10 17:38 & 1.1 & $\begin{array}{l}\text { dark } \\
\text { red }\end{array}$ & 20.6 & 8.55 & 18.86 & 10.31 & NA & NA & NA \\
\hline D1-LD-0 & 20 & 25 & NA & 10/18/10 7:07 & 10/18/10 7:08 & 1.1 & $\begin{array}{c}\text { dark } \\
\text { red }\end{array}$ & 24.2 & NA & NA & NA & 8.59 & 11.68 & 3.09 \\
\hline
\end{tabular}


Table A.34. Datasheet for Column D1 Pretreatment, Loading, and Rinsing Information

\begin{tabular}{|c|c|c|c|c|c|c|c|c|c|c|c|c|c|c|}
\hline \multirow{2}{*}{$\begin{array}{l}\text { Sample } \\
\text { ID No. }\end{array}$} & \multirow{2}{*}{$\begin{array}{c}\text { Bottle } \\
\text { Size } \\
(\mathrm{mL})\end{array}$} & \multirow{2}{*}{$\begin{array}{c}\text { Temp } \\
\text { Set } \\
\left({ }^{\circ} \mathrm{C}\right)\end{array}$} & \multirow{2}{*}{$\begin{array}{c}\text { Pump } \\
\text { Setting } \\
\text { (mL/min) }\end{array}$} & \multirow{2}{*}{$\begin{array}{l}\text { Sampling } \\
\text { Start Time }\end{array}$} & \multirow{2}{*}{$\begin{array}{l}\text { Sampling } \\
\text { Stop Time }\end{array}$} & \multirow{2}{*}{$\begin{array}{l}\text { Resin } \\
\text { Height } \\
\text { (cm) }\end{array}$} & \multirow{2}{*}{$\begin{array}{l}\text { Resin } \\
\text { Color }\end{array}$} & \multirow{2}{*}{$\begin{array}{l}\text { Temp } \\
\left({ }^{\circ} \mathrm{C}\right)\end{array}$} & \multicolumn{3}{|c|}{$\begin{array}{l}\text { Effluent Bottle } \\
\text { Weight,g }\end{array}$} & \multicolumn{3}{|c|}{ Sample Vial Weight, g } \\
\hline & & & & & & & & & Tare & Gross & Net & Tare & Gross & Net \\
\hline D1-LD-006 & 20 & 25 & 10.62 & 10/18/10 7:18 & 10/18/10 7:18 & NA & $\begin{array}{c}\text { dark } \\
\text { red }\end{array}$ & 23.1 & NA & NA & NA & 8.51 & 11.46 & 2.95 \\
\hline D1-LD-012 & 20 & 25 & 10.62 & 10/18/10 7:24 & 10/18/10 7:24 & NA & $\begin{array}{l}\text { darker } \\
\text { red }\end{array}$ & 22.5 & NA & NA & NA & 8.54 & 11.55 & 3.01 \\
\hline D1-LD-018 & 20 & 25 & 10.62 & 10/18/10 7:30 & $10 / 18 / 107: 30$ & NA & $\begin{array}{l}\text { darker } \\
\text { red }\end{array}$ & 22.5 & NA & NA & NA & 8.55 & 11.69 & 3.14 \\
\hline D1-LD-024 & 20 & 25 & 10.62 & 10/18/10 7:36 & 10/18/10 7:36 & NA & $\begin{array}{l}\text { darker } \\
\text { red }\end{array}$ & 22.7 & NA & NA & NA & 8.56 & 11.57 & 3.01 \\
\hline D1-LD-036 & 20 & 25 & 10.62 & 10/18/10 7:48 & 10/18/10 7:48 & NA & $\begin{array}{c}\text { very } \\
\text { dark } \\
\text { red }\end{array}$ & 23.5 & NA & NA & NA & 8.53 & 11.66 & 3.13 \\
\hline D1-LD-048 & 20 & 25 & 10.62 & 10/18/10 8:00 & 10/18/10 8:00 & NA & $\begin{array}{c}\text { very } \\
\text { dark } \\
\text { red }\end{array}$ & 24.1 & NA & NA & NA & 8.50 & 11.58 & 3.08 \\
\hline D1-LD-060 & 20 & 25 & 10.62 & 10/18/10 8:12 & 10/18/10 8:13 & NA & $\begin{array}{c}\text { very } \\
\text { dark } \\
\text { red }\end{array}$ & 24.6 & NA & NA & NA & 8.46 & 11.34 & 2.88 \\
\hline D1-LD-080 & 20 & 25 & 10.62 & 10/18/10 8:32 & 10/18/10 8:32 & NA & $\begin{array}{c}\text { very } \\
\text { dark } \\
\text { red }\end{array}$ & 24.9 & NA & NA & NA & 8.51 & 11.50 & 2.99 \\
\hline D1-LD-120 & 20 & 25 & 10.62 & 10/18/10 9:12 & 10/18/10 9:12 & NA & $\begin{array}{c}\text { very } \\
\text { dark } \\
\text { red }\end{array}$ & 25.2 & NA & NA & NA & 8.58 & 11.65 & 3.07 \\
\hline D1-LD-180 & 20 & 25 & 10.62 & 10/18/10 10:13 & 10/18/10 10:13 & NA & $\begin{array}{c}\text { very } \\
\text { dark } \\
\text { red }\end{array}$ & 25.2 & NA & NA & NA & 8.57 & 11.39 & 2.82 \\
\hline D1-LD-240 & 20 & 25 & 10.62 & 10/18/10 11:12 & 10/18/10 11:12 & NA & $\begin{array}{c}\text { very } \\
\text { dark } \\
\text { red }\end{array}$ & 25.9 & NA & NA & NA & 8.47 & 11.46 & 2.99 \\
\hline D1-LD-600 & 20 & 25 & 10.62 & 10/18/10 17:12 & 10/18/10 17:12 & 1.2 & $\begin{array}{l}\text { very } \\
\text { dark } \\
\text { red }\end{array}$ & 25.5 & NA & NA & NA & 8.50 & 11.47 & 2.97 \\
\hline
\end{tabular}


Table A.34. Datasheet for Column D1 Pretreatment, Loading, and Rinsing Information

\begin{tabular}{|c|c|c|c|c|c|c|c|c|c|c|c|c|c|c|}
\hline \multirow{2}{*}{$\begin{array}{l}\text { Sample } \\
\text { ID No. }\end{array}$} & \multirow{2}{*}{$\begin{array}{l}\text { Bottle } \\
\text { Size } \\
(\mathrm{mL})\end{array}$} & \multirow{2}{*}{$\begin{array}{l}\text { Temp } \\
\text { Set } \\
\left({ }^{\circ} \mathrm{C}\right) \\
\end{array}$} & \multirow{2}{*}{$\begin{array}{c}\text { Pump } \\
\text { Setting } \\
\text { (mL/min) }\end{array}$} & \multirow{2}{*}{$\begin{array}{l}\text { Sampling } \\
\text { Start Time }\end{array}$} & \multirow{2}{*}{$\begin{array}{l}\text { Sampling } \\
\text { Stop Time }\end{array}$} & \multirow{2}{*}{$\begin{array}{c}\text { Resin } \\
\text { Height } \\
\text { (cm) }\end{array}$} & \multirow{2}{*}{$\begin{array}{l}\text { Resin } \\
\text { Color }\end{array}$} & \multirow{2}{*}{$\begin{array}{l}\text { Temp } \\
\left({ }^{\circ} \mathrm{C}\right)\end{array}$} & \multicolumn{3}{|c|}{$\begin{array}{l}\text { Effluent Bottle } \\
\text { Weight, g }\end{array}$} & \multicolumn{3}{|c|}{ Sample Vial Weight, g } \\
\hline & & & & & & & & & Tare & Gross & Net & Tare & Gross & $\mathrm{Ne}$ \\
\hline D1-FD-CP & 20 & 25 & 0.09 & 10/18/10 17:18 & 10/18/10 19:48 & 1.2 & $\begin{array}{c}\text { very } \\
\text { dark } \\
\text { red }\end{array}$ & 25.3 & 8.48 & 22.16 & 13.68 & NA & NA & NA \\
\hline D1-FDI-CP & 20 & 25 & 0.09 & 10/18/10 19:55 & 10/18/10 22:25 & 1.15 & $\begin{array}{c}\text { very } \\
\text { dark } \\
\text { red }\end{array}$ & 25.2 & 8.57 & 20.51 & 11.94 & NA & NA & NA \\
\hline D1-AN-CP & 20 & 25 & 0.09 & 10/18/10 22:36 & 10/18/10 23:36 & 1.1 & $\begin{array}{c}\text { very } \\
\text { dark } \\
\text { red }\end{array}$ & 25.5 & 8.55 & 13.29 & 4.74 & NA & NA & NA \\
\hline
\end{tabular}

Table A.35. Datasheet for Column D1 Elution, Rinsing, and Regeneration Information

\begin{tabular}{|c|c|c|c|c|c|c|c|c|c|c|c|c|c|c|}
\hline Sample & Bottle & Temp & Pump & Sampling & Sampling & Resin & Resin & Temp & Efflu & g & Teight, & Sam & Vial W & ht, g \\
\hline ID No. & $\begin{array}{l}\text { Size } \\
(\mathrm{mL})\end{array}$ & $\begin{array}{l}\text { Set } \\
\left({ }^{\circ} \mathrm{C}\right)\end{array}$ & $\begin{array}{c}\text { Setting } \\
(\mathrm{mL} / \mathrm{min})\end{array}$ & Start Time & Stop Time & $\begin{array}{c}\text { Height } \\
(\mathrm{cm})\end{array}$ & Color & $\left({ }^{\circ} \mathrm{C}\right)$ & Tare & Gross & Net & Tare & Gross & Net \\
\hline \multicolumn{4}{|c|}{ Elution (EL) Phase Start Date/Time: } & 10/19/10 6:57 & & & & & & & & & & \\
\hline D1-EL-CP & 60 & 25 & 0.08 & 10/19/10 6:57 & 10/19/10 15:57 & 1.0 & orange & 25.3 & 14.90 & 54.32 & 39.42 & 8.49 & 11.05 & 2.56 \\
\hline D1-EDI-CP & 20 & 25 & 0.08 & $10 / 19 / 1016: 21$ & $10 / 19 / 1017: 21$ & 1.0 & orange & 24.6 & 8.48 & 12.70 & 4.22 & NA & NA & NA \\
\hline D1-RG-CP & 20 & 25 & 0.08 & $10 / 19 / 1017: 28$ & $10 / 19 / 1019: 58$ & 1.1 & $\begin{array}{l}\text { dark } \\
\text { red }\end{array}$ & 25.4 & 8.52 & 20.44 & 11.92 & NA & NA & NA \\
\hline
\end{tabular}

Table A.36. Datasheet for Column E1 Pretreatment, Loading, and Rinsing Information

\begin{tabular}{|c|c|c|c|c|c|c|c|c|c|c|c|c|c|c|}
\hline \multirow{2}{*}{$\begin{array}{l}\text { Sample } \\
\text { ID No. }\end{array}$} & \multirow{2}{*}{$\begin{array}{l}\text { Bottle } \\
\text { Size } \\
(\mathrm{mL})\end{array}$} & \multirow{2}{*}{$\begin{array}{l}\text { Temp } \\
\text { Set } \\
\left({ }^{\circ} \mathrm{C}\right)\end{array}$} & \multirow{2}{*}{$\begin{array}{c}\text { Pump } \\
\text { Setting } \\
\text { (mL/min) }\end{array}$} & \multirow{2}{*}{$\begin{array}{l}\text { Sampling } \\
\text { Start Time }\end{array}$} & \multirow{2}{*}{$\begin{array}{l}\text { Sampling } \\
\text { Stop Time }\end{array}$} & \multirow{2}{*}{$\begin{array}{c}\text { Resin } \\
\text { Height } \\
\text { (cm) }\end{array}$} & \multirow{2}{*}{$\begin{array}{l}\text { Resin } \\
\text { Color }\end{array}$} & \multirow{2}{*}{$\begin{array}{l}\text { Temp } \\
\left({ }^{\circ} \mathrm{C}\right)\end{array}$} & \multicolumn{3}{|c|}{$\begin{array}{c}\text { Effluent Bottle } \\
\text { Weight, g }\end{array}$} & \multicolumn{3}{|c|}{ Sample Vial Weight, g } \\
\hline & & & & & & & & & Tare & Gross & Net & Tare & Gross & Net \\
\hline E1-PT-DIW1 & 20 & 50 & 0.09 & $10 / 20 / 1015: 24$ & $10 / 20 / 1017: 54$ & 1.0 & $\begin{array}{c}\text { dark } \\
\text { red }\end{array}$ & 50.1 & 8.48 & 20.58 & 12.10 & NA & NA & NA \\
\hline E1-PT-ACID & 20 & 50 & 0.09 & 10/21/10 6:52 & $10 / 21 / 1010: 37$ & 1.0 & orange & 50.0 & 8.38 & 20.69 & 12.31 & NA & NA & NA \\
\hline
\end{tabular}


Table A.36. Datasheet for Column E1 Pretreatment, Loading, and Rinsing Information

\begin{tabular}{|c|c|c|c|c|c|c|c|c|c|c|c|c|c|c|}
\hline \multirow{2}{*}{$\begin{array}{l}\text { Sample } \\
\text { ID No. }\end{array}$} & \multirow{2}{*}{$\begin{array}{c}\text { Bottle } \\
\text { Size } \\
(\mathrm{mL})\end{array}$} & \multirow{2}{*}{$\begin{array}{c}\text { Temp } \\
\text { Set } \\
\left({ }^{\circ} \mathrm{C}\right)\end{array}$} & \multirow{2}{*}{$\begin{array}{c}\text { Pump } \\
\text { Setting } \\
\text { (mL/min) }\end{array}$} & \multirow{2}{*}{$\begin{array}{l}\text { Sampling } \\
\text { Start Time }\end{array}$} & \multirow{2}{*}{$\begin{array}{l}\text { Sampling } \\
\text { Stop Time }\end{array}$} & \multirow{2}{*}{$\begin{array}{c}\text { Resin } \\
\text { Height } \\
\text { (cm) }\end{array}$} & \multirow{2}{*}{$\begin{array}{l}\text { Resin } \\
\text { Color }\end{array}$} & \multirow{2}{*}{$\begin{array}{l}\text { Temp } \\
\left({ }^{\circ} \mathrm{C}\right)\end{array}$} & \multicolumn{3}{|c|}{$\begin{array}{l}\text { Effluent Bottle } \\
\text { Weight,g }\end{array}$} & \multicolumn{3}{|c|}{ Sample Vial Weight, g } \\
\hline & & & & & & & & & Tare & Gross & Net & Tare & Gross & Net \\
\hline E1-PT-DIW2 & 20 & 50 & 0.09 & 10/21/10 11:15 & $10 / 21 / 1012: 15$ & 1.0 & orange & NA & 8.42 & 12.52 & 4.10 & NA & NA & NA \\
\hline E1-PT-NaOH & 20 & 50 & 0.09 & 10/21/10 14:15 & 10/21/10 16:15 & 1.1 & $\begin{array}{c}\text { dark } \\
\text { red }\end{array}$ & 50.3 & 8.48 & 16.78 & 8.30 & NA & NA & NA \\
\hline E1-LD-0 & 20 & 50 & NA & 10/25/10 6:52 & $10 / 25 / 106: 52$ & NA & $\begin{array}{c}\text { dark } \\
\text { red }\end{array}$ & 51.3 & NA & NA & NA & 8.39 & 11.55 & 3.16 \\
\hline \multicolumn{4}{|c|}{ Loading (LD) Phase Start Date/Time: } & $10 / 25 / 107: 00$ & & & & & & & & & & \\
\hline E1-LD-006 & 20 & 50 & 10.62 & 10/25/10 7:06 & 10/25/10 7:06 & NA & $\begin{array}{c}\text { dark } \\
\text { red }\end{array}$ & 46.6 & NA & NA & NA & 8.58 & 11.60 & 3.02 \\
\hline E1-LD-012 & 20 & 50 & 10.62 & 10/25/10 7:12 & 10/25/10 7:12 & NA & $\begin{array}{c}\text { dark } \\
\text { red }\end{array}$ & 45.3 & NA & NA & NA & 8.57 & 11.67 & 3.10 \\
\hline E1-LD-018 & 20 & 50 & 10.62 & 10/25/10 7:18 & 10/25/10 7:18 & NA & $\begin{array}{l}\text { dark } \\
\text { red }\end{array}$ & 45.8 & NA & NA & NA & 8.56 & 11.61 & 3.05 \\
\hline E1-LD-024 & 20 & 50 & 10.62 & 10/25/10 7:24 & $10 / 25 / 107: 24$ & NA & $\begin{array}{c}\text { dark } \\
\text { red }\end{array}$ & 46.3 & NA & NA & NA & 8.57 & 11.69 & 3.12 \\
\hline E1-LD-036 & 20 & 50 & 10.62 & 10/25/10 7:36 & 10/25/10 7:36 & NA & $\begin{array}{l}\text { dark } \\
\text { red }\end{array}$ & 48.2 & NA & NA & NA & 8.42 & 11.14 & 2.72 \\
\hline E1-LD-048 & 20 & 50 & 10.62 & 10/25/10 7:48 & $10 / 25 / 107: 48$ & NA & $\begin{array}{c}\text { dark } \\
\text { red }\end{array}$ & 49.5 & NA & NA & NA & 8.56 & 11.64 & 3.08 \\
\hline E1-LD-060 & 20 & 50 & 10.62 & 10/25/10 8:00 & 10/25/10 8:00 & NA & $\begin{array}{l}\text { dark } \\
\text { red }\end{array}$ & 49.8 & NA & NA & NA & 8.51 & 11.72 & 3.21 \\
\hline E1-LD-080 & 20 & 50 & 10.62 & 10/25/10 8:20 & 10/25/10 8:20 & NA & $\begin{array}{c}\text { dark } \\
\text { red }\end{array}$ & 49.8 & NA & NA & NA & 8.34 & 11.17 & 2.83 \\
\hline E1-LD-120 & 20 & 50 & 10.62 & 10/25/10 9:00 & 10/25/10 9:00 & NA & $\begin{array}{c}\text { dark } \\
\text { red }\end{array}$ & 49.8 & NA & NA & NA & 8.46 & 11.64 & 3.18 \\
\hline E1-LD-180 & 20 & 50 & 10.62 & 10/25/10 10:00 & 10/25/10 10:00 & NA & $\begin{array}{c}\text { dark } \\
\text { red }\end{array}$ & 49.6 & NA & NA & NA & 8.49 & 11.45 & 2.96 \\
\hline E1-LD-240 & 20 & 50 & 10.62 & 10/25/10 11:00 & 10/25/10 11:00 & NA & $\begin{array}{c}\text { very } \\
\text { dark } \\
\text { red }\end{array}$ & 49.8 & NA & NA & NA & 8.44 & 10.88 & 2.44 \\
\hline E1-LD-600 & 20 & 50 & 10.62 & 10/25/10 17:00 & 10/25/10 17:00 & 1.1 & $\begin{array}{c}\text { very } \\
\text { dark } \\
\text { red }\end{array}$ & 49.9 & NA & NA & NA & 8.58 & 11.52 & 2.96 \\
\hline
\end{tabular}


Table A.36. Datasheet for Column E1 Pretreatment, Loading, and Rinsing Information

\begin{tabular}{|c|c|c|c|c|c|c|c|c|c|c|c|c|c|c|}
\hline \multirow{2}{*}{$\begin{array}{l}\text { Sample } \\
\text { ID No. }\end{array}$} & \multirow{2}{*}{$\begin{array}{l}\text { Bottle } \\
\text { Size } \\
(\mathrm{mL})\end{array}$} & \multirow{2}{*}{$\begin{array}{l}\text { Temp } \\
\text { Set } \\
\left({ }^{\circ} \mathrm{C}\right) \\
\end{array}$} & \multirow{2}{*}{$\begin{array}{c}\text { Pump } \\
\text { Setting } \\
\text { (mL/min) }\end{array}$} & \multirow{2}{*}{$\begin{array}{l}\text { Sampling } \\
\text { Start Time }\end{array}$} & \multirow{2}{*}{$\begin{array}{l}\text { Sampling } \\
\text { Stop Time }\end{array}$} & \multirow{2}{*}{$\begin{array}{c}\text { Resin } \\
\text { Height } \\
\text { (cm) }\end{array}$} & \multirow{2}{*}{$\begin{array}{l}\text { Resin } \\
\text { Color }\end{array}$} & \multirow{2}{*}{$\begin{array}{l}\text { Temp } \\
\left({ }^{\circ} \mathrm{C}\right)\end{array}$} & \multicolumn{3}{|c|}{$\begin{array}{l}\text { Effluent Bottle } \\
\text { Weight, g }\end{array}$} & \multicolumn{3}{|c|}{ Sample Vial Weight, g } \\
\hline & & & & & & & & & Tare & Gross & Net & Tare & Gross & $\mathrm{Ne}$ \\
\hline E1-FD-CP & 20 & 50 & 0.09 & 10/25/10 17:07 & 10/25/10 19:37 & 1.1 & $\begin{array}{c}\text { very } \\
\text { dark } \\
\text { red }\end{array}$ & 49.6 & 8.35 & 21.98 & 13.63 & NA & NA & NA \\
\hline E1-FDI-CP & 20 & 25 & 0.09 & 10/25/10 20:10 & $10 / 25 / 10$ 22:40 & 1.1 & $\begin{array}{c}\text { very } \\
\text { dark } \\
\text { red }\end{array}$ & 25.2 & 8.52 & 20.02 & 11.50 & NA & NA & NA \\
\hline E1-AN-CP & 20 & 25 & 0.09 & 10/25/10 23:00 & 10/26/10 00:00 & 1.1 & $\begin{array}{c}\text { very } \\
\text { dark } \\
\text { red }\end{array}$ & 25.7 & 8.47 & 13.10 & 4.63 & NA & NA & NA \\
\hline
\end{tabular}

Table A.37. Datasheet for Column E1 Elution, Rinsing, and Regeneration Information

\begin{tabular}{|c|c|c|c|c|c|c|c|c|c|c|c|c|c|c|}
\hline Sample & Bottle & Temp & Pump & Sampling & Sampling & Resin & Resin & Temp & Efflu & g & eight, & Samp & Vial W & ht, g \\
\hline ID No. & $\begin{array}{l}\text { Size } \\
(\mathrm{mL})\end{array}$ & $\begin{array}{l}\text { Set } \\
\left({ }^{\circ} \mathrm{C}\right)\end{array}$ & $\begin{array}{l}\text { Setting } \\
\text { (mL/min) }\end{array}$ & Start Time & Stop Time & $\begin{array}{l}\text { Height } \\
\text { (cm) }\end{array}$ & Color & $\left({ }^{\circ} \mathrm{C}\right)$ & Tare & Gross & Net & Tare & Gross & Net \\
\hline \multicolumn{4}{|c|}{ Elution (EL) Phase Start Date/Time: } & 10/26/10 7:05 & & & & & & & & & & \\
\hline E1-EL-CP & 60 & 25 & 0.08 & 10/26/10 7:05 & 10/26/10 16:05 & 0.9 & orange & 27.3 & 14.98 & 52.14 & 37.16 & 8.60 & 16.34 & 7.74 \\
\hline E1-EDI-CP & 20 & 25 & 0.09 & 10/26/10 16:21 & 10/26/10 17:21 & 0.95 & orange & 25.2 & 8.44 & 12.96 & 4.52 & NA & NA & NA \\
\hline E1-RG-CP & 20 & 25 & 0.09 & 10/26/10 17:30 & 10/26/10 19:50 & 1.1 & $\begin{array}{c}\text { dark } \\
\text { red }\end{array}$ & 25.4 & 8.46 & 19.13 & 10.67 & NA & NA & NA \\
\hline
\end{tabular}

Table A.38. Datasheet for Column E2 Loading and Rinsing Information

\begin{tabular}{|c|c|c|c|c|c|c|c|c|c|c|c|c|c|c|}
\hline Sample & Bottle & Temp & Pump & Sampling & Sampling & Resin & Resin & Temp & Efflu & $\begin{array}{c}\text { nt Bottle } \\
\mathrm{g}\end{array}$ & eight, & Sam & Vial W & ght, g \\
\hline ID No. & $\begin{array}{l}\text { Size } \\
(\mathrm{mL})\end{array}$ & $\begin{array}{l}\text { Set } \\
\left({ }^{\circ} \mathrm{C}\right)\end{array}$ & $\begin{array}{c}\text { Setting } \\
\text { (mL/min) }\end{array}$ & Start Time & Stop Time & $\begin{array}{c}\text { Height } \\
\text { (cm) }\end{array}$ & Color & $\left({ }^{\circ} \mathrm{C}\right)$ & Tare & Gross & Net & Tare & Gross & Net \\
\hline E2-LD-0 & 20 & 50 & NA & $10 / 27 / 106: 56$ & $10 / 27 / 106: 56$ & NA & $\begin{array}{c}\text { dark } \\
\text { red }\end{array}$ & 48.3 & NA & NA & NA & 8.58 & NA & 3.54 \\
\hline \multicolumn{4}{|c|}{ Loading (LD) Phase Start Date/Time: } & 10/27/10 7:00 & & & & & & & & & & \\
\hline
\end{tabular}


Table A.38. Datasheet for Column E2 Loading and Rinsing Information

\begin{tabular}{|c|c|c|c|c|c|c|c|c|c|c|c|c|c|c|}
\hline \multirow{2}{*}{$\begin{array}{l}\text { Sample } \\
\text { ID No. }\end{array}$} & \multirow{2}{*}{$\begin{array}{l}\text { Bottle } \\
\text { Size } \\
(\mathrm{mL})\end{array}$} & \multirow{2}{*}{$\begin{array}{l}\text { Temp } \\
\text { Set } \\
\left({ }^{\circ} \mathrm{C}\right)\end{array}$} & \multirow{2}{*}{$\begin{array}{c}\text { Pump } \\
\text { Setting } \\
\text { (mL/min) }\end{array}$} & \multirow{2}{*}{$\begin{array}{l}\text { Sampling } \\
\text { Start Time }\end{array}$} & \multirow{2}{*}{$\begin{array}{l}\text { Sampling } \\
\text { Stop Time }\end{array}$} & \multirow{2}{*}{$\begin{array}{l}\text { Resin } \\
\text { Height } \\
\text { (cm) }\end{array}$} & \multirow{2}{*}{$\begin{array}{l}\text { Resin } \\
\text { Color }\end{array}$} & \multirow{2}{*}{$\begin{array}{l}\text { Temp } \\
\left({ }^{\circ} \mathrm{C}\right)\end{array}$} & \multicolumn{3}{|c|}{$\begin{array}{l}\text { Effluent Bottle Weight, } \\
\text { g }\end{array}$} & \multicolumn{3}{|c|}{ Sample Vial Weight, g } \\
\hline & & & & & & & & & Tare & Gross & Net & Tare & Gross & Net \\
\hline E2-LD-006 & 20 & 50 & 10.62 & 10/27/10 7:06 & 10/27/10 7:06 & NA & $\begin{array}{c}\text { dark } \\
\text { red }\end{array}$ & 45.6 & NA & NA & NA & 8.51 & NA & 3.11 \\
\hline E2-LD-012 & 20 & 50 & 10.62 & 10/27/10 7:12 & 10/27/10 7:12 & NA & $\begin{array}{l}\text { dark } \\
\text { red }\end{array}$ & 45.1 & NA & NA & NA & 8.55 & NA & 3.31 \\
\hline E2-LD-018 & 20 & 50 & 10.62 & 10/27/10 7:18 & 10/27/10 7:18 & NA & $\begin{array}{c}\text { dark } \\
\text { red }\end{array}$ & 45.8 & NA & NA & NA & 8.52 & NA & 3.45 \\
\hline E2-LD-024 & 20 & 50 & 10.62 & 10/27/10 7:24 & 10/27/10 7:24 & NA & $\begin{array}{l}\text { dark } \\
\text { red }\end{array}$ & 46.4 & NA & NA & NA & 8.57 & NA & 3.16 \\
\hline E2-LD-036 & 20 & 50 & 10.62 & 10/27/10 7:36 & 10/27/10 7:36 & NA & $\begin{array}{l}\text { dark } \\
\text { red }\end{array}$ & 48.2 & NA & NA & NA & 8.47 & NA & 3.41 \\
\hline E2-LD-048 & 20 & 50 & 10.62 & 10/27/10 7:48 & 10/27/10 7:48 & NA & $\begin{array}{l}\text { dark } \\
\text { red }\end{array}$ & 49.3 & NA & NA & NA & 8.53 & NA & 3.22 \\
\hline E2-LD-060 & 20 & 50 & 10.62 & 10/27/10 8:00 & 10/27/10 8:00 & NA & $\begin{array}{l}\text { dark } \\
\text { red }\end{array}$ & 49.9 & NA & NA & NA & 8.47 & NA & 3.08 \\
\hline E2-LD-080 & 20 & 50 & 10.62 & 10/27/10 8:20 & 10/27/10 8:20 & NA & $\begin{array}{l}\text { dark } \\
\text { red }\end{array}$ & 50.4 & NA & NA & NA & 8.42 & NA & 3.31 \\
\hline E2-LD-120 & 20 & 50 & 10.62 & 10/27/10 9:00 & 10/27/10 9:00 & NA & $\begin{array}{l}\text { dark } \\
\text { red }\end{array}$ & 50.9 & NA & NA & NA & 8.43 & NA & 3.23 \\
\hline E2-LD-180 & 20 & 50 & 10.62 & 10/27/10 10:00 & 10/27/10 10:00 & NA & $\begin{array}{l}\text { dark } \\
\text { red }\end{array}$ & 50.6 & NA & NA & NA & 8.41 & NA & 3.24 \\
\hline E2-LD-240 & 20 & 50 & 10.62 & 10/27/10 11:00 & 10/27/10 11:00 & NA & $\begin{array}{l}\text { dark } \\
\text { red }\end{array}$ & 50.0 & NA & NA & NA & 8.46 & NA & 3.20 \\
\hline E2-LD-600 & 20 & 50 & 10.62 & 10/27/10 17:00 & 10/27/10 17:00 & 1.2 & $\begin{array}{l}\text { dark } \\
\text { red }\end{array}$ & 49.1 & NA & NA & NA & 8.45 & NA & 3.36 \\
\hline E2-FD-CP & 20 & 50 & 0.09 & 10/27/10 17:15 & $10 / 27 / 1017: 15$ & 1.2 & $\begin{array}{l}\text { dark } \\
\text { red }\end{array}$ & 50.2 & 8.47 & 22.75 & 14.28 & NA & NA & NA \\
\hline E2-FDI-CP & 20 & 25 & 0.09 & 10/27/10 20:10 & $10 / 27 / 1022: 40$ & 1.25 & $\begin{array}{l}\text { very } \\
\text { dark } \\
\text { red }\end{array}$ & 25.6 & 8.50 & 20.21 & 11.71 & NA & NA & NA \\
\hline E2-AN-CP & 20 & 25 & 0.09 & 10/27/10 23:00 & 10/28/10 00:00 & 1.25 & $\begin{array}{l}\text { very } \\
\text { dark } \\
\text { red }\end{array}$ & 23.9 & 8.42 & 13.08 & 4.66 & NA & NA & NA \\
\hline
\end{tabular}


Table A.39. Datasheet for Column E2 Elution, Rinsing, and Regeneration Information

\begin{tabular}{|c|c|c|c|c|c|c|c|c|c|c|c|c|c|c|}
\hline \multirow{2}{*}{$\begin{array}{l}\text { Sample } \\
\text { ID No. }\end{array}$} & \multirow{2}{*}{$\begin{array}{l}\text { Bottle } \\
\text { Size } \\
(\mathrm{mL}) \\
\end{array}$} & \multirow{2}{*}{$\begin{array}{l}\text { Temp } \\
\text { Set } \\
\left({ }^{\circ} \mathrm{C}\right) \\
\end{array}$} & \multirow{2}{*}{$\begin{array}{c}\text { Pump } \\
\text { Setting } \\
\text { (mL/min) }\end{array}$} & \multirow{2}{*}{$\begin{array}{l}\text { Sampling } \\
\text { Start Time }\end{array}$} & \multirow{2}{*}{$\begin{array}{l}\text { Sampling } \\
\text { Stop Time }\end{array}$} & \multirow{2}{*}{$\begin{array}{l}\text { Resin } \\
\text { Height } \\
\text { (cm) }\end{array}$} & \multirow{2}{*}{$\begin{array}{l}\text { Resin } \\
\text { Color }\end{array}$} & \multirow{2}{*}{$\begin{array}{l}\text { Temp } \\
\left({ }^{\circ} \mathrm{C}\right)\end{array}$} & \multicolumn{3}{|c|}{$\begin{array}{c}\text { Effluent Bottle Weight, } \\
\text { g }\end{array}$} & \multicolumn{3}{|c|}{ Sample Vial Weight, g } \\
\hline & & & & & & & & & Tare & Gross & Net & Tare & Gross & Net \\
\hline \multicolumn{4}{|c|}{ Elution (EL) Phase Start Date/Time: } & 10/28/10 6:55 & & & & & & & & & & \\
\hline E2-EL-CP & 60 & 25 & 0.08 & 10/28/10 6:55 & $10 / 28 / 1015: 55$ & 1.0 & orange & 26.5 & 14.88 & 55.65 & 40.77 & 8.49 & 13.78 & 5.29 \\
\hline E2-EDI-CP & 20 & 25 & 0.09 & 10/28/10 16:10 & $10 / 28 / 1017: 10$ & 1.0 & orange & 24.0 & 8.61 & 11.73 & 3.12 & NA & NA & NA \\
\hline E2-RG-CP & 20 & 25 & 0.09 & $10 / 28 / 1017: 22$ & $10 / 28 / 1020: 12$ & 1.2 & $\begin{array}{c}\text { dark } \\
\text { red }\end{array}$ & 25.2 & 8.41 & 19.20 & 10.79 & NA & NA & NA \\
\hline
\end{tabular}

Table A.40. Datasheet for Column E3 Loading and Rinsing Information

\begin{tabular}{|c|c|c|c|c|c|c|c|c|c|c|c|c|c|c|}
\hline Sample & Bottle & Temp & Pump & Sampling & Sampling & Resin & Resin & Temp & \multicolumn{3}{|c|}{ Effluent Bottle Weight, g } & \multicolumn{3}{|c|}{ Sample Vial Weight, g } \\
\hline ID No. & $\begin{array}{l}\text { Size } \\
(\mathrm{mL})\end{array}$ & $\begin{array}{l}\text { Set } \\
\left({ }^{\circ} \mathrm{C}\right)\end{array}$ & $\begin{array}{c}\text { Setting } \\
\text { (mL/min) }\end{array}$ & Start Time & Stop Time & $\begin{array}{l}\text { Height } \\
(\mathrm{cm})\end{array}$ & Color & $\left({ }^{\circ} \mathrm{C}\right)$ & Tare & Gross & Net & Tare & Gross & Net \\
\hline E3-LD-0 & 20 & 50 & NA & 11/1/10 6:55 & $11 / 1 / 106: 55$ & 1.2 & $\begin{array}{c}\text { dark } \\
\text { red }\end{array}$ & 54.2 & NA & NA & NA & 8.48 & NA & 3.57 \\
\hline \multicolumn{4}{|c|}{ Loading (LD) Phase Start Date/Time: } & 11/1/10 7:00 & & & & & & & & & & \\
\hline E3-LD-006 & 20 & 50 & 7.08 & 11/1/10 7:06 & 11/1/10 7:06 & NA & $\begin{array}{l}\text { dark } \\
\text { red }\end{array}$ & 51.6 & NA & NA & NA & 8.47 & NA & 3.20 \\
\hline E3-LD-012 & 20 & 50 & 7.08 & 11/1/10 7:12 & 11/1/10 7:12 & NA & $\begin{array}{l}\text { dark } \\
\text { red }\end{array}$ & 50.2 & NA & NA & NA & 8.42 & NA & 3.19 \\
\hline E3-LD-018 & 20 & 50 & 7.08 & 11/1/10 7:18 & 11/1/10 7:18 & NA & $\begin{array}{l}\text { dark } \\
\text { red }\end{array}$ & 49.2 & NA & NA & NA & 8.56 & NA & 3.13 \\
\hline E3-LD-024 & 20 & 50 & 7.08 & $11 / 1 / 107: 24$ & $11 / 1 / 107: 24$ & NA & $\begin{array}{l}\text { dark } \\
\text { red }\end{array}$ & 48.9 & NA & NA & NA & 8.59 & NA & 3.12 \\
\hline E3-LD-036 & 20 & 50 & 7.08 & $11 / 1 / 107: 36$ & $11 / 1 / 107: 36$ & NA & $\begin{array}{l}\text { dark } \\
\text { red }\end{array}$ & 49.8 & NA & NA & NA & 8.55 & NA & 3.07 \\
\hline E3-LD-048 & 20 & 50 & 7.08 & 11/1/10 7:48 & $11 / 1 / 107: 48$ & NA & $\begin{array}{l}\text { dark } \\
\text { red }\end{array}$ & 50.5 & NA & NA & NA & 8.49 & NA & 3.00 \\
\hline E3-LD-060 & 20 & 50 & 7.08 & 11/1/10 8:00 & $11 / 1 / 108: 00$ & NA & $\begin{array}{l}\text { dark } \\
\text { red }\end{array}$ & 50.3 & NA & NA & NA & 8.39 & NA & 3.11 \\
\hline
\end{tabular}


Table A.40. Datasheet for Column E3 Loading and Rinsing Information

\begin{tabular}{|c|c|c|c|c|c|c|c|c|c|c|c|c|c|c|}
\hline \multirow{2}{*}{$\begin{array}{l}\text { Sample } \\
\text { ID No. }\end{array}$} & \multirow{2}{*}{$\begin{array}{c}\text { Bottle } \\
\text { Size } \\
(\mathrm{mL}) \\
\end{array}$} & \multirow{2}{*}{$\begin{array}{c}\text { Temp } \\
\text { Set } \\
\left({ }^{\circ} \mathrm{C}\right) \\
\end{array}$} & \multirow{2}{*}{$\begin{array}{c}\text { Pump } \\
\text { Setting } \\
\text { (mL/min) }\end{array}$} & \multirow{2}{*}{$\begin{array}{l}\text { Sampling } \\
\text { Start Time }\end{array}$} & \multirow{2}{*}{$\begin{array}{l}\text { Sampling } \\
\text { Stop Time }\end{array}$} & \multirow{2}{*}{$\begin{array}{c}\text { Resin } \\
\text { Height } \\
(\mathrm{cm})\end{array}$} & \multirow{2}{*}{$\begin{array}{l}\text { Resin } \\
\text { Color }\end{array}$} & \multirow{2}{*}{$\begin{array}{l}\text { Temp } \\
\left({ }^{\circ} \mathrm{C}\right)\end{array}$} & \multicolumn{3}{|c|}{ Effluent Bottle Weight, g } & \multicolumn{3}{|c|}{ Sample Vial Weight, g } \\
\hline & & & & & & & & & Tare & Gross & Net & Tare & Gross & Net \\
\hline E3-LD-080 & 20 & 50 & 7.08 & $11 / 1 / 108: 20$ & $11 / 1 / 108: 20$ & NA & $\begin{array}{c}\text { dark } \\
\text { red }\end{array}$ & 49.8 & NA & NA & NA & 8.41 & NA & 3.24 \\
\hline E3-LD-120 & 20 & 50 & 7.08 & 11/1/10 9:02 & 11/1/10 9:02 & NA & $\begin{array}{l}\text { dark } \\
\text { red }\end{array}$ & 49.4 & NA & NA & NA & 8.44 & NA & 3.09 \\
\hline E3-LD-180 & 20 & 50 & 7.08 & 11/1/10 10:00 & 11/1/10 10:00 & NA & $\begin{array}{l}\text { dark } \\
\text { red }\end{array}$ & 50.1 & NA & NA & NA & 8.51 & NA & 3.05 \\
\hline E3-LD-240 & 20 & 50 & 7.08 & 11/1/10 11:00 & 11/1/10 11:00 & NA & $\begin{array}{l}\text { almost } \\
\text { black }\end{array}$ & 50.3 & NA & NA & NA & 8.46 & NA & 3.29 \\
\hline E3-LD-600 & 20 & 50 & 7.08 & 11/1/10 17:00 & $11 / 1 / 1017: 00$ & NA & $\begin{array}{l}\text { almost } \\
\text { black }\end{array}$ & 49.8 & NA & NA & NA & 8.51 & NA & 3.27 \\
\hline E3-FD-CP & 20 & 50 & 0.09 & 11/1/10 17:13 & $11 / 1 / 1019: 43$ & 1.1 & $\begin{array}{l}\text { almost } \\
\text { black }\end{array}$ & 48.3 & 8.47 & 23.48 & 15.01 & NA & NA & NA \\
\hline E3-FDI-CP & 20 & 25 & 0.09 & 11/1/10 20:17 & 11/1/10 22:47 & 1.0 & $\begin{array}{l}\text { very } \\
\text { dark } \\
\text { red }\end{array}$ & 26.1 & 8.51 & 20.67 & 12.16 & NA & NA & NA \\
\hline E3-AN-CP & 20 & 25 & 0.09 & 11/1/10 23:00 & 11/2/10 00:00 & 0.9 & $\begin{array}{l}\text { very } \\
\text { dark } \\
\text { red }\end{array}$ & 24.7 & 8.54 & 13.33 & 4.79 & NA & NA & NA \\
\hline
\end{tabular}

Table A.41. Datasheet for Column E3 Elution, Rinsing, and Regeneration Information

\begin{tabular}{|c|c|c|c|c|c|c|c|c|c|c|c|c|c|c|}
\hline \multirow{2}{*}{$\begin{array}{l}\text { Sample } \\
\text { ID No. }\end{array}$} & \multirow{2}{*}{$\begin{array}{c}\text { Bottle } \\
\text { Size } \\
(\mathrm{mL}) \\
\end{array}$} & \multirow{2}{*}{$\begin{array}{c}\text { Temp } \\
\text { Set } \\
\left({ }^{\circ} \mathrm{C}\right) \\
\end{array}$} & \multirow{2}{*}{$\begin{array}{c}\text { Pump } \\
\text { Setting } \\
(\mathrm{mL} / \mathrm{min})\end{array}$} & \multirow{2}{*}{$\begin{array}{l}\text { Sampling } \\
\text { Start Time }\end{array}$} & \multirow{2}{*}{$\begin{array}{l}\text { Sampling } \\
\text { Stop Time }\end{array}$} & \multirow{2}{*}{$\begin{array}{l}\text { Resin } \\
\text { Height } \\
(\mathrm{cm})\end{array}$} & \multirow{2}{*}{$\begin{array}{l}\text { Resin } \\
\text { Color }\end{array}$} & \multirow{2}{*}{$\begin{array}{l}\text { Temp } \\
\left({ }^{\circ} \mathrm{C}\right)\end{array}$} & \multicolumn{3}{|c|}{ Effluent Bottle Weight, g } & \multicolumn{3}{|c|}{ 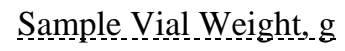 } \\
\hline & & & & & & & & & Tare & Gross & Net & Tare & Gross & Net \\
\hline Elution & L) $\mathrm{Ph}$ & e Start & ate/Time: & 11/2/10 7:00 & 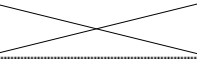 & 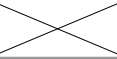 & & 8 & & $x^{2}$ & 8 & $>$ & 2 & $>$ \\
\hline E3-EL-CP & 60 & 25 & 0.08 & 11/2/10 7:00 & $11 / 2 / 1017: 00$ & 1.0 & orange & 26.4 & 14.92 & 57.73 & 42.81 & 8.50 & 14.95 & 6.45 \\
\hline E3-EDI-CP & 20 & 25 & 0.09 & $11 / 2 / 1017: 30$ & $11 / 21018: 30$ & NA & orange & 24.1 & 8.44 & 13.14 & 4.70 & NA & NA & NA \\
\hline E3-RG-CP & 20 & 25 & 0.09 & $11 / 2 / 1018: 40$ & 11/2/10 21:10 & 1.2 & $\begin{array}{l}\text { dark } \\
\text { red }\end{array}$ & 25.7 & 8.49 & 20.14 & 11.65 & NA & NA & NA \\
\hline
\end{tabular}


Table A.42. Datasheet for Column E4 Loading and Rinsing Information

\begin{tabular}{|c|c|c|c|c|c|c|c|c|c|c|c|c|c|c|}
\hline \multirow{2}{*}{$\begin{array}{l}\text { Sample } \\
\text { ID No. }\end{array}$} & \multirow{2}{*}{$\begin{array}{l}\text { Bottle } \\
\text { Size } \\
(\mathrm{mL})\end{array}$} & \multirow{2}{*}{$\begin{array}{l}\text { Temp } \\
\text { Set } \\
\left({ }^{\circ} \mathrm{C}\right)\end{array}$} & \multirow{2}{*}{$\begin{array}{c}\text { Pump } \\
\text { Setting } \\
\text { (mL/min) }\end{array}$} & \multirow{2}{*}{$\begin{array}{l}\text { Sampling } \\
\text { Start Time }\end{array}$} & \multirow{2}{*}{$\begin{array}{l}\text { Sampling } \\
\text { Stop Time }\end{array}$} & \multirow{2}{*}{$\begin{array}{l}\text { Resin } \\
\text { Height } \\
\text { (cm) }\end{array}$} & \multirow{2}{*}{$\begin{array}{l}\text { Resin } \\
\text { Color }\end{array}$} & \multirow{2}{*}{$\begin{array}{l}\text { Temp } \\
\left({ }^{\circ} \mathrm{C}\right)\end{array}$} & \multicolumn{3}{|c|}{ Effluent Bottle Weight, g } & \multicolumn{3}{|c|}{ Sample Vial Weight, g } \\
\hline & & & & & & & & & Tare & Gross & Net & Tare & Gross & Net \\
\hline E4-LD-0 & 20 & 50 & NA & $11 / 3 / 106: 48$ & $11 / 3 / 106: 48$ & 1.2 & $\begin{array}{l}\text { dark } \\
\text { red }\end{array}$ & 53.3 & NA & NA & NA & 8.44 & NA & 3.39 \\
\hline \multicolumn{4}{|c|}{ Loading (LD) Phase Start Date/Time: } & 11/3/10 6:55 & & & . & & & & & & $<$ & $>$ \\
\hline E4-LD-006 & 20 & 50 & 10.62 & 11/3/10 7:01 & 11/3/10 7:01 & NA & $\begin{array}{l}\text { dark } \\
\text { red }\end{array}$ & 51.6 & NA & NA & NA & 8.51 & NA & 3.11 \\
\hline E4-LD-012 & 20 & 50 & 10.62 & 11/3/10 7:07 & 11/3/10 7:07 & NA & $\begin{array}{l}\text { dark } \\
\text { red }\end{array}$ & 50.2 & NA & NA & NA & 8.61 & NA & 3.32 \\
\hline E4-LD-018 & 20 & 50 & 10.62 & 11/3/10 7:13 & 11/3/10 7:13 & NA & $\begin{array}{l}\text { dark } \\
\text { red }\end{array}$ & 49.7 & NA & NA & NA & 8.42 & NA & 3.22 \\
\hline E4-LD-024 & 20 & 50 & 10.62 & 11/3/10 7:19 & 11/3/10 7:19 & NA & $\begin{array}{l}\text { dark } \\
\text { red }\end{array}$ & 49.8 & NA & NA & NA & 8.50 & NA & 3.35 \\
\hline E4-LD-036 & 20 & 50 & 10.62 & 11/3/10 7:31 & 11/3/10 7:31 & NA & $\begin{array}{l}\text { dark } \\
\text { red }\end{array}$ & 49.9 & NA & NA & NA & 8.50 & NA & 3.26 \\
\hline E4-LD-048 & 20 & 50 & 10.62 & 11/3/10 7:43 & 11/3/10 7:43 & NA & $\begin{array}{l}\text { dark } \\
\text { red }\end{array}$ & 50.0 & NA & NA & NA & 8.59 & NA & 3.25 \\
\hline E4-LD-060 & 20 & 50 & 10.62 & 11/3/10 7:55 & 11/3/10 7:55 & NA & $\begin{array}{l}\text { dark } \\
\text { red }\end{array}$ & 50.1 & NA & NA & NA & 8.48 & NA & 3.26 \\
\hline E4-LD-080 & 20 & 50 & 10.62 & 11/310 8:15 & 11/310 8:15 & NA & $\begin{array}{c}\text { dark } \\
\text { red }\end{array}$ & 50.2 & NA & NA & NA & 8.45 & NA & 3.17 \\
\hline E4-LD-120 & 20 & 50 & 10.62 & 11/3/10 8:55 & 11/3/10 8:55 & NA & $\begin{array}{l}\text { dark } \\
\text { red }\end{array}$ & 50.3 & NA & NA & NA & 8.51 & NA & 3.31 \\
\hline E4-LD-180 & 20 & 50 & 10.62 & 11/3/10 9:55 & 11/3/10 9:55 & NA & $\begin{array}{l}\text { almost } \\
\text { black }\end{array}$ & 50.0 & NA & NA & NA & 8.56 & NA & 3.16 \\
\hline E4-LD-240 & 20 & 50 & 10.62 & 11/3/10 10:55 & 11/3/10 10:55 & NA & $\begin{array}{l}\text { almost } \\
\text { black }\end{array}$ & 50.3 & NA & NA & NA & 8.56 & NA & 3.12 \\
\hline E4-LD-600 & 20 & 50 & 10.62 & 11/3/10 16:55 & 11/3/10 16:55 & 1.3 & $\begin{array}{l}\text { almost } \\
\text { black }\end{array}$ & 50.0 & NA & NA & NA & 8.41 & NA & 3.31 \\
\hline E4-FD-CP & 20 & 50 & 0.09 & 11/3/10 17:05 & 11/3/10 19:35 & 1.2 & $\begin{array}{l}\text { almost } \\
\text { black }\end{array}$ & 48.8 & 8.31 & 22.37 & 14.06 & NA & NA & NA \\
\hline
\end{tabular}


Table A.43. Datasheet for Column E4B Loading and Rinsing Information

\begin{tabular}{|c|c|c|c|c|c|c|c|c|c|c|c|c|c|c|}
\hline \multirow{2}{*}{$\begin{array}{l}\text { Sample } \\
\text { ID No. }\end{array}$} & \multirow{2}{*}{$\begin{array}{l}\text { Bottle } \\
\text { Size } \\
(\mathrm{mL}) \\
\end{array}$} & \multirow{2}{*}{$\begin{array}{l}\text { Temp } \\
\text { Set } \\
\left({ }^{\circ} \mathrm{C}\right)\end{array}$} & \multirow{2}{*}{$\begin{array}{l}\text { Pump } \\
\text { Setting } \\
\text { (mL/min) }\end{array}$} & \multirow{2}{*}{$\begin{array}{l}\text { Sampling } \\
\text { Start Time }\end{array}$} & \multirow{2}{*}{$\begin{array}{l}\text { Sampling } \\
\text { Stop Time }\end{array}$} & \multirow{2}{*}{$\begin{array}{l}\text { Resin } \\
\text { Height } \\
(\mathrm{cm})\end{array}$} & \multirow{2}{*}{$\begin{array}{l}\text { Resin } \\
\text { Color }\end{array}$} & \multirow{2}{*}{$\begin{array}{l}\text { Temp } \\
\left({ }^{\circ} \mathrm{C}\right)\end{array}$} & \multicolumn{3}{|c|}{ Effluent Bottle Weight, g } & \multicolumn{3}{|c|}{ Sample Vial Weight, g } \\
\hline & & & & & & & & & Tare & Gross & Net & Tare & Gross & Net \\
\hline E4B-LD-0 & 20 & 50 & NA & 11/8/10 8:25 & 11/8/10 8:25 & 1.2 & $\begin{array}{c}\text { dark } \\
\text { red }\end{array}$ & 50.6 & NA & NA & NA & 8.53 & NA & 3.37 \\
\hline \multicolumn{4}{|c|}{ Loading (LD) Phase Start Date/Time: } & 11/8/10 8:30 & & & & & & & & & & \\
\hline E4B-LD-004 & 20 & 50 & 0.08 & $11 / 8 / 1012: 30$ & 11/8/10 12:30 & NA & $\begin{array}{c}\text { dark } \\
\text { red }\end{array}$ & 50.2 & NA & NA & NA & 8.47 & NA & 3.21 \\
\hline E4B-LD-008 & 20 & 50 & 0.08 & 11/8/10 16:30 & 11/8/10 16:30 & NA & $\begin{array}{l}\text { dark } \\
\text { red }\end{array}$ & 50.3 & NA & NA & NA & 8.43 & NA & 3.53 \\
\hline E4B-LD-012 & 20 & 50 & 0.08 & 11/8/10 20:30 & 11/8/10 20:30 & NA & $\begin{array}{l}\text { dark } \\
\text { red }\end{array}$ & 50.0 & NA & NA & NA & 8.45 & NA & 3.04 \\
\hline E4B-LD-024 & 20 & 50 & 0.08 & 11/9/10 8:30 & 11/9/10 8:30 & NA & $\begin{array}{l}\text { dark } \\
\text { red }\end{array}$ & 49.8 & NA & NA & NA & 8.53 & NA & 2.77 \\
\hline E4B-LD-072 & 20 & 50 & 0.08 & 11/11/10 8:30 & 11/11/10 8:30 & NA & $\begin{array}{c}\text { almost } \\
\text { black }\end{array}$ & 50.2 & NA & NA & NA & 8.54 & NA & 3.40 \\
\hline E4B-LD-120 & 20 & 50 & 0.08 & 11/13/10 8:30 & 11/13/10 8:30 & NA & $\begin{array}{l}\text { almost } \\
\text { black }\end{array}$ & 50.4 & NA & NA & NA & 8.55 & NA & 3.24 \\
\hline E4B-LD-168 & 20 & 50 & 0.08 & 11/15/10 8:30 & 11/15/10 8:30 & NA & $\begin{array}{l}\text { almost } \\
\text { black }\end{array}$ & 50.3 & NA & NA & NA & 8.40 & NA & 3.03 \\
\hline E4B-LD-336 & 20 & 50 & 0.08 & 11/22/10 8:30 & 11/22/10 8:30 & NA & $\begin{array}{l}\text { almost } \\
\text { black }\end{array}$ & 50.2 & NA & NA & NA & 8.55 & NA & 3.43 \\
\hline E4B-LD-504 & 20 & 50 & 0.08 & 11/29/10 8:31 & 11/29/10 8:31 & NA & $\begin{array}{l}\text { almost } \\
\text { black }\end{array}$ & 49.8 & NA & NA & NA & 8.52 & NA & 3.55 \\
\hline E4B-LD-672 & 20 & 50 & 0.08 & 12/6/10 8:31 & 12/6/10 8:31 & NA & $\begin{array}{l}\text { almost } \\
\text { black }\end{array}$ & 49.3 & NA & NA & NA & 8.58 & NA & 3.39 \\
\hline E4B-LD-720 & 20 & 50 & 0.08 & 12/8/10 8:30 & 12/8/10 8:30 & 1.4 & $\begin{array}{l}\text { almost } \\
\text { black }\end{array}$ & 50.2 & NA & NA & NA & 8.48 & NA & 3.37 \\
\hline E4B-FD-CP & 20 & 50 & 0.09 & $12 / 8 / 1011: 17$ & 12/8/10 13:17 & 1.4 & $\begin{array}{l}\text { almost } \\
\text { black }\end{array}$ & 50.1 & 8.51 & 21.67 & 13.16 & NA & NA & NA \\
\hline E4B-FDI-CP & 20 & 25 & 0.09 & $12 / 8 / 1014: 25$ & 12/8/10 16:55 & 1.4 & $\begin{array}{l}\text { almost } \\
\text { black }\end{array}$ & 24.8 & 8.59 & 19.87 & 11.28 & NA & NA & NA \\
\hline E4BAN-CP & 20 & 25 & 0.09 & 12/8/10 17:06 & 12/8/10 18:06 & 1.4 & $\begin{array}{l}\text { almost } \\
\text { black }\end{array}$ & 24.0 & 8.50 & 13.20 & 4.70 & NA & NA & NA \\
\hline
\end{tabular}


Table A.44. Datasheet for Column E4B Elution, Rinsing, and Regeneration Information

\begin{tabular}{|c|c|c|c|c|c|c|c|c|c|c|c|c|c|c|}
\hline Sample & Bottle & Temp & Pump & Sampling & Sampling & Resin & Resin & Temp & Efflue & Bottle. & ight, g & Samp & Vial W & ht, g \\
\hline ID No. & $\begin{array}{l}\text { Size } \\
(\mathrm{mL})\end{array}$ & $\begin{array}{l}\text { Set } \\
\left({ }^{\circ} \mathrm{C}\right)\end{array}$ & $\begin{array}{c}\text { Setting } \\
\text { (mL/min) }\end{array}$ & Start Time & Stop Time & $\begin{array}{c}\text { Height } \\
(\mathrm{cm})\end{array}$ & Color & $\left({ }^{\circ} \mathrm{C}\right)$ & Tare & Gross & Net & Tare & Gross & Net \\
\hline \multicolumn{4}{|c|}{ Elution (EL) Phase Start Date/Time: } & $12 / 9 / 106: 50$ & & & & & & & & & & \\
\hline E4B-EL-CP & 60 & 25 & 0.08 & 12/9/10 6:50 & $12 / 9 / 1016: 51$ & 1.2 & orange & 28.7 & 14.90 & 57.84 & 42.94 & 8.40 & 16.34 & 7.94 \\
\hline E4B-EDI-CP & 20 & 25 & 0.08 & 12/9/10 17:08 & 12/9/10 18:08 & 1.1 & orange & 26.0 & 8.42 & 12.62 & 4.20 & NA & NA & NA \\
\hline E4B-RG-CP & 20 & 25 & 0.09 & 12/9/10 18:20 & 12/9/10 20:20 & 1.3 & $\begin{array}{c}\text { dark } \\
\text { red }\end{array}$ & 26.5 & 8.51 & 20.32 & 11.81 & NA & NA & NA \\
\hline
\end{tabular}

Table A.45. Datasheet for Column E5 Loading and Rinsing Information

\begin{tabular}{|c|c|c|c|c|c|c|c|c|c|c|c|c|c|c|}
\hline \multirow{2}{*}{$\begin{array}{l}\text { Sample } \\
\text { ID No. }\end{array}$} & \multirow{2}{*}{$\begin{array}{l}\text { Bottle } \\
\text { Size } \\
(\mathrm{mL})\end{array}$} & \multirow{2}{*}{$\begin{array}{c}\text { Temp } \\
\text { Set } \\
\left({ }^{\circ} \mathrm{C}\right) \\
\end{array}$} & \multirow{2}{*}{$\begin{array}{c}\text { Pump } \\
\text { Setting } \\
\text { (mL/min) }\end{array}$} & \multirow{2}{*}{$\begin{array}{l}\text { Sampling } \\
\text { Start Time }\end{array}$} & \multirow{2}{*}{$\begin{array}{l}\text { Sampling } \\
\text { Stop Time }\end{array}$} & \multirow{2}{*}{$\begin{array}{l}\text { Resin } \\
\text { Height } \\
(\mathrm{cm}) \\
\end{array}$} & \multirow{2}{*}{$\begin{array}{l}\text { Resin } \\
\text { Color }\end{array}$} & \multirow{2}{*}{$\begin{array}{l}\text { Temp } \\
\left({ }^{\circ} \mathrm{C}\right)\end{array}$} & \multicolumn{3}{|c|}{ Effluent Bottle Weight, g } & \multicolumn{3}{|c|}{ Sample Vial Weight, g } \\
\hline & & & & & & & & & Tare & Gross & Net & Tare & Gross & Net \\
\hline E5-LD-0 & 20 & 50 & NA & $1 / 4 / 116: 54$ & $1 / 4 / 116: 54$ & 1.9 & $\begin{array}{c}\text { dark } \\
\text { brown }\end{array}$ & 50 & NA & NA & NA & 8.53 & 11.61 & 3.08 \\
\hline \multicolumn{4}{|c|}{ Loading (LD) Phase Start Date/Time: } & $1 / 4 / 117: 00$ & & & & & & & & & & \\
\hline E5-LD-006 & 20 & 50 & 10.62 & $1 / 4 / 117: 06$ & $1 / 4 / 117: 06$ & NA & $\begin{array}{l}\text { dark } \\
\text { brown }\end{array}$ & 45.5 & NA & NA & NA & 8.53 & 11.39 & 2.86 \\
\hline E5-LD-012 & 20 & 50 & 10.62 & $1 / 4 / 117: 12$ & $1 / 4 / 117: 12$ & NA & $\begin{array}{c}\text { dark } \\
\text { brown }\end{array}$ & 45.4 & NA & NA & NA & 8.50 & 11.42 & 2.92 \\
\hline E5-LD-018 & 20 & 50 & 10.62 & $1 / 4 / 117: 18$ & $1 / 4 / 117: 18$ & NA & $\begin{array}{c}\text { dark } \\
\text { brown }\end{array}$ & 45.6 & NA & NA & NA & 8.34 & 11.08 & 2.74 \\
\hline E5-LD-024 & 20 & 50 & 10.62 & $1 / 4 / 117: 24$ & $1 / 4 / 117: 24$ & NA & $\begin{array}{c}\text { dark } \\
\text { brown }\end{array}$ & 45.9 & NA & NA & NA & 8.50 & 11.56 & 3.06 \\
\hline E5-LD-036 & 20 & 50 & 10.62 & $1 / 4 / 117: 36$ & $1 / 4 / 117: 36$ & NA & $\begin{array}{c}\text { dark } \\
\text { brown }\end{array}$ & 46.2 & NA & NA & NA & 8.51 & 11.34 & 2.83 \\
\hline E5-LD-048 & 20 & 50 & 10.62 & $1 / 4 / 117: 48$ & $1 / 4 / 117: 48$ & NA & $\begin{array}{c}\text { dark } \\
\text { brown }\end{array}$ & 47.3 & NA & NA & NA & 8.50 & 11.11 & 2.61 \\
\hline E5-LD-060 & 20 & 50 & 10.62 & $1 / 4 / 118: 00$ & $1 / 4 / 118: 00$ & NA & $\begin{array}{l}\text { dark } \\
\text { brown }\end{array}$ & 50.5 & NA & NA & NA & 8.42 & 11.20 & 2.78 \\
\hline
\end{tabular}


Table A.45. Datasheet for Column E5 Loading and Rinsing Information

\begin{tabular}{|c|c|c|c|c|c|c|c|c|c|c|c|c|c|c|}
\hline \multirow{2}{*}{$\begin{array}{l}\text { Sample } \\
\text { ID No. }\end{array}$} & \multirow{2}{*}{$\begin{array}{l}\text { Bottle } \\
\text { Size } \\
(\mathrm{mL}) \\
\end{array}$} & \multirow{2}{*}{$\begin{array}{c}\text { Temp } \\
\text { Set } \\
\left({ }^{\circ} \mathrm{C}\right) \\
\end{array}$} & \multirow{2}{*}{$\begin{array}{c}\text { Pump } \\
\text { Setting } \\
\text { (mL/min) }\end{array}$} & \multirow{2}{*}{$\begin{array}{l}\text { Sampling } \\
\text { Start Time }\end{array}$} & \multirow{2}{*}{$\begin{array}{l}\text { Sampling } \\
\text { Stop Time }\end{array}$} & \multirow{2}{*}{$\begin{array}{l}\text { Resin } \\
\text { Height } \\
(\mathrm{cm}) \\
\end{array}$} & \multirow{2}{*}{$\begin{array}{l}\text { Resin } \\
\text { Color }\end{array}$} & \multirow{2}{*}{$\begin{array}{l}\text { Temp } \\
\left({ }^{\circ} \mathrm{C}\right) \\
\end{array}$} & \multicolumn{3}{|c|}{ Effluent Bottle Weight, g } & \multicolumn{3}{|c|}{ Sample Vial Weight, g } \\
\hline & & & & & & & & & Tare & Gross & Net & Tare & Gross & Net \\
\hline E5-LD-080 & 20 & 50 & 10.62 & 1/4/11 8:20 & $1 / 4 / 118: 20$ & NA & $\begin{array}{c}\text { dark } \\
\text { brown }\end{array}$ & 49.0 & NA & NA & NA & 8.35 & 11.28 & 2.93 \\
\hline E5-LD-120 & 20 & 50 & 10.62 & 1/4/11 21:15 & 1/4/11 21:15 & NA & $\begin{array}{c}\text { dark } \\
\text { brown }\end{array}$ & 41.5 & NA & NA & NA & 8.45 & 11.96 & 3.51 \\
\hline E5-LD-180 & 20 & 50 & 10.62 & 1/4/11 22:15 & 1/4/11 22:15 & NA & $\begin{array}{c}\text { dark } \\
\text { brown }\end{array}$ & 41.8 & NA & NA & NA & 8.48 & 11.67 & 3.19 \\
\hline E5-LD-240 & 20 & 50 & 10.62 & 1/4/11 23:15 & 1/4/11 23:15 & NA & $\begin{array}{c}\text { dark } \\
\text { brown }\end{array}$ & 42.9 & NA & NA & NA & 8.50 & 11.96 & 3.46 \\
\hline E5-LD-600 & 20 & 50 & 10.62 & 1/5/11 5:15 & 1/5/11 5:15 & NA & $\begin{array}{c}\text { dark } \\
\text { brown }\end{array}$ & 47.8 & NA & NA & NA & 8.54 & 11.41 & 2.87 \\
\hline E5-LD-900 & 20 & 50 & 10.62 & 1/5/11 10:15 & 1/5/11 10:15 & NA & $\begin{array}{c}\text { dark } \\
\text { brown }\end{array}$ & 48.8 & NA & NA & NA & 8.47 & 11.47 & 3.00 \\
\hline E5-LD-1200 & 20 & 50 & 10.62 & 1/5/11 15:15 & 1/5/11 15:15 & 1.9 & $\begin{array}{c}\text { dark } \\
\text { brown }\end{array}$ & 48.4 & NA & NA & NA & 8.56 & 11.48 & 2.92 \\
\hline E5-FD-CP & 20 & 50 & 0.09 & 1/5/11 15:25 & 1/5/11 18:05 & NA & $\begin{array}{c}\text { dark } \\
\text { brown }\end{array}$ & 58.1 & 8.56 & 21.73 & 13.17 & NA & NA & NA \\
\hline E5-FDI-CP & 20 & 25 & 0.09 & 1/5/11 18:17 & 1/5/11 20:47 & NA & $\begin{array}{c}\text { dark } \\
\text { brown }\end{array}$ & 26.8 & 8.50 & 21.00 & 12.50 & NA & NA & NA \\
\hline E5-AN-CP & 20 & 25 & 0.09 & 1/5/11 20:55 & 1/5/11 21:55 & NA & $\begin{array}{c}\text { dark } \\
\text { brown }\end{array}$ & NA & 8.46 & 13.07 & 4.61 & NA & NA & NA \\
\hline
\end{tabular}

Table A.46. Datasheet for Column E5 Elution, Rinsing, and Regeneration Information

\begin{tabular}{|c|c|c|c|c|c|c|c|c|c|c|c|c|c|c|}
\hline Sample & Bottle & Temp & Pump & Sampling & Sampling & Resin & Resin & Temp & Efflu- & gottle & eight, & Samp & Vial W & Sht, g \\
\hline ID No. & $\begin{array}{l}\text { Size } \\
(\mathrm{mL})\end{array}$ & $\begin{array}{l}\text { Set } \\
\left({ }^{\circ} \mathrm{C}\right)\end{array}$ & $\begin{array}{l}\text { Setting } \\
\text { (mL/min) }\end{array}$ & Start Time & Stop Time & $\begin{array}{l}\text { Height } \\
\text { (cm) }\end{array}$ & Color & $\left({ }^{\circ} \mathrm{C}\right)$ & Tare & Gross & Net & Tare & Gross & Net \\
\hline \multicolumn{4}{|c|}{ Elution (EL) Phase Start Date/Time: } & 1/5/11 22:04 & & & & & & & & & & \\
\hline E5-EL-CP & 60 & 25 & 0.09 & $1 / 5 / 1122: 04$ & $1 / 6 / 119: 04$ & 1.7 & $\begin{array}{l}\text { reddish } \\
\text { orange }\end{array}$ & 26.2 & 14.95 & 55.14 & 40.19 & 8.53 & 18.95 & 10.42 \\
\hline E5-EDI-CP & 20 & 25 & 0.09 & 1/6/11 9:10 & 1/6/11 10:13 & 1.6 & $\begin{array}{l}\text { reddish } \\
\text { orange }\end{array}$ & 25.1 & 8.39 & 12.47 & 4.08 & NA & NA & NA \\
\hline
\end{tabular}


Table A.47. Datasheet for Column F1 Pretreatment, Loading, and Rinsing Information

\begin{tabular}{|c|c|c|c|c|c|c|c|c|c|c|c|c|c|c|}
\hline \multirow{2}{*}{$\begin{array}{l}\text { Sample } \\
\text { ID No. }\end{array}$} & \multirow{2}{*}{$\begin{array}{l}\text { Bottle } \\
\text { Size } \\
(\mathrm{mL})\end{array}$} & \multirow{2}{*}{$\begin{array}{l}\text { Temp } \\
\text { Set } \\
\left({ }^{\circ} \mathrm{C}\right)\end{array}$} & \multirow{2}{*}{$\begin{array}{c}\text { Pump } \\
\text { Setting } \\
\text { (mL/min) }\end{array}$} & \multirow{2}{*}{$\begin{array}{l}\text { Sampling } \\
\text { Start Time }\end{array}$} & \multirow{2}{*}{$\begin{array}{l}\text { Sampling } \\
\text { Stop Time }\end{array}$} & \multirow{2}{*}{$\begin{array}{l}\text { Resin } \\
\text { Height } \\
(\mathrm{cm})\end{array}$} & \multirow{2}{*}{$\begin{array}{l}\text { Resin } \\
\text { Color }\end{array}$} & \multirow{2}{*}{$\begin{array}{l}\text { Temp } \\
\left({ }^{\circ} \mathrm{C}\right)\end{array}$} & \multicolumn{3}{|c|}{$\begin{array}{c}\text { Effluent Bottle Weight, } \\
\text { g }\end{array}$} & \multicolumn{3}{|c|}{ Sample Vial Weight, g } \\
\hline & & & & & & & & & Tare & Gross & Net & Tare & Gross & Net \\
\hline F1-PT-DIW1 & 20 & 25 & 0.09 & 4/25/11 12:16 & 4/25/11 14:46 & 1.1 & $\begin{array}{c}\text { dark } \\
\text { red }\end{array}$ & 23.8 & 8.50 & 21.49 & 12.99 & NA & NA & NA \\
\hline F1-PT-ACID & 20 & 25 & 0.09 & $4 / 25 / 11$ 14:51 & 4/25/11 18:30 & 1.0 & orange & 23.7 & 8.47 & 28.02 & 19.55 & NA & NA & NA \\
\hline F1-PT-DIW2 & 20 & 25 & 0.09 & $4 / 25 / 11$ 19:20 & 4/25/11 20:20 & 1.0 & orange & 23.4 & 8.50 & 13.48 & 4.98 & NA & NA & NA \\
\hline F1-PT-NaOH & 20 & 25 & 0.09 & 4/25/11 20:24 & 4/25/11 22:24 & 1.2 & $\begin{array}{c}\text { dark } \\
\text { red }\end{array}$ & 23.2 & 8.44 & 18.73 & 10.29 & NA & NA & NA \\
\hline F1-LD-0 & 20 & 55 & NA & 4/26/11 6:50 & 4/26/11 6:50 & 1.2 & $\begin{array}{c}\text { dark } \\
\text { red }\end{array}$ & 56.9 & NA & NA & NA & 8.50 & 15.67 & 7.17 \\
\hline \multicolumn{4}{|c|}{ Loading (LD) Phase Start Date/Time: } & 4/26/11 6:55 & & & & & & & & & & \\
\hline F1-LD-006 & 20 & 55 & 10.62 & 4/26/11 7:01 & 4/26/11 7:01 & NA & $\begin{array}{c}\text { dark } \\
\text { red }\end{array}$ & 52.9 & NA & NA & NA & 8.54 & 15.63 & 7.09 \\
\hline F1-LD-012 & 20 & 55 & 10.62 & 4/26/11 7:07 & 4/26/11 7:07 & NA & $\begin{array}{c}\text { dark } \\
\text { red }\end{array}$ & 51.0 & NA & NA & NA & 8.35 & 14.75 & 6.40 \\
\hline F1-LD-018 & 20 & 55 & 10.62 & 4/26/11 7:13 & 4/26/11 7:13 & NA & $\begin{array}{c}\text { dark } \\
\text { red }\end{array}$ & 50.3 & NA & NA & NA & 8.39 & 14.98 & 6.59 \\
\hline F1-LD-024 & 20 & 55 & 10.62 & 4/26/11 7:19 & 4/26/11 7:19 & NA & $\begin{array}{c}\text { dark } \\
\text { red }\end{array}$ & 50.4 & NA & NA & NA & 8.58 & 15.06 & 6.48 \\
\hline F1-LD-036 & 20 & 55 & 10.62 & 4/26/11 7:31 & 4/26/11 7:31 & NA & $\begin{array}{c}\text { dark } \\
\text { red }\end{array}$ & 51.4 & NA & NA & NA & 8.56 & 15.20 & 6.64 \\
\hline F1-LD-048 & 20 & 55 & 10.62 & 4/26/11 7:43 & 4/26/11 7:43 & NA & $\begin{array}{c}\text { dark } \\
\text { red }\end{array}$ & 52.0 & NA & NA & NA & 8.40 & 14.78 & 6.38 \\
\hline F1-LD-060 & 20 & 55 & 10.62 & 4/26/11 7:57 & 4/26/11 7:57 & NA & $\begin{array}{c}\text { dark } \\
\text { red }\end{array}$ & 52.9 & NA & NA & NA & 8.53 & 14.72 & 6.19 \\
\hline F1-LD-080 & 20 & 55 & 10.62 & 4/26/11 8:15 & 4/26/11 8:15 & NA & $\begin{array}{c}\text { dark } \\
\text { red }\end{array}$ & 53.6 & NA & NA & NA & 8.53 & 15.35 & 6.82 \\
\hline F1-LD-120 & 20 & 55 & 10.62 & 4/26/11 8:55 & 4/26/11 8:55 & NA & $\begin{array}{c}\text { dark } \\
\text { red }\end{array}$ & 54.4 & NA & NA & NA & 8.53 & 15.24 & 6.71 \\
\hline F1-LD-180 & 20 & 55 & 10.62 & 4/26/11 9:55 & 4/26/11 9:55 & NA & $\begin{array}{c}\text { dark } \\
\text { red }\end{array}$ & 54.8 & NA & NA & NA & 8.51 & 15.42 & 6.91 \\
\hline
\end{tabular}


Table A.47. Datasheet for Column F1 Pretreatment, Loading, and Rinsing Information

\begin{tabular}{|c|c|c|c|c|c|c|c|c|c|c|c|c|c|c|}
\hline \multirow{2}{*}{$\begin{array}{l}\text { Sample } \\
\text { ID No. }\end{array}$} & \multirow{2}{*}{$\begin{array}{l}\text { Bottle } \\
\text { Size } \\
(\mathrm{mL})\end{array}$} & \multirow{2}{*}{$\begin{array}{c}\text { Temp } \\
\text { Set } \\
\left({ }^{\circ} \mathrm{C}\right)\end{array}$} & \multirow{2}{*}{$\begin{array}{c}\text { Pump } \\
\text { Setting } \\
\text { (mL/min) }\end{array}$} & \multirow{2}{*}{$\begin{array}{l}\text { Sampling } \\
\text { Start Time }\end{array}$} & \multirow{2}{*}{$\begin{array}{l}\text { Sampling } \\
\text { Stop Time }\end{array}$} & \multirow{2}{*}{$\begin{array}{c}\text { Resin } \\
\text { Height } \\
\text { (cm) }\end{array}$} & \multirow{2}{*}{$\begin{array}{l}\text { Resin } \\
\text { Color }\end{array}$} & \multirow{2}{*}{$\begin{array}{l}\text { Temp } \\
\left({ }^{\circ} \mathrm{C}\right)\end{array}$} & \multicolumn{3}{|c|}{$\begin{array}{c}\text { Effluent Bottle Weight, } \\
\text { g }\end{array}$} & \multicolumn{3}{|c|}{ Sample Vial Weight, g } \\
\hline & & & & & & & & & Tare & Gross & Net & Tare & Gross & Net \\
\hline F1-LD-240 & 20 & 55 & 10.62 & 4/26/11 10:55 & 4/26/11 10:55 & NA & $\begin{array}{c}\text { dark } \\
\text { red }\end{array}$ & 54.8 & NA & NA & NA & 8.49 & 16.67 & 8.18 \\
\hline F1-LD-600 & 20 & 55 & 10.62 & 4/26/11 16:55 & 4/26/11 16:55 & NA & $\begin{array}{c}\text { dark } \\
\text { red }\end{array}$ & 54.9 & NA & NA & NA & 8.44 & 13.60 & 5.16 \\
\hline F1-FD-CP & 20 & 55 & 0.09 & 4/26/11 17:11 & 4/26/11 19:43 & NA & $\begin{array}{l}\text { dark } \\
\text { red }\end{array}$ & 56.0 & 8.53 & 23.03 & 14.50 & NA & NA & NA \\
\hline F1-FDI-CP & 20 & 25 & 0.09 & 4/26/11 20:13 & 4/26/11 23:02 & 1.2 & $\begin{array}{c}\text { dark } \\
\text { red }\end{array}$ & 24 & 8.44 & 20.53 & 12.09 & NA & NA & NA \\
\hline F1-AN-CP & 20 & 25 & 0.09 & 4/26/11 23:09 & 4/27/11 00:09 & 1.2 & $\begin{array}{l}\text { dark } \\
\text { red }\end{array}$ & 24 & 8.42 & 13.61 & 5.19 & NA & NA & NA \\
\hline
\end{tabular}

Table A.48. Datasheet for Column F1 Elution, Rinsing, and Regeneration Information

\begin{tabular}{|c|c|c|c|c|c|c|c|c|c|c|c|c|c|c|}
\hline \multirow{2}{*}{$\begin{array}{l}\text { Sample } \\
\text { ID No. }\end{array}$} & \multirow{2}{*}{$\begin{array}{c}\text { Bottle } \\
\text { Size } \\
(\mathrm{mL}) \\
\end{array}$} & \multirow{2}{*}{$\begin{array}{l}\text { Temp } \\
\text { Set } \\
\left({ }^{\circ} \mathrm{C}\right) \\
\end{array}$} & \multirow{2}{*}{$\begin{array}{c}\text { Pump } \\
\text { Setting } \\
\text { (mL/min) }\end{array}$} & \multirow{2}{*}{$\begin{array}{l}\text { Sampling } \\
\text { Start Time }\end{array}$} & \multirow{2}{*}{$\begin{array}{l}\text { Sampling } \\
\text { Stop Time }\end{array}$} & \multirow{2}{*}{$\begin{array}{l}\text { Resin } \\
\text { Height } \\
(\mathrm{cm}) \\
\end{array}$} & \multirow{2}{*}{$\begin{array}{l}\text { Resin } \\
\text { Color }\end{array}$} & \multirow{2}{*}{$\begin{array}{l}\text { Temp } \\
\left({ }^{\circ} \mathrm{C}\right)\end{array}$} & \multicolumn{3}{|c|}{ Effluent Bottle Weight, g } & \multicolumn{3}{|c|}{ Sample Vial Weight, g } \\
\hline & & & & & & & & & Tare & Gross & Net & Tare & Gross & Net \\
\hline \multicolumn{4}{|c|}{ Elution (EL) Phase Start Date/Time: } & $4 / 27 / 116: 47$ & & & & & & & & & & \\
\hline F1-EL-CP & 60 & 25 & 0.08 & $4 / 27 / 116: 47$ & $4 / 27 / 1117: 47$ & 1.0 & orange & 23.9 & 14.94 & 66.21 & 51.27 & 8.42 & 15.49 & 7.07 \\
\hline F1-EDI-CP & 20 & 25 & 0.09 & 4/27/11 17:59 & 4/27/11 18:59 & 1.0 & orange & 23.6 & 8.46 & 13.37 & 4.91 & NA & NA & NA \\
\hline F1-RG-CP & 20 & 25 & 0.09 & $4 / 27 / 11$ 19:04 & $4 / 27 / 1120: 34$ & 1.2 & $\begin{array}{c}\text { dark } \\
\text { red }\end{array}$ & 23.7 & 8.48 & 26.00 & 17.52 & NA & NA & NA \\
\hline
\end{tabular}

Table A.49. Datasheet for Column F2 Loading and Rinsing Information

\begin{tabular}{|c|c|c|c|c|c|c|c|c|c|c|c|c|c|c|}
\hline Sample & Bottle & Temp & Pump & Sampling & Sampling & Resin & Resin & Temp & \multicolumn{3}{|c|}{ Effluent Bottle Weight, g } & \multicolumn{3}{|c|}{ Sample Vial Weight, g } \\
\hline ID No. & $\begin{array}{l}\text { Size } \\
(\mathrm{mL})\end{array}$ & $\begin{array}{l}\text { Set } \\
\left({ }^{\circ} \mathrm{C}\right)\end{array}$ & $\begin{array}{l}\text { Setting } \\
\text { (mL/min) }\end{array}$ & Start Time & Stop Time & $\begin{array}{l}\text { Height } \\
\text { (cm) }\end{array}$ & Color & $\left({ }^{\circ} \mathrm{C}\right)$ & Tare & Gross & Net & Tare & Gross & Net \\
\hline F2-LD-0 & 20 & 55 & NA & $5 / 11 / 116: 34$ & $5 / 11 / 116: 34$ & 1.1 & $\begin{array}{c}\text { dark } \\
\text { red }\end{array}$ & 55.7 & NA & NA & NA & 8.49 & NA & 3.96 \\
\hline
\end{tabular}


Table A.49. Datasheet for Column F2 Loading and Rinsing Information

\begin{tabular}{|c|c|c|c|c|c|c|c|c|c|c|c|c|c|c|}
\hline \multirow{2}{*}{$\begin{array}{l}\text { Sample } \\
\text { ID No. }\end{array}$} & \multirow{2}{*}{$\begin{array}{l}\text { Bottle } \\
\text { Size } \\
(\mathrm{mL})\end{array}$} & \multirow{2}{*}{$\begin{array}{c}\text { Temp } \\
\text { Set } \\
\left({ }^{\circ} \mathrm{C}\right) \\
\end{array}$} & \multirow{2}{*}{$\begin{array}{c}\text { Pump } \\
\text { Setting } \\
\text { (mL/min) } \\
\end{array}$} & \multirow{2}{*}{$\begin{array}{l}\text { Sampling } \\
\text { Start Time }\end{array}$} & \multirow{2}{*}{$\begin{array}{l}\text { Sampling } \\
\text { Stop Time }\end{array}$} & \multirow{2}{*}{$\begin{array}{c}\text { Resin } \\
\text { Height } \\
(\mathrm{cm}) \\
\end{array}$} & \multirow{2}{*}{$\begin{array}{l}\text { Resin } \\
\text { Color }\end{array}$} & \multirow{2}{*}{$\begin{array}{l}\text { Temp } \\
\left({ }^{\circ} \mathrm{C}\right)\end{array}$} & \multicolumn{3}{|c|}{ Effluent Bottle Weight,g } & \multicolumn{3}{|c|}{ Sample Vial Weight, g } \\
\hline & & & & & & & & & Tare & Gross & Net & Tare & Gross & Net \\
\hline \multicolumn{4}{|c|}{ Loading (LD) Phase Start Date/Time: } & $5 / 11 / 116: 53$ & & & & & & & & & & \\
\hline F2-LD-006 & 20 & 55 & 10.62 & $5 / 11 / 116: 59$ & 5/11/11 6:59 & NA & $\begin{array}{c}\text { dark } \\
\text { red }\end{array}$ & 53.5 & NA & NA & NA & 8.61 & NA & 3.55 \\
\hline F2-LD-012 & 20 & 55 & 10.62 & 5/11/11 7:05 & 5/11/11 7:05 & NA & $\begin{array}{c}\text { dark } \\
\text { red }\end{array}$ & 52.9 & NA & NA & NA & 8.51 & NA & 3.17 \\
\hline F2-LD-018 & 20 & 55 & 10.62 & 5/11/11 7:11 & 5/11/11 7:11 & NA & $\begin{array}{c}\text { dark } \\
\text { red }\end{array}$ & 52.8 & NA & NA & NA & 8.47 & NA & 3.22 \\
\hline F2-LD-024 & 20 & 55 & 10.62 & 5/11/11 7:17 & $5 / 11 / 117: 17$ & NA & $\begin{array}{c}\text { dark } \\
\text { red }\end{array}$ & 52.8 & NA & NA & NA & 8.38 & NA & 3.41 \\
\hline F2-LD-036 & 20 & 55 & 10.62 & 5/11/11 7:31 & 5/11/11 7:31 & NA & $\begin{array}{c}\text { dark } \\
\text { red }\end{array}$ & 54.1 & NA & NA & NA & 8.52 & NA & 3.37 \\
\hline F2-LD-048 & 20 & 55 & 10.62 & 5/11/11 7:41 & 5/11/11 7:41 & NA & $\begin{array}{c}\text { dark } \\
\text { red }\end{array}$ & 53.9 & NA & NA & NA & 8.47 & NA & 3.43 \\
\hline F2-LD-060 & 20 & 55 & 10.62 & 5/11/11 7:53 & 5/11/11 7:53 & NA & $\begin{array}{c}\text { dark } \\
\text { red }\end{array}$ & 54.2 & NA & NA & NA & 8.45 & NA & 3.38 \\
\hline F2-LD-080 & 20 & 55 & 10.62 & 5/11/11 8:13 & 5/11/11 8:13 & NA & $\begin{array}{c}\text { dark } \\
\text { red }\end{array}$ & 54.6 & NA & NA & NA & 8.52 & NA & 3.24 \\
\hline F2-LD-120 & 20 & 55 & 10.62 & 5/11/11 8:53 & 5/11/11 8:53 & NA & $\begin{array}{c}\text { dark } \\
\text { red }\end{array}$ & 55.1 & NA & NA & NA & 8.47 & NA & 3.20 \\
\hline F2-LD-180 & 20 & 55 & 10.62 & 5/11/11 9:58 & 5/11/11 9:58 & NA & $\begin{array}{c}\text { dark } \\
\text { red }\end{array}$ & 54.5 & NA & NA & NA & 8.43 & NA & 3.65 \\
\hline F2-LD-240 & 20 & 55 & 10.62 & 5/11/11 10:53 & 5/11/11 10:53 & NA & $\begin{array}{c}\text { dark } \\
\text { red }\end{array}$ & 54.5 & NA & NA & NA & 8.49 & NA & 2.98 \\
\hline F2-LD-600 & 20 & 55 & 10.62 & 5/11/11 16:53 & 5/11/11 16:53 & 1.2 & $\begin{array}{c}\text { dark } \\
\text { red }\end{array}$ & 55.0 & NA & NA & NA & 8.46 & NA & 4.02 \\
\hline F2-FD-CP & 20 & 55 & 0.09 & 5/11/11 17:17 & 5/11/11 19:47 & 1.2 & $\begin{array}{c}\text { dark } \\
\text { red }\end{array}$ & 54.2 & 8.57 & 24.72 & 16.15 & NA & NA & NA \\
\hline F2-FDI-CP & 20 & 25 & 0.09 & 5/11/11 20:09 & 5/11/11 22:39 & 1.2 & $\begin{array}{c}\text { dark } \\
\text { red }\end{array}$ & 25.3 & 8.49 & 21.75 & 13.26 & NA & NA & NA \\
\hline F2-AN-CP & 20 & 25 & 0.09 & 5/11/11 22:46 & 5/11/11 23:46 & 1.2 & $\begin{array}{c}\text { dark } \\
\text { red }\end{array}$ & 25.3 & 8.40 & 13.66 & 5.26 & NA & NA & NA \\
\hline
\end{tabular}


Table A.50. Datasheet for Column F2 Elution, Rinsing, and Regeneration Information

\begin{tabular}{|c|c|c|c|c|c|c|c|c|c|c|c|c|c|c|}
\hline \multirow{2}{*}{$\begin{array}{l}\text { Sample } \\
\text { ID No. }\end{array}$} & \multirow{2}{*}{$\begin{array}{c}\text { Bottle } \\
\text { Size } \\
(\mathrm{mL})\end{array}$} & \multirow{2}{*}{$\begin{array}{c}\text { Temp } \\
\text { Set } \\
\left({ }^{\circ} \mathrm{C}\right) \\
\end{array}$} & \multirow{2}{*}{$\begin{array}{c}\text { Pump } \\
\text { Setting } \\
\text { (mL/min) }\end{array}$} & \multirow{2}{*}{$\begin{array}{l}\text { Sampling } \\
\text { Start Time }\end{array}$} & \multirow{2}{*}{$\begin{array}{l}\text { Sampling } \\
\text { Stop Time }\end{array}$} & \multirow{2}{*}{$\begin{array}{c}\text { Resin } \\
\text { Height } \\
\text { (cm) }\end{array}$} & \multirow{2}{*}{$\begin{array}{l}\text { Resin } \\
\text { Color }\end{array}$} & \multirow{2}{*}{$\begin{array}{l}\text { Temp } \\
\left({ }^{\circ} \mathrm{C}\right)\end{array}$} & \multicolumn{3}{|c|}{ Effluent Bottle Weight, g } & \multicolumn{3}{|c|}{ Sample Vial Weight, g } \\
\hline & & & & & & & & & Tare & Gross & Net & Tare & Gross & Net \\
\hline \multicolumn{4}{|c|}{ Elution (EL) Phase Start Date/Time: } & 5/12/11 6:40 & & & & & & & & & & \\
\hline F2-EL-CP & 60 & 25 & 0.09 & $5 / 12 / 116: 40$ & 5/12/11 18:40 & 1.2 & orange & $\mathrm{RT}$ & 14.91 & 71.44 & 56.53 & 8.49 & 18.39 & 9.90 \\
\hline F2-EDI-CP & 20 & 25 & 0.09 & 5/12/11 19:05 & 5/12/11 20:05 & 1.2 & orange & $\mathrm{RT}$ & 8.51 & 13.60 & 5.09 & NA & NA & NA \\
\hline F2-RG-CP & 20 & 25 & 0.10 & 5/12/11 20:10 & 5/12/11 22:40 & 1.2 & $\begin{array}{c}\text { dark } \\
\text { red }\end{array}$ & $\mathrm{RT}$ & 8.50 & 24.04 & 15.54 & NA & NA & NA \\
\hline
\end{tabular}

Table A.51. Datasheet for Column F3 Loading and Rinsing Information

\begin{tabular}{|c|c|c|c|c|c|c|c|c|c|c|c|c|c|c|}
\hline \multirow{2}{*}{$\begin{array}{l}\text { Sample } \\
\text { ID No. }\end{array}$} & \multirow{2}{*}{$\begin{array}{c}\text { Bottle } \\
\text { Size } \\
(\mathrm{mL}) \\
\end{array}$} & \multirow{2}{*}{$\begin{array}{c}\text { Temp } \\
\text { Set } \\
\left({ }^{\circ} \mathrm{C}\right) \\
\end{array}$} & \multirow{2}{*}{$\begin{array}{c}\text { Pump } \\
\text { Setting } \\
\text { (mL/min) }\end{array}$} & \multirow{2}{*}{$\begin{array}{l}\text { Sampling } \\
\text { Start Time }\end{array}$} & \multirow{2}{*}{$\begin{array}{l}\text { Sampling } \\
\text { Stop Time }\end{array}$} & \multirow{2}{*}{$\begin{array}{c}\text { Resin } \\
\text { Height } \\
(\mathrm{cm}) \\
\end{array}$} & \multirow{2}{*}{$\begin{array}{l}\text { Resin } \\
\text { Color }\end{array}$} & \multirow{2}{*}{$\begin{array}{l}\text { Temp } \\
\left({ }^{\circ} \mathrm{C}\right)\end{array}$} & \multicolumn{3}{|c|}{ Effluent Bottle Weight, g } & \multicolumn{3}{|c|}{ Sample Vial Weight, g } \\
\hline & & & & & & & & & Tare & Gross & Net & Tare & Gross & Net \\
\hline F3-LD-0 & 20 & 55 & NA & 5/17/11 6:42 & 5/17/11 6:42 & 1.1 & $\begin{array}{c}\text { dark } \\
\text { red }\end{array}$ & 60.0 & NA & NA & NA & 8.46 & NA & 3.82 \\
\hline \multicolumn{4}{|c|}{ Loading (LD) Phase Start Date/Time: } & $5 / 17 / 116: 48$ & & & & & & & & & & \\
\hline F3-LD-006 & 20 & 55 & 7.08 & $5 / 17 / 116: 54$ & $5 / 17 / 116: 54$ & NA & $\begin{array}{l}\text { almost } \\
\text { black }\end{array}$ & 55.6 & NA & NA & NA & 8.52 & NA & 4.12 \\
\hline F3-LD-012 & 20 & 55 & 7.08 & 5/17/11 7:00 & 5/17/11 7:00 & NA & $\begin{array}{l}\text { almost } \\
\text { black }\end{array}$ & 53.3 & NA & NA & NA & 8.53 & NA & 3.70 \\
\hline F3-LD-018 & 20 & 55 & 7.08 & 5/17/11 7:06 & 5/17/11 7:06 & NA & $\begin{array}{l}\text { almost } \\
\text { black }\end{array}$ & 52.2 & NA & NA & NA & 8.44 & NA & 4.03 \\
\hline F3-LD-024 & 20 & 55 & 7.08 & 5/17/11 7:12 & 5/17/11 7:12 & NA & $\begin{array}{l}\text { almost } \\
\text { black }\end{array}$ & 52.1 & NA & NA & NA & 8.46 & NA & 4.02 \\
\hline F3-LD-036 & 20 & 55 & 7.08 & $5 / 17 / 117: 24$ & $5 / 17 / 117: 24$ & NA & $\begin{array}{l}\text { almost } \\
\text { black }\end{array}$ & 53.0 & NA & NA & NA & 8.52 & NA & 3.84 \\
\hline F3-LD-048 & 20 & 55 & 7.08 & 5/17/11 7:36 & 5/17/11 7:36 & NA & $\begin{array}{l}\text { almost } \\
\text { black }\end{array}$ & 53.9 & NA & NA & NA & 8.61 & NA & 3.71 \\
\hline F3-LD-060 & 20 & 55 & 7.08 & 5/17/11 7:48 & 5/17/11 7:48 & NA & $\begin{array}{l}\text { almost } \\
\text { black }\end{array}$ & 54.6 & NA & NA & NA & 8.59 & NA & 3.93 \\
\hline F3-LD-080 & 20 & 55 & 7.08 & 5/17/11 8:08 & 5/17/11 8:08 & NA & $\begin{array}{l}\text { almost } \\
\text { black }\end{array}$ & 55.2 & NA & NA & NA & 8.58 & NA & 3.86 \\
\hline
\end{tabular}


Table A.51. Datasheet for Column F3 Loading and Rinsing Information

\begin{tabular}{|c|c|c|c|c|c|c|c|c|c|c|c|c|c|c|}
\hline \multirow{2}{*}{$\begin{array}{l}\text { Sample } \\
\text { ID No. }\end{array}$} & \multirow{2}{*}{$\begin{array}{l}\text { Bottle } \\
\text { Size } \\
(\mathrm{mL})\end{array}$} & \multirow{2}{*}{$\begin{array}{l}\text { Temp } \\
\text { Set } \\
\left({ }^{\circ} \mathrm{C}\right) \\
\end{array}$} & \multirow{2}{*}{$\begin{array}{c}\text { Pump } \\
\text { Setting } \\
(\mathrm{mL} / \mathrm{min})\end{array}$} & \multirow{2}{*}{$\begin{array}{l}\text { Sampling } \\
\text { Start Time }\end{array}$} & \multirow{2}{*}{$\begin{array}{l}\text { Sampling } \\
\text { Stop Time }\end{array}$} & \multirow{2}{*}{$\begin{array}{l}\text { Resin } \\
\text { Height } \\
(\mathrm{cm}) \\
\end{array}$} & \multirow{2}{*}{$\begin{array}{l}\text { Resin } \\
\text { Color }\end{array}$} & \multirow{2}{*}{$\begin{array}{l}\text { Temp } \\
\left({ }^{\circ} \mathrm{C}\right)\end{array}$} & \multicolumn{3}{|c|}{ 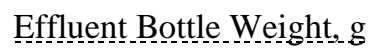 } & \multicolumn{3}{|c|}{ Sample Vial Weight,g g } \\
\hline & & & & & & & & & Tare & Gross & Net & Tare & Gross & Net \\
\hline F3-LD-120 & 20 & 55 & 7.08 & 5/17/11 8:58 & 5/17/11 8:58 & NA & $\begin{array}{l}\text { almost } \\
\text { black }\end{array}$ & 55.3 & NA & NA & NA & 8.49 & NA & 3.99 \\
\hline F3-LD-180 & 20 & 55 & 7.08 & 5/17/11 9:48 & 5/17/11 9:48 & NA & $\begin{array}{l}\text { almost } \\
\text { black }\end{array}$ & 55.3 & NA & NA & NA & 8.43 & NA & 4.08 \\
\hline F3-LD-240 & 20 & 55 & 7.08 & 5/17/11 10:48 & 5/17/11 10:48 & NA & $\begin{array}{l}\text { almost } \\
\text { black }\end{array}$ & 55.2 & NA & NA & NA & 8.52 & NA & 3.74 \\
\hline F3-LD-600 & 20 & 55 & 7.08 & 5/17/11 16:48 & 5/17/11 16:48 & NA & $\begin{array}{l}\text { almost } \\
\text { black }\end{array}$ & 54.7 & NA & NA & NA & 8.48 & NA & 4.19 \\
\hline F3-FD-CP & 20 & 55 & 0.08 & 5/17/11 17:06 & 5/17/11 19:36 & NA & $\begin{array}{l}\text { almost } \\
\text { black }\end{array}$ & 53.5 & 8.49 & 22.86 & 14.37 & NA & NA & NA \\
\hline F3-FDI-CP & 20 & 25 & 0.08 & 5/17/11 20:03 & 5/17/11 22:33 & NA & $\begin{array}{l}\text { almost } \\
\text { black }\end{array}$ & 23.2 & 8.54 & 20.48 & 11.94 & NA & NA & NA \\
\hline F3-AN-CP & 20 & 25 & 0.08 & 5/17/11 22:37 & 5/17/11 23:37 & 1.1 & $\begin{array}{l}\text { almost } \\
\text { black }\end{array}$ & 23.4 & 8.44 & 13.29 & 4.85 & NA & NA & NA \\
\hline
\end{tabular}

Table A.52. Datasheet for Column F3 Elution, Rinsing, and Regeneration Information

\begin{tabular}{|c|c|c|c|c|c|c|c|c|c|c|c|c|c|c|}
\hline \multirow{2}{*}{$\begin{array}{l}\text { Sample } \\
\text { ID No. }\end{array}$} & \multirow{2}{*}{$\begin{array}{l}\text { Bottle } \\
\text { Size } \\
(\mathrm{mL})\end{array}$} & \multirow{2}{*}{$\begin{array}{c}\text { Temp } \\
\text { Set } \\
\left({ }^{\circ} \mathrm{C}\right)\end{array}$} & \multirow{2}{*}{$\begin{array}{c}\text { Pump } \\
\text { Setting } \\
\text { (mL/min) }\end{array}$} & \multirow{2}{*}{$\begin{array}{l}\text { Sampling } \\
\text { Start Time }\end{array}$} & \multirow{2}{*}{$\begin{array}{l}\text { Sampling } \\
\text { Stop Time }\end{array}$} & \multirow{2}{*}{$\begin{array}{l}\text { Resin } \\
\text { Height } \\
(\mathrm{cm})\end{array}$} & \multirow{2}{*}{$\begin{array}{l}\text { Resin } \\
\text { Color }\end{array}$} & \multirow{2}{*}{$\begin{array}{l}\text { Temp } \\
\left({ }^{\circ} \mathrm{C}\right)\end{array}$} & \multicolumn{3}{|c|}{ Effluent Bottle Weight, g } & \multicolumn{3}{|c|}{ 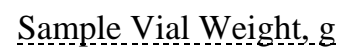 } \\
\hline & & & & & & & & & Tare & Gross & Net & Tare & Gross & Net \\
\hline Elution & L) $\mathrm{Ph}$ & e Start & ate/Time: & 5/18/11 6:50 & & & & & & & & & & \\
\hline F3-EL-CP & 60 & 25 & 0.08 & $5 / 18 / 116: 50$ & 5/18/11 18:50 & 0.8 & orange & 25.2 & 14.83 & 70.55 & 55.72 & 8.50 & 17.61 & 9.11 \\
\hline F3-EDI-CP & 20 & 25 & 0.09 & 5/18/11 19:03 & 5/18/11 20:03 & 0.8 & orange & RT & 8.39 & 13.38 & 4.99 & NA & NA & NA \\
\hline F3-RG-CP & 20 & 25 & 0.10 & 5/18/11 20:12 & 5/18/11 22:42 & 1.3 & $\begin{array}{l}\text { dark } \\
\text { red }\end{array}$ & 25.6 & 8.56 & 23.54 & 14.98 & NA & NA & NA \\
\hline
\end{tabular}


Table A.53. Datasheet for Column F4 Loading and Rinsing Information

\begin{tabular}{|c|c|c|c|c|c|c|c|c|c|c|c|c|c|c|}
\hline Sample & Bottle & Temp & Pump & Sampling & Sampling & Resin & Resin & Temp & \multicolumn{3}{|c|}{ Effluent Bottle Weight,g } & \multicolumn{3}{|c|}{ Sample Vial Weight, g } \\
\hline ID No. & $\begin{array}{l}\text { Size } \\
(\mathrm{mL})\end{array}$ & $\begin{array}{c}\text { Set } \\
\left({ }^{\circ} \mathrm{C}\right)\end{array}$ & $\begin{array}{c}\text { Setting } \\
(\mathrm{mL} / \mathrm{min})\end{array}$ & Start Time & Stop Time & $\begin{array}{l}\text { Height } \\
(\mathrm{cm})\end{array}$ & Color & $\left({ }^{\circ} \mathrm{C}\right)$ & Tare & Gross & Net & Tare & Gross & Net \\
\hline F4-LD-0 & 20 & 55 & NA & 5/25/11 6:51 & 5/25/11 6:51 & 1.2 & $\begin{array}{c}\text { dark } \\
\text { red }\end{array}$ & 63.5 & NA & NA & NA & 8.59 & NA & 3.40 \\
\hline \multicolumn{4}{|c|}{ Loading (LD) Phase Start Date/Time: } & 5/25/11 6:58 & & & & & & & & & & \\
\hline F4-LD-006 & 20 & 55 & 10.62 & 5/25/11 7:04 & 5/25/11 7:04 & NA & $\begin{array}{c}\text { dark } \\
\text { red }\end{array}$ & 57.8 & NA & NA & NA & 8.43 & NA & 3.20 \\
\hline F4-LD-012 & 20 & 55 & 10.62 & 5/25/11 7:10 & 5/25/11 7:10 & NA & $\begin{array}{c}\text { dark } \\
\text { red }\end{array}$ & 54.8 & NA & NA & NA & 8.58 & NA & 3.61 \\
\hline F4-LD-018 & 20 & 55 & 10.62 & 5/25/11 7:16 & 5/25/11 7:16 & NA & $\begin{array}{c}\text { dark } \\
\text { red }\end{array}$ & 52.7 & NA & NA & NA & 8.57 & NA & 3.60 \\
\hline F4-LD-024 & 20 & 55 & 10.62 & 5/25/11 7:22 & 5/25/11 7:22 & NA & $\begin{array}{c}\text { dark } \\
\text { red }\end{array}$ & 52.0 & NA & NA & NA & 8.56 & NA & 3.31 \\
\hline F4-LD-036 & 20 & 55 & 10.62 & 5/25/11 7:34 & 5/25/11 7:34 & NA & $\begin{array}{c}\text { dark } \\
\text { red }\end{array}$ & 52.5 & NA & NA & NA & 8.50 & NA & 3.34 \\
\hline F4-LD-048 & 20 & 55 & 10.62 & 5/25/11 7:46 & 5/25/11 7:46 & NA & $\begin{array}{c}\text { dark } \\
\text { red }\end{array}$ & 53.3 & NA & NA & NA & 8.55 & NA & 3.59 \\
\hline F4-LD-060 & 20 & 55 & 10.62 & 5/25/11 7:58 & 5/25/11 7:58 & NA & $\begin{array}{c}\text { dark } \\
\text { red }\end{array}$ & 53.7 & NA & NA & NA & 8.50 & NA & 3.59 \\
\hline F4-LD-080 & 20 & 55 & 10.62 & 5/25/11 8:18 & 5/25/11 8:18 & NA & $\begin{array}{c}\text { dark } \\
\text { red }\end{array}$ & 53.9 & NA & NA & NA & 8.46 & NA & 3.56 \\
\hline F4-LD-120 & 20 & 55 & 10.62 & 5/25/11 8:58 & 5/25/11 8:58 & NA & $\begin{array}{c}\text { dark } \\
\text { red }\end{array}$ & 54.3 & NA & NA & NA & 8.49 & NA & 3.48 \\
\hline F4-LD-180 & 20 & 55 & 10.62 & 5/25/11 9:58 & 5/25/11 9:58 & NA & $\begin{array}{c}\text { dark } \\
\text { red }\end{array}$ & 54.5 & NA & NA & NA & 8.54 & NA & 3.58 \\
\hline F4-LD-240 & 20 & 55 & 10.62 & 5/25/11 10:58 & 5/25/11 10:58 & NA & $\begin{array}{c}\text { dark } \\
\text { red }\end{array}$ & 54.2 & NA & NA & NA & 8.40 & NA & 3.62 \\
\hline F4-LD-600 & 20 & 55 & 10.62 & 5/25/11 16:58 & 5/25/11 16:58 & 1.2 & $\begin{array}{c}\text { dark } \\
\text { red }\end{array}$ & 54.9 & NA & NA & NA & 8.54 & NA & 3.73 \\
\hline F4-FD-CP & 20 & 55 & 0.09 & 5/25/11 17:16 & 5/25/11 19:46 & 1.2 & $\begin{array}{c}\text { dark } \\
\text { red }\end{array}$ & 55.2 & 8.55 & 23.31 & 14.76 & NA & NA & NA \\
\hline F4-FDI-CP & 20 & 25 & 0.09 & 5/25/11 20:19 & 5/25/11 22:49 & 1.2 & $\begin{array}{c}\text { dark } \\
\text { red }\end{array}$ & 25 & 8.46 & 21.40 & 12.94 & NA & NA & NA \\
\hline
\end{tabular}


Table A.54. Datasheet for Column F4B Loading and Rinsing Information

\begin{tabular}{|c|c|c|c|c|c|c|c|c|c|c|c|c|c|c|}
\hline \multirow{2}{*}{$\begin{array}{l}\text { Sample } \\
\text { ID No. }\end{array}$} & \multirow{2}{*}{$\begin{array}{l}\text { Bottle } \\
\text { Size } \\
(\mathrm{mL}) \\
\end{array}$} & \multirow{2}{*}{$\begin{array}{l}\text { Temp } \\
\text { Set } \\
\left({ }^{\circ} \mathrm{C}\right)\end{array}$} & \multirow{2}{*}{$\begin{array}{l}\text { Pump } \\
\text { Setting } \\
\text { (mL/min) }\end{array}$} & \multirow{2}{*}{$\begin{array}{l}\text { Sampling } \\
\text { Start Time }\end{array}$} & \multirow{2}{*}{$\begin{array}{l}\text { Sampling } \\
\text { Stop Time }\end{array}$} & \multirow{2}{*}{$\begin{array}{l}\text { Resin } \\
\text { Height } \\
(\mathrm{cm})\end{array}$} & \multirow{2}{*}{$\begin{array}{l}\text { Resin } \\
\text { Color }\end{array}$} & \multirow{2}{*}{$\begin{array}{l}\text { Temp } \\
\left({ }^{\circ} \mathrm{C}\right)\end{array}$} & \multicolumn{3}{|c|}{ Effluent Bottle Weight, g } & \multicolumn{3}{|c|}{ Sample Vial Weight, g } \\
\hline & & & & & & & & & Tare & Gross & Net & Tare & Gross & Net \\
\hline F4B-LD-0 & 20 & 55 & NA & 6/8/11 8:28 & 6/8/11 8:28 & 1.1 & $\begin{array}{l}\text { almost } \\
\text { black }\end{array}$ & 61.6 & NA & NA & NA & 8.56 & NA & 2.89 \\
\hline \multicolumn{4}{|c|}{ Loading (LD) Phase Start Date/Time: } & 6/8/11 8:33 & & & & & & & & & & \\
\hline F4B-LD-004 & 20 & 55 & 0.08 & 6/8/11 12:33 & 6/8/11 12:33 & NA & $\begin{array}{l}\text { almost } \\
\text { black }\end{array}$ & 57.7 & NA & NA & NA & 8.52 & NA & 3.31 \\
\hline F4B-LD-008 & 20 & 55 & 0.08 & 6/8/11 16:33 & 6/8/11 16:33 & NA & $\begin{array}{l}\text { almost } \\
\text { black }\end{array}$ & 55.1 & NA & NA & NA & 8.45 & NA & 3.88 \\
\hline F4B-LD-012 & 20 & 55 & 0.08 & 6/8/11 20:33 & 6/8/11 20:33 & NA & $\begin{array}{l}\text { almost } \\
\text { black }\end{array}$ & 55.5 & NA & NA & NA & 8.56 & NA & 3.72 \\
\hline F4B-LD-024 & 20 & 55 & 0.08 & 6/9/11 8:33 & 6/9/11 8:33 & NA & $\begin{array}{l}\text { almost } \\
\text { black }\end{array}$ & 55.7 & NA & NA & NA & 8.40 & NA & 3.74 \\
\hline F4B-LD-072 & 20 & 55 & 0.08 & 6/11/11 8:33 & 6/11/11 8:33 & NA & $\begin{array}{l}\text { almost } \\
\text { black }\end{array}$ & 55.4 & NA & NA & NA & 8.47 & NA & 3.67 \\
\hline F4B-LD-120 & 20 & 55 & 0.08 & 6/13/11 8:34 & 6/13/11 8:34 & NA & $\begin{array}{l}\text { almost } \\
\text { black }\end{array}$ & 55.3 & NA & NA & NA & 8.54 & NA & 3.85 \\
\hline F4B-LD-168 & 20 & 55 & 0.08 & 6/15/11 8:33 & 6/15/11 8:33 & NA & $\begin{array}{l}\text { almost } \\
\text { black }\end{array}$ & 56.0 & NA & NA & NA & 8.54 & NA & 3.59 \\
\hline F4B-LD-336 & 20 & 55 & 0.08 & 6/22/11 8:30 & 6/22/11 8:30 & NA & $\begin{array}{l}\text { almost } \\
\text { black }\end{array}$ & 55.1 & NA & NA & NA & 8.47 & NA & 2.80 \\
\hline F4B-LD-504 & 20 & 55 & 0.08 & 6/29/11 8:30 & 6/29/11 8:30 & NA & $\begin{array}{l}\text { almost } \\
\text { black }\end{array}$ & 55.6 & NA & NA & NA & 8.46 & NA & 3.74 \\
\hline F4B-FD-CP & 20 & 55 & 0.09 & 7/1/11 14:25 & 7/1/11 16:55 & 1.7 & black & 55.4 & 8.59 & 25.06 & 16.47 & NA & NA & NA \\
\hline F4B-FDI-CP & 20 & 25 & 0.09 & 7/1/11 17:08 & 7/1/11 19:38 & 1.7 & black & 25.1 & 8.36 & 21.54 & 13.18 & NA & NA & NA \\
\hline F4B-AN-CP & 20 & 25 & 0.09 & 7/5/11 9:45 & 7/5/11 10:45 & 1.6 & $\begin{array}{l}\text { reddish } \\
\text { brown }\end{array}$ & 25.3 & 8.57 & 14.08 & 5.51 & NA & NA & NA \\
\hline
\end{tabular}


Table A.55. Datasheet for Column F4B Elution, Rinsing, and Regeneration Information

\begin{tabular}{|c|c|c|c|c|c|c|c|c|c|c|c|c|c|c|}
\hline \multirow{2}{*}{$\begin{array}{l}\text { Sample } \\
\text { ID No. }\end{array}$} & \multirow{2}{*}{$\begin{array}{l}\text { Bottle } \\
\text { Size } \\
(\mathrm{mL})\end{array}$} & \multirow{2}{*}{$\begin{array}{l}\text { Temp } \\
\text { Set } \\
\left({ }^{\circ} \mathrm{C}\right)\end{array}$} & \multirow{2}{*}{$\begin{array}{c}\text { Pump } \\
\text { Setting } \\
\text { (mL/min) }\end{array}$} & \multirow{2}{*}{$\begin{array}{l}\text { Sampling } \\
\text { Start Time }\end{array}$} & \multirow{2}{*}{$\begin{array}{l}\text { Sampling } \\
\text { Stop Time }\end{array}$} & \multirow{2}{*}{$\begin{array}{l}\text { Resin } \\
\text { Height } \\
\text { (cm) }\end{array}$} & \multirow{2}{*}{$\begin{array}{l}\text { Resin } \\
\text { Color }\end{array}$} & \multirow{2}{*}{$\begin{array}{l}\text { Temp } \\
\left({ }^{\circ} \mathrm{C}\right)\end{array}$} & \multicolumn{3}{|c|}{$\begin{array}{l}\text { Effluent Bottle Weight, } \\
\text { g }\end{array}$} & \multicolumn{3}{|c|}{ Sample Vial Weight, g } \\
\hline & & & & & & & & & Tare & Gross & Net & Tare & Gross & Net \\
\hline \multicolumn{4}{|c|}{ Elution (EL) Phase Start Date/Time: } & 7/6/11 6:37 & & & & & & & & & & \\
\hline F4B-EL-CP & 60 & 25 & 0.08 & 7/6/11 6:37 & 7/6/11 16:37 & 1.3 & $\begin{array}{l}\text { brownish } \\
\text { red }\end{array}$ & RT & 14.92 & 60.55 & 45.63 & 8.37 & 15.99 & 7.62 \\
\hline F4B-EDI-CP & 20 & 25 & 0.08 & 7/6/11 16:52 & 7/6/11 17:52 & 1.3 & $\begin{array}{l}\text { brownish } \\
\text { red }\end{array}$ & RT & 8.46 & 12.93 & 4.47 & NA & NA & NA \\
\hline F4B-RG-CP & 20 & 25 & 0.09 & 7/6/11 18:03 & 7/6/11 20:03 & 1.7 & $\begin{array}{l}\text { brownish } \\
\text { red }\end{array}$ & RT & 8.40 & 21.25 & 12.85 & NA & NA & NA \\
\hline
\end{tabular}

Table A.56. Datasheet for Column F5 Loading and Rinsing Information

\begin{tabular}{|c|c|c|c|c|c|c|c|c|c|c|c|c|c|c|}
\hline Sample & Bottle & Temp & Pump & Sampling & Sampling & Resin & Resin & Temp & \multicolumn{3}{|c|}{ Effluent Bottle Weight, g } & \multicolumn{3}{|c|}{ Sample Vial Weight, g } \\
\hline ID No. & $\begin{array}{l}\text { Size } \\
(\mathrm{mL})\end{array}$ & $\begin{array}{l}\text { Set } \\
\left({ }^{\circ} \mathrm{C}\right)\end{array}$ & $\begin{array}{l}\text { Setting } \\
\text { (mL/min) }\end{array}$ & Start Time & Stop Time & $\begin{array}{c}\text { Height } \\
(\mathrm{cm})\end{array}$ & Color & $\left({ }^{\circ} \mathrm{C}\right)$ & Tare & Gross & Net & Tare & Gross & Net \\
\hline F5-LD-0 & 20 & 55 & NA & 7/7/11 6:37 & 7/7/11 6:37 & 1.5 & $\begin{array}{l}\text { brownish } \\
\text { red }\end{array}$ & 59.9 & NA & NA & NA & 8.53 & 12.07 & 3.54 \\
\hline \multicolumn{4}{|c|}{ Loading (LD) Phase Start Date/Time: } & 7/7/11 6:48 & & & & & & & & & & \\
\hline F5-LD-006 & 20 & 55 & 10.62 & 7/7/11 6:54 & 7/7/11 6:54 & NA & $\begin{array}{l}\text { brownish } \\
\text { red }\end{array}$ & 54.2 & NA & NA & NA & 8.39 & 11.79 & 3.40 \\
\hline F5-LD-012 & 20 & 55 & 10.62 & 7/7/11 7:00 & 7/7/11 7:00 & NA & $\begin{array}{l}\text { brownish } \\
\text { red }\end{array}$ & 51.8 & NA & NA & NA & 8.60 & 12.25 & 3.65 \\
\hline F5-LD-018 & 20 & 55 & 10.62 & 7/7/11 7:06 & 7/7/11 7:06 & NA & $\begin{array}{l}\text { brownish } \\
\text { red }\end{array}$ & 50.7 & NA & NA & NA & 8.64 & 12.16 & 3.52 \\
\hline F5-LD-024 & 20 & 55 & 10.62 & 7/7/11 7:12 & 7/7/11 7:12 & NA & $\begin{array}{l}\text { brownish } \\
\text { red }\end{array}$ & 50.3 & NA & NA & NA & 8.46 & 12.12 & 3.66 \\
\hline F5-LD-036 & 20 & 55 & 10.62 & 7/7/11 7:24 & 7/7/11 7:24 & NA & $\begin{array}{l}\text { brownish } \\
\text { red }\end{array}$ & 51.5 & NA & NA & NA & 8.54 & 11.90 & 3.36 \\
\hline F5-LD-048 & 20 & 55 & 10.62 & 7/7/11 7:36 & 7/7/11 7:36 & NA & $\begin{array}{l}\text { brownish } \\
\text { red }\end{array}$ & 52.3 & NA & NA & NA & 8.57 & 12.02 & 3.45 \\
\hline F5-LD-060 & 20 & 55 & 10.62 & 7/7/11 7:48 & 7/7/11 7:48 & NA & $\begin{array}{l}\text { dark } \\
\text { brown }\end{array}$ & 52.9 & NA & NA & NA & 8.43 & 11.95 & 3.52 \\
\hline
\end{tabular}


Table A.56. Datasheet for Column F5 Loading and Rinsing Information

\begin{tabular}{|c|c|c|c|c|c|c|c|c|c|c|c|c|c|c|}
\hline \multirow{2}{*}{$\begin{array}{l}\text { Sample } \\
\text { ID No. } \\
\end{array}$} & \multirow{2}{*}{$\begin{array}{c}\text { Bottle } \\
\text { Size } \\
(\mathrm{mL})\end{array}$} & \multirow{2}{*}{$\begin{array}{l}\text { Temp } \\
\text { Set } \\
\left({ }^{\circ} \mathrm{C}\right)\end{array}$} & \multirow{2}{*}{$\begin{array}{c}\text { Pump } \\
\text { Setting } \\
\text { (mL/min) }\end{array}$} & \multirow{2}{*}{$\begin{array}{l}\text { Sampling } \\
\text { Start Time }\end{array}$} & \multirow{2}{*}{$\begin{array}{l}\text { Sampling } \\
\text { Stop Time }\end{array}$} & \multirow{2}{*}{$\begin{array}{l}\text { Resin } \\
\text { Height } \\
(\mathrm{cm})\end{array}$} & \multirow{2}{*}{$\begin{array}{l}\text { Resin } \\
\text { Color }\end{array}$} & \multirow{2}{*}{$\begin{array}{l}\text { Temp } \\
\left({ }^{\circ} \mathrm{C}\right)\end{array}$} & \multicolumn{3}{|c|}{ Effluent Bottle Weight, g } & \multicolumn{3}{|c|}{ Sample Vial Weight,g g } \\
\hline & & & & & & & & & Tare & Gross & Net & Tare & Gross & Net \\
\hline F5-LD-080 & 20 & 55 & 10.62 & 7/7/11 8:08 & 7/7/11 8:08 & NA & $\begin{array}{c}\text { dark } \\
\text { brown }\end{array}$ & 53.0 & NA & NA & NA & 8.58 & 12.13 & 3.55 \\
\hline F5-LD-120 & 20 & 55 & 10.62 & 7/7/11 8:48 & 7/7/11 8:48 & NA & $\begin{array}{c}\text { dark } \\
\text { brown }\end{array}$ & 53.3 & NA & NA & NA & 8.39 & 11.79 & 3.40 \\
\hline F5-LD-180 & 20 & 55 & 10.62 & 7/7/11 9:48 & 7/7/11 9:48 & NA & $\begin{array}{c}\text { dark } \\
\text { brown }\end{array}$ & 53.6 & NA & NA & NA & 8.68 & 12.03 & 3.35 \\
\hline F5-LD-240 & 20 & 55 & 10.62 & 7/7/11 10:48 & 7/7/11 10:48 & NA & $\begin{array}{c}\text { dark } \\
\text { brown }\end{array}$ & 54.5 & NA & NA & NA & 8.57 & 12.03 & 3.46 \\
\hline F5-LD-600 & 20 & 55 & 10.62 & 7/7/11 16:48 & 7/7/11 16:48 & NA & $\begin{array}{c}\text { dark } \\
\text { brown }\end{array}$ & 55.1 & NA & NA & NA & 8.52 & 12.71 & 4.19 \\
\hline F5-FD-CP & 20 & 55 & 0.09 & 7/7/11 17:10 & 7/7/11 19:40 & NA & $\begin{array}{c}\text { dark } \\
\text { brown }\end{array}$ & NA & 8.61 & 23.68 & 15.07 & NA & NA & NA \\
\hline F5-FDI-CP & 20 & 25 & 0.09 & 7/7/11 19:58 & 7/7/11 22:28 & NA & $\begin{array}{c}\text { dark } \\
\text { brown }\end{array}$ & NA & 8.48 & 21.17 & 12.69 & NA & NA & NA \\
\hline F5-AN-CP & 20 & 25 & 0.09 & 7/7/11 22:32 & 7/7/11 23:32 & NA & $\begin{array}{c}\text { dark } \\
\text { brown }\end{array}$ & NA & 8.60 & 13.70 & 5.10 & NA & NA & NA \\
\hline
\end{tabular}

Table A.57. Datasheet for Column F5 Elution, Rinsing, and Regeneration Information

\begin{tabular}{|c|c|c|c|c|c|c|c|c|c|c|c|c|c|c|}
\hline Sample & Bottle & Temp & Pump & Sampling & Sampling & Resin & Resin & Temp & Efflu & te Bottle & leight, & Samp & Vial W & hht, g \\
\hline ID No. & $\begin{array}{l}\text { Size } \\
(\mathrm{mL})\end{array}$ & $\begin{array}{l}\text { Set } \\
\left({ }^{\circ} \mathrm{C}\right) \\
\end{array}$ & $\begin{array}{l}\text { Setting } \\
\text { (mL/min) }\end{array}$ & Start Time & Stop Time & $\begin{array}{l}\text { Height } \\
(\mathrm{cm})\end{array}$ & Color & $\left({ }^{\circ} \mathrm{C}\right)$ & Tare & Gross & Net & Tare & Gross & Net \\
\hline \multicolumn{4}{|c|}{ Elution (EL) Phase Start Date/Time: } & 7/11/11 6:40 & & & & & & & & & & \\
\hline F5-EL-CP & 60 & 25 & 0.08 & 7/11/11 6:40 & 7/11/11 16:40 & 1.1 & $\begin{array}{c}\text { orange } \\
\text { red }\end{array}$ & RT & 14.87 & 60.68 & 45.81 & 8.53 & 19.69 & 11.16 \\
\hline F5-EDI-CP & 20 & 25 & 0.08 & 7/11/11 16:48 & 7/11/11 17:48 & 1.1 & $\begin{array}{c}\text { orange } \\
\text { red }\end{array}$ & RT & 8.48 & 13.09 & 4.61 & NA & NA & NA \\
\hline
\end{tabular}


Table A.58. Datasheet for Column G1 Pretreatment, Loading, and Rinsing Information

\begin{tabular}{|c|c|c|c|c|c|c|c|c|c|c|c|c|c|c|}
\hline Sample & Bottle & Temp & Pump & Sampling & Sampling & Resin & Resin & Temp & \multicolumn{3}{|c|}{ Effluent Bottle Weight, g } & \multicolumn{3}{|c|}{ Sample Vial Weight, g } \\
\hline ID No. & $\begin{array}{l}\text { Size } \\
(\mathrm{mL})\end{array}$ & $\begin{array}{l}\text { Set } \\
\left({ }^{\circ} \mathrm{C}\right)\end{array}$ & $\begin{array}{l}\text { Setting } \\
\text { (mL/min) }\end{array}$ & Start Time & Stop Time & $\begin{array}{c}\text { Height } \\
\text { (cm) }\end{array}$ & Color & $\left({ }^{\circ} \mathrm{C}\right)$ & Tare & Gross & Net & Tare & Gross & Net \\
\hline G1-PT-DIW1 & 20 & 25 & 0.09 & 4/25/11 12:16 & 4/25/11 14:46 & 1.1 & $\begin{array}{c}\text { dark } \\
\text { red }\end{array}$ & 23.4 & 8.53 & 19.65 & 11.12 & NA & NA & NA \\
\hline G1-PT-ACID & 20 & 25 & 0.09 & $4 / 25 / 1114: 51$ & 4/25/11 19:01 & 1.0 & orange & 23.7 & NA & NA & 35.91 & NA & NA & NA \\
\hline G1-PT-DIW2 & 20 & 25 & 0.09 & 4/25/11 19:20 & $4 / 25 / 1120: 20$ & 1.0 & orange & 23.2 & 8.47 & 13.12 & 4.65 & NA & NA & NA \\
\hline G1-PT-NaOH & 20 & 25 & 0.09 & $4 / 25 / 1120: 24$ & 4/25/11 22:34 & 1.3 & $\begin{array}{c}\text { dark } \\
\text { red }\end{array}$ & 23.1 & 8.57 & 19.08 & 10.51 & NA & NA & NA \\
\hline G1-LD-0 & 20 & 60 & NA & 4/26/11 6:53 & 4/26/11 6:53 & 1.3 & $\begin{array}{l}\text { dark } \\
\text { red }\end{array}$ & 60.1 & NA & NA & NA & 8.54 & 15.29 & 6.75 \\
\hline \multicolumn{4}{|c|}{ Loading (LD) Phase Start Date/Time: } & 4/26/11 6:58 & & & & & & & & & & \\
\hline G1-LD-006 & 20 & 60 & 10.62 & 4/26/11 7:04 & 4/26/11 7:04 & NA & $\begin{array}{c}\text { dark } \\
\text { red }\end{array}$ & 55.5 & NA & NA & NA & 8.55 & 14.63 & 6.08 \\
\hline G1-LD-012 & 20 & 60 & 10.62 & 4/26/11 7:10 & 4/26/11 7:10 & NA & $\begin{array}{c}\text { dark } \\
\text { red }\end{array}$ & 53.2 & NA & NA & NA & 8.47 & 13.92 & 5.45 \\
\hline G1-LD-018 & 20 & 60 & 10.62 & 4/26/11 7:16 & 4/26/11 7:16 & NA & $\begin{array}{c}\text { dark } \\
\text { red }\end{array}$ & 52.5 & NA & NA & NA & 8.50 & 15.02 & 6.52 \\
\hline G1-LD-024 & 20 & 60 & 10.62 & 4/26/11 7:22 & 4/26/11 7:22 & NA & $\begin{array}{c}\text { dark } \\
\text { red }\end{array}$ & 52.5 & NA & NA & NA & 8.50 & 14.97 & 6.47 \\
\hline G1-LD-036 & 20 & 60 & 10.62 & 4/26/11 7:34 & 4/26/11 7:34 & NA & $\begin{array}{c}\text { dark } \\
\text { red }\end{array}$ & 53.0 & NA & NA & NA & 8.50 & 14.81 & 6.31 \\
\hline G1-LD-048 & 20 & 60 & 10.62 & 4/26/11 7:46 & 4/26/11 7:46 & NA & $\begin{array}{c}\text { dark } \\
\text { red }\end{array}$ & 53.3 & NA & NA & NA & 8.53 & 15.07 & 6.54 \\
\hline G1-LD-060 & 20 & 60 & 10.62 & 4/26/11 7:58 & 4/26/11 7:58 & NA & $\begin{array}{c}\text { dark } \\
\text { red }\end{array}$ & 54.0 & NA & NA & NA & 8.48 & 15.10 & 6.62 \\
\hline G1-LD-080 & 20 & 60 & 10.62 & 4/26/11 8:18 & 4/26/11 8:18 & NA & $\begin{array}{l}\text { dark } \\
\text { red }\end{array}$ & 54.5 & NA & NA & NA & 8.55 & 14.15 & 5.60 \\
\hline G1-LD-120 & 20 & 60 & 10.62 & 4/26/11 8:58 & 4/26/11 8:58 & NA & $\begin{array}{c}\text { dark } \\
\text { red }\end{array}$ & 55.3 & NA & NA & NA & 8.51 & 14.43 & 5.92 \\
\hline G1-LD-180 & 20 & 60 & 10.62 & 4/26/11 9:58 & 4/26/11 9:58 & NA & $\begin{array}{c}\text { dark } \\
\text { red }\end{array}$ & 57.1 & NA & NA & NA & 8.49 & 14.05 & 5.56 \\
\hline G1-LD-240 & 20 & 60 & 10.62 & $4 / 26 / 1110: 58$ & $4 / 26 / 1110: 58$ & NA & $\begin{array}{c}\text { dark } \\
\text { red }\end{array}$ & 57.4 & NA & NA & NA & 8.54 & 15.62 & 7.08 \\
\hline
\end{tabular}


Table A.58. Datasheet for Column G1 Pretreatment, Loading, and Rinsing Information

\begin{tabular}{|c|c|c|c|c|c|c|c|c|c|c|c|c|c|c|}
\hline \multirow{2}{*}{$\begin{array}{l}\text { Sample } \\
\text { ID No. }\end{array}$} & \multirow{2}{*}{$\begin{array}{c}\text { Bottle } \\
\text { Size } \\
(\mathrm{mL})\end{array}$} & \multirow{2}{*}{$\begin{array}{c}\text { Temp } \\
\text { Set } \\
\left({ }^{\circ} \mathrm{C}\right)\end{array}$} & \multirow{2}{*}{$\begin{array}{c}\text { Pump } \\
\text { Setting } \\
\text { (mL/min) }\end{array}$} & \multirow{2}{*}{$\begin{array}{l}\text { Sampling } \\
\text { Start Time }\end{array}$} & \multirow{2}{*}{$\begin{array}{l}\text { Sampling } \\
\text { Stop Time }\end{array}$} & \multirow{2}{*}{$\begin{array}{c}\text { Resin } \\
\text { Height } \\
\text { (cm) }\end{array}$} & \multirow{2}{*}{$\begin{array}{l}\text { Resin } \\
\text { Color }\end{array}$} & \multirow{2}{*}{$\begin{array}{l}\text { Temp } \\
\left({ }^{\circ} \mathrm{C}\right)\end{array}$} & \multicolumn{3}{|c|}{ Effluent Bottle Weight,g } & \multicolumn{3}{|c|}{ Sample Vial Weight, g } \\
\hline & & & & & & & & & Tare & Gross & Net & Tare & Gross & Net \\
\hline G1-LD-600 & 20 & 60 & 10.62 & 4/26/11 16:58 & 4/26/11 16:58 & NA & $\begin{array}{c}\text { dark } \\
\text { red }\end{array}$ & 59.7 & NA & NA & NA & 8.48 & 12.98 & 4.50 \\
\hline G1-FD-CP & 20 & 60 & 0.09 & 4/26/11 17:11 & 4/26/11 19:43 & NA & $\begin{array}{c}\text { dark } \\
\text { red }\end{array}$ & 59.9 & 8.46 & 24.85 & 16.39 & NA & NA & NA \\
\hline G1-FDI-CP & 20 & 25 & 0.09 & 4/26/11 20:13 & 4/26/11 23:02 & 1.3 & $\begin{array}{c}\text { dark } \\
\text { red }\end{array}$ & 24 & 8.54 & 18.36 & 9.82 & NA & NA & NA \\
\hline G1-AN-CP & 20 & 25 & 0.09 & 4/26/11 23:09 & 4/27/11 00:09 & 1.3 & $\begin{array}{c}\text { dark } \\
\text { red }\end{array}$ & 24 & 8.51 & 13.24 & 4.73 & NA & NA & NA \\
\hline
\end{tabular}

Table A.59. Datasheet for Column G1 Elution, Rinsing, and Regeneration Information

\begin{tabular}{|c|c|c|c|c|c|c|c|c|c|c|c|c|c|c|}
\hline Sample & Bottle & Temp & Pump & Sampling & Sampling & Resin & Resin & Temp & \multicolumn{3}{|c|}{ Effluent Bottle Weight, g } & \multicolumn{3}{|c|}{ Sample Vial Weight, g } \\
\hline ID No. & $\begin{array}{l}\text { Size } \\
(\mathrm{mL})\end{array}$ & $\begin{array}{l}\text { Set } \\
\left({ }^{\circ} \mathrm{C}\right)\end{array}$ & $\begin{array}{c}\text { Setting } \\
\text { (mL/min) }\end{array}$ & Start Time & Stop Time & $\begin{array}{c}\text { Height } \\
(\mathrm{cm})\end{array}$ & Color & $\left({ }^{\circ} \mathrm{C}\right)$ & Tare & Gross & Net & Tare & Gross & Net \\
\hline \multicolumn{4}{|c|}{ Elution (EL) Phase Start Date/Time: } & $4 / 27 / 116: 47$ & & & & & & & & & & \\
\hline G1-EL-CP & 60 & 25 & 0.08 & $4 / 27 / 116: 47$ & 4/27/11 17:47 & 0.9 & orange & 25 & 14.96 & 61.72 & 46.76 & 8.50 & 16.38 & 7.88 \\
\hline G1-EDI-CP & 20 & 25 & 0.09 & 4/27/11 17:59 & 4/27/11 18:59 & 0.9 & orange & 25.0 & 8.56 & 13.22 & 4.66 & NA & NA & NA \\
\hline G1-RG-CP & 20 & 25 & 0.20 & 4/27/11 19:04 & $4 / 27 / 1120: 34$ & 1.3 & $\begin{array}{l}\text { dark } \\
\text { red }\end{array}$ & 25.7 & 8.40 & 24.35 & 15.95 & NA & NA & NA \\
\hline
\end{tabular}

Table A.60. Datasheet for Column G2 Loading and Rinsing Information

\begin{tabular}{|c|c|c|c|c|c|c|c|c|c|c|c|c|c|c|}
\hline Sample & Bottle & Temp & Pump & Sampling & Sampling & Resin & Resin & Temp & \multicolumn{3}{|c|}{ Effluent Bottle Weight,g } & \multicolumn{3}{|c|}{ Sample Vial Weight, g } \\
\hline ID No. & $\begin{array}{l}\text { Size } \\
(\mathrm{mL})\end{array}$ & $\begin{array}{l}\text { Set } \\
\left({ }^{\circ} \mathrm{C}\right)\end{array}$ & $\begin{array}{c}\text { Setting } \\
\text { (mL/min) }\end{array}$ & Start Time & Stop Time & $\begin{array}{c}\text { Height } \\
(\mathrm{cm})\end{array}$ & Color & $\left({ }^{\circ} \mathrm{C}\right)$ & Tare & Gross & Net & Tare & Gross & Net \\
\hline G2-LD-0 & 20 & 60 & NA & 5/11/11 6:36 & 5/11/11 6:36 & 1.2 & $\begin{array}{c}\text { dark } \\
\text { red }\end{array}$ & 60.4 & NA & NA & NA & 8.48 & NA & 4.10 \\
\hline \multicolumn{4}{|c|}{ Loading (LD) Phase Start Date/Time: } & $5 / 11 / 116: 50$ & & & & & & & & & & \\
\hline G2-LD-006 & 20 & 60 & 10.62 & $5 / 11 / 116: 56$ & 5/11/11 6:56 & NA & $\begin{array}{c}\text { dark } \\
\text { red }\end{array}$ & 57.6 & NA & NA & NA & 8.56 & NA & 3.08 \\
\hline
\end{tabular}


Table A.60. Datasheet for Column G2 Loading and Rinsing Information

\begin{tabular}{|c|c|c|c|c|c|c|c|c|c|c|c|c|c|c|}
\hline \multirow{2}{*}{$\begin{array}{l}\text { Sample } \\
\text { ID No. }\end{array}$} & \multirow{2}{*}{$\begin{array}{l}\text { Bottle } \\
\text { Size } \\
(\mathrm{mL})\end{array}$} & \multirow{2}{*}{$\begin{array}{c}\text { Temp } \\
\text { Set } \\
\left({ }^{\circ} \mathrm{C}\right) \\
\end{array}$} & \multirow{2}{*}{$\begin{array}{c}\text { Pump } \\
\text { Setting } \\
(\mathrm{mL} / \mathrm{min}) \\
\end{array}$} & \multirow{2}{*}{$\begin{array}{l}\text { Sampling } \\
\text { Start Time }\end{array}$} & \multirow{2}{*}{$\begin{array}{l}\text { Sampling } \\
\text { Stop Time }\end{array}$} & \multirow{2}{*}{$\begin{array}{l}\text { Resin } \\
\text { Height } \\
(\mathrm{cm}) \\
\end{array}$} & \multirow{2}{*}{$\begin{array}{l}\text { Resin } \\
\text { Color }\end{array}$} & \multirow{2}{*}{$\begin{array}{l}\text { Temp } \\
\left({ }^{\circ} \mathrm{C}\right)\end{array}$} & \multicolumn{3}{|c|}{ Effluent Bottle Weight, g } & \multicolumn{3}{|c|}{ Sample Vial Weight, g } \\
\hline & & & & & & & & & Tare & Gross & Net & Tare & Gross & Net \\
\hline G2-LD-012 & 20 & 60 & 10.62 & 5/11/11 7:02 & 5/11/11 7:02 & NA & $\begin{array}{c}\text { dark } \\
\text { red }\end{array}$ & 56.8 & NA & NA & NA & 8.49 & NA & 3.37 \\
\hline G2-LD-018 & 20 & 60 & 10.62 & 5/11/11 7:08 & 5/11/11 7:08 & NA & $\begin{array}{l}\text { dark } \\
\text { red }\end{array}$ & 56.3 & NA & NA & NA & 8.50 & NA & 2.86 \\
\hline G2-LD-024 & 20 & 60 & 10.62 & 5/11/11 7:14 & 5/11/11 7:14 & NA & $\begin{array}{l}\text { dark } \\
\text { red }\end{array}$ & 56.1 & NA & NA & NA & 8.58 & NA & 3.27 \\
\hline G2-LD-036 & 20 & 60 & 10.62 & 5/11/11 7:27 & 5/11/11 7:27 & NA & $\begin{array}{l}\text { dark } \\
\text { red }\end{array}$ & 56.0 & NA & NA & NA & 8.42 & NA & 3.42 \\
\hline G2-LD-048 & 20 & 60 & 10.62 & 5/11/11 7:38 & 5/11/11 7:38 & NA & $\begin{array}{c}\text { dark } \\
\text { red }\end{array}$ & 56.3 & NA & NA & NA & 8.48 & NA & 3.48 \\
\hline G2-LD-060 & 20 & 60 & 10.62 & 5/11/11 7:51 & $5 / 11 / 117: 51$ & NA & $\begin{array}{l}\text { dark } \\
\text { red }\end{array}$ & 56.9 & NA & NA & NA & 8.47 & NA & 3.21 \\
\hline G2-LD-080 & 20 & 60 & 10.62 & 5/11/11 8:10 & 5/11/11 8:10 & NA & $\begin{array}{l}\text { dark } \\
\text { red }\end{array}$ & 57.4 & NA & NA & NA & 8.49 & NA & 3.05 \\
\hline G2-LD-120 & 20 & 60 & 10.62 & 5/11/11 8:50 & 5/11/11 8:50 & NA & $\begin{array}{l}\text { dark } \\
\text { red }\end{array}$ & 57.7 & NA & NA & NA & 8.49 & NA & 3.32 \\
\hline G2-LD-180 & 20 & 60 & 10.62 & 5/11/11 9:57 & 5/11/11 9:57 & NA & $\begin{array}{l}\text { dark } \\
\text { red }\end{array}$ & 58.2 & NA & NA & NA & 8.46 & NA & 3.33 \\
\hline G2-LD-240 & 20 & 60 & 10.62 & 5/11/11 10:50 & $5 / 11 / 1110: 50$ & NA & $\begin{array}{l}\text { dark } \\
\text { red }\end{array}$ & 58.1 & NA & NA & NA & 8.45 & NA & 3.37 \\
\hline G2-LD-600 & 20 & 60 & 10.62 & 5/11/11 16:50 & 5/11/11 16:50 & NA & $\begin{array}{l}\text { dark } \\
\text { red }\end{array}$ & 59.4 & NA & NA & NA & 8.56 & NA & 3.69 \\
\hline G2-FD-CP & 20 & 60 & 0.09 & $5 / 11 / 11$ 17:17 & 5/11/11 19:47 & 1.2 & $\begin{array}{l}\text { dark } \\
\text { red }\end{array}$ & 61.3 & 8.48 & 22.63 & 14.15 & NA & NA & NA \\
\hline G2-FDI-CP & 20 & 25 & 0.09 & 5/11/11 20:09 & 5/11/11 22:39 & 1.2 & $\begin{array}{l}\text { dark } \\
\text { red }\end{array}$ & 25.3 & 8.43 & 19.93 & 11.50 & NA & NA & NA \\
\hline G2-AN-CP & 20 & 25 & 0.09 & 5/11/11 22:46 & 5/11/11 23:46 & 1.2 & $\begin{array}{l}\text { dark } \\
\text { red }\end{array}$ & 25.3 & 8.52 & 13.17 & 4.65 & NA & NA & NA \\
\hline
\end{tabular}


Table A.61. Datasheet for Column G2 Elution, Rinsing, and Regeneration Information

\begin{tabular}{|c|c|c|c|c|c|c|c|c|c|c|c|c|c|c|}
\hline \multirow{2}{*}{$\begin{array}{l}\text { Sample } \\
\text { ID No. }\end{array}$} & \multirow{2}{*}{$\begin{array}{l}\text { Bottle } \\
\text { Size } \\
(\mathrm{mL})\end{array}$} & \multirow{2}{*}{$\begin{array}{c}\text { Temp } \\
\text { Set } \\
\left({ }^{\circ} \mathrm{C}\right)\end{array}$} & \multirow{2}{*}{$\begin{array}{c}\text { Pump } \\
\text { Setting } \\
(\mathrm{mL} / \mathrm{min})\end{array}$} & \multirow{2}{*}{$\begin{array}{l}\text { Sampling } \\
\text { Start Time }\end{array}$} & \multirow{2}{*}{$\begin{array}{l}\text { Sampling } \\
\text { Stop Time }\end{array}$} & \multirow{2}{*}{$\begin{array}{c}\text { Resin } \\
\text { Height } \\
\text { (cm) }\end{array}$} & \multirow{2}{*}{$\begin{array}{l}\text { Resin } \\
\text { Color }\end{array}$} & \multirow{2}{*}{$\begin{array}{l}\text { Temp } \\
\left({ }^{\circ} \mathrm{C}\right)\end{array}$} & \multicolumn{3}{|c|}{ Effluent Bottle Weight, g } & \multicolumn{3}{|c|}{ Sample Vial Weight,g } \\
\hline & & & & & & & & & Tare & Gross & Net & Tare & Gross & Net \\
\hline \multicolumn{4}{|c|}{ Elution (EL) Phase Start Date/Time: } & $5 / 12 / 116: 40$ & & & & & & & & & & \\
\hline G2-EL-CP & 60 & 25 & 0.08 & 5/12/11 6:40 & $5 / 12 / 11$ 18:40 & 1.0 & orange & $\mathrm{RT}$ & 14.90 & 64.92 & 50.02 & 8.52 & 17.84 & 9.32 \\
\hline G2-EDI-CP & 20 & 25 & 0.09 & 5/12/11 19:05 & 5/12/11 20:05 & 1.0 & orange & RT & 8.46 & 13.02 & 4.56 & NA & NA & NA \\
\hline G2-RG-CP & 20 & 25 & 0.10 & 5/12/11 20:10 & 5/12/11 22:40 & 1.2 & $\begin{array}{c}\text { dark } \\
\text { red }\end{array}$ & RT & 8.45 & 21.95 & 13.50 & NA & NA & NA \\
\hline
\end{tabular}

Table A.62. Datasheet for Column G3 Loading and Rinsing Information

\begin{tabular}{|c|c|c|c|c|c|c|c|c|c|c|c|c|c|c|}
\hline Sample & Bottle & Temp & Pump & Sampling & Sampling & Resin & Resin & Temp & \multicolumn{3}{|c|}{ Effluent Bottle Weight, g } & \multicolumn{3}{|c|}{ Sample Vial Weight, g } \\
\hline ID No. & $\begin{array}{l}\text { Size } \\
(\mathrm{mL})\end{array}$ & $\begin{array}{l}\text { Set } \\
\left({ }^{\circ} \mathrm{C}\right)\end{array}$ & $\begin{array}{c}\text { Setting } \\
(\mathrm{mL} / \mathrm{min})\end{array}$ & Start Time & Stop Time & $\begin{array}{l}\text { Height } \\
(\mathrm{cm})\end{array}$ & Color & $\left({ }^{\circ} \mathrm{C}\right)$ & Tare & Gross & Net & Tare & Gross & Net \\
\hline G3-LD-0 & 20 & 60 & NA & 5/17/11 6:40 & 5/17/11 6:40 & 1.2 & $\begin{array}{c}\text { dark } \\
\text { red }\end{array}$ & 65.5 & NA & NA & NA & 8.50 & NA & 4.55 \\
\hline \multicolumn{4}{|c|}{ Loading (LD) Phase Start Date/Time: } & 5/17/11 6:45 & & & & & & & & & & \\
\hline G3-LD-006 & 20 & 60 & 7.08 & 5/17/11 6:51 & 5/17/11 6:51 & NA & $\begin{array}{l}\text { almost } \\
\text { black }\end{array}$ & 60.5 & NA & NA & NA & 8.48 & NA & 3.79 \\
\hline G3-LD-012 & 20 & 60 & 7.08 & 5/17/11 6:57 & 5/17/11 6:57 & NA & $\begin{array}{c}\text { almost } \\
\text { black }\end{array}$ & 57.8 & NA & NA & NA & 8.48 & NA & 3.94 \\
\hline G3-LD-018 & 20 & 60 & 7.08 & 5/17/11 7:03 & 5/17/11 7:03 & NA & $\begin{array}{l}\text { almost } \\
\text { black }\end{array}$ & 56.3 & NA & NA & NA & 8.46 & NA & 4.01 \\
\hline G3-LD-024 & 20 & 60 & 7.08 & 5/17/11 7:09 & 5/17/11 7:09 & NA & $\begin{array}{l}\text { almost } \\
\text { black }\end{array}$ & 55.9 & NA & NA & NA & 8.40 & NA & 3.87 \\
\hline G3-LD-036 & 20 & 60 & 7.08 & 5/17/11 7:21 & 5/17/11 7:21 & NA & $\begin{array}{l}\text { almost } \\
\text { black }\end{array}$ & 56.6 & NA & NA & NA & 8.56 & NA & 3.79 \\
\hline G3-LD-048 & 20 & 60 & 7.08 & 5/17/11 7:33 & 5/17/11 7:33 & NA & $\begin{array}{l}\text { almost } \\
\text { black }\end{array}$ & 57.5 & NA & NA & NA & 8.48 & NA & 3.44 \\
\hline G3-LD-060 & 20 & 60 & 7.08 & 5/17/11 7:45 & 5/17/11 7:45 & NA & $\begin{array}{l}\text { almost } \\
\text { black }\end{array}$ & 58.4 & NA & NA & NA & 8.48 & NA & 3.75 \\
\hline G3-LD-080 & 20 & 60 & 7.08 & 5/17/11 8:05 & 5/17/11 8:05 & NA & $\begin{array}{l}\text { almost } \\
\text { black }\end{array}$ & 59.6 & NA & NA & NA & 8.47 & NA & 3.62 \\
\hline
\end{tabular}


Table A.62. Datasheet for Column G3 Loading and Rinsing Information

\begin{tabular}{|c|c|c|c|c|c|c|c|c|c|c|c|c|c|c|}
\hline \multirow{2}{*}{$\begin{array}{l}\text { Sample } \\
\text { ID No. }\end{array}$} & \multirow{2}{*}{$\begin{array}{c}\text { Bottle } \\
\text { Size } \\
(\mathrm{mL}) \\
\end{array}$} & \multirow{2}{*}{$\begin{array}{c}\text { Temp } \\
\text { Set } \\
\left({ }^{\circ} \mathrm{C}\right) \\
\end{array}$} & \multirow{2}{*}{$\begin{array}{c}\text { Pump } \\
\text { Setting } \\
\text { (mL/min) }\end{array}$} & \multirow{2}{*}{$\begin{array}{l}\text { Sampling } \\
\text { Start Time }\end{array}$} & \multirow{2}{*}{$\begin{array}{l}\text { Sampling } \\
\text { Stop Time }\end{array}$} & \multirow{2}{*}{$\begin{array}{l}\text { Resin } \\
\text { Height } \\
(\mathrm{cm})\end{array}$} & \multirow{2}{*}{$\begin{array}{l}\text { Resin } \\
\text { Color }\end{array}$} & \multirow{2}{*}{$\begin{array}{l}\text { Temp } \\
\left({ }^{\circ} \mathrm{C}\right)\end{array}$} & \multicolumn{3}{|c|}{ Effluent Bottle Weight,g } & \multicolumn{3}{|c|}{ Sample Vial Weight,g } \\
\hline & & & & & & & & & Tare & Gross & Net & Tare & Gross & Net \\
\hline G3-LD-120 & 20 & 60 & 7.08 & 5/17/11 8:57 & $5 / 17 / 118: 57$ & NA & $\begin{array}{l}\text { almost } \\
\text { black }\end{array}$ & 60.4 & NA & NA & NA & 8.51 & NA & 3.62 \\
\hline G3-LD-180 & 20 & 60 & 7.08 & 5/17/11 9:45 & 5/17/11 9:45 & NA & $\begin{array}{l}\text { almost } \\
\text { black }\end{array}$ & 60.9 & NA & NA & NA & 8.52 & NA & 3.72 \\
\hline G3-LD-240 & 20 & 60 & 7.08 & 5/17/11 10:45 & 5/17/11 10:45 & NA & $\begin{array}{l}\text { almost } \\
\text { black }\end{array}$ & 60.3 & NA & NA & NA & 8.55 & NA & 3.87 \\
\hline G3-LD-600 & 20 & 60 & 7.08 & $5 / 17 / 1116: 45$ & 5/17/11 16:45 & NA & $\begin{array}{l}\text { almost } \\
\text { black }\end{array}$ & 59.6 & NA & NA & NA & 8.41 & NA & 3.39 \\
\hline G3-FD-CP & 20 & 60 & 0.08 & 5/17/11 17:06 & 5/17/11 19:36 & NA & $\begin{array}{c}\text { almost } \\
\text { black }\end{array}$ & 61.8 & 8.46 & 21.42 & 12.96 & NA & NA & NA \\
\hline G3-FDI-CP & 20 & 25 & 0.08 & 5/17/11 20:03 & 5/17/11 22:33 & NA & $\begin{array}{l}\text { almost } \\
\text { black }\end{array}$ & 21.8 & 8.51 & 18.94 & 10.43 & NA & NA & NA \\
\hline G3-AN-CP & 20 & 25 & 0.08 & 5/17/11 22:37 & 5/17/11 23:37 & 1.2 & $\begin{array}{l}\text { almost } \\
\text { black }\end{array}$ & 22.4 & 8.52 & 12.75 & 4.23 & NA & NA & NA \\
\hline
\end{tabular}

Table A.63. Datasheet for Column G3 Elution, Rinsing, and Regeneration Information

\begin{tabular}{|c|c|c|c|c|c|c|c|c|c|c|c|c|c|c|}
\hline \multirow{2}{*}{$\begin{array}{l}\text { Sample } \\
\text { ID No. }\end{array}$} & \multirow{2}{*}{$\begin{array}{l}\text { Bottle } \\
\text { Size } \\
(\mathrm{mL})\end{array}$} & \multirow{2}{*}{$\begin{array}{c}\text { Temp } \\
\text { Set } \\
\left({ }^{\circ} \mathrm{C}\right)\end{array}$} & \multirow{2}{*}{$\begin{array}{c}\text { Pump } \\
\text { Setting } \\
\text { (mL/min) }\end{array}$} & \multirow{2}{*}{$\begin{array}{l}\text { Sampling } \\
\text { Start Time }\end{array}$} & \multirow{2}{*}{$\begin{array}{l}\text { Sampling } \\
\text { Stop Time }\end{array}$} & \multirow{2}{*}{$\begin{array}{l}\text { Resin } \\
\text { Height } \\
(\mathrm{cm})\end{array}$} & \multirow{2}{*}{$\begin{array}{l}\text { Resin } \\
\text { Color }\end{array}$} & \multirow{2}{*}{$\begin{array}{l}\text { Temp } \\
\left({ }^{\circ} \mathrm{C}\right)\end{array}$} & \multicolumn{3}{|c|}{ Effluent Bottle Weight, g } & \multicolumn{3}{|c|}{ Sample Vial Weight,g g } \\
\hline & & & & & & & & & Tare & Gross & Net & Tare & Gross & Net \\
\hline Elution & L) $\mathrm{Ph}$ & e Start & ate/Time: & 5/18/11 6:50 & & & & & & & & & & \\
\hline G3-EL-CP & 60 & 25 & 0.08 & $5 / 18 / 116: 50$ & 5/18/11 18:50 & 1.1 & orange & 25.8 & 14.93 & 65.12 & 50.19 & 8.52 & 16.07 & 7.55 \\
\hline G3-EDI-CP & 20 & 25 & 0.09 & 5/18/11 19:03 & 5/18/11 20:03 & 1.1 & orange & RT & 8.43 & 13.01 & 4.58 & NA & NA & NA \\
\hline G3-RG-CP & 20 & 25 & 0.10 & 5/18/11 20:12 & 5/18/11 22:42 & 1.4 & $\begin{array}{l}\text { dark } \\
\text { red }\end{array}$ & 24.9 & 8.51 & 21.82 & 13.31 & NA & NA & NA \\
\hline
\end{tabular}


Table A.64. Datasheet for Column G4 Loading and Rinsing Information

\begin{tabular}{|c|c|c|c|c|c|c|c|c|c|c|c|c|c|c|}
\hline \multirow{2}{*}{$\begin{array}{l}\text { Sample } \\
\text { ID No. }\end{array}$} & \multirow{2}{*}{$\begin{array}{l}\text { Bottle } \\
\text { Size } \\
(\mathrm{mL}) \\
\end{array}$} & \multirow{2}{*}{$\begin{array}{l}\text { Temp } \\
\text { Set } \\
\left({ }^{\circ} \mathrm{C}\right) \\
\end{array}$} & \multirow{2}{*}{$\begin{array}{c}\text { Pump } \\
\text { Setting } \\
\text { (mL/min) } \\
\end{array}$} & \multirow{2}{*}{$\begin{array}{l}\text { Sampling } \\
\text { Start Time }\end{array}$} & \multirow{2}{*}{$\begin{array}{l}\text { Sampling } \\
\text { Stop Time }\end{array}$} & \multirow{2}{*}{$\begin{array}{l}\text { Resin } \\
\text { Height } \\
(\mathrm{cm}) \\
\end{array}$} & \multirow{2}{*}{$\begin{array}{l}\text { Resin } \\
\text { Color }\end{array}$} & \multirow{2}{*}{$\begin{array}{l}\text { Temp } \\
\left({ }^{\circ} \mathrm{C}\right)\end{array}$} & \multicolumn{3}{|c|}{ Effluent Bottle Weight, g } & \multicolumn{3}{|c|}{ Sample Vial Weight, g } \\
\hline & & & & & & & & & Tare & Gross & Net & Tare & Gross & Net \\
\hline G4-LD-0 & 20 & 60 & NA & $5 / 25 / 116: 50$ & $5 / 25 / 116: 50$ & 1.3 & $\begin{array}{l}\text { dark } \\
\text { red }\end{array}$ & 66.9 & NA & NA & NA & 8.53 & NA & 3.43 \\
\hline \multicolumn{4}{|c|}{ Loading (LD) Phase Start Date/Time: } & 5/25/11 6:55 & & & & & & & & & & \\
\hline G4-LD-006 & 20 & 60 & 10.62 & 5/25/11 7:01 & $5 / 25 / 117: 01$ & NA & $\begin{array}{l}\text { dark } \\
\text { red }\end{array}$ & 61.0 & NA & NA & NA & 8.45 & NA & 3.83 \\
\hline G4-LD-012 & 20 & 60 & 10.62 & $5 / 25 / 117: 07$ & $5 / 25 / 117: 07$ & NA & $\begin{array}{l}\text { dark } \\
\text { red }\end{array}$ & 58.9 & NA & NA & NA & 8.48 & NA & 3.55 \\
\hline G4-LD-018 & 20 & 60 & 10.62 & 5/25/11 7:13 & 5/25/11 7:13 & NA & $\begin{array}{l}\text { dark } \\
\text { red }\end{array}$ & 58.1 & NA & NA & NA & 8.58 & NA & 3.61 \\
\hline G4-LD-024 & 20 & 60 & 10.62 & 5/25/11 7:19 & 5/25/11 7:19 & NA & $\begin{array}{l}\text { dark } \\
\text { red }\end{array}$ & 58.0 & NA & NA & NA & 8.43 & NA & 3.05 \\
\hline G4-LD-036 & 20 & 60 & 10.62 & 5/25/11 7:31 & 5/25/11 7:31 & NA & $\begin{array}{l}\text { dark } \\
\text { red }\end{array}$ & 58.6 & NA & NA & NA & 8.52 & NA & 3.52 \\
\hline G4-LD-048 & 20 & 60 & 10.62 & 5/25/11 7:43 & 5/25/11 7:43 & NA & $\begin{array}{l}\text { dark } \\
\text { red }\end{array}$ & 59.2 & NA & NA & NA & 8.53 & NA & 3.27 \\
\hline G4-LD-060 & 20 & 60 & 10.62 & 5/25/11 7:55 & 5/25/11 7:55 & NA & $\begin{array}{l}\text { dark } \\
\text { red }\end{array}$ & 59.5 & NA & NA & NA & 8.58 & NA & 3.19 \\
\hline G4-LD-080 & 20 & 60 & 10.62 & 5/25/11 8:15 & 5/25/11 8:15 & NA & $\begin{array}{l}\text { dark } \\
\text { red }\end{array}$ & 59.6 & NA & NA & NA & 8.42 & NA & 3.30 \\
\hline G4-LD-120 & 20 & 60 & 10.62 & 5/25/11 8:55 & 5/25/11 8:55 & NA & $\begin{array}{l}\text { dark } \\
\text { red }\end{array}$ & 59.8 & NA & NA & NA & 8.55 & NA & 3.11 \\
\hline G4-LD-180 & 20 & 60 & 10.62 & 5/25/11 9:55 & 5/25/11 9:55 & NA & $\begin{array}{l}\text { dark } \\
\text { red }\end{array}$ & 59.6 & NA & NA & NA & 8.42 & NA & 3.34 \\
\hline G4-LD-240 & 20 & 60 & 10.62 & $5 / 25 / 11$ 10:55 & 5/25/11 10:55 & NA & $\begin{array}{l}\text { almost } \\
\text { black }\end{array}$ & 59.1 & NA & NA & NA & 8.47 & NA & 3.47 \\
\hline G4-LD-600 & 20 & 60 & 10.62 & 5/25/11 16:55 & 5/25/11 16:55 & 1.3 & $\begin{array}{l}\text { almost } \\
\text { black }\end{array}$ & 60.1 & NA & NA & NA & 8.47 & NA & 3.92 \\
\hline G4-FD-CP & 20 & 60 & 0.09 & 5/25/11 17:16 & 5/25/11 19:46 & 1.3 & $\begin{array}{l}\text { almost } \\
\text { black }\end{array}$ & 60.3 & 8.53 & 22.81 & 14.28 & NA & NA & NA \\
\hline G4-FDI-CP & 20 & 25 & 0.09 & 5/25/11 20:19 & 5/25/11 22:49 & 1.3 & $\begin{array}{l}\text { almost } \\
\text { black }\end{array}$ & 25 & 8.38 & 20.50 & 12.12 & NA & NA & NA \\
\hline
\end{tabular}


Table A.65. Datasheet for Column G4B Loading and Rinsing Information

\begin{tabular}{|c|c|c|c|c|c|c|c|c|c|c|c|c|c|c|}
\hline \multirow{2}{*}{$\begin{array}{l}\text { Sample } \\
\text { ID No. }\end{array}$} & \multirow{2}{*}{$\begin{array}{l}\text { Bottle } \\
\text { Size } \\
(\mathrm{mL}) \\
\end{array}$} & \multirow{2}{*}{$\begin{array}{l}\text { Temp } \\
\text { Set } \\
\left({ }^{\circ} \mathrm{C}\right) \\
\end{array}$} & \multirow{2}{*}{$\begin{array}{c}\text { Pump } \\
\text { Setting } \\
\text { (mL/min) }\end{array}$} & \multirow{2}{*}{$\begin{array}{l}\text { Sampling } \\
\text { Start Time }\end{array}$} & \multirow{2}{*}{$\begin{array}{l}\text { Sampling } \\
\text { Stop Time }\end{array}$} & \multirow{2}{*}{$\begin{array}{l}\text { Resin } \\
\text { Height } \\
(\mathrm{cm})\end{array}$} & \multirow{2}{*}{$\begin{array}{l}\text { Resin } \\
\text { Color }\end{array}$} & \multirow{2}{*}{$\begin{array}{l}\text { Temp } \\
\left({ }^{\circ} \mathrm{C}\right)\end{array}$} & \multicolumn{3}{|c|}{ Effluent Bottle Weight, g } & \multicolumn{3}{|c|}{ Sample Vial Weight, g } \\
\hline & & & & & & & & & Tare & Gross & Net & Tare & Gross & Net \\
\hline G4B-LD-0 & 20 & 60 & NA & 6/8/11 8:27 & 6/8/11 8:27 & 1.3 & $\begin{array}{l}\text { almost } \\
\text { black }\end{array}$ & 66.9 & NA & NA & NA & 8.53 & NA & 3.44 \\
\hline \multicolumn{4}{|c|}{ Loading (LD) Phase Start Date/Time: } & 6/8/11 8:30 & & & & & & & & & & \\
\hline G4B-LD-004 & 20 & 60 & 0.08 & 6/8/11 12:30 & 6/8/11 12:30 & NA & $\begin{array}{l}\text { almost } \\
\text { black }\end{array}$ & 61.2 & NA & NA & NA & 8.47 & NA & 3.59 \\
\hline G4B-LD-008 & 20 & 60 & 0.08 & 6/8/11 16:30 & 6/8/11 16:30 & NA & $\begin{array}{l}\text { almost } \\
\text { black }\end{array}$ & 60.0 & NA & NA & NA & 8.45 & NA & 3.92 \\
\hline G4B-LD-012 & 20 & 60 & 0.08 & 6/8/11 20:30 & 6/8/11 20:30 & NA & $\begin{array}{l}\text { almost } \\
\text { black }\end{array}$ & 60.5 & NA & NA & NA & 8.45 & NA & 3.88 \\
\hline G4B-LD-024 & 20 & 60 & 0.08 & 6/9/11 8:30 & 6/9/11 8:30 & NA & $\begin{array}{l}\text { almost } \\
\text { black }\end{array}$ & 60.7 & NA & NA & NA & 8.59 & NA & 3.92 \\
\hline G4B-LD-072 & 20 & 60 & 0.08 & 6/11/11 8:30 & 6/11/11 8:30 & NA & $\begin{array}{l}\text { almost } \\
\text { black }\end{array}$ & 60.2 & NA & NA & NA & 8.51 & NA & 3.50 \\
\hline G4B-LD-120 & 20 & 60 & 0.08 & 6/13/11 8:33 & 6/13/11 8:33 & NA & $\begin{array}{l}\text { almost } \\
\text { black }\end{array}$ & 60.1 & NA & NA & NA & 8.42 & NA & 3.62 \\
\hline G4B-LD-168 & 20 & 60 & 0.08 & 6/15/11 8:32 & 6/15/11 8:32 & NA & $\begin{array}{l}\text { almost } \\
\text { black }\end{array}$ & 60.9 & NA & NA & NA & 8.48 & NA & 3.28 \\
\hline G4B-LD-336 & 20 & 60 & 0.08 & 6/22/11 8:31 & 6/22/11 8:31 & NA & $\begin{array}{l}\text { almost } \\
\text { black }\end{array}$ & NA & NA & NA & NA & 8.47 & NA & 2.83 \\
\hline G4B-FD-CP & 20 & 60 & 0.09 & 7/1/11 13:38 & 7/1/11 16:08 & 1.6 & black & 60.2 & 8.53 & 21.75 & 13.22 & NA & NA & NA \\
\hline G4B-FDI-CP & 20 & 25 & 0.09 & 7/1/11 16:10 & 7/1/11 18:40 & 1.6 & black & 23.8 & 8.54 & 20.70 & 12.16 & NA & NA & NA \\
\hline G4B-AN-CP & 20 & 25 & 0.09 & 7/5/11 9:45 & 7/5/11 10:45 & 1.5 & $\begin{array}{l}\text { reddish } \\
\text { brown }\end{array}$ & 25.3 & 8.44 & 13.38 & 4.94 & NA & NA & NA \\
\hline
\end{tabular}


Table A.66. Datasheet for Column G4B Elution, Rinsing, and Regeneration Information

\begin{tabular}{|c|c|c|c|c|c|c|c|c|c|c|c|c|c|c|}
\hline \multirow{2}{*}{$\begin{array}{l}\text { Sample } \\
\text { ID No. }\end{array}$} & \multirow{2}{*}{$\begin{array}{l}\text { Bottle } \\
\text { Size } \\
(\mathrm{mL})\end{array}$} & \multirow{2}{*}{$\begin{array}{l}\text { Temp } \\
\text { Set } \\
\left({ }^{\circ} \mathrm{C}\right)\end{array}$} & \multirow{2}{*}{$\begin{array}{l}\text { Pump } \\
\text { Setting } \\
\text { (mL/min) }\end{array}$} & \multirow{2}{*}{$\begin{array}{l}\text { Sampling } \\
\text { Start Time }\end{array}$} & \multirow{2}{*}{$\begin{array}{l}\text { Sampling } \\
\text { Stop Time }\end{array}$} & \multirow{2}{*}{$\begin{array}{l}\text { Resin } \\
\text { Height } \\
\text { (cm) }\end{array}$} & \multirow{2}{*}{$\begin{array}{l}\text { Resin } \\
\text { Color }\end{array}$} & \multirow{2}{*}{$\begin{array}{l}\text { Temp } \\
\left({ }^{\circ} \mathrm{C}\right)\end{array}$} & \multicolumn{3}{|c|}{ Effluent Bottle Weight, } & \multicolumn{3}{|c|}{ Sample Vial Weight, g } \\
\hline & & & & & & & & & Tare & Gross & Net & Tare & Gross & Net \\
\hline \multicolumn{4}{|c|}{ Elution (EL) Phase Start Date/Time: } & 7/6/11 6:37 & & & & & & & & & & \\
\hline G4B-EL-CP & 60 & 25 & 0.08 & 7/6/11 6:37 & 7/6/11 16:37 & 1.2 & $\begin{array}{l}\text { brownish } \\
\text { red }\end{array}$ & RT & 14.92 & 58.08 & 43.16 & 8.46 & 17.42 & 8.96 \\
\hline G4B-EDI-CP & 20 & 25 & 0.08 & 7/6/11 16:52 & 7/6/11 17:52 & 1.2 & $\begin{array}{l}\text { brownish } \\
\text { red }\end{array}$ & RT & 8.48 & 12.78 & 4.30 & NA & NA & NA \\
\hline G4B-RG-CP & 20 & 25 & 0.09 & 7/6/11 18:03 & 7/6/11 20:03 & 1.6 & $\begin{array}{l}\text { brownish } \\
\text { red }\end{array}$ & RT & 8.48 & 20.98 & 12.50 & NA & NA & NA \\
\hline
\end{tabular}

Table A.67. Datasheet for Column G5 Loading and Rinsing Information

\begin{tabular}{|c|c|c|c|c|c|c|c|c|c|c|c|c|c|c|}
\hline Sample & Bottle & Temp & Pump & Sampling & Sampling & Resin & Resin & Temp & \multicolumn{3}{|c|}{ Effluent Bottle Weight, g } & \multicolumn{3}{|c|}{ Sample Vial Weight, g } \\
\hline ID No. & $\begin{array}{l}\text { Size } \\
(\mathrm{mL})\end{array}$ & $\begin{array}{l}\text { Set } \\
\left({ }^{\circ} \mathrm{C}\right)\end{array}$ & $\begin{array}{l}\text { Setting } \\
\text { (mL/min) }\end{array}$ & Start Time & Stop Time & $\begin{array}{c}\text { Height } \\
(\mathrm{cm})\end{array}$ & Color & $\left({ }^{\circ} \mathrm{C}\right)$ & Tare & Gross & Net & Tare & Gross & Net \\
\hline G5-LD-0 & 20 & 60 & NA & 7/7/11 6:39 & 7/7/11 6:39 & 1.5 & $\begin{array}{l}\text { brownish } \\
\text { red }\end{array}$ & 63.2 & NA & NA & NA & 8.44 & 11.85 & 3.41 \\
\hline \multicolumn{4}{|c|}{ Loading (LD) Phase Start Date/Time: } & 7/7/11 6:45 & & & & & & & & & & \\
\hline G5-LD-006 & 20 & 60 & 10.62 & 7/7/11 6:51 & 7/7/11 6:51 & NA & $\begin{array}{l}\text { brownish } \\
\text { red }\end{array}$ & 57.2 & NA & NA & NA & 8.44 & 11.85 & 3.41 \\
\hline G5-LD-012 & 20 & 60 & 10.62 & 7/7/11 6:57 & 7/7/11 6:57 & NA & $\begin{array}{l}\text { brownish } \\
\text { red }\end{array}$ & 54.5 & NA & NA & NA & 8.54 & 11.88 & 3.34 \\
\hline G5-LD-018 & 20 & 60 & 10.62 & 7/7/11 7:03 & 7/7/11 7:03 & NA & $\begin{array}{l}\text { brownish } \\
\text { red }\end{array}$ & 53.2 & NA & NA & NA & 8.54 & 12.04 & 3.50 \\
\hline G5-LD-024 & 20 & 60 & 10.62 & 7/7/11 7:09 & 7/7/11 7:09 & NA & $\begin{array}{l}\text { brownish } \\
\text { red }\end{array}$ & 52.7 & NA & NA & NA & 8.49 & 11.82 & 3.33 \\
\hline G5-LD-036 & 20 & 60 & 10.62 & 7/7/11 7:21 & 7/7/11 7:21 & NA & $\begin{array}{l}\text { brownish } \\
\text { red }\end{array}$ & 53.5 & NA & NA & NA & 8.50 & 12.04 & 3.54 \\
\hline G5-LD-048 & 20 & 60 & 10.62 & 7/7/11 7:33 & 7/7/11 7:33 & NA & $\begin{array}{l}\text { brownish } \\
\text { red }\end{array}$ & 54.4 & NA & NA & NA & 8.51 & 11.80 & 3.29 \\
\hline G5-LD-060 & 20 & 60 & 10.62 & 7/7/11 7:45 & 7/7/11 7:45 & NA & $\begin{array}{l}\text { dark } \\
\text { brown }\end{array}$ & 55.0 & NA & NA & NA & 8.58 & 11.96 & 3.38 \\
\hline
\end{tabular}


Table A.67. Datasheet for Column G5 Loading and Rinsing Information

\begin{tabular}{|c|c|c|c|c|c|c|c|c|c|c|c|c|c|c|}
\hline \multirow{2}{*}{$\begin{array}{l}\text { Sample } \\
\text { ID No. }\end{array}$} & \multirow{2}{*}{$\begin{array}{l}\text { Bottle } \\
\text { Size } \\
(\mathrm{mL})\end{array}$} & \multirow{2}{*}{$\begin{array}{l}\text { Temp } \\
\text { Set } \\
\left({ }^{\circ} \mathrm{C}\right) \\
\end{array}$} & \multirow{2}{*}{$\begin{array}{l}\text { Pump } \\
\text { Setting } \\
\text { (mL/min) }\end{array}$} & \multirow{2}{*}{$\begin{array}{l}\text { Sampling } \\
\text { Start Time }\end{array}$} & \multirow{2}{*}{$\begin{array}{l}\text { Sampling } \\
\text { Stop Time }\end{array}$} & \multirow{2}{*}{$\begin{array}{l}\text { Resin } \\
\text { Height } \\
(\mathrm{cm}) \\
\end{array}$} & \multirow{2}{*}{$\begin{array}{l}\text { Resin } \\
\text { Color }\end{array}$} & \multirow{2}{*}{$\begin{array}{l}\text { Temp } \\
\left({ }^{\circ} \mathrm{C}\right)\end{array}$} & \multicolumn{3}{|c|}{ Effluent Bottle Weight, g } & \multicolumn{3}{|c|}{ Sample Vial Weight, g } \\
\hline & & & & & & & & & Tare & Gross & Net & Tare & Gross & Net \\
\hline G5-LD-080 & 20 & 60 & 10.62 & 7/7/11 8:05 & 7/7/11 8:05 & NA & $\begin{array}{c}\text { dark } \\
\text { brown }\end{array}$ & 55.2 & NA & NA & NA & 8.49 & 11.90 & 3.41 \\
\hline G5-LD-120 & 20 & 60 & 10.62 & 7/7/11 8:45 & 7/7/11 8:45 & NA & $\begin{array}{c}\text { dark } \\
\text { brown }\end{array}$ & 57.1 & NA & NA & NA & 8.52 & 12.01 & 3.49 \\
\hline G5-LD-180 & 20 & 60 & 10.62 & 7/7/11 9:45 & 7/7/11 9:45 & NA & $\begin{array}{c}\text { dark } \\
\text { brown }\end{array}$ & 57.8 & NA & NA & NA & 8.58 & 11.93 & 3.35 \\
\hline G5-LD-240 & 20 & 60 & 10.62 & 7/7/11 10:45 & 7/7/11 10:45 & NA & $\begin{array}{c}\text { dark } \\
\text { brown }\end{array}$ & 58.8 & NA & NA & NA & 8.48 & 11.94 & 3.46 \\
\hline G5-LD-600 & 20 & 60 & 10.62 & 7/7/11 16:45 & 7/7/11 16:45 & NA & $\begin{array}{c}\text { dark } \\
\text { brown }\end{array}$ & 60.4 & NA & NA & NA & 8.55 & 12.62 & 4.07 \\
\hline G5-FD-CP & 20 & 60 & 0.09 & 7/7/11 17:10 & 7/7/11 19:40 & 1.5 & $\begin{array}{c}\text { dark } \\
\text { brown }\end{array}$ & 60.0 & 8.43 & 21.97 & 13.54 & NA & NA & NA \\
\hline G5-FDI-CP & 20 & 25 & 0.09 & 7/7/11 19:58 & 7/7/11 22:28 & 1.5 & $\begin{array}{c}\text { dark } \\
\text { brown }\end{array}$ & 25.2 & 8.58 & 20.20 & 11.62 & NA & NA & NA \\
\hline G5-AN-CP & 20 & 25 & 0.09 & 7/7/11 22:32 & 7/7/11 23:32 & 1.5 & $\begin{array}{l}\text { dark } \\
\text { brown }\end{array}$ & 25.2 & 8.39 & 13.01 & 4.62 & NA & NA & NA \\
\hline
\end{tabular}

Table A.68. Datasheet for Column G5 Elution, Rinsing, and Regeneration Information

\begin{tabular}{|c|c|c|c|c|c|c|c|c|c|c|c|c|c|c|}
\hline \multirow{2}{*}{$\begin{array}{l}\text { Sample } \\
\text { ID No. }\end{array}$} & \multirow{2}{*}{$\begin{array}{l}\text { Bottle } \\
\text { Size } \\
(\mathrm{mL})\end{array}$} & \multirow{2}{*}{$\begin{array}{c}\text { Temp } \\
\text { Set } \\
\left({ }^{\circ} \mathrm{C}\right) \\
\end{array}$} & \multirow{2}{*}{$\begin{array}{c}\text { Pump } \\
\text { Setting } \\
(\mathrm{mL} / \mathrm{min}) \\
\end{array}$} & \multirow{2}{*}{$\begin{array}{l}\text { Sampling } \\
\text { Start Time }\end{array}$} & \multirow{2}{*}{$\begin{array}{l}\text { Sampling } \\
\text { Stop Time }\end{array}$} & \multirow{2}{*}{$\begin{array}{l}\text { Resin } \\
\text { Height } \\
(\mathrm{cm}) \\
\end{array}$} & \multirow{2}{*}{$\begin{array}{l}\text { Resin } \\
\text { Color }\end{array}$} & \multirow{2}{*}{$\begin{array}{l}\text { Temp } \\
\left({ }^{\circ} \mathrm{C}\right)\end{array}$} & \multicolumn{3}{|c|}{ Effluent Bottle Weight, g } & \multicolumn{3}{|c|}{ Sample Vial Weight, g } \\
\hline & & & & & & & & & Tare & Gross & Net & Tare & Gross & Net \\
\hline \multicolumn{4}{|c|}{ Elution (EL) Phase Start Date/Time: } & 7/11/11 6:40 & & & & & & & & & & \\
\hline G5-EL-CP & 60 & 25 & 0.08 & 7/11/11 6:40 & 7/11/11 16:40 & 1.0 & $\begin{array}{l}\text { orange } \\
\text { red }\end{array}$ & RT & 14.93 & 57.74 & 42.81 & 8.52 & 19.26 & 10.74 \\
\hline G5-EDI-CP & 20 & 25 & 0.08 & 7/11/11 16:48 & 7/11/11 17:48 & 1.2 & $\begin{array}{l}\text { orange } \\
\text { red }\end{array}$ & $\mathrm{RT}$ & 8.54 & 13.04 & 4.50 & NA & NA & NA \\
\hline
\end{tabular}





\section{Appendix B: Analytical Data}



The corr. in the concentration columns is equal to the raw data multiplied by the dilution factor. This corrects the raw data based on the sample dilution.

Table B.1. Column A1 Test Analytical Data $\left(T=45^{\circ} \mathrm{C}\right.$, Flow rate $\left.=10.62 \mathrm{~mL} / \mathrm{min}\right)$

\begin{tabular}{|c|c|c|c|c|c|c|c|c|c|c|c|c|c|c|}
\hline Sample ID & $\begin{array}{l}\text { Loading Time } \\
\quad \text { (min) }\end{array}$ & $\begin{array}{l}\text { Dilution } \\
\text { Factor }\end{array}$ & $\begin{array}{l}\text { Cs (raw) } \\
\text { (mg/kg) }\end{array}$ & $\begin{array}{c}\mathrm{Al} \\
(\mathrm{raw}) \\
(\mathrm{mg} / \mathrm{k} \\
\mathrm{g})\end{array}$ & $\begin{array}{c}\mathrm{Na} \\
(\mathrm{raw}) \\
(\mathrm{mg} / \mathrm{kg})\end{array}$ & $\begin{array}{c}\mathrm{Cs} \\
\text { (corr.) } \\
\text { (mg/kg) }\end{array}$ & $\begin{array}{c}\mathrm{Al} \\
(\mathrm{corr} .) \\
(\mathrm{mg} / \mathrm{kg})\end{array}$ & $\begin{array}{c}\mathrm{Na} \\
(\mathrm{corr} .) \\
(\mathrm{mg} / \mathrm{kg})\end{array}$ & $\begin{array}{c}\text { OH-Free } \\
\text { (corr.) } \\
\text { (meq/mL) }\end{array}$ & $\begin{array}{c}\text { OH-Total } \\
\text { (corr.) } \\
\text { (meq/mL) }\end{array}$ & $\begin{array}{c}\mathrm{Cl} \\
(\mathrm{raw}) \\
(\mathrm{mg} / \mathrm{kg})\end{array}$ & $\begin{array}{c}\mathrm{NO}_{3} \\
\text { (raw) } \\
\text { (mg/kg) }\end{array}$ & $\begin{array}{c}\mathrm{Cl} \\
\text { (corr.) } \\
\text { (mg/kg) }\end{array}$ & $\begin{array}{c}\mathrm{NO}_{3} \\
\text { (corr.) } \\
\text { (mg/kg) }\end{array}$ \\
\hline A1-LD-00 & 0 & 1 & 2.93 & 2450 & 94400 & 2.93 & 2450 & 94400 & 1.53 & 1.68 & 53600 & 20200 & 53600 & 20200 \\
\hline A1-LD-06 & 6 & 1 & 2.53 & 2370 & 90200 & 2.53 & 2370 & 90200 & 1.48 & 1.63 & 51400 & 19300 & 51400 & 19300 \\
\hline A1-LD-12 & 12 & 1 & 2.43 & 2390 & 91100 & 2.43 & 2390 & 91100 & 1.48 & 1.63 & 51200 & 19000 & 51200 & 19000 \\
\hline A1-LD-18 & 18 & 1 & 2.25 & 2370 & 89700 & 2.25 & 2370 & 89700 & 1.48 & 1.63 & 51400 & 19200 & 51400 & 19200 \\
\hline A1-LD-24 & 24 & 1 & 2.24 & 2390 & 91900 & 2.24 & 2390 & 91900 & 1.48 & 1.63 & 51600 & 19300 & 51600 & 19300 \\
\hline A1-LD-36 & 36 & 1 & 2.28 & 2390 & 91800 & 2.28 & 2390 & 91800 & 1.49 & 1.64 & 50900 & 19000 & 50900 & 19000 \\
\hline A1-LD-48 & 48 & 1 & 2.12 & 2410 & 91400 & 2.12 & 2410 & 91400 & 1.49 & 1.64 & 50400 & 18900 & 50400 & 18900 \\
\hline A1-LD-60 & 60 & 1 & 1.94 & 2370 & 91900 & 1.94 & 2370 & 91900 & 1.48 & 1.63 & 50500 & 19000 & 50500 & 19000 \\
\hline A1-LD-80 & 80 & 1 & 1.73 & 2380 & 90900 & 1.73 & 2380 & 90900 & 1.48 & 1.63 & 50400 & 19000 & 50400 & 19000 \\
\hline A1-LD-120 & 120 & 1 & 1.23 & 2400 & 90700 & 1.23 & 2400 & 90700 & 1.48 & 1.62 & 51300 & 19000 & 51300 & 19000 \\
\hline A1-LD-180 & 180 & 1 & 1.02 & 2340 & 87400 & 1.02 & 2340 & 87400 & 1.48 & 1.63 & 51000 & 19000 & 51000 & 19000 \\
\hline A1-LD-240 & 240 & 1 & 0.848 & 2370 & 88700 & 0.848 & 2370 & 88700 & 1.48 & 1.63 & 51800 & 19400 & 51800 & 19400 \\
\hline A1-LD-600 & 600 & 1 & 0.479 & 2360 & 90300 & 0.479 & 2360 & 90300 & 1.48 & 1.63 & 50600 & 19000 & 50600 & 19000 \\
\hline A1-FD-CP & $\begin{array}{c}\text { Feed } \\
\text { Displacement }\end{array}$ & 1 & 0.278 & 1400 & 52700 & 0.278 & 1400 & 52700 & 0.886 & 0.963 & 29400 & 10900 & 29400 & 10900 \\
\hline A1-EL-CP & Elution & 1 & 10.6 & 4.47 & 1150 & 10.6 & 4.47 & 1150 & $<0.05$ & $<0.05$ & 58.1 & 2780 & 58.1 & 2780 \\
\hline Target & -- & -- & -- & -- & -- & 2.62 & 2570 & 95000 & 1.55 & 2.01 & -- & -- & 48900 & 19300 \\
\hline
\end{tabular}


Table B.2. Column A2 Test Analytical Data $\left(\mathrm{T}=45^{\circ} \mathrm{C}\right.$, Flow rate $\left.=10.62 \mathrm{~mL} / \mathrm{min}\right)$

\begin{tabular}{|c|c|c|c|c|c|c|c|c|c|c|c|c|c|c|}
\hline Sample ID & $\begin{array}{l}\text { Loading Time } \\
\text { (min) }\end{array}$ & $\begin{array}{c}\text { Dilution } \\
\text { Factor }\end{array}$ & $\begin{array}{c}\mathrm{Cs} \\
(\mathrm{raw}) \\
(\mathrm{mg} / \mathrm{kg})\end{array}$ & $\begin{array}{c}\mathrm{Al} \\
(\mathrm{raw}) \\
(\mathrm{mg} / \mathrm{kg})\end{array}$ & $\begin{array}{c}\mathrm{Na} \\
(\mathrm{raw}) \\
(\mathrm{mg} / \mathrm{kg})\end{array}$ & $\begin{array}{c}\mathrm{Cs} \\
\text { (corr.) } \\
\text { (mg/kg) }\end{array}$ & $\begin{array}{c}\mathrm{Al} \\
\text { (corr.) } \\
\text { (mg/kg) }\end{array}$ & $\begin{array}{c}\mathrm{Na} \\
\text { (corr.) } \\
\text { (mg/kg) }\end{array}$ & $\begin{array}{c}\text { OH-Free } \\
\text { (corr.) } \\
\text { (meq/mL) }\end{array}$ & $\begin{array}{c}\text { OH-Total } \\
\text { (corr.) } \\
\text { (meq/mL) }\end{array}$ & $\begin{array}{c}\mathrm{Cl} \\
(\mathrm{raw}) \\
(\mathrm{mg} / \mathrm{kg})\end{array}$ & $\begin{array}{c}\mathrm{NO}_{3} \\
\text { (raw) } \\
\text { (mg/kg) }\end{array}$ & $\begin{array}{c}\mathrm{Cl} \\
\text { (corr.) } \\
\text { (mg/kg) }\end{array}$ & $\begin{array}{c}\mathrm{NO}_{3} \\
\text { (corr.) } \\
\text { (mg/kg) }\end{array}$ \\
\hline A2-LD-00 & 0 & 1.67 & 1.69 & 1600 & 74200 & 2.82 & 2670 & 124000 & 1.64 & 1.80 & $<34.0$ & 40700 & $<56.7$ & 67900 \\
\hline A2-LD-06 & 6 & 1.70 & 1.54 & 1540 & 70900 & 2.62 & 2620 & 121000 & 1.59 & 1.75 & $<34.4$ & 38800 & $<58.5$ & 66000 \\
\hline A2-LD-12 & 12 & 1.66 & 1.49 & 1570 & 72100 & 2.47 & 2610 & 120000 & 1.61 & 1.76 & $<33.7$ & 39100 & $<56.0$ & 64900 \\
\hline A2-LD-18 & 18 & 1.69 & 1.39 & 1500 & 69300 & 2.35 & 2530 & 117000 & 1.60 & 1.76 & $<33.9$ & 38900 & $<57.2$ & 65700 \\
\hline A2-LD-24 & 24 & 1.91 & 1.23 & 1370 & 62100 & 2.35 & 2620 & 119000 & 1.55 & 1.71 & $<34.4$ & 33900 & $<65.7$ & 64700 \\
\hline A2-LD-36 & 36 & 1.66 & 1.29 & 1530 & 69100 & 2.14 & 2540 & 115000 & 1.59 & 1.76 & $<33.8$ & 39400 & $<56.1$ & 65400 \\
\hline A2-LD-48 & 48 & 1.65 & 1.27 & 1580 & 70700 & 2.10 & 2610 & 117000 & 1.61 & 1.77 & $<34.1$ & 40300 & $<56.4$ & 66700 \\
\hline A2-LD-60 & 60 & 1.67 & 1.21 & 1590 & 73400 & 2.02 & 2650 & 122000 & 1.60 & 1.77 & $<33.6$ & 39300 & $<56.0$ & 65500 \\
\hline A2-LD-80 & 80 & 1.73 & 1.07 & 1510 & 69400 & 1.85 & 2610 & 120000 & 1.58 & 1.73 & $<33.9$ & 37900 & $<58.7$ & 65600 \\
\hline A2-LD-120 & 120 & 1.64 & 0.998 & 1570 & 72900 & 1.63 & 2570 & 119000 & 1.61 & 1.77 & $<33.5$ & 39500 & $<54.8$ & 64600 \\
\hline A2-LD-180 & 180 & 1.64 & 0.860 & 1560 & 71900 & 1.41 & 2560 & 118000 & 1.60 & 1.77 & $<33.5$ & 39200 & $<54.9$ & 64300 \\
\hline A2-LD-240 & 240 & 1.60 & 0.801 & 1630 & 73900 & 1.28 & 2620 & 119000 & 1.60 & 1.76 & $<33.5$ & 40900 & $<53.7$ & 65600 \\
\hline A2-LD-600 & 600 & 1.75 & 0.558 & 1530 & 70200 & 0.974 & 2670 & 123000 & 1.59 & 1.75 & $<33.7$ & 37200 & $<58.8$ & 64900 \\
\hline A2-FD-CP & $\begin{array}{c}\text { Feed } \\
\text { Displacement }\end{array}$ & 1 & 0.637 & 1630 & 78500 & 0.637 & 1630 & 78500 & 1.11 & 1.21 & 125 & 40800 & 125 & 40800 \\
\hline A2-EL-CP & Elution & 1 & 8.79 & 8.40 & 1420 & 8.79 & 8.40 & 1420 & $<0.05$ & $<0.05$ & $<40.2$ & 2590 & $<40.2$ & 2590 \\
\hline Target & -- & -- & -- & -- & -- & 2.79 & 2720 & 134000 & 1.86 & 2.41 & -- & -- & 0 & 61200 \\
\hline
\end{tabular}


Table B.3. Column A3 Test Analytical Data $\left(\mathrm{T}=45^{\circ} \mathrm{C}\right.$, Flow rate $\left.=7.08 \mathrm{~mL} / \mathrm{min}\right)$

\begin{tabular}{|c|c|c|c|c|c|c|c|c|c|c|c|c|c|c|}
\hline Sample ID & $\begin{array}{l}\text { Loading Time } \\
\text { (min) }\end{array}$ & $\begin{array}{l}\text { Dilution } \\
\text { Factor }\end{array}$ & $\begin{array}{c}\mathrm{Cs} \\
(\mathrm{raw}) \\
(\mathrm{mg} / \mathrm{kg})\end{array}$ & $\begin{array}{c}\mathrm{Al} \\
(\mathrm{raw}) \\
(\mathrm{mg} / \mathrm{kg})\end{array}$ & $\begin{array}{c}\mathrm{Na} \\
(\mathrm{raw}) \\
(\mathrm{mg} / \mathrm{kg})\end{array}$ & $\begin{array}{c}\mathrm{Cs} \\
\text { (corr.) } \\
\text { (mg/kg) }\end{array}$ & $\begin{array}{c}\mathrm{Al} \\
(\mathrm{corr} .) \\
(\mathrm{mg} / \mathrm{kg})\end{array}$ & $\begin{array}{c}\mathrm{Na} \\
(\text { corr.) } \\
(\mathrm{mg} / \mathrm{kg})\end{array}$ & $\begin{array}{c}\text { OH-Free } \\
\text { (corr.) } \\
\text { (meq/mL) }\end{array}$ & $\begin{array}{c}\text { OH-Total } \\
\text { (corr.) } \\
\text { (meq/mL) }\end{array}$ & $\begin{array}{c}\mathrm{Cl} \\
(\mathrm{raw}) \\
(\mathrm{mg} / \mathrm{kg})\end{array}$ & $\begin{array}{c}\mathrm{NO}_{3} \\
\text { (raw) } \\
\text { (mg/kg) }\end{array}$ & $\begin{array}{c}\mathrm{Cl} \\
\text { (corr.) } \\
(\mathrm{mg} / \mathrm{kg})\end{array}$ & $\begin{array}{c}\mathrm{NO}_{3} \\
\text { (corr.) } \\
(\mathrm{mg} / \mathrm{kg})\end{array}$ \\
\hline A3-LD-00 & 0 & 1.58 & 1.82 & 1660 & 76700 & 2.88 & 2630 & 121000 & 1.65 & 1.80 & $<33.1$ & 41800 & $<52.4$ & 66200 \\
\hline A3-LD-06 & 6 & 1.64 & 1.58 & 1540 & 70900 & 2.58 & 2520 & 116000 & 1.59 & 1.75 & $<33.8$ & 40000 & $<55.3$ & 65400 \\
\hline A3-LD-12 & 12 & 1.66 & 1.50 & 1550 & 71400 & 2.50 & 2580 & 119000 & 1.59 & 1.75 & $<33.7$ & 38900 & $<56.1$ & 64700 \\
\hline A3-LD-18 & 18 & 1.79 & 1.30 & 1420 & 65100 & 2.32 & 2540 & 116000 & 1.57 & 1.71 & $<34.2$ & 36500 & $<61.1$ & 65200 \\
\hline A3-LD-24 & 24 & 1.80 & 1.23 & 1400 & 63600 & 2.22 & 2520 & 115000 & 1.57 & 1.72 & $<34.2$ & 35900 & $<61.6$ & 64700 \\
\hline A3-LD-36 & 36 & 1.56 & 1.36 & 1640 & 74400 & 2.12 & 2560 & 116000 & 1.59 & 1.75 & $<33.0$ & 40500 & $<51.5$ & 63200 \\
\hline A3-LD-48 & 48 & 1.71 & 1.14 & 1500 & 68300 & 1.95 & 2570 & 117000 & 1.59 & 1.76 & $<33.8$ & 37900 & $<57.8$ & 64800 \\
\hline A3-LD-60 & 60 & 1.57 & 1.16 & 1610 & 73400 & 1.83 & 2540 & 116000 & 1.61 & 1.76 & $<33.2$ & 41500 & $<52.3$ & 65300 \\
\hline A3-LD-80 & 80 & 1.62 & 1.04 & 1570 & 71600 & 1.68 & 2540 & 116000 & 1.60 & 1.75 & $<33.6$ & 40100 & $<54.3$ & 64800 \\
\hline A3-LD-120 & 120 & 1.54 & 0.940 & 1660 & 75800 & 1.45 & 2560 & 117000 & 1.60 & 1.76 & $<33.2$ & 41800 & $<51.2$ & 64500 \\
\hline A3-LD-180 & 180 & 1.61 & 0.774 & 1590 & 73200 & 1.24 & 2560 & 118000 & 1.59 & 1.74 & $<33.4$ & 40000 & $<53.7$ & 64300 \\
\hline A3-LD-240 & 240 & 1.61 & 0.684 & 1590 & 72600 & 1.10 & 2560 & 117000 & 1.61 & 1.77 & $<33.6$ & 40800 & $<54.0$ & 65600 \\
\hline A3-LD-600 & 600 & 1.63 & 0.510 & 1580 & 71800 & 0.830 & 2570 & 117000 & 1.59 & 1.74 & $<33.4$ & 39400 & $<54.4$ & 64100 \\
\hline A3-FD-CP & $\begin{array}{c}\text { Feed } \\
\text { Displacement }\end{array}$ & 1 & 0.585 & 1680 & 77700 & 0.585 & 1680 & 77700 & 1.16 & 1.26 & 110 & 42200 & 110 & 42200 \\
\hline A3-EL-CP & Elution & 1 & 10.50 & 4.92 & 1160 & 10.5 & 4.92 & 1160 & $<0.05$ & $<0.05$ & $<40.3$ & 2750 & $<40.3$ & 2750 \\
\hline Target & -- & -- & -- & -- & -- & 2.79 & 2720 & 134000 & 1.86 & 2.41 & -- & -- & 0 & 61200 \\
\hline
\end{tabular}


Table B.4. Column A4 Test Analytical Data $\left(\mathrm{T}=45^{\circ} \mathrm{C}\right.$, Flow rate $\left.=10.62 \mathrm{~mL} / \mathrm{min}\right)$

\begin{tabular}{|c|c|c|c|c|c|c|c|c|c|c|c|c|c|c|}
\hline Sample ID & $\begin{array}{l}\text { Loading Time } \\
\text { (min) }\end{array}$ & $\begin{array}{l}\text { Dilution } \\
\text { Factor }\end{array}$ & $\begin{array}{c}\mathrm{Cs} \\
(\mathrm{raw}) \\
(\mathrm{mg} / \mathrm{kg})\end{array}$ & $\begin{array}{c}\mathrm{Al} \\
(\mathrm{raw}) \\
(\mathrm{mg} / \mathrm{kg})\end{array}$ & $\begin{array}{c}\mathrm{Na} \\
(\mathrm{raw}) \\
(\mathrm{mg} / \mathrm{kg})\end{array}$ & $\begin{array}{c}\mathrm{Cs} \\
\text { (corr.) } \\
\text { (mg/kg) }\end{array}$ & $\begin{array}{c}\mathrm{Al} \\
(\mathrm{corr} .) \\
(\mathrm{mg} / \mathrm{kg})\end{array}$ & $\begin{array}{c}\mathrm{Na} \\
(\mathrm{corr} .) \\
(\mathrm{mg} / \mathrm{kg})\end{array}$ & $\begin{array}{c}\text { OH-Free } \\
\text { (corr.) } \\
\text { (meq/mL) }\end{array}$ & $\begin{array}{c}\text { OH-Total } \\
\text { (corr.) } \\
\text { (meq/mL) }\end{array}$ & $\begin{array}{c}\mathrm{Cl} \\
(\mathrm{raw}) \\
(\mathrm{mg} / \mathrm{kg})\end{array}$ & $\begin{array}{c}\mathrm{NO}_{3} \\
\text { (raw) } \\
\text { (mg/kg) }\end{array}$ & $\begin{array}{c}\mathrm{Cl} \\
\text { (corr.) } \\
(\mathrm{mg} / \mathrm{kg})\end{array}$ & $\begin{array}{c}\mathrm{NO}_{3} \\
\text { (corr.) } \\
(\mathrm{mg} / \mathrm{kg})\end{array}$ \\
\hline A4-LD-00 & 0 & 1.65 & 3.71 & 3910 & 78700 & 6.11 & 6440 & 130000 & 3.23 & 3.61 & $<33.8$ & 27100 & $<55.7$ & 44700 \\
\hline A4-LD-06 & 6 & 1.76 & 3.18 & 3600 & 71700 & 5.59 & 6330 & 126000 & 3.11 & 3.46 & $<34.2$ & 24400 & $<60.1$ & 42900 \\
\hline A4-LD-12 & 12 & 1.61 & 3.38 & 4000 & 80200 & 5.44 & 6440 & 129000 & 3.17 & 3.54 & $<33.8$ & 27000 & $<54.4$ & 43500 \\
\hline A4-LD-18 & 18 & 1.67 & 3.00 & 3760 & 75400 & 5.02 & 6290 & 126000 & 3.16 & 3.53 & $<33.8$ & 26000 & $<56.5$ & 43500 \\
\hline A4-LD-24 & 24 & 1.66 & 2.92 & 3860 & 77100 & 4.84 & 6400 & 128000 & 3.15 & 3.53 & $<33.8$ & 26100 & $<56.0$ & 43300 \\
\hline A4-LD-36 & 36 & 1.63 & 2.74 & 3920 & 78400 & 4.48 & 6400 & 128000 & 3.17 & 3.51 & $<33.8$ & 26300 & $<55.2$ & 43000 \\
\hline A4-LD-48 & 48 & 1.68 & 2.46 & 3750 & 74400 & 4.12 & 6290 & 125000 & 3.12 & 3.50 & $<33.7$ & 25600 & $<56.5$ & 42900 \\
\hline A4-LD-60 & 60 & 1.66 & 2.46 & 3780 & 75900 & 4.08 & 6270 & 126000 & 3.14 & 3.52 & $<33.7$ & 26100 & $<55.9$ & 43300 \\
\hline A4-LD-80 & 80 & 1.60 & 2.52 & 4050 & 81200 & 4.04 & 6490 & 130000 & 3.16 & 3.54 & $<33.8$ & 27200 & $<54.2$ & 43600 \\
\hline A4-LD-120 & 120 & 1.64 & 2.27 & 3870 & 76700 & 3.73 & 6360 & 126000 & 3.15 & 3.52 & $<33.8$ & 26600 & $<55.5$ & 43700 \\
\hline A4-LD-180 & 180 & 1.72 & 2.03 & 3680 & 72900 & 3.50 & 6340 & 126000 & 3.12 & 3.48 & $<33.8$ & 24900 & $<58.2$ & 42900 \\
\hline A4-LD-240 & 240 & 1.64 & 2.01 & 3850 & 76600 & 3.29 & 6300 & 125000 & 3.17 & 3.52 & $<33.8$ & 26200 & $<55.3$ & 42800 \\
\hline A4-LD-600 & 600 & 1.65 & 1.58 & 3840 & 77300 & 2.60 & 6320 & 127000 & 3.16 & 3.52 & $<34.5$ & 27100 & $<56.8$ & 44600 \\
\hline A4-FD-CP & $\begin{array}{c}\text { Feed } \\
\text { Displacement }\end{array}$ & 1 & 1.73 & 5480 & 114000 & 1.73 & 5480 & 114000 & 3.13 & 3.50 & $<31.3$ & 38500 & $<31.3$ & 38500 \\
\hline Target & -- & -- & -- & -- & -- & 5.68 & 6690 & 137000 & 3.67 & 5.00 & -- & -- & 0 & 40800 \\
\hline
\end{tabular}


Table B.5. Column A4B Test Analytical Data $\left(\mathrm{T}=45^{\circ} \mathrm{C}\right.$, Flow rate $\left.=0.08 \mathrm{~mL} / \mathrm{min}\right)$

\begin{tabular}{|c|c|c|c|c|c|c|c|c|c|c|c|c|c|c|}
\hline Sample ID & $\begin{array}{c}\text { Loading Time } \\
\text { (hrs) }\end{array}$ & $\begin{array}{c}\text { Dilution } \\
\text { Factor }\end{array}$ & $\begin{array}{c}\mathrm{Cs} \\
(\mathrm{raw}) \\
(\mathrm{mg} / \mathrm{kg})\end{array}$ & $\begin{array}{c}\mathrm{Al} \\
(\mathrm{raw}) \\
(\mathrm{mg} / \mathrm{kg})\end{array}$ & $\begin{array}{c}\mathrm{Na} \\
(\mathrm{raw}) \\
(\mathrm{mg} / \mathrm{kg})\end{array}$ & $\begin{array}{c}\text { Cs } \\
\text { (corr.) } \\
\text { (mg/kg) }\end{array}$ & $\begin{array}{c}\mathrm{Al} \\
\text { (corr.) } \\
\text { (mg/kg) }\end{array}$ & $\begin{array}{c}\mathrm{Na} \\
(\mathrm{corr} .) \\
(\mathrm{mg} / \mathrm{kg})\end{array}$ & $\begin{array}{c}\text { OH-Free } \\
\text { (corr.) } \\
\text { (meq/mL) }\end{array}$ & $\begin{array}{c}\text { OH-Total } \\
\text { (corr.) } \\
\text { (meq/mL) }\end{array}$ & $\begin{array}{c}\mathrm{Cl} \\
(\mathrm{raw}) \\
(\mathrm{mg} / \mathrm{kg})\end{array}$ & $\begin{array}{c}\mathrm{NO}_{3} \\
\text { (raw) } \\
(\mathrm{mg} / \mathrm{kg})\end{array}$ & $\begin{array}{c}\mathrm{Cl} \\
\text { (corr.) } \\
\text { (mg/kg) }\end{array}$ & $\begin{array}{c}\mathrm{NO}_{3} \\
\text { (corr.) } \\
\text { (mg/kg) }\end{array}$ \\
\hline A4B-LD-00 & 0 & 1.61 & 3.84 & 4030 & 81300 & 6.20 & 6500 & 131000 & 3.31 & 3.66 & $<33.4$ & 27400 & $<53.9$ & 44200 \\
\hline A4B-LD-04 & 4 & 1.61 & 3.74 & 4020 & 78600 & 6.03 & 6480 & 127000 & 3.22 & 3.61 & $<33.5$ & 27200 & $<54.0$ & 43800 \\
\hline A4B-LD-08 & 8 & 1.63 & 3.57 & 4020 & 76300 & 5.83 & 6560 & 125000 & 3.22 & 3.59 & $<33.7$ & 26500 & $<55.0$ & 43300 \\
\hline A4B-LD-12 & 12 & 1.69 & 5.50 & 6190 & 119000 & 9.31 & 10500 & 201000 & 5.62 & 6.28 & $<31.5$ & 41600 & $<53.3$ & 70400 \\
\hline A4B-LD-24 & 24 & 1.56 & 4.95 & 5990 & 111000 & 7.71 & 9330 & 173000 & 4.67 & 5.23 & $<31.7$ & 38600 & $<49.4$ & 60100 \\
\hline A4B-LD-72 & 72 & 1.61 & 3.12 & 3980 & 80300 & 5.04 & 6430 & 130000 & 10.13 & 10.55 & $<33.4$ & 27100 & $<53.9$ & 43800 \\
\hline A4B-LD-120 & 120 & 1.62 & 2.77 & 3950 & 78100 & 4.50 & 6420 & 127000 & 3.25 & 3.64 & $<33.7$ & 27100 & $<54.7$ & 44000 \\
\hline A4B-LD-168 & 168 & 1.64 & 2.51 & 4020 & 80800 & 4.11 & 6590 & 132000 & 3.24 & 3.64 & $<33.7$ & 27300 & $<55.2$ & 44700 \\
\hline A4B-LD-336 & 336 & 1.67 & 1.99 & 4080 & 79800 & 3.32 & 6810 & 133000 & 3.24 & 3.66 & $<33.3$ & 24700 & $<55.6$ & 41200 \\
\hline A4B-LD-504 & 504 & 1.65 & 1.98 & 4010 & 82200 & 3.27 & 6630 & 136000 & 3.34 & 3.72 & $<33.6$ & 25400 & $<55.5$ & 42000 \\
\hline A4B-LD-672 & 672 & 1.63 & 2.03 & 4240 & 84800 & 3.32 & 6920 & 138000 & 3.38 & 3.80 & $<34.1$ & 27200 & $<55.7$ & 44400 \\
\hline A4B-LD-720 & 720 & 1.65 & 2.01 & 4060 & 82900 & 3.32 & 6700 & 137000 & 3.37 & 3.81 & $<34.2$ & 26700 & $<56.4$ & 44000 \\
\hline A4B-FD-CP & $\begin{array}{c}\text { Feed } \\
\text { Displacement }\end{array}$ & 1 & 1.93 & 3560 & 75600 & 1.93 & 3560 & 75600 & 1.78 & 2.00 & $<37.7$ & 21700 & $<37.7$ & 21700 \\
\hline A4B-EL-CP & Elution & 1 & 31.0 & 46.5 & 1610 & 31.0 & 46.5 & 1610 & $<0.05$ & $<0.05$ & $<40.6$ & 2490 & $<40.6$ & 2490 \\
\hline Target & -- & -- & -- & -- & -- & 5.68 & 6690 & 137000 & 3.67 & 5.00 & -- & -- & 0 & 40800 \\
\hline
\end{tabular}


Table B.6. Column A5 Test Analytical Data $\left(\mathrm{T}=45^{\circ} \mathrm{C}\right.$, Flow rate $\left.=10.62 \mathrm{~mL} / \mathrm{min}\right)$

\begin{tabular}{|c|c|c|c|c|c|c|c|c|c|c|c|c|c|c|}
\hline Sample ID & $\begin{array}{l}\text { Loading Time } \\
\text { (min) }\end{array}$ & $\begin{array}{c}\text { Dilution } \\
\text { Factor }\end{array}$ & $\begin{array}{c}\text { Cs } \\
(\mathrm{raw}) \\
(\mathrm{mg} / \mathrm{kg})\end{array}$ & $\begin{array}{c}\mathrm{Al} \\
(\mathrm{raw}) \\
(\mathrm{mg} / \mathrm{kg})\end{array}$ & $\begin{array}{c}\mathrm{Na} \\
(\mathrm{raw}) \\
(\mathrm{mg} / \mathrm{kg})\end{array}$ & $\begin{array}{c}\text { Cs } \\
\text { (corr.) } \\
\text { (mg/kg) }\end{array}$ & $\begin{array}{c}\mathrm{Al} \\
\text { (corr.) } \\
(\mathrm{mg} / \mathrm{kg})\end{array}$ & $\begin{array}{c}\mathrm{Na} \\
(\text { corr. }) \\
(\mathrm{mg} / \mathrm{kg})\end{array}$ & $\begin{array}{c}\text { OH-Free } \\
\text { (corr.) } \\
\text { (meq/mL) }\end{array}$ & $\begin{array}{c}\text { OH-Total } \\
\text { (corr.) } \\
\text { (meq/mL) }\end{array}$ & $\begin{array}{c}\mathrm{Cl} \\
(\mathrm{raw}) \\
(\mathrm{mg} / \mathrm{kg})\end{array}$ & $\begin{array}{c}\mathrm{NO}_{3} \\
\text { (raw) } \\
\text { (mg/kg) }\end{array}$ & $\begin{array}{c}\mathrm{Cl} \\
\text { (corr.) } \\
\text { (mg/kg) }\end{array}$ & $\begin{array}{c}\mathrm{NO}_{3} \\
\text { (corr.) } \\
\text { (mg/kg) } \\
\end{array}$ \\
\hline A5-LD-00 & 0 & 1 & 2.98 & 2560 & 88200 & 2.98 & 2560 & 88200 & 1.55 & 1.70 & 51700 & 18500 & 51700 & 18500 \\
\hline A5-LD-06 & 6 & 1 & 2.49 & 2530 & 85600 & 2.49 & 2530 & 85600 & 1.50 & 1.66 & 50200 & 18200 & 50200 & 18200 \\
\hline A5-LD-12 & 12 & 1 & 2.15 & 2570 & 84900 & 2.15 & 2570 & 84900 & 1.50 & 1.67 & 49600 & 17800 & 49600 & 17800 \\
\hline A5-LD-18 & 18 & 1 & 1.91 & 2570 & 85500 & 1.91 & 2570 & 85500 & 1.51 & 1.66 & 50300 & 18100 & 50300 & 18100 \\
\hline A5-LD-24 & 24 & 1 & 1.73 & 2550 & 85500 & 1.73 & 2550 & 85500 & 1.50 & 1.65 & 50000 & 17900 & 50000 & 17900 \\
\hline A5-LD-36 & 36 & 1 & 1.45 & 2580 & 85000 & 1.45 & 2580 & 85000 & 1.50 & 1.65 & 49800 & 17700 & 49800 & 17700 \\
\hline A5-LD-48 & 48 & 1 & 1.29 & 2500 & 86500 & 1.29 & 2500 & 86500 & 1.49 & 1.65 & 49600 & 17900 & 49600 & 17900 \\
\hline A5-LD-60 & 60 & 1 & 1.18 & 2580 & 89300 & 1.18 & 2580 & 89300 & 1.51 & 1.66 & 50300 & 18000 & 50300 & 18000 \\
\hline A5-LD-80 & 80 & 1 & 1.01 & 2510 & 83600 & 1.01 & 2510 & 83600 & 1.50 & 1.65 & 51100 & 18400 & 51100 & 18400 \\
\hline A5-LD-120 & 120 & 1 & 0.828 & 2570 & 85000 & 0.828 & 2570 & 85000 & 1.50 & 1.65 & 49700 & 17900 & 49700 & 17900 \\
\hline A5-LD-180 & 180 & 1 & 0.702 & 2570 & 86700 & 0.702 & 2570 & 86700 & 1.50 & 1.65 & 50100 & 18000 & 50100 & 18000 \\
\hline A5-LD-240 & 240 & 1 & 0.644 & 2480 & 85000 & 0.644 & 2480 & 85000 & 1.50 & 1.65 & 49700 & 17900 & 49700 & 17900 \\
\hline A5-LD-600 & 600 & 1 & 0.620 & 2580 & 85100 & 0.620 & 2580 & 85100 & 1.50 & 1.65 & 50000 & 17800 & 50000 & 17800 \\
\hline A5-LD-900 & 900 & 1 & 0.649 & 2560 & 85200 & 0.649 & 2560 & 85200 & 1.51 & 1.66 & 51000 & 18300 & 51000 & 18300 \\
\hline A5-LD-1200 & 1200 & 1 & 0.646 & 2530 & 85600 & 0.646 & 2530 & 85600 & 1.51 & 1.66 & 49400 & 17800 & 49400 & 17800 \\
\hline A5-FD-CP & $\begin{array}{c}\text { Feed } \\
\text { Displacement }\end{array}$ & 1 & 0.445 & 1500 & 51700 & 0.445 & 1500 & 51700 & 0.927 & 1.01 & 29700 & 10800 & 29700 & 10800 \\
\hline A5-EL-CP & Elution & 1 & 11.2 & 7.16 & 950 & 11.2 & 7.16 & 950 & $<0.05$ & $<0.05$ & $<40.8$ & 2490 & $<40.8$ & 2490 \\
\hline Target & -- & -- & -- & -- & -- & 2.62 & 2570 & 95000 & 1.55 & 2.01 & -- & -- & 48900 & 19300 \\
\hline
\end{tabular}


Table B.7. Column B1 Test Analytical Data $\left(\mathrm{T}=50^{\circ} \mathrm{C}\right.$, Flow rate $\left.=10.62 \mathrm{~mL} / \mathrm{min}\right)$

\begin{tabular}{|c|c|c|c|c|c|c|c|c|c|c|c|c|c|c|}
\hline Sample ID & $\begin{array}{l}\text { Loading Time } \\
\text { (min) }\end{array}$ & $\begin{array}{c}\text { Dilution } \\
\text { Factor }\end{array}$ & $\begin{array}{c}\text { Cs } \\
(\mathrm{raw}) \\
(\mathrm{mg} / \mathrm{kg})\end{array}$ & $\begin{array}{c}\mathrm{Al} \\
(\mathrm{raw}) \\
(\mathrm{mg} / \mathrm{kg})\end{array}$ & $\begin{array}{c}\mathrm{Na} \\
(\mathrm{raw}) \\
(\mathrm{mg} / \mathrm{kg})\end{array}$ & $\begin{array}{c}\text { Cs } \\
\text { (corr.) } \\
(\mathrm{mg} / \mathrm{kg})\end{array}$ & $\begin{array}{c}\mathrm{Al} \\
\text { (corr.) } \\
(\mathrm{mg} / \mathrm{kg})\end{array}$ & $\begin{array}{c}\mathrm{Na} \\
(\text { corr. }) \\
(\mathrm{mg} / \mathrm{kg})\end{array}$ & $\begin{array}{c}\text { OH-Free } \\
\text { (corr.) } \\
\text { (meq/mL) }\end{array}$ & $\begin{array}{c}\text { OH-Total } \\
\text { (corr.) } \\
\text { (meq/mL) }\end{array}$ & $\begin{array}{c}\mathrm{Cl} \\
(\mathrm{raw}) \\
(\mathrm{mg} / \mathrm{kg})\end{array}$ & $\begin{array}{c}\mathrm{NO}_{3} \\
\text { (raw) } \\
\text { (mg/kg) }\end{array}$ & $\begin{array}{c}\mathrm{Cl} \\
\text { (corr.) } \\
\text { (mg/kg) }\end{array}$ & $\begin{array}{c}\mathrm{NO}_{3} \\
\text { (corr.) } \\
\text { (mg/kg) }\end{array}$ \\
\hline B1-LD-00 & 0 & 1 & 3.18 & 2690 & 92900 & 3.18 & 2690 & 92900 & 1.56 & 1.71 & 50500 & 18200 & 50500 & 18200 \\
\hline B1-LD-06 & 6 & 1 & 2.60 & 2540 & 87900 & 2.60 & 2540 & 87900 & 1.50 & 1.65 & 48500 & 17500 & 48500 & 17500 \\
\hline B1-LD-12 & 12 & 1 & 2.32 & 2530 & 87800 & 2.32 & 2530 & 87800 & 1.50 & 1.66 & 49300 & 17700 & 49300 & 17700 \\
\hline B1-LD-18 & 18 & 1 & 2.04 & 2420 & 87300 & 2.04 & 2420 & 87300 & 1.49 & 1.64 & 50400 & 18200 & 50400 & 18200 \\
\hline B1-LD-24 & 24 & 1 & 1.87 & 2520 & 90500 & 1.87 & 2520 & 90500 & 1.49 & 1.65 & 48800 & 17400 & 48800 & 17400 \\
\hline B1-LD-36 & 36 & 1 & 1.55 & 2630 & 90300 & 1.55 & 2630 & 90300 & 1.49 & 1.65 & 49100 & 17600 & 49100 & 17600 \\
\hline B1-LD-48 & 48 & 1 & 1.22 & 2460 & 86000 & 1.22 & 2460 & 86000 & 1.50 & 1.64 & 49900 & 18000 & 49900 & 18000 \\
\hline B1-LD-60 & 60 & 1 & 1.09 & 2590 & 88200 & 1.09 & 2590 & 88200 & 1.50 & 1.65 & 48800 & 17700 & 48800 & 17700 \\
\hline B1-LD-80 & 80 & 1 & 0.930 & 2520 & 88600 & 0.930 & 2520 & 88600 & 1.49 & 1.64 & 48400 & 17400 & 48400 & 17400 \\
\hline B1-LD-120 & 120 & 1 & 0.699 & 2580 & 86900 & 0.699 & 2580 & 86900 & 1.50 & 1.65 & 49200 & 17600 & 49200 & 17600 \\
\hline B1-LD-180 & 180 & 1 & 0.562 & 2600 & 88800 & 0.562 & 2600 & 88800 & 1.50 & 1.64 & 49100 & 17700 & 49100 & 17700 \\
\hline B1-LD-240 & 240 & 1 & 0.500 & 2490 & 90000 & 0.500 & 2490 & 90000 & 1.49 & 1.64 & 49800 & 18000 & 49800 & 18000 \\
\hline B1-LD-600 & 600 & 1 & 0.382 & 2510 & 86900 & 0.382 & 2510 & 86900 & 1.50 & 1.65 & 49000 & 17600 & 49000 & 17600 \\
\hline B1-LD-900 & 900 & 1 & 0.383 & 2550 & 88700 & 0.383 & 2550 & 88700 & 1.49 & 1.64 & 48700 & 17700 & 48700 & 17700 \\
\hline B1-LD-1200 & 1200 & 1 & 0.402 & 2650 & 89500 & 0.402 & 2650 & 89500 & 1.51 & 1.66 & 49200 & 17700 & 49200 & 17700 \\
\hline B1-FD-CP & $\begin{array}{c}\text { Feed } \\
\text { Displacement }\end{array}$ & 1 & 0.294 & 1590 & 55600 & 0.294 & 1590 & 55600 & 0.958 & 1.04 & 32100 & 11600 & 32100 & 11600 \\
\hline B1-EL-CP & Elution & 1 & 11.5 & 4.17 & 1170 & 11.5 & 4.17 & 1170 & $<0.05$ & $<0.05$ & $<41.4$ & 2500 & $<41.4$ & 2500 \\
\hline Target & -- & -- & -- & -- & -- & 2.63 & 2570 & 95000 & 1.55 & 2.01 & -- & -- & 48900 & 19300 \\
\hline
\end{tabular}


Table B.8. Column B2 Test Analytical Data $\left(T=50^{\circ} \mathrm{C}\right.$, Flow rate $\left.=14.16 \mathrm{~mL} / \mathrm{min}\right)$

\begin{tabular}{|c|c|c|c|c|c|c|c|c|c|c|c|c|c|c|}
\hline Sample ID & $\begin{array}{l}\text { Loading Time } \\
\text { (min) }\end{array}$ & $\begin{array}{c}\text { Dilution } \\
\text { Factor }\end{array}$ & $\begin{array}{c}\text { Cs } \\
(\mathrm{raw}) \\
(\mathrm{mg} / \mathrm{kg})\end{array}$ & $\begin{array}{c}\mathrm{Al} \\
(\mathrm{raw}) \\
(\mathrm{mg} / \mathrm{kg})\end{array}$ & $\begin{array}{c}\mathrm{Na} \\
(\mathrm{raw}) \\
(\mathrm{mg} / \mathrm{kg})\end{array}$ & $\begin{array}{c}\text { Cs } \\
\text { (corr.) } \\
\text { (mg/kg) }\end{array}$ & $\begin{array}{c}\mathrm{Al} \\
\text { (corr.) } \\
(\mathrm{mg} / \mathrm{kg})\end{array}$ & $\begin{array}{c}\mathrm{Na} \\
\text { (corr.) } \\
\text { (mg/kg) }\end{array}$ & $\begin{array}{c}\text { OH-Free } \\
\text { (corr.) } \\
\text { (meq/mL) }\end{array}$ & $\begin{array}{c}\text { OH-Total } \\
\text { (corr.) } \\
\text { (meq/mL) }\end{array}$ & $\begin{array}{c}\mathrm{Cl} \\
(\mathrm{raw}) \\
(\mathrm{mg} / \mathrm{kg})\end{array}$ & $\begin{array}{c}\mathrm{NO}_{3} \\
\text { (raw) } \\
\text { (mg/kg) }\end{array}$ & $\begin{array}{c}\mathrm{Cl} \\
\text { (corr.) } \\
\text { (mg/kg) }\end{array}$ & $\begin{array}{c}\mathrm{NO}_{3} \\
\text { (corr.) } \\
\text { (mg/kg) }\end{array}$ \\
\hline B2-LD-00 & 0 & 1 & 1.60 & 798 & 47900 & 1.60 & 798 & 47900 & 0.462 & 0.506 & 27000 & 8440 & 27000 & 8440 \\
\hline B2-LD-06 & 6 & 1 & 1.24 & 769 & 41500 & 1.24 & 769 & 41500 & 0.463 & 0.507 & 26000 & 8130 & 26000 & 8130 \\
\hline B2-LD-12 & 12 & 1 & 0.992 & 778 & 38300 & 0.992 & 778 & 38300 & 0.452 & 0.500 & 26100 & 8120 & 26100 & 8120 \\
\hline B2-LD-18 & 18 & 1 & 0.830 & 774 & 51200 & 0.830 & 774 & 51200 & 0.461 & 0.505 & 26000 & 8110 & 26000 & 8110 \\
\hline B2-LD-24 & 24 & 1 & 0.695 & 777 & 41300 & 0.695 & 777 & 41300 & 0.462 & 0.505 & 26200 & 8120 & 26200 & 8120 \\
\hline B2-LD-36 & 36 & 1 & 0.497 & 758 & 37000 & 0.497 & 758 & 37000 & 0.460 & 0.502 & 26000 & 8150 & 26000 & 8150 \\
\hline B2-LD-48 & 48 & 1 & 0.385 & 742 & 35600 & 0.385 & 742 & 35600 & 0.453 & 0.505 & 25900 & 8190 & 25900 & 8190 \\
\hline B2-LD-60 & 60 & 1 & 0.339 & 781 & 46500 & 0.339 & 781 & 46500 & 0.459 & 0.506 & 26000 & 8110 & 26000 & 8110 \\
\hline B2-LD-80 & 80 & 1 & 0.262 & 765 & 37400 & 0.262 & 765 & 37400 & 0.461 & 0.502 & 25700 & 8150 & 25700 & 8150 \\
\hline B2-LD-120 & 120 & 1 & 0.203 & 778 & 47700 & 0.203 & 778 & 47700 & 0.466 & 0.509 & 26100 & 8160 & 26100 & 8160 \\
\hline B2-LD-180 & 180 & 1 & 0.169 & 799 & 39800 & 0.169 & 799 & 39800 & 0.462 & 0.507 & 25700 & 8140 & 25700 & 8140 \\
\hline B2-LD-240 & 240 & 1 & 0.148 & 783 & 43200 & 0.148 & 783 & 43200 & 0.457 & 0.502 & 26300 & 8220 & 26300 & 8220 \\
\hline B2-LD-600 & 600 & 1 & 0.127 & 770 & 37100 & 0.127 & 770 & 37100 & 0.459 & 0.509 & 26600 & 8330 & 26600 & 8330 \\
\hline B2-LD-900 & 900 & 1 & 0.142 & 793 & 43400 & 0.142 & 793 & 43400 & 0.468 & 0.515 & 26500 & 8360 & 26500 & 8360 \\
\hline B2-LD-1200 & 1200 & 1 & 0.144 & 763 & 38300 & 0.144 & 763 & 38300 & 0.465 & 0.510 & 26300 & 8220 & 26300 & 8220 \\
\hline B2-FD-CP & $\begin{array}{c}\text { Feed } \\
\text { Displacement }\end{array}$ & 1 & 0.104 & 477 & 26100 & 0.104 & 477 & 26100 & 0.334 & 0.362 & 15800 & 4720 & 15800 & 4720 \\
\hline B2-EL-CP & Elution & 1 & 7.68 & $<2.00$ & 1160 & 7.68 & $<2.00$ & 1160 & $<0.05$ & $<0.05$ & 157 & 2310 & 157 & 2310 \\
\hline Target & -- & -- & -- & -- & -- & 1.71 & 808 & 42400 & 0.468 & 0.598 & -- & -- & 27200 & 8590 \\
\hline
\end{tabular}


Table B.9. Column B3 Test Analytical Data $\left(\mathrm{T}=50^{\circ} \mathrm{C}\right.$, Flow rate $\left.=7.08 \mathrm{~mL} / \mathrm{min}\right)$

\begin{tabular}{|c|c|c|c|c|c|c|c|c|c|c|c|c|c|c|}
\hline Sample ID & $\begin{array}{l}\text { Loading Time } \\
\text { (min) }\end{array}$ & $\begin{array}{c}\text { Dilution } \\
\text { Factor }\end{array}$ & $\begin{array}{c}\text { Cs } \\
(\mathrm{raw}) \\
(\mathrm{mg} / \mathrm{kg})\end{array}$ & $\begin{array}{c}\mathrm{Al} \\
(\mathrm{raw}) \\
(\mathrm{mg} / \mathrm{kg})\end{array}$ & $\begin{array}{c}\mathrm{Na} \\
(\mathrm{raw}) \\
(\mathrm{mg} / \mathrm{kg})\end{array}$ & $\begin{array}{c}\text { Cs } \\
\text { (corr.) } \\
\text { (mg/kg) }\end{array}$ & $\begin{array}{c}\mathrm{Al} \\
\text { (corr.) } \\
(\mathrm{mg} / \mathrm{kg})\end{array}$ & $\begin{array}{c}\mathrm{Na} \\
(\text { corr. }) \\
(\mathrm{mg} / \mathrm{kg})\end{array}$ & $\begin{array}{c}\text { OH-Free } \\
\text { (corr.) } \\
\text { (meq/mL) }\end{array}$ & $\begin{array}{c}\text { OH-Total } \\
\text { (corr.) } \\
\text { (meq/mL) }\end{array}$ & $\begin{array}{c}\mathrm{Cl} \\
(\mathrm{raw}) \\
(\mathrm{mg} / \mathrm{kg})\end{array}$ & $\begin{array}{c}\mathrm{NO}_{3} \\
\text { (raw) } \\
\text { (mg/kg) }\end{array}$ & $\begin{array}{c}\mathrm{Cl} \\
\text { (corr.) } \\
\text { (mg/kg) }\end{array}$ & $\begin{array}{c}\mathrm{NO}_{3} \\
\text { (corr.) } \\
\text { (mg/kg) } \\
\end{array}$ \\
\hline B3-LD-00 & 0 & 1 & 1.57 & 756 & 39300 & 1.57 & 756 & 39300 & 0.466 & 0.509 & 27300 & 8600 & 27300 & 8600 \\
\hline B3-LD-06 & 6 & 1 & 1.33 & 736 & 36600 & 1.33 & 736 & 36600 & 0.456 & 0.497 & 25700 & 7990 & 25700 & 7990 \\
\hline B3-LD-12 & 12 & 1 & 1.24 & 765 & 37500 & 1.24 & 765 & 37500 & 0.458 & 0.501 & 25700 & 8020 & 25700 & 8020 \\
\hline B3-LD-18 & 18 & 1 & 1.12 & 761 & 38200 & 1.12 & 761 & 38200 & 0.460 & 0.503 & 26400 & 8200 & 26400 & 8200 \\
\hline B3-LD-24 & 24 & 1 & 1.00 & 761 & 38400 & 1.00 & 761 & 38400 & 0.461 & 0.505 & 24900 & 7820 & 24900 & 7820 \\
\hline B3-LD-36 & 36 & 1 & 0.786 & 736 & 36800 & 0.786 & 736 & 36800 & 0.462 & 0.503 & 25500 & 7940 & 25500 & 7940 \\
\hline B3-LD-48 & 48 & 1 & 0.657 & 749 & 37800 & 0.657 & 749 & 37800 & 0.462 & 0.504 & 26000 & 8170 & 26000 & 8170 \\
\hline B3-LD-60 & 60 & 1 & 0.532 & 759 & 37200 & 0.532 & 759 & 37200 & 0.459 & 0.503 & 25600 & 8020 & 25600 & 8020 \\
\hline B3-LD-80 & 80 & 1 & 0.432 & 754 & 38100 & 0.432 & 754 & 38100 & 0.457 & 0.502 & 25600 & 8000 & 25600 & 8000 \\
\hline B3-LD-120 & 120 & 1 & 0.288 & 756 & 38600 & 0.288 & 756 & 38600 & 0.459 & 0.504 & 25700 & 8080 & 25700 & 8080 \\
\hline B3-LD-180 & 180 & 1 & 0.205 & 757 & 37700 & 0.205 & 757 & 37700 & 0.454 & 0.499 & 25600 & 8020 & 25600 & 8020 \\
\hline B3-LD-240 & 240 & 1 & 0.159 & 743 & 37800 & 0.159 & 743 & 37800 & 0.464 & 0.506 & 25900 & 8110 & 25900 & 8110 \\
\hline B3-LD-600 & 600 & 1 & 0.125 & 746 & 37200 & 0.125 & 746 & 37200 & 0.458 & 0.503 & 25800 & 8070 & 25800 & 8070 \\
\hline B3-LD-900 & 900 & 1 & 0.131 & 750 & 38100 & 0.131 & 750 & 38100 & 0.468 & 0.509 & 25800 & 8110 & 25800 & 8110 \\
\hline B3-LD-1200 & 1200 & 1 & 0.134 & 757 & 38500 & 0.134 & 757 & 38500 & 0.462 & 0.508 & 26300 & 8180 & 26300 & 8180 \\
\hline B3-FD-CP & $\begin{array}{c}\text { Feed } \\
\text { Displacement }\end{array}$ & 1 & 0.104 & 442 & 23200 & 0.104 & 442 & 23200 & 0.333 & 0.363 & 15800 & 4650 & 15800 & 4650 \\
\hline B3-EL-CP & Elution & 1 & 7.15 & $<2.00$ & 1130 & 7.15 & $<2.00$ & 1130 & $<0.05$ & $<0.05$ & $<101$ & 2340 & $<101$ & 2340 \\
\hline Target & -- & -- & -- & -- & -- & 1.71 & 808 & 42400 & 0.468 & 0.598 & -- & -- & 27200 & 8590 \\
\hline
\end{tabular}


Table B.10. Column B4 Test Analytical Data $\left(T=50^{\circ} \mathrm{C}\right.$, Flow rate $\left.=7.08 \mathrm{~mL} / \mathrm{min}\right)$

\begin{tabular}{|c|c|c|c|c|c|c|c|c|c|c|c|c|c|c|}
\hline Sample ID & $\begin{array}{l}\text { Loading Time } \\
(\mathrm{min})\end{array}$ & $\begin{array}{c}\text { Dilution } \\
\text { Factor }\end{array}$ & $\begin{array}{c}\mathrm{Cs} \\
(\mathrm{raw}) \\
(\mathrm{mg} / \mathrm{kg})\end{array}$ & $\begin{array}{c}\mathrm{Al} \\
(\mathrm{raw}) \\
(\mathrm{mg} / \mathrm{kg})\end{array}$ & $\begin{array}{c}\mathrm{Na} \\
(\mathrm{raw}) \\
(\mathrm{mg} / \mathrm{kg})\end{array}$ & $\begin{array}{c}\text { Cs } \\
\text { (corr.) } \\
\text { (mg/kg) }\end{array}$ & $\begin{array}{c}\mathrm{Al} \\
(\mathrm{corr} .) \\
(\mathrm{mg} / \mathrm{kg})\end{array}$ & $\begin{array}{c}\mathrm{Na} \\
\text { (corr.) } \\
\text { (mg/kg) }\end{array}$ & $\begin{array}{c}\text { OH-Free } \\
\text { (corr.) } \\
\text { (meq/mL) }\end{array}$ & $\begin{array}{c}\text { OH-Total } \\
\text { (corr.) } \\
\text { (meq/mL) }\end{array}$ & $\begin{array}{c}\mathrm{Cl} \\
(\mathrm{raw}) \\
(\mathrm{mg} / \mathrm{kg})\end{array}$ & $\begin{array}{c}\mathrm{NO}_{3} \\
(\mathrm{raw}) \\
(\mathrm{mg} / \mathrm{kg})\end{array}$ & $\begin{array}{c}\mathrm{Cl} \\
\text { (corr.) } \\
\text { (mg/kg) }\end{array}$ & $\begin{array}{c}\mathrm{NO}_{3} \\
\text { (corr.) } \\
\text { (mg/kg) }\end{array}$ \\
\hline B4-LD-00 & 0 & 1.62 & 1.76 & 4240 & 78400 & 2.85 & 6870 & 127000 & 3.21 & 3.58 & $<86.1$ & 24600 & $<140$ & 39900 \\
\hline B4-LD-06 & 6 & 1.71 & 1.53 & 3720 & 71100 & 2.62 & 6370 & 122000 & 3.10 & 3.48 & $<85.9$ & 22200 & $<147$ & 38000 \\
\hline B4-LD-12 & 12 & 1.67 & 1.51 & 3990 & 74700 & 2.53 & 6680 & 125000 & 3.10 & 3.48 & $<84.7$ & 22700 & $<142$ & 38000 \\
\hline B4-LD-18 & 18 & 1.76 & 1.37 & 3860 & 70000 & 2.41 & 6780 & 123000 & 3.13 & 3.48 & $<85.3$ & 21600 & $<150$ & 37900 \\
\hline B4-LD-24 & 24 & 1.69 & 1.36 & 3990 & 72000 & 2.30 & 6750 & 122000 & 3.13 & 3.50 & $<86.1$ & 22700 & $<146$ & 38400 \\
\hline B4-LD-36 & 36 & 1.65 & 1.25 & 3910 & 72800 & 2.06 & 6460 & 120000 & 3.12 & 3.48 & $<84.7$ & 23400 & $<140$ & 38600 \\
\hline B4-LD-48 & 48 & 1.74 & 1.11 & 3530 & 69500 & 1.93 & 6150 & 121000 & 3.05 & 3.41 & $<85.9$ & 21400 & $<150$ & 37300 \\
\hline B4-LD-60 & 60 & 1.64 & 1.09 & 3660 & 72800 & 1.79 & 6000 & 119000 & 3.10 & 3.47 & $<84.7$ & 23000 & $<139$ & 37700 \\
\hline B4-LD-80 & 80 & 1.93 & 0.836 & 3190 & 61500 & 1.61 & 6150 & 119000 & 3.05 & 3.39 & $<87.0$ & 19300 & $<168$ & 37200 \\
\hline B4-LD-120 & 120 & 1.83 & 0.784 & 3550 & 68300 & 1.44 & 6510 & 125000 & 3.04 & 3.43 & $<86.2$ & 20600 & $<158$ & 37800 \\
\hline B4-LD-180 & 180 & 1.69 & 0.698 & 3840 & 71600 & 1.18 & 6500 & 121000 & 3.13 & 3.49 & $<85.5$ & 22400 & $<145$ & 37900 \\
\hline B4-LD-240 & 240 & 1.68 & 0.631 & 3910 & 73700 & 1.06 & 6570 & 124000 & 3.11 & 3.46 & $<88.2$ & 23400 & $<148$ & 39300 \\
\hline B4-LD-600 & 600 & 1.72 & 0.644 & 5050 & 98400 & 1.11 & 8700 & 170000 & 4.83 & 5.38 & $<80.0$ & 32600 & $<138$ & 56200 \\
\hline B4-FD-CP & $\begin{array}{c}\text { Feed } \\
\text { Displacement }\end{array}$ & 1 & 0.630 & 4300 & 80400 & 0.630 & 4300 & 80400 & 2.14 & 2.38 & $<89.1$ & 24600 & $<89.1$ & 24600 \\
\hline Target & -- & -- & -- & -- & -- & 2.87 & 6710 & 137000 & 3.67 & 5.00 & -- & -- & 0 & 41700 \\
\hline
\end{tabular}


Table B.11. Column B4B Test Analytical Data $\left(T=65^{\circ} \mathrm{C}\right.$, Flow rate $\left.=0.08 \mathrm{~mL} / \mathrm{min}\right)$

\begin{tabular}{|c|c|c|c|c|c|c|c|c|c|c|c|c|c|c|}
\hline Sample ID & $\begin{array}{l}\text { Loading Time } \\
\text { (hrs) }\end{array}$ & $\begin{array}{l}\text { Dilution } \\
\text { Factor }\end{array}$ & $\begin{array}{c}\mathrm{Cs} \\
(\mathrm{raw}) \\
(\mathrm{mg} / \mathrm{kg})\end{array}$ & $\begin{array}{c}\mathrm{Al} \\
(\mathrm{raw}) \\
(\mathrm{mg} / \mathrm{kg})\end{array}$ & $\begin{array}{c}\mathrm{Na} \\
(\mathrm{raw}) \\
(\mathrm{mg} / \mathrm{kg})\end{array}$ & $\begin{array}{c}\mathrm{Cs} \\
\text { (corr.) } \\
\text { (mg/kg) }\end{array}$ & $\begin{array}{c}\mathrm{Al} \\
(\mathrm{corr} .) \\
(\mathrm{mg} / \mathrm{kg})\end{array}$ & $\begin{array}{c}\mathrm{Na} \\
(\mathrm{corr} .) \\
(\mathrm{mg} / \mathrm{kg})\end{array}$ & $\begin{array}{c}\text { OH-Free } \\
\text { (corr.) } \\
\text { (meq/mL) }\end{array}$ & $\begin{array}{c}\text { OH-Total } \\
\text { (corr.) } \\
\text { (meq/mL) }\end{array}$ & $\begin{array}{c}\mathrm{Cl} \\
(\mathrm{raw}) \\
(\mathrm{mg} / \mathrm{kg})\end{array}$ & $\begin{array}{c}\mathrm{NO}_{3} \\
\text { (raw) } \\
\text { (mg/kg) }\end{array}$ & $\begin{array}{c}\mathrm{Cl} \\
\text { (corr.) } \\
(\mathrm{mg} / \mathrm{kg})\end{array}$ & $\begin{array}{c}\mathrm{NO}_{3} \\
\text { (corr.) } \\
(\mathrm{mg} / \mathrm{kg})\end{array}$ \\
\hline B4B-LD-00 & 0 & 1.75 & 1.61 & 3520 & 70400 & 2.82 & 6160 & 123000 & 3.20 & 3.55 & $<86.5$ & 22600 & $<151$ & 39600 \\
\hline B4B-LD-04 & 4 & 1.72 & 1.58 & 3690 & 71300 & 2.72 & 6360 & 123000 & 3.12 & 3.48 & $<86.7$ & 22200 & $<150$ & 38300 \\
\hline B4B-LD-08 & 8 & 1.73 & 1.51 & 3440 & 69800 & 2.61 & 5940 & 120000 & 3.09 & 3.45 & $<85.3$ & 22000 & $<147$ & 38000 \\
\hline B4B-LD-12 & 12 & 1.68 & 1.55 & 4030 & 72400 & 2.61 & 6780 & 122000 & 3.11 & 3.50 & $<84.3$ & 22600 & $<142$ & 38000 \\
\hline B4B-LD-24 & 24 & 1.65 & 1.53 & 3860 & 76000 & 2.53 & 6380 & 126000 & 3.17 & 3.57 & $<84.9$ & 23700 & $<140$ & 39100 \\
\hline B4B-LD-72 & 72 & 1.63 & 1.49 & 4090 & 77200 & 2.43 & 6660 & 126000 & 3.24 & 3.63 & $<86.5$ & 24200 & $<141$ & 39400 \\
\hline B4B-LD-120 & 120 & 1.63 & 1.58 & 4220 & 79800 & 2.58 & 6890 & 130000 & 3.35 & 3.74 & $<83.5$ & 24600 & $<136$ & 40100 \\
\hline B4B-LD-168 & 168 & 1.66 & 1.59 & 4270 & 81100 & 2.65 & 7110 & 135000 & 3.38 & 3.78 & $<87.0$ & 24300 & $<145$ & 40500 \\
\hline B4B-LD-336 & 336 & 1.64 & 1.70 & 4470 & 86400 & 2.79 & 7320 & 142000 & 3.57 & 4.01 & $<82.5$ & 26400 & $<135$ & 43300 \\
\hline B4B-LD-504 & 504 & 1.65 & 1.90 & 4870 & 92400 & 3.13 & 8020 & 152000 & 3.84 & 4.32 & $<81.7$ & 27500 & $<135$ & 45300 \\
\hline B4B-FD-CP & $\begin{array}{c}\text { Feed } \\
\text { Displacement }\end{array}$ & 1 & 0.198 & 106 & 5550 & 0.198 & 106 & 5550 & 0.18 & 0.19 & 313 & 805 & 313 & 805 \\
\hline B4B-EL-CP & Elution & 1 & 9.18 & 255 & 1260 & 9.18 & 255 & 1260 & $<0.05$ & $<0.05$ & $<101$ & 2400 & $<101$ & 2400 \\
\hline Target & -- & -- & -- & -- & -- & 2.87 & 6710 & 137000 & 3.67 & 5.00 & -- & -- & 0 & 41700 \\
\hline
\end{tabular}


Table B.12. Column B5 Test Analytical Data $\left(\mathrm{T}=50^{\circ} \mathrm{C}\right.$, Flow rate $\left.=10.62 \mathrm{~mL} / \mathrm{min}\right)$

\begin{tabular}{|c|c|c|c|c|c|c|c|c|c|c|c|c|c|c|}
\hline Sample ID & $\begin{array}{l}\text { Loading Time } \\
\text { (min) }\end{array}$ & $\begin{array}{l}\text { Dilution } \\
\text { Factor }\end{array}$ & $\begin{array}{c}\mathrm{Cs} \\
(\mathrm{raw}) \\
(\mathrm{mg} / \mathrm{kg})\end{array}$ & $\begin{array}{c}\mathrm{Al} \\
(\mathrm{raw}) \\
(\mathrm{mg} / \mathrm{kg})\end{array}$ & $\begin{array}{c}\mathrm{Na} \\
(\mathrm{raw}) \\
(\mathrm{mg} / \mathrm{kg})\end{array}$ & $\begin{array}{c}\mathrm{Cs} \\
\text { (corr.) } \\
\text { (mg/kg) }\end{array}$ & $\begin{array}{c}\mathrm{Al} \\
(\mathrm{corr} .) \\
(\mathrm{mg} / \mathrm{kg})\end{array}$ & $\begin{array}{c}\mathrm{Na} \\
(\text { corr.) } \\
(\mathrm{mg} / \mathrm{kg})\end{array}$ & $\begin{array}{c}\text { OH-Free } \\
\text { (corr.) } \\
\text { (meq/mL) }\end{array}$ & $\begin{array}{c}\text { OH-Total } \\
\text { (corr.) } \\
\text { (meq/mL) }\end{array}$ & $\begin{array}{c}\mathrm{Cl} \\
(\mathrm{raw}) \\
(\mathrm{mg} / \mathrm{kg})\end{array}$ & $\begin{array}{c}\mathrm{NO}_{3} \\
\text { (raw) } \\
\text { (mg/kg) }\end{array}$ & $\begin{array}{c}\mathrm{Cl} \\
\text { (corr.) } \\
(\mathrm{mg} / \mathrm{kg})\end{array}$ & $\begin{array}{c}\mathrm{NO}_{3} \\
\text { (corr.) } \\
(\mathrm{mg} / \mathrm{kg})\end{array}$ \\
\hline B5-LD-00 & 0 & 1 & 5.17 & 2670 & 94000 & 5.17 & 2670 & 94000 & 1.58 & 1.73 & 49900 & 18200 & 49900 & 18200 \\
\hline B5-LD-06 & 6 & 1 & 4.36 & 2520 & 89600 & 4.36 & 2520 & 89600 & 1.54 & 1.69 & 48900 & 17800 & 48900 & 17800 \\
\hline B5-LD-12 & 12 & 1 & 3.99 & 2510 & 89100 & 3.99 & 2510 & 89100 & 1.54 & 1.69 & 48700 & 17900 & 48700 & 17900 \\
\hline B5-LD-18 & 18 & 1 & 3.87 & 2600 & 93400 & 3.87 & 2600 & 93400 & 1.54 & 1.69 & 48800 & 17900 & 48800 & 17900 \\
\hline B5-LD-24 & 24 & 1 & 3.53 & 2550 & 90900 & 3.53 & 2550 & 90900 & 1.54 & 1.69 & 49000 & 17800 & 49000 & 17800 \\
\hline B5-LD-36 & 36 & 1 & 3.14 & 2560 & 89000 & 3.14 & 2560 & 89000 & 1.54 & 1.69 & 48900 & 17800 & 48900 & 17800 \\
\hline B5-LD-48 & 48 & 1 & 2.96 & 2610 & 92300 & 2.96 & 2610 & 92300 & 1.53 & 1.69 & 48600 & 17800 & 48600 & 17800 \\
\hline B5-LD-60 & 60 & 1 & 2.72 & 2540 & 90400 & 2.72 & 2540 & 90400 & 1.53 & 1.68 & 48600 & 17700 & 48600 & 17700 \\
\hline B5-LD-80 & 80 & 1 & 2.54 & 2600 & 90200 & 2.54 & 2600 & 90200 & 1.54 & 1.68 & 48500 & 17700 & 48500 & 17700 \\
\hline B5-LD-120 & 120 & 1 & 2.24 & 2510 & 88900 & 2.24 & 2510 & 88900 & 1.55 & 1.70 & 48900 & 17800 & 48900 & 17800 \\
\hline B5-LD-180 & 180 & 1 & 2.12 & 2520 & 88700 & 2.12 & 2520 & 88700 & 1.54 & 1.69 & 48700 & 17800 & 48700 & 17800 \\
\hline B5-LD-240 & 240 & 1 & 2.15 & 2720 & 92500 & 2.15 & 2720 & 92500 & 1.54 & 1.69 & 49300 & 18000 & 49300 & 18000 \\
\hline B5-LD-600 & 600 & 1 & 2.09 & 2550 & 89900 & 2.09 & 2550 & 89900 & 1.55 & 1.70 & 49000 & 18000 & 49000 & 18000 \\
\hline B5-FD-CP & $\begin{array}{c}\text { Feed } \\
\text { Displacement }\end{array}$ & 1 & 1.59 & 1610 & 59400 & 1.59 & 1610 & 59400 & 1.03 & 1.12 & 30600 & 11400 & 30600 & 11400 \\
\hline B5-EL-CP & Elution & 1 & 16.0 & 35.0 & 1220 & 16.0 & 35.0 & 1220 & $<0.05$ & $<0.05$ & $<100$ & 2400 & $<100$ & 2400 \\
\hline Target & -- & -- & -- & -- & -- & 2.62 & 2570 & 95000 & 1.55 & 2.01 & -- & -- & 48900 & 19300 \\
\hline
\end{tabular}


Table B.13. Column C1 Test Analytical Data $\left(\mathrm{T}=50^{\circ} \mathrm{C}\right.$, Flow rate $\left.=10.62 \mathrm{~mL} / \mathrm{min}\right)$

\begin{tabular}{|c|c|c|c|c|c|c|c|c|c|c|c|c|c|c|}
\hline Sample ID & $\begin{array}{l}\text { Loading Time } \\
\text { (min) }\end{array}$ & $\begin{array}{c}\text { Dilution } \\
\text { Factor }\end{array}$ & $\begin{array}{c}\mathrm{Cs} \\
(\mathrm{raw}) \\
(\mathrm{mg} / \mathrm{kg})\end{array}$ & $\begin{array}{c}\mathrm{Al} \\
(\mathrm{raw}) \\
(\mathrm{mg} / \mathrm{kg})\end{array}$ & $\begin{array}{c}\mathrm{Na} \\
(\mathrm{raw}) \\
(\mathrm{mg} / \mathrm{kg})\end{array}$ & $\begin{array}{c}\text { Cs } \\
\text { (corr.) } \\
\text { (mg/kg) }\end{array}$ & $\begin{array}{c}\mathrm{Al} \\
\text { (corr.) } \\
(\mathrm{mg} / \mathrm{kg})\end{array}$ & $\begin{array}{c}\mathrm{Na} \\
\text { (corr.) } \\
\text { (mg/kg) }\end{array}$ & $\begin{array}{c}\text { OH-Free } \\
\text { (corr.) } \\
\text { (meq/mL) }\end{array}$ & $\begin{array}{c}\text { OH-Total } \\
\text { (corr.) } \\
\text { (meq/mL) }\end{array}$ & $\begin{array}{c}\mathrm{Cl} \\
(\mathrm{raw}) \\
(\mathrm{mg} / \mathrm{kg})\end{array}$ & $\begin{array}{c}\mathrm{NO}_{3} \\
\text { (raw) } \\
\text { (mg/kg) }\end{array}$ & $\begin{array}{c}\mathrm{Cl} \\
\text { (corr.) } \\
(\mathrm{mg} / \mathrm{kg}) \\
\end{array}$ & $\begin{array}{c}\mathrm{NO}_{3} \\
\text { (corr.) } \\
\text { (mg/kg) }\end{array}$ \\
\hline C1-LD-00 & 0 & 1 & 3.02 & 2600 & 92700 & 3.02 & 2600 & 92700 & 1.54 & 1.70 & 50800 & 18300 & 50800 & 18300 \\
\hline C1-LD-06 & 6 & 1 & 2.68 & 2570 & 91200 & 2.68 & 2570 & 91200 & 1.49 & 1.64 & 50000 & 17700 & 50000 & 17700 \\
\hline C1-LD-12 & 12 & 1 & 2.47 & 2570 & 88900 & 2.47 & 2570 & 88900 & 1.50 & 1.66 & 52700 & 18700 & 52700 & 18700 \\
\hline C1-LD-18 & 18 & 1 & 2.30 & 2600 & 89100 & 2.30 & 2600 & 89100 & 1.48 & 1.63 & 49700 & 17900 & 49700 & 17900 \\
\hline C1-LD-24 & 24 & 1 & 2.19 & 2540 & 88500 & 2.19 & 2540 & 88500 & 1.49 & 1.63 & 49400 & 17900 & 49400 & 17900 \\
\hline C1-LD-36 & 36 & 1 & 1.97 & 2500 & 88800 & 1.97 & 2500 & 88800 & 1.49 & 1.64 & 48700 & 17600 & 48700 & 17600 \\
\hline C1-LD-48 & 48 & 1 & 1.81 & 2710 & 89500 & 1.81 & 2710 & 89500 & 1.49 & 1.64 & 48900 & 17600 & 48900 & 17600 \\
\hline C1-LD-60 & 60 & 1 & 1.65 & 2590 & 89700 & 1.65 & 2590 & 89700 & 1.48 & 1.63 & 48900 & 17600 & 48900 & 17600 \\
\hline C1-LD-80 & 80 & 1 & 1.39 & 2490 & 87300 & 1.39 & 2490 & 87300 & 1.49 & 1.64 & 49800 & 17900 & 49800 & 17900 \\
\hline C1-LD-120 & 120 & 1 & 1.12 & 2570 & 88800 & 1.12 & 2570 & 88800 & 1.48 & 1.63 & 50000 & 17900 & 50000 & 17900 \\
\hline C1-LD-180 & 180 & 1 & 0.845 & 2550 & 88200 & 0.845 & 2550 & 88200 & 1.49 & 1.63 & 49200 & 17700 & 49200 & 17700 \\
\hline C1-LD-240 & 240 & 1 & 0.691 & 2630 & 89800 & 0.691 & 2630 & 89800 & 1.49 & 1.64 & 51400 & 18700 & 51400 & 18700 \\
\hline C1-LD-600 & 600 & 1 & 0.464 & 2580 & 88600 & 0.464 & 2580 & 88600 & 1.49 & 1.64 & 49900 & 18000 & 49900 & 18000 \\
\hline C1-LD-900 & 900 & 1 & 0.452 & 2520 & 87500 & 0.452 & 2520 & 87500 & 1.50 & 1.65 & 50100 & 18000 & 50100 & 18000 \\
\hline C1-LD-1200 & 1200 & 1 & 0.434 & 2660 & 88700 & 0.434 & 2660 & 88700 & 1.49 & 1.65 & 50800 & 18400 & 50800 & 18400 \\
\hline C1-FD-CP & $\begin{array}{c}\text { Feed } \\
\text { Displacement }\end{array}$ & 1 & 0.420 & 2060 & 72900 & 0.420 & 2060 & 72900 & 1.21 & 1.33 & 39900 & 14400 & 39900 & 14400 \\
\hline C1-EL-CP & Elution & 1 & 7.96 & 5.68 & 981 & 7.96 & 5.68 & 981 & $<0.05$ & $<0.05$ & 58.8 & 2250 & 58.8 & 2250 \\
\hline Target & -- & -- & -- & -- & -- & 2.62 & 2570 & 95000 & 1.55 & 2.01 & -- & -- & 48900 & 19300 \\
\hline
\end{tabular}


Table B.14. Column C2 Test Analytical Data $\left(\mathrm{T}=50^{\circ} \mathrm{C}\right.$, Flow rate $\left.=14.16 \mathrm{~mL} / \mathrm{min}\right)$

\begin{tabular}{|c|c|c|c|c|c|c|c|c|c|c|c|c|c|c|}
\hline Sample ID & $\begin{array}{l}\text { Loading Time } \\
\text { (min) }\end{array}$ & $\begin{array}{c}\text { Dilution } \\
\text { Factor }\end{array}$ & $\begin{array}{c}\mathrm{Cs} \\
(\mathrm{raw}) \\
(\mathrm{mg} / \mathrm{kg})\end{array}$ & $\begin{array}{c}\mathrm{Al} \\
(\mathrm{raw}) \\
(\mathrm{mg} / \mathrm{kg})\end{array}$ & $\begin{array}{c}\mathrm{Na} \\
(\mathrm{raw}) \\
(\mathrm{mg} / \mathrm{kg})\end{array}$ & $\begin{array}{c}\text { Cs } \\
\text { (corr.) } \\
\text { (mg/kg) }\end{array}$ & $\begin{array}{c}\mathrm{Al} \\
(\mathrm{corr} .) \\
(\mathrm{mg} / \mathrm{kg})\end{array}$ & $\begin{array}{c}\mathrm{Na} \\
(\mathrm{corr} .) \\
(\mathrm{mg} / \mathrm{kg})\end{array}$ & $\begin{array}{c}\text { OH-Free } \\
\text { (corr.) } \\
\text { (meq/mL) }\end{array}$ & $\begin{array}{c}\text { OH-Total } \\
\text { (corr.) } \\
\text { (meq/mL) }\end{array}$ & $\begin{array}{c}\mathrm{Cl} \\
(\mathrm{raw}) \\
(\mathrm{mg} / \mathrm{kg})\end{array}$ & $\begin{array}{c}\mathrm{NO}_{3} \\
\text { (raw) } \\
(\mathrm{mg} / \mathrm{kg})\end{array}$ & $\begin{array}{c}\mathrm{Cl} \\
\text { (corr.) } \\
\text { (mg/kg) }\end{array}$ & $\begin{array}{c}\mathrm{NO}_{3} \\
\text { (corr.) } \\
\text { (mg/kg) }\end{array}$ \\
\hline C2-LD-00 & 0 & 1 & 1.63 & 1760 & 41100 & 1.63 & 1760 & 41100 & 0.938 & 1.03 & 11200 & 8590 & 11200 & 8590 \\
\hline C2-LD-06 & 6 & 1 & 1.36 & 1670 & 39500 & 1.36 & 1670 & 39500 & 0.912 & 1.01 & 11000 & 8340 & 11000 & 8340 \\
\hline C2-LD-12 & 12 & 1 & 1.19 & 1680 & 39000 & 1.19 & 1680 & 39000 & 0.912 & 1.00 & 11000 & 8310 & 11000 & 8310 \\
\hline C2-LD-18 & 18 & 1 & 1.10 & 1670 & 39800 & 1.10 & 1670 & 39800 & 0.901 & 1.00 & 10900 & 8320 & 10900 & 8320 \\
\hline C2-LD-24 & 24 & 1 & 0.980 & 1650 & 39000 & 0.980 & 1650 & 39000 & 0.917 & 1.02 & 10900 & 8330 & 10900 & 8330 \\
\hline C2-LD-36 & 36 & 1 & 0.813 & 1680 & 40200 & 0.813 & 1680 & 40200 & 0.901 & 1.00 & 11000 & 8320 & 11000 & 8320 \\
\hline C2-LD-48 & 48 & 1 & 0.636 & 1670 & 39500 & 0.636 & 1670 & 39500 & 0.901 & 0.995 & 11000 & 8450 & 11000 & 8450 \\
\hline C2-LD-60 & 60 & 1 & 0.525 & 1650 & 38700 & 0.525 & 1650 & 38700 & 0.907 & 1.00 & 11100 & 8460 & 11100 & 8460 \\
\hline C2-LD-80 & 80 & 1 & 0.402 & 1650 & 40100 & 0.402 & 1650 & 40100 & 0.912 & 1.01 & 11000 & 8420 & 11000 & 8420 \\
\hline C2-LD-120 & 120 & 1 & 0.274 & 1630 & 39800 & 0.274 & 1630 & 39800 & 0.912 & 1.01 & 10900 & 8420 & 10900 & 8420 \\
\hline C2-LD-180 & 180 & 1 & 0.201 & 1690 & 39300 & 0.201 & 1690 & 39300 & 0.907 & 1.00 & 11200 & 8580 & 11200 & 8580 \\
\hline C2-LD-240 & 240 & 1 & 0.152 & 787 & 38800 & 0.152 & 787 & 38800 & 0.455 & 0.499 & 25700 & 8040 & 25700 & 8040 \\
\hline C2-LD-600 & 600 & 1 & 0.130 & 1660 & 39700 & 0.130 & 1660 & 39700 & 0.922 & 1.02 & 11200 & 8420 & 11200 & 8420 \\
\hline C2-LD-900 & 900 & 1 & 0.132 & 1690 & 38500 & 0.132 & 1690 & 38500 & 0.917 & 1.02 & 11200 & 8540 & 11200 & 8540 \\
\hline C2-LD-1200 & 1200 & 1 & 0.137 & 1710 & 40300 & 0.137 & 1710 & 40300 & 0.917 & 1.03 & 11400 & 8720 & 11400 & 8720 \\
\hline C2-FD-CP & $\begin{array}{c}\text { Feed } \\
\text { Displacement }\end{array}$ & 1 & 0.112 & 1090 & 28300 & 0.112 & 1090 & 28300 & 0.653 & 0.715 & 7170 & 5480 & 7170 & 5480 \\
\hline C2-EL-CP & Elution & 1 & 7.94 & $<2.00$ & 1030 & 7.94 & $<2.00$ & 1030 & $<0.05$ & $<0.05$ & $<99.8$ & 2240 & $<99.8$ & 2240 \\
\hline Target & -- & -- & -- & -- & -- & 1.70 & 1670 & 42300 & 0.933 & 1.20 & -- & -- & 10900 & 8580 \\
\hline
\end{tabular}


Table B.15. Column C3 Test Analytical Data $\left(T=50^{\circ} \mathrm{C}\right.$, Flow rate $\left.=7.08 \mathrm{~mL} / \mathrm{min}\right)$

\begin{tabular}{|c|c|c|c|c|c|c|c|c|c|c|c|c|c|c|}
\hline Sample ID & $\begin{array}{l}\text { Loading Time } \\
\text { (min) }\end{array}$ & $\begin{array}{l}\text { Dilution } \\
\text { Factor }\end{array}$ & $\begin{array}{c}\mathrm{Cs} \\
(\mathrm{raw}) \\
(\mathrm{mg} / \mathrm{kg})\end{array}$ & $\begin{array}{c}\mathrm{Al} \\
(\mathrm{raw}) \\
(\mathrm{mg} / \mathrm{kg})\end{array}$ & $\begin{array}{c}\mathrm{Na} \\
(\mathrm{raw}) \\
(\mathrm{mg} / \mathrm{kg})\end{array}$ & $\begin{array}{c}\mathrm{Cs} \\
\text { (corr.) } \\
\text { (mg/kg) }\end{array}$ & $\begin{array}{c}\mathrm{Al} \\
(\mathrm{corr} .) \\
(\mathrm{mg} / \mathrm{kg})\end{array}$ & $\begin{array}{c}\mathrm{Na} \\
(\mathrm{corr} .) \\
(\mathrm{mg} / \mathrm{kg})\end{array}$ & $\begin{array}{c}\text { OH-Free } \\
\text { (corr.) } \\
\text { (meq/mL) }\end{array}$ & $\begin{array}{c}\text { OH-Total } \\
\text { (corr.) } \\
\text { (meq/mL) }\end{array}$ & $\begin{array}{c}\mathrm{Cl} \\
(\mathrm{raw}) \\
(\mathrm{mg} / \mathrm{kg})\end{array}$ & $\begin{array}{c}\mathrm{NO}_{3} \\
\text { (raw) } \\
\text { (mg/kg) }\end{array}$ & $\begin{array}{c}\mathrm{Cl} \\
\text { (corr.) } \\
(\mathrm{mg} / \mathrm{kg})\end{array}$ & $\begin{array}{c}\mathrm{NO}_{3} \\
\text { (corr.) } \\
(\mathrm{mg} / \mathrm{kg})\end{array}$ \\
\hline C3-LD-00 & 0 & 1 & 1.53 & 1570 & 38000 & 1.53 & 1570 & 38000 & 0.901 & 0.984 & 10800 & 8180 & 10800 & 8180 \\
\hline C3-LD-06 & 6 & 1 & 1.40 & 1530 & 37000 & 1.40 & 1530 & 37000 & 0.870 & 0.958 & 10500 & 7950 & 10500 & 7950 \\
\hline C3-LD-12 & 12 & 1 & 1.30 & 1510 & 36400 & 1.30 & 1510 & 36400 & 0.881 & 0.963 & 10400 & 7900 & 10400 & 7900 \\
\hline C3-LD-18 & 18 & 1 & 1.24 & 1560 & 36400 & 1.24 & 1560 & 36400 & 0.875 & 0.963 & 10500 & 8010 & 10500 & 8010 \\
\hline C3-LD-24 & 24 & 1 & 1.16 & 1510 & 35500 & 1.16 & 1510 & 35500 & 0.875 & 0.963 & 10400 & 7950 & 10400 & 7950 \\
\hline C3-LD-36 & 36 & 1 & 1.06 & 1570 & 37500 & 1.06 & 1570 & 37500 & 0.881 & 0.969 & 10400 & 8000 & 10400 & 8000 \\
\hline C3-LD-48 & 48 & 1 & 0.943 & 1550 & 36500 & 0.943 & 1550 & 36500 & 0.875 & 0.963 & 10500 & 8010 & 10500 & 8010 \\
\hline C3-LD-60 & 60 & 1 & 0.863 & 1560 & 37300 & 0.863 & 1560 & 37300 & 0.881 & 0.969 & 10400 & 7960 & 10400 & 7960 \\
\hline C3-LD-80 & 80 & 1 & 0.802 & 1580 & 38100 & 0.802 & 1580 & 38100 & 0.881 & 0.969 & 10500 & 8040 & 10500 & 8040 \\
\hline C3-LD-120 & 120 & 1 & 0.594 & 1560 & 36400 & 0.594 & 1560 & 36400 & 0.875 & 0.958 & 10500 & 8010 & 10500 & 8010 \\
\hline C3-LD-180 & 180 & 1 & 0.407 & 1540 & 36100 & 0.407 & 1540 & 36100 & 0.881 & 0.969 & 10600 & 8060 & 10600 & 8060 \\
\hline C3-LD-240 & 240 & 1 & 0.317 & 1540 & 36500 & 0.317 & 1540 & 36500 & 0.881 & 0.963 & 10400 & 7950 & 10400 & 7950 \\
\hline C3-LD-600 & 600 & 1 & 0.153 & 1550 & 36300 & 0.153 & 1550 & 36300 & 0.881 & 0.969 & 10600 & 8000 & 10600 & 8000 \\
\hline C3-LD-900 & 900 & 1 & 0.126 & 1540 & 37000 & 0.126 & 1540 & 37000 & 0.875 & 0.969 & 10700 & 8090 & 10700 & 8090 \\
\hline C3-LD-1200 & 1200 & 1 & 0.114 & 1470 & 36700 & 0.114 & 1470 & 36700 & 0.886 & 0.969 & 10500 & 8020 & 10500 & 8020 \\
\hline С3-FD-CP & $\begin{array}{c}\text { Feed } \\
\text { Displacement }\end{array}$ & 1 & 0.103 & 938 & 24200 & 0.103 & 938 & 24200 & 0.591 & 0.648 & 6310 & 4810 & 6310 & 4810 \\
\hline C3-EL-CP & Elution & 1 & 6.78 & $<2.01$ & 1070 & 6.78 & $<2.01$ & 1070 & $<0.05$ & $<0.05$ & $<100$ & 2300 & $<100$ & 2300 \\
\hline Target & -- & -- & -- & -- & -- & 1.70 & 1670 & 42300 & 0.933 & 1.20 & -- & -- & 10900 & 8580 \\
\hline
\end{tabular}


Table B.16. Column C4 Test Analytical Data $\left(\mathrm{T}=50^{\circ} \mathrm{C}\right.$, Flow rate $\left.=14.16 \mathrm{~mL} / \mathrm{min}\right)$

\begin{tabular}{|c|c|c|c|c|c|c|c|c|c|c|c|c|c|c|}
\hline Sample ID & $\begin{array}{l}\text { Loading Time } \\
\text { (min) }\end{array}$ & $\begin{array}{c}\text { Dilution } \\
\text { Factor }\end{array}$ & $\begin{array}{c}\mathrm{Cs} \\
(\mathrm{raw}) \\
(\mathrm{mg} / \mathrm{kg})\end{array}$ & $\begin{array}{c}\mathrm{Al} \\
(\mathrm{raw}) \\
(\mathrm{mg} / \mathrm{kg})\end{array}$ & $\begin{array}{c}\mathrm{Na} \\
(\mathrm{raw}) \\
(\mathrm{mg} / \mathrm{kg})\end{array}$ & $\begin{array}{c}\text { Cs } \\
\text { (corr.) } \\
(\mathrm{mg} / \mathrm{kg})\end{array}$ & $\begin{array}{c}\text { Al } \\
\text { (corr.) } \\
\text { (mg/kg) }\end{array}$ & $\begin{array}{c}\mathrm{Na} \\
(\mathrm{corr} .) \\
(\mathrm{mg} / \mathrm{kg})\end{array}$ & $\begin{array}{c}\text { OH-Free } \\
\text { (corr.) } \\
\text { (meq/mL) }\end{array}$ & $\begin{array}{c}\text { OH-Total } \\
\text { (corr.) } \\
\text { (meq/mL) }\end{array}$ & $\begin{array}{c}\mathrm{Cl} \\
(\mathrm{raw}) \\
(\mathrm{mg} / \mathrm{kg})\end{array}$ & $\begin{array}{c}\mathrm{NO}_{3} \\
(\mathrm{raw}) \\
(\mathrm{mg} / \mathrm{kg})\end{array}$ & $\begin{array}{c}\mathrm{Cl} \\
\text { (corr.) } \\
(\mathrm{mg} / \mathrm{kg})\end{array}$ & $\begin{array}{c}\mathrm{NO}_{3} \\
\text { (corr.) } \\
\text { (mg/kg) } \\
\end{array}$ \\
\hline C4-LD-00 & 0 & 1.53 & 2.42 & 4570 & 84500 & 3.71 & 7000 & 130000 & 3.30 & 3.68 & $<82.6$ & 26000 & $<127$ & 39900 \\
\hline C4-LD-06 & 6 & 1.62 & 2.04 & 3920 & 75600 & 3.31 & 6350 & 123000 & 3.19 & 3.55 & $<83.8$ & 23900 & $<136$ & 38700 \\
\hline C4-LD-12 & 12 & 1.66 & 1.89 & 3900 & 75200 & 3.13 & 6460 & 125000 & 3.15 & 3.51 & $<83.8$ & 23000 & $<139$ & 38100 \\
\hline C4-LD-18 & 18 & 1.66 & 1.80 & 3890 & 75600 & 2.99 & 6450 & 125000 & 3.15 & 3.53 & $<84.2$ & 23400 & $<140$ & 38800 \\
\hline C4-LD-24 & 24 & 1.65 & 1.72 & 3950 & 75000 & 2.83 & 6500 & 123000 & 3.16 & 3.52 & $<85.9$ & 23200 & $<141$ & 38200 \\
\hline C4-LD-36 & 36 & 1.68 & 1.54 & 3790 & 73500 & 2.59 & 6380 & 124000 & 3.13 & 3.50 & $<84.6$ & 23000 & $<142$ & 38700 \\
\hline C4-LD-48 & 48 & 1.71 & 1.47 & 3800 & 73800 & 2.52 & 6520 & 127000 & 3.12 & 3.50 & $<84.0$ & 22300 & $<144$ & 38200 \\
\hline C4-LD-60 & 60 & 1.73 & 1.33 & 3740 & 72200 & 2.30 & 6460 & 125000 & 3.07 & 3.44 & $<84.6$ & 21900 & $<146$ & 37800 \\
\hline C4-LD-80 & 80 & 1.66 & 1.27 & 3880 & 75900 & 2.10 & 6430 & 126000 & 3.13 & 3.50 & $<84.5$ & 23100 & $<140$ & 38300 \\
\hline C4-LD-120 & 120 & 1.70 & 1.08 & 3770 & 73400 & 1.84 & 6420 & 125000 & 3.10 & 3.49 & $<84.5$ & 22500 & $<144$ & 38300 \\
\hline C4-LD-180 & 180 & 1.67 & 0.929 & 3850 & 73800 & 1.56 & 6450 & 124000 & 3.15 & 3.52 & $<84.7$ & 23000 & $<142$ & 38500 \\
\hline C4-LD-240 & 240 & 1.71 & 0.836 & 3800 & 73100 & 1.43 & 6490 & 125000 & 3.13 & 3.49 & $<84.3$ & 22300 & $<144$ & 38100 \\
\hline C4-LD-600 & 600 & 1.70 & 0.653 & 3730 & 72500 & 1.11 & 6340 & 123000 & 3.10 & 3.49 & $<84.5$ & 22600 & $<144$ & 38400 \\
\hline C4-FD-CP & $\begin{array}{c}\text { Feed } \\
\text { Displacement }\end{array}$ & 1 & 0.932 & 4540 & 86600 & 0.932 & 4540 & 86600 & 2.33 & 2.62 & 84.6 & 26800 & 84.6 & 26800 \\
\hline Target & -- & -- & -- & -- & -- & 2.86 & 6750 & 138000 & 3.67 & 5.00 & -- & -- & 0 & 41900 \\
\hline
\end{tabular}


Table B.17. Column C4B Test Analytical Data $\left(\mathrm{T}=75^{\circ} \mathrm{C}\right.$, Flow rate $\left.=0.08 \mathrm{~mL} / \mathrm{min}\right)$

\begin{tabular}{|c|c|c|c|c|c|c|c|c|c|c|c|c|c|c|}
\hline Sample ID & $\begin{array}{c}\text { Loading } \\
\text { Time (hrs) }\end{array}$ & $\begin{array}{l}\text { Dilution } \\
\text { Factor }\end{array}$ & $\begin{array}{c}\text { Cs } \\
(\text { raw) } \\
(\mathrm{mg} / \mathrm{kg})\end{array}$ & $\begin{array}{c}\mathrm{Al} \\
(\mathrm{raw}) \\
(\mathrm{mg} / \mathrm{kg})\end{array}$ & $\begin{array}{c}\mathrm{Na} \\
(\mathrm{raw}) \\
(\mathrm{mg} / \mathrm{kg})\end{array}$ & $\begin{array}{c}\text { Cs } \\
\text { (corr.) } \\
\text { (mg/kg) }\end{array}$ & $\begin{array}{c}\mathrm{Al} \\
(\mathrm{corr} .) \\
(\mathrm{mg} / \mathrm{kg})\end{array}$ & $\begin{array}{c}\mathrm{Na} \\
(\text { corr. }) \\
(\mathrm{mg} / \mathrm{kg})\end{array}$ & $\begin{array}{c}\text { OH-Free } \\
\text { (corr.) } \\
\text { (meq/mL) }\end{array}$ & $\begin{array}{c}\text { OH-Total } \\
\text { (corr.) } \\
\text { (meq/mL) }\end{array}$ & $\begin{array}{c}\mathrm{Cl} \\
(\mathrm{raw}) \\
(\mathrm{mg} / \mathrm{kg})\end{array}$ & $\begin{array}{c}\mathrm{NO}_{3} \\
\text { (raw) } \\
\text { (mg/kg) }\end{array}$ & $\begin{array}{c}\mathrm{Cl} \\
\text { (corr.) } \\
\text { (mg/kg) }\end{array}$ & $\begin{array}{c}\mathrm{NO}_{3} \\
\text { (corr.) } \\
\text { (mg/kg) } \\
\end{array}$ \\
\hline C4B-LD-00 & 0 & 1.82 & 1.94 & 3550 & 68500 & 3.52 & 6440 & 124000 & 3.21 & 3.58 & $<84.7$ & 21600 & $<153.7$ & 39200 \\
\hline C4B-LD-04 & 4 & 1.73 & 2.15 & 4000 & 76800 & 3.71 & 6900 & 133000 & 3.47 & 3.87 & $<82.9$ & 24100 & $<143.1$ & 41600 \\
\hline C4B-LD-08 & 8 & 1.66 & 2.09 & 3890 & 74900 & 3.46 & 6450 & 124000 & 3.18 & 3.55 & $<84.5$ & 23400 & $<140.0$ & 38800 \\
\hline C4B-LD-12 & 12 & 1.64 & 2.13 & 3990 & 77400 & 3.50 & 6550 & 127000 & 3.17 & 3.53 & $<83.9$ & 23700 & $<137.8$ & 38900 \\
\hline C4B-LD-24 & 24 & 1.70 & 2.07 & 3900 & 76200 & 3.51 & 6610 & 129000 & 3.19 & 3.56 & $<85.6$ & 23200 & $<145.1$ & 39300 \\
\hline C4B-EL-NEW & New Feed & 1.73 & 2.04 & 3990 & 73500 & 3.53 & 6900 & 127000 & 3.13 & 3.53 & $<84.9$ & 22400 & $<146.8$ & 38700 \\
\hline C4B-LD-72 & 72 & 1.67 & 2.23 & 4340 & 81500 & 3.72 & 7240 & 136000 & 3.37 & 3.79 & $<85.0$ & 24600 & $<141.8$ & 41000 \\
\hline C4B-LD-120 & 120 & 1.75 & 2.16 & 3980 & 75600 & 3.79 & 6980 & 133000 & 3.24 & 3.65 & $<84.6$ & 22700 & $<148.3$ & 39800 \\
\hline C4B-LD-168 & 168 & 1.67 & 2.35 & 4200 & 80100 & 3.93 & 7030 & 134000 & 3.35 & 3.75 & $<87.1$ & 24600 & $<145.7$ & 41100 \\
\hline C4B-LD-336 & 336 & 1.72 & 2.76 & 4900 & 92000 & 4.76 & 8450 & 159000 & 4.09 & 4.57 & $<82.1$ & 28400 & $<141.5$ & 49000 \\
\hline C4B-FD-CP & $\begin{array}{c}\text { Feed } \\
\text { Displacement }\end{array}$ & 1 & 0.187 & 133 & 4220 & 0.187 & 133 & 4220 & 0.136 & 0.147 & 163 & 630 & 163 & 630 \\
\hline C4B-EL-CP & Elution & 1 & 6.00 & 650 & 1650 & 6.00 & 650 & 1650 & $<0.05$ & $<0.05$ & $<99.2$ & 2650 & $<99.2$ & 2650 \\
\hline Target & -- & -- & -- & -- & -- & 3.73 & 6710 & 137000 & 3.67 & 5.00 & -- & -- & 0 & 41700 \\
\hline
\end{tabular}


Table B.18. Column C5 Test Analytical Data $\left(\mathrm{T}=50^{\circ} \mathrm{C}\right.$, Flow rate $\left.=10.62 \mathrm{~mL} / \mathrm{min}\right)$

\begin{tabular}{|c|c|c|c|c|c|c|c|c|c|c|c|c|c|c|}
\hline Sample ID & $\begin{array}{l}\text { Loading Time } \\
\text { (min) }\end{array}$ & $\begin{array}{l}\text { Dilution } \\
\text { Factor }\end{array}$ & $\begin{array}{c}\text { Cs } \\
(\mathrm{raw}) \\
(\mathrm{mg} / \mathrm{kg})\end{array}$ & $\begin{array}{c}\mathrm{Al} \\
(\mathrm{raw}) \\
(\mathrm{mg} / \mathrm{kg})\end{array}$ & $\begin{array}{c}\mathrm{Na} \\
(\mathrm{raw}) \\
(\mathrm{mg} / \mathrm{kg})\end{array}$ & $\begin{array}{c}\text { Cs } \\
\text { (corr.) } \\
(\mathrm{mg} / \mathrm{kg})\end{array}$ & $\begin{array}{c}\mathrm{Al} \\
(\text { corr.) } \\
(\mathrm{mg} / \mathrm{kg})\end{array}$ & $\begin{array}{c}\mathrm{Na} \\
\text { (corr.) } \\
\text { (mg/kg) }\end{array}$ & $\begin{array}{c}\text { OH-Free } \\
\text { (corr.) } \\
\text { (meq/mL) }\end{array}$ & $\begin{array}{c}\text { OH-Total } \\
\text { (corr.) } \\
\text { (meq/mL) }\end{array}$ & $\begin{array}{c}\mathrm{Cl} \\
(\mathrm{raw}) \\
(\mathrm{mg} / \mathrm{kg})\end{array}$ & $\begin{array}{c}\mathrm{NO}_{3} \\
\text { (raw) } \\
\text { (mg/kg) }\end{array}$ & $\begin{array}{c}\mathrm{Cl} \\
\text { (corr.) } \\
\text { (mg/kg) }\end{array}$ & $\begin{array}{c}\mathrm{NO}_{3} \\
\text { (corr.) } \\
\text { (mg/kg) }\end{array}$ \\
\hline C5-LD-00 & 0 & 1 & 5.05 & 2700 & 90500 & 5.05 & 2700 & 90500 & 1.57 & 1.72 & 49200 & 18100 & 49200 & 18100 \\
\hline C5-LD-06 & 6 & 1 & 4.45 & 2610 & 89600 & 4.45 & 2610 & 89600 & 1.54 & 1.69 & 48400 & 17700 & 48400 & 17700 \\
\hline C5-LD-12 & 12 & 1 & 4.10 & 2600 & 88700 & 4.10 & 2600 & 88700 & 1.53 & 1.68 & 47900 & 17600 & 47900 & 17600 \\
\hline C5-LD-18 & 18 & 1 & 3.74 & 2610 & 89400 & 3.74 & 2610 & 89400 & 1.52 & 1.67 & 47900 & 17600 & 47900 & 17600 \\
\hline C5-LD-24 & 24 & 1 & 3.38 & 2520 & 84900 & 3.38 & 2520 & 84900 & 1.51 & 1.66 & 47800 & 17500 & 47800 & 17500 \\
\hline C5-LD-36 & 36 & 1 & 3.16 & 2620 & 88300 & 3.16 & 2620 & 88300 & 1.51 & 1.66 & 47600 & 17400 & 47600 & 17400 \\
\hline C5-LD-48 & 48 & 1 & 2.98 & 2670 & 90800 & 2.98 & 2670 & 90800 & 1.52 & 1.66 & 48100 & 17500 & 48100 & 17500 \\
\hline C5-LD-60 & 60 & 1 & 2.80 & 2600 & 87500 & 2.80 & 2600 & 87500 & 1.53 & 1.67 & 48000 & 17600 & 48000 & 17600 \\
\hline C5-LD-80 & 80 & 1 & 2.68 & 2650 & 88200 & 2.68 & 2650 & 88200 & 1.52 & 1.66 & 47700 & 17500 & 47700 & 17500 \\
\hline C5-LD-120 & 120 & 1 & 2.58 & 2590 & 87400 & 2.58 & 2590 & 87400 & 1.52 & 1.66 & 48000 & 17500 & 48000 & 17500 \\
\hline C5-LD-180 & 180 & 1 & 2.40 & 2640 & 87700 & 2.40 & 2640 & 87700 & 1.52 & 1.67 & 47700 & 17500 & 47700 & 17500 \\
\hline C5-LD-240 & 240 & 1 & 2.38 & 2620 & 86200 & 2.38 & 2620 & 86200 & 1.52 & 1.67 & 47900 & 17500 & 47900 & 17500 \\
\hline C5-LD-600 & 600 & 1 & 2.43 & 2620 & 87800 & 2.43 & 2620 & 87800 & 1.52 & 1.67 & 48200 & 17600 & 48200 & 17600 \\
\hline C5-FD-CP & $\begin{array}{c}\text { Feed } \\
\text { Displacement }\end{array}$ & 1 & 0.559 & 458 & 17800 & 0.559 & 458 & 17800 & 0.327 & 0.358 & 8390 & 3260 & 8390 & 3260 \\
\hline C5-EL-CP & Elution & 1 & 11.2 & 158 & 1050 & 11.2 & 158 & 1050 & $<0.05$ & $<0.05$ & $<102$ & 2280 & $<102$ & 2280 \\
\hline Target & -- & -- & -- & -- & -- & 2.62 & 2570 & 95000 & 1.55 & 2.01 & -- & -- & 48900 & 19300 \\
\hline
\end{tabular}


Table B.19. Column D1 Test Analytical Data $\left(\mathrm{T}=25^{\circ} \mathrm{C}\right.$, Flow rate $\left.=10.62 \mathrm{~mL} / \mathrm{min}\right)$

\begin{tabular}{|c|c|c|c|c|c|c|c|c|c|c|c|c|c|c|}
\hline Sample ID & $\begin{array}{l}\text { Loading Time } \\
\text { (min) }\end{array}$ & $\begin{array}{l}\text { Dilution } \\
\text { Factor }\end{array}$ & $\begin{array}{l}\text { Cs (raw) } \\
\text { (mg/kg) }\end{array}$ & $\begin{array}{l}\mathrm{Al}(\mathrm{raw}) \\
(\mathrm{mg} / \mathrm{kg})\end{array}$ & $\begin{array}{l}\text { Na (raw) } \\
\text { (mg/kg) }\end{array}$ & $\begin{array}{l}\text { Cs (corr.) } \\
\text { (mg/kg) }\end{array}$ & $\begin{array}{l}\text { Al (corr.) } \\
\text { (mg/kg) }\end{array}$ & $\begin{array}{c}\mathrm{Na} \\
\text { (corr.) } \\
\text { (mg/kg) }\end{array}$ & $\begin{array}{c}\text { OH-Free } \\
\text { (corr.) } \\
\text { (meq/mL) }\end{array}$ & $\begin{array}{c}\text { OH-Total } \\
\text { (corr.) } \\
\text { (meq/mL) }\end{array}$ & $\begin{array}{l}\mathrm{Cl} \text { (raw) } \\
\text { (mg/kg) }\end{array}$ & $\begin{array}{c}\mathrm{NO}_{3} \\
\text { (raw) } \\
\text { (mg/kg) }\end{array}$ & $\begin{array}{l}\text { Cl (corr.) } \\
\text { (mg/kg) }\end{array}$ & $\begin{array}{c}\mathrm{NO}_{3} \\
\text { (corr.) } \\
\text { (mg/kg) }\end{array}$ \\
\hline D1-LD-00 & 0 & 1 & 2.96 & 2610 & 89400 & 2.96 & 2610 & 89400 & 1.52 & 1.68 & 50500 & 18600 & 50500 & 18600 \\
\hline D1-LD-06 & 6 & 1 & 2.56 & 2620 & 85200 & 2.56 & 2620 & 85200 & 1.48 & 1.63 & 48500 & 17800 & 48500 & 17800 \\
\hline D1-LD-12 & 12 & 1 & 2.32 & 2490 & 85300 & 2.32 & 2490 & 85300 & 1.48 & 1.63 & 49500 & 18200 & 49500 & 18200 \\
\hline D1-LD-18 & 18 & 1 & 2.11 & 2430 & 82900 & 2.11 & 2430 & 82900 & 1.48 & 1.63 & 49700 & 18300 & 49700 & 18300 \\
\hline D1-LD-24 & 24 & 1 & 1.98 & 2440 & 84100 & 1.98 & 2440 & 84100 & 1.48 & 1.63 & 46500 & 17000 & 46500 & 17000 \\
\hline D1-LD-36 & 36 & 1 & 1.69 & 2510 & 84000 & 1.69 & 2510 & 84000 & 1.48 & 1.64 & 49000 & 18100 & 49000 & 18100 \\
\hline D1-LD-48 & 48 & 1 & 1.56 & 2540 & 85100 & 1.56 & 2540 & 85100 & 1.48 & 1.63 & 48900 & 18000 & 48900 & 18000 \\
\hline D1-LD-60 & 60 & 1 & 1.42 & 2570 & 84700 & 1.42 & 2570 & 84700 & 1.48 & 1.63 & 48700 & 17900 & 48700 & 17900 \\
\hline D1-LD-80 & 80 & 1 & 1.25 & 2510 & 83900 & 1.25 & 2510 & 83900 & 1.47 & 1.63 & 48600 & 17900 & 48600 & 17900 \\
\hline D1-LD-120 & 120 & 1 & 0.946 & 2470 & 82600 & 0.946 & 2470 & 82600 & 1.48 & 1.63 & 48600 & 18000 & 48600 & 18000 \\
\hline D1-LD-180 & 180 & 1 & 0.673 & 2520 & 84900 & 0.673 & 2520 & 84900 & 1.49 & 1.64 & 49200 & 18100 & 49200 & 18100 \\
\hline D1-LD-240 & 240 & 1 & 0.531 & 2580 & 84400 & 0.531 & 2580 & 84400 & 1.48 & 1.63 & 49800 & 18300 & 49800 & 18300 \\
\hline D1-LD-600 & 600 & 1 & 0.260 & 2540 & 84600 & 0.260 & 2540 & 84600 & 1.47 & 1.63 & 48100 & 17600 & 48100 & 17600 \\
\hline D1-FD-CP & $\begin{array}{c}\text { Feed } \\
\text { Displacement }\end{array}$ & 1 & 0.189 & 1760 & 61300 & 0.189 & 1760 & 61300 & 1.09 & 1.19 & 33700 & 12200 & 33700 & 12200 \\
\hline D1-EL-CP & Elution & 1 & $<0.00016$ & $<2.0$ & $<10.0$ & $<0.00016$ & $<2.0$ & $<10.0$ & $<0.05$ & $<0.05$ & $<39.6$ & 2450 & $<39.6$ & 2450 \\
\hline Target & -- & -- & -- & -- & -- & 2.62 & 2570 & 95000 & 1.55 & 2.01 & -- & -- & 48900 & 19300 \\
\hline
\end{tabular}


Table B.20. Column E1 Test Analytical Data $\left(\mathrm{T}=50^{\circ} \mathrm{C}\right.$, Flow rate $\left.=10.62 \mathrm{~mL} / \mathrm{min}\right)$

\begin{tabular}{|c|c|c|c|c|c|c|c|c|c|c|c|c|c|c|}
\hline Sample ID & $\begin{array}{l}\text { Loading Time } \\
\text { (min) }\end{array}$ & $\begin{array}{l}\text { Dilution } \\
\text { Factor }\end{array}$ & $\begin{array}{c}\mathrm{Cs} \\
(\mathrm{raw}) \\
(\mathrm{mg} / \mathrm{kg})\end{array}$ & $\begin{array}{c}\mathrm{Al} \\
(\mathrm{raw}) \\
(\mathrm{mg} / \mathrm{kg})\end{array}$ & $\begin{array}{c}\mathrm{Na} \\
(\mathrm{raw}) \\
(\mathrm{mg} / \mathrm{kg})\end{array}$ & $\begin{array}{c}\mathrm{Cs} \\
\text { (corr.) } \\
\text { (mg/kg) }\end{array}$ & $\begin{array}{c}\mathrm{Al} \\
(\mathrm{corr} .) \\
(\mathrm{mg} / \mathrm{kg})\end{array}$ & $\begin{array}{c}\mathrm{Na} \\
(\text { corr.) } \\
(\mathrm{mg} / \mathrm{kg})\end{array}$ & $\begin{array}{c}\text { OH-Free } \\
\text { (corr.) } \\
\text { (meq/mL) }\end{array}$ & $\begin{array}{c}\text { OH-Total } \\
\text { (corr.) } \\
\text { (meq/mL) }\end{array}$ & $\begin{array}{c}\mathrm{Cl} \\
(\mathrm{raw}) \\
(\mathrm{mg} / \mathrm{kg})\end{array}$ & $\begin{array}{c}\mathrm{NO}_{3} \\
\text { (raw) } \\
\text { (mg/kg) }\end{array}$ & $\begin{array}{c}\mathrm{Cl} \\
\text { (corr.) } \\
(\mathrm{mg} / \mathrm{kg})\end{array}$ & $\begin{array}{c}\mathrm{NO}_{3} \\
\text { (corr.) } \\
(\mathrm{mg} / \mathrm{kg})\end{array}$ \\
\hline E1-LD-00 & 0 & 1 & 3.59 & 2930 & 113000 & 3.59 & 2930 & 113000 & 1.97 & 2.16 & 66700 & 25300 & 66700 & 25300 \\
\hline E1-LD-06 & 6 & 1 & 3.00 & 2890 & 112000 & 3.00 & 2890 & 112000 & 1.86 & 2.05 & 62700 & 23600 & 62700 & 23600 \\
\hline E1-LD-12 & 12 & 1 & 2.82 & 2870 & 110000 & 2.82 & 2870 & 110000 & 1.88 & 2.06 & 60800 & 23000 & 60800 & 23000 \\
\hline E1-LD-18 & 18 & 1 & 2.53 & 2830 & 108000 & 2.53 & 2830 & 108000 & 1.88 & 2.06 & 62900 & 23700 & 62900 & 23700 \\
\hline E1-LD-24 & 24 & 1 & 2.35 & 2820 & 108000 & 2.35 & 2820 & 108000 & 1.89 & 2.07 & 62100 & 23600 & 62100 & 23600 \\
\hline E1-LD-36 & 36 & 1 & 2.00 & 2850 & 109000 & 2.00 & 2850 & 109000 & 1.89 & 2.07 & 62800 & 23500 & 62800 & 23500 \\
\hline E1-LD-48 & 48 & 1 & 1.74 & 2780 & 107000 & 1.74 & 2780 & 107000 & 1.89 & 2.07 & 60500 & 23000 & 60500 & 23000 \\
\hline E1-LD-60 & 60 & 1 & 1.57 & 2750 & 106000 & 1.57 & 2750 & 106000 & 1.88 & 2.07 & 60500 & 22900 & 60500 & 22900 \\
\hline E1-LD-80 & 80 & 1 & 1.35 & 2780 & 106000 & 1.35 & 2780 & 106000 & 1.90 & 2.08 & 61900 & 23500 & 61900 & 23500 \\
\hline E1-LD-120 & 120 & 1 & 1.01 & 2850 & 110000 & 1.01 & 2850 & 110000 & 1.88 & 2.07 & 61000 & 23300 & 61000 & 23300 \\
\hline E1-LD-180 & 180 & 1 & 0.856 & 2810 & 108000 & 0.856 & 2810 & 108000 & 1.89 & 2.07 & 62400 & 23500 & 62400 & 23500 \\
\hline E1-LD-240 & 240 & 1 & 0.663 & 2810 & 109000 & 0.663 & 2810 & 109000 & 1.88 & 2.07 & 61000 & 23800 & 61000 & 23800 \\
\hline E1-LD-600 & 600 & 1 & 0.532 & 2780 & 109000 & 0.532 & 2780 & 109000 & 1.89 & 2.08 & 61900 & 23200 & 61900 & 23200 \\
\hline E1-FD-CP & $\begin{array}{c}\text { Feed } \\
\text { Displacement }\end{array}$ & 1 & 0.456 & 2070 & 80800 & 0.456 & 2070 & 80800 & 1.38 & 1.51 & 44300 & 16700 & 44300 & 16700 \\
\hline E1-EL-CP & Elution & 1 & 10.4 & 5.65 & 1090 & 10.4 & 5.65 & 1090 & $<0.05$ & $<0.05$ & 81.1 & 2490 & 81.1 & 2490 \\
\hline Target & -- & -- & -- & -- & -- & 2.62 & 2570 & 95000 & 1.55 & 2.01 & -- & -- & 48900 & 19300 \\
\hline
\end{tabular}


Table B.21. Column E2 Test Analytical Data $\left(\mathrm{T}=50^{\circ} \mathrm{C}\right.$, Flow rate $\left.=10.62 \mathrm{~mL} / \mathrm{min}\right)$

\begin{tabular}{|c|c|c|c|c|c|c|c|c|c|c|c|c|c|c|}
\hline Sample ID & $\begin{array}{l}\text { Loading Time } \\
\text { (min) }\end{array}$ & $\begin{array}{l}\text { Dilution } \\
\text { Factor }\end{array}$ & $\begin{array}{c}\text { Cs } \\
\text { (raw) } \\
(\mathrm{mg} / \mathrm{kg})\end{array}$ & $\begin{array}{c}\mathrm{Al} \\
(\mathrm{raw}) \\
(\mathrm{mg} / \mathrm{kg})\end{array}$ & $\begin{array}{c}\mathrm{Na} \\
(\mathrm{raw}) \\
(\mathrm{mg} / \mathrm{kg})\end{array}$ & $\begin{array}{c}\text { Cs } \\
\text { (corr.) } \\
(\mathrm{mg} / \mathrm{kg})\end{array}$ & $\begin{array}{c}\mathrm{Al} \\
\text { (corr.) } \\
\text { (mg/kg) }\end{array}$ & $\begin{array}{c}\mathrm{Na} \\
\text { (corr.) } \\
\text { (mg/kg) }\end{array}$ & $\begin{array}{c}\text { OH-Free } \\
\text { (corr.) } \\
\text { (meq/mL) }\end{array}$ & $\begin{array}{c}\text { OH-Total } \\
\text { (corr.) } \\
\text { (meq/mL) }\end{array}$ & $\begin{array}{c}\mathrm{Cl} \\
(\mathrm{raw}) \\
(\mathrm{mg} / \mathrm{kg})\end{array}$ & $\begin{array}{c}\mathrm{NO}_{3} \\
(\mathrm{raw}) \\
(\mathrm{mg} / \mathrm{kg})\end{array}$ & $\begin{array}{c}\mathrm{Cl} \\
\text { (corr.) } \\
(\mathrm{mg} / \mathrm{kg})\end{array}$ & $\begin{array}{c}\mathrm{NO}_{3} \\
\text { (corr.) } \\
(\mathrm{mg} / \mathrm{kg})\end{array}$ \\
\hline E2-LD-00 & 0 & 1.60 & 1.99 & 1620 & 75600 & 3.19 & 2600 & 121000 & 1.65 & 1.79 & $<33.8$ & 40600 & $<54.1$ & 65000 \\
\hline E2-LD-06 & 6 & 1.67 & 1.68 & 1500 & 69900 & 2.81 & 2500 & 117000 & 1.59 & 1.74 & $<33.9$ & 38200 & $<56.7$ & 63871 \\
\hline E2-LD-12 & 12 & 1.62 & 1.65 & 1570 & 72700 & 2.68 & 2550 & 118000 & 1.60 & 1.75 & $<33.5$ & 39000 & $<54.3$ & 63272 \\
\hline E2-LD-18 & 18 & 1.59 & 1.54 & 1570 & 72800 & 2.45 & 2500 & 116000 & 1.59 & 1.75 & $<33.1$ & 39800 & $<52.7$ & 63334 \\
\hline E2-LD-24 & 24 & 1.63 & 1.44 & 1550 & 71900 & 2.35 & 2530 & 117000 & 1.59 & 1.75 & $<33.5$ & 38700 & $<54.7$ & 63194 \\
\hline E2-LD-36 & 36 & 1.60 & 1.32 & 1570 & 72600 & 2.11 & 2510 & 116000 & 1.60 & 1.74 & $<33.4$ & 40400 & $<53.3$ & 64450 \\
\hline E2-LD-48 & 48 & 1.64 & 1.18 & 1550 & 71800 & 1.93 & 2540 & 118000 & 1.59 & 1.73 & $<33.6$ & 39300 & $<55.0$ & 64320 \\
\hline E2-LD-60 & 60 & 1.66 & 1.08 & 1540 & 70800 & 1.79 & 2560 & 117000 & 1.58 & 1.74 & $<33.7$ & 38500 & $<55.9$ & 63875 \\
\hline E2-LD-80 & 80 & 1.62 & 0.983 & 1550 & 70900 & 1.60 & 2520 & 115000 & 1.59 & 1.74 & $<33.5$ & 38900 & $<54.3$ & 63110 \\
\hline E2-LD-120 & 120 & 1.65 & 0.820 & 1530 & 70900 & 1.35 & 2520 & 117000 & 1.59 & 1.73 & $<33.5$ & 38300 & $<55.2$ & 63082 \\
\hline E2-LD-180 & 180 & 1.66 & 0.683 & 1500 & 69200 & 1.13 & 2490 & 115000 & 1.58 & 1.74 & $<33.8$ & 38300 & $<56.1$ & 63597 \\
\hline E2-LD-240 & 240 & 1.64 & 0.616 & 1510 & 70100 & 1.01 & 2480 & 115000 & 1.58 & 1.74 & $<33.6$ & 39000 & $<55.1$ & 63984 \\
\hline E2-LD-600 & 600 & 1.63 & 0.498 & 1580 & 72900 & 0.809 & 2570 & 118000 & 1.59 & 1.74 & $<33.5$ & 39300 & $<54.4$ & 63863 \\
\hline E2-FD-CP & $\begin{array}{c}\text { Feed } \\
\text { Displacement }\end{array}$ & 1 & 0.659 & 1890 & 94200 & 0.659 & 1890 & 94200 & 1.37 & 1.50 & $<32.5$ & 48400 & $<32.5$ & 48400 \\
\hline E2-EL-CP & Elution & 1 & 13.3 & 5.44 & 1340 & 13.3 & 5.44 & 1340 & $<0.05$ & $<0.05$ & $<40.2$ & 2660 & $<40.2$ & 2660 \\
\hline Target & -- & -- & -- & -- & -- & 2.79 & 2720 & 134000 & 1.86 & 2.41 & -- & -- & 0 & 61248 \\
\hline
\end{tabular}


Table B.22. Column E3 Test Analytical Data $\left(\mathrm{T}=50^{\circ} \mathrm{C}\right.$, Flow rate $\left.=7.08 \mathrm{~mL} / \mathrm{min}\right)$

\begin{tabular}{|c|c|c|c|c|c|c|c|c|c|c|c|c|c|c|}
\hline Sample ID & $\begin{array}{l}\text { Loading Time } \\
\text { (min) }\end{array}$ & $\begin{array}{c}\text { Dilution } \\
\text { Factor }\end{array}$ & $\begin{array}{c}\mathrm{Cs} \\
(\mathrm{raw}) \\
(\mathrm{mg} / \mathrm{kg})\end{array}$ & $\begin{array}{c}\mathrm{Al} \\
(\mathrm{raw}) \\
(\mathrm{mg} / \mathrm{kg})\end{array}$ & $\begin{array}{c}\mathrm{Na} \\
(\mathrm{raw}) \\
(\mathrm{mg} / \mathrm{kg})\end{array}$ & $\begin{array}{c}\text { Cs } \\
\text { (corr.) } \\
\text { (mg/kg) }\end{array}$ & $\begin{array}{c}\mathrm{Al} \\
\text { (corr.) } \\
\text { (mg/kg) }\end{array}$ & $\begin{array}{c}\mathrm{Na} \\
(\mathrm{corr} .) \\
(\mathrm{mg} / \mathrm{kg})\end{array}$ & $\begin{array}{c}\text { OH-Free } \\
\text { (corr.) } \\
\text { (meq/mL) }\end{array}$ & $\begin{array}{c}\text { OH-Total } \\
\text { (corr.) } \\
\text { (meq/mL) }\end{array}$ & $\begin{array}{c}\mathrm{Cl} \\
(\mathrm{raw}) \\
(\mathrm{mg} / \mathrm{kg})\end{array}$ & $\begin{array}{c}\mathrm{NO}_{3} \\
\text { (raw) } \\
(\mathrm{mg} / \mathrm{kg})\end{array}$ & $\begin{array}{c}\mathrm{Cl} \\
\text { (corr.) } \\
\text { (mg/kg) }\end{array}$ & $\begin{array}{c}\mathrm{NO}_{3} \\
\text { (corr.) } \\
\text { (mg/kg) }\end{array}$ \\
\hline E3-LD-00 & 0 & 1.64 & 1.78 & 1740 & 78900 & 2.91 & 2850 & 129000 & 1.67 & 1.83 & $<33.2$ & 41200 & $<54.3$ & 67400 \\
\hline E3-LD-06 & 6 & 1.64 & 1.66 & 1710 & 77600 & 2.72 & 2800 & 127000 & 1.62 & 1.78 & $<33.3$ & 39800 & $<54.5$ & 65200 \\
\hline E3-LD-12 & 12 & 1.67 & 1.59 & 1700 & 75200 & 2.66 & 2840 & 126000 & 1.62 & 1.77 & $<33.6$ & 39400 & $<56.1$ & 65800 \\
\hline E3-LD-18 & 18 & 1.66 & 1.56 & 1680 & 78200 & 2.58 & 2780 & 129000 & 1.63 & 1.79 & $<33.5$ & 40600 & $<55.4$ & 67200 \\
\hline E3-LD-24 & 24 & 1.63 & 1.54 & 1700 & 77700 & 2.52 & 2780 & 127000 & 1.63 & 1.80 & $<33.8$ & 40100 & $<55.3$ & 65500 \\
\hline E3-LD-36 & 36 & 1.65 & 1.45 & 1750 & 76900 & 2.39 & 2890 & 127000 & 1.62 & 1.78 & $<33.6$ & 40300 & $<55.5$ & 66600 \\
\hline E3-LD-48 & 48 & 1.68 & 1.35 & 1670 & 75600 & 2.27 & 2810 & 127000 & 1.61 & 1.78 & $<33.4$ & 39300 & $<56.2$ & 66200 \\
\hline E3-LD-60 & 60 & 1.65 & 1.35 & 1760 & 77400 & 2.23 & 2910 & 128000 & 1.62 & 1.78 & $<33.4$ & 39800 & $<55.2$ & 65800 \\
\hline E3-LD-80 & 80 & 1.64 & 1.23 & 1690 & 76500 & 2.02 & 2770 & 125000 & 1.63 & 1.79 & $<33.6$ & 40700 & $<55.1$ & 66700 \\
\hline E3-LD-120 & 120 & 1.68 & 0.983 & 1640 & 74500 & 1.65 & 2760 & 125000 & 1.62 & 1.78 & $<33.6$ & 39700 & $<56.4$ & 66700 \\
\hline E3-LD-180 & 180 & 1.68 & 0.841 & 1680 & 75900 & 1.41 & 2820 & 127000 & 1.62 & 1.78 & $<33.6$ & 39400 & $<56.4$ & 66100 \\
\hline E3-LD-240 & 240 & 1.63 & 0.741 & 1650 & 77800 & 1.21 & 2690 & 127000 & 1.62 & 1.80 & $<33.2$ & 40200 & $<54.2$ & 65600 \\
\hline E3-LD-600 & 600 & 1.64 & 0.544 & 1700 & 77500 & 0.890 & 2780 & 127000 & 1.64 & 1.80 & $<33.4$ & 40500 & $<54.6$ & 66300 \\
\hline E3-FD-CP & $\begin{array}{c}\text { Feed } \\
\text { Displacement }\end{array}$ & 1 & 0.787 & 2110 & 97500 & 0.787 & 2110 & 97500 & 1.38 & 1.52 & $<32.9$ & 51200 & $<32.9$ & 51200 \\
\hline E3-EL-CP & Elution & 1 & 12.6 & 3.71 & 25.4 & 12.6 & 3.71 & 25.4 & $<0.05$ & $<0.05$ & $<40.2$ & 2700 & $<40.2$ & 2700 \\
\hline Target & -- & -- & -- & -- & -- & 2.79 & 2720 & 134000 & 1.86 & 2.41 & -- & -- & 0 & 61200 \\
\hline
\end{tabular}


Table B.23. Column E4 Test Analytical Data $\left(\mathrm{T}=50^{\circ} \mathrm{C}\right.$, Flow rate $\left.=10.62 \mathrm{~mL} / \mathrm{min}\right)$

\begin{tabular}{|c|c|c|c|c|c|c|c|c|c|c|c|c|c|c|}
\hline Sample ID & $\begin{array}{l}\text { Loading Time } \\
\text { (min) }\end{array}$ & $\begin{array}{l}\text { Dilution } \\
\text { Factor }\end{array}$ & $\begin{array}{c}\text { Cs } \\
(\mathrm{raw}) \\
(\mathrm{mg} / \mathrm{kg})\end{array}$ & $\begin{array}{c}\mathrm{Al} \\
(\mathrm{raw}) \\
(\mathrm{mg} / \mathrm{kg})\end{array}$ & $\begin{array}{c}\mathrm{Na} \\
(\mathrm{raw}) \\
(\mathrm{mg} / \mathrm{kg})\end{array}$ & $\begin{array}{c}\text { Cs } \\
(\text { corr.) } \\
(\mathrm{mg} / \mathrm{kg})\end{array}$ & $\begin{array}{c}\mathrm{Al} \\
(\text { corr.) } \\
(\mathrm{mg} / \mathrm{kg})\end{array}$ & $\begin{array}{c}\mathrm{Na} \\
(\text { corr.) } \\
(\mathrm{mg} / \mathrm{kg})\end{array}$ & $\begin{array}{c}\text { OH-Free } \\
\text { (corr.) } \\
\text { (meq/mL) }\end{array}$ & $\begin{array}{c}\text { OH-Total } \\
\text { (corr.) } \\
\text { (meq/mL) }\end{array}$ & $\begin{array}{c}\mathrm{Cl} \\
(\mathrm{raw}) \\
(\mathrm{mg} / \mathrm{kg})\end{array}$ & $\begin{array}{c}\mathrm{NO}_{3} \\
(\mathrm{raw}) \\
(\mathrm{mg} / \mathrm{kg})\end{array}$ & $\begin{array}{c}\mathrm{Cl} \\
\text { (corr.) } \\
\text { (mg/kg) }\end{array}$ & $\begin{array}{c}\mathrm{NO}_{3} \\
\text { (corr.) } \\
(\mathrm{mg} / \mathrm{kg})\end{array}$ \\
\hline E4-LD-00 & 0 & 1.56 & 4.03 & 4460 & 85600 & 6.29 & 6960 & 134000 & 3.31 & 3.71 & $<33.3$ & 28900 & $<52.0$ & 45100 \\
\hline E4-LD-06 & 6 & 1.66 & 3.39 & 4090 & 78300 & 5.61 & 6773 & 130000 & 3.15 & 3.53 & $<33.9$ & 26200 & $<56.1$ & 43400 \\
\hline E4-LD-12 & 12 & 1.59 & 3.24 & 4130 & 80000 & 5.16 & 6581 & 127000 & 3.17 & 3.54 & $<33.9$ & 27200 & $<54.0$ & 43300 \\
\hline E4-LD-18 & 18 & 1.63 & 2.97 & 4170 & 78300 & 4.84 & 6799 & 128000 & 3.18 & 3.55 & $<34.4$ & 27000 & $<56.1$ & 44000 \\
\hline E4-LD-24 & 24 & 1.62 & 2.88 & 4360 & 80100 & 4.66 & 7054 & 130000 & 3.17 & 3.54 & $<33.7$ & 26600 & $<54.5$ & 43000 \\
\hline E4-LD-36 & 36 & 1.60 & 2.54 & 4090 & 78800 & 4.07 & 6562 & 126000 & 3.16 & 3.55 & $<33.7$ & 26900 & $<54.1$ & 43200 \\
\hline E4-LD-48 & 48 & 1.62 & 2.32 & 4200 & 78200 & 3.76 & 6810 & 127000 & 3.15 & 3.52 & $<33.8$ & 26600 & $<54.8$ & 43100 \\
\hline E4-LD-60 & 60 & 1.61 & 2.16 & 4250 & 78600 & 3.48 & 6844 & 127000 & 3.17 & 3.54 & $<33.8$ & 26900 & $<54.4$ & 43300 \\
\hline E4-LD-80 & 80 & 1.63 & 1.98 & 4330 & 78700 & 3.23 & 7062 & 128000 & 3.20 & 3.57 & $<32.7$ & 26000 & $<53.3$ & 42404 \\
\hline E4-LD-120 & 120 & 1.61 & 1.70 & 4220 & 79900 & 2.74 & 6795 & 129000 & 3.20 & 3.57 & $<33.7$ & 27000 & $<54.3$ & 43500 \\
\hline E4-LD-180 & 180 & 1.63 & 1.43 & 4200 & 79500 & 2.33 & 6845 & 130000 & 3.19 & 3.57 & $<33.8$ & 26500 & $<55.1$ & 43200 \\
\hline E4-LD-240 & 240 & 1.64 & 1.26 & 4120 & 78700 & 2.07 & 6761 & 129000 & 3.18 & 3.54 & $<33.7$ & 26200 & $<55.3$ & 43000 \\
\hline E4-LD-600 & 600 & 1.61 & 1.00 & 4250 & 79100 & 1.61 & 6856 & 128000 & 3.19 & 3.57 & $<33.8$ & 27100 & $<54.5$ & 43700 \\
\hline E4-FD-CP & $\begin{array}{c}\text { Feed } \\
\text { Displacement }\end{array}$ & 1 & 1.46 & 5170 & 100000 & 1.46 & 5170 & 100000 & 2.65 & 2.94 & $<32.4$ & 32000 & $<32.4$ & 32000 \\
\hline Target & -- & -- & -- & -- & -- & 5.68 & 6690 & 136509 & 3.67 & 5.00 & -- & -- & 0 & 40800 \\
\hline
\end{tabular}


Table B.24. Column E4B Test Analytical Data $\left(T=50^{\circ} \mathrm{C}\right.$, Flow rate $\left.=0.08 \mathrm{~mL} / \mathrm{min}\right)$

\begin{tabular}{|c|c|c|c|c|c|c|c|c|c|c|c|c|c|c|}
\hline Sample ID & $\begin{array}{c}\text { Loading Time } \\
\text { (hrs) }\end{array}$ & $\begin{array}{c}\text { Dilution } \\
\text { Factor }\end{array}$ & $\begin{array}{c}\text { Cs } \\
(\mathrm{raw}) \\
(\mathrm{mg} / \mathrm{kg})\end{array}$ & $\begin{array}{c}\mathrm{Al} \\
(\mathrm{raw}) \\
(\mathrm{mg} / \mathrm{kg})\end{array}$ & $\begin{array}{c}\mathrm{Na} \\
(\mathrm{raw}) \\
(\mathrm{mg} / \mathrm{kg})\end{array}$ & $\begin{array}{c}\text { Cs } \\
\text { (corr.) } \\
\text { (mg/kg) }\end{array}$ & $\begin{array}{c}\mathrm{Al} \\
\text { (corr.) } \\
\text { (mg/kg) }\end{array}$ & $\begin{array}{c}\mathrm{Na} \\
(\mathrm{corr} .) \\
(\mathrm{mg} / \mathrm{kg})\end{array}$ & $\begin{array}{c}\text { OH-Free } \\
\text { (corr.) } \\
\text { (meq/mL) }\end{array}$ & $\begin{array}{c}\text { OH-Total } \\
\text { (corr.) } \\
\text { (meq/mL) }\end{array}$ & $\begin{array}{c}\mathrm{Cl} \\
(\mathrm{raw}) \\
(\mathrm{mg} / \mathrm{kg})\end{array}$ & $\begin{array}{c}\mathrm{NO}_{3} \\
\text { (raw) } \\
(\mathrm{mg} / \mathrm{kg})\end{array}$ & $\begin{array}{c}\mathrm{Cl} \\
\text { (corr.) } \\
\text { (mg/kg) }\end{array}$ & $\begin{array}{c}\mathrm{NO}_{3} \\
\text { (corr.) } \\
\text { (mg/kg) }\end{array}$ \\
\hline E4B-LD-00 & 0 & 1.59 & 3.98 & 4190 & 82400 & 6.33 & 6660 & 131000 & 3.29 & 3.69 & $<33.2$ & 28300 & $<52.8$ & 45000 \\
\hline E4B-LD-04 & 4 & 1.60 & 3.76 & 3980 & 79700 & 6.02 & 6370 & 128000 & 3.19 & 3.55 & $<33.2$ & 26800 & $<53.2$ & 42900 \\
\hline E4B-LD-08 & 8 & 1.59 & 3.67 & 4080 & 80100 & 5.84 & 6500 & 128000 & 3.20 & 3.57 & $<34.4$ & 27300 & $<54.8$ & 43500 \\
\hline E4B-LD-12 & 12 & 1.68 & 3.30 & 3830 & 74700 & 5.56 & 6450 & 126000 & 3.17 & 3.54 & $<33.4$ & 25400 & $<56.3$ & 42800 \\
\hline E4B-LD-24 & 24 & 1.74 & 3.06 & 4200 & 78700 & 5.31 & 7290 & 137000 & 4.05 & 4.53 & $<33.6$ & 31300 & $<58.3$ & 54400 \\
\hline E4B-LD-72 & 72 & 1.62 & 2.36 & 3970 & 78800 & 3.82 & 6420 & 127000 & 3.22 & 3.59 & $<33.7$ & 27100 & $<54.5$ & 43800 \\
\hline E4B-LD-120 & 120 & 1.64 & 2.30 & 3990 & 78700 & 3.77 & 6540 & 129000 & 3.26 & 3.65 & $<33.4$ & 26900 & $<54.7$ & 44100 \\
\hline E4B-LD-168 & 168 & 1.70 & 2.29 & 3880 & 76700 & 3.89 & 6600 & 130000 & 3.25 & 3.64 & $<33.8$ & 26900 & $<57.4$ & 45700 \\
\hline E4B-LD-336 & 336 & 1.60 & 2.40 & 4260 & 86100 & 3.83 & 6810 & 138000 & 3.50 & 3.95 & $<32.8$ & 27800 & $<52.4$ & 44400 \\
\hline E4B-LD-504 & 504 & 1.56 & 2.47 & 4470 & 89600 & 3.92 & 7100 & 142000 & 3.57 & 4.05 & $<35.7$ & 31100 & $<56.7$ & 49400 \\
\hline E4B-LD-672 & 672 & 1.61 & 2.57 & 4600 & 92200 & 4.14 & 7410 & 148000 & 3.78 & 4.28 & $<32.8$ & 29900 & $<52.8$ & 48200 \\
\hline E4B-LD-720 & 720 & 1.59 & 2.60 & 4560 & 93700 & 4.14 & 7240 & 149000 & 3.78 & 4.29 & $<32.8$ & 30800 & $<52.1$ & 48900 \\
\hline E4B-FD-CP & $\begin{array}{c}\text { Feed } \\
\text { Displacement }\end{array}$ & 1 & 1.87 & 3370 & 68100 & 1.87 & 3370 & 68100 & 1.76 & 1.98 & 132 & 21300 & 132 & 21300 \\
\hline E4B-EL-CP & Elution & 1 & 35.7 & 79.2 & 1390 & 35.7 & 79.2 & 1390 & $<0.05$ & $<0.05$ & $<43.9$ & 2760 & $<43.9$ & 2760 \\
\hline Target & -- & -- & -- & -- & -- & 5.68 & 6690 & 137000 & 3.67 & 5.00 & -- & -- & 0 & 40800 \\
\hline
\end{tabular}


Table B.25. Column E5 Test Analytical Data $\left(\mathrm{T}=50^{\circ} \mathrm{C}\right.$, Flow rate $\left.=10.62 \mathrm{~mL} / \mathrm{min}\right)$

\begin{tabular}{|c|c|c|c|c|c|c|c|c|c|c|c|c|c|c|}
\hline Sample ID & $\begin{array}{l}\text { Loading Time } \\
\text { (min) }\end{array}$ & $\begin{array}{l}\text { Dilution } \\
\text { Factor }\end{array}$ & $\begin{array}{c}\mathrm{Cs} \\
(\mathrm{raw}) \\
(\mathrm{mg} / \mathrm{kg})\end{array}$ & $\begin{array}{c}\mathrm{Al} \\
(\mathrm{raw}) \\
(\mathrm{mg} / \mathrm{kg})\end{array}$ & $\begin{array}{c}\mathrm{Na} \\
(\mathrm{raw}) \\
(\mathrm{mg} / \mathrm{kg})\end{array}$ & $\begin{array}{c}\text { Cs } \\
\text { (corr.) } \\
\text { (mg/kg) }\end{array}$ & $\begin{array}{c}\mathrm{Al} \\
(\mathrm{corr} .) \\
(\mathrm{mg} / \mathrm{kg})\end{array}$ & $\begin{array}{c}\mathrm{Na} \\
(\mathrm{corr} .) \\
(\mathrm{mg} / \mathrm{kg})\end{array}$ & $\begin{array}{c}\text { OH-Free } \\
\text { (corr.) } \\
\text { (meq/mL) }\end{array}$ & $\begin{array}{c}\text { OH-Total } \\
\text { (corr.) } \\
\text { (meq/mL) }\end{array}$ & $\begin{array}{c}\mathrm{Cl} \\
(\mathrm{raw}) \\
(\mathrm{mg} / \mathrm{kg})\end{array}$ & $\begin{array}{c}\mathrm{NO}_{3} \\
\text { (raw) } \\
(\mathrm{mg} / \mathrm{kg})\end{array}$ & $\begin{array}{c}\mathrm{Cl} \\
\text { (corr.) } \\
\text { (mg/kg) }\end{array}$ & $\begin{array}{c}\mathrm{NO}_{3} \\
\text { (corr.) } \\
\text { (mg/kg) }\end{array}$ \\
\hline E5-LD-00 & 0 & 1 & 3.20 & 2760 & 91500 & 3.20 & 2760 & 91500 & 1.55 & 1.71 & 52200 & 18900 & 52200 & 18900 \\
\hline E5-LD-06 & 6 & 1 & 2.38 & 2440 & 85200 & 2.38 & 2440 & 85200 & 1.51 & 1.66 & 49500 & 17600 & 49500 & 17600 \\
\hline E5-LD-12 & 12 & 1 & 2.06 & 2480 & 86400 & 2.06 & 2480 & 86400 & 1.50 & 1.65 & 49200 & 17700 & 49200 & 17700 \\
\hline E5-LD-18 & 18 & 1 & 1.81 & 2550 & 85500 & 1.81 & 2550 & 85500 & 1.49 & 1.65 & 49400 & 17900 & 49400 & 17900 \\
\hline E5-LD-24 & 24 & 1 & 1.59 & 2500 & 84200 & 1.59 & 2500 & 84200 & 1.50 & 1.66 & 49000 & 17600 & 49000 & 17600 \\
\hline E5-LD-36 & 36 & 1 & 1.32 & 2470 & 84500 & 1.32 & 2470 & 84500 & 1.50 & 1.65 & 49700 & 17900 & 49700 & 17900 \\
\hline E5-LD-48 & 48 & 1 & 1.15 & 2500 & 84500 & 1.15 & 2500 & 84500 & 1.49 & 1.65 & 49400 & 17800 & 49400 & 17800 \\
\hline E5-LD-60 & 60 & 1 & 1.09 & 2500 & 84600 & 1.09 & 2500 & 84600 & 1.50 & 1.66 & 50000 & 17900 & 50000 & 17900 \\
\hline E5-LD-80 & 80 & 1 & 0.910 & 2500 & 84200 & 0.910 & 2500 & 84200 & 1.49 & 1.65 & 50800 & 18200 & 50800 & 18200 \\
\hline E5-LD-120 & 120 & 1 & 0.551 & 2570 & 86100 & 0.551 & 2570 & 86100 & 1.51 & 1.66 & 49500 & 17800 & 49500 & 17800 \\
\hline E5-LD-180 & 180 & 1 & 0.476 & 2500 & 84700 & 0.476 & 2500 & 84700 & 1.50 & 1.66 & 50500 & 18100 & 50500 & 18100 \\
\hline E5-LD-240 & 240 & 1 & 0.472 & 2430 & 84000 & 0.472 & 2430 & 84000 & 1.51 & 1.66 & 51100 & 18400 & 51100 & 18400 \\
\hline E5-LD-600 & 600 & 1 & 0.534 & 2530 & 84900 & 0.534 & 2530 & 84900 & 1.50 & 1.66 & 49700 & 17800 & 49700 & 17800 \\
\hline E5-LD-900 & 900 & 1 & 0.566 & 2530 & 84200 & 0.566 & 2530 & 84200 & 1.51 & 1.67 & 50000 & 18200 & 50000 & 18200 \\
\hline E5-LD-1200 & 1200 & 1 & 0.594 & 2530 & 87100 & 0.594 & 2530 & 87100 & 1.52 & 1.68 & 50300 & 18100 & 50300 & 18100 \\
\hline E5-FD-CP & $\begin{array}{c}\text { Feed } \\
\text { Displacement }\end{array}$ & 1 & 0.515 & 1880 & 64400 & 0.515 & 1880 & 64400 & 1.12 & 1.23 & 36500 & 13000 & 36500 & 13000 \\
\hline E5-EL-CP & Elution & 1 & 10.1 & 12.0 & 1260 & 10.1 & 12.0 & 1260 & $<0.05$ & $<0.05$ & $<40.0$ & 2330 & $<40.0$ & 2330 \\
\hline Target & -- & -- & -- & -- & -- & 2.62 & 2570 & 95000 & 1.55 & 2.01 & -- & -- & 48900 & 19300 \\
\hline
\end{tabular}


Table B.26. Column F1 Test Analytical Data $\left(T=55^{\circ} \mathrm{C}\right.$, Flow rate $\left.=10.62 \mathrm{~mL} / \mathrm{min}\right)$

\begin{tabular}{|c|c|c|c|c|c|c|c|c|c|c|c|c|c|c|}
\hline Sample ID & $\begin{array}{l}\text { Loading Time } \\
(\mathrm{min})\end{array}$ & $\begin{array}{c}\text { Dilution } \\
\text { Factor }\end{array}$ & $\begin{array}{c}\mathrm{Cs} \\
(\mathrm{raw}) \\
(\mathrm{mg} / \mathrm{kg})\end{array}$ & $\begin{array}{c}\mathrm{Al} \\
(\mathrm{raw}) \\
(\mathrm{mg} / \mathrm{kg})\end{array}$ & $\begin{array}{c}\mathrm{Na} \\
(\mathrm{raw}) \\
(\mathrm{mg} / \mathrm{kg})\end{array}$ & $\begin{array}{c}\text { Cs } \\
\text { (corr.) } \\
\text { (mg/kg) }\end{array}$ & $\begin{array}{c}\mathrm{Al} \\
\text { (corr.) } \\
\text { (mg/kg) }\end{array}$ & $\begin{array}{c}\mathrm{Na} \\
(\mathrm{corr} .) \\
(\mathrm{mg} / \mathrm{kg})\end{array}$ & $\begin{array}{c}\text { OH-Free } \\
\text { (corr.) } \\
\text { (meq/mL) }\end{array}$ & $\begin{array}{c}\text { OH-Total } \\
\text { (corr.) } \\
\text { (meq/mL) }\end{array}$ & $\begin{array}{c}\mathrm{Cl} \\
(\mathrm{raw}) \\
(\mathrm{mg} / \mathrm{kg})\end{array}$ & $\begin{array}{c}\mathrm{NO}_{3} \\
\text { (raw) } \\
(\mathrm{mg} / \mathrm{kg})\end{array}$ & $\begin{array}{c}\mathrm{Cl} \\
\text { (corr.) } \\
\text { (mg/kg) }\end{array}$ & $\begin{array}{c}\mathrm{NO}_{3} \\
\text { (corr.) } \\
\text { (mg/kg) }\end{array}$ \\
\hline F1-LD-00 & 0 & 1 & 2.12 & 2550 & 92900 & 2.12 & 2550 & 92900 & 1.59 & 1.74 & 49500 & 18000 & 49500 & 18000 \\
\hline F1-LD-06 & 6 & 1 & 1.74 & 2380 & 88700 & 1.74 & 2380 & 88700 & 1.52 & 1.67 & 48000 & 17400 & 48000 & 17400 \\
\hline F1-LD-12 & 12 & 1 & 1.53 & 2440 & 90700 & 1.53 & 2440 & 90700 & 1.51 & 1.66 & 47800 & 17500 & 47800 & 17500 \\
\hline F1-LD-18 & 18 & 1 & 1.36 & 2440 & 90200 & 1.36 & 2440 & 90200 & 1.52 & 1.66 & 47700 & 17600 & 47700 & 17600 \\
\hline F1-LD-24 & 24 & 1 & 1.21 & 2470 & 89800 & 1.21 & 2470 & 89800 & 1.51 & 1.66 & 47500 & 17600 & 47500 & 17600 \\
\hline F1-LD-36 & 36 & 1 & 1.01 & 2460 & 90100 & 1.01 & 2460 & 90100 & 1.51 & 1.65 & 47800 & 17700 & 47800 & 17700 \\
\hline F1-LD-48 & 48 & 1 & 0.863 & 2390 & 90500 & 0.863 & 2390 & 90500 & 1.51 & 1.65 & 47400 & 17400 & 47400 & 17400 \\
\hline F1-LD-60 & 60 & 1 & 0.729 & 2480 & 89700 & 0.729 & 2480 & 89700 & 1.51 & 1.66 & 47900 & 17600 & 47900 & 17600 \\
\hline F1-LD-80 & 80 & 1 & 0.618 & 2430 & 90900 & 0.618 & 2430 & 90900 & 1.51 & 1.65 & 47600 & 17400 & 47600 & 17400 \\
\hline F1-LD-120 & 120 & 1 & 0.476 & 2450 & 88800 & 0.476 & 2450 & 88800 & 1.52 & 1.66 & 47600 & 17500 & 47600 & 17500 \\
\hline F1-LD-180 & 180 & 1 & 0.378 & 2440 & 91200 & 0.378 & 2440 & 91200 & 1.52 & 1.66 & 47800 & 17500 & 47800 & 17500 \\
\hline F1-LD-240 & 240 & 1 & 0.329 & 2430 & 90200 & 0.329 & 2430 & 90200 & 1.51 & 1.66 & 47100 & 17400 & 47100 & 17400 \\
\hline F1-LD-600 & 600 & 1 & 0.268 & 2440 & 92100 & 0.268 & 2440 & 92100 & 1.52 & 1.67 & 47500 & 17300 & 47500 & 17300 \\
\hline F1-FD-CP & $\begin{array}{c}\text { Feed } \\
\text { Displacement }\end{array}$ & 1 & 0.190 & 1340 & 51900 & 0.190 & 1340 & 51900 & 0.880 & 0.960 & 25400 & 9390 & 25400 & 9390 \\
\hline F1-EL-CP & Elution & 1 & 7.52 & 3.15 & 1110 & 7.52 & 3.15 & 1110 & $<0.05$ & $<0.05$ & $<98.2$ & 2330 & $<98.2$ & 2330 \\
\hline Target & -- & -- & -- & -- & -- & 2.63 & 2570 & 95000 & 1.55 & 2.01 & -- & -- & 48900 & 19300 \\
\hline
\end{tabular}


Table B.27. Column F2 Test Analytical Data $\left(T=55^{\circ} \mathrm{C}\right.$, Flow rate $\left.=10.62 \mathrm{~mL} / \mathrm{min}\right)$

\begin{tabular}{|c|c|c|c|c|c|c|c|c|c|c|c|c|c|c|}
\hline Sample ID & $\begin{array}{l}\text { Loading Time } \\
\text { (min) }\end{array}$ & $\begin{array}{l}\text { Dilution } \\
\text { Factor }\end{array}$ & $\begin{array}{c}\text { Cs } \\
(\mathrm{raw}) \\
(\mathrm{mg} / \mathrm{kg})\end{array}$ & $\begin{array}{c}\mathrm{Al} \\
(\mathrm{raw}) \\
(\mathrm{mg} / \mathrm{kg})\end{array}$ & $\begin{array}{c}\mathrm{Na} \\
(\mathrm{raw}) \\
(\mathrm{mg} / \mathrm{kg})\end{array}$ & $\begin{array}{c}\text { Cs } \\
\text { (corr.) } \\
(\mathrm{mg} / \mathrm{kg})\end{array}$ & $\begin{array}{c}\mathrm{Al} \\
(\mathrm{corr} .) \\
(\mathrm{mg} / \mathrm{kg})\end{array}$ & $\begin{array}{c}\mathrm{Na} \\
(\mathrm{corr} .) \\
(\mathrm{mg} / \mathrm{kg})\end{array}$ & $\begin{array}{c}\text { OH-Free } \\
\text { (corr.) } \\
\text { (meq/mL) }\end{array}$ & $\begin{array}{c}\text { OH-Total } \\
\text { (corr.) } \\
\text { (meq/mL) }\end{array}$ & $\begin{array}{c}\mathrm{Cl} \\
(\mathrm{raw}) \\
(\mathrm{mg} / \mathrm{kg})\end{array}$ & $\begin{array}{c}\mathrm{NO}_{3} \\
\text { (raw) } \\
(\mathrm{mg} / \mathrm{kg})\end{array}$ & $\begin{array}{c}\mathrm{Cl} \\
\text { (corr.) } \\
(\mathrm{mg} / \mathrm{kg})\end{array}$ & $\begin{array}{c}\mathrm{NO}_{3} \\
\text { (corr.) } \\
\text { (mg/kg) }\end{array}$ \\
\hline F2-LD-00 & 0 & 1.75 & 1.78 & 1550 & 76900 & 3.12 & 2710 & 135000 & 1.63 & 1.79 & $<83.1$ & 33400 & $<145$ & 58500 \\
\hline F2-LD-06 & 6 & 1.85 & 1.49 & 1460 & 70400 & 2.76 & 2710 & 130000 & 1.56 & 1.71 & $<86.2$ & 30800 & $<160$ & 57100 \\
\hline F2-LD-12 & 12 & 2.02 & 1.26 & 1290 & 64400 & 2.54 & 2600 & 130000 & 1.52 & 1.68 & $<85.6$ & 28200 & $<173$ & 56800 \\
\hline F2-LD-18 & 18 & 1.91 & 1.24 & 1420 & 68100 & 2.36 & 2710 & 130000 & 1.56 & 1.71 & $<84.7$ & 29700 & $<162$ & 56600 \\
\hline F2-LD-24 & 24 & 1.88 & 1.18 & 1390 & 69400 & 2.22 & 2610 & 130000 & 1.53 & 1.67 & $<84.5$ & 30000 & $<159$ & 56300 \\
\hline F2-LD-36 & 36 & 1.89 & 1.08 & 1420 & 69800 & 2.04 & 2680 & 132000 & 1.57 & 1.71 & $<84.0$ & 30100 & $<159$ & 56900 \\
\hline F2-LD-48 & 48 & 1.86 & 0.997 & 1400 & 70700 & 1.86 & 2610 & 132000 & 1.55 & 1.70 & $<84.3$ & 30200 & $<157$ & 56300 \\
\hline F2-LD-60 & 60 & 1.89 & 0.893 & 1390 & 68500 & 1.69 & 2630 & 130000 & 1.55 & 1.71 & $<84.7$ & 30000 & $<160$ & 56800 \\
\hline F2-LD-80 & 80 & 1.94 & 0.778 & 1380 & 67200 & 1.51 & 2670 & 130000 & 1.53 & 1.68 & $<84.6$ & 28900 & $<164$ & 55900 \\
\hline F2-LD-120 & 120 & 1.93 & 0.657 & 1370 & 66300 & 1.27 & 2650 & 128000 & 1.55 & 1.70 & $<84.9$ & 29300 & $<164$ & 56600 \\
\hline F2-LD-180 & 180 & 1.82 & 0.587 & 1480 & 71100 & 1.07 & 2700 & 130000 & 1.57 & 1.72 & $<86.1$ & 30900 & $<157$ & 56300 \\
\hline F2-LD-240 & 240 & 1.99 & 0.495 & 1340 & 65200 & 0.987 & 2670 & 130000 & 1.56 & 1.72 & $<84.7$ & 28400 & $<169$ & 56600 \\
\hline F2-LD-600 & 600 & 1.74 & 0.472 & 1500 & 75600 & 0.823 & 2620 & 132000 & 1.58 & 1.74 & $<82.4$ & 33000 & $<144$ & 57500 \\
\hline F2-FD-CP & $\begin{array}{c}\text { Feed } \\
\text { Displacement }\end{array}$ & 1 & 0.603 & 1550 & 79900 & 0.603 & 1550 & 79900 & 0.880 & 1.14 & 145 & 34000 & 145 & 34000 \\
\hline F2-EL-CP & Elution & 1 & 7.12 & 4.31 & 1210 & 7.12 & 4.31 & 1210 & $<0.05$ & $<0.05$ & $<99.0$ & 2380 & $<99.0$ & 2380 \\
\hline Target & -- & -- & -- & -- & -- & 2.81 & 2720 & 134000 & 1.86 & 2.41 & -- & -- & 0 & 61200 \\
\hline
\end{tabular}


Table B.28. Column F3 Test Analytical Data $\left(\mathrm{T}=55^{\circ} \mathrm{C}\right.$, Flow rate $\left.=7.08 \mathrm{~mL} / \mathrm{min}\right)$

\begin{tabular}{|c|c|c|c|c|c|c|c|c|c|c|c|c|c|c|}
\hline Sample ID & $\begin{array}{l}\text { Loading Time } \\
\text { (min) }\end{array}$ & $\begin{array}{l}\text { Dilution } \\
\text { Factor }\end{array}$ & $\begin{array}{c}\text { Cs } \\
(\mathrm{raw}) \\
(\mathrm{mg} / \mathrm{kg})\end{array}$ & $\begin{array}{c}\mathrm{Al} \\
(\mathrm{raw}) \\
(\mathrm{mg} / \mathrm{kg})\end{array}$ & $\begin{array}{c}\mathrm{Na} \\
(\mathrm{raw}) \\
(\mathrm{mg} / \mathrm{kg})\end{array}$ & $\begin{array}{c}\text { Cs } \\
\text { (corr.) } \\
(\mathrm{mg} / \mathrm{kg})\end{array}$ & $\begin{array}{c}\mathrm{Al} \\
(\mathrm{corr} .) \\
(\mathrm{mg} / \mathrm{kg})\end{array}$ & $\begin{array}{c}\mathrm{Na} \\
(\mathrm{corr} .) \\
(\mathrm{mg} / \mathrm{kg})\end{array}$ & $\begin{array}{c}\text { OH-Free } \\
\text { (corr.) } \\
\text { (meq/mL) }\end{array}$ & $\begin{array}{c}\text { OH-Total } \\
\text { (corr.) } \\
\text { (meq/mL) }\end{array}$ & $\begin{array}{c}\mathrm{Cl} \\
(\mathrm{raw}) \\
(\mathrm{mg} / \mathrm{kg})\end{array}$ & $\begin{array}{c}\mathrm{NO}_{3} \\
\text { (raw) } \\
(\mathrm{mg} / \mathrm{kg})\end{array}$ & $\begin{array}{c}\mathrm{Cl} \\
\text { (corr.) } \\
(\mathrm{mg} / \mathrm{kg})\end{array}$ & $\begin{array}{c}\mathrm{NO}_{3} \\
\text { (corr.) } \\
\text { (mg/kg) }\end{array}$ \\
\hline F3-LD-00 & 0 & 1.78 & 1.80 & 1510 & 74300 & 3.21 & 2690 & 132000 & 1.63 & 1.78 & $<83.8$ & 33100 & $<149$ & 59000 \\
\hline F3-LD-06 & 6 & 1.72 & 1.71 & 1560 & 75700 & 2.94 & 2690 & 130000 & 1.58 & 1.72 & $<83.6$ & 33200 & $<144$ & 57100 \\
\hline F3-LD-12 & 12 & 1.82 & 1.53 & 1490 & 73100 & 2.78 & 2710 & 133000 & 1.56 & 1.72 & $<84.5$ & 31000 & $<154$ & 56300 \\
\hline F3-LD-18 & 18 & 1.76 & 1.45 & 1550 & 73900 & 2.56 & 2740 & 130000 & 1.58 & 1.74 & $<85.2$ & 32100 & $<150$ & 56600 \\
\hline F3-LD-24 & 24 & 1.75 & 1.46 & 1510 & 76000 & 2.55 & 2640 & 133000 & 1.58 & 1.74 & $<85.8$ & 32600 & $<150$ & 56900 \\
\hline F3-LD-36 & 36 & 1.81 & 1.21 & 1420 & 70800 & 2.19 & 2570 & 128000 & 1.56 & 1.72 & $<85.5$ & 31500 & $<155$ & 56900 \\
\hline F3-LD-48 & 48 & 1.81 & 1.14 & 1510 & 73100 & 2.06 & 2740 & 132000 & 1.57 & 1.73 & $<85.5$ & 31200 & $<155$ & 56500 \\
\hline F3-LD-60 & 60 & 1.77 & 1.06 & 1470 & 73000 & 1.87 & 2600 & 129000 & 1.58 & 1.74 & $<84.9$ & 32100 & $<150$ & 56800 \\
\hline F3-LD-80 & 80 & 1.77 & 0.972 & 1470 & 73400 & 1.72 & 2610 & 130000 & 1.58 & 1.74 & $<84.2$ & 31800 & $<149$ & 56400 \\
\hline F3-LD-120 & 120 & 1.74 & 0.813 & 1490 & 74500 & 1.41 & 2590 & 130000 & 1.59 & 1.74 & $<84.0$ & 32600 & $<146$ & 56700 \\
\hline F3-LD-180 & 180 & 1.75 & 0.714 & 1560 & 74900 & 1.25 & 2730 & 131000 & 1.57 & 1.74 & $<83.8$ & 32400 & $<146$ & 56600 \\
\hline F3-LD-240 & 240 & 1.79 & 0.627 & 1480 & 72900 & 1.12 & 2650 & 130000 & 1.58 & 1.73 & $<84.3$ & 31700 & $<151$ & 56700 \\
\hline F3-LD-600 & 600 & 1.72 & 0.538 & 1550 & 75800 & 0.920 & 2660 & 130000 & 1.60 & 1.75 & $<85.5$ & 33200 & $<147$ & 57000 \\
\hline F3-FD-CP & $\begin{array}{c}\text { Feed } \\
\text { Displacement }\end{array}$ & 1 & 0.773 & 1690 & 85300 & 0.773 & 1690 & 85300 & 1.12 & 1.22 & 109 & 36200 & 109 & 36200 \\
\hline F3-EL-CP & Elution & 1 & 7.12 & 4.05 & 1210 & 7.12 & 4.05 & 1210 & $<0.05$ & $<0.05$ & $<100$ & 2540 & $<100$ & 2540 \\
\hline Target & -- & -- & -- & -- & -- & 2.81 & 2720 & 134000 & 1.86 & 2.41 & -- & -- & 0 & 61200 \\
\hline
\end{tabular}


Table B.29. Column F4 Test Analytical Data $\left(T=55^{\circ} \mathrm{C}\right.$, Flow rate $\left.=10.62 \mathrm{~mL} / \mathrm{min}\right)$

\begin{tabular}{|c|c|c|c|c|c|c|c|c|c|c|c|c|c|c|}
\hline Sample ID & $\begin{array}{l}\text { Loading Time } \\
\text { (min) }\end{array}$ & $\begin{array}{c}\text { Dilution } \\
\text { Factor }\end{array}$ & $\begin{array}{c}\text { Cs } \\
(\mathrm{raw}) \\
(\mathrm{mg} / \mathrm{kg})\end{array}$ & $\begin{array}{c}\mathrm{Al} \\
(\mathrm{raw}) \\
(\mathrm{mg} / \mathrm{kg})\end{array}$ & $\begin{array}{c}\mathrm{Na} \\
(\mathrm{raw}) \\
(\mathrm{mg} / \mathrm{kg})\end{array}$ & $\begin{array}{c}\text { Cs } \\
(\text { corr.) } \\
(\mathrm{mg} / \mathrm{kg})\end{array}$ & $\begin{array}{c}\mathrm{Al} \\
(\text { corr.) } \\
(\mathrm{mg} / \mathrm{kg})\end{array}$ & $\begin{array}{c}\mathrm{Na} \\
(\text { corr.) } \\
(\mathrm{mg} / \mathrm{kg})\end{array}$ & $\begin{array}{c}\text { OH-Free } \\
\text { (corr.) } \\
\text { (meq/mL) }\end{array}$ & $\begin{array}{c}\text { OH-Total } \\
\text { (corr.) } \\
\text { (meq/mL) }\end{array}$ & $\begin{array}{c}\mathrm{Cl} \\
(\mathrm{raw}) \\
(\mathrm{mg} / \mathrm{kg})\end{array}$ & $\begin{array}{c}\mathrm{NO}_{3} \\
(\mathrm{raw}) \\
(\mathrm{mg} / \mathrm{kg})\end{array}$ & $\begin{array}{c}\mathrm{Cl} \\
\text { (corr.) } \\
\text { (mg/kg) }\end{array}$ & $\begin{array}{c}\mathrm{NO}_{3} \\
\text { (corr.) } \\
(\mathrm{mg} / \mathrm{kg})\end{array}$ \\
\hline F4-LD-00 & 0 & 1.87 & 3.46 & 3620 & 74300 & 6.48 & 6780 & 139000 & 3.24 & 3.62 & $<84.2$ & 21100 & $<158$ & 39500 \\
\hline F4-LD-06 & 6 & 1.93 & 2.86 & 3300 & 68100 & 5.51 & 6360 & 131000 & 3.10 & 3.45 & $<85.5$ & 19300 & $<165$ & 37200 \\
\hline F4-LD-12 & 12 & 1.81 & 2.82 & 3570 & 73000 & 5.12 & 6480 & 132000 & 3.14 & 3.50 & $<84.5$ & 20800 & $<153$ & 37700 \\
\hline F4-LD-18 & 18 & 1.81 & 2.61 & 3470 & 73500 & 4.73 & 6290 & 133000 & 3.16 & 3.50 & $<84.5$ & 20600 & $<153$ & 37400 \\
\hline F4-LD-24 & 24 & 1.88 & 2.35 & 3450 & 70800 & 4.41 & 6470 & 133000 & 3.15 & 3.49 & $<84.5$ & 20100 & $<159$ & 37700 \\
\hline F4-LD-36 & 36 & 1.91 & 2.07 & 3330 & 70100 & 3.95 & 6360 & 134000 & 3.09 & 3.46 & $<84.6$ & 19400 & $<162$ & 37100 \\
\hline F4-LD-48 & 48 & 1.81 & 1.97 & 3700 & 73800 & 3.57 & 6710 & 134000 & 3.12 & 3.50 & $<85.2$ & 20700 & $<155$ & 37500 \\
\hline F4-LD-60 & 60 & 1.82 & 1.80 & 3530 & 73200 & 3.28 & 6440 & 134000 & 3.14 & 3.50 & $<85.3$ & 20600 & $<156$ & 37600 \\
\hline F4-LD-80 & 80 & 1.85 & 1.54 & 3490 & 71300 & 2.85 & 6450 & 132000 & 3.12 & 3.49 & $<85.6$ & 20300 & $<158$ & 37500 \\
\hline F4-LD-120 & 120 & 1.85 & 1.31 & 3570 & 72800 & 2.43 & 6620 & 135000 & 3.11 & 3.48 & $<84.2$ & 20400 & $<156$ & 37800 \\
\hline F4-LD-180 & 180 & 1.83 & 1.11 & 3470 & 72300 & 2.03 & 6360 & 132000 & 3.13 & 3.48 & $<84.3$ & 20200 & $<155$ & 37000 \\
\hline F4-LD-240 & 240 & 1.82 & 0.995 & 3600 & 74200 & 1.81 & 6560 & 135000 & 3.12 & 3.48 & $<84.0$ & 20600 & $<153$ & 37600 \\
\hline F4-LD-600 & 600 & 1.79 & 0.832 & 3510 & 74000 & 1.49 & 6280 & 132000 & 3.18 & 3.52 & $<85.3$ & 21100 & $<153$ & 37700 \\
\hline F4-FD-CP & $\begin{array}{c}\text { Feed } \\
\text { Displacement }\end{array}$ & 1 & 1.27 & 4100 & 87300 & 1.27 & 4100 & 87300 & 2.19 & 2.43 & $<94.0$ & 24200 & $<94.0$ & 24200 \\
\hline Target & -- & -- & -- & -- & -- & 5.72 & 6690 & 137000 & 3.67 & 5.00 & -- & -- & 0 & 40800 \\
\hline
\end{tabular}


Table B.30. Column F4B Test Analytical Data $\left(T=55^{\circ} \mathrm{C}\right.$, Flow rate $\left.=0.08 \mathrm{~mL} / \mathrm{min}\right)$

\begin{tabular}{|c|c|c|c|c|c|c|c|c|c|c|c|c|c|c|}
\hline Sample ID & $\begin{array}{l}\text { Loading Time } \\
\text { (hrs) }\end{array}$ & $\begin{array}{l}\text { Dilution } \\
\text { Factor }\end{array}$ & $\begin{array}{c}\mathrm{Cs} \\
(\mathrm{raw}) \\
(\mathrm{mg} / \mathrm{kg})\end{array}$ & $\begin{array}{c}\mathrm{Al} \\
(\mathrm{raw}) \\
(\mathrm{mg} / \mathrm{kg})\end{array}$ & $\begin{array}{c}\mathrm{Na} \\
(\mathrm{raw}) \\
(\mathrm{mg} / \mathrm{kg})\end{array}$ & $\begin{array}{c}\mathrm{Cs} \\
\text { (corr.) } \\
\text { (mg/kg) }\end{array}$ & $\begin{array}{c}\mathrm{Al} \\
(\mathrm{corr} .) \\
(\mathrm{mg} / \mathrm{kg})\end{array}$ & $\begin{array}{c}\mathrm{Na} \\
(\mathrm{corr} .) \\
(\mathrm{mg} / \mathrm{kg})\end{array}$ & $\begin{array}{c}\text { OH-Free } \\
\text { (corr.) } \\
\text { (meq/mL) }\end{array}$ & $\begin{array}{c}\text { OH-Total } \\
\text { (corr.) } \\
\text { (meq/mL) }\end{array}$ & $\begin{array}{c}\mathrm{Cl} \\
(\mathrm{raw}) \\
(\mathrm{mg} / \mathrm{kg})\end{array}$ & $\begin{array}{c}\mathrm{NO}_{3} \\
\text { (raw) } \\
\text { (mg/kg) }\end{array}$ & $\begin{array}{c}\mathrm{Cl} \\
\text { (corr.) } \\
(\mathrm{mg} / \mathrm{kg})\end{array}$ & $\begin{array}{c}\mathrm{NO}_{3} \\
\text { (corr.) } \\
(\mathrm{mg} / \mathrm{kg})\end{array}$ \\
\hline F4B-LD-00 & 0 & 1.98 & 3.37 & 3490 & 69900 & 6.68 & 6920 & 139000 & 3.27 & 3.65 & $<85.6$ & 19700 & $<170$ & 39100 \\
\hline F4B-LD-04 & 4 & 1.89 & 3.23 & 3490 & 71200 & 6.12 & 6610 & 135000 & 3.13 & 3.49 & $<85.9$ & 19800 & $<163$ & 37500 \\
\hline F4B-LD-08 & 8 & 1.74 & 3.43 & 3670 & 75900 & 5.98 & 6390 & 132000 & 3.15 & 3.50 & $<84.6$ & 21500 & $<147$ & 37500 \\
\hline F4B-LD-12 & 12 & 1.78 & 3.16 & 3580 & 75500 & 5.64 & 6390 & 135000 & 3.14 & 3.52 & $<85.0$ & 21500 & $<152$ & 38400 \\
\hline F4B-LD-24 & 24 & 1.78 & 2.99 & 3740 & 76300 & 5.32 & 6660 & 136000 & 3.22 & 3.56 & $<84.6$ & 21300 & $<151$ & 37930 \\
\hline F4B-LD-72 & 72 & 1.81 & 2.04 & 3680 & 74600 & 3.70 & 6680 & 135000 & 3.18 & 3.54 & $<84.0$ & 21000 & $<152$ & 38100 \\
\hline F4B-LD-120 & 120 & 1.77 & 1.22 & 3840 & 77300 & 2.16 & 6790 & 137000 & 3.25 & 3.64 & $<84.6$ & 21800 & $<150$ & 38600 \\
\hline F4B-LD-168 & 168 & 1.82 & 2.07 & 3630 & 76200 & 3.77 & 6610 & 139000 & 3.24 & 3.61 & $<84.3$ & 21200 & $<154$ & 38600 \\
\hline F4B-LD-336 & 336 & 2.04 & 2.16 & 3470 & 70900 & 4.40 & 7060 & 144000 & 3.34 & 3.73 & $<85.6$ & 19700 & $<174$ & 40100 \\
\hline F4B-LD-504 & 504 & 1.79 & 2.49 & 3900 & 76100 & 4.45 & 6970 & 136000 & 3.50 & 3.91 & $<83.6$ & 23200 & $<149$ & 41400 \\
\hline F4B-FD-CP & $\begin{array}{c}\text { Feed } \\
\text { Displacement }\end{array}$ & 1 & 2.28 & 3160 & 68600 & 2.28 & 3160 & 68600 & 1.64 & 1.81 & 100 & 17600 & 100 & 17600 \\
\hline F4B-EL-CP & Elution & 1 & 27.3 & 145 & 1500 & 27.3 & 145 & 1500 & $<0.05$ & $<0.05$ & $<99.6$ & 2440 & $<99.6$ & 2440 \\
\hline Target & -- & -- & -- & -- & -- & 5.72 & 6690 & 137000 & 3.67 & 5.00 & -- & -- & 0 & 40800 \\
\hline
\end{tabular}


Table B.31. Column F5 Test Analytical Data $\left(T=55^{\circ} \mathrm{C}\right.$, Flow rate $\left.=10.62 \mathrm{~mL} / \mathrm{min}\right)$

\begin{tabular}{|c|c|c|c|c|c|c|c|c|c|c|c|c|c|c|}
\hline Sample ID & $\begin{array}{l}\text { Loading Time } \\
\text { (min) }\end{array}$ & $\begin{array}{l}\text { Dilution } \\
\text { Factor }\end{array}$ & $\begin{array}{c}\mathrm{Cs} \\
(\mathrm{raw}) \\
(\mathrm{mg} / \mathrm{kg})\end{array}$ & $\begin{array}{c}\mathrm{Al} \\
(\mathrm{raw}) \\
(\mathrm{mg} / \mathrm{kg})\end{array}$ & $\begin{array}{c}\mathrm{Na} \\
(\mathrm{raw}) \\
(\mathrm{mg} / \mathrm{kg})\end{array}$ & $\begin{array}{c}\mathrm{Cs} \\
\text { (corr.) } \\
\text { (mg/kg) }\end{array}$ & $\begin{array}{c}\mathrm{Al} \\
(\mathrm{corr} .) \\
(\mathrm{mg} / \mathrm{kg})\end{array}$ & $\begin{array}{c}\mathrm{Na} \\
(\text { corr.) } \\
(\mathrm{mg} / \mathrm{kg})\end{array}$ & $\begin{array}{c}\text { OH-Free } \\
\text { (corr.) } \\
\text { (meq/mL) }\end{array}$ & $\begin{array}{c}\text { OH-Total } \\
\text { (corr.) } \\
\text { (meq/mL) }\end{array}$ & $\begin{array}{c}\mathrm{Cl} \\
(\mathrm{raw}) \\
(\mathrm{mg} / \mathrm{kg})\end{array}$ & $\begin{array}{c}\mathrm{NO}_{3} \\
\text { (raw) } \\
\text { (mg/kg) }\end{array}$ & $\begin{array}{c}\mathrm{Cl} \\
\text { (corr.) } \\
(\mathrm{mg} / \mathrm{kg})\end{array}$ & $\begin{array}{c}\mathrm{NO}_{3} \\
\text { (corr.) } \\
(\mathrm{mg} / \mathrm{kg})\end{array}$ \\
\hline F5-LD-00 & 0 & 1 & 2.19 & 2560 & 94900 & 2.19 & 2560 & 94900 & 1.56 & 1.71 & 47900 & 17800 & 47900 & 17800 \\
\hline F5-LD-06 & 6 & 1 & 1.69 & 2380 & 90600 & 1.69 & 2380 & 90600 & 1.50 & 1.65 & 47100 & 17100 & 47100 & 17100 \\
\hline F5-LD-12 & 12 & 1 & 1.48 & 2580 & 93200 & 1.48 & 2580 & 93200 & 1.50 & 1.64 & 46300 & 17100 & 46300 & 17100 \\
\hline F5-LD-18 & 18 & 1 & 1.33 & 2540 & 92300 & 1.33 & 2540 & 92300 & 1.50 & 1.64 & 47100 & 17300 & 47100 & 17300 \\
\hline F5-LD-24 & 24 & 1 & 1.20 & 2440 & 92700 & 1.20 & 2440 & 92700 & 1.50 & 1.65 & 46500 & 17200 & 46500 & 17200 \\
\hline F5-LD-36 & 36 & 1 & 0.981 & 2480 & 82900 & 0.981 & 2480 & 82900 & 1.49 & 1.64 & 45800 & 16900 & 45800 & 16900 \\
\hline F5-LD-48 & 48 & 1 & 0.899 & 2610 & 91100 & 0.899 & 2610 & 91100 & 1.50 & 1.65 & 45800 & 16800 & 45800 & 16800 \\
\hline F5-LD-60 & 60 & 1 & 0.784 & 2510 & 91000 & 0.784 & 2510 & 91000 & 1.50 & 1.65 & 46600 & 17000 & 46600 & 17000 \\
\hline F5-LD-80 & 80 & 1 & 0.669 & 2420 & 90800 & 0.669 & 2420 & 90800 & 1.49 & 1.64 & 47100 & 17400 & 47100 & 17400 \\
\hline F5-LD-120 & 120 & 1 & 0.582 & 2400 & 92900 & 0.582 & 2400 & 92900 & 1.50 & 1.65 & 46200 & 17000 & 46200 & 17000 \\
\hline F5-LD-180 & 180 & 1 & 0.521 & 2520 & 91900 & 0.521 & 2520 & 91900 & 1.50 & 1.65 & 46700 & 17100 & 46700 & 17100 \\
\hline F5-LD-240 & 240 & 1 & 0.500 & 2530 & 90200 & 0.500 & 2530 & 90200 & 1.50 & 1.65 & 46900 & 17200 & 46900 & 17200 \\
\hline F5-LD-600 & 600 & 1 & 0.493 & 2500 & 92400 & 0.493 & 2500 & 92400 & 1.51 & 1.65 & 46400 & 17000 & 46400 & 17000 \\
\hline F5-FD-CP & $\begin{array}{c}\text { Feed } \\
\text { Displacement }\end{array}$ & 1 & 0.386 & 1500 & 56500 & 0.386 & 1500 & 56500 & 0.953 & 1.04 & 26800 & 10100 & 26800 & 10100 \\
\hline F5-EL-CP & Elution & 1 & 9.13 & 7.77 & 1420 & 9.13 & 7.77 & 1420 & $<0.05$ & $<0.05$ & 107 & 2370 & 107 & 2370 \\
\hline Target & -- & -- & -- & -- & -- & 2.63 & 2570 & 95000 & 1.55 & 2.01 & -- & -- & 48900 & 19300 \\
\hline
\end{tabular}


Table B.32. Column G1 Test Analytical Data $\left(\mathrm{T}=60^{\circ} \mathrm{C}\right.$, Flow rate $\left.=10.62 \mathrm{~mL} / \mathrm{min}\right)$

\begin{tabular}{|c|c|c|c|c|c|c|c|c|c|c|c|c|c|c|}
\hline Sample ID & $\begin{array}{l}\text { Loading Time } \\
(\mathrm{min})\end{array}$ & $\begin{array}{c}\text { Dilution } \\
\text { Factor }\end{array}$ & $\begin{array}{c}\mathrm{Cs} \\
(\mathrm{raw}) \\
(\mathrm{mg} / \mathrm{kg})\end{array}$ & $\begin{array}{c}\mathrm{Al} \\
(\mathrm{raw}) \\
(\mathrm{mg} / \mathrm{kg})\end{array}$ & $\begin{array}{c}\mathrm{Na} \\
(\mathrm{raw}) \\
(\mathrm{mg} / \mathrm{kg})\end{array}$ & $\begin{array}{c}\text { Cs } \\
\text { (corr.) } \\
\text { (mg/kg) }\end{array}$ & $\begin{array}{c}\mathrm{Al} \\
\text { (corr.) } \\
\text { (mg/kg) }\end{array}$ & $\begin{array}{c}\mathrm{Na} \\
(\mathrm{corr} .) \\
(\mathrm{mg} / \mathrm{kg})\end{array}$ & $\begin{array}{c}\text { OH-Free } \\
\text { (corr.) } \\
\text { (meq/mL) }\end{array}$ & $\begin{array}{c}\text { OH-Total } \\
\text { (corr.) } \\
\text { (meq/mL) }\end{array}$ & $\begin{array}{c}\mathrm{Cl} \\
(\mathrm{raw}) \\
(\mathrm{mg} / \mathrm{kg})\end{array}$ & $\begin{array}{c}\mathrm{NO}_{3} \\
\text { (raw) } \\
(\mathrm{mg} / \mathrm{kg})\end{array}$ & $\begin{array}{c}\mathrm{Cl} \\
\text { (corr.) } \\
\text { (mg/kg) }\end{array}$ & $\begin{array}{c}\mathrm{NO}_{3} \\
\text { (corr.) } \\
\text { (mg/kg) }\end{array}$ \\
\hline G1-LD-00 & 0 & 1 & 2.08 & 2490 & 91200 & 2.08 & 2490 & 91200 & 1.55 & 1.70 & 48200 & 17600 & 48200 & 17600 \\
\hline G1-LD-06 & 6 & 1 & 1.84 & 2400 & 89700 & 1.84 & 2400 & 89700 & 1.51 & 1.65 & 47100 & 17400 & 47100 & 17400 \\
\hline G1-LD-12 & 12 & 1 & 1.67 & 2430 & 89400 & 1.67 & 2430 & 89400 & 1.51 & 1.65 & 47500 & 17400 & 47500 & 17400 \\
\hline G1-LD-18 & 18 & 1 & 1.49 & 2400 & 90600 & 1.49 & 2400 & 90600 & 1.50 & 1.64 & 47000 & 17200 & 47000 & 17200 \\
\hline G1-LD-24 & 24 & 1 & 1.36 & 2390 & 89700 & 1.36 & 2390 & 89700 & 1.50 & 1.65 & 46600 & 17100 & 46600 & 17100 \\
\hline G1-LD-36 & 36 & 1 & 1.15 & 2440 & 88200 & 1.15 & 2440 & 88200 & 1.50 & 1.64 & 46700 & 17200 & 46700 & 17200 \\
\hline G1-LD-48 & 48 & 1 & 0.980 & 2430 & 91300 & 0.980 & 2430 & 91300 & 1.51 & 1.65 & 46900 & 17200 & 46900 & 17200 \\
\hline G1-LD-60 & 60 & 1 & 0.836 & 2350 & 90500 & 0.836 & 2350 & 90500 & 1.50 & 1.64 & 46900 & 17100 & 46900 & 17100 \\
\hline G1-LD-80 & 80 & 1 & 0.677 & 2440 & 91100 & 0.677 & 2440 & 91100 & 1.50 & 1.64 & 46300 & 17000 & 46300 & 17000 \\
\hline G1-LD-120 & 120 & 1 & 0.483 & 2410 & 89900 & 0.483 & 2410 & 89900 & 1.50 & 1.64 & 47700 & 17500 & 47700 & 17500 \\
\hline G1-LD-180 & 180 & 1 & 0.351 & 2360 & 88300 & 0.351 & 2360 & 88300 & 1.50 & 1.65 & 47200 & 17300 & 47200 & 17300 \\
\hline G1-LD-240 & 240 & 1 & 0.309 & 2440 & 91000 & 0.309 & 2440 & 91000 & 1.50 & 1.64 & 46800 & 17200 & 46800 & 17200 \\
\hline G1-LD-600 & 600 & 1 & 0.253 & 2450 & 88800 & 0.253 & 2450 & 88800 & 1.51 & 1.66 & 46600 & 17000 & 46600 & 17000 \\
\hline G1-FD-CP & $\begin{array}{c}\text { Feed } \\
\text { Displacement }\end{array}$ & 1 & 0.189 & 1390 & 54300 & 0.189 & 1390 & 54300 & 0.907 & 0.989 & 25500 & 9560 & 25500 & 9560 \\
\hline G1-EL-CP & Elution & 1 & 7.32 & 2.64 & 1170 & 7.32 & 2.64 & 1170 & $<0.05$ & $<0.05$ & $<98.0$ & 2360 & $<98.0$ & 2360 \\
\hline Target & -- & -- & -- & -- & -- & 2.63 & 2570 & 95000 & 1.55 & 2.01 & -- & -- & 48900 & 19300 \\
\hline
\end{tabular}


Table B.33. Column G2 Test Analytical Data $\left(\mathrm{T}=60^{\circ} \mathrm{C}\right.$, Flow rate $\left.=10.62 \mathrm{~mL} / \mathrm{min}\right)$

\begin{tabular}{|c|c|c|c|c|c|c|c|c|c|c|c|c|c|c|}
\hline Sample ID & $\begin{array}{l}\text { Loading Time } \\
\text { (min) }\end{array}$ & $\begin{array}{l}\text { Dilution } \\
\text { Factor }\end{array}$ & $\begin{array}{c}\text { Cs } \\
(\mathrm{raw}) \\
(\mathrm{mg} / \mathrm{kg})\end{array}$ & $\begin{array}{c}\mathrm{Al} \\
(\mathrm{raw}) \\
(\mathrm{mg} / \mathrm{kg})\end{array}$ & $\begin{array}{c}\mathrm{Na} \\
(\mathrm{raw}) \\
(\mathrm{mg} / \mathrm{kg})\end{array}$ & $\begin{array}{c}\text { Cs } \\
\text { (corr.) } \\
(\mathrm{mg} / \mathrm{kg})\end{array}$ & $\begin{array}{c}\mathrm{Al} \\
(\mathrm{corr} .) \\
(\mathrm{mg} / \mathrm{kg})\end{array}$ & $\begin{array}{c}\mathrm{Na} \\
(\mathrm{corr} .) \\
(\mathrm{mg} / \mathrm{kg})\end{array}$ & $\begin{array}{c}\text { OH-Free } \\
\text { (corr.) } \\
\text { (meq/mL) }\end{array}$ & $\begin{array}{c}\text { OH-Total } \\
\text { (corr.) } \\
\text { (meq/mL) }\end{array}$ & $\begin{array}{c}\mathrm{Cl} \\
(\mathrm{raw}) \\
(\mathrm{mg} / \mathrm{kg})\end{array}$ & $\begin{array}{c}\mathrm{NO}_{3} \\
\text { (raw) } \\
(\mathrm{mg} / \mathrm{kg})\end{array}$ & $\begin{array}{c}\mathrm{Cl} \\
\text { (corr.) } \\
(\mathrm{mg} / \mathrm{kg})\end{array}$ & $\begin{array}{c}\mathrm{NO}_{3} \\
\text { (corr.) } \\
\text { (mg/kg) }\end{array}$ \\
\hline G2-LD-00 & 0 & 1.67 & 1.90 & 1600 & 81300 & 3.17 & 2670 & 136000 & 1.63 & 1.79 & $<83.5$ & 35300 & $<140$ & 59000 \\
\hline G2-LD-06 & 6 & 1.96 & 1.41 & 1350 & 66200 & 2.76 & 2640 & 130000 & 1.54 & 1.69 & $<86.1$ & 28600 & $<169$ & 56000 \\
\hline G2-LD-12 & 12 & 1.87 & 1.38 & 1440 & 69800 & 2.58 & 2690 & 130000 & 1.55 & 1.70 & $<85.5$ & 30100 & $<160$ & 56200 \\
\hline G2-LD-18 & 18 & 2.04 & 1.20 & 1290 & 64300 & 2.45 & 2630 & 131000 & 1.53 & 1.68 & $<86.8$ & 27400 & $<177$ & 56000 \\
\hline G2-LD-24 & 24 & 1.92 & 1.21 & 1400 & 68400 & 2.32 & 2680 & 131000 & 1.57 & 1.72 & $<86.4$ & 29500 & $<166$ & 56600 \\
\hline G2-LD-36 & 36 & 1.85 & 1.13 & 1450 & 70000 & 2.10 & 2690 & 130000 & 1.56 & 1.73 & $<84.0$ & 30600 & $<156$ & 56700 \\
\hline G2-LD-48 & 48 & 1.92 & 1.14 & 1470 & 70900 & 2.19 & 2820 & 136000 & 1.55 & 1.70 & $<85.8$ & 29500 & $<165$ & 56600 \\
\hline G2-LD-60 & 60 & 1.93 & 0.944 & 1380 & 67400 & 1.83 & 2670 & 130000 & 1.53 & 1.69 & $<86.7$ & 28600 & $<168$ & 55300 \\
\hline G2-LD-80 & 80 & 2.00 & 0.817 & 1270 & 63600 & 1.63 & 2540 & 127000 & 1.53 & 1.69 & $<86.8$ & 28000 & $<173$ & 55900 \\
\hline G2-LD-120 & 120 & 1.92 & 0.756 & 1360 & 67000 & 1.46 & 2620 & 129000 & 1.56 & 1.71 & $<86.2$ & 29000 & $<166$ & 55800 \\
\hline G2-LD-180 & 180 & 1.89 & 0.655 & 1410 & 68800 & 1.24 & 2670 & 130000 & 1.54 & 1.70 & $<85.8$ & 29400 & $<162$ & 55600 \\
\hline G2-LD-240 & 240 & 1.91 & 0.626 & 1370 & 68800 & 1.19 & 2610 & 131000 & 1.55 & 1.70 & $<85.9$ & 29600 & $<164$ & 56400 \\
\hline G2-LD-600 & 600 & 1.82 & 0.543 & 1520 & 72400 & 0.987 & 2760 & 132000 & 1.58 & 1.55 & $<84.9$ & 31300 & $<154$ & 56900 \\
\hline G2-FD-CP & $\begin{array}{c}\text { Feed } \\
\text { Displacement }\end{array}$ & 1 & 0.898 & 2070 & 102000 & 0.898 & 2070 & 102000 & 1.36 & 1.48 & 102 & 43300 & 102 & 43300 \\
\hline G2-EL-CP & Elution & 1 & 8.75 & 4.36 & 1470 & 8.75 & 4.36 & 1470 & $<0.05$ & $<0.05$ & $<101$ & 2340 & $<101$ & 2340 \\
\hline Target & -- & -- & -- & -- & -- & 2.81 & 2720 & 134000 & 1.86 & 2.41 & -- & -- & 0 & 61200 \\
\hline
\end{tabular}


Table B.34. Column G3 Test Analytical Data $\left(\mathrm{T}=60^{\circ} \mathrm{C}\right.$, Flow rate $\left.=7.08 \mathrm{~mL} / \mathrm{min}\right)$

\begin{tabular}{|c|c|c|c|c|c|c|c|c|c|c|c|c|c|c|}
\hline Sample ID & $\begin{array}{l}\text { Loading Time } \\
\text { (min) }\end{array}$ & $\begin{array}{c}\text { Dilution } \\
\text { Factor }\end{array}$ & $\begin{array}{c}\mathrm{Cs} \\
(\mathrm{raw}) \\
(\mathrm{mg} / \mathrm{kg})\end{array}$ & $\begin{array}{c}\mathrm{Al} \\
(\mathrm{raw}) \\
(\mathrm{mg} / \mathrm{kg})\end{array}$ & $\begin{array}{c}\mathrm{Na} \\
(\mathrm{raw}) \\
(\mathrm{mg} / \mathrm{kg})\end{array}$ & $\begin{array}{c}\text { Cs } \\
\text { (corr.) } \\
\text { (mg/kg) }\end{array}$ & $\begin{array}{c}\mathrm{Al} \\
\text { (corr.) } \\
\text { (mg/kg) }\end{array}$ & $\begin{array}{c}\mathrm{Na} \\
(\mathrm{corr} .) \\
(\mathrm{mg} / \mathrm{kg})\end{array}$ & $\begin{array}{c}\text { OH-Free } \\
\text { (corr.) } \\
\text { (meq/mL) }\end{array}$ & $\begin{array}{c}\text { OH-Total } \\
\text { (corr.) } \\
\text { (meq/mL) }\end{array}$ & $\begin{array}{c}\mathrm{Cl} \\
(\mathrm{raw}) \\
(\mathrm{mg} / \mathrm{kg})\end{array}$ & $\begin{array}{c}\mathrm{NO}_{3} \\
\text { (raw) } \\
(\mathrm{mg} / \mathrm{kg})\end{array}$ & $\begin{array}{c}\mathrm{Cl} \\
\text { (corr.) } \\
\text { (mg/kg) }\end{array}$ & $\begin{array}{c}\mathrm{NO}_{3} \\
\text { (corr.) } \\
\text { (mg/kg) }\end{array}$ \\
\hline G3-LD-00 & 0 & 1.66 & 1.94 & 1670 & 80100 & 3.22 & 2770 & 133000 & 1.63 & 1.81 & $<82.2$ & 35700 & $<136$ & 59200 \\
\hline G3-LD-06 & 6 & 1.79 & 1.62 & 1470 & 71700 & 2.89 & 2620 & 128000 & 1.56 & 1.72 & $<83.5$ & 31500 & $<149$ & 56300 \\
\hline G3-LD-12 & 12 & 1.78 & 1.54 & 1490 & 73500 & 2.74 & 2650 & 131000 & 1.58 & 1.73 & $<83.3$ & 32000 & $<148$ & 56900 \\
\hline G3-LD-18 & 18 & 1.74 & 1.46 & 1500 & 73900 & 2.54 & 2620 & 129000 & 1.58 & 1.73 & $<83.2$ & 32100 & $<145$ & 56000 \\
\hline G3-LD-24 & 24 & 1.77 & 1.36 & 1540 & 73000 & 2.41 & 2730 & 129000 & 1.57 & 1.73 & $<84.3$ & 31900 & $<149$ & 56500 \\
\hline G3-LD-36 & 36 & 1.79 & 1.24 & 1510 & 72400 & 2.22 & 2710 & 130000 & 1.55 & 1.71 & $<83.8$ & 31200 & $<150$ & 56000 \\
\hline G3-LD-48 & 48 & 1.87 & 1.11 & 1450 & 69100 & 2.07 & 2710 & 129000 & 1.55 & 1.70 & $<84.9$ & 30100 & $<159$ & 56300 \\
\hline G3-LD-60 & 60 & 1.81 & 1.08 & 1540 & 72400 & 1.95 & 2780 & 131000 & 1.58 & 1.73 & $<83.8$ & 31300 & $<152$ & 56600 \\
\hline G3-LD-80 & 80 & 1.83 & 0.981 & 1470 & 71900 & 1.79 & 2690 & 131000 & 1.57 & 1.72 & $<83.9$ & 30400 & $<153$ & 55600 \\
\hline G3-LD-120 & 120 & 1.83 & 0.827 & 1460 & 70600 & 1.51 & 2670 & 129000 & 1.58 & 1.73 & $<84.0$ & 30900 & $<154$ & 56600 \\
\hline G3-LD-180 & 180 & 1.80 & 0.759 & 1480 & 72000 & 1.37 & 2670 & 130000 & 1.57 & 1.73 & $<83.5$ & 31500 & $<151$ & 56800 \\
\hline G3-LD-240 & 240 & 1.76 & 0.712 & 1520 & 72400 & 1.25 & 2680 & 127000 & 1.56 & 1.71 & $<83.8$ & 32000 & $<148$ & 56300 \\
\hline G3-LD-600 & 600 & 1.88 & 0.591 & 1500 & 69900 & 1.11 & 2820 & 132000 & 1.57 & 1.73 & $<84.5$ & 30000 & $<159$ & 56500 \\
\hline G3-FD-CP & $\begin{array}{c}\text { Feed } \\
\text { Displacement }\end{array}$ & 1 & 1.10 & 2080 & 102000 & 1.10 & 2080 & 102000 & 1.39 & 1.52 & 99.0 & 44800 & 99.0 & 44800 \\
\hline G3-EL-CP & Elution & 1 & 8.32 & 4.17 & 1410 & 8.32 & 4.17 & 1410 & $<0.05$ & $<0.05$ & $<98.8$ & 2350 & $<98.8$ & 2350 \\
\hline Target & -- & -- & -- & -- & -- & 2.81 & 2720 & 134000 & 1.86 & 2.41 & -- & -- & 0 & 61200 \\
\hline
\end{tabular}


Table B.35. Column G4 Test Analytical Data $\left(\mathrm{T}=60^{\circ} \mathrm{C}\right.$, Flow rate $\left.=10.62 \mathrm{~mL} / \mathrm{min}\right)$

\begin{tabular}{|c|c|c|c|c|c|c|c|c|c|c|c|c|c|c|}
\hline Sample ID & $\begin{array}{l}\text { Loading Time } \\
\text { (min) }\end{array}$ & $\begin{array}{l}\text { Dilution } \\
\text { Factor }\end{array}$ & $\begin{array}{c}\mathrm{Cs} \\
(\mathrm{raw}) \\
(\mathrm{mg} / \mathrm{kg})\end{array}$ & $\begin{array}{c}\mathrm{Al} \\
(\mathrm{raw}) \\
(\mathrm{mg} / \mathrm{kg})\end{array}$ & $\begin{array}{c}\mathrm{Na} \\
(\mathrm{raw}) \\
(\mathrm{mg} / \mathrm{kg})\end{array}$ & $\begin{array}{c}\text { Cs } \\
\text { (corr.) } \\
\text { (mg/kg) }\end{array}$ & $\begin{array}{c}\mathrm{Al} \\
(\mathrm{corr} .) \\
(\mathrm{mg} / \mathrm{kg})\end{array}$ & $\begin{array}{c}\mathrm{Na} \\
(\text { corr.) } \\
(\mathrm{mg} / \mathrm{kg})\end{array}$ & $\begin{array}{c}\text { OH-Free } \\
\text { (corr.) } \\
\text { (meq/mL) }\end{array}$ & $\begin{array}{c}\text { OH-Total } \\
\text { (corr.) } \\
\text { (meq/mL) }\end{array}$ & $\begin{array}{c}\mathrm{Cl} \\
(\mathrm{raw}) \\
(\mathrm{mg} / \mathrm{kg})\end{array}$ & $\begin{array}{c}\mathrm{NO}_{3} \\
\text { (raw) } \\
\text { (mg/kg) }\end{array}$ & $\begin{array}{c}\mathrm{Cl} \\
\text { (corr.) } \\
(\mathrm{mg} / \mathrm{kg})\end{array}$ & $\begin{array}{c}\mathrm{NO}_{3} \\
\text { (corr.) } \\
(\mathrm{mg} / \mathrm{kg})\end{array}$ \\
\hline G4-LD-00 & 0 & 1.87 & 3.51 & 3660 & 72500 & 6.56 & 6840 & 135000 & 3.20 & 3.59 & $<84.7$ & 20400 & $<158$ & 38100 \\
\hline G4-LD-06 & 6 & 1.79 & 3.24 & 3800 & 74800 & 5.79 & 6796 & 134000 & 3.17 & 3.51 & $<86.7$ & 20500 & $<155$ & 36700 \\
\hline G4-LD-12 & 12 & 1.85 & 2.80 & 3600 & 71200 & 5.17 & 6642 & 131000 & 3.16 & 3.51 & $<88.7$ & 20200 & $<164$ & 37300 \\
\hline G4-LD-18 & 18 & 1.83 & 2.56 & 3530 & 70300 & 4.67 & 6444 & 128000 & 3.12 & 3.49 & $<85.0$ & 20100 & $<155$ & 37000 \\
\hline G4-LD-24 & 24 & 1.99 & 2.23 & 3360 & 67200 & 4.45 & 6698 & 134000 & 3.09 & 3.45 & $<86.5$ & 18300 & $<172$ & 36500 \\
\hline G4-LD-36 & 36 & 1.84 & 2.20 & 3580 & 72300 & 4.04 & 6570 & 133000 & 3.14 & 3.49 & $<85.5$ & 20000 & $<157$ & 36700 \\
\hline G4-LD-48 & 48 & 1.91 & 1.94 & 3340 & 69000 & 3.70 & 6363 & 131000 & 3.14 & 3.49 & $<85.8$ & 19400 & $<164$ & 37000 \\
\hline G4-LD-60 & 60 & 1.92 & 1.75 & 3400 & 68600 & 3.37 & 6544 & 132000 & 3.12 & 3.46 & $<98.2$ & 19100 & $<189$ & 36800 \\
\hline G4-LD-80 & 80 & 1.90 & 1.54 & 3260 & 67900 & 2.93 & 6204 & 129000 & 3.08 & 3.44 & $<85.8$ & 19000 & $<163$ & 36200 \\
\hline G4-LD-120 & 120 & 1.96 & 1.37 & 3490 & 68400 & 2.68 & 6834 & 134000 & 3.13 & 3.49 & $<85.9$ & 19000 & $<168$ & 37200 \\
\hline G4-LD-180 & 180 & 1.89 & 1.18 & 3480 & 69500 & 2.23 & 6574 & 131000 & 3.12 & 3.46 & $<85.9$ & 19500 & $<162$ & 36800 \\
\hline G4-LD-240 & 240 & 1.87 & 1.11 & 3480 & 70800 & 2.07 & 6499 & 132000 & 3.10 & 3.45 & $<85.3$ & 19800 & $<159$ & 37000 \\
\hline G4-LD-600 & 600 & 1.76 & 1.04 & 3720 & 76300 & 1.83 & 6557 & 134000 & 3.21 & 3.58 & $<84.5$ & 21300 & $<149$ & 37500 \\
\hline G4-FD-CP & $\begin{array}{c}\text { Feed } \\
\text { Displacement }\end{array}$ & 1 & 1.62 & 4720 & 92900 & 1.62 & 4720 & 92900 & 2.38 & 2.65 & $<85.3$ & 26200 & $<85.3$ & 26200 \\
\hline Target & -- & -- & -- & -- & -- & 5.72 & 6690 & 137000 & 3.67 & 5.00 & -- & -- & 0 & 40800 \\
\hline
\end{tabular}


Table B.36. Column G4B Test Analytical Data $\left(T=60^{\circ} \mathrm{C}\right.$, Flow rate $\left.=0.08 \mathrm{~mL} / \mathrm{min}\right)$

\begin{tabular}{|c|c|c|c|c|c|c|c|c|c|c|c|c|c|c|}
\hline Sample ID & $\begin{array}{c}\text { Loading Time } \\
\text { (hrs) }\end{array}$ & $\begin{array}{c}\text { Dilution } \\
\text { Factor }\end{array}$ & $\begin{array}{c}\text { Cs } \\
(\mathrm{raw}) \\
(\mathrm{mg} / \mathrm{kg})\end{array}$ & $\begin{array}{c}\mathrm{Al} \\
(\mathrm{raw}) \\
(\mathrm{mg} / \mathrm{kg})\end{array}$ & $\begin{array}{c}\mathrm{Na} \\
(\mathrm{raw}) \\
(\mathrm{mg} / \mathrm{kg})\end{array}$ & $\begin{array}{c}\text { Cs } \\
\text { (corr.) } \\
\text { (mg/kg) }\end{array}$ & $\begin{array}{c}\mathrm{Al} \\
(\mathrm{corr} .) \\
(\mathrm{mg} / \mathrm{kg})\end{array}$ & $\begin{array}{c}\mathrm{Na} \\
(\text { corr.) } \\
(\mathrm{mg} / \mathrm{kg})\end{array}$ & $\begin{array}{c}\text { OH-Free } \\
\text { (corr.) } \\
\text { (meq/mL) }\end{array}$ & $\begin{array}{c}\text { OH-Total } \\
\text { (corr.) } \\
\text { (meq/mL) }\end{array}$ & $\begin{array}{c}\mathrm{Cl} \\
(\mathrm{raw}) \\
(\mathrm{mg} / \mathrm{kg})\end{array}$ & $\begin{array}{c}\mathrm{NO}_{3} \\
\text { (raw) } \\
\text { (mg/kg) }\end{array}$ & $\begin{array}{c}\mathrm{Cl} \\
\text { (corr.) } \\
\text { (mg/kg) }\end{array}$ & $\begin{array}{c}\mathrm{NO}_{3} \\
\text { (corr.) } \\
\text { (mg/kg) }\end{array}$ \\
\hline G4B-LD-00 & 0 & 1.86 & 3.61 & 3940 & 75200 & 6.72 & 7330 & 140000 & 3.26 & 3.63 & $<85.2$ & 20800 & $<159$ & 38700 \\
\hline G4B-LD-04 & 4 & 1.85 & 3.47 & 3770 & 72800 & 6.43 & 6983 & 135000 & 3.15 & 3.50 & $<85.9$ & 19900 & $<159$ & 36900 \\
\hline G4B-LD-08 & 8 & 1.82 & 3.69 & 3840 & 75700 & 6.71 & 6984 & 138000 & 3.18 & 3.53 & $<85.5$ & 20700 & $<156$ & 37700 \\
\hline G4B-LD-12 & 12 & 1.85 & 3.21 & 3700 & 71100 & 5.92 & 6828 & 131000 & 3.17 & 3.54 & $<85.2$ & 20700 & $<157$ & 38200 \\
\hline G4B-LD-24 & 24 & 1.74 & 3.16 & 4080 & 77400 & 5.49 & 7088 & 134000 & 3.23 & 3.60 & $<84.2$ & 22100 & $<146$ & 38400 \\
\hline G4B-LD-72 & 72 & 1.84 & 2.55 & 3870 & 73200 & 4.70 & 7132 & 135000 & 3.24 & 3.63 & $<84.7$ & 21000 & $<156$ & 38700 \\
\hline G4B-LD-120 & 120 & 1.81 & 2.60 & 4060 & 77400 & 4.70 & 7346 & 140000 & 3.35 & 3.75 & $<84.2$ & 22100 & $<152$ & 40000 \\
\hline G4B-LD-168 & 168 & 1.89 & 2.36 & 3890 & 74600 & 4.45 & 7341 & 141000 & 3.42 & 3.81 & $<84.6$ & 21700 & $<160$ & 41000 \\
\hline G4B-LD-336 & 336 & 2.05 & 2.37 & 3820 & 73800 & 4.87 & 7842 & 152000 & 3.53 & 3.96 & $<85.0$ & 20900 & $<175$ & 42900 \\
\hline G4B-FD-CP & $\begin{array}{c}\text { Feed } \\
\text { Displacement }\end{array}$ & 1 & 2.68 & 3080 & 74800 & 2.68 & 3080 & 74800 & 1.63 & 1.82 & 144 & 23300 & 144 & 23300 \\
\hline G4B-EL-CP & Elution & 1 & 22.4 & 251 & 1900 & 22.4 & 251 & 1900 & $<0.05$ & $<0.05$ & $<100$ & 2420 & $<100$ & 2420 \\
\hline Target & -- & -- & -- & -- & -- & 5.72 & 6690 & 137000 & 3.67 & 5.00 & -- & -- & 0 & 40800 \\
\hline
\end{tabular}


Table B.37. Column G5 Test Analytical Data $\left(\mathrm{T}=60^{\circ} \mathrm{C}\right.$, Flow rate $\left.=10.62 \mathrm{~mL} / \mathrm{min}\right)$

\begin{tabular}{|c|c|c|c|c|c|c|c|c|c|c|c|c|c|c|}
\hline Sample ID & $\begin{array}{l}\text { Loading Time } \\
\text { (min) }\end{array}$ & $\begin{array}{l}\text { Dilution } \\
\text { Factor }\end{array}$ & $\begin{array}{c}\text { Cs } \\
(\mathrm{raw}) \\
(\mathrm{mg} / \mathrm{kg})\end{array}$ & $\begin{array}{c}\mathrm{Al} \\
(\mathrm{raw}) \\
(\mathrm{mg} / \mathrm{kg})\end{array}$ & $\begin{array}{c}\mathrm{Na} \\
(\mathrm{raw}) \\
(\mathrm{mg} / \mathrm{kg})\end{array}$ & $\begin{array}{c}\text { Cs } \\
\text { (corr.) } \\
(\mathrm{mg} / \mathrm{kg})\end{array}$ & $\begin{array}{c}\mathrm{Al} \\
\text { (corr.) } \\
(\mathrm{mg} / \mathrm{kg})\end{array}$ & $\begin{array}{c}\mathrm{Na} \\
\text { (corr.) } \\
(\mathrm{mg} / \mathrm{kg})\end{array}$ & $\begin{array}{c}\text { OH-Free } \\
\text { (corr.) } \\
\text { (meq/mL) }\end{array}$ & $\begin{array}{c}\text { OH-Total } \\
\text { (corr.) } \\
\text { (meq/mL) }\end{array}$ & $\begin{array}{c}\mathrm{Cl} \\
(\mathrm{raw}) \\
(\mathrm{mg} / \mathrm{kg})\end{array}$ & $\begin{array}{c}\mathrm{NO}_{3} \\
\text { (raw) } \\
\text { (mg/kg) }\end{array}$ & $\begin{array}{c}\mathrm{Cl} \\
\text { (corr.) } \\
\text { (mg/kg) }\end{array}$ & $\begin{array}{c}\mathrm{NO}_{3} \\
\text { (corr.) } \\
\text { (mg/kg) }\end{array}$ \\
\hline G5-LD-00 & 0 & 1 & 2.22 & 2770 & 93600 & 2.22 & 2770 & 93600 & 1.55 & 1.70 & 47500 & 17600 & 47500 & 17600 \\
\hline G5-LD-06 & 6 & 1 & 1.82 & 2610 & 89100 & 1.82 & 2610 & 89100 & 1.49 & 1.64 & 46200 & 17100 & 46200 & 17100 \\
\hline G5-LD-12 & 12 & 1 & 1.59 & 2660 & 90300 & 1.59 & 2660 & 90300 & 1.49 & 1.63 & 46500 & 17100 & 46500 & 17100 \\
\hline G5-LD-18 & 18 & 1 & 1.43 & 2600 & 87900 & 1.43 & 2600 & 87900 & 1.49 & 1.64 & 46500 & 17100 & 46500 & 17100 \\
\hline G5-LD-24 & 24 & 1 & 1.37 & 2670 & 90500 & 1.37 & 2670 & 90500 & 1.50 & 1.64 & 46400 & 17100 & 46400 & 17100 \\
\hline G5-LD-36 & 36 & 1 & 1.23 & 2610 & 88000 & 1.23 & 2610 & 88000 & 1.49 & 1.64 & 46400 & 17000 & 46400 & 17000 \\
\hline G5-LD-48 & 48 & 1 & 1.14 & 2670 & 90700 & 1.14 & 2670 & 90700 & 1.50 & 1.64 & 46700 & 17000 & 46700 & 17000 \\
\hline G5-LD-60 & 60 & 1 & 1.05 & 2630 & 89700 & 1.05 & 2630 & 89700 & 1.50 & 1.64 & 46300 & 17000 & 46300 & 17000 \\
\hline G5-LD-80 & 80 & 1 & 1.04 & 2760 & 93900 & 1.04 & 2760 & 93900 & 1.49 & 1.64 & 45300 & 16700 & 45300 & 16700 \\
\hline G5-LD-120 & 120 & 1 & 0.979 & 2710 & 91300 & 0.979 & 2710 & 91300 & 1.49 & 1.64 & 45500 & 16700 & 45500 & 16700 \\
\hline G5-LD-180 & 180 & 1 & 0.954 & 2660 & 89900 & 0.954 & 2660 & 89900 & 1.49 & 1.64 & 46300 & 16900 & 46300 & 16900 \\
\hline G5-LD-240 & 240 & 1 & 0.946 & 2690 & 91400 & 0.946 & 2690 & 91400 & 1.50 & 1.64 & 46400 & 17000 & 46400 & 17000 \\
\hline G5-LD-600 & 600 & 1 & 1.01 & 2610 & 88900 & 1.01 & 2610 & 88900 & 1.50 & 1.65 & 45800 & 16900 & 45800 & 16900 \\
\hline G5-FD-CP & $\begin{array}{c}\text { Feed } \\
\text { Displacement }\end{array}$ & 1 & 0.847 & 1860 & 65700 & 0.847 & 1860 & 65700 & 1.06 & 1.16 & 30100 & 11600 & 30100 & 11600 \\
\hline G5-EL-CP & Elution & 1 & 12.2 & 32.3 & 1700 & 12.2 & 32.3 & 1700 & $<0.05$ & $<0.05$ & 112 & 2330 & 112 & 2330 \\
\hline Target & -- & -- & -- & -- & -- & 2.63 & 2570 & 95000 & 1.55 & 2.01 & -- & -- & 48900 & 19300 \\
\hline
\end{tabular}


Table B.38. Column O1 Test Analytical Data $\left(\mathrm{T}=45^{\circ} \mathrm{C}\right.$, Flow rate $\left.=10.62 \mathrm{~mL} / \mathrm{min}\right)$

\begin{tabular}{|c|c|c|c|c|c|c|c|c|c|c|c|c|c|c|}
\hline Sample ID & $\begin{array}{l}\text { Loading Time } \\
\text { (min) }\end{array}$ & $\begin{array}{l}\text { Dilution } \\
\text { Factor }\end{array}$ & $\begin{array}{c}\text { Cs } \\
(\mathrm{raw}) \\
(\mathrm{mg} / \mathrm{kg})\end{array}$ & $\begin{array}{c}\mathrm{Al} \\
(\mathrm{raw}) \\
(\mathrm{mg} / \mathrm{kg})\end{array}$ & $\begin{array}{c}\mathrm{Na} \\
(\mathrm{raw}) \\
(\mathrm{mg} / \mathrm{kg})\end{array}$ & $\begin{array}{c}\text { Cs } \\
\text { (corr.) } \\
\text { (mg/kg) }\end{array}$ & $\begin{array}{c}\mathrm{Al} \\
(\text { corr.) } \\
(\mathrm{mg} / \mathrm{kg})\end{array}$ & $\begin{array}{c}\mathrm{Na} \\
\text { (corr.) } \\
\text { (mg/kg) }\end{array}$ & $\begin{array}{c}\text { OH-Free } \\
\text { (corr.) } \\
\text { (meq/mL) }\end{array}$ & $\begin{array}{c}\text { OH-Total } \\
\text { (corr.) } \\
\text { (meq/mL) }\end{array}$ & $\begin{array}{c}\text { TIC } \\
\text { (corr.) } \\
\text { (mg/L) }\end{array}$ & $\begin{array}{c}\text { TOC } \\
\text { (corr.) } \\
\text { (mg/L) }\end{array}$ & $\begin{array}{c}\mathrm{Cl} \\
\text { (corr.) } \\
\text { (mg/kg) }\end{array}$ & $\begin{array}{c}\mathrm{NO}_{3} \\
\text { (corr.) } \\
\text { (mg/kg) }\end{array}$ \\
\hline Before Filter & -- & -- & -- & -- & -- & -- & -- & -- & -- & -- & 25.8 & 55700 & -- & -- \\
\hline After Filter & -- & -- & -- & -- & -- & -- & -- & -- & -- & -- & 63.4 & 51350 & -- & -- \\
\hline O1-LD-00 & 0 & 1 & 2.95 & 2770 & 97600 & 2.95 & 2770 & 97600 & 1.56 & 1.71 & 69.0 & 43800 & 54800 & 19700 \\
\hline O1-LD-06 & 6 & 1 & 2.57 & 2660 & 93700 & 2.57 & 2660 & 93700 & 1.50 & 1.67 & 83.7 & 45900 & 53900 & 19300 \\
\hline O1-LD-12 & 12 & 1 & 2.50 & 2630 & 95500 & 2.50 & 2630 & 95500 & 1.49 & 1.65 & 65.2 & 46150 & 53100 & 19200 \\
\hline O1-LD-18 & 18 & 1 & 2.37 & 2640 & 94300 & 2.37 & 2640 & 94300 & 1.52 & 1.68 & 66.1 & 46150 & 53200 & 19200 \\
\hline O1-LD-24 & 24 & 1 & 2.27 & 2610 & 93400 & 2.27 & 2610 & 93400 & 1.51 & 1.67 & 100 & 43550 & 53300 & 19300 \\
\hline O1-LD-36 & 36 & 1 & 2.22 & 2660 & 95000 & 2.22 & 2660 & 95000 & 1.49 & 1.66 & 91.8 & 45550 & 52500 & 19000 \\
\hline O1-LD-48 & 48 & 1 & 2.12 & 2520 & 94300 & 2.12 & 2520 & 94300 & 1.49 & 1.66 & 108 & 45800 & 52500 & 19000 \\
\hline O1-LD-60 & 60 & 1 & 2.04 & 2600 & 94200 & 2.04 & 2600 & 94200 & 1.49 & 1.65 & 65.9 & 45200 & 52700 & 19000 \\
\hline O1-LD-80 & 80 & 1 & 1.98 & 2580 & 95300 & 1.98 & 2580 & 95300 & 1.51 & 1.67 & 69.9 & 45800 & 53200 & 19100 \\
\hline O1-LD-120 & 120 & 1 & 1.61 & 2770 & 94500 & 1.61 & 2770 & 94500 & 1.49 & 1.66 & 93.6 & 45200 & 53100 & 19100 \\
\hline O1-LD-180 & 180 & 1 & 0.999 & 2730 & 95300 & 0.999 & 2730 & 95300 & 1.51 & 1.67 & 74.1 & 44700 & 52300 & 18800 \\
\hline O1-LD-240 & 240 & 1 & 0.745 & 2530 & 94800 & 0.745 & 2530 & 94800 & 1.50 & 1.66 & 91.0 & 44800 & 52800 & 19000 \\
\hline O1-LD-600 & 600 & 1 & 0.420 & 2770 & 96900 & 0.420 & 2770 & 96900 & 1.53 & 1.68 & 70.0 & 44900 & 52800 & 19100 \\
\hline O1-FD-CP & $\begin{array}{c}\text { Feed } \\
\text { Displacement }\end{array}$ & 1 & 0.299 & 1810 & 66100 & 0.299 & 1810 & 66100 & 1.04 & 1.14 & 70.0 & 28700 & 35300 & 12600 \\
\hline O1-EL-CP & Elution & 1 & 9.48 & 4.50 & 1390 & 9.48 & 4.50 & 1390 & $<0.05$ & $<0.05$ & $<10.0$ & 170 & 113 & 2480 \\
\hline Target & -- & -- & -- & -- & -- & 2.63 & 2570 & 95000 & 1.55 & 2.01 & -- & -- & 48900 & 19300 \\
\hline
\end{tabular}


Table B.39. Aging Batch Test Analytical Data

\begin{tabular}{|c|c|c|c|c|c|c|c|c|c|c|c|c|c|c|}
\hline Sample ID & $\begin{array}{c}\text { Loading } \\
\text { Time } \\
\text { (hrs) }\end{array}$ & $\begin{array}{c}\text { Dilution } \\
\text { Factor }\end{array}$ & $\begin{array}{l}\text { Cs (raw) } \\
\text { (mg/kg) }\end{array}$ & $\begin{array}{l}\mathrm{Al} \text { (raw) } \\
\text { (mg/kg) }\end{array}$ & $\begin{array}{c}\text { Na (raw) } \\
\text { (mg/kg) }\end{array}$ & $\begin{array}{c}\text { Cs (corr.) } \\
\text { (mg/kg) }\end{array}$ & $\begin{array}{c}\text { Al (corr.) } \\
\text { (mg/kg) }\end{array}$ & $\begin{array}{c}\text { Na (corr.) } \\
\text { (mg/kg) }\end{array}$ & $\begin{array}{c}\text { OH-Free } \\
\text { (corr.) } \\
\text { (meq/mL) }\end{array}$ & $\begin{array}{c}\text { OH-Total } \\
\text { (corr.) } \\
\text { (meq/mL) }\end{array}$ & $\begin{array}{l}\mathrm{Cl} \text { (raw) } \\
\text { (mg/kg) }\end{array}$ & $\begin{array}{c}\mathrm{NO}_{3} \\
(\mathrm{raw}) \\
(\mathrm{mg} / \mathrm{kg})\end{array}$ & $\begin{array}{c}\text { Cl (corr.) } \\
\text { (mg/kg) }\end{array}$ & $\begin{array}{c}\mathrm{NO}_{3} \text { (corr.) } \\
(\mathrm{mg} / \mathrm{kg})\end{array}$ \\
\hline Test-25-A-0 & 0 & 1 & 3.90 & 2650 & 96300 & 3.90 & 2650 & 96300 & 1.54 & 1.68 & 50200 & 18000 & 50200 & 18000 \\
\hline Test-25-A-1 & 1 & 1 & 1.58 & 2590 & 93900 & 1.58 & 2590 & 93900 & 1.54 & 1.68 & 50600 & 18100 & 50600 & 18100 \\
\hline Test-25-A-4 & 4 & 1 & 0.373 & 2620 & 95600 & 0.373 & 2620 & 95600 & 1.51 & 1.66 & 49700 & 17800 & 49700 & 17800 \\
\hline Test-25-A-10 & 10 & 1 & 0.272 & 2550 & 94300 & 0.272 & 2550 & 94300 & 1.52 & 1.67 & 50900 & 18200 & 50900 & 18200 \\
\hline Test-25-A-24 & 24 & 1 & 0.271 & 2600 & 94800 & 0.271 & 2600 & 94800 & 1.50 & 1.65 & 49800 & 17900 & 49800 & 17900 \\
\hline Test-25-B-0 & 0 & 1 & 3.90 & 2650 & 96300 & 3.90 & 2650 & 96300 & 1.54 & 1.68 & 50200 & 18000 & 50200 & 18000 \\
\hline Test-25-B-1 & 1 & 1 & 1.58 & 2550 & 94300 & 1.58 & 2550 & 94300 & 1.50 & 1.66 & 50000 & 18000 & 50000 & 18000 \\
\hline Test-25-B-4 & 4 & 1 & 0.379 & 2510 & 95100 & 0.379 & 2510 & 95100 & 1.51 & 1.65 & 49800 & 17900 & 49800 & 17900 \\
\hline Test-25-B-10 & 10 & 1 & 0.288 & 2570 & 94300 & 0.288 & 2570 & 94300 & 1.53 & 1.67 & 50300 & 18000 & 50300 & 18000 \\
\hline Test-25-B-24 & 24 & 1 & 0.269 & 2590 & 93400 & 0.269 & 2590 & 93400 & 1.51 & 1.66 & 50200 & 18000 & 50200 & 18000 \\
\hline Test-25-C-0 & 0 & 1 & 3.90 & 2650 & 96300 & 3.90 & 2650 & 96300 & 1.54 & 1.68 & 50200 & 18000 & 50200 & 18000 \\
\hline Test-25-C-1 & 1 & 1 & 1.66 & 2440 & 94300 & 1.66 & 2440 & 94300 & 1.50 & 1.65 & 49800 & 17900 & 49800 & 17900 \\
\hline Test-25-C-4 & 4 & 1 & 0.408 & 2550 & 93200 & 0.408 & 2550 & 93200 & 1.49 & 1.65 & 49900 & 17900 & 49900 & 17900 \\
\hline Test-25-C-10 & 10 & 1 & 0.309 & 2490 & 93900 & 0.309 & 2490 & 93900 & 1.50 & 1.65 & 50100 & 18000 & 50100 & 18000 \\
\hline Test-25-C-24 & 24 & 1 & 0.337 & 2590 & 94100 & 0.337 & 2590 & 94100 & 1.49 & 1.65 & 49900 & 17900 & 49900 & 17900 \\
\hline Test-25-D-0 & 0 & 1 & 3.90 & 2650 & 96300 & 3.90 & 2650 & 96300 & 1.54 & 1.68 & 50200 & 18000 & 50200 & 18000 \\
\hline Test-25-D-1 & 1 & 1 & 1.63 & 2540 & 92900 & 1.63 & 2540 & 92900 & 1.51 & 1.66 & 50200 & 17900 & 50200 & 17900 \\
\hline Test-25-D-4 & 4 & 1 & 0.460 & 2480 & 94700 & 0.460 & 2480 & 94700 & 1.51 & 1.66 & 50200 & 17900 & 50200 & 17900 \\
\hline Test-25-D-10 & 10 & 1 & 0.292 & 2530 & 93900 & 0.292 & 2530 & 93900 & 1.51 & 1.66 & 50300 & 18000 & 50300 & 18000 \\
\hline Test-25-D-24 & 24 & 1 & 0.318 & 2510 & 94700 & 0.318 & 2510 & 94700 & 1.51 & 1.66 & 49900 & 17800 & 49900 & 17800 \\
\hline Test-45-A-0 & 0 & 1 & 3.90 & 2650 & 96300 & 3.90 & 2650 & 96300 & 1.54 & 1.68 & 50200 & 18000 & 50200 & 18000 \\
\hline Test-45-A-1 & 1 & 1 & 2.01 & 2580 & 95400 & 2.01 & 2580 & 95400 & 1.51 & 1.65 & 48800 & 17500 & 48800 & 17500 \\
\hline Test-45-A-4 & 4 & 1 & 1.09 & 2510 & 94000 & 1.09 & 2510 & 94000 & 1.50 & 1.65 & 48800 & 17500 & 48800 & 17500 \\
\hline Test-45-A-10 & 10 & 1 & 1.11 & 2490 & 94400 & 1.11 & 2490 & 94400 & 1.50 & 1.65 & 48800 & 17500 & 48800 & 17500 \\
\hline Test-45-A-24 & 24 & 1 & 0.611 & 2450 & 92200 & 0.611 & 2450 & 92200 & 1.47 & 1.62 & 48200 & 17300 & 48200 & 17300 \\
\hline Test-45-B-0 & 0 & 1 & 3.90 & 2650 & 96300 & 3.90 & 2650 & 96300 & 1.54 & 1.68 & 50200 & 18000 & 50200 & 18000 \\
\hline Test-45-B-1 & 1 & 1 & 2.12 & 2600 & 94700 & 2.12 & 2600 & 94700 & 1.49 & 1.65 & 49300 & 17700 & 49300 & 17700 \\
\hline Test-45-B-4 & 4 & 1 & 0.732 & 2580 & 95900 & 0.732 & 2580 & 95900 & 1.52 & 1.66 & 49400 & 17700 & 49400 & 17700 \\
\hline Test-45-B-10 & 10 & 1 & 0.911 & 2490 & 94000 & 0.911 & 2490 & 94000 & 1.51 & 1.66 & 49000 & 17500 & 49000 & 17500 \\
\hline Test-45-B-24 & 24 & 1 & 1.16 & 2550 & 94200 & 1.16 & 2550 & 94200 & 1.50 & 1.65 & 48900 & 17500 & 48900 & 17500 \\
\hline Target & -- & -- & -- & -- & -- & 2.63 & 2570 & 95000 & 1.55 & 2.01 & -- & -- & 48900 & 19300 \\
\hline
\end{tabular}



PNNL-21109

WTP-RPT-214

\section{Distribution*}

No. of

Copies

3 Bechtel National, Inc.
SM Barnes

DJ Sherwood

WTP R\&T Docs

No. of

Copies

5 Battelle Pacific Northwest National Laboratory

GN Brown

RA Peterson

DE Rinehart

RL Russell

Project File

Information Release (pdf)

P7-25

K6-24

K6-24

K3-52

H4-02

H4-02

H4-02

*All distribution will be made electronically.

Dist. 1 


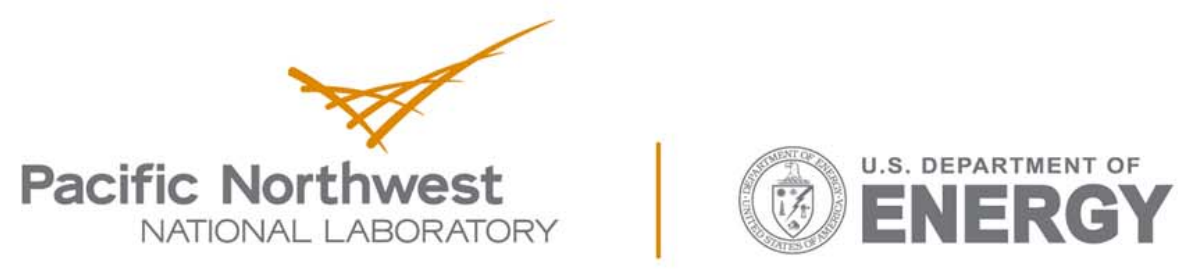

Proudly Operated by Battelle Since 1965

902 Battelle Boulevard

P.O. Box 999

Richland, WA 99352

1-888-375-PNNL (7665)

www.pnnl.gov 